PNNL-18007

WTP-RPT-171, Rev. 0

\title{
Laboratory Demonstration of the Pretreatment Process with Caustic and Oxidative Leaching Using Actual Hanford Tank Waste
}

SK Fiskum

JM Billing

EC Buck

RC Daniel
KE Draper

MK Edwards

ED Jenson

AE Kozelisky
PJ MacFarlan

RA Peterson

RW Shimskey

LA Snow

January 2009 


\title{
DISCLAIMER
}

This report was prepared as an account of work sponsored by an agency of the United States Government. Neither the United States Government nor any agency thereof, nor Battelle Memorial Institute, nor any of their employees, makes any warranty, express or implied, or assumes any legal liability or responsibility for the accuracy, completeness, or usefulness of any information, apparatus, product, or process disclosed, or represents that its use would not infringe privately owned rights. Reference herein to any specific commercial product, process, or service by trade name, trademark, manufacturer, or otherwise does not necessarily constitute or imply its endorsement, recommendation, or favoring by the United States Government or any agency thereof, or Battelle Memorial Institute. The views and opinions of authors expressed herein do not necessarily state or reflect those of the United States Government or any agency thereof.

\author{
PACIFIC NORTHWEST NATIONAL LABORATORY \\ operated by \\ BATTELLE \\ for the \\ UNITED STATES DEPARTMENT OF ENERGY \\ under Contract DE-AC05-76RL01830
}

Printed in the United States of America
Available to DOE and DOE contractors from the
Office of Scientific and Technical Information,
P.O. Box 62, Oak Ridge, TN 37831-0062;
ph: (865) 576-8401
fax: (865) 5765728
email: reports@adonis.osti.gov

\footnotetext{
Available to the public from the National Technical Information Service, U.S. Department of Commerce, 5285 Port Royal Rd., Springfield, VA 22161 ph: (800) 553-6847 fax: (703) 605-6900

email: orders@nits.fedworld.gov

online ordering: http://www.ntis.gov/ordering.htm
} 
PNNL-18007

WTP-RPT-171, Rev. 0

\section{Laboratory Demonstration of the Pretreatment Process with Caustic and Oxidative Leaching Using Actual Hanford Tank Waste in Support of the Waste Treatment and Immobilization Plant}

$\begin{array}{lll}\text { SK Fiskum } & \text { KE Draper } & \text { PJ MacFarlan } \\ \text { JM Billing } & \text { MK Edwards } & \text { RA Peterson } \\ \text { EC Buck } & \text { ED Jenson } & \text { RW Shimskey } \\ \text { RC Daniel } & \text { AE Kozelisky } & \text { LA Snow }\end{array}$

January 2009

Test specification: 24590-PTF-TSP-RT-06-002, Rev. 0

Test plan: TP-RPP-WTP-456, Rev. 0

Test exceptions: None

R\&T focus area: Pretreatment

Test Scoping Statement(s): B-89a

Pacific Northwest National Laboratory

Richland, Washington 99352 


\section{COMPLETENESS OF TESTING}

This report describes the results of work and testing specified by Test Specification 24590-PTF-TSP-RT-06-002, Rev. 0 "Process Development for Design of Oxidative Leaching of Hanford Wastes" and Test Plan TP-RPP-WTP-456, Rev. 0 "Pretreatment Demonstration Applying Oxidative Leaching to Hanford Tank Waste." The work and any associated testing followed the quality assurance requirements outlined in the Test Specification/Plan. The descriptions provided in this test report are an accurate account of both the conduct of the work and the data collected. Test plan results are reported. Also reported are any unusual or anomalous occurrences that are different from expected results. The test results and this report have been reviewed and verified.

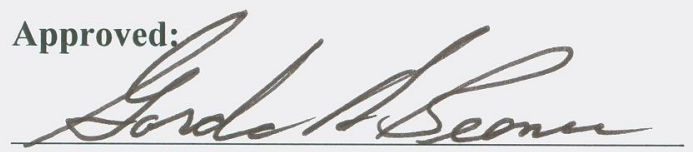

Gordon H. Beeman, Manager WTP R\&T Support Project

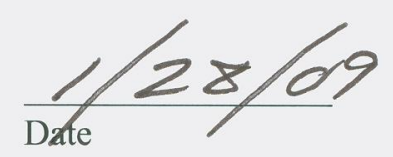

Date 


\section{Contents}

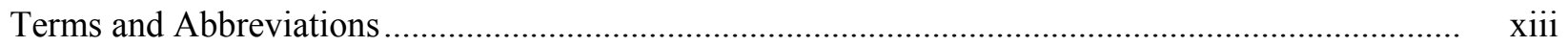





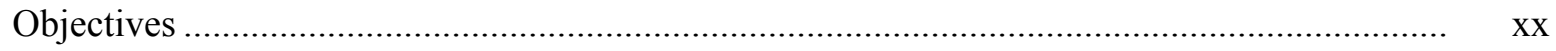



Results and Performance Against Success Criteria ............................................................ xxii

Quality Requirements ........................................................................................................ x



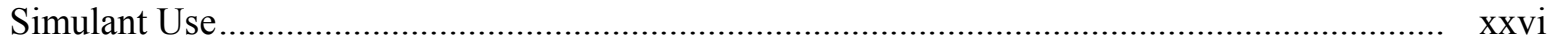

Discrepancies and Follow-on Tests ................................................................................ xxvi

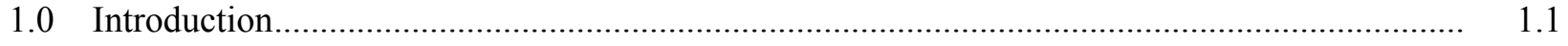

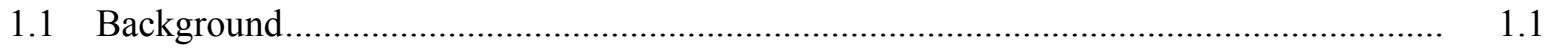

1.1.1 Integrated Pretreatment Flowsheet...............................................................

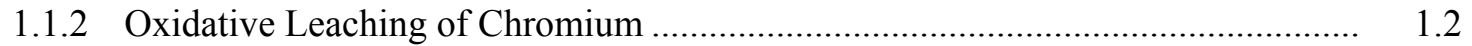



1.1.4 Caustic Leaching and Ultrafiltration............................................................ 1.3

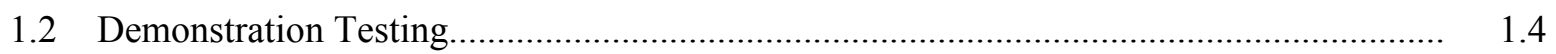

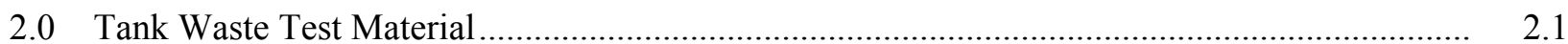

3.0 Permanganate Dosage Determination for Combined Group 5 (REDOX Sludge) and Group 6 (S-Saltcake) Oxidative Leaching .......................................................................... 3.1



3.1.1 Phase 1 Test Material ............................................................................. 3.2

3.1.2 Phase 1 Caustic Leaching and Washing ........................................................ 3.2

3.1.3 Phase 1 Oxidative Leach Test Matrix ..................................................................... 3.4

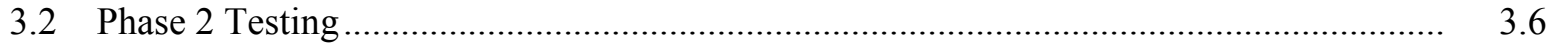

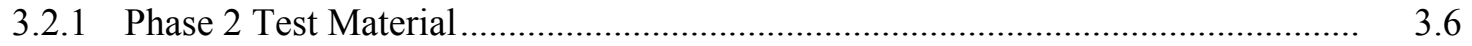

3.2.2 Phase 2 Processing Conditions ..................................................................... 3.6

3.3 Phase 1 Testing Oxidative Leach Test Results ............................................................... 3.7

3.3.1 Initial Caustic Leach and Wash ....................................................................... 3.7

3.4 Phase 2 Testing Oxidative Leach Test Results ........................................................... 3.15

3.5 Recommended Permanganate Dosage ....................................................................... 3.17

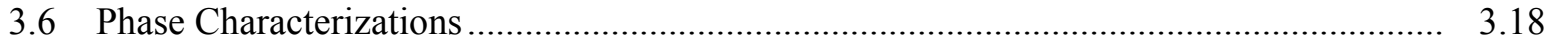



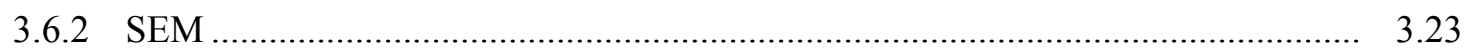



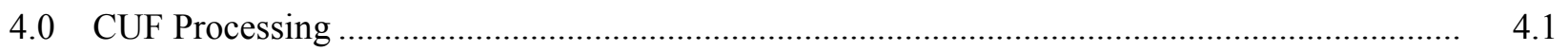

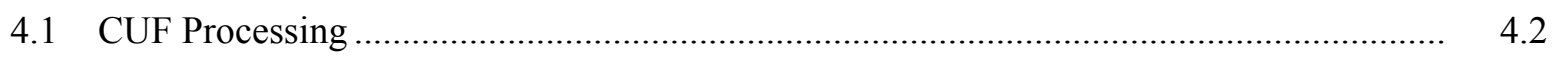




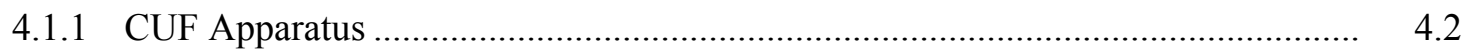

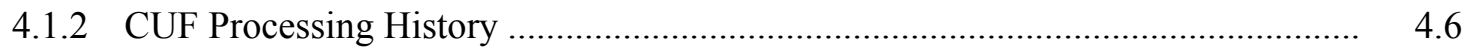

4.1.3 Tank Waste Group 5/6 Test Matrix Preparation .................................................. 4.6

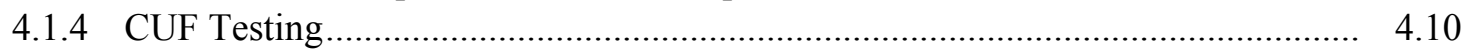

4.1.5 Sampling and Analysis ............................................................................ 4.16

4.2 CUF Process Results............................................................................................. 4.18

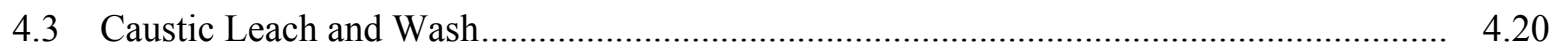



4.5 Comparison of CUF Testing to Oxidant Dosage (Parametric) Testing ............................ 4.35

4.6 Surface Area and Crystal Habit of the Product Solids........................................................ 4.36

4.7 Filtration, Rheological, and PSD Results .................................................................. 4.42

4.8 Assessment of CUF Surfaces for Pu Accumulation .................................................. 4.42

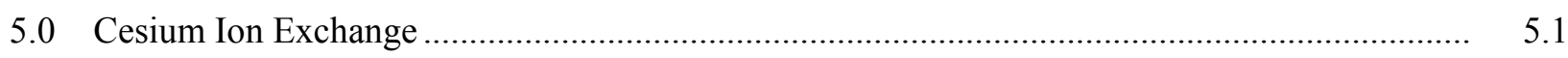

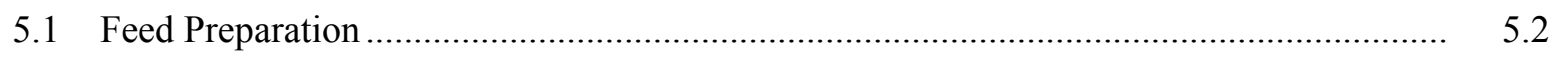

5.2 Resorcinol-Formaldehyde Test Resin .................................................................. 5.23



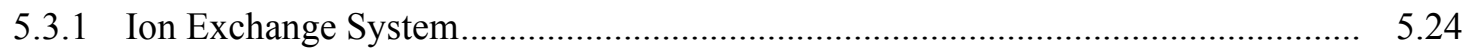



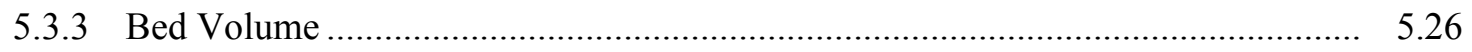

5.3.4 Ion Exchange Processing Conditions................................................................ 5.26

5.4 Ion Exchange Processing Data Analysis ........................................................................ 5.27

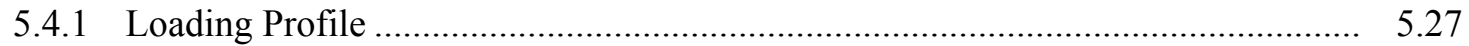

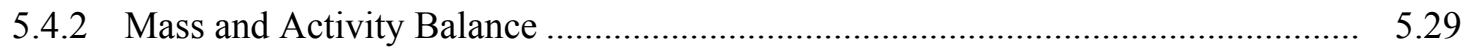

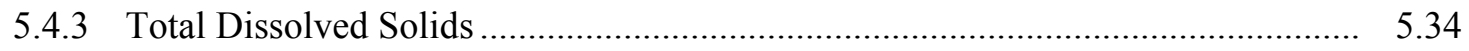

6.0 Evaporation and Concentration .................................................................................. 6.1



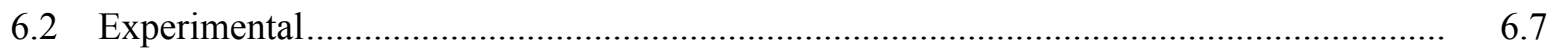

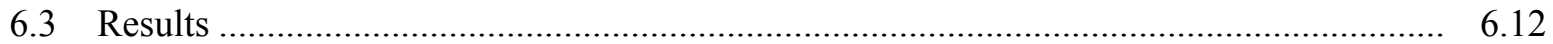

6.3.1 Physical Properties of Slurries ................................................................... 6.12

6.3.2 Evaporator Concentrate ......................................................................... 6.13

6.3.3 Post-Evaporation Container Leaching ......................................................... 6.27

6.3.4 Evaporator Concentrate Combined with Tank Waste Supernate........................... 6.28





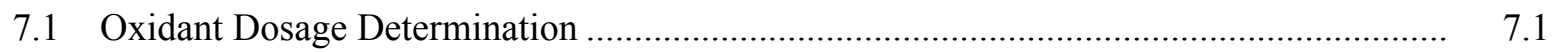

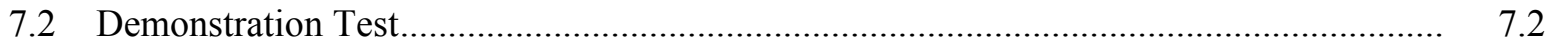

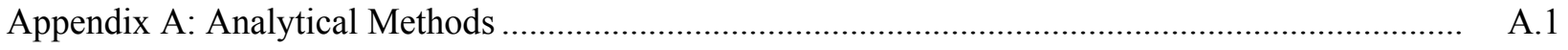

Appendix B: Parametric Leach Data …............................................................................. B.1

Appendix C: Concurrence Requests .................................................................................. C. 


\section{Figures}

Figure No.

Caption

Page No.

1.1. Chromium Distribution in Tank Waste Saltcake after Caustic Leaching (BBI) ...................... 1.2

1.2. Overall Process Flow for the Demonstration Test.................................................................

3.1. Parametric Testing Overview for Permanganate Dosage and Free-Hydroxide Concentration .. 3.1

3.2. Phase 1 Caustic-Leaching, Washing, and Analysis Flowchart............................................... 3.3

3.3. Phase 1 Oxidative Leaching Test .......................................................................................

3.4. Sample Handling of Oxidatively Leached Solids................................................................

3.5. Phase 2 Sample Processing and Analysis ............................................................................ 3.7

3.6. Chromate Concentration Versus Oxidative Leach Time at Four $\mathrm{Mn} / \mathrm{Cr}$ Molar Ratios ............. 3.11

3.7. Cr Dissolution in Group 5/6 Composite as a Function of the $\mathrm{Mn} / \mathrm{Cr}$ Mole Ratio .................... 3.12

3.8. $\mathrm{Cr}$ in Leachate as a Function of Time and $\mathrm{NaOH}$ Concentration, $\mathrm{Mn} / \mathrm{Cr}$ Mole Ratio $=1.25 \ldots . \quad 3.15$

3.9. $\mathrm{Pu}$ Leachate Concentration as Function of Time and $\mathrm{NaOH}$ Concentration, $\mathrm{Mn} / \mathrm{Cr}$ Mole

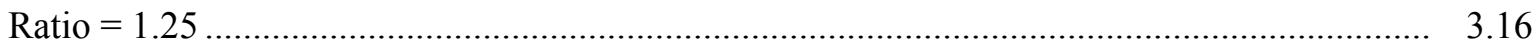

3.10. Equilibrium $\mathrm{Pu}$ Leachate Concentration as a Function of $\mathrm{NaOH}$ Concentration ..................... 3.16

3.11. Comparison of Parametric Pu Dissolution Study to Previously Published Results .................. 3.17

3.12. XRD Pattern for Initial Group 5/6 Composite (TI546-G5n6-S1) a) Raw diffraction pattern and b) Background-Subtracted with Stick-Phase Identification.......................................... 3.20

3.13. XRD Pattern for Caustic-Leached and Washed Group 5/6 Composite (TI546-G5\&6-CLS) a) Raw Diffraction Pattern and b) Background-Subtracted with Stick-Phase Identification ..... 3.21

3.14. XRD Pattern for Oxidatively Leached and Washed Group 5/6 Composite (TI546-G5\&6-1a-LS) - a) Raw Diffraction Pattern (no background subtraction) and

b) Background-Subtracted with Stick-Phase Identification ................................................ 3.22



3.16. Additional SEM Images with EDS Evaluations of the Initial Group 5/6 Solids ..................... 3.24

3.17. SEM Image with EDS Examination of the Caustic-Leached Group 5/6 Solids....................... 3.25

3.18. Various SEM Images of the Oxidatively Leached Group 5/6 Solids .................................... 3.25

3.19. SEM Image with Elemental Mapping of the Oxidatively Leached Group 5/6 Solids ............. 3.26

3.20. SEM-EDS Analysis of Oxidatively Leached Group 5/6 Solids ............................................ 3.27

3.21. Group5/6 Oxidatively Leached and Washed Solids (Sample TI546-1a-LS-TEM)

(a) TEM Image of Boehmite Particles and (b) Log-Normal Distribution of Particle Sizes Based on Several TEM Images ........................................................................................ 3.28

3.22. Group5/6 Oxidatively Leached and Washed Solids (a) STEM-HAADF Image (b) X-Ray EDS Analysis of Uranium-Rich Area 
3.23. Group5/6 Oxidatively Leached and Washed Solids STEM-HAADF Image of ManganeseRich Particle $(\mathrm{Bar}=200 \mathrm{~nm})$ with EDS Analysis of the Mn-Rich Area.

3.24. Group5/6 Oxidatively Leached and Washed Solids (a) Scanning STEM-HAADF Image of Uranium-Rich Region Oxidative Leached Material (b) EDS Analysis of Area.

3.25. Energy-Filtered TEM Image of Oxidatively Leached and Washed Group 5/6 Solids..... 3.30

3.26. STEM- HAADF Image of Oxidatively Leached and Washed Group 5/6 Solids (inverted contrast) and EDS Analyses of Alumino-Silicate Phases.

3.27. TEM Image of Agglomerate $\mathrm{Al}$ and $\mathrm{U}$ Phases in Oxidatively Leached and Washed Group 5/6 Solids; EDS Analyses from the Region are Shown.

3.28. Oxidatively Leached and Washed Group 5/6 Solids (a) TEM Image of Region Highlighted in Previous and (b) EDS Analysis of Uranium Phase.....

3.29. Oxidatively Leached and Washed Group 5/6 Solids High Resolution TEM Image of Uranium Oxide Phase Showing the Crystalline Nature of the Phase.

4.1. Pretreatment Operations in the CUF Supporting the Demonstration Test ......

4.2. Piping Diagram of CUF Apparatus (Not to Scale)

4.3. Filter Assembly Sketch (Not to Scale)

4.4. CUF Testing Apparatus Before Hot Cell Installation

4.5. Group 5/6 CUF Processing Flowchart-Initial Compositing and Filtering

4.6. Group 5/6 CUF Processing Flowchart-Caustic Leaching and Rinsing

4.7. Group 5/6 CUF Processing Flowchart-Oxidative Leaching and Rinsing...

4.8. Final Filtration Testing with Added Group 5 Caustic-Leached Solids and CUF System Cleanout.

4.9. CUF Slurry Characterization Scheme

4.10. Analyte Concentration Changes during Caustic Leach and Solids Wash

4.11. $\mathrm{Cr}$ and $\mathrm{Pu}$ Leachate Concentrations as a Function of Time during CUF Oxidative Leaching...

4.12. Comparison of CUF Pu Dissolution During Oxidative Leaching to Parametric Testing and Previously Published Results (Delegard 2006)

4.13. Analyte Concentration as a Function of Oxidative Leach and Wash Step

4.14. XRD Pattern of the Caustic and Oxidatively Leached and Washed Group 5/6 Solids a) Raw Diffraction Pattern, b) Background-Subtracted Diffraction Pattern with StickPhase Identification (Rutile is the internal standard)

4.15. Best Estimate of Product Phase Identification

4.16. SEM Images with EDS Evaluation of Oxidatively Leached and Washed Solids 
4.18. TEM Images with EDS Evaluation a) Particle Agglomerates Dominated by Al and O b) Calcite Particle c) Uranium Associated with an Alumino-Silicate Phase, Possibly

Cancrinite

4.19. Analyte Concentrations Normalized to $137 \mathrm{Cs}$ Concentration for the Oxidatively Leached Solids and the $2 \mathrm{M} \mathrm{HNO}_{3}$ CUF Surfaces Leach Solution

5.1. Pretreatment Operations with Ion Exchange Supporting the Demonstration Test.

5.2. Ion Exchange Process Steps Supporting the Demonstration Test.....

5.3. Solids Collected on Two Filters from the Ion Exchange Feed Composite Filter diameters are $75 \mathrm{~mm}$. a) not sampled; b) after sub-sampling.

5.4. SEM Micrographs with EDS Evaluation of the Filtered Solids

5.5. SEM Micrographs of the Cesium Ion Exchange Filtered Solids (a) 6000×, (b) $9000 \times$, (c) $10,000 \times$

5.6. X-Ray Powder Diffraction Pattern of Filtered Solids with Rutile $\left(\mathrm{TiO}_{2}\right)$ Internal Standard a) Raw Spectral Pattern b) Background-Subtracted Spectral Pattern

5.7. TEM Micrographs of the Cesium Ion Exchange Filtered Solids.

5.8. (a) Evidence for the Nano-Crystalline Nature of the Manganese Phases (b) Histogram over Selected Region, and (c) Enlarged Region Showing a 0.7-nm Lattice Spacing.

5.9. High Resolution TEM Images of Manganese Particles.....

5.10. X-Ray Energy Dispersive Analysis of the Mn Phase

5.11. Electron Energy-Loss Analysis of Mn Phase.

5.12. Cumulative Distribution Plot of Manganese Particle Sizes Observed in the TEM

5.13. Schematic Representation of the Key Processes to be Performed in the PTF.

5.14. Ion Exchange Column Processing System Schematic.

5.15. Photograph of the Ion Exchange Column Processing System (During In-Column Resin Conditioning)

5.16. Cesium Load Profile

6.1. Pretreatment Operations with Evaporation Supporting the Demonstration Test

6.2. Evaporation Process Steps Supporting the Demonstration Test...

6.3. Preparation of Composite Feed TI525-EvFA

6.4. Preparation of Composite Feed TI525-EvFB

6.5. Component Evaporator Feeds

6.6. Evaporation Vessel Before Test a) with ruler in place, b) with cover in place

6.7. Sludge Coating the Impeller, Shaft, and Evaporator Post-Evaporation 
6.9. Processing and Splits of the Evaporator Concentrate, TI525-EvConc ................................... 6.10

6.10. Aged (7-Day) Evaporator Concentrate Mixed with Supernatant (TI525-EvConc+Spnt) ........ 6.11

6.11. Processing of the Evaporator Concentrate Plus Supernatant................................................ 6.11

6.12. Analytical Processing Scheme for Slurry Characterization................................................ 6.12

6.13. SEM Images of Washed Evaporator Solids .................................................................... 6.19

6.14. SEM Imaging with EDS Evaluation of Evaporator Product Washed Solids ........................... 6.19

6.15. STEM Image (inverted contrast) Showing Particles from the Evaporator Product ................. 6.20

6.16. Cumulative Distribution Plot of Particle Sizes and a Mathematical (Log Normal) Fit to the Data.

6.17. (a) High Resolution Filtered Image of a Mixed Mn-Fe Phase, (b) Diffraction Pattern, and (c) X-ray Energy Dispersive Analysis of the Material

6.18. (a) Histogram of Lattice Spacings (Intensity vs distance in $\mathrm{nm}$ ), (b) High Resolution TEM Image of Mn-Fe Phase, (c) Enlarged region taken along a Zone Axis, and (d) A Filtered High Resolution Image.

6.19. Raw X-Ray Powder Diffraction Pattern of the Evaporator Product Washed Precipitated Solids with Rutile $\left(\mathrm{TiO}_{2}\right)$ Internal Standard

6.20. Background-Subtracted X-Ray Powder Diffraction Pattern of the Evaporator Product Washed Precipitated Solids with Rutile $\left(\mathrm{TiO}_{2}\right)$ Internal Standard and Stick-Phase Identifications.

6.21. Raw X-Ray Powder Diffraction Pattern of the Evaporator Product Unwashed Precipitated Solids with Rutile $\left(\mathrm{TiO}_{2}\right)$ Internal Standard

6.22. Background-Subtracted X-Ray Powder Diffraction Pattern of the Evaporator Product Unwashed Precipitated Solids with Rutile $\left(\mathrm{TiO}_{2}\right)$ Internal Standard and Stick-Phase Identifications

7.1. Plutonium Dissolution and Fraction Removed as Functions of $\mathrm{NaOH}$ Concentration during Parametric Testing and CUF Testing

7.2. Pu Partitioning Through the Demonstration Test. 


\section{Tables}

Table No.

Caption

Page No.

2.1. Compositional Summary of Group 5 and Group 6 Tank Wastes .......................................... 2.2



3.2. Caustic-Leaching Process Solutions and Solids Composition .............................................. 3.9

3.3. Oxidative Leaching Process Solutions and Solids Composition .......................................... 3.13

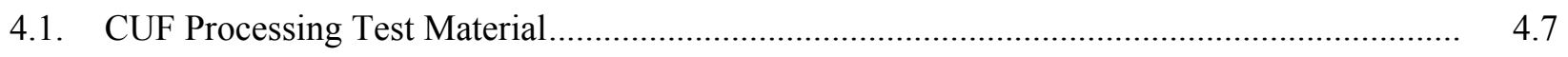

4.2. Calculated Composited Groups 5 and 6 Composition—Demonstration Test ......................... 4.8

4.3. Summary of Group 6/5 CUF Tests .................................................................................. 4.18

4.4. Caustic Leach and Wash Solution Composition ................................................................... 4.22

4.5. Solids Composition Before and After Caustic Leach and Wash ............................................ 4.26

4.6. Analyte Concentrations in Leachate as a Function of Time During Oxidative Leaching ......... 4.29

4.7. Oxidative Leach and Wash Solutions....................................................................... 4.31

4.8. Solids Composition after Oxidative Leach and Wash with Leach Factors ............................. 4.34

4.9. Rheology, PSD, and Filtration Testing Supporting the Demonstration Test............................ 4.42

4.10. 2 M Nitric Acid CUF Leach Solution ........................................................................... 4.42

5.1. Ion Exchange Feed Component Inputs...................................................................... 5.3

5.2. Radionuclide Analysis of the Ion Exchange Feed Components........................................... 5.4

5.3. Chemical Composition of the Ion Exchange Feed Components ........................................... 5.5

5.4. Ion Exchange Processing Feed Metal and Anion Composition ............................................ 5.8

5.5. Ion Exchange Processing Feed Radionuclide Composition ................................................. 5.10

5.6. Radiochemical Composition of the Filtered Feed Solids .................................................... 5.11

5.7. Metals (ICP-OES) Composition of the Filtered Solids ...................................................... 5.12

5.8. Ion Exchange Process Steps and Conditions ................................................................... 5.27

5.9. Cs Ion Exchange Effluent Sample Results ...................................................................... 5.28

5.10. Process Solution Compositions and Analyte Recoveries: ICP-OES Metals, Anions, Free Hydroxide, TOC, and TIC ........................................................................................ 5.30

5.11. Process Solution Compositions and Analyte Recoveries: Radionuclides ............................. 5.33

5.12. Total Dissolved Solids Content in Process Solutions .......................................................... 5.34

6.1. Fractional Feed Process Streams to the Demonstration Test FEP (Evaporator) ....................... 6.3

6.2. Radionuclide Composition of the Evaporator Feed Components ............................................ 6.5

6.3. Chemical Composition of the Evaporator Feed Components ............................................. 6.6 
Table No.

Page No.

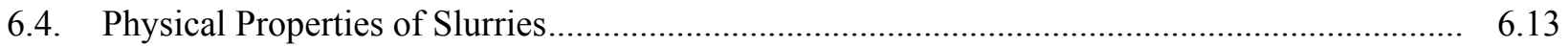

6.5. $\quad$ FEP Evaporation Products, Radionuclides ........................................................................... 6.14



6.7. FEP Concentrate with Group 1/2, Bismuth Phosphate Supernatant, Radionuclides ................ 6.30

6.8. FEP Concentrate with Group 1/2, Bismuth Phosphate Supernatant, Metals and Anions.......... 6.31

6.9. Evaporator Concentrate Combined with Tank Waste Supernatant, Aqueous Phase Analysis... 6.34

7.1. Selected Analyte Partitioning Through CUF Processing .................................................... 7.5

7.2. Selected Analyte Partitioning Through Ion Exchange ........................................................

7.3. Selected Analyte Partitioning Through Evaporation........................................................ 


\section{Terms and Abbreviations}

\begin{tabular}{|c|c|}
\hline ASR & analytical services request \\
\hline AV & apparatus volume \\
\hline BBI & Best Basis Inventory \\
\hline BET & Brunauer, Emmett, and Teller (a method for measuring surface areas) \\
\hline $\mathrm{BNI}$ & Bechtel National, Inc. \\
\hline BS & blank spike \\
\hline BV & bed volume \\
\hline $\mathrm{CCD}$ & charge coupled device \\
\hline $\mathrm{C} / \mathrm{Co}$ & analyte concentration in column effluent divided by analyte concentration in feed \\
\hline $\mathrm{CF}$ & concentration factor \\
\hline CUF & cell unit filter \\
\hline DACS & Data Acquisition System \\
\hline DF & decontamination factor \\
\hline DI & deionized (water) \\
\hline DOE & U.S. Department of Energy \\
\hline EDS & electron dispersive spectrometry \\
\hline EELS & electron energy-loss spectroscopy \\
\hline EFTEM & energy-filtered transmission electron microscopy \\
\hline EQL & estimated quantitation limit \\
\hline FEP & feed evaporator process \\
\hline GEA & gamma energy analysis \\
\hline GIF & Gatan Imaging Filter \\
\hline HAADF & high-angle annular dark field \\
\hline HLW & high-level waste \\
\hline HP & hot persulfate \\
\hline IC & ion chromatography \\
\hline ICDD & International Centre for Diffraction Data \\
\hline $\mathrm{ICP}$ & inductively coupled plasma \\
\hline ICSD & Inorganic Crystal Structure Database \\
\hline IHLW & immobilized high-level waste \\
\hline
\end{tabular}


$\mathrm{KOH} \quad$ potassium hydroxide

KPA kinetic phosphorescence analysis

LAW low-activity waste

LCS laboratory control sample

LEPS Low-Energy Photon Spectroscopy

MDL method detection limit

MS matrix spike

NIST National Institute of Standards and Technology

OES optical emission spectroscopy

ORP Office of River Protection (DOE)

PB preparation blank

PFTE polytetrafluoroethylene

PNNL Pacific Northwest National Laboratory

QA quality assurance

QAM Quality Assurance Manual

QARD Quality Assurance Requirements and Descriptions

QC quality control

RCRA Resource Conservation and Recovery Act

REDOX reduction oxidation

RF resorcinol-formaldehyde

RPD relative percent difference

RPP-WTP River Protection Project-Waste Treatment and Immobilization Plant

R\&T research and technology

RTD resistance temperature detector

SBS submerged bed scrubber

SEM scanning electron microscopy

SRNL Savannah River National Laboratory

STEM scanning transmission electron microscopy

SRF spherical resorcinol formaldehyde

TCLP Toxicity Characteristic Leaching Procedure

TDS total dissolved solids

TEM transmission electron microscopy 
TIC

TMP

TOC

TRU

UDS

UFP

UV-vis

VSL

WTP

XRD total inorganic carbon

trans-membrane pressure

total organic carbon

transuranic (waste)

undissolved solids

ultrafiltration process

ultraviolet visible

Vitreous State Laboratory (located at Catholic University of America, Washington D.C.)

Hanford Tank Waste Treatment and Immobilization Plant

X-ray diffraction

\section{Terms of Measurement}

$\begin{array}{ll}\mu \mathrm{Ci} & \text { microcurie } \\ \mu \mathrm{g} & \text { microgram } \\ \mathrm{C} / \mathrm{C}_{\mathrm{o}} & \text { analyte concentration in column effluent divided by analyte concentration in feed } \\ \text { F-factor } & \text { ratio of dry resin mass to wet resin mass } \\ \mathrm{g} & \text { gram } \\ \mathrm{h} & \text { hour } \\ \mathrm{M} & \text { molarity } \\ \mathrm{min} & \text { minute } \\ \mathrm{mL} & \text { milliliter }\end{array}$





\section{References}

Buck EC, BK McNamara. 2004. Precipitation of nitrate - Cancrinite in Hanford tank sludge. Environmental Science and Technology, Vol. 38, Issue 16, pages 4432-4438.

Buckingham JS. 1967. Waste Management Technical Manual. ISO-100 DEL, Hanford Atomic Products Operation, Richland, WA.

Burgeson IE, DL Blanchard, Jr., BJ Cook, JR Deschane. 2004. Elution Testing of ResorcinolFormaldehyde Resins, with AN-105 Simulant, PNWD-3388, WTP-RPT-105 Rev. 0, Battelle Pacific Northwest Division, Richland, WA.

Delegard CH. 1985. Solubility of $\mathrm{PuO}_{2} \cdot \mathrm{xH}_{2} \mathrm{O}$ in Alkaline Hanford High-Level Waste Solution. RHO-RE-SA-75 P, Rockwell Hanford Operations, Richland, WA. Also published in 1987, Radiochimica Acta 41:11-21.

Delegard CH. 1996. Liaison Activities with the Institute of Physical Chemistry of the Russian Academy of Sciences: Midyear Report, WHC-SP-1184, Westinghouse Hanford Company, Richland, WA.

Delegard C. 2006. Literature Review of Plutonium(IV) Hydrous Oxide Solubility in Dilute Sodium Hydroxide and in Dilute Nitric Acid Solutions. WTP-RPT-149, Rev. 0, Battelle-Pacific Northwest Division, Richland, WA.

Duff MC, DB Hunter, DT Hobbs, A Jurgensen, and SD Fink. 2002. Characterization of Plutonium, Neptunium, Strontium on Manganese Solids from Permanganate Reduction. WSRC-TR-2002-00366, Rev. 0. Savannah River Site, Aiken, SC.

Dietz NL, JA Fortner, Z Dai, JP Bradley, MC Duff, DT Hobbs, and SD Fink. 2002. Transmission Electron Microscopy Analyses of Strontium and Actinide-Bearing Monosodium Titanate and Permanganate Treatment Solids. WSRC-TR-2002-00363, Rev. 0, Savannah River Site, Aiken, SC.

Fiskum SK, ST Arm, DL Blanchard, Jr., and BM Rapko. 2004a. Small Column Ion Exchange Testing of SuperLig ${ }^{\circledR} 644$ for Removal of ${ }^{137}$ Cs from Hanford Waste Tank 241-AP-101 Diluted Feed (Envelope A). PNWD-3198, Rev. 1 (WTP-RPT-016, Rev. 1), Battelle-Pacific Northwest Division, Richland, WA.

Fiskum SK, ST Arm, and DL Blanchard, Jr. 2004b. Small Column Ion Exchange Testing of SuperLig ${ }^{\circledR}$ 644 for Removal of ${ }^{137}$ Cs from Hanford Waste Tank 241-AZ-101 (Envelope B). PNWD-3266, Rev. 1 (WTP-RPT-053, Rev. 1). Battelle_-Pacific Northwest Division, Richland, WA.

Fiskum SK, ST Arm, WC Buchmiller, T Trang-Le, JE Martinez, J Matyas, MJ Steele, KK Thomas, DL Blanchard, Jr. 2006a. Comparison Testing of Multiple Spherical Resorcinol-Formaldehyde Resins for the River Protection Project-Waste Treatment Plant. WTP-RPT- 143, PNWD-3785, Battelle_Pacific Northwest Division, Richland, WA. 
Fiskum SK, ST Arm, MS Fountain, MJ Steele, DL Blanchard, Jr. 2006b. Spherical ResorcinolFormaldehyde Resin Testing for ${ }^{137}$ Cs Removal from Simulated and Actual Hanford Waste Tank 241-AP101 Diluted Feed (Envelope A) Using Small Column Ion Exchange. WTP-RPT-134, PNWD-3697, Battelle_-Pacific Northwest Division, Richland, WA.

Fiskum SK, IE Burgeson, OT Farmer III, LR Greenwood, CZ Soderquist, MJ Steele, MP Thomas. 2006c. Spherical Resorcinol-Formaldehyde Resin Analysis Following Actual Hanford Tank Waste Processing. WTP-RPT-144, Rev. 0, PNWD-3752, Battelle-Pacific Northwest Division, Richland, WA.

Fiskum SK, ST Arm, MK Edwards, MJ Steele, KK Thomas. 2007. Storage and Aging Effects on Spherical Resorcinol-Formaldehyde Resin Ion Exchange Performance. WTP-RPT-148, Rev. 0, PNNL16832, Richland, WA.

Fiskum SK, EC Buck, RC Daniel, KE Draper, MK Edwards, TL Hubler, LK Jagoda, ED Jenson, AE Kozelisky, GJ Lumetta, PJ MacFarlan, BK McNamara, RA Peterson, SI Sinkov, LA Snow, and RG Swoboda. 2008. Characterization and Leach Testing for REDOX Sludge and S-Saltcake Actual Waste Sample Composites. WTP-RPT-157, Pacific Northwest National Laboratory, Richland, WA.

Klug HP, and LE Alexander. 1974. X-Ray Diffraction Procedures for Polycrystalline and Amorphous Materials. John Wiley \& Sons, Inc., New York, NY.

Krot NN, VP Shilov, AB Yusov, IG Tananaev, MS Grigoriev, AY Garnov, VP Perminov, and LN Astafurova. 1998. Plutonium(IV) Precipitates Formed in Alkaline Media in the Presence of Various Anions. PNNL-11901, Pacific Northwest National Laboratory, Richland, WA.

Li H, J Addai-Mensah, JC Thomas, and AR Gerson. 2005. "The Influence of Al(III) Supersaturation and $\mathrm{NaOH}$ Concentration on the Rate of Crystallization of $\mathrm{Al}(\mathrm{OH})_{3}$ Precursor Particles From Sodium Aluminate Solutions," Journal of Colloid and Interface Science 286:511-519.

Lumetta GL, and RT Hallen. 2007. Review of Caustic Leaching Testing With Hanford Tank Waste Sludges. WTP-RPT-151, Battelle—Pacific Northwest Division, Richland, WA.

Lumetta GL, EC Buck, RC Daniel, K Draper, MK Edwards, SK Fsikum, LK Jagoda, ED Jenson, AE Kozelisky, PJ MacFarlan, RA Peterson, RW Shimskey, SI Sinkov, and LA Snow. In press.

Characterization, Leaching, and Filtration Testing forBismuth Phosphate Sludge (Group 1) and Bismuth Phosphaet Saltcake (Group 2) Actual Waste Sample Composites. WTP-RPT-166, Pacific Northwest National Laboratory, Richland, WA.

Music S, D Dracevic, S Popovic, and N Vdovic. 1998. "Microstructural properties of boehmite formed under hydrothermal conditions." Mater. Sci. Eng. 52:145-153.

Peretrukhin VF, SV Kryutchkov, VI Silin, and IG Tananaev. 1996. Determination of the Solubility of Np(IV)-(V), Pu(III)-(VI), Am(III)-(VI) and Tc(IV),(V) Hydroxo Compounds in 0.5 - 14 M NaOH Solutions. WHC-EP-0897, Westinghouse Hanford Company, Richland, WA. 
Rapko BM, JGH Geeting, SI Sinkov, and JD Vienna. 2004. Oxidative-Alkaline Leaching of Washed 241-SY-102 and 241-SX-101 Tank Sludge. PNWD-3512 (WTP-RPT-117, Rev. 0), Battelle-Pacific Northwest Division, Richland, WA.

Rapko BM, GJ Lumetta, JR Deschane, and RA Peterson. 2007. Process Development for Permanganate Addition During Oxidative Leaching of Hanford Tank Sludge Simulants. PNWD-16794 (WTP-RPT164), October 2007. Battelle_-Pacific Northwest Division, Richland, WA.

Shimskey RW, JM Billing, EC Buck, RC Daniel, K Draper, MK Edwards, JGH Geeting, RT Hallen, ED Jenson, AE Kozelisky, PJ MacFarlan, RA Peterson, LA Snow, and RG Swoboda. In press. Filtration and Leach Testing for REDOX Sludge and S-Saltcake Actual Waste Sample Composites. WTP-RPT-172, Pacific Northwest National Laboratory, Richland, WA. 


\section{Testing Summary}

This report describes the bench-scale pretreatment processing of actual tank waste materials through the entire nominal WTP pretreatment flowsheet in an effort to demonstrate the efficacy of the defined leaching processes on actual Hanford tank waste sludge and the potential impacts on downstream pretreatment processing. The test material was a combination of reduction oxidation (REDOX) tank waste composited materials containing aluminum primarily in the form of boehmite and dissolved S-saltcake containing $\mathrm{Cr}$ (III)-rich entrained solids. The pretreatment processing steps tested included

- caustic leaching for Al removal

- solids crossflow filtration through the cell unit filter (CUF)

- stepwise solids washing using decreasing concentrations of sodium hydroxide with filtration through the CUF

- oxidative leaching using sodium permanganate for removing $\mathrm{Cr}$

- solids filtration with the CUF

- follow-on solids washing and filtration through the CUF

- ion exchange processing for Cs removal

- evaporation processing of waste stream recycle for volume reduction

- combination of the evaporated product with dissolved saltcake.

The effectiveness of each process step was evaluated by following the mass balance of key components (such as $\mathrm{Al}, \mathrm{B}, \mathrm{Cd}, \mathrm{Cr}, \mathrm{Pu}, \mathrm{Ni}, \mathrm{Mn}$, and $\mathrm{Fe}$ ), demonstrating component ( $\mathrm{Al}, \mathrm{Cr}, \mathrm{Cs}$ ) removal, demonstrating filterability by evaluating filter flux rates under various processing conditions (transmembrane pressure, crossflow velocities, wt $\%$ undissolved solids, and PSD) and filter fouling, and identifying potential issues for WTP. The filterability was reported separately (Shimskey et al. 2008) and is not repeated herein.

\section{Objectives}

The test objectives and discussion are provided in Table S.1. 
Table S.1. Test Objectives

\begin{tabular}{|c|c|c|}
\hline Test Objective & $\begin{array}{c}\text { Objective } \\
\text { Met? }\end{array}$ & Discussion \\
\hline $\begin{array}{l}\text { Investigate the efficacy of defined } \\
\text { oxidant dosage through bench-scale } \\
\text { experimental testing with two actual } \\
\text { Hanford tank waste sludges. }\end{array}$ & Yes & $\begin{array}{l}\text { Two waste sludges were evaluated to define the sodium } \\
\text { permanganate oxidant dosage: Group } 5 \text { REDOX sludge } \\
\text { in combination with Group } 6 \text { S-Saltcake (Group 5/6), } \\
\text { reported herein; and Group } 1 \text { bismuth phosphate sludge } \\
\text { in combination with Group } 2 \text { bismuth phosphate } \\
\text { saltcake, which is reported separately (WTP-RPT-166, } \\
\text { per direction of the research and technology (R\&T) } \\
\text { Lead). } \\
\text { Permangante:Cr mole ratios of } 0.79 \text { to } 1.38 \text { in } 0.25 \mathrm{M} \\
\text { sodium hydroxide solutions were tested with } \\
\text { corresponding } 78 \% \text { to } 99 \% \mathrm{Cr} \text { dissolution. Dissolved } \mathrm{Cr} \\
\text { was measured as a function of time for } 6 \mathrm{~h} \text {; in all cases, } \\
\text { equilibrium Cr concentration was reached in } \leq 1 \mathrm{~h} \text {. } \\
\text { Increasing the sodium hydroxide concentration from } \\
0.25 \mathrm{M} \text { to } 1.4 \mathrm{M} \text { resulted in a } 7 \times \text { increase in the dissolved } \\
\text { Pu concentration. The Group } 5 / 6 \text { oxidant dosage } \\
\text { discussion is provided in Section } 3 \text {. }\end{array}$ \\
\hline $\begin{array}{l}\text { Demonstrate the oxidative leaching } \\
\text { process in the laboratory using actual } \\
\text { waste at conditions that represent the } \\
\text { anticipated plant flowsheet conditions } \\
\text { for all anticipated process systems. }\end{array}$ & Yes/No & $\begin{array}{l}\text { The oxidative leaching process was demonstrated on the } \\
\text { Group } 5 / 6 \text { actual waste. This material was subjected to } \\
\text { the caustic leaching and washing process such that } \\
\text { representative sludge would remain for the oxidative } \\
\text { leaching. The oxidant dosage ( } 1.7: 1 \text { permanganate:Cr } \\
\text { mole ratio) was higher than the targeted dosage of } 1: 1 \text {. } \\
\text { Chromium was mobilized from the solids phase to the } \\
\text { aqueous phase with } \geq 90 \% \text { efficiency. The aqueous } \mathrm{Cr} \\
\text { concentration was measured over a } 6 \text { - } \mathrm{h} \text { period; the } \\
\text { equilibrium Cr concentration was reached in } \leq 0.5 \mathrm{~h} \text {. } \\
\text { Test details are provided in Section } 4 \text {. }\end{array}$ \\
\hline $\begin{array}{l}\text { Develop information on the fate of } \mathrm{Pu} \\
\text { and neutron absorbers (B and } \mathrm{Cd} \text { ) for } \\
\text { both process design verification and } \\
\text { process criticality safety assessment. } \\
\text { Specifically, information that will be } \\
\text { obtained is the concentration of Pu in } \\
\text { the oxidative leachate and the oxidation } \\
\text { state(s) of the Pu (using techniques } \\
\text { being developed in the current Pu } \\
\text { speciation determination activity). }{ }^{\text {(a) }} \\
\text { Further, changes in the Pu oxidation } \\
\text { state will be monitored during the } \\
\text { nominal processing steps of the } \\
\text { leachate, and material balances will be } \\
\text { monitored to assess the potential to } \\
\text { precipitate Pu during any of the steps } \\
\text { before ion exchange. Finally, the fate } \\
\text { of Pu during ion exchange (using } \\
\text { spherical resorcinol-formaldehyde) will } \\
\text { be determined using feed adjusted to } \\
5 \mathrm{M} \text { Na (through evaporative }\end{array}$ & Yes/No & $\begin{array}{l}\text { Concentrations of } \mathrm{Pu}, \mathrm{Cd}, \mathrm{B}, \mathrm{Fe}, \mathrm{Mn} \text {, and Ni were } \\
\text { measured in all solutions to assess their fates in the } \\
\text { flowsheet. Nominally } 0.043 \% \text { of the Pu was found to } \\
\text { mobilize during the oxidative leach ( } 1.7: 1 \mathrm{Mn} \text { :Cr mole } \\
\text { ratio) processing. } \\
\text { Minimal } \mathrm{Pu}(0.019 \%) \text { mobilized from the solids phase } \\
\text { during caustic leaching. However, } 0.12 \% \text { of the Pu was } \\
\text { mobilized from the solids during the washing process of } \\
\text { the caustic-leached solids. } \\
\text { The concentration of Pu was monitored through all } \\
\text { succeeding steps (ion exchange and evaporation) to } \\
\text { assess precipitation. Ion exchange processing was } \\
\text { conducted using nominal plant operations with spherical } \\
\text { RF resin. Only } \sim 0.18 \% \text { of the total Pu in the } \\
\text { demonstration test ended up in the ion exchange feed. } \\
\text { The combination of caustic leaching solution with the } \\
\text { supernatant and oxidative leaching solution to support } \\
\text { ion exchange feed preparation resulted in co- } \\
\text { precipitation of } \sim 30 \% \text { of the available Pu in a Mn-rich } \\
\text { solid phase. Plutonium recovery in the ion exchange }\end{array}$ \\
\hline
\end{tabular}


Table S.1 (Contd)

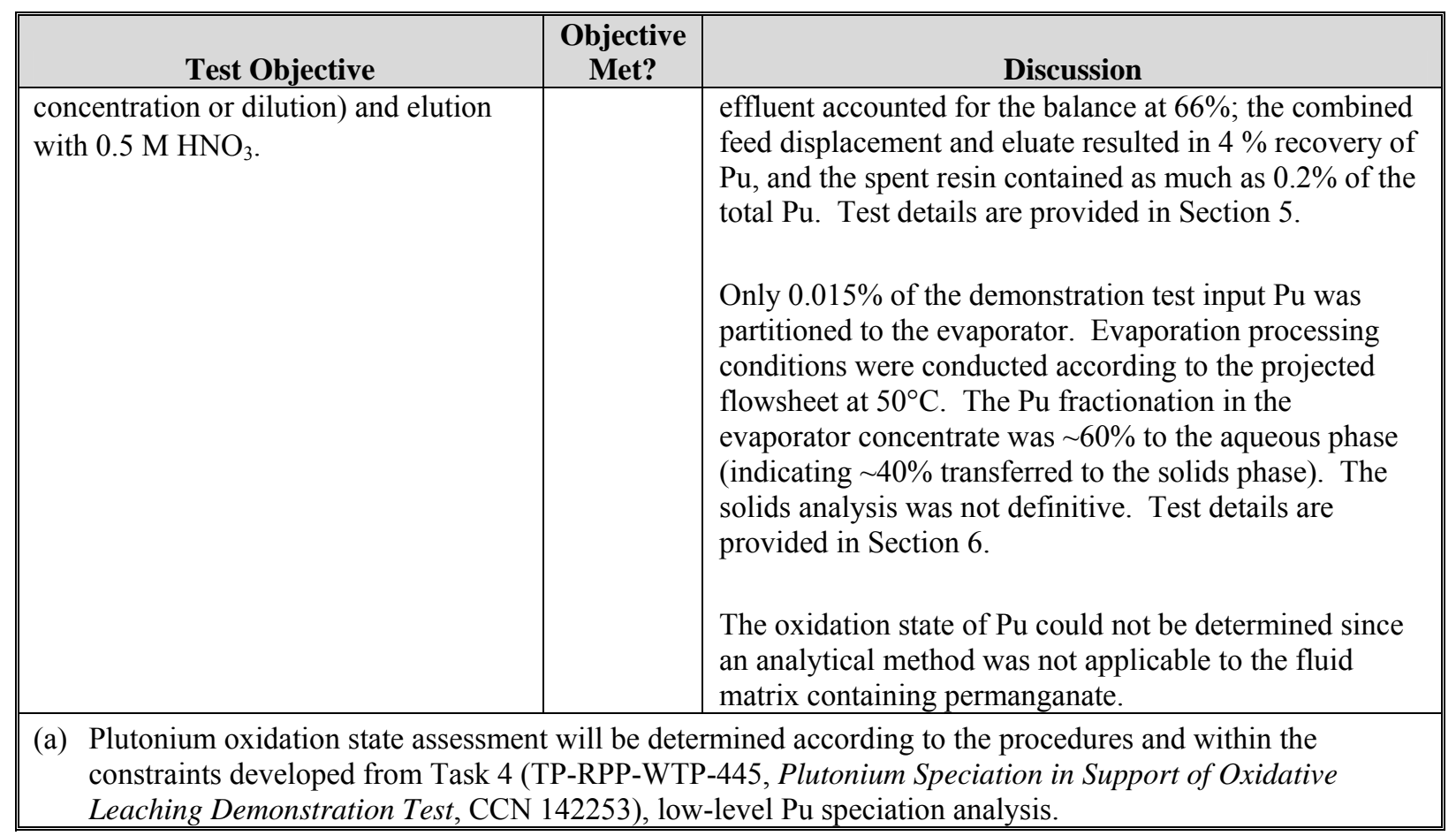

\section{Test Exceptions}

No test exceptions were applied to the test scope.

\section{Results and Performance Against Success Criteria}

The test success criteria are listed in Table S.2 along with discussion of how the criteria were met. 
Table S.2. Test Success Criteria

\begin{tabular}{|c|c|}
\hline Success Criteria & Explanation \\
\hline $\begin{array}{l}\text { Successful demonstration of the } \\
\text { oxidative leaching process using } \\
\text { actual waste under conditions that } \\
\text { simulate the anticipated plant } \\
\text { flowsheet conditions for the } \\
\text { anticipated pretreatment process } \\
\text { systems: cross-flow ultra-filtration, } \\
\text { caustic leaching, water washing, } \\
\text { oxidative leaching, water washing, } \\
\text { ion exchange, and evaporation. } \\
\text { This includes demonstration of Cr } \\
\text { removal from the solids fraction, } \\
\text { effective filtration through the CUF, } \\
\text { and no measurable retention of Pu in } \\
\text { the ion exchanger. }\end{array}$ & $\begin{array}{l}\text { The entire pretreatment operation was applied to the combination of } \\
\text { Group } 5 \text { REDOX sludge combined with Group } 6 \mathrm{~S} \text {-Saltcake. All } \\
\text { specific CUF processing conditions were pre-approved by WTP staff } \\
\text { before the test. A parametric filtration test matrix was conducted to } \\
\text { obtain filtration data under a variety of test conditions for this particular } \\
\text { waste form. Caustic leaching was conducted at } 100^{\circ} \mathrm{C} \text { for } 8 \mathrm{~h} \text { (excluding } \\
\text { heat ramp and cool-down) at a final free-hydroxide concentration of } \\
6.2 \mathrm{M} \text {. Oxidative leaching was conducted at } 28^{\circ} \mathrm{C} \text { in a } 0.09 \mathrm{M} \text { free- } \\
\text { hydroxide matrix with } 1.7: 1 \text { permangante:Cr mole ratio for } 6 \mathrm{~h} \text { (note that } \\
\text { the oxidant dosage was } 1.7 \times \text { higher than targeted). Caustic leaching } \\
\text { mobilized } 2 \text { to } 6 \% \text { of the } \mathrm{Cr} \text { from the solids phase, while washing } \\
\text { removed } 17 \% \text { of the } \mathrm{Cr} \text { and } 0.13 \% \mathrm{Pu} \text { from the total inventory. } \\
\text { Oxidative leaching mobilized }>90 \% \text { of the } \mathrm{Cr} \text { and } 0.043 \% \text { of the Pu from } \\
\text { the solids phase. After three equal volume rinses, the final washed slurry } \\
\text { contained } 5,890 \mu \mathrm{g} \text { Cr per } \mathrm{g} \text { (dry mass basis). } \\
\text { The ion exchange processing through the spherical resorcinol } \\
\text { formaldehyde resin resulted in minimal Pu retention: up to } 4 \% \text { of the IX } \\
\text { input Pu was fractionated to the eluate, and } 0.2 \% \text { of the Pu remained on } \\
\text { the resin. Overall retention of Pu following the waste feed processing } \\
\text { was therefore bounded at } 4.4 \% \text { of the total Pu actually fed to the ion } \\
\text { exchanger. }\end{array}$ \\
\hline $\begin{array}{l}\text { Determination of concentrations, } \\
\text { closure of mass balances, and } \\
\text { speciation of } \mathrm{Cr}, \mathrm{Pu} \text {, and } \mathrm{Mn} \text { in } \\
\text { solution as well as the fate of } \mathrm{B}, \mathrm{Cd} \text {, } \\
\mathrm{Cr}, \mathrm{Pu}, \mathrm{Fe} \text {, and } \mathrm{Ni} \text { in solution for the } \\
\text { anticipated pretreatment process } \\
\text { systems (cross-flow filtration, } \\
\text { caustic leaching, water washing, } \\
\text { oxidative leaching, water washing, } \\
\text { ion exchange, and evaporation). }\end{array}$ & $\begin{array}{l}\text { The mass balance of the } \mathrm{Cr}, \mathrm{Pu}, \mathrm{Mn}, \mathrm{B}, \mathrm{Cr}, \mathrm{Pu}, \mathrm{Fe} \text {, and } \mathrm{Ni} \text { were } \\
\text { determined. The fate of } \mathrm{Cd} \text { could not be determined since its } \\
\text { concentration was too low to detect. } \\
\text { Manganese was introduced as permanganate oxidizing agent, and a } \\
\text { fraction of the permanganate-bearing material was combined with the ion } \\
\text { exchange process feeds. Virtually } 100 \% \text { of the Mn precipitated upon } \\
\text { addition to the supernatant before ion exchange. The ion exchange feed } \\
\text { required filtration to avoid fouling of the resin bed during ion exchange } \\
\text { processing. } \\
\text { The speciation of } \mathrm{Pu} \text { could not be determined; mobilized } \mathrm{Cr} \text { was found to } \\
\text { be } \mathrm{Cr}(\mathrm{VI}) \text {. }\end{array}$ \\
\hline $\begin{array}{l}\text { Measurement of selected metal } \\
\text { concentrations of solids (that are } \\
\text { soluble in } 2 \mathrm{M} \text { nitric acid) } \\
\text { associated with the pretreatment- } \\
\text { system component surfaces, } \\
\text { including Pu (for potential } \\
\text { enrichment). }\end{array}$ & $\begin{array}{l}\text { Component surfaces in the CUF and the evaporator were leached with } \\
2 \mathrm{M} \mathrm{HNO}_{3} \text {. In both cases, the Pu that was recovered was found to be } \\
\text { simply associated with residual slurry adhering to the surfaces. }\end{array}$ \\
\hline $\begin{array}{l}\text { Determination of selected metal } \\
\text { analyte composition, including } \mathrm{Pu} \text {, } \\
\text { of bulk precipitated solids (if any) in } \\
\text { the feed evaporator process system } \\
\text { (evaporator bottoms and scale). }\end{array}$ & $\begin{array}{l}\text { The washed evaporator bottoms were analyzed for chemical and } \\
\text { radiochemical constituents as well as crystal form and habit using } \\
\text { scanning electron microscopy (SEM), SEM electron dispersive } \\
\text { spectroscopy, transmission electron microscopy, and X-ray diffraction } \\
\text { (XRD). Both washed and unwashed solids were evaluated by XRD. }\end{array}$ \\
\hline
\end{tabular}




\section{Quality Requirements}

PNNL implemented the RPP-WTP quality requirements by performing work in accordance with the River Protection Project - Waste Treatment Plant Support Program (RPP-WTP) Quality Assurance Plan (RPP-WTP-QA-001, QAP). Work was performed to the quality requirements of NQA-1-1989 Part I, Basic and Supplementary Requirements, NQA-2a-1990, Part 2.7, and DOE/RW-0333P, Rev 13, Quality Assurance Requirements and Descriptions (QARD). These quality requirements were implemented through the River Protection Project - Waste Treatment Plant Support Program (RPP-WTP) Quality Assurance Manual (RPP-WTP-QA-003, QAM). The quality assurance requirements of DOE/RW-0333P, Rev 13, Quality Assurance Requirements and Descriptions (QARD), and DOE Order 414.1C were not identified as a requirement for this work in the test specification.

PNNL addressed internal verification and validation activities by conducting an Independent Technical Review of the final data report in accordance with PNNL's procedure QA-RPP-WTP604, part of PNNL's RPP-WTP Quality Assurance Manual. This review verified that the reported results were traceable, inferences and conclusions were soundly based, and the reported work satisfied the Test Plan objectives.

\section{R\&T Test Conditions}

Table S.4 summarizes the various R\&T test conditions and briefly discusses how the test conditions were followed.

Table S.4. R\&T Test Conditions

\begin{tabular}{|l|l||}
\hline R\&T Test Condition & Were Test Condition(s) Followed? \\
\hline $\begin{array}{l}\text { Actual Waste Selection and } \\
\text { Compositing }\end{array}$ & \\
\hline $\begin{array}{l}4 \text { to } 5 \mathrm{~L} \text { of actual tank waste will be } \\
\text { obtained with sludge, saltcake, and } \\
\text { supernatant components. Saltcake will } \\
\text { be dissolved in water before being } \\
\text { added to sludge. }\end{array}$ & $\begin{array}{l}\text { Yes. The samples, homogenization, and subdivision of } \\
\text { Group 5 REDOX sludge (1.97 kg hydrated to } 4.28 \mathrm{~kg} \text { ) and } \\
\text { Group 6 S Saltcake (Cr-limited waste, } 1.68 \mathrm{~kg} \text { hydrated or } \\
\text { dissolved to 3.79 } \mathrm{kg} \text { ) were previously described (Fiskum et al. } \\
\text { 2008). Sufficient mass of the combined materials was } \\
\text { available to support all test activities. Fractions of these waste } \\
\text { composites were combined to create working composites } \\
\text { supporting oxidant dosage testing and CUF processing. }\end{array}$ \\
\hline $\begin{array}{l}\text { The tank waste components will be } \\
\text { composited in a stainless steel vessel. } \\
\text { Mixing will be effected using an } \\
\text { overhead stirrer equipped with a } \\
\text { suitable stir blade. Homogenization } \\
\text { will be evaluated from three sub- } \\
\text { samples collected from the vessel at } \\
\text { three different levels (one sample per } \\
\text { level) and will be based on equal }\end{array}$ & $\begin{array}{l}\text { Yes. These processes were previously described by Fiskum } \\
\text { et al. (2008). The Group 5 and Group 6 materials were } \\
\text { homogenized separately and subdivided. Sub-samples were } \\
\text { provided to support follow-on testing. Sub-samples of } \\
\text { Group 5 and Group 6 were added to the stainless steel CUF } \\
\text { holding tank and blended (993 g Group 5 slurry, 602 g Group } \\
\text { 6 slurry, and 2317g Group 6 supernatant). }\end{array}$ \\
\hline \begin{tabular}{l} 
Smaller sub-samples of Group 5 and 6 were blended to \\
\hline
\end{tabular} \\
\hline
\end{tabular}


Table S.4 (Contd)

\begin{tabular}{|c|c|}
\hline R\&T Test Condition & Were Test Condition(s) Followed? \\
\hline$( \pm 1.5 \%)$ slurry densities. & $\begin{array}{l}\text { support the parametric leach testing ( } 56.4 \text { g Group } 5 \text { slurry, } \\
29.7 \text { g Group } 6 \text { slurry, and } 102.8 \text { g Group } 6 \text { supernatant) } \\
\text { mimicking the composition used in the CUF test. These were } \\
\text { combined in a polyethylene bottle and shaken. }\end{array}$ \\
\hline \multicolumn{2}{|l|}{ Oxidant Dosage Testing } \\
\hline \multirow[t]{3}{*}{$\begin{array}{l}\text { Specific steps are too numerous to } \\
\text { delineate (see Figure } 1 \text { in the } \\
\text { controlling test plan, TP-RPP-WTP- } \\
456 \text {, for a summary) }\end{array}$} & $\begin{array}{l}\text { Yes. The Group } 5 \text { and } 6 \text { composite material was caustically } \\
\text { leached in } 6.1 \mathrm{M} \mathrm{NaOH} \text { solution at } 100^{\circ} \mathrm{C} \text { for } 12 \mathrm{~h} \text {. The solids } \\
\text { were washed with water until the aqueous phase contained } \\
0.23 \mathrm{M} \mathrm{NaOH} \text {. The washed solids were subjected to a } \\
\text { parametric oxidant dosage test. The oxidant dosage was } \\
\text { derived from a parametric test matrix conducted in a solid-to- } \\
\text { liquid phase ratio of } 1: 100 \text { in a } 0.25-\mathrm{M} \mathrm{NaOH} \text { matrix at four } \\
\text { different } \mathrm{Mn}: \mathrm{Cr} \text { mole ratios }(0.85,1.0,1.25 \text {, and } 1.5) \text {. All tests } \\
\text { were conducted at room temperature }\left(\sim 22^{\circ} \mathrm{C}\right) \text {. The reaction } \\
\text { rate was assessed by monitoring Cr concentration in the } \\
\text { aqueous phase over a } 6 \text {-h contact period. }\end{array}$ \\
\hline & $\begin{array}{l}\text { A second parametric leach test was conducted on the caustic- } \\
\text { leached solids retrieved from the CUF to evaluate the effect of } \\
\text { free-hydroxide concentration on Pu mobilization. In this case, } \\
\text { the } \mathrm{Mn}: \mathrm{Cr} \text { mole ratio was held constant at } 1.0 \text { while varying } \\
\text { the } \mathrm{NaOH} \text { molarity }(0.25 \mathrm{M}, 0.50 \mathrm{M}, 0.75 \mathrm{M}, 1.0 \mathrm{M} \text {, and } \\
1.25 \mathrm{M}) \text {. Other test conditions were similar to the first test. }\end{array}$ \\
\hline & $\begin{array}{l}\text { The mass balance of fluids and solids was tracked to the extent } \\
\text { practical. The closure of mass balance could not be obtained. } \\
\text { There were no applicable methods for Pu speciation } \\
\text { determination. Chromium speciation as chromate was } \\
\text { confirmed with ultraviolet (UV) visible spectrophotometry. }\end{array}$ \\
\hline \multicolumn{2}{|l|}{ Demonstration Test } \\
\hline \multirow[t]{3}{*}{$\begin{array}{l}\text { Specific steps are too numerous to } \\
\text { delineate (see Figures } 2,3 \text {, and } 4 \text { in the } \\
\text { controlling test plan, TP-RPP-WTP- } \\
456 \text {, for a summary) }\end{array}$} & $\begin{array}{l}\text { Caustic leaching } \\
\text { Yes. Group } 5 \text { and } 6 \text { materials were composited in the CUF } \\
\text { slurry reservoir, dewatered to } 13 \mathrm{wt} \% \mathrm{UDS} \text {, and leached for } \\
8 \mathrm{~h} \text { at } 100^{\circ} \mathrm{C} \text { in a final equilibrated } 6.2-\mathrm{M} \text { free-hydroxide } \\
\text { solution. The solids were washed with six contacts of } \\
\text { progressively decreasing NaOH solutions to a final free- } \\
\text { hydroxide concentration of } 0.17 \mathrm{M} \text {. }\end{array}$ \\
\hline & $\begin{array}{l}\text { Oxidative leaching } \\
\text { Yes and No. The caustic leached and washed solids were } \\
\text { contacted with sufficient } 1 \mathrm{M} \mathrm{NaMnO}_{4} \text { to reach a } \mathrm{Mn}: \mathrm{Cr} \text { of } \\
\text { 1.7:1. This ratio was higher than the target of } 1: 1 \text {. The } \\
\text { aqueous phase was measured periodically to assess the } \\
\text { reaction kinetics and compare the oxidant dosage testing from } \\
\text { small-scale testing to the CUF results. }\end{array}$ \\
\hline & $\begin{array}{l}\text { Ion exchange processing } \\
\text { Yes. The } 4.5 \mathrm{~L} \text { of ion exchange feed was a composite of } \\
24 \text { vol } \% \text { initial CUF filtrate (primarily supernatant and } \\
\text { dissolved saltcake), } 52 \text { vol } \% \text { caustic leach solution, } 23 \text { vol } \% \\
\text { oxidative leach solution, and } 24 \text { vol } \% \text { caustic leach wash }\end{array}$ \\
\hline
\end{tabular}


Table S.4 (Contd)

\begin{tabular}{|c|c|}
\hline \multirow[t]{4}{*}{ R\&T Test Condition } & Were Test Condition(s) Followed? \\
\hline & $\begin{array}{l}\text { filtrate from a secondary leach test. Processing was conducted } \\
\text { through a single } 22-\mathrm{mL} \text { resin bed of spherical RF resin with an } \\
\mathrm{L} / \mathrm{D} \text { of } 1.47 \text { at } 3 \mathrm{BV} / \mathrm{h} \text { and at a cell temperature of } 25 \pm 2^{\circ} \mathrm{C} \text {. } \\
\text { No Cs was detected in the effluent after processing } 209 \mathrm{BVs} \text { of } \\
\text { feed. }\end{array}$ \\
\hline & $\begin{array}{l}\text { Evaporation } \\
\text { Yes. Prototypic volumes of ion exchange feed displacement } \\
\text { and water rinse, caustic leach wash solutions, oxidative leach } \\
\text { solution, oxidative leach wash solutions, and simulant } \\
\text { submerged bed scrubber and UFP cleaning solution ( } 2 \text {-L total } \\
\text { volume) were combined into the evaporator and volume- } \\
\text { reduced to } 0.3 \mathrm{~L} \text { at } 50^{\circ} \mathrm{C} \text {. The final Na concentration was } \\
4.6 \mathrm{M} \text {. The solids and solution phases were characterized. } \\
\text { The combination of supernatant with the post-evaporated } \\
\text { slurry was evaluated by adding Group } 2 \text { bismuth phosphate } \\
\text { saltcake. The resulting solids and aqueous phases were } \\
\text { characterized. }\end{array}$ \\
\hline & $\begin{array}{l}\text { Component surfaces } \\
\text { Yes. The CUF was leached with } 2 \mathrm{M} \mathrm{HNO}_{3} \text { at } 27 \pm 3{ }^{\circ} \mathrm{C} \text { for } 1 \\
\text { h. The evaporator was leached at sub-boiling for } 4 \mathrm{~h} \text { with } 2 \mathrm{M} \\
\mathrm{HNO}_{3} \text {. The leach solution was measured for Pu concentration } \\
\text { relative to other process solids. }\end{array}$ \\
\hline
\end{tabular}

\section{Simulant Use}

Virtually all testing was conducted with actual tank waste and tank waste processing streams. Two simulants were supplied, representing the submerged-bed scrubber and the UFP cleaningsolution components. These simulants were added to the final evaporation test mixture. These simulants were required because it was not feasible to obtain these materials from operations associated with the limited amounts of available waste.

\section{Discrepancies and Follow-on Tests}

The behavior of $\mathrm{Pu}$ during the evaporation process was confounded from the inability to close the mass balance. The aqueous phase analysis indicated that $\sim 77 \%$ of the Pu remained in the aqueous phase. The solids analysis results indicated that excess ( $>200 \%)$ Pu was recovered in the solids phase. Furthermore, the fate of $\mathrm{Pu}$ during the combination of evaporator bottoms with tank waste supernatant was not clear. The ${ }^{238} \mathrm{Pu}$ concentration reduced by half, indicating post-

combination precipitation; the ${ }^{239+240} \mathrm{Pu}$ concentration slightly increased, indicating that no further precipitation occurred. It is recommended that additional testing be conducted to confirm the $\mathrm{Pu}$ behavior.

The tests also did not assess the potential for unreacted permanganate (or manganate) to persist through the evaporator and to react with slurry feeds upon blending downstream of the evaporator. Oxidation of $\mathrm{Pu}$ by this excess permanganate has the potential to result in additional 
$\mathrm{Pu}$ dissolution supported by the potentially higher hydroxide concentration in the resultant blended solution. Simultaneously, the blended feed would have additional reducing species (such as nitrite), which would consume some of the oxidant. Additional tests would shed insight into the potential for additional $\mathrm{Pu}$ solubilization.

A fraction ( $\sim 50 \%)$ of Mn precipitated after adding the Group 1/2 supernate to the evaporator concentrate. In contrast, virtually $100 \%$ of the Mn had precipitated when Group 5/6 permeate was added to permanganate-bearing solution in preparation for ion exchange. Specific matrix parameters (e.g., nitrite and/or reducing organics) appeared to enhance the permanganate reduction and precipitation. Further work will be required to determine what specific matrix conditions enhance the permanganate precipitation. 


\subsection{Introduction}

This report is one in a series that defines the characterization, parametric leaching, and filtration testing of actual Hanford tank wastes in support of the Hanford Waste Treatment and Immobilization Plant (WTP) pretreatment process development and demonstration. ${ }^{(a)}$ The tests reported herein were conducted according to, and complete the scope of, TP-RPP-WTP-456, ${ }^{(\mathrm{b})}$ which was written in response to Test Specification 24590-PTF-TSP-RT-06-002 Rev. 0. ${ }^{\text {(c) }}$

The purpose of this work was threefold: 1$)$ to test on a bench scale ( $<10 \mathrm{~g})$ the efficacy of the defined oxidative leaching processes on actual Hanford tank waste sludge, 2) to demonstrate on a lab-scale ( $>500 \mathrm{~g}$ ) the proposed WTP flowsheet pretreatment process incorporating the oxidative leaching of $\mathrm{Cr}$ from actual Hanford tank waste sludge, and 3) to determine the fate of Pu during the post oxidative leaching processing of the product streams through ion exchange and evaporation. The demonstration test included sludge caustic leaching, oxidative leaching, filtration, filtered solids washing, ion exchange processing, and evaporation incorporating waste stream recycle. The mass balances of process-significant components (such as $\mathrm{Al}$ and $\mathrm{Cr}$ ) and the fates of $\mathrm{Pu}, \mathrm{B}, \mathrm{Cd}, \mathrm{Ni}, \mathrm{Mn}$, and Fe were assessed during the pretreatment processing steps.

\subsection{Background}

The integration of the pretreatment flowsheet, tank waste $\mathrm{Cr}$ oxidation, fate of $\mathrm{Pu}$, and filtration are key concerns to the WTP and are discussed in the following sections.

\subsubsection{Integrated Pretreatment Flowsheet}

The WTP pretreatment facility is designed to reduce the Hanford tank waste mass fraction that is partitioned to the HLW vitrification facility so that the HLW immobilization process is economically viable. To this end, targeted removal of key components (e.g., $\mathrm{Na}, \mathrm{Al}$, and $\mathrm{Cr}$ ) from the tank waste sludge is to be undertaken through a series of sludge treatment (washing, caustic leaching, and oxidative leaching) and filtration processes. Sodium is mostly associated with the soluble salts and is largely removed during sludge washing. The $\mathrm{Al}$ is present mainly as gibbsite and boehmite, which are largely removed through caustic leaching. The insoluble $\mathrm{Cr}$ composition is least understood.

Limited lab-scale testing on actual waste steps has been conducted on specific steps of the pretreatment process. The limitations of the actual waste tests were discussed in the Oxidative Leaching Oversight Report (D-05-DESIGN-013) ${ }^{(\mathrm{d})}$ from the U.S. Department of Energy's (DOE’s) Office of River

(a) Other testing with overlapping scope were conducted according to TP-RPP-WTP-467, Rev. 0, SK Fiskum, 2/2/07 and Rev. 1 7/31/07, Characterization and Small Scale Testing of Hanford Wastes to Support the Development and Demonstration of Leaching and Ultrafiltration Pretreatment Processes.

(b) SK Fiskum, TP-RPP-WTP-456, Rev. 0, 11/20/06, Pretreatment Demonstration Applying Oxidative Leaching to Hanford Tank Waste.

(c) PS Sundar. 2006. 24590-PTF-TSP-RT-06-002 Rev. 0, Process Development for Design of Oxidative Leaching of Hanford Wastes.

(d) D-05-DESIGN-013: WTP Oxidative Leaching Design Oversight Report: D-05-DESIGN-013, Issued August 2005 by DOE-ORP. 
Protection (DOE-ORP). Results from the testing reported herein are intended to help BNI close two open items in the Oversight Report.

- Open item \#2 "BNI should perform a proof of process demonstration test(s) following finalization of process parameters to demonstrate the oxidative leaching process at conditions that more closely represent the anticipated plant flowsheet conditions for all anticipated process systems. Based upon the results of this work, the contractor should re-assess the benefits of the proposed process.”

- Open item \#4 "BNI should evaluate all data, including that to be collected in the proof of process demonstration experiment, on oxidative leaching using permanganate to provide a defensible basis for the assumed oxidative leach factor(s) and the addition rate of permanganate (e.g., mole permanganate to mole chromium) to be used in the modeling efforts."

\subsubsection{Oxidative Leaching of Chromium}

Based on the Best Basis Inventory (BBI) ${ }^{(\mathrm{a})}$, 48 wt\% (283 metric tons) of the total tank waste $\mathrm{Cr}$ inventory is estimated to remain in the solid phase even after caustic leaching, presumably in the form of one or more $\mathrm{Cr}(\mathrm{III})$ compounds. Of this mass, $79 \mathrm{wt} \%$ is associated with the insoluble solids suspended in saltcake, mostly in the S-Saltcake as shown in Figure 1.1.

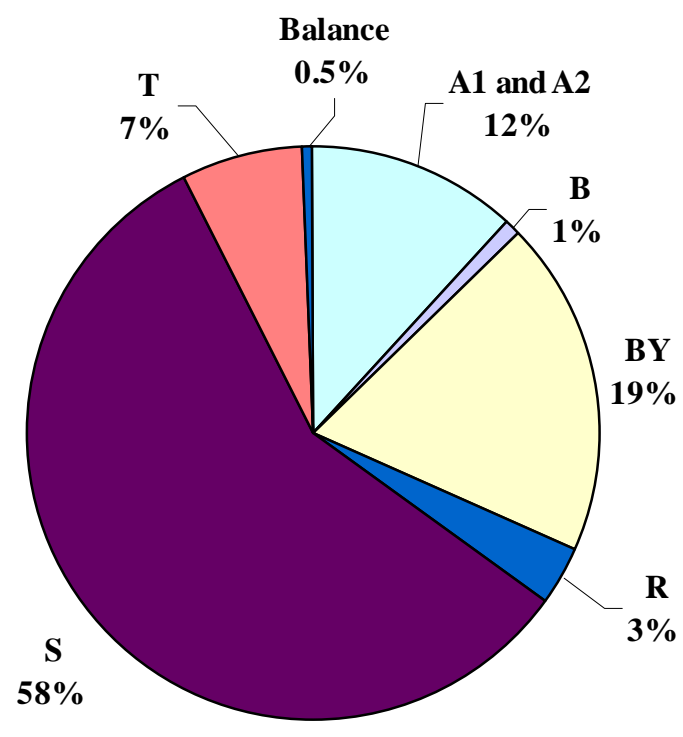

\begin{tabular}{|l|l|}
\hline Symbol & Definition (from BBI) \\
\hline S & $\begin{array}{l}\text { Saltcake from 242-S evaporator } \\
\text { campaign }\end{array}$ \\
\hline BY-102 & $\begin{array}{l}\text { Saltcake from in-tank } \\
\text { solidification (ITS) in BY-Farm }\end{array}$ \\
\hline $\begin{array}{l}\text { A1 and } \\
\text { A2 }\end{array}$ & $\begin{array}{l}\text { Saltcake from 242-A evaporator } \\
\text { campaign }\end{array}$ \\
\hline R & $\begin{array}{l}\text { Saltcake from self-concentration } \\
\text { in S- and SX-Farms }\end{array}$ \\
\hline B & $\begin{array}{l}\text { Saltcake from 242-B evaporator } \\
\text { operation }\end{array}$ \\
\hline T & $\begin{array}{l}\text { Saltcake from the first 242-T } \\
\text { evaporator campaign using 241- } \\
\text { TX-118 feed tank }\end{array}$ \\
\hline
\end{tabular}

Figure 1.1. Chromium Distribution in Tank Waste Saltcake after Caustic Leaching (BBI)

High chromium concentrations in the melter feed have been shown to limit waste loading in the immobilized high-level waste (IHLW) glass. This limitation stems from increasing the liquidus temperature of spinels, the precipitation of $\mathrm{Cr}_{2} \mathrm{O}_{3}$, or promoting molten salt segregation as previously summarized (Rapko et al. 2004). Removing $\mathrm{Cr}$ from the solid waste fraction will increase loading of the

(a) The BBI was accessed through the Tank Waste Information Network System sponsored by the U.S. Department of Energy. 
high-level waste (HLW) into glass. The separated Cr would then be processed with the low-activity waste (LAW) stream. Oxidation of the $\mathrm{Cr}(\mathrm{III})$ to $\mathrm{Cr}(\mathrm{VI})$ provides an effective manner to mobilize $\mathrm{Cr}$ from the solids phase to the aqueous phase. This allows the $\mathrm{Cr}$ to be processed in the larger volume LAW waste form where the $\mathrm{Cr}$ concentration is no longer a limiting glass-loading factor. Bench scale oxidative leaching tests of waste solids from 241-SY-102 and 241-SX-101 tank sludge were completed, and sodium permanganate $\left(\mathrm{NaMnO}_{4}\right)$ in a weak caustic $(0.25 \mathrm{M} \mathrm{NaOH})$ solution was identified as a suitable oxidant for chromium (Rapko et al. 2004).

\subsubsection{Fate of Plutonium}

The concentration of plutonium during pretreatment processing is of concern with regard to criticality safety in the WTP. Plutonium removal from sludge (which is undesirable) was enhanced under selected oxidative conditions (e.g., in a $3 \mathrm{M} \mathrm{NaOH}$ matrix) (Rapko et al. 2004; Fiskum et al. 2008). This likely occurred through oxidizing $\mathrm{Pu}^{4+}$ to the more soluble higher oxidation states (either $\mathrm{Pu}^{5+}$ or $\mathrm{Pu}^{6+}$ ). During plant operations, the process streams containing these higher oxidation state plutonium species would subsequently be contacted with more reducing solutions resulting in localized precipitation of plutonium as plutonium(IV) hydroxide.

Plutonium has also been shown to collect onto the Cs ion exchange resin SL-644 and elute with 0.5 M nitric acid. Nominally $72 \%$ of the Pu in AP-101 supernatant and 60\% of the Pu in AZ-101 supernatant were removed during ion exchange processing with SL-644 and partitioned to the eluate (Fiskum et al. 2004a and 2004b). Separating trace Pu from the large-volume LAW onto the ion exchanger also poses a potential criticality hazard. A shift from the use of SL-644 to spherical resorcinol-formaldehyde (RF) resin has recently been made by WTP. Only a very limited number of actual waste tests have been conducted to date to assess the potential of Pu to similarly be retained on the spherical resorcinolformaldehyde (RF) resin.

A project report (24590-WTP-RPT-NS-05-001) ${ }^{(a)}$ on the criticality safety aspects of oxidative leaching identified the potential for $\mathrm{Pu}$ accumulation as an issue, depending upon its fate in the pretreatment process. Resolution of this potential issue is important to safe operation of the WTP and requires an investigation into the fate of $\mathrm{Cr}, \mathrm{Pu}$, and other criticality safety-related components in solution resulting from oxidative leaching with permanganate. Additionally, BNI-WTP Engineering carried out an assessment of its information needs to verify oxidative leaching design and complete the criticality safety assessment of the pretreatment process (CCN 122601). ${ }^{\text {(b) }}$ In particular, the testing and information requirements identified by Engineering were to determine the stability of $\mathrm{Pu}$ in the wash/rinse solutions from oxidative leaching and ion-exchange operations as they are recycled in the pretreatment process to the Feed Evaporator Process (FEP).

\subsubsection{Caustic Leaching and Ultrafiltration}

Much of the tank waste sludge is composed of $\mathrm{Al}(4,440$ metric tons per the BBI), primarily in the form of gibbsite and boehmite. The Al mass inventory can be dramatically decreased through caustic

(a) Criticality Safety Aspects of Oxidative Leach, prepared by RE Miles, WTP Document: 24590-WTP-RPT-NS05-001 Rev. A, May 2005.

(b) CCN 122601: Required Research \& Technology Work to Support Development of Oxidative Leaching Design Baseline, dated June 15, 2005 from G. Duncan Deputy, Manager—Engineering to W. Tamosaitis, Manager Research \& Technology. 
leaching, which dissolves both gibbsite and boehmite while leaving transuranic (TRU) components, U, and $\mathrm{Sr}$ in the solids phase. Significant testing campaigns have been conducted to evaluate and optimize the gibbsite and boehmite leach conditions in small-scale processing, which have been previously summarized (Lumetta and Hallen 2007). Boehmite is the more challenging of the two phases to leach in that it requires higher leaching temperature, higher caustic demand, and longer leaching times to solubilize an equivalent mass of $\mathrm{Al}$ (compared to gibbsite).

Cross-flow filtration will be used in the WTP to separate undissolved solids from solution after leaching operations. Limited testing has been conducted in evaluating different waste types for filterability and associated limitations (summarized by Lumetta and Hallen 2007). Only four wastes have been filtered following caustic leaching (241-C-104, 241-AY-102/241-C-106, 241-AZ-101, and 241-AZ102) and two wastes have been filtered following Sr/TRU precipitation (241-AN-102 and 241-AN-107).

The oversight report has asserted that testing to date did not demonstrate the leaching process under conditions that more closely represent the anticipated plant flowsheet conditions for all of the anticipated process systems, including ultrafiltration and the feed evaporator.

\subsection{Demonstration Testing}

This report describes the pretreatment processing of actual tank waste materials through the proposed WTP pretreatment flowsheet incorporating caustic and oxidative leaching in an effort to demonstrate in the laboratory the efficacy of the defined leaching processes on actual Hanford tank waste sludge. It is thus termed the "demonstration test." The pretreatment processing steps tested include:

- definition of the permanganate dosage to apply to the oxidative leaching in the cell unit filter (CUF)

- solids crossflow filtration through the CUF

- caustic leaching for Al removal

- stepwise washing of the caustic-leached solids using decreasing concentrations of sodium hydroxide with filtration through the CUF

- oxidative leaching using sodium permanganate for $\mathrm{Cr}(\mathrm{III})$ removal

- $\quad$ solids filtration with the CUF

- follow-on solids washing and filtration through the CUF

- ion exchange processing using spherical resorcinol formaldehyde (SRF) resin

- evaporation of waste stream recycle and leach-solution streams from oxidative leaching for volume reduction

- combination of the evaporated product with tank waste supernatant.

The overall process flowsheet for the demonstration test is summarized in Figure 1.2. The Group 5 and Group 6 indicated in the figure depict two classes of tank waste, boehmite-rich REDOX sludge and 
Cr-rich S-Saltcake, respectively. ${ }^{(a)}$ Specific experimental details and results of the process steps are provided within subsections of this report.

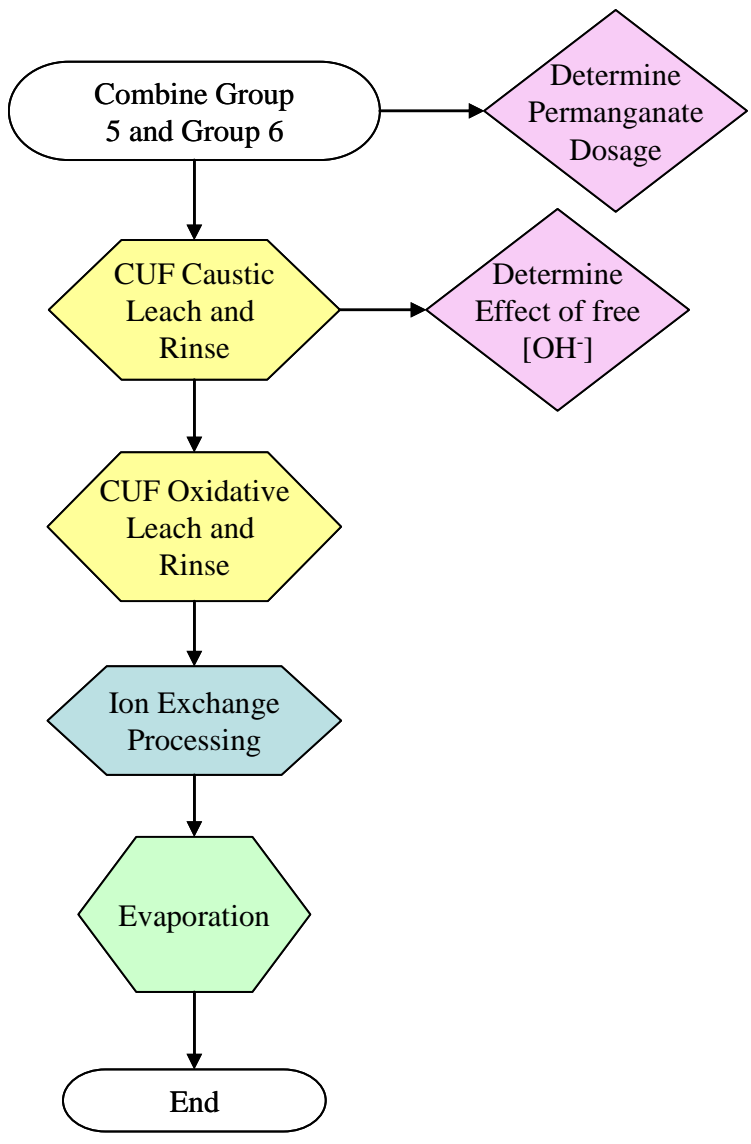

Figure 1.2. Overall Process Flow for the Demonstration Test

(Details of each process step are provided within each corresponding section of this report.)

During testing, the following activities were undertaken to provide additional data to support the WTP pretreatment flowsheet.

- Determining the material balances and leaching kinetics for $\mathrm{Al}$ and $\mathrm{Cr}$ to define processing requirements to meet target removal requirements for these glass-limiting components.

- Collecting information to support criticality control including:

o material balance of $\mathrm{Pu}, \mathrm{Ni}, \mathrm{Mn}$, and Fe to support criticality control requirements

0 information on the fate of neutron absorbers (B and Cd)

o assessment of the potential for Pu to accumulate during various process steps such as ion exchange, precipitation, and plating on component surfaces.

(a) The Hanford tank wastes were broadly categorized into 8 groups as previously described (Fiskum et al. 2008). The groupings were based on specific challenges to the pretreatment processing flowsheet and the significance of the key component mass term in the tank waste inventory. 
- Demonstrating the process for determining the permanganate dosage requirements to achieve effective oxidative leaching of Cr.

- Evaluating free hydroxide content before and after caustic leaching to support the definition of sludge washing requirements.

- Demonstrate the caustic and oxidative leaching processing. 


\subsection{Tank Waste Test Material}

The primary objective of the work described in this report was to demonstrate the oxidative leaching process within the framework of the pretreatment process flowsheet. Therefore, the actual waste test material needed to contain a significant fraction of insoluble $\mathrm{Cr}$ (III). Group 6 S-Saltcake waste was selected as the source of the Cr-rich insoluble solids. Based on the mass distribution of caustic unleachable $\mathrm{Cr}$ in the tank waste inventory (see Figure 1.1), the Group 6 material should represent the majority of insoluble $\mathrm{Cr}$ that will be submitted to the WTP. However, insufficient insoluble solids were present in the Group 6 composite to support a complete demonstration of the WTP pretreatment flowsheet. Therefore, this material was supplemented with a high-Al source in the Group 5 REDOX waste material.

The Group 5 solids contained $33 \mathrm{wt} \% \mathrm{Al} ;$ $90 \mathrm{wt} \%$ of the Al existed in the form of boehmite (AlOOH) (Fiskum et al. 2008). This Al form provided a challenging test for the caustic leach processing and sufficient solids to carry out filtration testing. The Group 6 water-insoluble solids contained $9.3 \mathrm{wt} \% \mathrm{Cr} ;>90 \mathrm{wt} \%$ of the $\mathrm{Cr}$ appeared to exist as a nanocrystalline or amorphous form of $\mathrm{Cr}_{2} \mathrm{O}_{3}$ (Fiskum et al. 2008). The dissolved saltcake associated with Group 6 provided a suitable aqueous matrix for process testing at nominally $5 \mathrm{M}$ Na. Additionally, the combined Group 5/6 waste matrix was determined to have sufficient Pu concentration to allow adequate detection of Pu partitioning during the various process steps.

The Group 5 and Group 6 tank waste material sources, compositions, and physical properties have been previously described (Fiskum et al. 2008). Salient properties and component concentrations are reproduced in Table 2.1.

For ease in handling in the hot cells, the Group 6 solids had been physically isolated into a slurry concentrate. Subsamples from the Group 6 slurry, Group 6 supernatant, and Group 5 slurry were combined in two separate campaigns, one to support parametric testing and one to support the CUF processing. The nominal waste blends for parametric and CUF processing were intended to result in a common mass ratio of 1.88 of Group 5 slurry to Group 6 slurry. The combination of the slurry with the Group 6 supernatant was intended to reach a starting condition of $7 \mathrm{wt} \%$ UDS. ${ }^{(a)}$ The overall targeted mass fractionation of these three components is

- $\quad 31.6$ wt\% Group 5 slurry

- 16.8 wt\% Group 6 slurry

- $\quad 51.6$ wt\% Group 6 supernatant.

(a) Reference concurrence letter, WTP/RPP-MOA-PNNL-00102, from G Beeman to H Hazen, 9/10/07. 
Table 2.1. Compositional Summary of Group 5 and Group 6 Tank Wastes

\begin{tabular}{|c|c|c|c|c|}
\hline \multirow[t]{2}{*}{ Parameter } & \multicolumn{2}{|c|}{ Group 5} & \multicolumn{2}{|c|}{ Group 6} \\
\hline & Supernatant & Solids ${ }^{(a)}$ & Supernatant & Solids ${ }^{(a)}$ \\
\hline \multirow[t]{2}{*}{ Density } & $1.16 \mathrm{~g} / \mathrm{mL}$ & na & $1.23 \mathrm{~g} / \mathrm{mL}$ & na \\
\hline & $\mu \mathrm{Ci} / \mathbf{m L}$ & $\mu \mathrm{Ci} / \mathrm{g}$ & $\mu \mathrm{Ci} / \mathrm{mL}$ & $\mu \mathrm{Ci} / \mathrm{g}$ \\
\hline${ }^{238} \mathrm{Pu}$ & $1.35 \mathrm{E}-6$ & $2.27 \mathrm{E}-2$ & $<2 \mathrm{E}-5$ & $1.22 \mathrm{E}-1$ \\
\hline \multirow{2}{*}{${ }^{239+240} \mathrm{Pu}$} & $1.95 \mathrm{E}-5$ & $8.83 \mathrm{E}-1$ & $8.83 \mathrm{E}-5$ & $9.23 \mathrm{E}-1$ \\
\hline & $\mu \mathrm{g} / \mathrm{mL}$ & $\mu \mathrm{g} / \mathrm{g}$ & $\mu \mathrm{g} / \mathrm{mL}$ & $\mu \mathrm{g} / \mathrm{g}$ \\
\hline $\mathrm{Al}$ & 2,595 & 326,500 & 7,590 & 187,000 \\
\hline B & 45.8 & [81] & 30.3 & $<95$ \\
\hline $\mathrm{Cd}$ & $<0.3$ & $<3$ & $<0.2$ & 139 \\
\hline $\mathrm{Cr}$ & 1,225 & 2,110 & 535 & 92,850 \\
\hline $\mathrm{Fe}$ & $<2$ & 7,265 & $<2$ & 14,700 \\
\hline $\mathrm{Mn}$ & $<0.2$ & 4,500 & $<0.2$ & 4,680 \\
\hline $\mathrm{Na}$ & 73,700 & 55,200 & 117,500 & 93,500 \\
\hline $\mathrm{Ni}$ & $<0.6$ & 308 & {$[2.2]$} & 1,035 \\
\hline $\mathrm{U}$ & $\mathrm{n} / \mathrm{a}$ & 20,200 & $\mathrm{n} / \mathrm{a}$ & 4,415 \\
\hline free hydroxide & 4,000 & na & 12,200 & na \\
\hline nitrate & 89,600 & na & 119,500 & na \\
\hline nitrite & 24,500 & na & 37,650 & na \\
\hline oxalate & 873 & $\mathrm{n} / \mathrm{a}$ & $<5.8$ & $\mathrm{n} / \mathrm{a}$ \\
\hline \multicolumn{5}{|c|}{$\begin{array}{l}\text { Analyte uncertainties were typically within } \pm 15 \% \text {; results in brackets indicate that the analyte } \\
\text { concentrations were greater than the minimum detection limit (MDL) and less than the estimated } \\
\text { quantitation limit (EQL), and uncertainties were }>15 \% \text {. }\end{array}$} \\
\hline Data taken from & um et al. (2008) & & & \\
\hline
\end{tabular}




\subsection{Permanganate Dosage Determination for Combined Group 5 (REDOX Sludge) and Group 6 (S-Saltcake) Oxidative Leaching}

It was directed that permanganate dosage testing be conducted on two distinct actual wastes. Group 6 (S-Saltcake) and Group 2 (Bismuth Phosphate Saltcake) are Cr-limited tank waste composites. Both the Group 2 and Group 6 parametric oxidant dosage testing are reported separately (Lumetta et al. in press and Fiskum et al. 2008, respectively). Since CUF processing was conducted on combined Groups 5 (REDOX sludge) and 6 and combined Groups 1 and 2, the oxidant dosage was evaluated on both combined waste forms as well. However, the results of the combined Group 1 (Bismuth Phosphate Sludge) and Group 2 tank waste material are reported in conjunction with the CUF processing results (Lumetta et al. in press). Only the Group 5 combined with Group 6 processing is reported herein.

This section describes the experimental conditions used in the conduct of determining the oxidant dosage (permanganate) as well as experimental results and interpretations. Specific target process conditions along with the basis were predefined in a processing concurrence request. ${ }^{\text {(a) }}$ The test matrix was a combination of Group 5 and Group 6. Testing was conducted in two test phases. Phase 1 test initial process conditions emulated processing inclusive of caustic leaching that would be expected in the CUF. Follow-on parametric oxidative leach processing was conducted on the caustic-leached and rinsed solids product at constant $\mathrm{NaOH}$ molarity $(0.25)$ with varying permanganate addition. Test Phase 2 was conducted on the solids obtained following the combined Group 5 and Group 6 caustic leaching and washing in the CUF at constant permanganate dosage $(\mathrm{Mn} / \mathrm{Cr}$ mole ratio of 1.25$)$ and varying hydroxide concentrations. The processes covered in this section in relationship to the overall demonstration test are shown in bold in Figure 3.1.

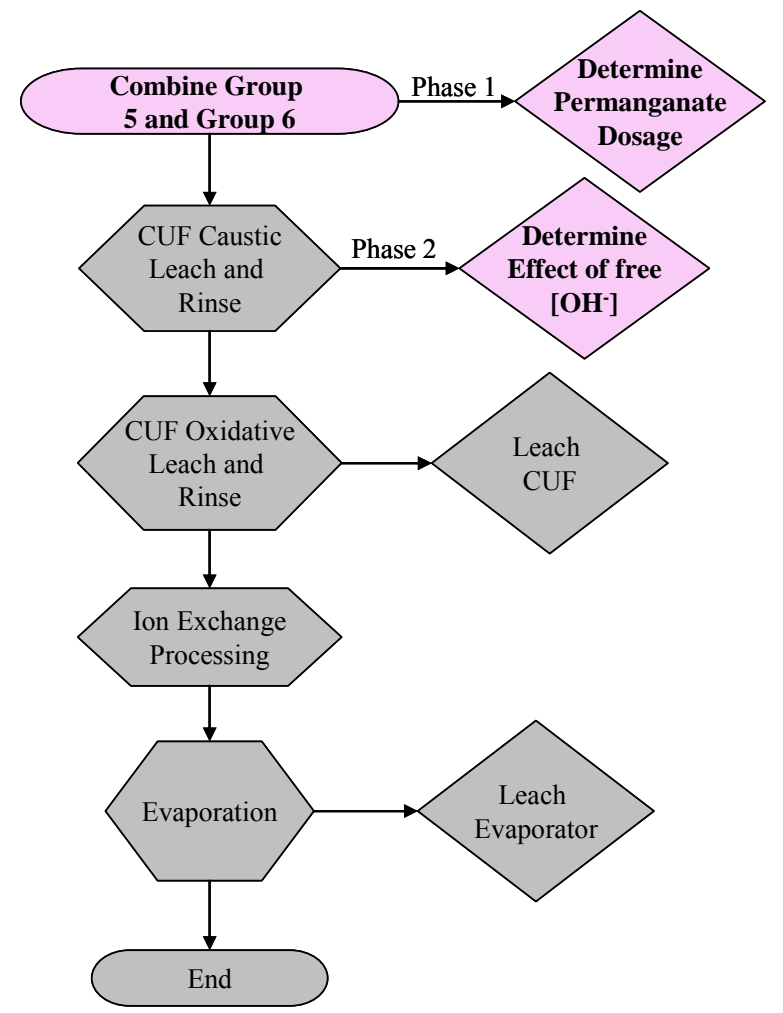

Figure 3.1. Parametric Testing Overview for Permanganate Dosage and Free-Hydroxide Concentration

(a) Letter from G Beeman to H Hazen 9/10/2007, reference number WTP/RPP-MOA-PNNL-00103, see Appendix C. 


\subsection{Phase 1 Testing}

This section discusses experimental conditions employed for the Phase 1 test conditions. ${ }^{(a)}$ The objective was to evaluate the $\mathrm{Cr}$ removal as a function of the permanganate dosage.

\subsubsection{Phase 1 Test Material}

The test material was created by combining Group 5 (REDOX Sludge) with Group 6 (S-Saltcake) sludge composite and supernatant composite prototypic of the CUF processing (Shimskey et al. 2008). The characteristics of these tank waste composites have been previously described (Fiskum et al. 2008). The Group 5 and Group 6 slurry materials were mixed with an overhead stirrer to re-suspend solids before sub-sampling. Transfers were conducted with large disposable polyethylene transfer pipets into a 200-mL plastic centrifuge bottle; transfers were determined gravimetrically. The masses and mass fractions of the components combined for Phase 1 testing are shown in Table 3.1.

Table 3.1. Phase 1 Test Material

\begin{tabular}{|c|c|c|c|}
\hline Component & Mass, $\mathrm{g}$ & $\begin{array}{c}\text { Mass } \\
\text { Fraction, \% } \\
\end{array}$ & $\mathrm{Wt}^{\%}$ UDS $^{(\mathbf{b})}$ \\
\hline Group 5 slurry $^{(a)}$ & 56.4 & 29.9 & 18.5 \\
\hline Group 6 slurry $^{(\mathrm{c})}$ & 29.7 & 15.7 & 14.7 \\
\hline Group 6 supernatant & 102.8 & 54.4 & 0 \\
\hline Sum & 188.9 & 100.0 & -- \\
\hline $\begin{array}{l}\text { Group 5/Group } 6 \\
\text { slurry mass ratio }\end{array}$ & 1.90 & -- & -- \\
\hline \multicolumn{4}{|c|}{$\begin{array}{l}\text { (a) Taken from sample TI477-G5-AR-J3. } \\
\text { (b) Reported in RPT-WTP-157, Fiskum et al. (2008). } \\
\text { (c) Taken from sample TI490-G6-AR. }\end{array}$} \\
\hline
\end{tabular}

\subsubsection{Phase 1 Caustic Leaching and Washing}

Figure 3.2 summarizes the material processing flow for caustic leaching, washing, and analysis. The composite slurry was sub-sampled after suspending solids using an overhead stirrer. Duplicate 3-g slurry samples and one 10 -g slurry sample were taken for analysis. The remaining slurry was centrifuged for $15 \mathrm{~min}$ at $1000 \mathrm{G}$. Supernatant (106 g) was removed from the slurry resulting in $\sim 18 \mathrm{wt} \%$ undissolved solids (UDS). The remaining concentrated sludge was combined with $84 \mathrm{~mL} 9.5 \mathrm{M} \mathrm{NaOH}$, a magnetic stir bar was added, and then the slurry was heated in a boiling water bath. Stirring was provided by a magnetic stir bar, and pressure relief was accommodated with a modified lid equipped with a condenser. The solids were caustic leached for $12 \mathrm{~h}$ in the boiling water bath $\left(\sim 100^{\circ} \mathrm{C}\right)$. Water was added periodically to replace water loss due to evaporation. At the conclusion of the leach, the material was removed from the water bath and allowed to come to ambient temperature overnight.

The caustic-leached slurry was centrifuged for $35 \mathrm{~min}$ at $1000 \mathrm{G}$, resulting in well-compacted solids ( $\sim 40$-mL centrifuged solids volume). The leachate $(81.7 \mathrm{~g}$ ) was decanted and measured for inductively

(a) Testing was conducted according to TI-RPP-WTP-546, Bench Scale Oxidative Leach Actual Waste Test with Group 5\&6 Hanford Tank Waste, L Snow, September, 2007. 
coupled plasma-optical emission spectroscopy (ICP-OES) metals, $\mathrm{Pu}$, and free hydroxide. Solids were contacted with six sequential washes of $40-\mathrm{mL} 0.01 \mathrm{M} \mathrm{NaOH}$. Each wash solution was mixed with the solids for $15 \mathrm{~min}$ and then centrifuged $10 \mathrm{~min}$ at $1000 \mathrm{G}$ and decanted. The final solution free-hydroxide concentration was measured to be $0.23 \mathrm{M}$. The six washes were combined and measured for ICP-OES metals and $\mathrm{Pu}$.

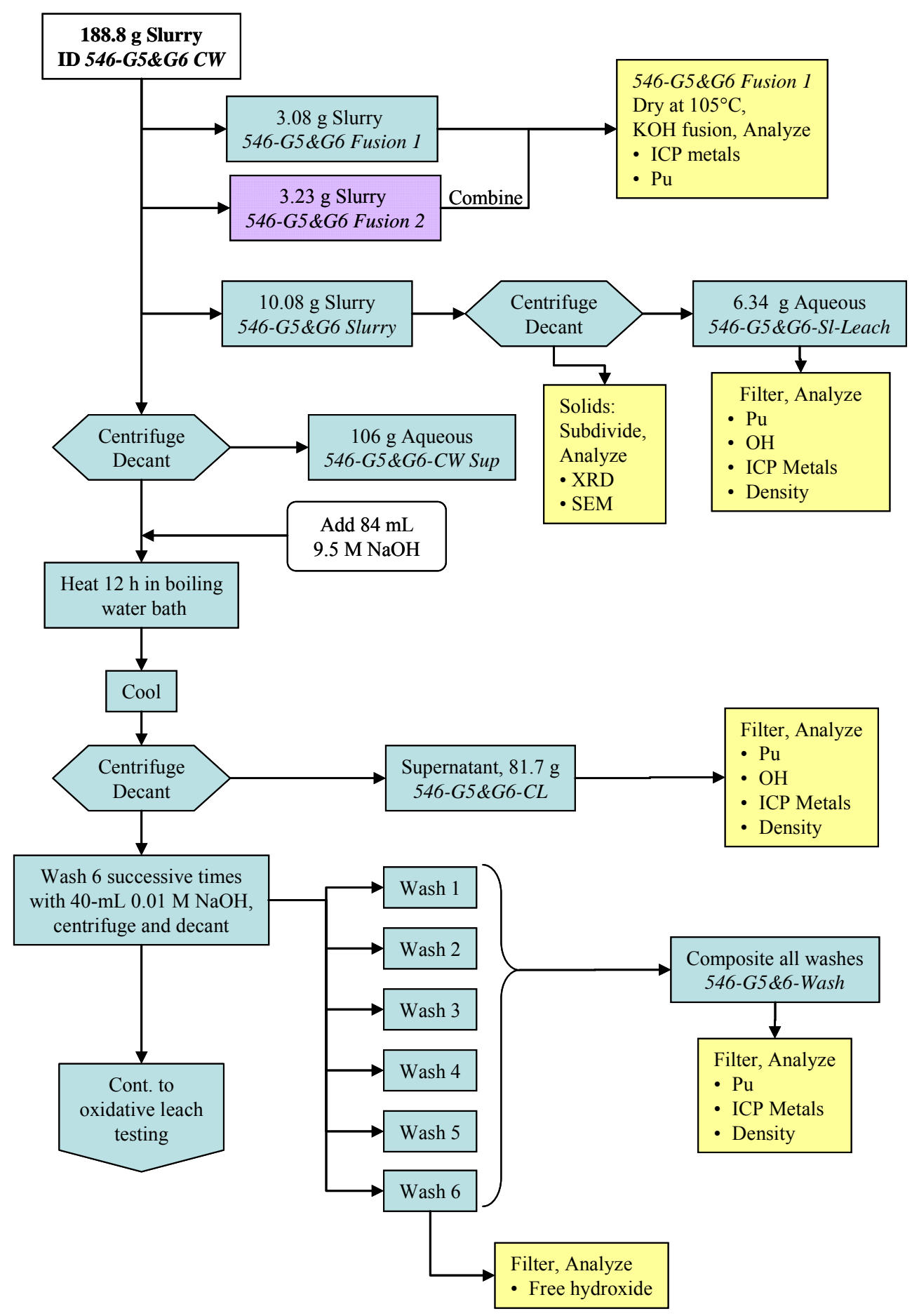

Figure 3.2. Phase 1 Caustic-Leaching, Washing, and Analysis Flowchart 


\subsubsection{Phase 1 Oxidative Leach Test Matrix}

Figure 3.3 summarizes material manipulation in support of the oxidative leach testing and analysis. A $100-\mathrm{mL}$ volume of $0.25 \mathrm{M} \mathrm{NaOH}$ was added to the caustic-leached and washed solids slurry, resulting in a 137-g final mass. The slurry was mixed using an overhead stirrer to uniformly suspend solids and subdivided into five $125-\mathrm{mL}$ high-density polyethylene (HDPE) bottles (22.8 g slurry in each, corresponding to $1.23 \mathrm{~g}$ dry solids per test and $60.3 \mathrm{mg} \mathrm{Cr}$ per test) with the aid of a plastic transfer pipet. The samples were removed from the hot cell for follow-on processing at the fume hood workstation. One additional sample (546-G5\&6-CL-Sl) containing $\sim 9.4 \mathrm{~g}$ of slurry (equivalent to $0.5 \mathrm{~g}$ dry solids) was transferred to a 60-mL HDPE bottle and removed from the hot cell to support analytical testing. This sample was centrifuged and the aqueous fraction collected for determination of density, free hydroxide, $\mathrm{Pu}$, and ICPOES metals. The centrifuged solids were suspended in $2 \mathrm{~mL}$ deionized (DI) water and sub-divided for X-ray diffraction (XRD), SEM, and transmission electron microscopy (TEM) analysis. Another aliquot was submitted for analyses: wt $\%$ UDS and potassium hydroxide $(\mathrm{KOH})$ fusion with follow-on analyses of $\mathrm{Pu}$ and ICP-OES metals.

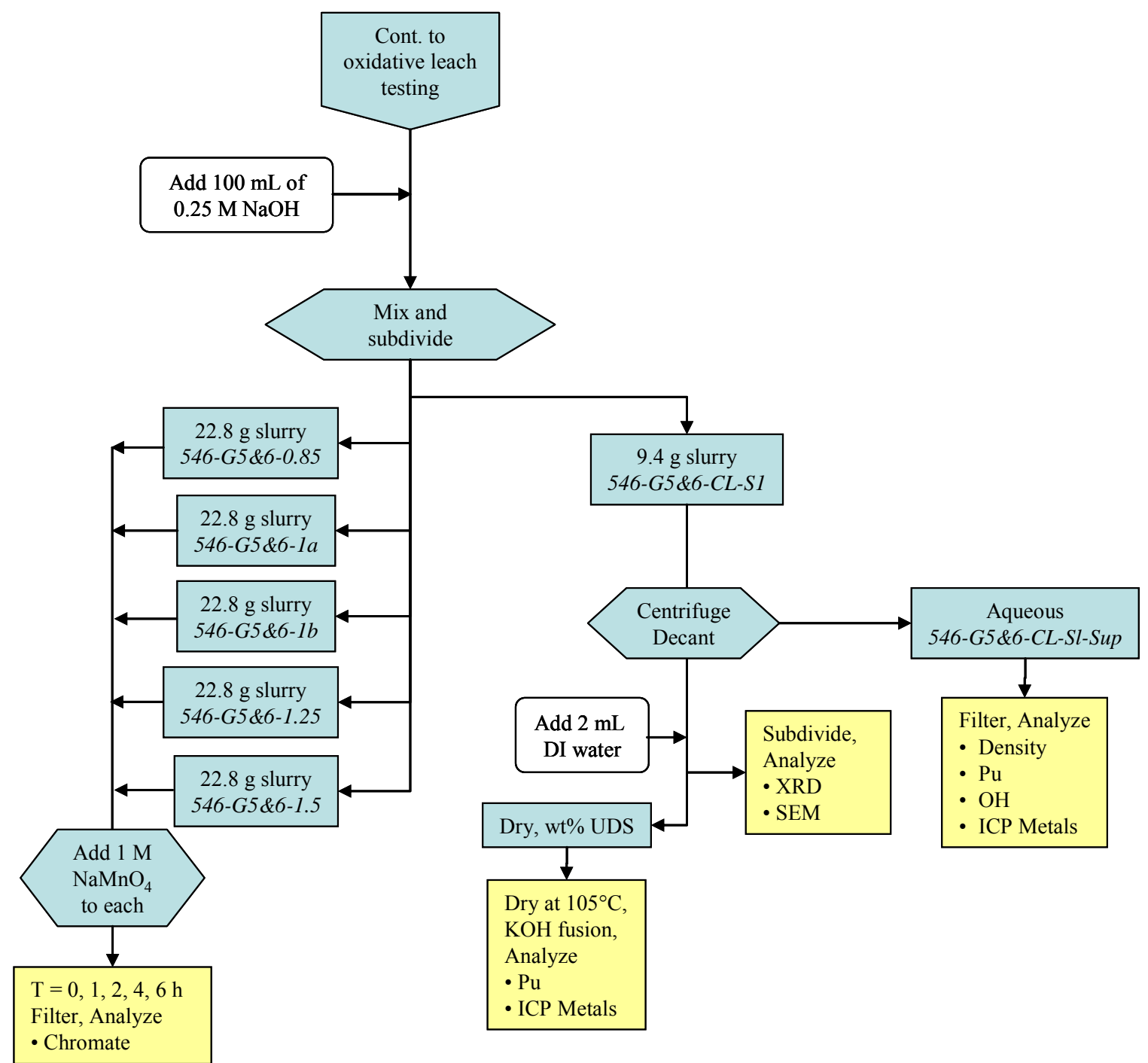

Figure 3.3. Phase 1 Oxidative Leaching Test 
A sufficient volume of $0.25 \mathrm{M} \mathrm{NaOH}$ was added to each oxidative leach test sample to create a 100 -mL slurry. The samples were hand-shaken for $30 \mathrm{sec}$, and the solids were allowed to settle until the aqueous fraction had cleared sufficiently to withdraw a 2-mL sample. The aqueous sample was filtered, and $1 \mathrm{~mL}$ of the filtrate was submitted for chromate analysis (defined as the chromate concentration at $\mathrm{T}_{0}$ ). The residual filtrate was returned to the reaction vessel. An aliquot of $1 \mathrm{M} \mathrm{NaMnO}_{4}$ was added to each reaction vessel, resulting in $\mathrm{Mn} / \mathrm{Cr}$ mole ratios of $0.79,0.95$ (in duplicate), 1.21, and 1.38; the added volume ranged from $0.92 \mathrm{~mL}$ to $1.6 \mathrm{~mL}$. The addition time was defined as $\mathrm{T}_{0}$.

The mixtures were immediately placed on a 6-position magnetic stir plate; each position was set to a 500-rpm stir speed. Supernatant sub-samples were removed from each sample after 1-, 2-, 4-, and 6-h reaction times using the technique described for taking the initial sample (before $\mathrm{NaMnO}_{4}$ was added). The process temperature was considered the room temperature, nominally $22^{\circ} \mathrm{C}$. Each sample was analyzed for chromate using ultraviolet visible (UV-Vis) spectrometry as previously described (Rapko et al. 2007).

Only the duplicate samples leached at a $\mathrm{Mn} / \mathrm{Cr}$ ratio of 0.95 were processed for further analytical testing; the process flowchart for sample handling and analysis is shown in Figure 3.4 (sample 546G5\&6-1a is shown; the duplicate was handled the same). After completing the oxidative leach, the samples were centrifuged at $1000 \mathrm{G}$ for $5 \mathrm{~min}$. All but $\sim 10 \mathrm{~mL}$ of the leach solutions was decanted. The decanted aqueous fractions were measured for density. Analytical fractions were filtered and submitted for Pu and ICP-OES metals analysis. The oxidatively leached solids were washed three sequential times with 70 to $85 \mathrm{~mL}$ of $0.01 \mathrm{M} \mathrm{NaOH}$. Each wash solution was contacted with the solids for $15 \mathrm{~min}$ followed by centrifuging and decanting (leaving $\sim 10-\mathrm{mL}$ solution with the solids phase). The last wash required a 40-min centrifuge time to clarify the aqueous phase. The three successive wash solutions were combined for each sample and analyzed for ICP-OES metals and Pu. The washed slurry was subaliquoted for various analyses: XRD, SEM, TEM, and KOH fusion with follow-on ICP-OES metals and $\mathrm{Pu}$ analysis.

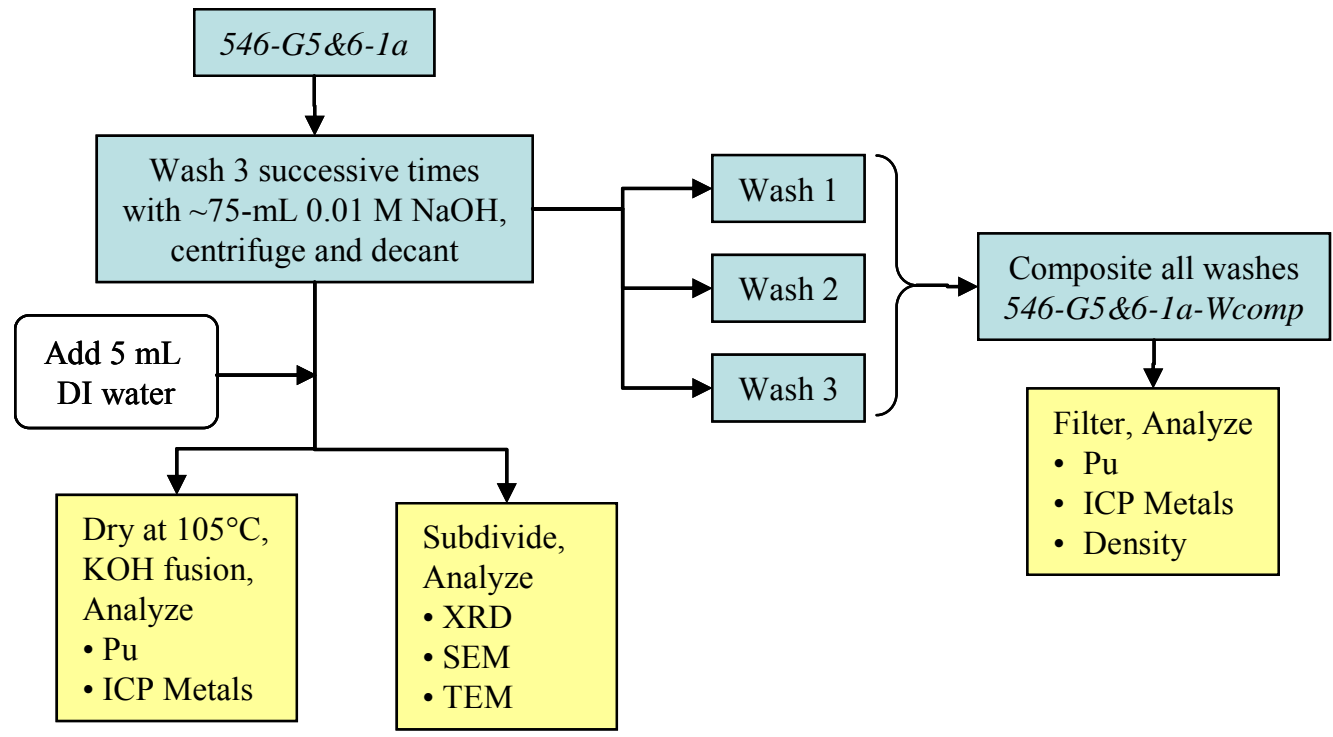

Figure 3.4. Sample Handling of Oxidatively Leached Solids 


\subsection{Phase 2 Testing}

This section discusses the Phase 2 test conditions. ${ }^{(a)}$ The specific objective was to determine the fraction of $\mathrm{Pu}$ mobilized to the aqueous phase as a function of the sodium hydroxide concentration.

\subsubsection{Phase 2 Test Material}

A $34.4 \mathrm{~g}$ aliquot of caustic-leached and washed solids was removed from the Group 6/5 CUF run process. An additional $17 \mathrm{~mL}$ of water was added to aid the mixing operation and uniformly suspend solids for aliquoting; the diluted material contained $\sim 11 \mathrm{wt} \%$ UDS.

\subsubsection{Phase 2 Processing Conditions}

A nominal $6.05 \mathrm{~g}( \pm 0.66 \mathrm{~g})$ of slurry was subdivided into six 50 -mL poly bottles. Each slurry sample represented $0.678 \mathrm{~g}$ UDS. An appropriate aliquot of $19 \mathrm{M} \mathrm{NaOH}$ was added to each sample, which was then promptly diluted to $50 \mathrm{~mL}$. The final $\mathrm{NaOH}$ concentrations were $0.25 \mathrm{M}, 0.5 \mathrm{M}, 0.75 \mathrm{M}$ (in duplicate), 1.0 M, and 1.25 M. After dilution, one 1.5-mL aqueous sub-sample was removed from each container (as described in Section 3.1.3) to represent the $\mathrm{T}_{0}$ supernatant sample. Then $0.66 \mathrm{~g} 1 \mathrm{M}$ $\mathrm{NaMnO}_{4}(\mathrm{Mn}: \mathrm{Cr}$ mole ratio of 1.25) was added to each sample marking the start time for oxidative leaching. The samples were shaken at room temperature $\left(22^{\circ} \mathrm{C}\right)$ and at $200 \mathrm{rpm}$. Sub-samples $(1.5 \mathrm{~mL})$ were removed after 1-, 2-, 4-, and 6-h process times. Each subsample was split and analyzed for chromate by UV-vis spectrometry, Pu, and ICP-OES metals. A summary of the sample handling and analysis processes is shown in Figure 3.5.

(a) Testing was conducted according to TI-RPP-WTP-554, Parametric Caustic and Oxidative Leach Test of Group 5/6 Hanford Tank Waste, Post CUF Test, L Snow, November, 2007. 


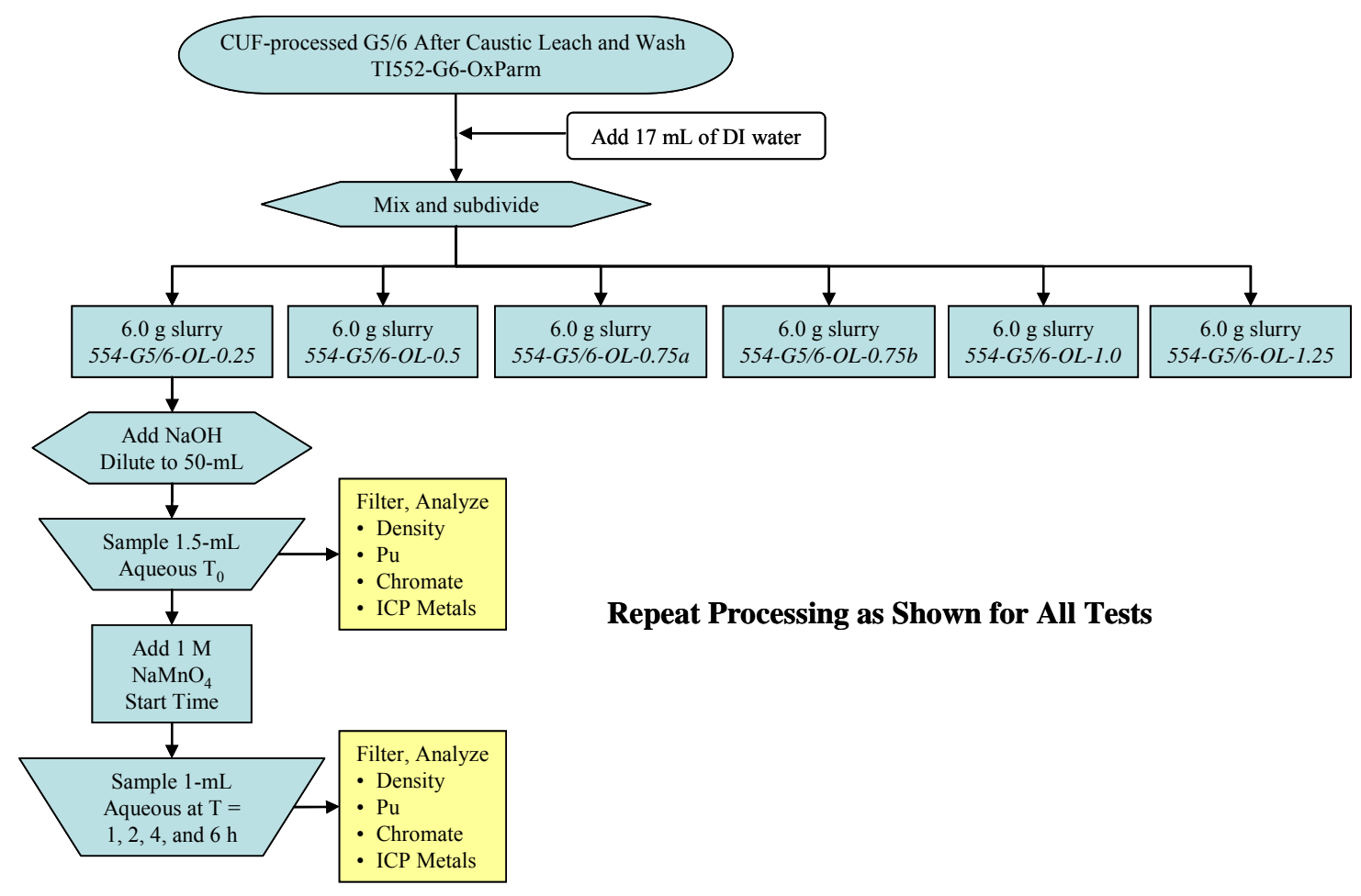

Figure 3.5. Phase 2 Sample Processing and Analysis

\subsection{Phase 1 Testing Oxidative Leach Test Results}

The results of the caustic leach and wash, and oxidative leach results are considered separately in the following sections.

\subsubsection{Initial Caustic Leach and Wash}

The Al leach factor from caustic leaching and washing was calculated from the measured initial solids and measured washed solids analysis. This, however, resulted in a low Al leach factor of $\sim 4 \%$. Analysis of the caustic-leach and wash solutions indicated that $37 \%$ of the $\mathrm{Al}$ was leached. The mathematical combination of the input feeds based from the initial characterization results (Fiskum et al. 2008) was applied to the leach factor calculation. In this case, the Al leach factor was determined to be $38 \%$, in close agreement with the aqueous result calculations. As such, the caustic-leached and washed solids composition will be compared to the mathematically derived composition from the initial characterization.

The mathematically combined supernatant composition was compared with the measured combined supernatant composition. Within experimental uncertainty $( \pm 15 \%)$, all analyte concentrations were in agreement. However, one exception was noted: the measured aqueous Pu concentration was $2 \times$ higher than the calculated value. It is hypothesized that the increased $\mathrm{Pu}$ concentration was associated with chemistry specific to the combination of Group 6 saltcake supernatant and Group 5 solids. The same Pu concentration effect was observed in the CUF feed (see Section 4), and in this case, fluoride and oxalate concentrations were measured and were markedly higher than the simple mathematically combined 
values. Both fluoride and oxalate are known to complex $\mathrm{Pu}$, and dissolution of these components would reasonably correspond to $\mathrm{Pu}$ dissolution.

Table 3.2 provides the compositions of the input solids, input supernatant, caustic-leach solution, composite-solids wash solutions, and washed solids. The percent of analyte leached from the solids as a result of the caustic leaching process is also provided using two calculation methods: 1) evaluation of component concentrations in the aqueous phases and 2) evaluation of the caustic-leached and washed solids. The first method calculated the total mass of dissolved analyte before caustic leaching and again after caustic leaching. The net increase in dissolved mass was attributed to leaching from the solids component. This net dissolved mass was ratioed to the initial analyte mass in the solids to determine the fraction leached. The second method is the same that was previously reported in Fiskum et al. (2008). The analysis of the leachate solutions showed that $\mathrm{Fe}, \mathrm{Mn}$, and $\mathrm{Sr}$ were not dissolved by caustic leaching. The relative concentration factor (CF) of these analytes averaged 1.48 in the final leached solids, based on the ratio of concentration after caustic leaching to the concentration before leaching. This term was used to determine the specific analyte leach factors according to Equation 3.1:

$$
L F=1-\left(\frac{C_{L}}{C_{I} \times 1.48}\right)
$$

where LF is the caustic-leach factor, $\mathrm{C}_{\mathrm{L}}$ is the caustic leached and washed analyte concentration in the solids, and $\mathrm{C}_{\mathrm{I}}$ is the initial analyte concentration in the solids. 
Table 3.2. Caustic-Leaching Process Solutions and Solids Composition

\begin{tabular}{|c|c|c|c|c|c|c|c|c|}
\hline $\begin{array}{l}\text { Sample } \\
\text { Description> }\end{array}$ & Initial Solids & Supernatant & $\begin{array}{c}\text { Caustic-Leach } \\
\text { Solution } \\
\end{array}$ & $\begin{array}{c}\text { Combined } \\
\text { Wash Solution }\end{array}$ & $\begin{array}{c}\text { Final Contact } \\
\text { Solution }^{(a)}\end{array}$ & $\begin{array}{l}\text { Fraction } \\
\text { Leached }\end{array}$ & $\begin{array}{c}\text { Caustic- } \\
\text { Leached and } \\
\text { Washed Solids }\end{array}$ & $\begin{array}{l}\text { Fraction } \\
\text { Leached }\end{array}$ \\
\hline Sample ID> & Calculated & $\begin{array}{c}\text { 546-G5\&6-Sl- } \\
\text { L } \\
\end{array}$ & 546-G5\&6-CL2 & $\begin{array}{c}\text { 546-G5\&6- } \\
\text { Wash } \\
\end{array}$ & $\begin{array}{c}\text { 546-G5\&6-CL- } \\
\text { S1 Sup } \\
\end{array}$ & $\begin{array}{l}\text { Solutions } \\
\text { Analysis }\end{array}$ & $\begin{array}{c}\text { 546-G5\&6-CLS- } \\
\text { Fus1 }\end{array}$ & $\begin{array}{c}\text { Solids } \\
\text { analysis }^{(e)} \\
\end{array}$ \\
\hline Analyte & $\mu \mathrm{Ci} / \mathrm{g}^{(\mathbf{b})}$ & $\mu \mathrm{Ci} / \mathrm{mL}$ & $\mu \mathrm{Ci} / \mathrm{mL}$ & $\mu \mathrm{Ci} / \mathrm{mL}$ & $\mu \mathrm{Ci} / \mathrm{mL}$ & $\%$ & $\mu \mathrm{Ci} / \mathbf{g}^{(\mathbf{b})}$ & $\%$ \\
\hline${ }^{238} \mathrm{Pu}$ & $5.68 \mathrm{E}-2$ & $2.13 \mathrm{E}-5$ & $4.14 \mathrm{E}-6$ & $4.23 \mathrm{E}-7$ & $6.21 \mathrm{E}-7$ & $-0.059^{\text {(d) }}$ & $7.97 \mathrm{E}-2$ & 5.1 \\
\hline${ }^{239+240} \mathrm{Pu}$ & $9.79 \mathrm{E}-1$ & $1.53 \mathrm{E}-4$ & $3.13 \mathrm{E}-5$ & $4.36 \mathrm{E}-6$ & $2.67 \mathrm{E}-6$ & $-0.023^{(\mathrm{d})}$ & $1.46 \mathrm{E}+0$ & $-0.60^{(\mathrm{d})}$ \\
\hline${ }^{238+239+240} \mathrm{Pu}$ & $1.04 \mathrm{E}+0$ & $1.74 \mathrm{E}-4$ & $3.54 \mathrm{E}-5$ & $4.78 \mathrm{E}-6$ & $3.29 \mathrm{E}-6$ & $-0.025^{(\mathrm{d})}$ & $1.54 \mathrm{E}+0$ & $-0.29^{(\mathrm{d})}$ \\
\hline${ }^{90} \mathrm{Sr}$ & $5.97 \mathrm{E}+2$ & \multirow{6}{*}{\multicolumn{5}{|c|}{$\mathrm{n} / \mathrm{a}$}} & $8.55 \mathrm{E}+2$ & 3.2 \\
\hline${ }^{60} \mathrm{Co}$ & $3.00 \mathrm{E}-2$ & & & & & & $4.20 \mathrm{E}-2$ & 5.4 \\
\hline${ }^{137} \mathrm{Cs}$ & $7.35 \mathrm{E}+1$ & & & & & & $7.59 \mathrm{E}+1$ & 30 \\
\hline${ }^{154} \mathrm{Eu}$ & $5.56 \mathrm{E}-1$ & & & & & & $8.33 \mathrm{E}-1$ & $-1.2^{(\mathrm{d})}$ \\
\hline${ }^{155} \mathrm{Eu}$ & $2.15 \mathrm{E}-1$ & & & & & & $2.99 \mathrm{E}-1$ & 6.0 \\
\hline${ }^{241} \mathrm{Am}$ & $1.70 \mathrm{E}+0$ & & & & & & $2.73 \mathrm{E}+0$ & $-8.6^{(\mathrm{d})}$ \\
\hline Analyte & $\mu \mathrm{g} / \mathrm{g}$ & $\mu \mathrm{g} / \mathrm{mL}$ & $\mu \mathrm{g} / \mathrm{mL}$ & $\mu \mathrm{g} / \mathrm{mL}$ & $\mu \mathrm{g} / \mathrm{mL}$ & $\%$ & $\mu \mathrm{g} / \mathrm{g}$ & $\%$ \\
\hline $\mathrm{Al}$ & 312,500 & 5,246 & 15,180 & 2,540 & 280 & 34 & 288,000 & 38 \\
\hline $\mathrm{B}$ & $<93$ & 40.0 & 27.4 & {$[8.7]$} & {$[1.5]$} & {$[200]^{(\mathrm{c})}$} & $<206$ & na \\
\hline $\mathrm{Cd}$ & 48 & $<0.31$ & $<0.32$ & $<0.31$ & $<0.062$ & $<17$ & {$[64]$} & 10 \\
\hline $\mathrm{Cr}$ & 31,600 & 821 & 433 & 75.7 & 180 & 8.1 & 39,650 & 15 \\
\hline $\mathrm{Fe}$ & 10,360 & $<2.6$ & {$[10]$} & $<2.6$ & $<0.52$ & {$[0.45]$} & 14,950 & 2.4 \\
\hline $\mathrm{Mn}$ & 4,986 & $<0.26$ & $<0.27$ & $<0.26$ & $<0.053$ & $<0.14$ & 7,395 & $-0.28^{(\mathrm{d})}$ \\
\hline $\mathrm{Na}$ & {$[73,000]$} & 109,300 & 186,200 & 31,150 & 7,328 & na & {$[58,500]$} & 46 \\
\hline $\mathrm{S}$ & $<490$ & 1,617 & 512 & {$[84]$} & {$[16]$} & na & {$[1,853]$} & na \\
\hline $\mathrm{Si}$ & 11,800 & 71.2 & 50.0 & {$[5.0]$} & 10.2 & {$[1.7]$} & 20,100 & $-15^{(d)}$ \\
\hline $\mathrm{Sr}$ & [920] & {$[0.034]$} & {$[0.030]$} & $<0.022$ & $<0.004$ & {$[0.0035]$} & 1,385 & $-2.1^{(\mathrm{d})}$ \\
\hline $\mathrm{U}$ & {$[17,000]$} & $<11$ & $<11$ & $<11$ & $<2.2$ & $<1.6$ & {$[27,000]$} & $-5.3^{(\mathrm{d})}$ \\
\hline $\mathrm{Zn}$ & 377 & $<0.73$ & 8.24 & {$[1.3]$} & $<0.15$ & {$[17]$} & [320] & 43 \\
\hline $\mathrm{Zr}$ & [230] & $<1.0$ & {$[1.2]$} & $<1.0$ & $<0.21$ & {$[2.4]$} & [143] & 59 \\
\hline
\end{tabular}


Table 3.2 (contd)

\begin{tabular}{|c|c|c|c|c|c|c|c|c|}
\hline $\begin{array}{l}\text { Sample } \\
\text { Description> }\end{array}$ & Initial Solids & Supernatant & $\begin{array}{c}\text { Caustic-Leach } \\
\text { Solution }\end{array}$ & $\begin{array}{c}\text { Combined } \\
\text { Wash Solution }\end{array}$ & $\begin{array}{l}\text { Final Contact } \\
\text { Solution }^{(a)}\end{array}$ & $\begin{array}{l}\text { Fraction } \\
\text { Leached }\end{array}$ & $\begin{array}{c}\text { Caustic- } \\
\text { Leached and } \\
\text { Washed Solids }\end{array}$ & $\begin{array}{l}\text { Fraction } \\
\text { Leached }\end{array}$ \\
\hline Sample ID> & Calculated & $\begin{array}{c}\text { 546-G5\&6-SI- } \\
\text { L }\end{array}$ & 546-G5\&6-CL2 & $\begin{array}{c}\text { 546-G5\&6- } \\
\text { Wash }\end{array}$ & $\begin{array}{c}\text { 546-G5\&6-CL- } \\
\text { S1 Sup }\end{array}$ & $\begin{array}{l}\text { Solutions } \\
\text { Analysis }\end{array}$ & $\begin{array}{c}\text { 546-G5\&6-CLS- } \\
\text { Fus1 }\end{array}$ & $\begin{array}{c}\text { Solids } \\
\text { analysis }^{(\mathrm{e})}\end{array}$ \\
\hline Analyte & $\mu \mathrm{Ci} / \mathbf{g}^{(\mathbf{b})}$ & $\mu \mathrm{Ci} / \mathrm{mL}$ & $\mu \mathrm{Ci} / \mathrm{mL}$ & $\mu \mathrm{Ci} / \mathrm{mL}$ & $\mu \mathrm{Ci} / \mathrm{mL}$ & $\%$ & $\mu \mathrm{Ci} / \mathbf{g}^{(\mathbf{b})}$ & $\%$ \\
\hline $\mathrm{U}$ (KPA) & 17,020 & \multicolumn{5}{|c|}{$\mathrm{n} / \mathrm{a}$} & $2.63 \mathrm{E}+4$ & $-4.6^{(\mathrm{d})}$ \\
\hline Analyte & na & $\mathbf{M}$ & $\mathbf{M}$ & $\mathbf{M}$ & $\mathbf{M}$ & & & \\
\hline $\mathrm{OH}$ & na & 0.59 & 6.13 & $\mathrm{n} / \mathrm{a}$ & 0.23 & -- & -- & -- \\
\hline $\begin{array}{l}\text { (a) Final aqu } \\
\text { (b) Dried, w } \\
\text { (c) The high } \\
\text { (d) Two sigr } \\
\text { uncertair } \\
\text { (e) The fract } \\
\text { Notes: } \\
\text { Analyte unce } \\
\text { detection lim } \\
\text { ASR = 8032 } \\
\text { na = not appl }\end{array}$ & $\begin{array}{l}\text { ous componen } \\
\text { hed solids bas } \\
3 \text { recovery was } \\
\text { ficant figures a } \\
\text {, see text. } \\
\text { n leached was } \\
\text { ainties were ty } \\
\text { (MDL) and les } \\
\text { able; } \mathrm{n} / \mathrm{a}=\text { not }\end{array}$ & $\begin{array}{l}\text { that was in cont } \\
\text { onsidered an ar } \\
\text { shown for info } \\
\text { letermined acco } \\
\text { cally within } \pm 1 \\
\text { than the estima } \\
\text { nalyze date: Noven }\end{array}$ & $\begin{array}{l}\text { t with the causti } \\
\text { act of the analyt } \\
\text { nation; negative } \\
\text { ing to Equation } \\
\text { o; results in brac } \\
\text { d quantitation lir } \\
\text { er } 5,2007 \text {. }\end{array}$ & $\begin{array}{l}\text {-leached and wa } \\
\text { cal process; it wo } \\
\text { each values are } r \\
1 \\
\text { rets indicate that } \\
\text { it (EQL), and ur }\end{array}$ & $\begin{array}{l}\text { hed solids. } \\
\text { probably extrac } \\
\text { tt realistic. How } \\
\text { he analyte conce } \\
\text { certainties were }>\end{array}$ & $\begin{array}{l}\text { from the } b \\
\text { r, they are } \\
\text { ations were } \\
\% \text {. }\end{array}$ & $\begin{array}{l}\text { osilicate glass con } \\
\text { dicative of the cal } \\
\text { reater than the min }\end{array}$ & $\begin{array}{l}\text { iner. } \\
\text { lation } \\
\text { mum }\end{array}$ \\
\hline
\end{tabular}


Calculated negative leach factors were artifacts of the analytical uncertainties in the initial and final aqueous phase and solids phase concentrations. Ideally, the leach factors calculated using both methods will agree. However, the solution analysis typically resulted in superior detection limits resulting and less sampling uncertainty leading to greater confidence in more accurate leach factors. The two methods used for determining the caustic-leach factors agreed reasonably well for $\mathrm{Al}(36 \%)$; the $\mathrm{Cr}$ caustic-leach factors varied by a factor of $\sim 2(8 \%$ and $15 \%)$. The ${ }^{239+240} \mathrm{Pu}$ caustic-leach factor varied between the two methods $(-0.023 \%$ and $0.60 \%)$ although it was low in either case.

The $\mathrm{Cr}$ oxidative leach characteristics as a function of time for various $\mathrm{Mn} / \mathrm{Cr}$ mole ratios determined as part of Phase 1 testing are shown in Figure 3.6 (plotted values are provided in Appendix B). If all $\mathrm{Cr}$ dissolved, the final $\mathrm{Cr}$ concentration would be $0.0116 \mathrm{M}$ (incorporates a calculated $15 \% \mathrm{Cr}$ leach factor during caustic leaching and washing - refer to Table 3.2). Under all $\mathrm{Mn} / \mathrm{Cr}$ mole ratio conditions, equilibrium was reached within $1 \mathrm{~h}$.

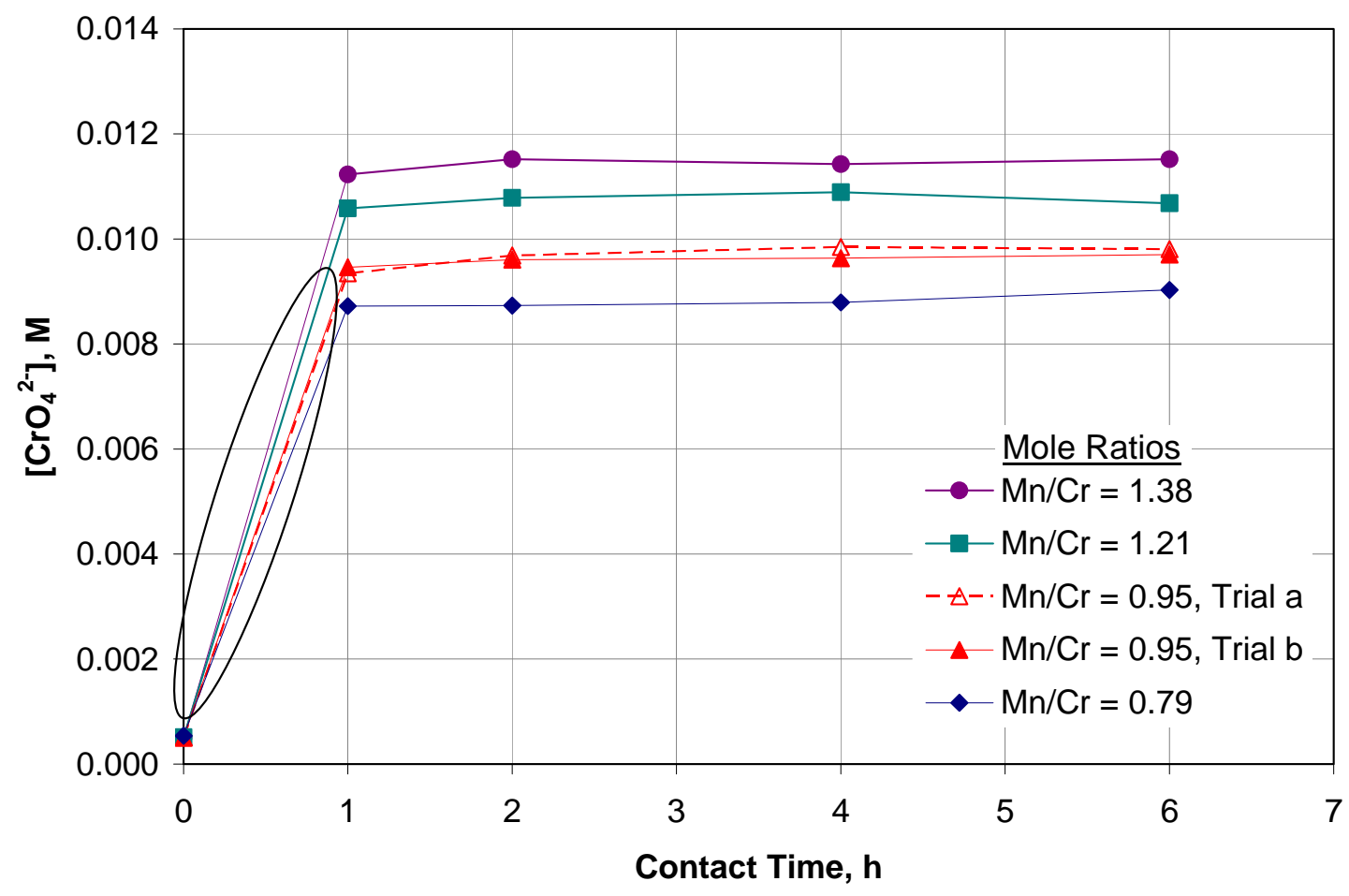

Figure 3.6. Chromate Concentration Versus Oxidative Leach Time at Four Mn/Cr Molar Ratios Process conditions: $0.25 \mathrm{M} \mathrm{NaOH}$ matrix at room temperature Chromate was measured by UV-Vis spectrophotometry.

The actual dissolution behavior identified by the lines shown in the ellipse was not measured and is not known.

Figure 3.7 shows the relationship of the $\mathrm{Cr}$ fraction leached from the solids phase as a function of $\mathrm{Mn} / \mathrm{Cr}$ mole ratio (6-h contact time). The $\mathrm{Cr}$ leach function of the Group 5/6 composite showed a fairly linear relationship within the range of $\mathrm{Mn} / \mathrm{Cr}$ mole ratios tested according to Equation 3.1.

$$
L F_{C r}=0.35 \times R+0.50
$$


where $\mathrm{LF}_{\mathrm{Cr}}=$ chromium leach factor, and $\mathrm{R}=\mathrm{Mn} / \mathrm{Cr}$ mole ratio. For comparison, the data generated from Group 6 parametric testing ( $0.25 \mathrm{M} \mathrm{NaOH}$ matrix) are also provided. The slopes of the lines are different; however, within analytical uncertainties, they might be comparable.

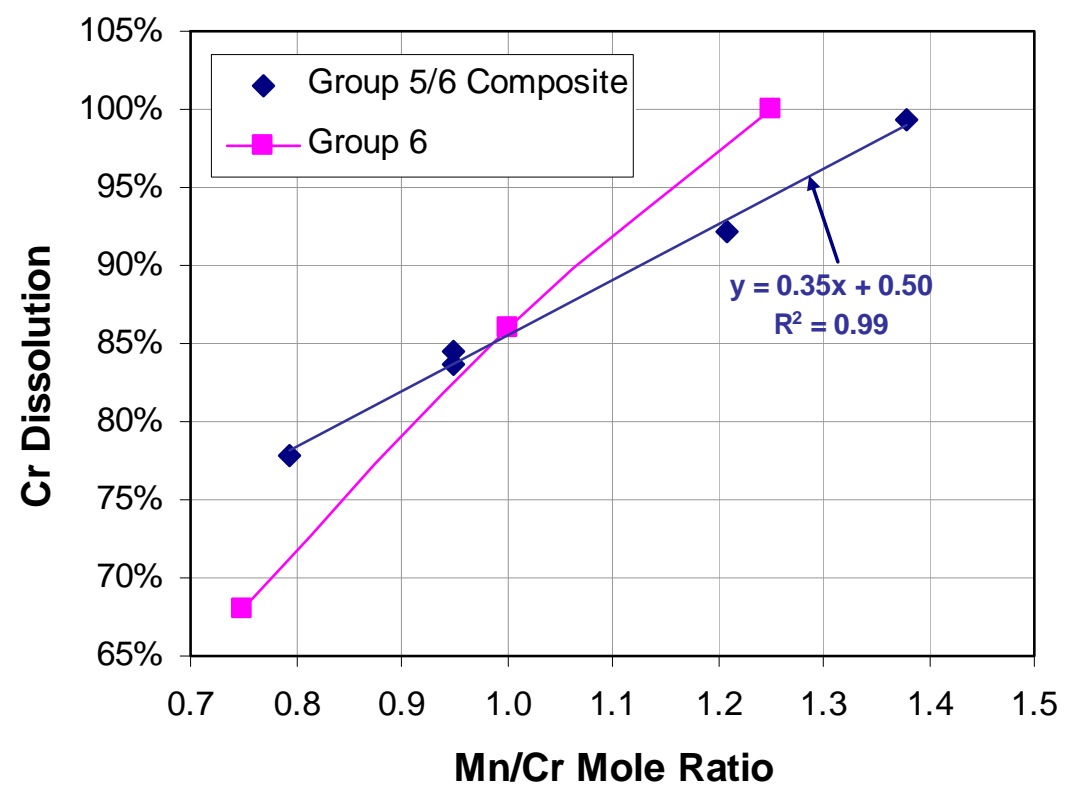

Figure 3.7. Cr Dissolution in Group 5/6 Composite as a Function of the Mn/Cr Mole Ratio

$$
\begin{array}{ll}
\text { Notes: } & \text { Matrix } \\
\text { Contact time } & =6.25 \mathrm{M} \mathrm{NaOH} \\
\text { Leach temperature } \approx 25^{\circ} \mathrm{C} \\
\text { Group } 6 \text { data from Fiskum et al. (2008) }
\end{array}
$$

The solids remaining after oxidative leaching at a $\mathrm{Mn} / \mathrm{Cr}$ ratio of 0.95 were washed and analyzed. The analysis was conducted on each of the duplicates in parallel. The average analytical results with RPDs (a measure of duplicate precision) of the wash solution and solids are shown in Table 3.3. The corresponding leach factors are also provided. Leach factors were calculated from the sum of analyte measured in the oxidative leach and wash solution. Leach factors were also calculated from the solids composition with incorporation of the calculated concentration factor, 1.10 , an average of the $\mathrm{Pu}, \mathrm{U},{ }^{90} \mathrm{Sr}$, ${ }^{241} \mathrm{Am}, \mathrm{Al}, \mathrm{Cd}, \mathrm{Fe}$, and $\mathrm{Zn}$ concentrations. In the case of $\mathrm{Cr}$, the leach factor derived from the solids analysis, $93 \%$, was considered more definitive than that derived from the solutions analysis. In the latter case, the mass balance was too high. About 1.0 to $2.9 \%$ of the Pu was mobilized during the oxidative leach process. 
Table 3.3. Oxidative Leaching Process Solutions and Solids Composition

\begin{tabular}{|c|c|c|c|c|c|c|c|c|c|}
\hline \multirow{3}{*}{\begin{tabular}{||l|l}
$\begin{array}{l}\text { Sample } \\
\text { Description> }\end{array}$ \\
\cline { 2 - 3 } \\
Sample ID>
\end{tabular}} & \multirow{3}{*}{\begin{tabular}{|c|} 
Initial Solids \\
546-G5\&6- \\
CLS-Fus1 \\
$\mu \mathrm{Ci} / \mathbf{g}^{(\mathbf{b})}$
\end{tabular}} & \multirow{2}{*}{\multicolumn{2}{|c|}{$\begin{array}{c}\text { Average Leach Solution } \\
546-G 5 \& 6-1.0 a \\
\text { and }-1.0 b^{(a)}\end{array}$}} & \multirow{2}{*}{\multicolumn{2}{|c|}{$\begin{array}{c}\text { Average Wash Composite } \\
\text { 546-G5\&6-1-Wcomp-1a } \\
\text { and -1b }\end{array}$}} & \multirow{3}{*}{$\begin{array}{c}\begin{array}{c}\text { Fraction } \\
\text { Leached }\end{array} \\
\text { (Solutions } \\
\text { Analysis) } \\
\% \\
\end{array}$} & \multirow{2}{*}{\multicolumn{2}{|c|}{$\begin{array}{c}\begin{array}{c}\text { Oxidatively Leached and } \\
\text { Washed Solids }\end{array} \\
\text { 546-G5\&6-1a-LS } \\
\text { and 1b-LS }\end{array}$}} & \multirow{3}{*}{$\begin{array}{c}\begin{array}{c}\text { Fraction } \\
\text { Leached }\end{array} \\
\begin{array}{c}\text { (Solids } \\
\text { Analysis) }\end{array} \\
\% \\
\%\end{array}$} \\
\hline & & & & & & & & & \\
\hline & & $\mu \mathrm{Ci} / \mathrm{mL}$ & RPD \% & $\mu \mathrm{Ci} / \mathrm{mL}$ & RPD \% & & $\mu \mathrm{Ci} / \mathbf{g}^{(\mathbf{b})}$ & RPD \% & \\
\hline${ }^{238} \mathrm{Pu}$ & $7.97 \mathrm{E}-2$ & $2.92 \mathrm{E}-5$ & 0.7 & $<4 . \mathrm{E}-7$ & na & 2.4 & $9.33 \mathrm{E}-2$ & $21 \%$ & $-6.6^{(\mathrm{d})}$ \\
\hline${ }^{239+240} \mathrm{Pu}$ & $1.46 \mathrm{E}+0$ & $2.10 \mathrm{E}-4$ & 8.0 & $4.28 \mathrm{E}-6$ & 30 & 1.0 & $1.55 \mathrm{E}+0$ & $2.1 \%$ & 2.9 \\
\hline${ }^{238+239+240} \mathrm{Pu}$ & $1.54 \mathrm{E}+0$ & $2.39 \mathrm{E}-4$ & 6.9 & $4.58 \mathrm{E}-6$ & 32 & 1.0 & $1.65 \mathrm{E}+0$ & $0.8 \%$ & 2.4 \\
\hline${ }^{90} \mathrm{Sr}$ & $8.55 \mathrm{E}+2$ & & & & & & $9.66 \mathrm{E}+2$ & $0.41 \%$ & $-3.0^{(\mathrm{d})}$ \\
\hline${ }^{60} \mathrm{Co}$ & $4.20 \mathrm{E}-2$ & & & & & & $4.69 \mathrm{E}-2$ & $0.21 \%$ & $-1.6^{(\mathrm{d})}$ \\
\hline${ }^{137} \mathrm{Cs}$ & $7.59 \mathrm{E}+1$ & & & $\mathrm{n} / \mathrm{a}$ & & & $6.53 \mathrm{E}+1$ & $1.5 \%$ & 22 \\
\hline${ }^{154} \mathrm{Eu}$ & $8.33 \mathrm{E}-1$ & & & & & & $7.84 \mathrm{E}-1$ & $19 \%$ & 14 \\
\hline${ }^{155} \mathrm{Eu}$ & $2.99 \mathrm{E}-1$ & & & & & & $2.62 \mathrm{E}-1$ & $22 \%$ & 20 \\
\hline${ }^{241} \mathrm{Am}$ & $2.73 \mathrm{E}+0$ & & & & & & $2.84 \mathrm{E}+0$ & $1.8 \%$ & 5.4 \\
\hline Analyte & $\mu \mathrm{g} / \mathrm{g}$ & $\mu \mathrm{g} / \mathrm{mL}$ & RPD \% & $\mu \mathrm{g} / \mathrm{mL}$ & RPD \% & $\%$ & $\mu \mathrm{g} / \mathrm{g}$ & RPD \% & $\%$ \\
\hline $\mathrm{Al}$ & 288,000 & 102 & 2.2 & 19.6 & 0.1 & 2.3 & 313,500 & $0.32 \%$ & 0.86 \\
\hline $\mathrm{B}$ & $<206$ & $<0.53$ & na & $<0.47$ & na & $<17$ & [120] & [8.3\%] & [47] \\
\hline $\mathrm{Cd}$ & {$[64]$} & $<0.062$ & na & $<0.063$ & na & $<6.4$ & [71] & {$[1.1 \%]$} & {$[-1.7]^{(d)}$} \\
\hline $\mathrm{Cr}$ & 39,650 & 566 & 1.8 & 31.0 & 1.6 & 94 & 3,020 & $10.6 \%$ & 93 \\
\hline $\mathrm{Fe}$ & 14,950 & $<0.52$ & na & $<0.53$ & na & $<0.23$ & 15,920 & $5.97 \%$ & 3.0 \\
\hline $\mathrm{Mn}$ & 7,395 & 32.6 & 77 & {$[0.088]$} & 59 & na & 52,170 & $0.10 \%$ & na \\
\hline $\mathrm{Na}$ & {$[58,500]$} & 6,356 & 0.89 & 567 & 1.9 & na & {$[33,500]$} & {$[3.0 \%]$} & na \\
\hline $\mathrm{S}$ & {$[1,900]$} & $<8.3$ & na & $<8.5$ & na & $<30$ & $<798$ & na & na \\
\hline $\mathrm{Si}$ & 20,100 & 6.08 & 4.1 & {$[1.2]$} & 10 & 2.0 & 19,420 & $2.32 \%$ & 12 \\
\hline $\mathrm{Sr}$ & 1,385 & $<0.005$ & na & {$[0.005]$} & 14 & $<0.03$ & 1,510 & $0.66 \%$ & 0.70 \\
\hline $\mathrm{U}$ & {$[27,000]$} & $<2.14$ & na & $<2.2$ & na & $<0.52$ & 29,370 & $0.85 \%$ & 0.91 \\
\hline $\mathrm{Zn}$ & {$[320]$} & $<0.15$ & na & {$[0.42]$} & 49 & $<3.0$ & [353] & {$[41 \%]$} & $-0.33^{(\mathrm{d})}$ \\
\hline $\mathrm{Zr}$ & [140] & $<0.21$ & na & $<0.21$ & na & $<10$ & [392] & [49\%] & {$[-150]^{(\mathrm{d})}$} \\
\hline $\mathrm{U}(\mathrm{KPA})$ & 26,300 & & & $\mathrm{n} / \mathrm{a}$ & & & 29,100 & $2.4 \%$ & -0.65 \\
\hline
\end{tabular}


Table 3.3 (notes)

(a) The nominal free-hydroxide concentration during the oxidative leach processing was estimated to be $0.23 \mathrm{M}$, based on the final-solution freehydroxide concentration in contact with the caustic leached and washed solids (see Table 3.2).

(b) Dried, washed solids basis.

(c) The fraction leached was determined according to Equation 3.1

(d) Two significant figures are shown for information; negative leach values are not realistic. However, they are indicative of the calculation uncertainty—see text.

Notes:

Analyte uncertainties were typically within $\pm 15 \%$; results in brackets indicate that the analyte concentrations were greater than the minimum detection

limit (MDL) and less than the estimated quantitation limit (EQL), and uncertainties were $>15 \%$.

$\mathrm{ASR}=8032$ and 8020; Reference date: November 5, 2007.

$\mathrm{RPD}=$ relative percent difference

na $=$ not applicable; $\mathrm{n} / \mathrm{a}=$ not analyzed

The leach fraction calculated from the solutions analysis was considered more realistic relative to that calculated from the solids analysis. 


\subsection{Phase 2 Testing Oxidative Leach Test Results}

Figure 3.8 shows the leachate $\mathrm{Cr}$ concentration as a function of time for the range of $\mathrm{NaOH}$ concentrations tested (plotted data are provided in Appendix B, Table B.2). The sodium hydroxide concentration was based on the measured sodium concentration by ICP-OES. The Cr concentration did not substantially change from the $0.3 \mathrm{M}$ to the $1.4 \mathrm{M} \mathrm{NaOH}$ matrices.

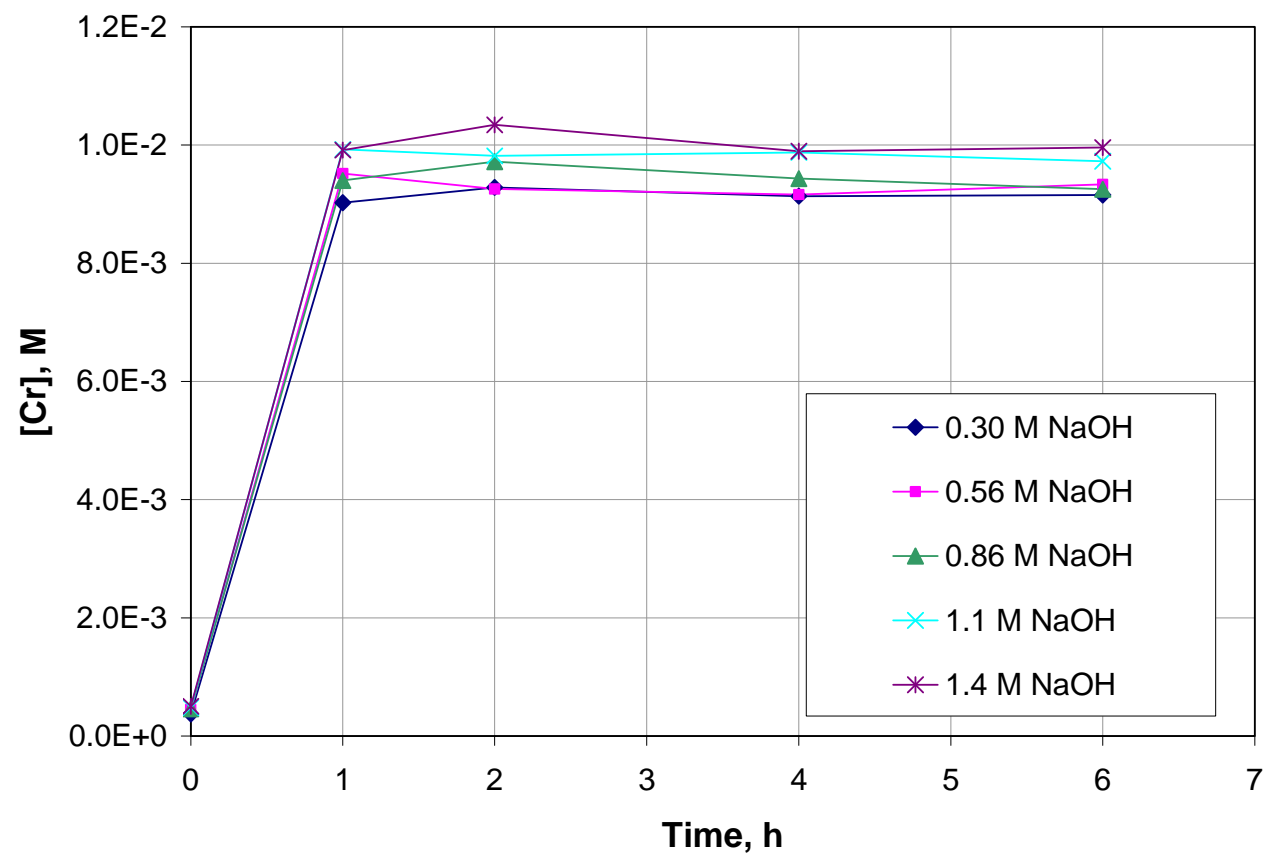

Figure 3.8. $\mathrm{Cr}$ in Leachate as a Function of Time and $\mathrm{NaOH}$ Concentration, $\mathrm{Mn} / \mathrm{Cr}$ Mole Ratio $=1.25$

Figure 3.9 shows the leachate $\mathrm{Pu}$ concentration as function of time for the various $\mathrm{NaOH}$ test matrices (plotted data are provided Appendix B, Table B.2). Clearly, increasing the sodium hydroxide concentration resulted in increasing Pu mobilization. Changing the sodium hydroxide concentration from $0.30 \mathrm{M}$ to $1.4 \mathrm{M}$ resulted in a 5-fold increase in the dissolved $\mathrm{Pu}$.

The final two Pu concentration values (hours 4 and 6) for each sodium hydroxide matrix were averaged and plotted as a function of $\mathrm{NaOH}$ concentration. Figure 3.10 shows the relationship of $\mathrm{Pu}$ activity concentration $\left({ }^{239+240} \mathrm{Pu}\right.$ plus $\left.{ }^{238} \mathrm{Pu}\right)$ as a function of the sodium hydroxide concentration. Also included is the datum associated with the Phase 1 test at $0.25 \mathrm{M} \mathrm{NaOH}$. A clear trend was observed with increasing $\mathrm{Pu}$ mobilization as a function of $\mathrm{NaOH}$ concentration. The slight variation in the $\mathrm{Mn} / \mathrm{Cr}$ mole ratio did not appear to disrupt the trend.

The relative amount of $\mathrm{Pu}$ mobilized from the solids phase to the aqueous phase is also provided in Figure 3.10. With $\mathrm{NaOH}$ concentrations $<0.25 \mathrm{M}$, the $\mathrm{Pu}$ mobilization during oxidative leaching is $\leq 1.5 \%$. 


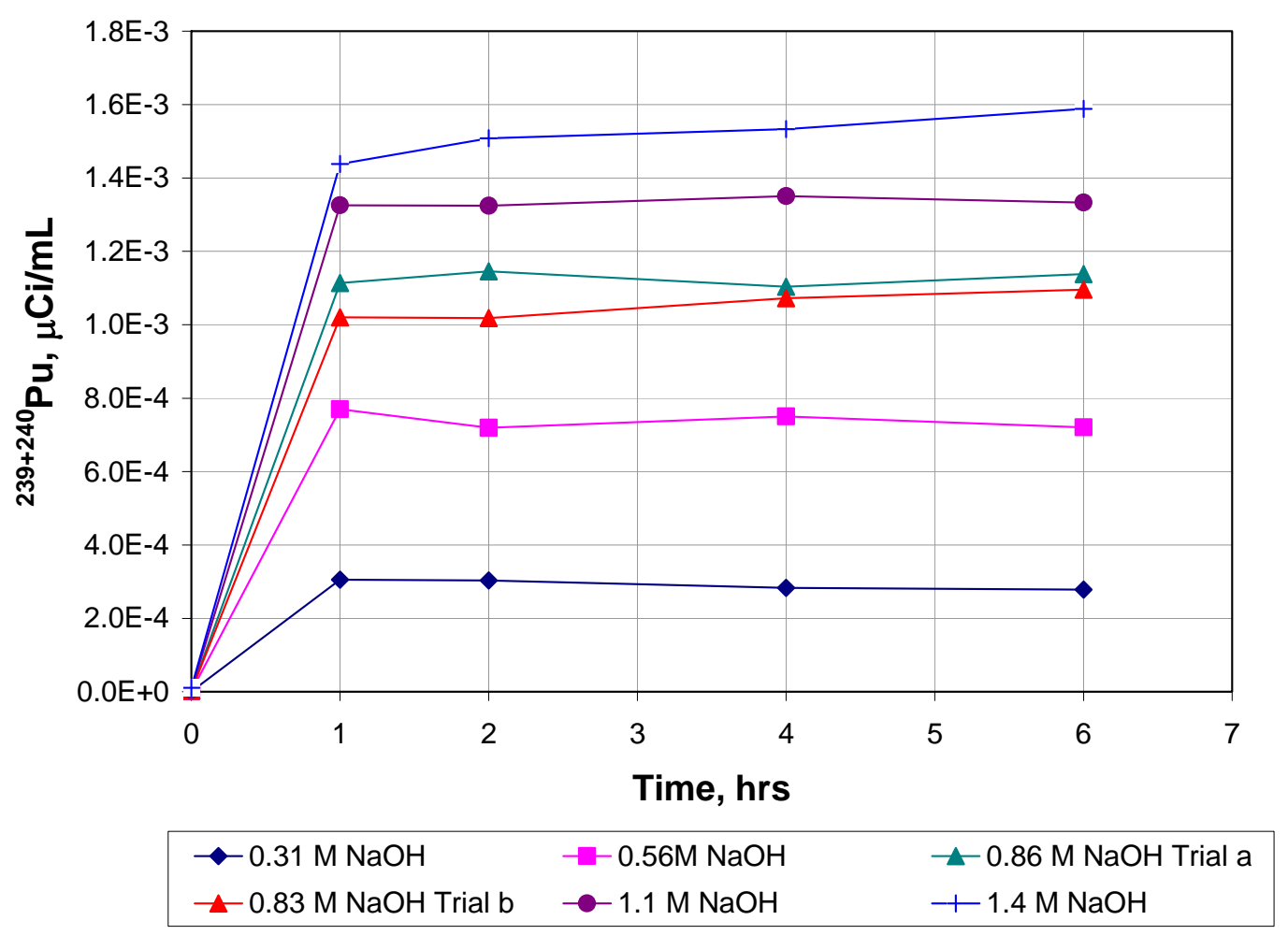

Figure 3.9. $\mathrm{Pu}$ Leachate Concentration as Function of Time and $\mathrm{NaOH}$ Concentration, $\mathrm{Mn} / \mathrm{Cr}$ Mole Ratio $=1.25$

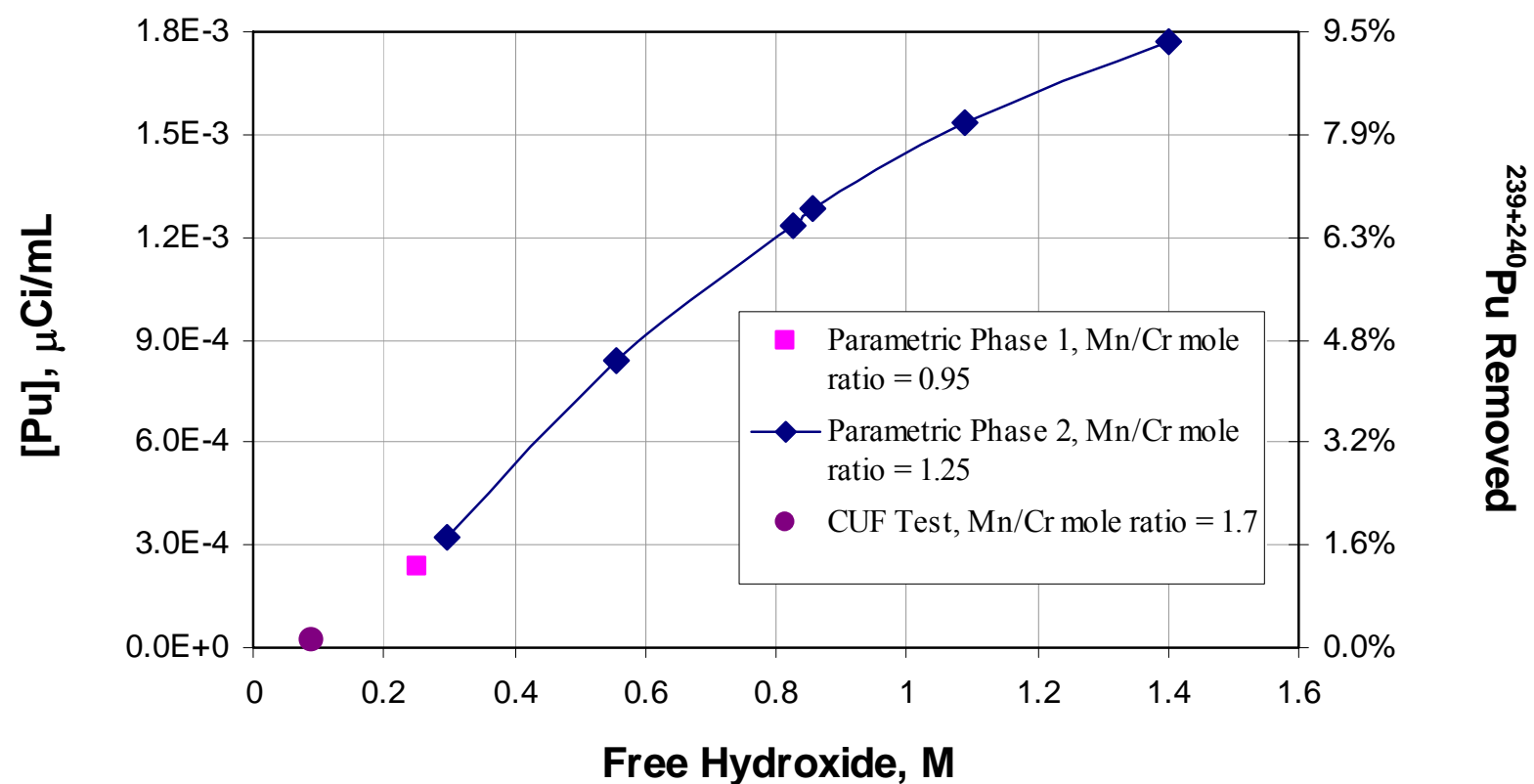

Figure 3.10. Equilibrium $\mathrm{Pu}$ Leachate Concentration as a Function of $\mathrm{NaOH}$ Concentration 
The $\mathrm{Pu}$ mobilization increase with increasing $\mathrm{NaOH}$ concentration was consistent with previous reported results (Delegard 2006). The parametric test results are compared to the data reported by Delegard in Figure 3.11. In this case, the Pu results were converted from activity concentration $(\mu \mathrm{Ci} / \mathrm{mL})$ to molarity using the specific activity of each $\mathrm{Pu}$ isotope. Since the isotopic distribution of $\mathrm{Pu}$ was not measured, the ${ }^{239+240} \mathrm{Pu}$ concentration was evaluated in two ways: as $100 \%{ }^{239} \mathrm{Pu}$ and as $100 \%{ }^{240} \mathrm{Pu}$. The difference between these calculations is a factor of 3.67; the true $\mathrm{Pu}$ concentration is anticipated to be in between these values. The ${ }^{238} \mathrm{Pu}$ concentration could be converted to molarity directly. No other $\mathrm{Pu}$ isotopic source (e.g., ${ }^{240} \mathrm{Pu}$ ) was included in this evaluation. The experimental dissolved $\mathrm{Pu}$ concentrations agreed well with the previously-published data.



\footnotetext{
$\multimap$ Current Parametric Test (calculated as Pu-239 + Pu-238)

- C Current Parametric Test (calculated as Pu-240 + Pu-238)

$+\mathrm{NaOH}$ only, 20 min (2 nm filter); Krot et al. (1998)

$\times \mathrm{NaOH}$ only, 2 days (3 nm filter); Delegard (1985)

$\square \quad$ With $1 \mathrm{MNaNO} 2$ \& 1 M NaNO3, 2 days (1.8 nm filter); Delegard, unpublished data

$\triangle$ With 0.1 M N2H4, 3 days (filter not stated); Peretrukhin et al. (1996)

O With $0.05 \mathrm{M} \mathrm{N} 2 \mathrm{H} 4,21$ days (3.6 nm filter); Delegard (1996)
}

Figure 3.11. Comparison of Parametric Pu Dissolution Study to Previously Published Results (Delegard 2006)

The parametric test data used in the plots are provided in Appendix B.

\subsection{Recommended Permanganate Dosage}

The amount of permanganate added to a slurry in an effort to oxidize $\mathrm{Cr}$ (III) to chromate will depend on the amount of chromium mobilization targeted to meet WTP processing and vitrification objectives. This will be driven in part by evaluating the glass-loading criteria relative to the waste form and 
composition at hand. The results indicated that nominally 1 mole of permanganate mobilized nominally 0.85 mole of $\mathrm{Cr}$; a $20 \%$ to $40 \%$ excess amount of permanganate was required to reach nearly $100 \% \mathrm{Cr}$ mobilization. The oxidation reaction was complete within $1 \mathrm{~h}$ at ambient temperature, so duration was shown to not be a critical parameter. Increased permanganate availability had no direct impact on enhanced $\mathrm{Pu}$ dissolution. The free-hydroxide concentration in the matrix did not affect the $\mathrm{Cr}$ oxidation/dissolution rate. However, to minimize concomitant $\mathrm{Pu}$ dissolution, the free-hydroxide concentration should be maintained low (see Figure 3.10).

The conditions forwarded for testing in the CUF were 1:1 Mn:Cr mole ratio, ambient process temperature, 6-h contact time, and $<0.25 \mathrm{M}$ free hydroxide.

\subsection{Phase Characterizations}

The crystal habit for both the caustic-leached and washed solids and the oxidatively leached and washed solids are described in the following sections.

\subsubsection{XRD}

The initial solids crystalline characteristics are shown in Figure 3.12. Supernatant entrainment was evident from the presence of sodium nitrate and sodium nitrite. As expected, boehmite $(\mathrm{AlOOH})$, gibbsite $\left(\mathrm{Al}(\mathrm{OH})_{3}\right)$, hydroxycancrinite $\left(1.06 \mathrm{Na}_{2} \mathrm{O} \cdot \mathrm{Al}_{2} \mathrm{O}_{3} \cdot 1.6 \mathrm{SiO}_{2} \cdot 1.6 \mathrm{H}_{2} \mathrm{O}\right)$, and cancrinite $\left(\mathrm{Na}_{7.14} \mathrm{Al}_{6} \mathrm{Si}_{7.08} \mathrm{O}_{26.73}\left(\mathrm{H}_{2} \mathrm{O}\right)_{4.87}\right)$ were identified by XRD. The sample also contained an amorphous component as indicated by the broad peak from about 12 to $24^{\circ} 2-\theta$ in the raw diffraction pattern (not background subtracted). These results agreed with a duplicate sample prepared with an internal standard (not shown).

Other phases in the initial solids were identified as possibly present. Three phases match peaks which could not be otherwise identified but could not be confirmed due to low intensity of confirming lines: silicon dioxide $\left(\mathrm{SiO}_{2}\right)$ matches the $14.94^{\circ} 2-\theta$ peak but required a $-2.4 \%$ shift in the A lattice parameter and $\mathrm{a}+3.0 \%$ shift in the $\mathrm{C}$ lattice parameter. Shifts this large are unusual and could be an indication that the actual phase is something closely related to that phase, particularly with the same structure and similar lattice parameter values, but could have completely different chemistry. A small peak at $30.79^{\circ} 2-\theta$ remains unmatched. A minor peak at $7.03^{\circ} 2-\theta$ could be due to silicon oxide $\left(\mathrm{Si}_{17} \mathrm{O}_{34}\right)$ but confirming lines were too low in intensity to detect. Sodium aluminum silicate nitrate hydrate $\left(\mathrm{Na}_{7.92}\left(\mathrm{AlSiO}_{4}\right)_{6}\left(\mathrm{NO}_{3}\right)_{1.74}\left(\mathrm{H}_{2} \mathrm{O}\right)_{2.34}\right)$ is similar to hydroxycancrinite and cancrinite. It has the same structural type (hexagonal) and the lattice parameter components differ by less than $0.5 \%$. The high $2-\theta$ degree line positions are slightly higher for this phase and not quiet as good of a match as hydroxycancrinite and cancrinite. Nitrate-cancrinite has been identified in Hanford tank wastes previously (Buck and McNamara 2004).

The XRD pattern for caustic-leached and washed solids is shown in Figure 3.13. Major phases identified by $\mathrm{XRD}$ were boehmite $(\mathrm{AlOOH})$, sodium uranium oxide $\left(\mathrm{Na}_{2} \mathrm{U}_{2} \mathrm{O}_{7}\right)$, cancrinite $\left(\mathrm{Na}_{7.14} \mathrm{Al}_{6} \mathrm{Si}_{7.08} \mathrm{O}_{26.73}\left(\mathrm{H}_{2} \mathrm{O}\right)_{4.87}\right)$, and hydroxycancrinite $\left(1.06 \mathrm{Na}_{2} \mathrm{O} \cdot \mathrm{Al}_{2} \mathrm{O}_{3} \cdot 1.6 \mathrm{SiO}_{2} \cdot 1.6 \mathrm{H}_{2} \mathrm{O}\right)$. Most peaks were well-matched by the identified phases but the $26.43^{\circ} 2-\theta$ peak intensity is only about half matched. The sample was moderately amorphous as indicated by the broad peak from about 12 to $24^{\circ} 2-\theta$ in the 
raw diffraction pattern (not background subtracted). Notably the gibbsite was absent and was thus successfully removed during the caustic-leach processing.

Phases possibly present in the caustic-leached and washed solids were calcium aluminum oxide hydrate $\left(\mathrm{Ca}_{2} \mathrm{Al}_{2} \mathrm{O}_{5} \cdot 8 \mathrm{H}_{2} \mathrm{O}\right)$ and hydrogen aluminum silicate $\left(\mathrm{H}_{12} \mathrm{Al}_{12} \mathrm{Si}_{36} \mathrm{O}_{96}\right)$. Calcium was not a significant chemical component so the possibility of calcium aluminum oxide hydrate was diminished. Confirming lines for hydrogen aluminum silicate were not detectable.

The oxidatively leached and washed solids X-ray diffraction pattern is shown in Figure 3.14. Major phases identified were boehmite $(\mathrm{AlOOH})$, sodium uranium oxide $\left(\mathrm{Na}_{2} \mathrm{U}_{2} \mathrm{O}_{7}\right)$, hydroxycancrinite $\left(1.06 \mathrm{Na}_{2} \mathrm{O} \cdot \mathrm{Al}_{2} \mathrm{O}_{3} \cdot 1.6 \mathrm{SiO}_{2} \cdot 1.6 \mathrm{H}_{2} \mathrm{O}\right)$, and cancrinite $\left(\mathrm{Na}_{7.14} \mathrm{Al}_{6} \mathrm{Si}_{7.08} \mathrm{O}_{26.73}\left(\mathrm{H}_{2} \mathrm{O}\right)_{4.87}\right)$. These phases provided a complete match to the observed diffraction pattern. The duplicate process sample (TI546-G5\&6-1b-LS) resulted in identical phase identification. The sample was highly amorphous as indicated by the broad peak from about 12 to $30^{\circ} 2-\theta$ in the raw diffraction pattern (not background subtracted). No indication of crystalline manganese dioxide $\left(\mathrm{MnO}_{2}\right)$ was seen. An internal standard was integrated in duplicate preparations of these samples; the results (not shown) were the same. 
a)



b)

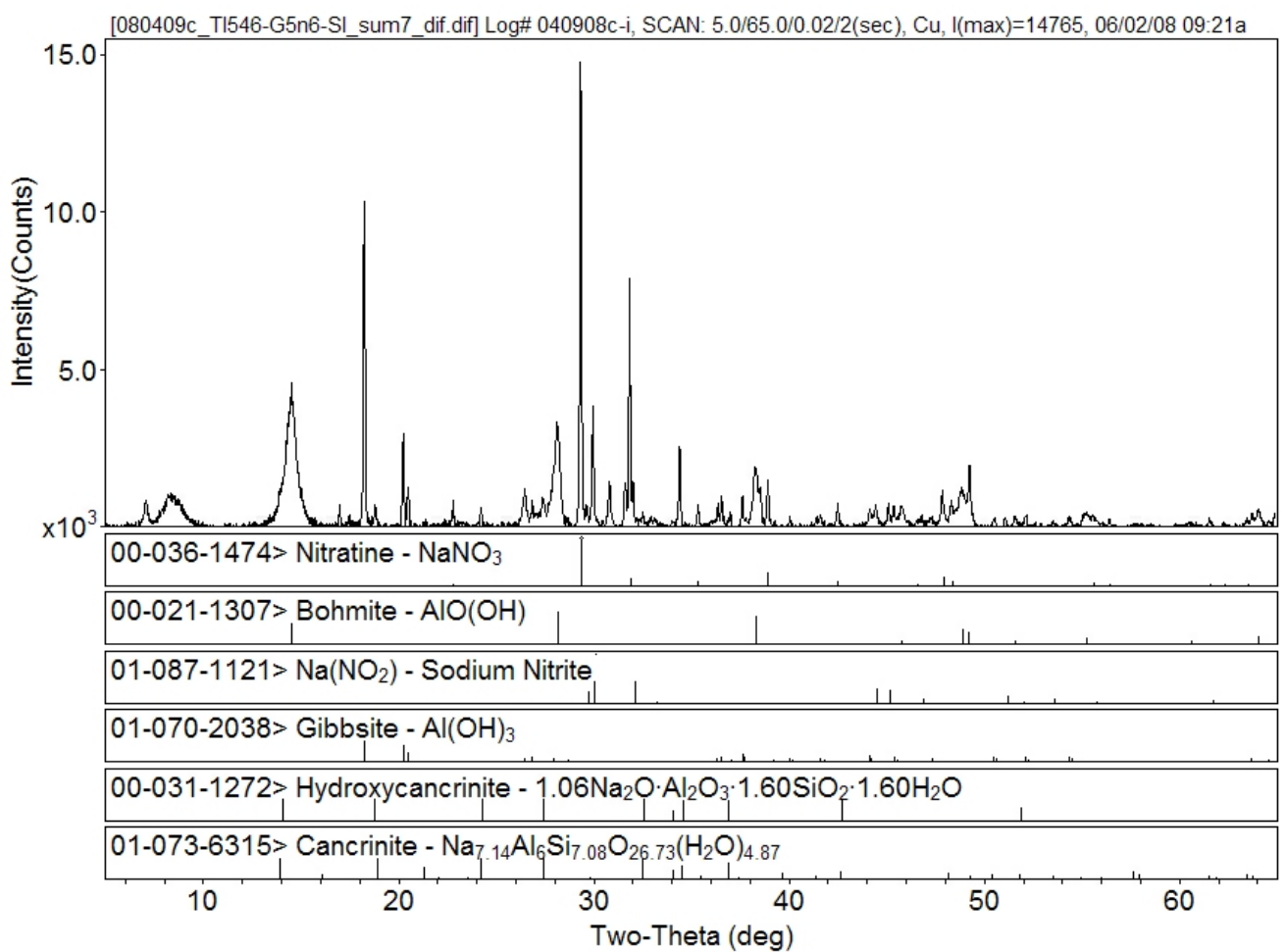

Figure 3.12. XRD Pattern for Initial Group 5/6 Composite (TI546-G5n6-S1) a) Raw diffraction pattern (no background subtraction) and b) Background-Subtracted with Stick-Figure Phase Identification 
a)



b)

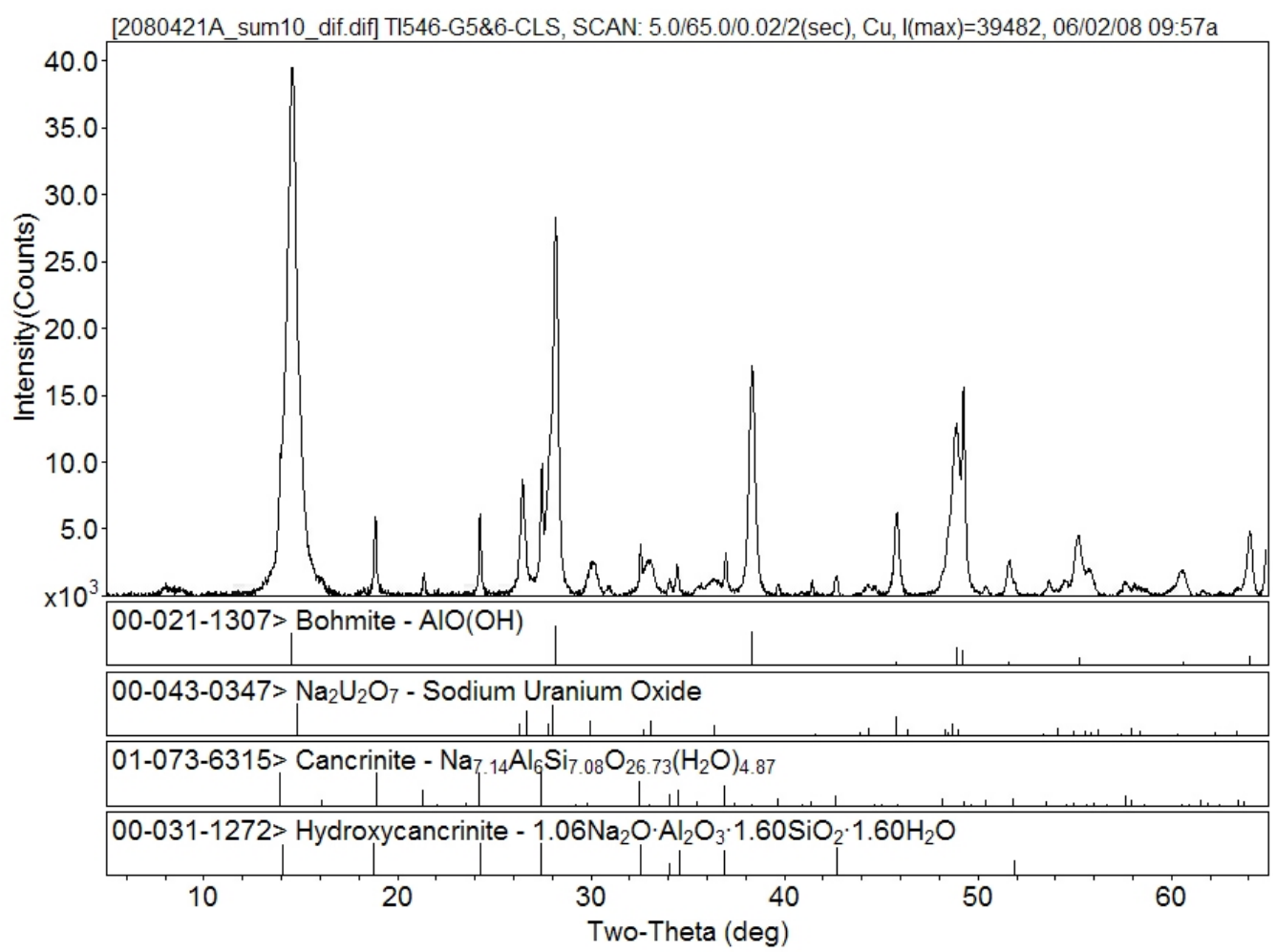

Figure 3.13. XRD Pattern for Caustic-Leached and Washed Group 5/6 Composite (TI546-G5\&6-CLS) a) Raw Diffraction Pattern (no background subtraction) and b) Background-Subtracted with Stick-Figure Phase Identification 
a)

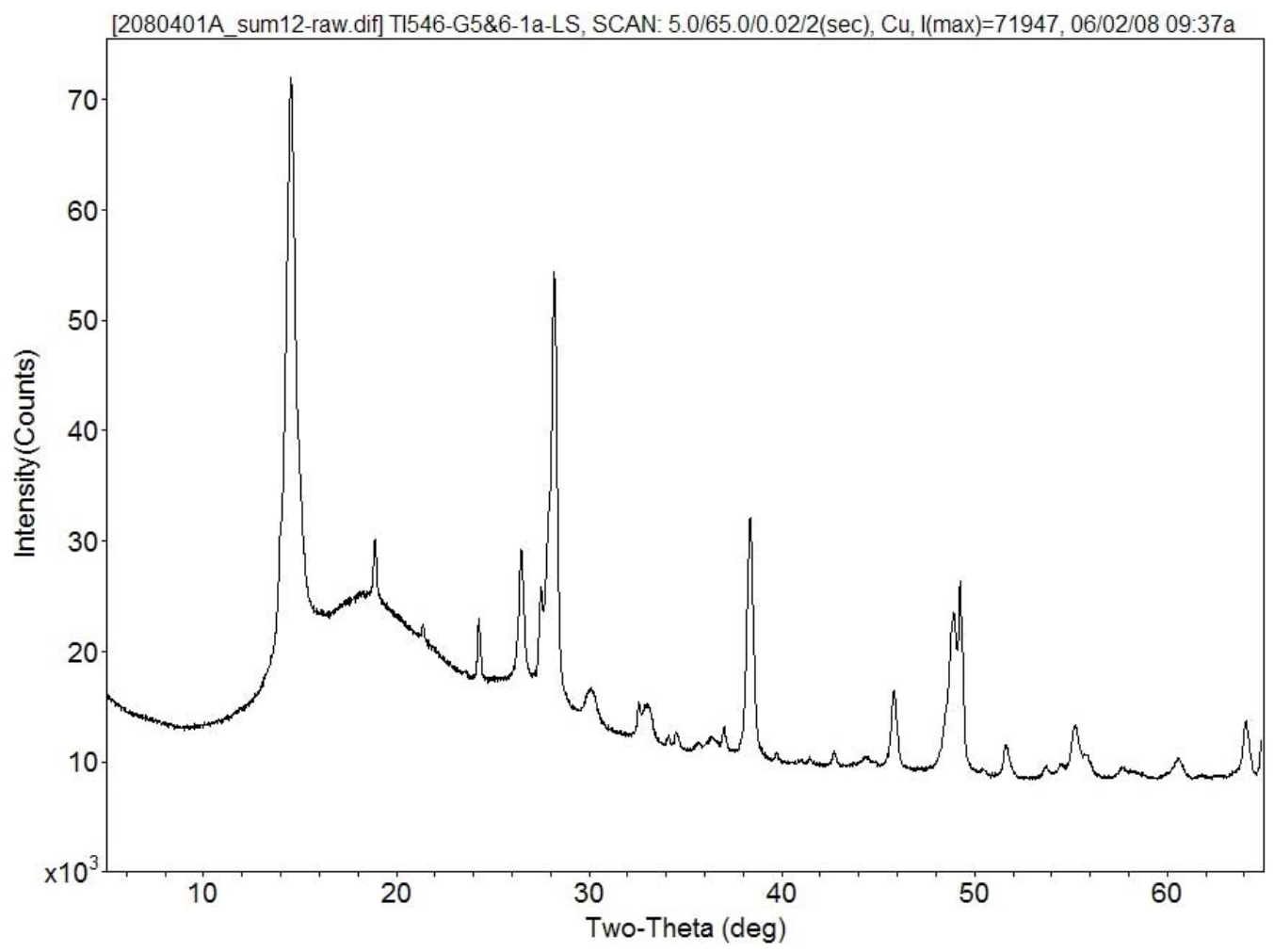

b)

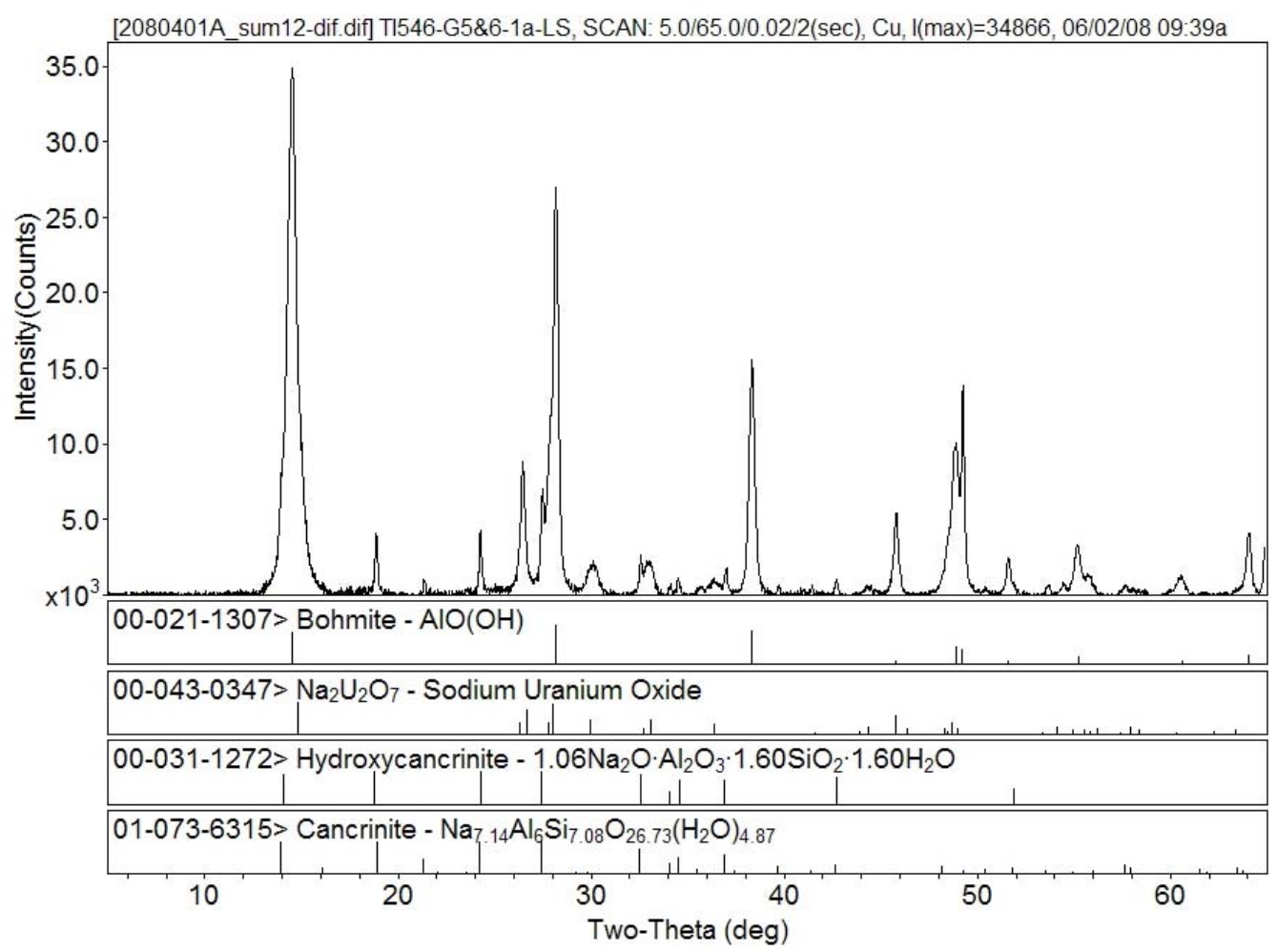

Figure 3.14. XRD Pattern for Oxidatively Leached and Washed Group 5/6 Composite (TI546-G5\&6-1a-LS) - a) Raw Diffraction Pattern (no background subtraction) and b) Background-Subtracted with Stick-Figure Phase Identification 
The boehmite crystallite size was estimated on each XRD sample mount. ${ }^{(a)}$ The boehmite crystallite size for the initial solids ranged from 250 to $270 \AA$ ( $n=2$, where $n=$ the number of samples on which the measurement was made); the boehmite crystallite size for the caustic-leached and washed solids ranged from 300 to $360 \AA(n=2)$; and the boehmite crystallite size for the oxidatively leached and washed solids ranged from 230 to $310 \AA(n=4)$. Within the uncertainty of analysis, there was no clear trend in changing the boehmite primary crystallite size as a function of process step.

\subsubsection{SEM}

Scanning electron microscopy (SEM) imaging with electron dispersive spectrometry (EDS) evaluation of the solids before leaching, after caustic leaching, and after oxidative leaching are shown in Figure 3.15 through Figure 3.20. In all cases, the EDS evaluation resulted in primarily Al and O peaks consistent with the predominant boehmite composition. The caustic-leached solids composition from EDS analysis did not appear to deviate significantly from that of the initial characterization sample. The Mn peak in the oxidatively leached and washed solids was associated with the precipitated Mn phase; the Cr was absent, which was consistent with removal from oxidative leaching.

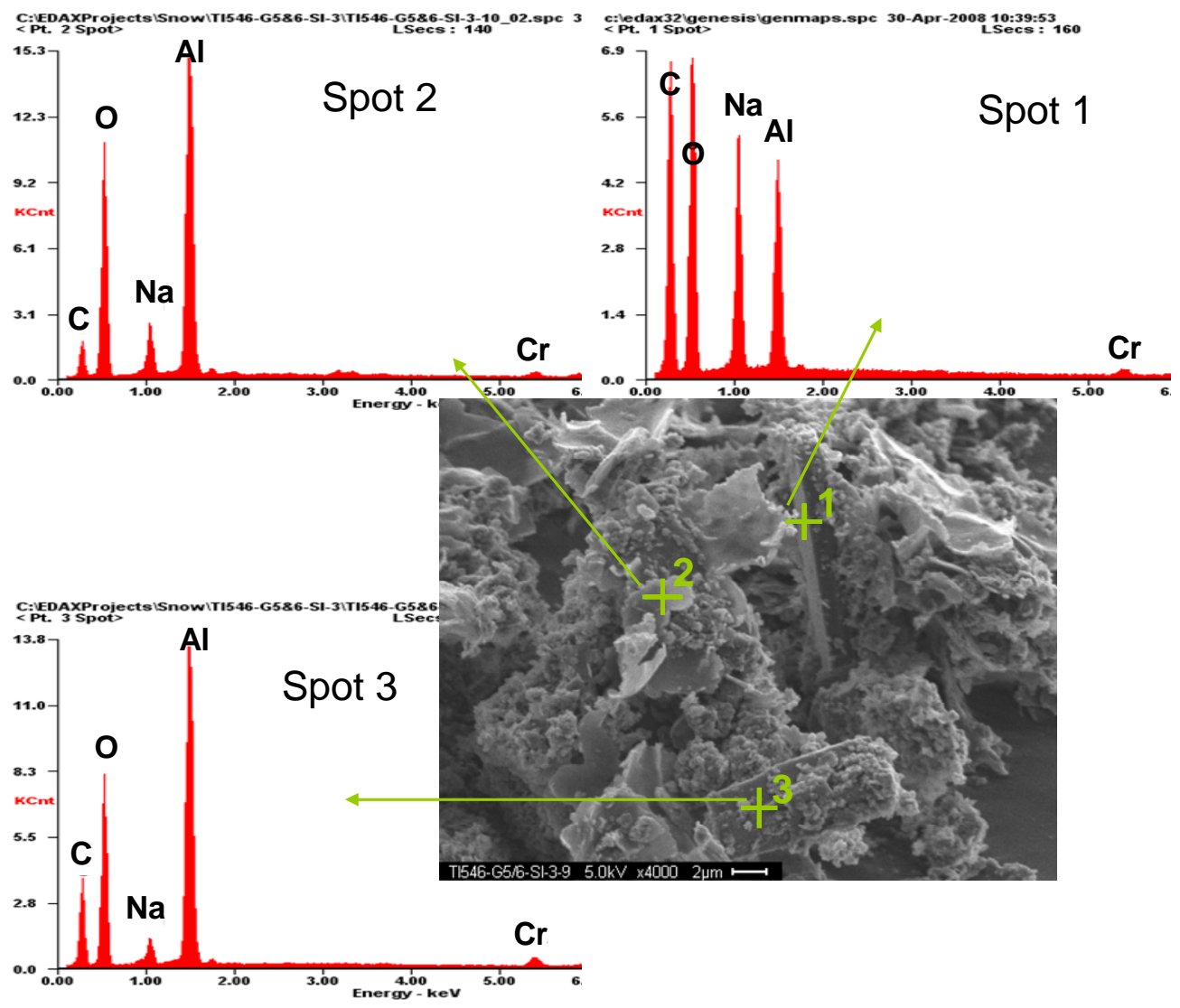

Figure 3.15. SEM Image of the Initial Group 5/6 Solids

(Note: EDS examination was conducted at $20 \mathrm{kV}$; image shown at $5 \mathrm{kV}$ had better clarity.)

(a) The JADE operating software applied the Scherrer equation to estimate the crystallite size (Klug and Alexander 1974, pp. 687-690). 

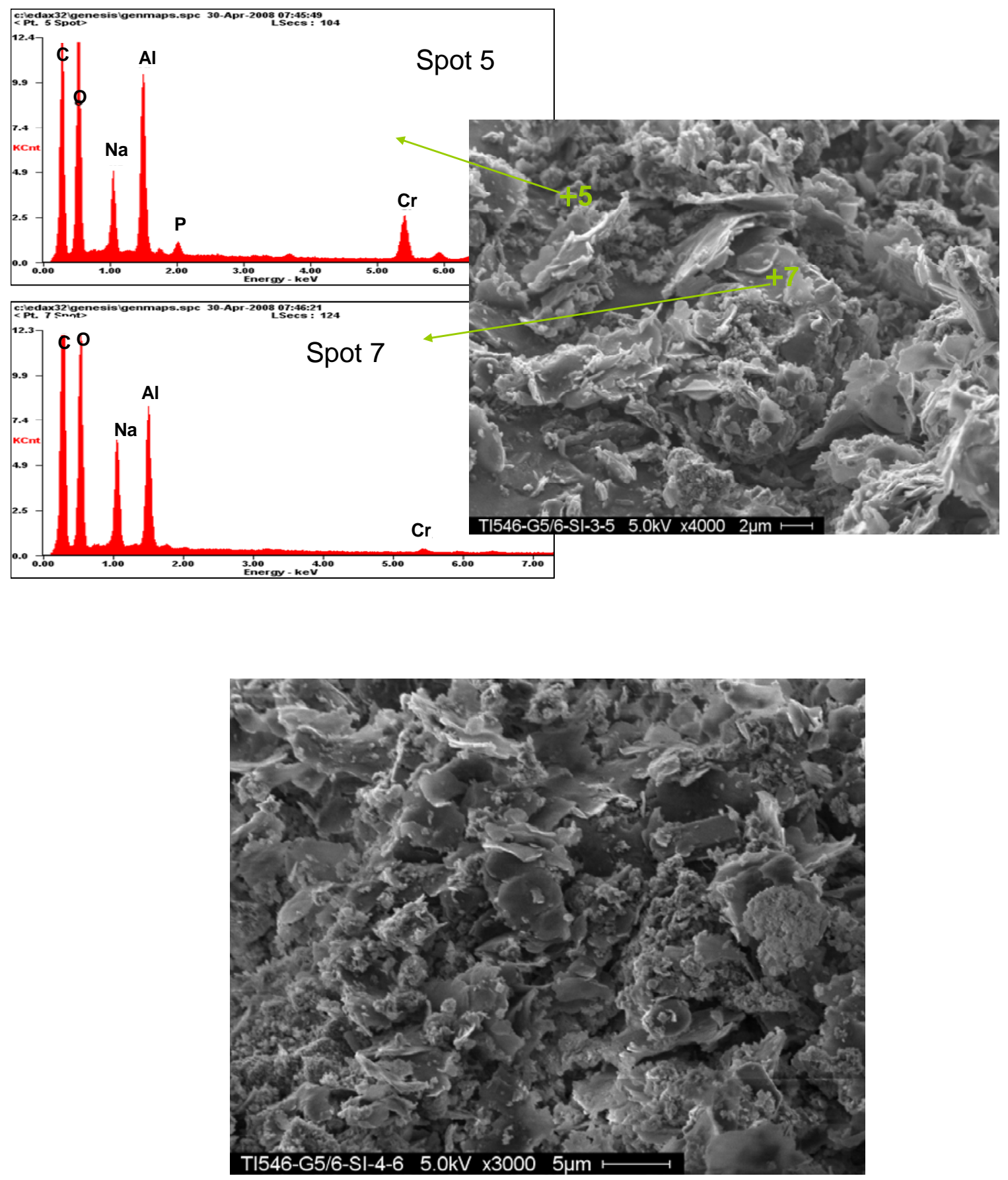

Figure 3.16. Additional SEM Images with EDS Evaluations of the Initial Group 5/6 Solids (Note: EDS analysis was conducted at $20 \mathrm{kV}$; the $5 \mathrm{kV}$ image provided better clarity.) 


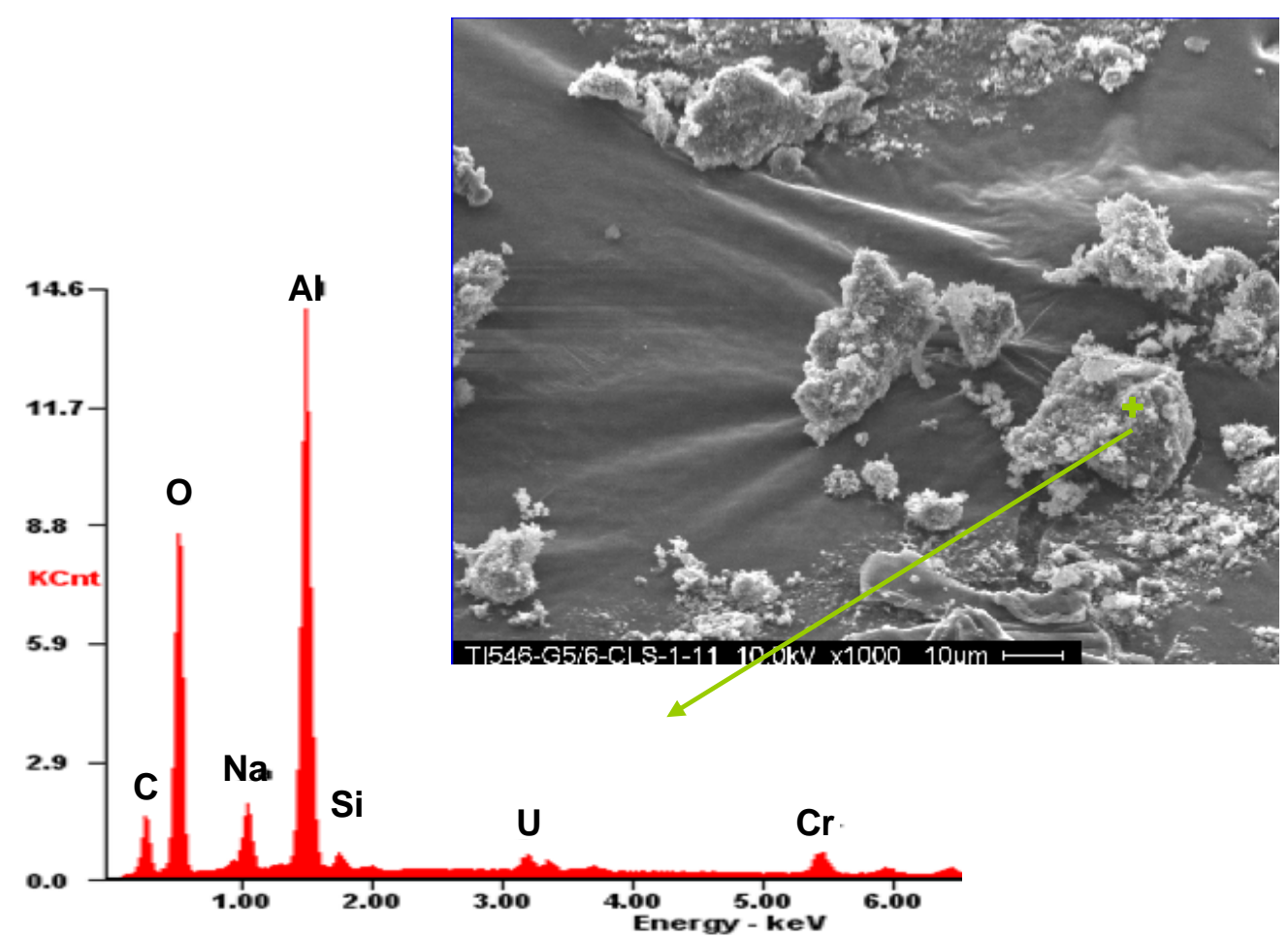

Figure 3.17. SEM Image with EDS Examination of the Caustic-Leached Group 5/6 Solids (Note: EDS analysis was conducted at $20 \mathrm{kV}$; the $10 \mathrm{kV}$ image provided better clarity.)

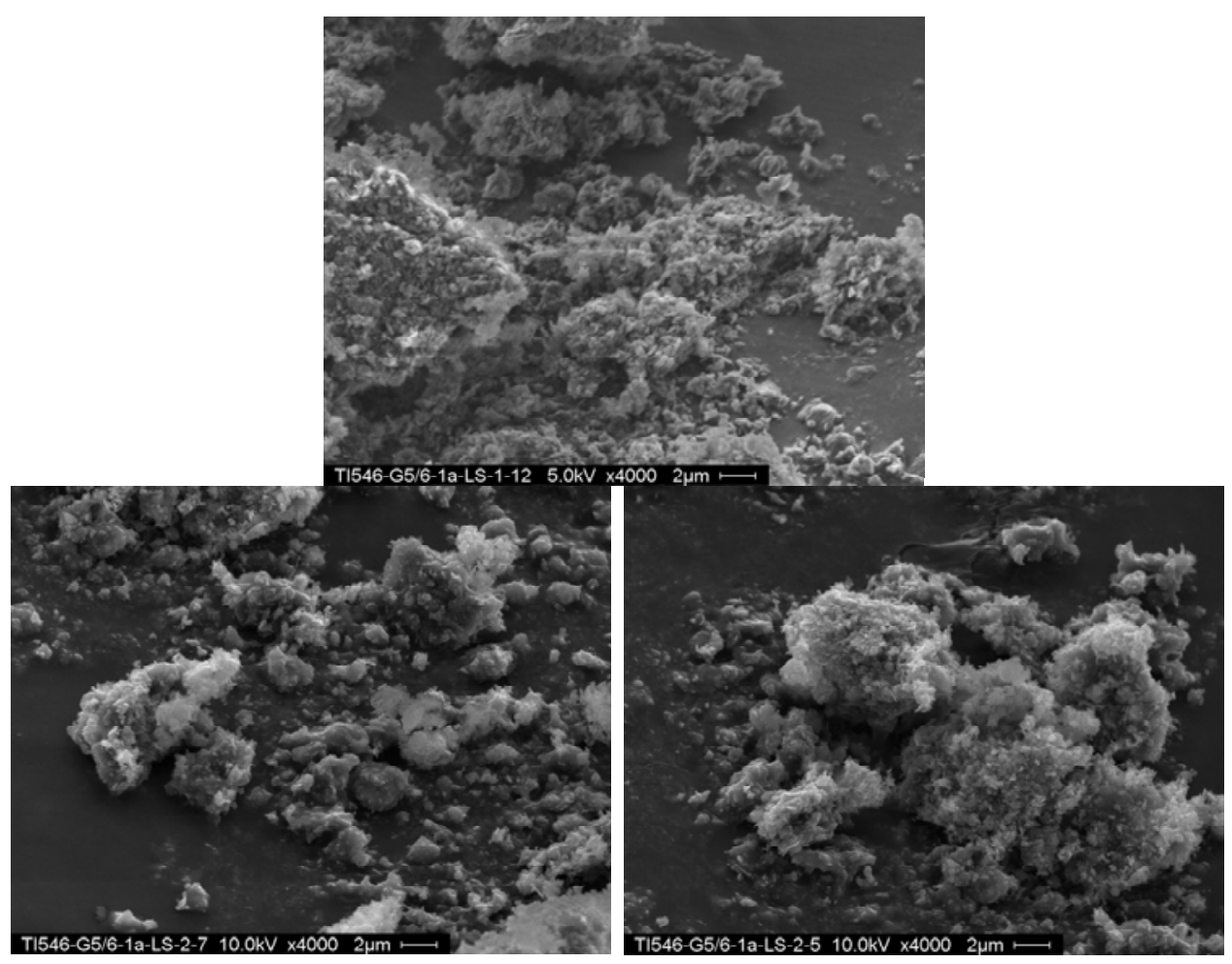

Figure 3.18. Various SEM Images of the Oxidatively Leached Group 5/6 Solids 

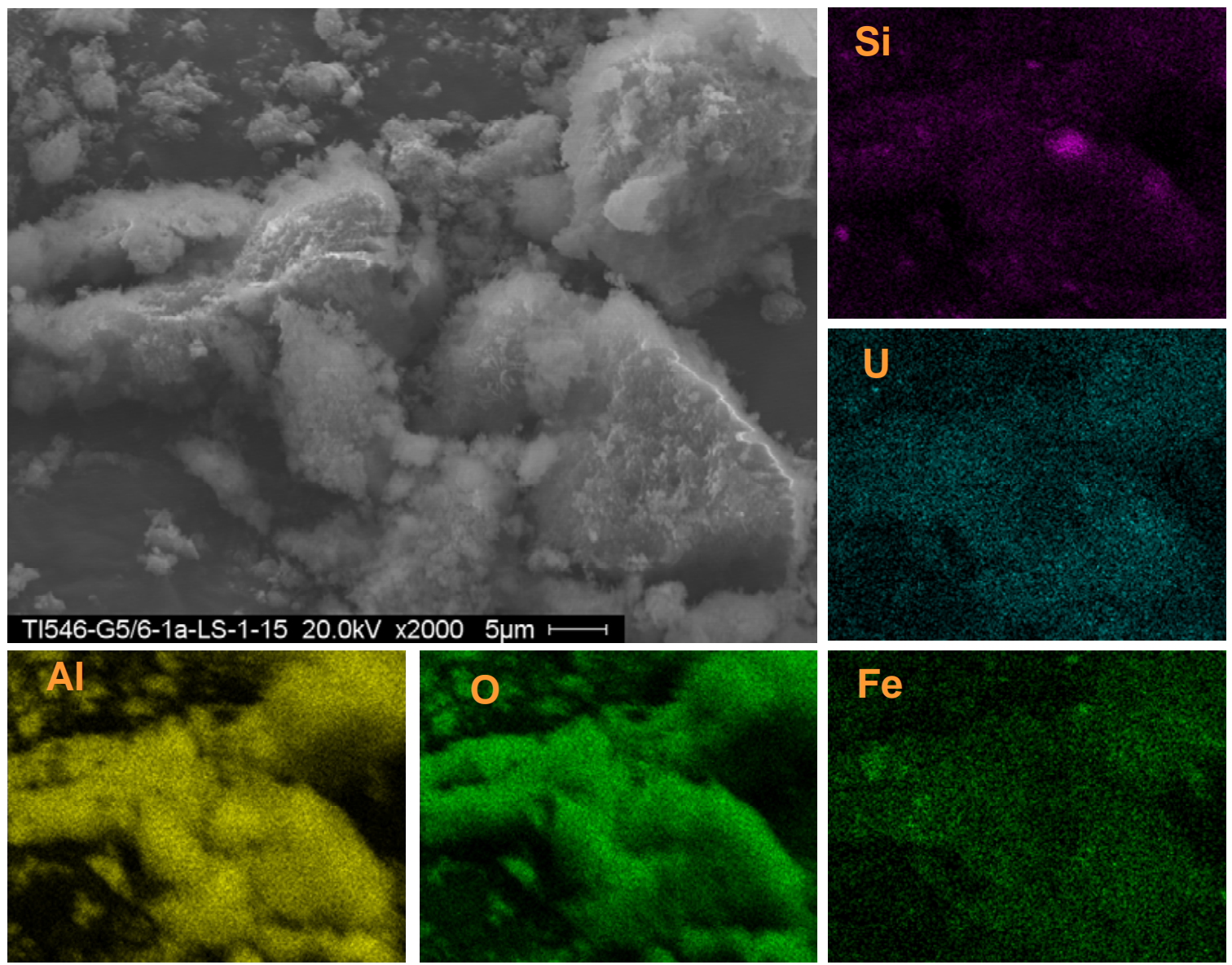

\section{$\mathrm{Fe}$}

Figure 3.19. SEM Image with Elemental Mapping of the Oxidatively Leached Group $5 / 6$ Solids 


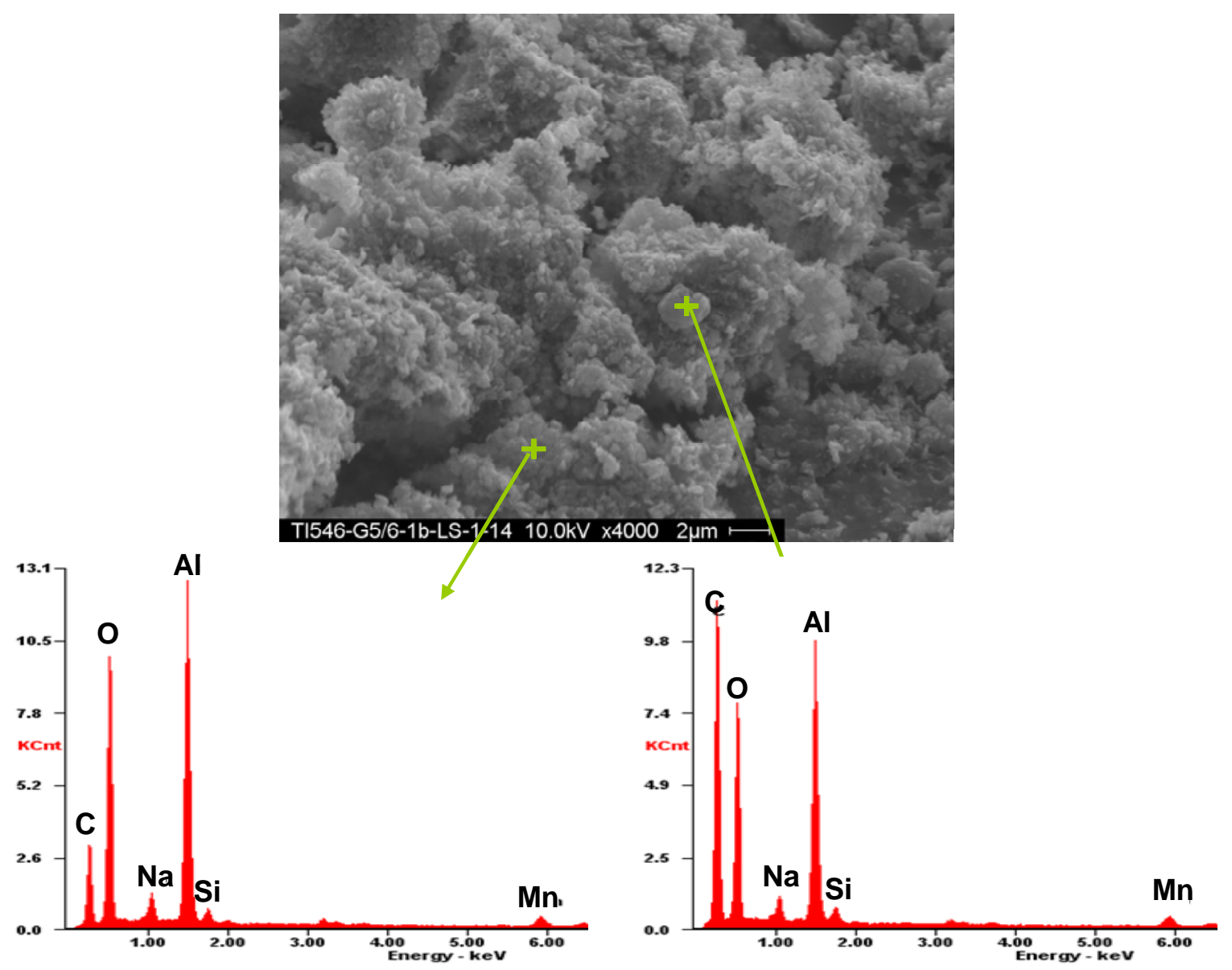

Figure 3.20. SEM-EDS Analysis of Oxidatively Leached Group 5/6 Solids

(Note: EDS analysis was conducted at $20 \mathrm{kV}$; the $10 \mathrm{kV}$ sample image is provided for better clarity.)

\subsubsection{TEM}

Aluminum phases were the predominant solids in the oxidatively leached waste with clear evidence of the presence of boehmite through TEM. The phase was identified by its hexagonal platelet-like morphology. Boehmite is sometimes observed to be fibrous or acicular, so such observations are not necessarily diagnostic. However, boehmite will precipitate as rhombohedral plates changing over to more hexagonal-like plates in the presence of nitrate (Music et al. 1998).

The characteristic planar crystal form of boehmite particles is shown in the TEM image in Figure 3.21a. The darker round particles are uranium-rich phases. Figure $3.21 \mathrm{~b}$ presents a cumulative distribution with a log-normal fit to the data that describes the probability of the boehmite particle sizes. The data were extracted from a series of TEM images of these particles by measuring the diagonal length. The individual measurements were accurate to $\pm 10 \%$. 

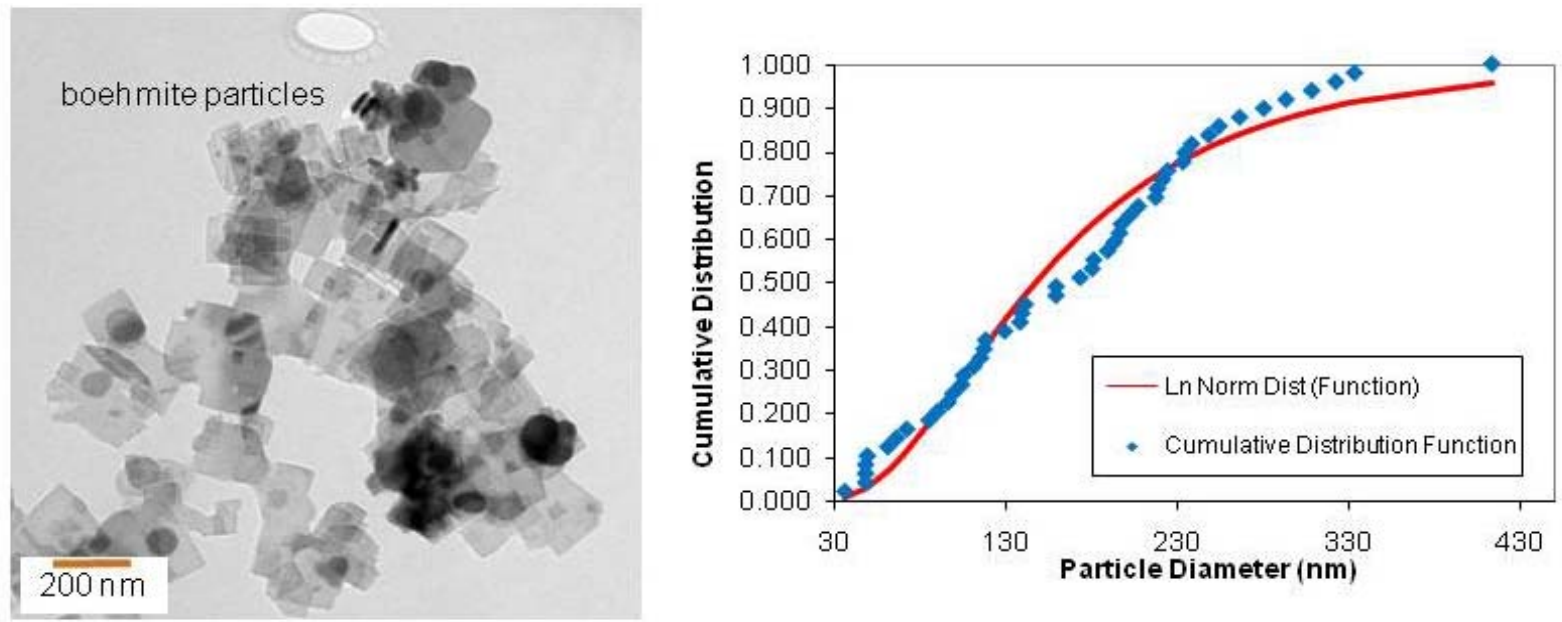

Figure 3.21. Group5/6 Oxidatively Leached and Washed Solids (Sample TI546-1a-LS-TEM) (a) TEM Image of Boehmite Particles and (b) Log-Normal Distribution of Particle Sizes Based on Several TEM Images

Using scanning transmission electron microscopy (STEM) high-angle annular dark field (HAADF) imaging, the high $\mathrm{Z}$ ( $\mathrm{Z}$ refers to atomic weight) particles become highlighted. In Figure 3.22 through Figure 3.24, various types of phases are shown. The agglomerates in the sample often contain multiple phases. Owing to the small size of the particles, it is difficult to obtain a composition with the EDS probe that represents an individual phase. Manganese- and uranium-rich particles were observed. Figure 3.24 also reveals an alumino-silicate in close proximity to the uranium phase that has a composition consistent with cancrinite. Electron diffraction data were not collected from the particles.
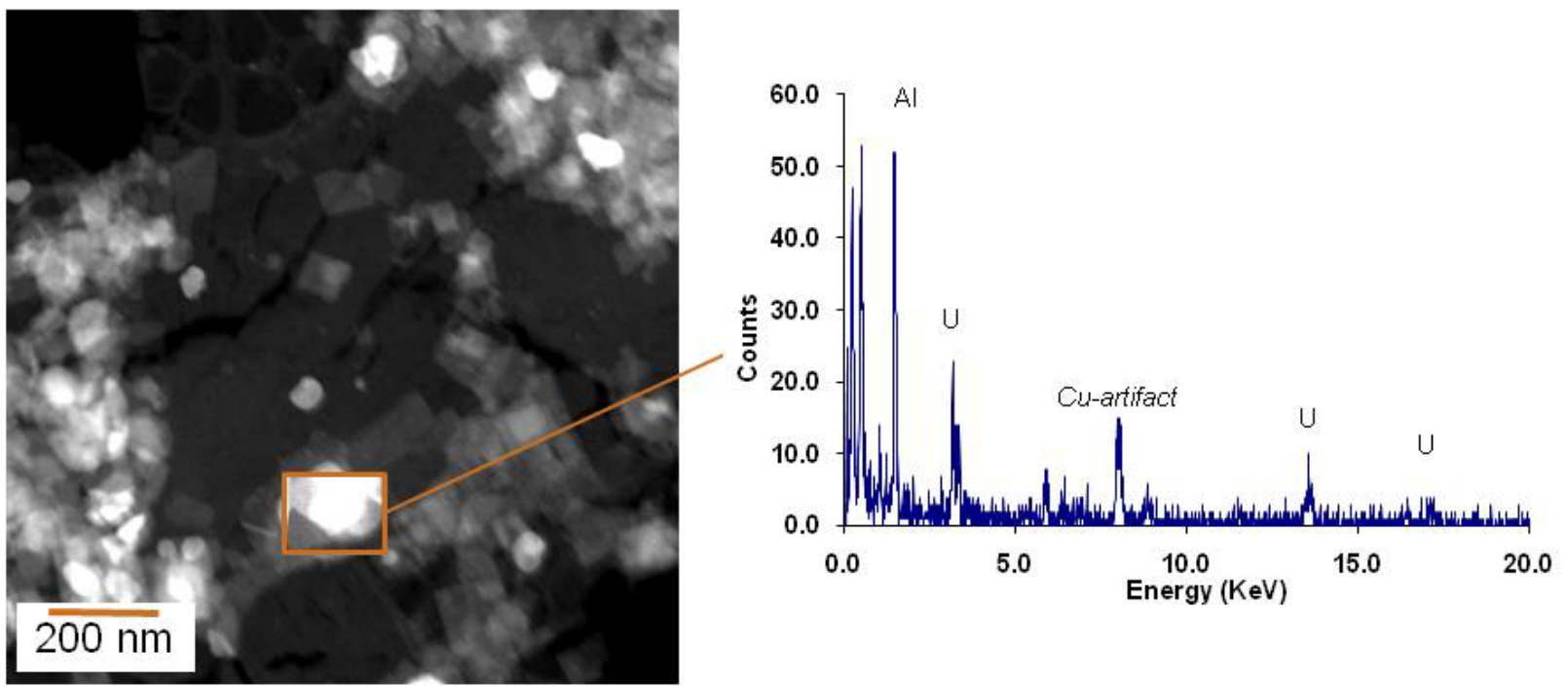

Figure 3.22. Group5/6 Oxidatively Leached and Washed Solids (a) STEM-HAADF Image (b) X-Ray EDS Analysis of Uranium-Rich Area 


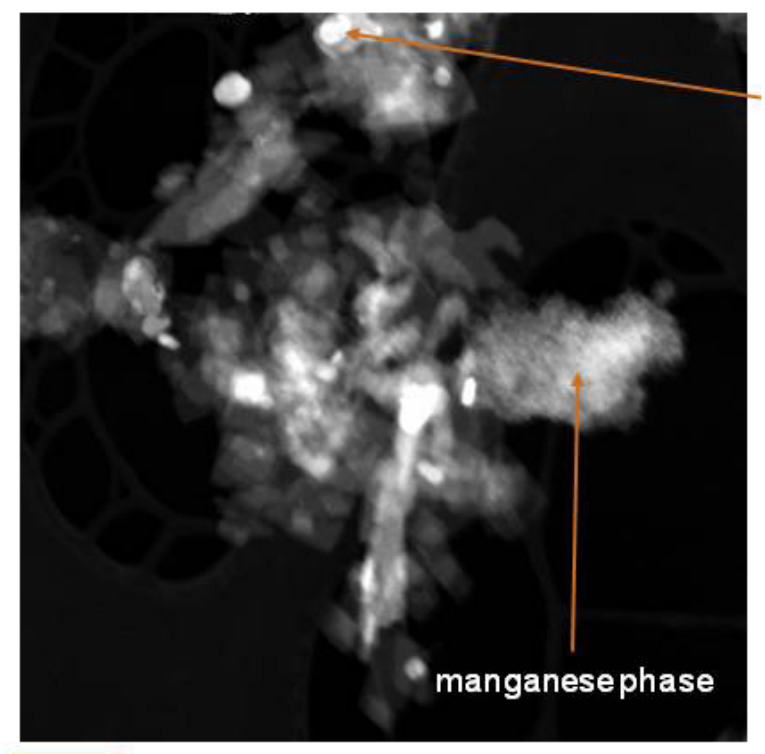

uranium oxide phase



$200 \mathrm{~nm}$

Figure 3.23. Group5/6 Oxidatively Leached and Washed Solids STEM-HAADF Image of ManganeseRich Particle (Bar $=200 \mathrm{~nm}$ ) with EDS Analysis of the Mn-Rich Area


Figure 3.24. Group5/6 Oxidatively Leached and Washed Solids (a) Scanning STEM-HAADF Image of Uranium-Rich Region Oxidative Leached Material (b) EDS Analysis of Area

Energy-filtered TEM imaging is a method for highlighting specific phases. Figure 3.25 shows the presence of discrete, nano-sized particles of uranium dispersed in the more abundant aluminum phase. The carbon map shows the construct of the lacy grid supporting the sample. 

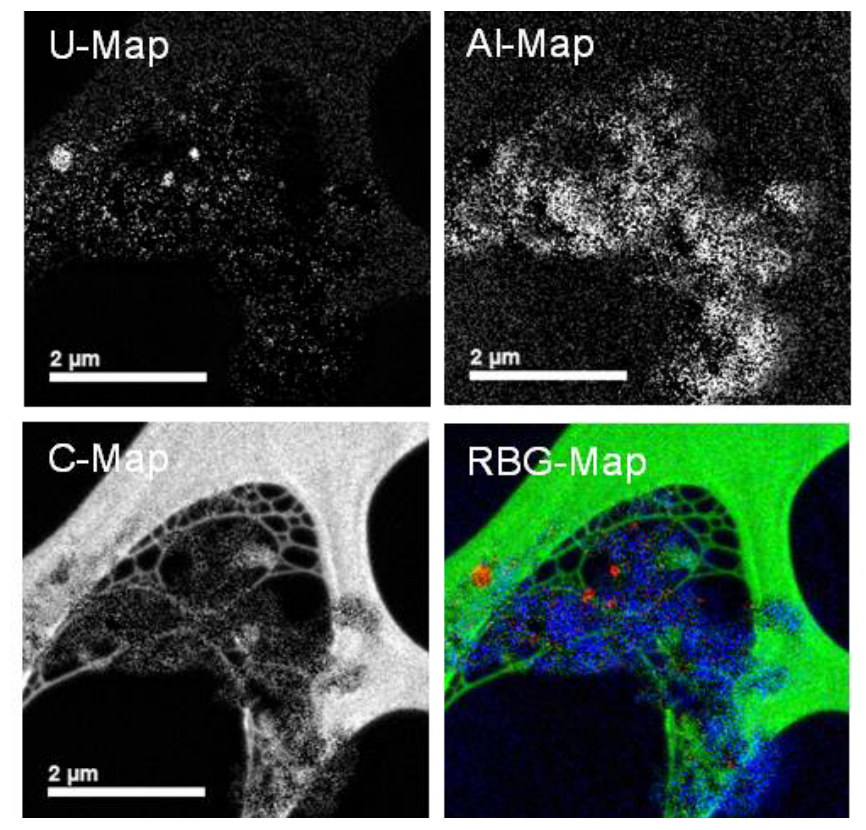

Figure 3.25. Energy-Filtered TEM Image of Oxidatively Leached and Washed Group 5/6 Solids

During STEM-HAADF analyses of agglomerates, an acicular form was found that was determined with EDS to be an aluminum oxide. The particles were around 100 to $300 \mathrm{~nm}$ in length (see Figure 3.26 and Figure 3.27). These can be seen in both STEM and normal TEM mode images. In Figure 3.26, boehmite particles can be clearly seen in the STEM-HAADF image. The contrast in the image was reversed so that the high $\mathrm{Z}$ material appears dark. Inversion of contrast made the boehmite particles more clearly visible in the image. The region also contained compositions consistent with cancrinite as well as uranium oxide particles. The ubiquitous aluminum phases were visible as platy square crystals and as elongated particles. 


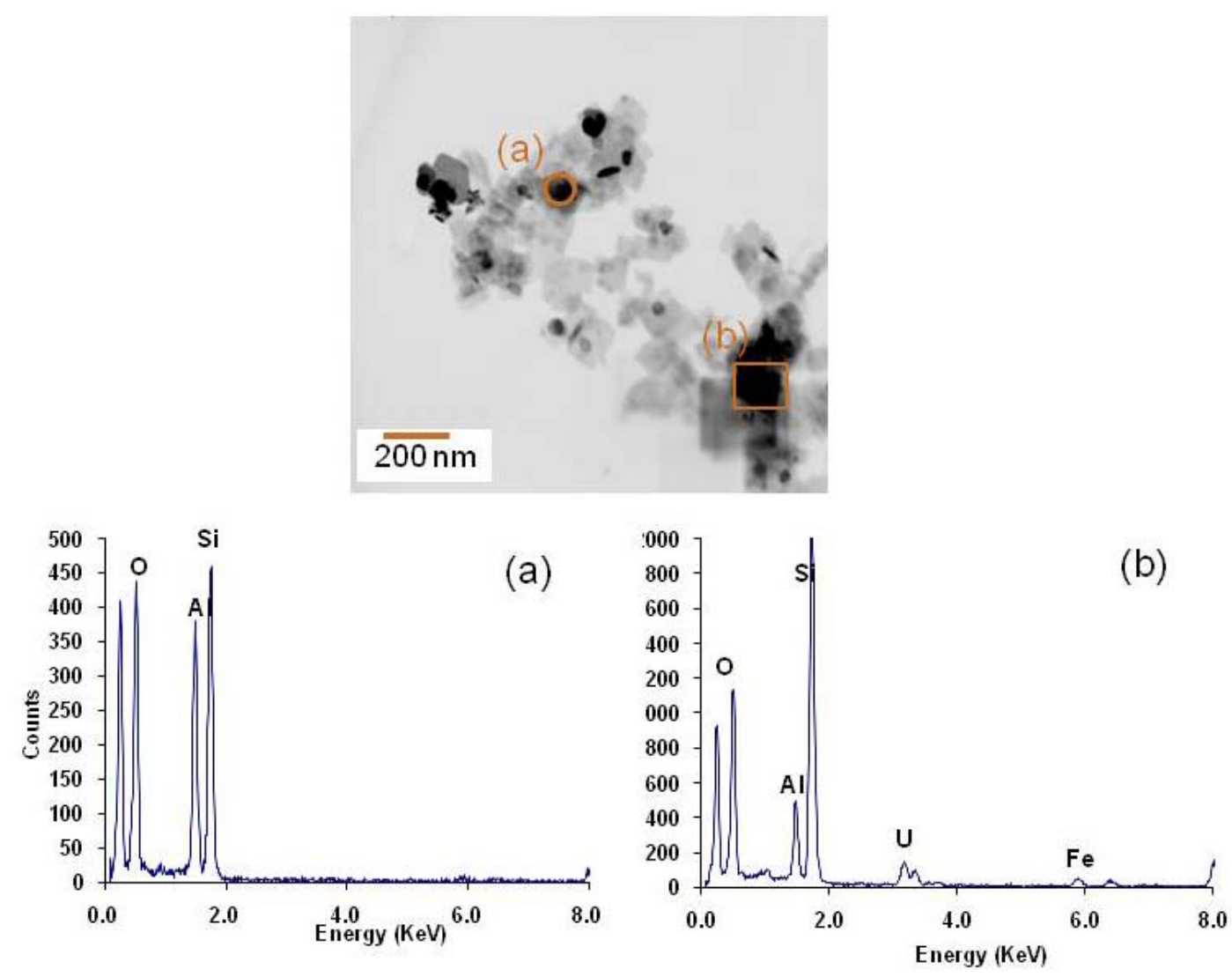

Figure 3.26. STEM- HAADF Image of Oxidatively Leached and Washed Group 5/6 Solids (inverted contrast) and EDS Analyses of Alumino-Silicate Phases

The uranium phases have a shape that is uncharacteristic for $\mathrm{U}(\mathrm{VI})$ oxide hydrate phases of any type. The uranium particles are visible in the energy-filtered transmission electron microscopy (EFTEM) image (see Figure 3.25). U(VI) phases typically possess platy elongated, boat-like, or needle forms. In these samples, the uranium particles were spherical. Unlike hydrated U(VI), these phases were resistant to the electron beam and retained crystallinity in spite of an intense beam.

A small quantity of strontium can be seen in the EDS analyses from the uranium oxide phases in Figure 3.27. The Sr:U atomic ratio measured with EDS was between 0.05 and 0.29 . The sodium content in the uranium phase did not agree completely with the XRD assignment for sodium diuranate $\left(\mathrm{Na}_{2} \mathrm{U}_{2} \mathrm{O}_{7}\right)$; however, it is clear that the uranium oxide phase contains significant amounts of strontium and lesser amounts of sodium. Sodium can also be easily evaporated from some phases, such as borosilicate glasses, during electron-beam analysis, and this will reduce the observed sodium X-ray line intensity. The EDS system on the TEM is a light element detector, as evidence from the strong oxygen X-ray line, so there was little attenuation of the signal. Overlap from neighboring phases could not be completely excluded during the analyses even in the TEM with its excellent spatial resolution. 
(a)

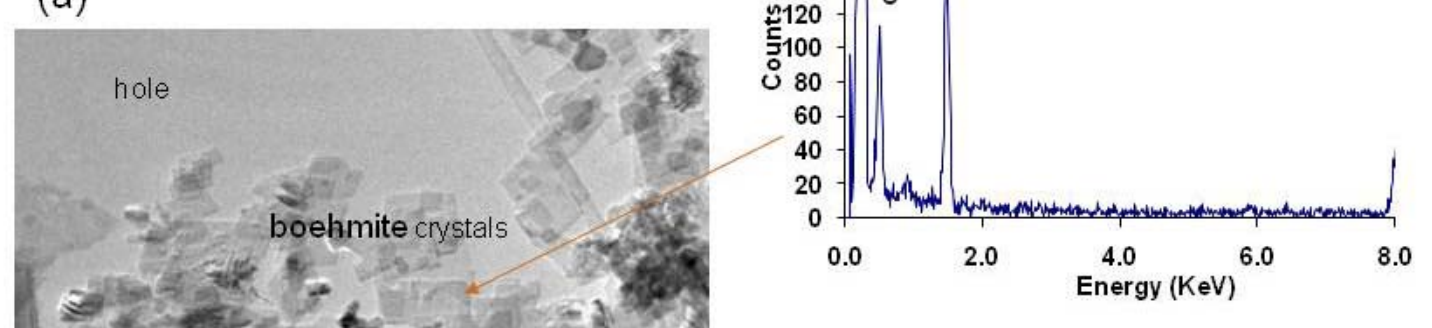

(b)

(c)

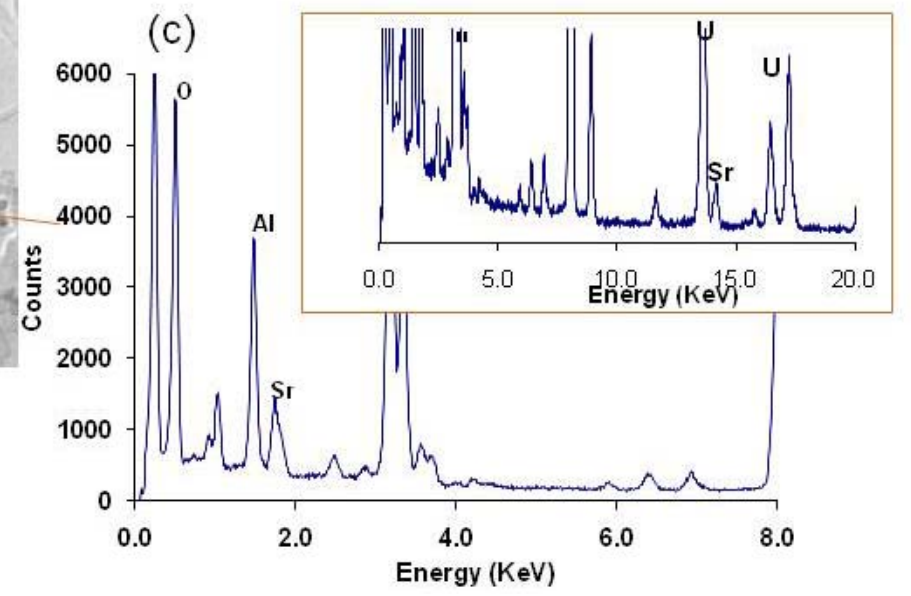

Figure 3.27. TEM Image of Agglomerate Al and U Phases in Oxidatively Leached and Washed Group 5/6 Solids; EDS Analyses from the Region are Shown

A typical TEM image of an agglomerate in Figure 3.28 shows three major mineral forms: platy boehmite crystals, elongated aluminum oxide crystals, and spherical alkali uranium oxide particles. The uranium phase contains strontium based on the EDS analysis of the phase. The Sr:U ratio was estimated by standardless analysis. The spectra were first background subtracted and the peak areas integrated. Possible errors arise from the strontium L-line strong overlap with the Si-K line and because the Sr-K line is within the tail of the stronger uranium L-lines (see Figure 3.27c).

High-resolution images of the uranium oxide phase indicated that the phase was crystalline (see Figure 3.29). A lattice spacing of $0.460 \mathrm{~nm}$ was obtained from an image. This is consistent with some form of mixed alkali uranium oxide. 



Figure 3.28. Oxidatively Leached and Washed Group 5/6 Solids (a) TEM Image of Region Highlighted in Previous Figure and (b) EDS Analysis of Uranium Phase. Note: The aluminum signal was from the boehmite particles on the uranium oxide particle.

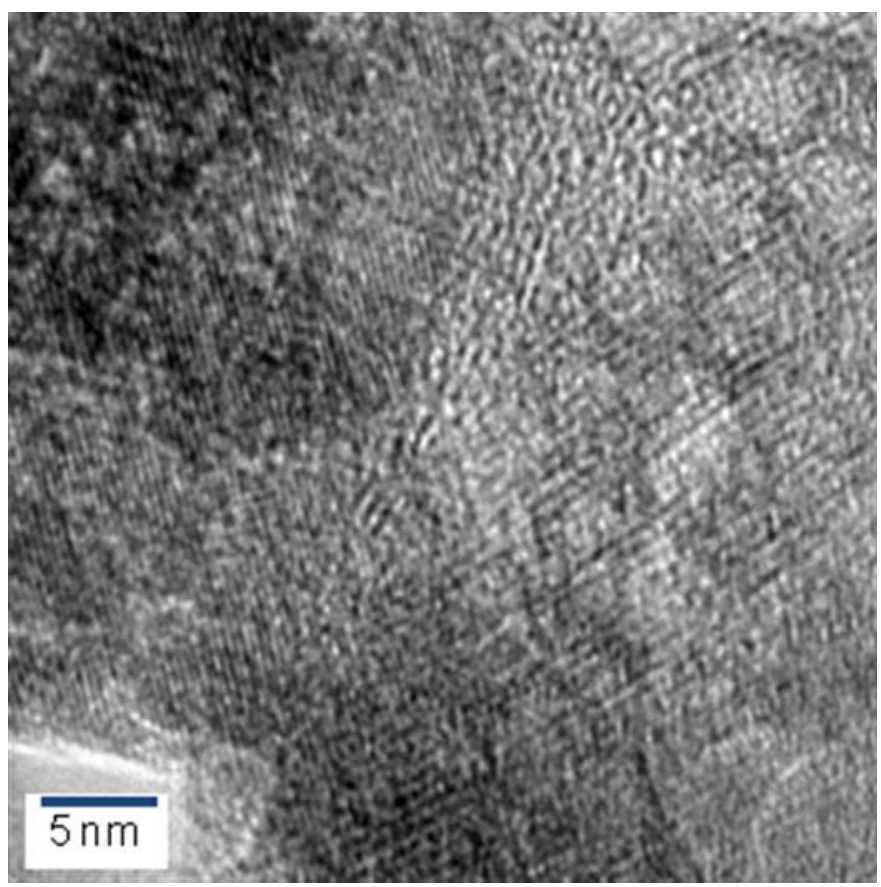

Figure 3.29. Oxidatively Leached and Washed Group 5/6 Solids High Resolution TEM Image of Uranium Oxide Phase Showing the Crystalline Nature of the Phase 


\subsection{CUF Processing}

The application of the oxidant dosage developed in parametric testing was to be demonstrated in the bench-scale CUF test. To this end, the pretreatment flowsheet incorporating caustic leaching and washing as well as oxidative leaching and washing was applied to the waste processing as part of the demonstration test. Process-stream chemical characterization, analyte partitioning, leach factors, and $\mathrm{Cr}$ and $\mathrm{Pu}$ dissolution behaviors are the main discussion points in this section. Extensive filtration and physical-property testing were also conducted to expand the knowledge base of tank waste process issues; these results were reported separately (Shimskey et al. in press).

This section describes the experimental conditions, equipment, and results from the caustic leaching and oxidative leaching tests on the combined composites of Group 5 REDOX sludge and Group $6 \mathrm{~S}$ Saltcake waste samples. The processes covered in this section in relation to the whole demonstration test are shown in bold in Figure 4.1. Many of these test results are reported separately (Shimskey et al. in press), however including the redundant description of equipment, processes, and chemical analysis results in this report was considered necessary to complete the event string supporting the demonstration test.



Figure 4.1. Pretreatment Operations in the CUF Supporting the Demonstration Test 


\subsection{CUF Processing}

This section describes the CUF apparatus, CUF processing history, tank waste test material composition, and CUF processing conditions.

\subsubsection{CUF Apparatus}

The CUF apparatus schematic is shown in Figure 4.2. The main components of the CUF apparatus include:

- slurry reservoir tank

- pump

- heat exchanger

- cross-flow filter

- slurry recirculation loop

- permeate flow loop

- permeate back pulse tank

- data acquisition system (DACS).



Figure 4.2. Piping Diagram of CUF Apparatus (Not to Scale)

(Notes: $\mathrm{P}=$ pressure gauge, $\mathrm{TC}=$ thermocouple) 
All fluid-contacting components were made of stainless steel except as noted. Tubing and connections were typically $1 / 4$ to $3 / 8$-in. inside diameter on the permeate side, while the slurry side was made with $1 / 2$-in. inside diameter tubing. The minimum operating volume for the CUF was $\sim 1.2 \mathrm{~L}$, driven primarily by the required volume of the slurry in the circulation loop to prevent air intake.

The slurry reservoir tank was a cylindrical stainless steel tank with a 4-L capacity. The bottom of the vessel was sloped at a $15^{\circ}$ angle allowing for easy drainage; this outlet fed into the connection piping leading to the slurry recirculation pump. Agitation in the tank was provided from an overhead mixer using a 2-in.-diameter 3-blade impeller. Baffles were installed inside the tank to aid mixing of the slurry. Heat tape was installed around the exterior walls of the tank to provide controlled heating (heat ramp, soak, and cooling) in support of caustic leaching. The electrical load to the heat tape was controlled via a temperature controller connected to a dual Type-K thermocouple installed inside the tank reservoir (which extended just below the overhead mixing impeller). The secondary thermocouple output was sent to the DACS.

The pump was a positive displacement rotary lobe pump (Johnson Pump, model SLAL/0059/10, Eastborne, UK), manufactured with 316 stainless steel internal components and capable of flow rates up to 60 liters/min. The pump was powered using a 4-horsepower air motor (Gast Manufacturing, Model 6AM-FRV-5A, Benton Harbor, MI); compressed air was supplied from an air compressor located externally to the hot cell. A regulator controlled the air pressure, which in turn controlled the pump speed. The pump speed was measured with an optical tachometer, which in turn measured the rotational speed of reflective tape fixed to the rotating connection coupling.

The heat exchanger removed excess heat from the slurry caused by mechanical mixing and frictional flow. It was constructed as a single-pass heat exchanger with counter-current flow. The HLW slurry ran through the inside tube, which was constructed of $5 / 8$-in. $\times 0.065$-in. stainless steel tubing. The outer tube was constructed of 1 -in. schedule 40 pipe (1.315 in. $\times 0.133$ in.) and $28.5 \mathrm{in.} \mathrm{long.} \mathrm{The} \mathrm{exterior} \mathrm{shell} \mathrm{of}$ the heat exchanger was connected to a circulating chiller (VWR International, model 1179PD) located externally from the hot cell. The circulating fluid (water/anti-freeze mixture) was radiologically isolated from the hot cell. The chiller temperature was regulated with feedback control from a resistance temperature detector (RTD) installed in the heat exchanger slurry discharge line.

The cross flow ultra-filter was a porous sintered metal tube supplied by the Mott Corporation (Farmington, CT) under specification WTP-070110 (schematic shown in Figure 4.3). The filter element was 24 -in. long, $1 / 2$-in. ID, and $5 / 8$-in. OD and was rated for particles with a $0.1-\mu \mathrm{m}$ diameter. The filter element was received in a shell-in-tube configuration. The outer tube surrounding the filter element contained the filtrate while the slurry remained in the central core. The slurry inlet and outlet were welded to steel tubing of matching outer and inner diameters that extended past the shell. The shell (or filtrate) side had two $3 / 8$-in. tubes exiting from the filter assembly; one was in the center to collect filtrate, and the other was near the slurry inlet and was used as a drain. Pressure ports equipped with digital pressure transmitters (Cecomp Electronics, Model DPG1000DR100PSIG-V, Libertyville, IL) were installed at the filter inlet and outlet to measure the slurry-side pressure. 


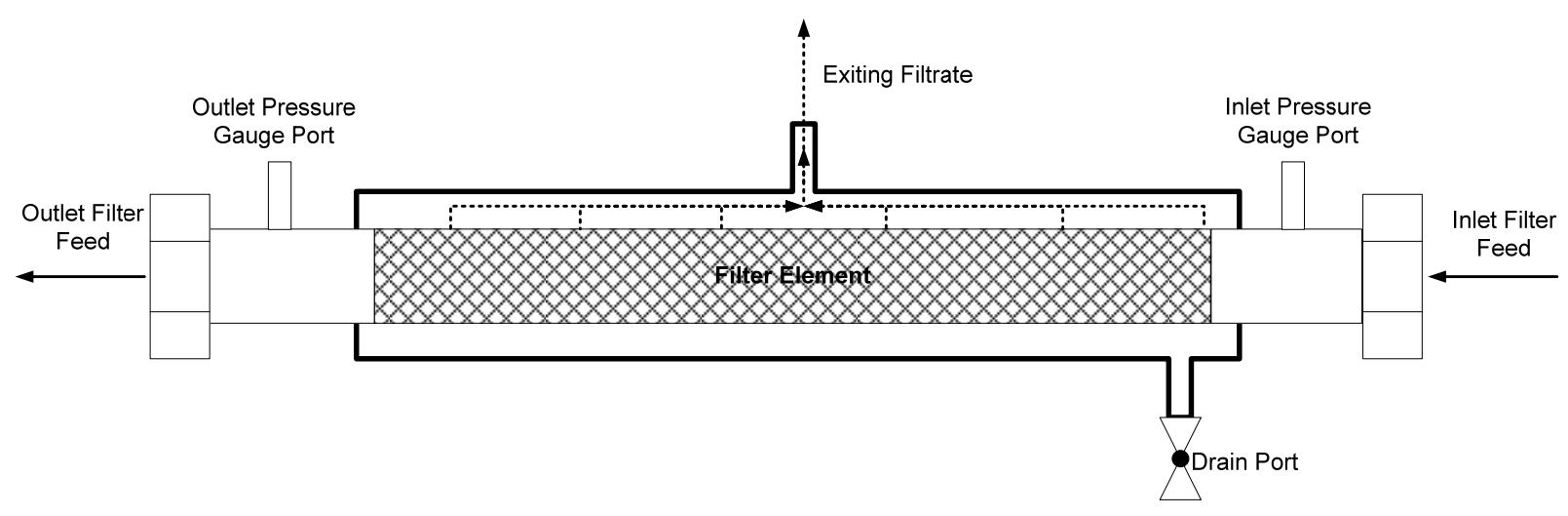

Figure 4.3. Filter Assembly Sketch (Not to Scale)

The slurry flowed axially through the filter while the feed permeate (synonymous with filtrate) passed radially through the filter tube walls. Filtration occurred when sufficient back-pressure was applied to the slurry feed flowing through the filter element driving the aqueous component through the sintered metal walls. Because the slurry was flowing across the filter walls, solids buildup was minimized allowing filtration to occur continuously with minimal downtime for back-pulsing (to remove solids buildup).

The slurry recirculation loop was defined as the slurry flow from the slurry reservoir tank, through the heat exchanger, through the CUF filter assembly, and back into the reservoir. Process parameters such as flowrate (axial velocity) and pressure (trans-membrane pressure) were recorded in the slurry recirculation loop to support the filtration parametric testing. The slurry recirculation loop was equipped as follows.

1) The volumetric flow of the slurry inside the slurry recirculation loop was measured with the magnetic flow meter (Krohne, Optiflux 5000, Germany). The sensor's output was displayed on an external panel meter that generated an analog output signal monitored and recorded by the DACS. The data from this device were used to calculate the axial velocity inside the filter element.

2) Digital pressure transmitters with displays installed on the inlet and outlet port of the filter displayed the pressure in pounds per inch squared, gauge (psig). The gauges also transmitted analog output signals monitored by the DACS. The data from these devices were used to calculate the average pressure inside the filter and were supported in part by the calculated axial pressure drop across the filter, also termed trans-membrane pressure (TMP).

3) A manual pinch valve was located at the discharge of the filter. Tightening the valve increased the slurry back-pressure and drove permeate flow through the filter wall. The output side was connected to the slurry reservoir tank, thus completing the circulation loop. The pinch valve was closed completely when the slurry reservoir tank was isolated for leaching.

The permeate flow loop was used to define permeate collection rates from the filtration process, aid in the determination of the TMP, and collect permeate from the CUF apparatus. The permeate flow loop began at the center of the filter assembly where a $3 / 8$-in. polyethylene tube connected the filter to a manifold. The manifold was used to direct permeate through a series of measurement devices before 
returning it to the slurry reservoir tank or directing it to a sample collection container. The permeate flow loop was equipped as follows.

1) A digital pressure gauge was installed in the manifold to measure the pressure on the permeate side of the filter. Like the other two digital gauges, this instrument transmitted an analog output to a data-collection system. The pressure drop across the filter (TMP) was then calculated by subtracting the pressure on the permeate side of the filter from the average (input and output) pressure of the slurry inside the filter.

2) Flow from the filter was diverted either through a calibrated mass flow meter (Brooks Instrument, Quantum QMBM4L, Hatfield, PA) or through a user-calibrated rotometer (Aalborg, P16S4VA0A-064-63-CA-VA, Orangeburg, New York). The mass flow meter measured flow rates up to $180 \mathrm{~mL} / \mathrm{min}$ as well as the permeate density. Both measurements were transmitted as two analog output signals to the DACS. The rotometer was a manual read-out device for flow rates up to $30 \mathrm{~mL} / \mathrm{s}$.

3) An in-line volumetric cylinder was installed on the discharge of both meters to support manual measurements of the permeate flowrate. Flow rates were determined after closing a valve at the bottom of the cylinder and measuring the collected permeate volume in a measured time interval. Flow was re-established after re-opening the lower valve.

4) Flow from the volumetric cylinder passed through a 3-way valve. This valve directed flow either back to the slurry reservoir tank to be mixed with the slurry or to a sampling hose that was used to direct permeate out of the system and into a collection container.

The permeate back-pulse tank was used to force solids from the filter by pushing permeate from the outer filter shell inward to the slurry side. The tank was situated adjacent to the permeate flow loop and shared the connection to the filter with the permeate flow loop via the permeate pressure gauge. The back-pulse tank was an $\sim 0.5$-L vessel equipped with a sight-glass to track the fluid volume. The tank had three entry ports: 1) a line at the bottom connecting to the permeate side of the filter, 2) a line at the top connecting to a funnel, and 3) a line on the side connecting to compressed air. The bottom line was used to fill the chamber with permeate (diverted from the permeate flow loop) and then send pressurized permeate backwards to the filter as a back-pulse. The funnel on the top of the chamber was used to introduce cleaning and rinse solutions directly to the back-pulse tank. The compressed gas line was used to pressurize the back-pulse chamber to $80 \mathrm{psig}$. Once the chamber was half-filled with permeate, compressed gas was introduced to the chamber to pressurize the fluid. The chamber was then isolated from the compressed gas line, and the slurry pressure was dropped below the pressure back-pulse tank (under 20 psig). The valve at the bottom of the back-pulse tank was opened, and the pressurized permeate inside the tank flowed backwards through the filter. After the back-pulse was completed, the chamber was either vented to atmospheric pressure through a 3-way valve or re-pressurized with compressed gas.

The DACS was used to monitor and control processes remotely from the hot cell. Most of the sensors transmitted analog data to LabView DACS software (National Instruments, Austin, Texas) operating on a computer desktop system with Windows XP, service pack 2. The software program scaled the analog data, recorded the data electronically, and displayed it on the computer monitor. The program operation was verified per project requirements. All reported data were collected with calibrated instrumentation that included the external DACS board. 
The CUF apparatus was mounted on a series of skids to allow entry into the hot cell facility. A photograph of the complete system (sans DACS) is shown in Figure 4.4.



Figure 4.4. CUF Testing Apparatus Before Hot Cell Installation

\subsubsection{CUF Processing History}

The CUF assembly was cleaned with a 1:100 dilution of Alconox detergent (White Plains, NY) and then rinsed with DI water in an effort to remove cutting oils and soils from the fabrication process and shipping before introduction into the hot cell. Baseline filter fluxes were measured with $0.01 \mathrm{M} \mathrm{NaOH}$ (called the clean water flux) and then strontium carbonate slurry using standardized test conditions. After testing, the contents were removed, and the system was rinsed with $\sim 10 \mathrm{~L}$ DI water.

The CUF system was used to process Group 5 REDOX sludge. This entailed parametric filtration testing, caustic leaching, and solids rinsing. Results of these tests were reported separately (Shimskey et al. in press). The CUF system was rinsed with water, and baseline process operating conditions were confirmed during water processing. The CUF was then used to process Group 6 S-Saltcake (low solids) matrix to define filtration properties only, and results were reported separately (Shimskey et al. in press). After Group 6 filtration testing was completed, the demonstration test was initiated with a composite of Group 5 and Group 6 slurries.

\subsubsection{Tank Waste Group 5/6 Test Matrix Preparation}

Group 5 tank waste material was added to the Group 6 tank waste in the slurry reservoir tank. The starting composite masses of Group 5 combined with Group 6 are shown in Table 4.1 along with 
comparison to the parametric test mass fractions. The mass fractions and slurry mass ratios between the parametric test and CUF test were reasonably close. The average Group 5/Group 6 slurry mass ratio in the parametric and CUF tests was $1.77 \pm 7 \%$. Given the experimental constraints of working in the hot cells, this difference was acceptable.

Table 4.1. CUF Processing Test Material

\begin{tabular}{|c|c|c|c|c|c|}
\hline Component & Mass, $\mathrm{g}$ & $\begin{array}{l}\text { Wt\% } \\
\text { UDS }\end{array}$ & $\begin{array}{c}\text { Expected } \\
\text { Undissolved } \\
\text { Solids, g } \\
\end{array}$ & $\begin{array}{c}\text { Mass } \\
\text { Fraction in } \\
\text { CUF, \% }\end{array}$ & $\begin{array}{c}\text { Mass Fraction } \\
\text { in Parametric } \\
\text { Test, \% }\end{array}$ \\
\hline Group 5 slurry $^{(\mathrm{a}, \mathrm{b})}$ & 993.1 & 18.5 & 183.7 & 25.4 & 29.9 \\
\hline Group 6 slurry $^{(\mathrm{a}, \mathrm{c})}$ & 601.8 & 14.7 & 88.5 & 15.4 & 15.7 \\
\hline Group 6 supernatant ${ }^{(\mathrm{a}, \mathrm{d})}$ & 2,317 & 0 & 0 & 59.2 & 54.4 \\
\hline Sum & 3912 & -- & 272.2 & 100.0 & 100.0 \\
\hline $\begin{array}{l}\text { Group 5/Group } 6 \text { slurry } \\
\text { mass ratio }\end{array}$ & -- & -- & -- & 1.65 & 1.90 \\
\hline \multicolumn{6}{|c|}{$\begin{array}{l}\text { (a) Material compositing and physical property characteristics reported in RPT-WTP-157 (Fiskum et al. } \\
\text { 2008). } \\
\text { (b) Taken from samples TI477-G5-AR-J1, -J2, and -J3 (Fiskum et al. 2008). } \\
\text { (c) Taken from sample TI490-G6-AR. } \\
\text { (d) Taken from samples TI488-G6-AR-J1 through -J3 and -J8 through -J16 (Fiskum et al. 2008). }\end{array}$} \\
\hline
\end{tabular}

The waste samples were introduced to the CUF through the top of the slurry reservoir tank. Initially, approximately $80 \%$ of the Group 6 supernatant was added to the tank while it was isolated from the slurry piping. After the supernatant was added, the Group 6 slurry was added to the tank. The overhead mixer was turned on for $30 \mathrm{~min}$. The valves isolating the slurry reservoir from the slurry circulating loop were then opened, and the pump was turned on. Filtration testing of the diluted Group 6 slurry was then performed as previously described (Shimskey et al, in press) while permeate was recycled back to the slurry reservoir. After the filtration test was completed, the circulation pump and overhead mixer were turned off. The Group 5 slurry samples and remaining Group 6 supernatant were added to the slurry reservoir. The overhead mixer was turned on and the circulation pump was allowed to run for 30 min with permeate recycling back to the slurry reservoir tank prior to filtering the slurry before leaching.

The slurry was calculated to contain $7.0 \mathrm{wt} \%$ UDS based on the measured component UDS concentrations (Fiskum et al. 2008). Table 4.2 shows the projected composite formulation estimated from the independent characterizations of the Group 5 and Group 6 materials (Fiskum et al. 2008). All initial process assumptions were based on the estimated composition. The measured combined Group 5/6 composite solids and supernatant compositions are also provided in Table 4.2. Measured results were obtained from a slurry sample pulled from the CUF mixing reservoir in support of the parametric leach test and before the caustic leach solution was added. The solids sample had been well-washed with $0.01 \mathrm{M} \mathrm{NaOH}$ to remove entrained supernatant before analysis. 
Table 4.2. Calculated Composited Groups 5 and 6 Composition-Demonstration Test

\begin{tabular}{|c|c|c|c|c|}
\hline \multirow[b]{3}{*}{ Analyte } & \multicolumn{2}{|c|}{ Washed Solids } & \multicolumn{2}{|c|}{ Supernate } \\
\hline & Calculated $^{(\mathbf{a})}$ & Measured $^{(\mathbf{b})}$ & Calculated & Measured $^{(\mathrm{c})}$ \\
\hline & $\mu \mathrm{Ci} / \mathrm{g}$ & $\mu \mathrm{Ci} / \mathrm{g}$ & $\mu \mathrm{Ci} / \mathrm{mL}$ & $\mu \mathrm{Ci} / \mathrm{mL}$ \\
\hline${ }^{137} \mathrm{Cs}$ & $6.85 \mathrm{E}+1$ & $6.61 \mathrm{E}+1$ & $7.26 \mathrm{E}+1$ & $7.24 \mathrm{E}+1$ \\
\hline${ }^{60} \mathrm{Co}$ & $2.89 \mathrm{E}-2$ & $2.61 \mathrm{E}-2$ & $<2 \mathrm{E}-4$ & $<1 \mathrm{E}-4$ \\
\hline${ }^{241} \mathrm{Am}$ & $1.68 \mathrm{E}+0$ & $1.63 \mathrm{E}+0$ & $<2 \mathrm{E}-2$ & $<8 \mathrm{E}-3$ \\
\hline${ }^{90} \mathrm{Sr}$ & $5.33 \mathrm{E}+2$ & $5.72 \mathrm{E}+2$ & $6.10 \mathrm{E}-2$ & $4.88 \mathrm{E}-2$ \\
\hline${ }^{238} \mathrm{Pu}$ & $5.48 \mathrm{E}-2$ & $5.06 \mathrm{E}-2$ & $1.06 \mathrm{E}-5$ & $2.08 \mathrm{E}-5$ \\
\hline${ }^{239+240} \mathrm{Pu}$ & $8.96 \mathrm{E}-1$ & $8.90 \mathrm{E}-1$ & $7.22 \mathrm{E}-5$ & $1.55 \mathrm{E}-4$ \\
\hline Gross alpha & $2.39 \mathrm{E}+0$ & $2.71 \mathrm{E}+0$ & $<4 \mathrm{E}-4$ & $<3 \mathrm{E}-3$ \\
\hline Gross beta & $1.23 \mathrm{E}+3$ & $1.23 \mathrm{E}+3$ & $6.79 \mathrm{E}+1$ & $7.44 \mathrm{E}+1$ \\
\hline Analyte & $\mu \mathrm{g} / \mathrm{g}$ & $\mu g / g$ & $\mu \mathrm{g} / \mathrm{mL}$ & $\mu \mathrm{g} / \mathrm{mL}$ \\
\hline $\mathrm{Al}$ & 281,000 & 335,500 & 6,420 & 6,310 \\
\hline $\mathrm{B}$ & [55] & [210] & 33.9 & 30.2 \\
\hline $\mathrm{Bi}$ & 154 & {$[880]$} & $<2.4$ & $<2.3$ \\
\hline $\mathrm{Cd}$ & 45 & {$[18]$} & $<0.25$ & $<0.24$ \\
\hline $\mathrm{Cr}$ & 31,600 & 26,250 & 697 & 729 \\
\hline $\mathrm{Fe}$ & 9,680 & 11,250 & $<2.3$ & $<2.0$ \\
\hline $\mathrm{K}$ & $<6800$ & na & 987 & 954 \\
\hline $\mathrm{Mn}$ & 4,560 & 4,970 & $<0.21$ & $<0.20$ \\
\hline $\mathrm{Na}$ & 67,600 & {$[25,500]$} & 107,000 & 109,000 \\
\hline $\mathrm{Ni}$ & 544 & na & [1.9] & {$[2.5]$} \\
\hline $\mathrm{P}$ & {$[1,180]$} & {$[1,400]$} & 2,140 & 2,520 \\
\hline $\mathrm{S}$ & [244] & {$[1,650]$} & 2,060 & 1,640 \\
\hline $\mathrm{Si}$ & 11,000 & 14,350 & 82 & 52.0 \\
\hline $\mathrm{Sr}$ & 804 & 943 & $<0.022$ & [0.032] \\
\hline $\mathrm{U}$ & 15,400 & 17,600 & $<8.6$ & $<8.4$ \\
\hline $\mathrm{Zn}$ & 372 & 199 & $<0.58$ & $<0.57$ \\
\hline $\mathrm{Zr}$ & [222] & {$[140]$} & $<0.83$ & $<0.81$ \\
\hline U (KPA) & 15,100 & 15,300 & -- & 5.22 \\
\hline Nitrite & -- & -- & 34,600 & 37,200 \\
\hline Nitrate & -- & -- & 113,000 & 126,000 \\
\hline Phosphate & -- & -- & 6,670 & 8,310 \\
\hline Sulfate & - & -- & 6,260 & 6,690 \\
\hline free hydroxide & -- & -- & $0.603 \underline{\mathrm{M}}$ & $0.625 \underline{\mathrm{M}}$ \\
\hline Oxalate & -- & -- & 204 & 894 \\
\hline TOC-C & - & -- & 1,160 & -- \\
\hline $\mathrm{TIC}-\mathrm{C}$ & -- & -- & 5,980 & -- \\
\hline Fluoride & -- & -- & 98 & 273 \\
\hline Chloride & -- & -- & $>2,400$ & -- \\
\hline $\mathrm{Ag}$ & {$[7.8]$} & [15] & $<0.44$ & $<0.42$ \\
\hline
\end{tabular}


Table 4.2 (cont)

\begin{tabular}{|c|c|c|c|c|}
\hline \multirow{3}{*}{$\begin{array}{l}\text { Opportunistic } \\
\text { Analytes }\end{array}$} & \multicolumn{2}{|c|}{ Washed Solids } & \multicolumn{2}{|c|}{ Supernate } \\
\hline & Calculated $^{(a)}$ & Measured $^{(\mathrm{b})}$ & Calculated & Measured $^{(\mathrm{c})}$ \\
\hline & $\mu \mathrm{g} / \mathrm{g}$ & $\mu \mathrm{g} / \mathrm{g}$ & $\mu \mathrm{g} / \mathrm{mL}$ & $\mu \mathrm{g} / \mathrm{mL}$ \\
\hline As & $<120$ & $<160$ & $<7.2$ & $<7.0$ \\
\hline $\mathrm{Ba}$ & [99] & 118 & $<0.35$ & $<0.34$ \\
\hline $\mathrm{Be}$ & {$[1.2]$} & [0.75] & {$[0.025]$} & $<0.01$ \\
\hline $\mathrm{Ca}$ & 2,600 & $<4400$ & 21.6 & [20] \\
\hline $\mathrm{Ce}$ & 71.8 & $<33$ & $<1.3$ & $<1.2$ \\
\hline $\mathrm{Co}$ & {$[2.0]$} & $<13$ & $<0.42$ & $<0.39$ \\
\hline $\mathrm{Cu}$ & [57] & 101 & $<0.50$ & $<0.48$ \\
\hline Dy & $<17$ & $<12$ & $<0.36$ & $<0.35$ \\
\hline $\mathrm{Eu}$ & {$[1.6]$} & {$[3.8]$} & $<0.11$ & $<0.11$ \\
\hline $\mathrm{La}$ & [94] & [60] & {$[0.27]$} & {$[0.20]$} \\
\hline $\mathrm{Li}$ & 60.8 & [66] & $<0.56$ & $<0.54$ \\
\hline $\mathrm{Mg}$ & [380] & 344 & {$[2.0]$} & $<0.70$ \\
\hline Mo & $<12$ & [44] & 29.9 & 30.5 \\
\hline $\mathrm{Nd}$ & $<240$ & [130] & $<1.8$ & $<1.7$ \\
\hline $\mathrm{Pb}$ & 491 & {$[370]$} & $<3.8$ & $<3.7$ \\
\hline $\mathrm{Pd}$ & $<61$ & $<26$ & $<1.3$ & [1.7] \\
\hline $\mathrm{Rh}$ & $<48$ & $<52$ & $<2.6$ & $<2.5$ \\
\hline $\mathrm{Ru}$ & $<19$ & $<27$ & {$[3.6]$} & {$[3.8]$} \\
\hline $\mathrm{Sb}$ & $<66$ & $<125$ & $<3.3$ & $<3.1$ \\
\hline $\mathrm{Se}$ & [23] & [500] & [6.5] & [8.0] \\
\hline $\mathrm{Sn}$ & [24] & $<100$ & [10] & [3.2] \\
\hline $\mathrm{Ta}$ & $<24$ & $<80$ & $<1.4$ & $<1.3$ \\
\hline $\mathrm{Te}$ & $<84$ & $<110$ & $<3.2$ & $<3.1$ \\
\hline Th & 88.4 & [55] & $<1.6$ & $<1.2$ \\
\hline $\mathrm{Ti}$ & [39] & 81.0 & [0.17] & $<0.10$ \\
\hline $\mathrm{Tl}$ & $<93$ & $<120$ & $<6.7$ & $<6.5$ \\
\hline $\mathrm{V}$ & $<6$ & $<13$ & [1.07] & [1.6] \\
\hline $\mathrm{W}$ & [11] & {$[100]$} & 46.1 & 52.9 \\
\hline $\mathrm{Y}$ & 20.6 & 23.8 & $<0.09$ & $<0.08$ \\
\hline
\end{tabular}

(a) Solids concentrations are reported on a washed, dry mass basis. Reference date March May, 2007. Despite wash, $\geq 10 \mathrm{wt} \%$ supernatant salts were entrained.

(b) The solids analyte concentrations were obtained from sample 554-G5/6-WL Solids-Fus, Analytical Services Request (ASR) 8060 (RPL ID 08-00508), which was obtained from the slurry aliquot that was removed for additional parametric caustic leach testing (refer to Figure 4.5); the sample solids had been well-washed before analysis.

(c) Supernatant measured from the combined Group 5/6 composite at start of CUF test, ASR 8055, sample TI552-G6-B (RPL ID 08-00219); reference date November 5, 2007.

Analyte uncertainties were typically within $\pm 15 \%$; results in brackets indicate that the analyte concentrations were greater than the method detection limit (MDL) and less than the estimated quantitation limit (EQL), and uncertainties were $>15 \%$.

Opportunistic analytes are reported for information only; quality control (QC) requirements did not apply to these analytes. 
Generally the measured supernatant concentrations agreed with calculated concentrations. However, $\mathrm{Pu}, \mathrm{F}$, and oxalate concentrations in the supernatant were higher than anticipated by factors of $2.0,2.8$, and 4.3, respectively. The analyte concentrations in the solid phase represent the water-washed insoluble components reported on a dry mass basis. The measured ICP-OES metals concentrations in the solids were generally higher than the calculated concentrations. Some supernatant entrainment had been reported in the initial characterization samples, which would tend to bias the calculated concentration low. In contrast, the measured composite sample solids were well-washed before analysis, improving the removal of water-insoluble components and supernatant. Radionuclides, $\mathrm{U}$, and $\mathrm{Cr}$ concentrations, however, appeared to agree well with the calculated results.

Crystal form and habit characterization activities (SEM, TEM, and XRD) were not conducted on the composite material since these activities have been previously performed on the individual composites (Fiskum et al. 2008).

\subsubsection{CUF Testing}

Figure 4.5 through Figure 4.8 outline the testing of the blended Group 5/6 sample. Specific target process conditions along with the basis were predefined in a processing concurrence request with concurrence from WTP. ${ }^{\text {(a) }}$ The characterization activities supporting each step are shown as well as splits taken for downstream process testing of the CUF products and byproducts in support of additional parametric testing, ion exchange testing, and evaporation testing.

(a) Letter from G Beeman to H Hazen 7/31/2008, reference number WTP/RPP-MOA-PNNL-00259, see Appendix C. 


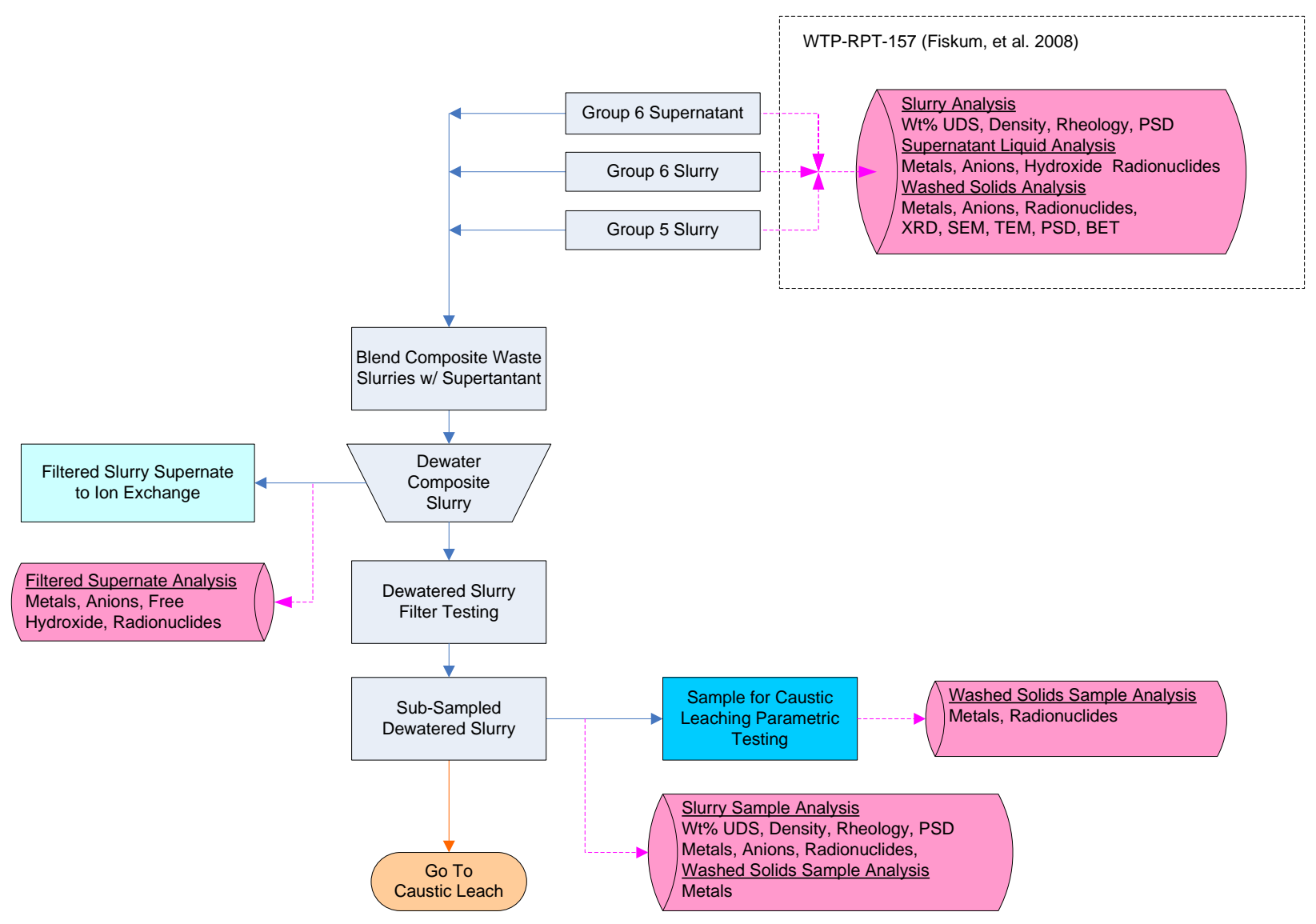

Figure 4.5. Group 5/6 CUF Processing Flowchart-Initial Compositing and Filtering 


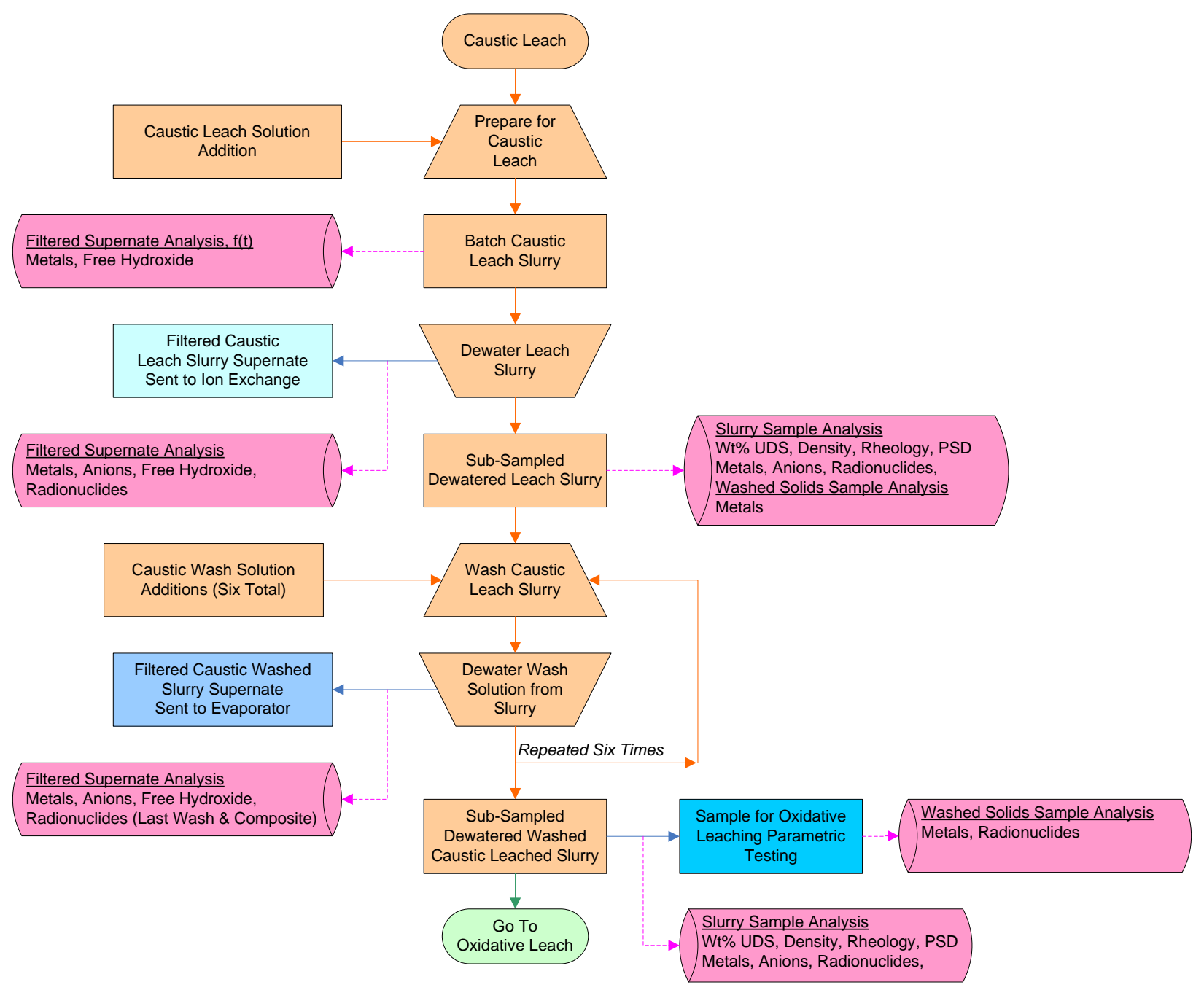

Figure 4.6. Group 5/6 CUF Processing Flowchart-Caustic Leaching and Rinsing 


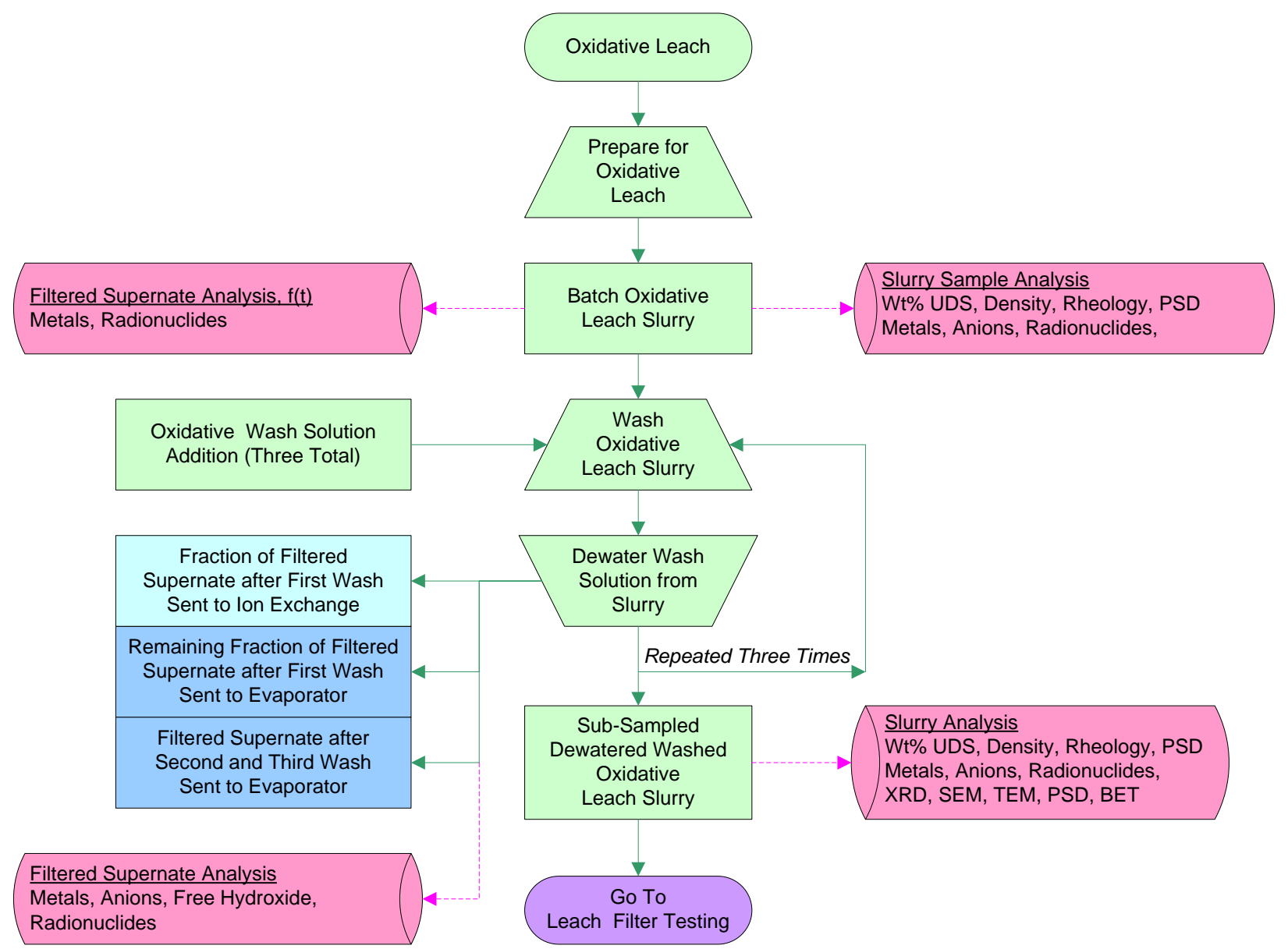

Figure 4.7. Group 5/6 CUF Processing Flowchart-Oxidative Leaching and Rinsing 


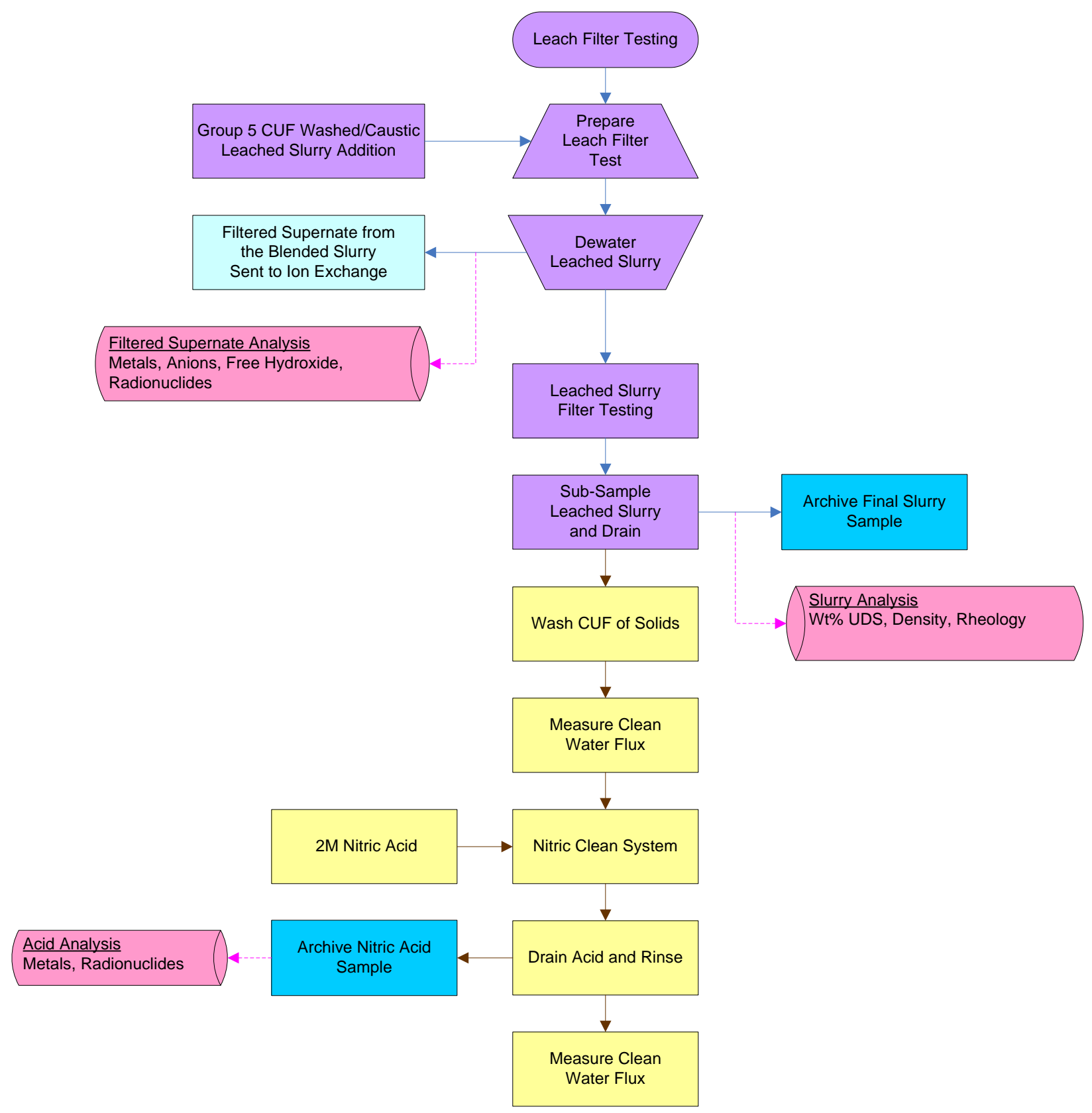

Figure 4.8. Final Filtration Testing with Added Group 5 Caustic-Leached Solids and CUF System Cleanout

\section{Compositing and Initial Filtration Testing (Figure 4.5)}

After compositing the slurries and supernatant, the Group 5/6 slurry was dewatered to $13 \mathrm{wt} \%$ UDS. The filtrate was saved for follow-on ion exchange testing. The slurry was subjected to a filtration parametric test matrix as described separately (Shimskey et al. in press). A fraction of the slurry was submitted for caustic leach parametric testing, results of which are also discussed separately (Shimskey et al., in press). Aliquots of this fraction were washed and characterized for radioisotopes and metals, providing a firm foundation for the Group 5/6 solids chemical composition before caustic leaching. 


\section{Caustic Leaching and Rinsing (Figure 4.6)}

After filtration testing, the dewatered waste slurry was removed from the slurry recirculation loop and consolidated in the slurry reservoir tank. The slurry was mixed constantly using the overhead mixer/impeller during the caustic leach processing. A 2.3-L volume of $10.9 \mathrm{M} \mathrm{NaOH}$ was blended with the concentrated slurry. (The sodium hydroxide volume and molarity were established to mimic the anticipated conditions in the UFP2 vessel where process water is added from heating with steam injection). The leach solution was ramped to $100^{\circ} \mathrm{C}\left(+5^{\circ} /-10^{\circ} \mathrm{C}\right)$ in $5.3 \mathrm{~h}$ and held for $8 \mathrm{~h}$. The slurry permeate was sampled during the heat ramp and temperature soak to evaluate the aluminum dissolution rate during these two periods. Afterwards, the solution was cooled $\left(\mathrm{T}=25^{\circ} \mathrm{C}\right)$ over a 12 -h period. The leached and cooled slurry was then dewatered to minimum volume of 1.2 to $1.4 \mathrm{~L}$, resulting in a slurry containing $8.9 \mathrm{wt} \%$ UDS. The basis for these conditions is contained in WTP-/RPP-MOA-PNNL-00259.

The leached solids were rinsed six sequential times. After adding a 1.2-L volume of rinse solution, the slurry was mixed by pumping through the slurry recirculation loop for 5 to 10 minutes and then dewatered to a 1.2- to 1.4-L slurry volume. Each rinse permeate was collected separately. The $\mathrm{NaOH}$ concentration of each added rinse solution was established to provide sufficient free-hydroxide concentration to maintain the solubility of dissolved aluminum (based on 100\% Al dissolution).The amount of added caustic was determined using the gibbsite solubility data reported by Li et al. (2005). The added sequential $\mathrm{NaOH}$ rinse solutions were $1.53 \mathrm{M}, 0.66 \mathrm{M}, 0.24 \mathrm{M}, 0.09 \mathrm{M}, 0.02 \mathrm{M}$, and $0.01 \mathrm{M}$. After the sixth rinse, the free-hydroxide level of the washed permeate was predicted to be below $0.25 \mathrm{M}$.

\section{Oxidative Leaching and Rinsing (Figure 4.7)}

The slurry was drained from the slurry circulation loop and consolidated in the slurry reservoir tank in preparation for oxidative leaching. A $195-\mathrm{mL}$ volume of $1.03 \mathrm{M} \mathrm{NaMnO}_{4}$ was added to the slurry. This inadvertent over-addition of $\mathrm{NaMnO}_{4}$ achieved a 1.7:1 molar ratio of $\mathrm{Mn}$ to $\mathrm{Cr}$ in the waste solids, which exceeded the targeted 1:1 Mn to $\mathrm{Cr}$ mole ratio. The slurry was mixed using the overhead mixer for $6 \mathrm{~h}$ at cell temperature $\left(27 \pm 3^{\circ} \mathrm{C}\right)$. Aqueous samples were collected at $0.5 \mathrm{~h}, 1 \mathrm{~h}, 2 \mathrm{~h}, 4 \mathrm{~h}$, and $6 \mathrm{~h}$ to evaluate the $\mathrm{Cr}$ and $\mathrm{Pu}$ dissolution rate as a function of time. The slurry volume at this point was too low to support dewatering; therefore, the first of three $0.01-\mathrm{M} \mathrm{NaOH}$ rinse solutions $(1200 \mathrm{~mL})$ was added before dewatering the oxidatively leached slurry. Mixing was accomplished by circulating the slurry in the circulation loop for 20 to $30 \mathrm{~min}$, and then $1200 \mathrm{~mL}$ of permeate was removed. A portion of the permeate was sent to the ion exchange feed, and another portion sent for evaporation testing. The solids were rinsed twice more with $0.01 \mathrm{M} \mathrm{NaOH}(1200 \mathrm{~mL}$ each rinse). Each time, the slurry was allowed to circulate with the solution for 20 to 30 min with both the overhead mixer and circulation pump running before filtration (1200 $\mathrm{mL}$ removed). The second and third rinse solutions were saved for evaporation testing. After the final rinse, the measured slurry solid concentration was $9.7 \mathrm{wt} \%$ UDS.

\section{Final Filtration Testing (Figure 4.8)}

After dewatering the last rinse solution, the oxidatively leached and rinsed slurry was combined with the remaining caustic-leached and washed slurry from a previous CUF test with Group 5 (3.8 wt\% UDS) 


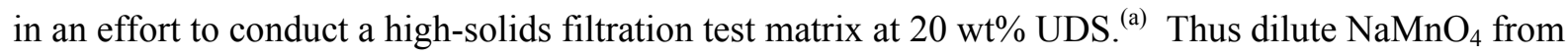
Group 5/6 testing contacted the caustically leached and washed Group 5 solids. This combined slurry was dewatered to a minimum volume. A portion of the filtrate was provided for ion exchange testing. The final measured solids concentration was $8.0 \mathrm{wt} \%$ UDS. The dewatered slurry was then subjected to an abridged filter matrix test.

\section{CUF Cleanout and Leaching (Figure 4.8)}

The final slurry was drained from the CUF after filtration testing was completed and kept as an archive sample. The inside of the slurry reservoir was then manually scrubbed and rinsed with DI water until all visible solids were removed from the inside walls of the tank. The rinse solutions from the tank were drained and disposed of as waste. Afterwards, $2 \mathrm{~L}$ of DI water was added to the CUF and circulated through the slurry loop to remove solids from the piping. The rinse water was then drained and disposed of. This step was repeated two more times until the rinse water appeared clear. At that point, $2 \mathrm{~L}$ of $0.01 \mathrm{M} \mathrm{NaOH}$ were added to the CUF to measure the clean water flux. The solution was drained after testing.

The system was then acid leached using $2 \mathrm{~L}$ of $2 \mathrm{M}$ nitric acid at cell temperature $\left(\sim 27^{\circ} \mathrm{C}\right)$. Half of the solution was added to the CUF through the filter's back-pulse chamber while half was added directly to the slurry reservoir. The acid solution was circulated through the slurry and permeate piping for approximately $1 \mathrm{~h}$. Before the circulation pump was turned off, three back pulses were performed on the filter. The acid was then drained and archived. The archived sample was later sub-sampled for ICP-OES metals and radionuclide analyses. The CUF was then rinsed twice with $2 \mathrm{~L}$ DI water and once with $2 \mathrm{~L}$ $0.01 \mathrm{M} \mathrm{NaOH}$. After verifying that the $\mathrm{pH}$ of the final rinse solution was close to neutral using $\mathrm{pH}$ paper, another $2 \mathrm{~L}$ of $0.01 \mathrm{M} \mathrm{NaOH}$ was added to the CUF. The clean water flux was measured again to quantify the impact of cleaning on filtration performance.

\subsubsection{Sampling and Analysis}

Samples were collected throughout the CUF testing to measure the physical and chemical properties of the waste slurry and permeate.

Slurry samples were collected from two separate locations on the system. Small slurry samples ( $\leq 20$-mL for $\mathrm{wt} \%$ UDS and chemical characterization) were collected from the top of the slurry tank reservoir with transfer pipets while the mixer was operating. The tips of the pipets were cut at an angle to minimize the potential for plugging. Larger samples $(\sim 100 \mathrm{~mL}$ for rheology) were obtained from the drain valve on the pump discharge while the pump was running. When rheology samples were available, they were sub-sampled to support wt\% UDS, PSD, and chemical characterization in lieu of sampling from the slurry tank reservoir.

During dewatering operations, the three-way valve on the permeate collection port was positioned to divert permeate to the permeate sample line and away from recycling to the slurry reservoir. Permeate exiting the sample line was collected in 1.5-L polypropylene bottles to be processed later for ion exchange or evaporation testing. Permeate sub-samples were collected directly from the 1.5 -L collection bottles for chemical analysis. Sampling of the aqueous-phase was more difficult during leaching

(a) This step was identified in the concurrence request WTP/RPP-MOA-PNNL-00259 and concurred with by WTP. 
operations (i.e., the samples of the leachate that were collected as a function of time to assess leach kinetics). In this case, a slurry sample was collected from the slurry reservoir tank as previously described. The sample was then transferred into a $5-\mathrm{mL}$ plastic disposable syringe barrel equipped with a $0.45-\mu \mathrm{m}$ pore size nylon syringe filter in polytetrafluoroethylene (PTFE) housing. Once $\sim 5$-mL of slurry was in the syringe barrel, the syringe plunger was installed, and the contents were filtered into a plastic sample vial.

Rheological properties were measured directly on the slurry samples. Because the rheology sample size $(100 \mathrm{~mL})$ was rather large, the rheology samples were tested and then returned to the CUF for continued treatment. Samples collected for $\mathrm{w} t \%$ UDS determinations were processed directly, and PSD samples were diluted with $0.01 \mathrm{M} \mathrm{NaOH}$ before measurement. The aqueous-phase samples were split for direct analysis by IC for anions, potentiometric titration for free hydroxide, acid digestion followed by ICP-OES analysis for metals, U by kinetic phosphorescence analysis (KPA), radiochemical separations, and counting for radionuclides. Characterization activities of the solids phase were conducted as shown in Figure 4.9. In this case, additional solids washing on the slurry analytical sample was not conducted; the solids washing in the CUF was considered adequate for the purpose. Selected duplicate slurry samples were washed three sequential times with $0.01 \mathrm{M} \mathrm{NaOH}$ (wash solution was $\sim 2 \times$ volume of centrifuged solids) using centrifuging and decanting for phase separation. The washed solids were aciddigested (HF-assisted) and then analyzed by ICP-OES to better understand the residual solids metal concentrations free of entrained supernatant components.

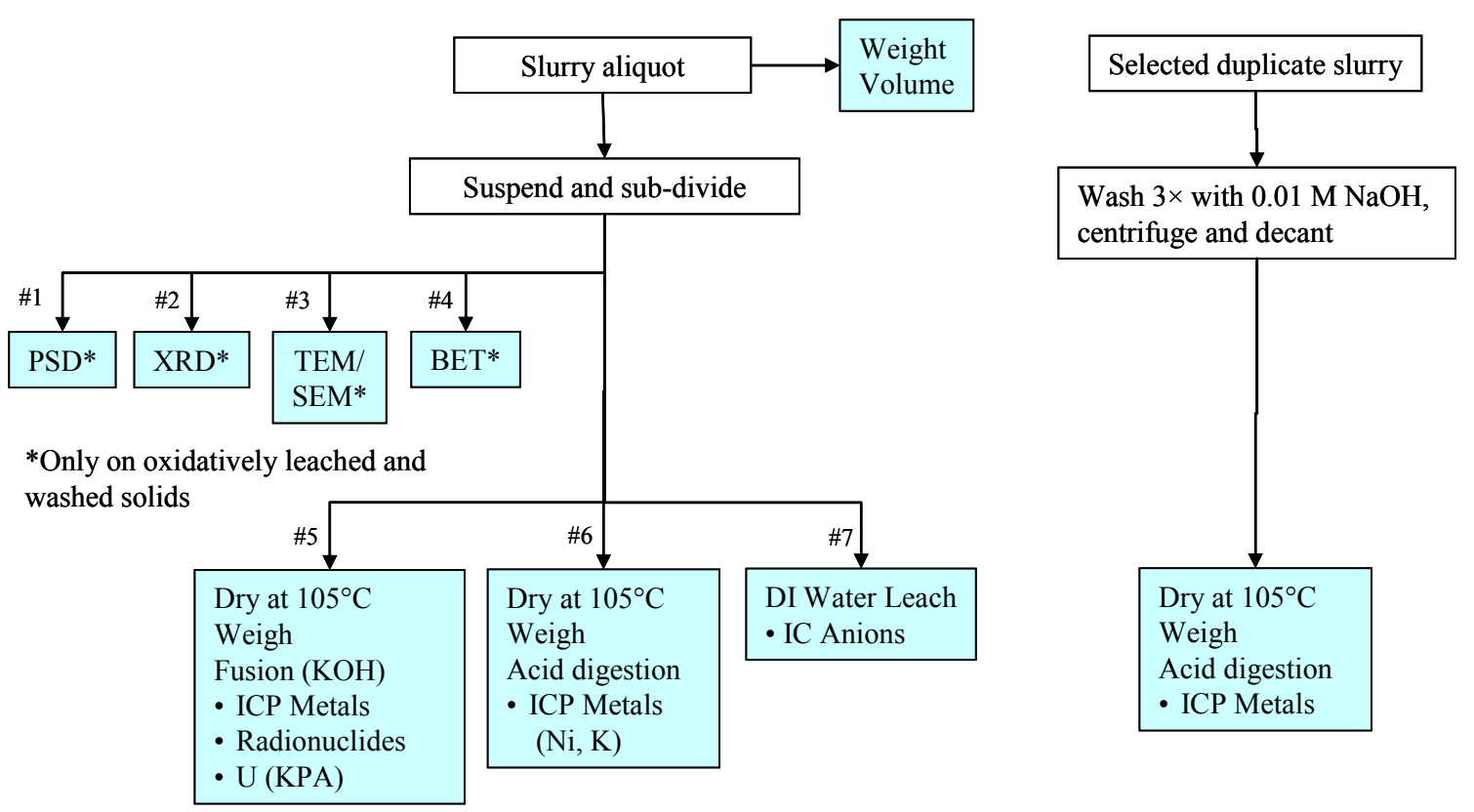

Figure 4.9. CUF Slurry Characterization Scheme

\section{Chemical Leach Factors for Caustic and Oxidative Leaching}

The chemical leach factor was defined as the percentage difference in mass of a solids component in the waste before and after chemical leaching and washing as defined in Equation 4.1. 


$$
f_{i}=1-\frac{m_{i}^{\text {final }}}{m_{i}^{\text {initial }}}
$$

where $f_{i}$ is the leach factor for component $\mathrm{I}, m_{i}^{\text {initial }}$ is the initial solid mass of component $\mathrm{i}$, and $m_{i}^{\text {final }}$ is the final solid mass of component $i$.

The methods used to derive the initial and final mass of a component in the solids included:

- overall mass balance of the system along with wt $\%$ UDS measurement of the slurry

- mass balance before and after leaching using insoluble components such as uranium and iron to trace the fractional change in mass

- mass balance of the liquid permeate before and after leaching measuring dissolved analytes of interest.

\subsection{CUF Process Results}

This section summarizes the demonstration test CUF processing results from a chemistry perspective. Physical properties such as filtration behavior, PSD, rheology, and wt $\%$ UDS were reported separately (Shimskey et al. in press); salient features are summarized in Table 4.3.

Table 4.3. Summary of Group 6/5 CUF Tests

\begin{tabular}{|c|c|c|}
\hline Filtration Step & Property & Group 6/5 Test \\
\hline \multirow{2}{*}{$\begin{array}{l}\text { Dewatering of Waste Prior } \\
\text { to Caustic Leaching }\end{array}$} & Initial Flux & $0.01-0.02 \mathrm{gpm} / \mathrm{ft}^{2}$ \\
\hline & Final Flux & $\begin{array}{l}0.03 \mathrm{gpm} / \mathrm{ft}^{2} \\
\text { (After Group } 5 \text { addition) }\end{array}$ \\
\hline \multirow{5}{*}{$\begin{array}{l}\text { Filtration Conditions } \\
\text { TMP: } 40 \text { psid } \\
A V: 13 \mathrm{fps}\end{array}$} & Final UDS & $13 \mathrm{wt} \%$ \\
\hline & Final water content in slurry & $62 \mathrm{wt} \%$ \\
\hline & Behavior & Time Dependent Decay \\
\hline & Baseline Flux & $0.02-0.03 \mathrm{gpm} / \mathrm{ft}^{2}$ \\
\hline & Controlling Parameter & TMP and Time both Dominant \\
\hline \multirow{7}{*}{$\begin{array}{l}\text { Caustic Leach Dewater } \\
\text { Baseline Condition TMP: } 40 \\
\text { psid } \\
\text { AV: } 13 \text { fps }\end{array}$} & Initial Flux & 0.010 \\
\hline & Final Filter Flux & $0.006 \mathrm{gpm} / \mathrm{ft}^{2}$ \\
\hline & Final UDS & $8.9 \mathrm{wt} \%$ \\
\hline & Final water content in slurry & $61 \mathrm{wt} \%$ \\
\hline & Behavior & Decay over time \\
\hline & Rheology & \begin{tabular}{|l|} 
Non-Newtonian \\
Yield Stress: $11-23 \mathrm{~Pa}$ \\
Consistency: $29-15 \mathrm{mPa} \cdot \mathrm{s}$ \\
\end{tabular} \\
\hline & Particle Size & $\begin{array}{l}d(10): 0.56 \mu \mathrm{m} \\
\mathrm{d}(50): 1.9 \mu \mathrm{m} \\
\mathrm{d}(90): 6.9 \mu \mathrm{m} \\
\end{array}$ \\
\hline \multirow{3}{*}{$\begin{array}{l}\text { Caustic Wash } 1 \\
\text { Filtration Conditions } \\
T M P: 40 \text { psid } \\
A V: 13 \mathrm{fps}\end{array}$} & Wash Solution & $1.53 \mathrm{M} \mathrm{NaOH}$ \\
\hline & Permeate Conc. & $\begin{array}{l}\mathrm{Na}]: 5.0 \mathrm{M} \\
{[\mathrm{OH}]: 4.0 \mathrm{M}} \\
\end{array}$ \\
\hline & Filter Flux & $0.02 \mathrm{gpm} / \mathrm{ft}^{2}$ \\
\hline
\end{tabular}


Table 4.3. Summary of Group 6/5 CUF Tests

\begin{tabular}{|c|c|c|}
\hline Filtration Step & Property & "Group 6/5 Test \\
\hline \multirow{3}{*}{$\begin{array}{l}\text { Caustic Wash } 2 \\
\text { Filtration Conditions } \\
T M P: 40 \text { psid } \\
A V: 13 \mathrm{fps}\end{array}$} & Wash Solution & $0.66 \mathrm{M} \mathrm{NaOH}$ \\
\hline & Permeate Conc. & $\begin{array}{l}{[\mathrm{Na}]: 3.2 \mathrm{M}} \\
{[\mathrm{OH}]: 2.4 \mathrm{M}}\end{array}$ \\
\hline & Filter Flux & $0.04 \mathrm{gpm} / \mathrm{ft}^{2}$ \\
\hline \multirow{3}{*}{$\begin{array}{l}\text { Caustic Wash } 3 \\
\text { Filtration Conditions } \\
\text { TMP: } 40 \text { psid } \\
A V: 13 \mathrm{fps}\end{array}$} & Wash Solution & $0.24 \mathrm{M} \mathrm{NaOH}$ \\
\hline & Permeate Conc. & $\begin{array}{l}{[\mathrm{Na}]: 1.8 \mathrm{M}} \\
{[\mathrm{OH}]: 1.4 \mathrm{M}}\end{array}$ \\
\hline & Filter Flux & $0.1 \mathrm{gpm} / \mathrm{ft}^{2}$ \\
\hline \multirow{3}{*}{$\begin{array}{l}\text { Caustic Wash } 4 \\
\text { Filtration Conditions } \\
\text { TMP: } 40 \text { psid } \\
A V: 13 \mathrm{fps}\end{array}$} & Wash Solution & $0.09 \mathrm{M} \mathrm{NaOH}$ \\
\hline & Permeate Conc. & $\begin{array}{l}{[\mathrm{Na}]: 0.92 \mathrm{M}} \\
{[\mathrm{OH}]: 0.73 \mathrm{M}}\end{array}$ \\
\hline & Filter Flux & $0.1 \mathrm{gpm} / \mathrm{ft}^{2}$ \\
\hline \multirow{3}{*}{$\begin{array}{l}\text { Caustic Wash } 5 \\
\text { Filtration Conditions } \\
\text { TMP: } 40 \text { psid } \\
A V: 13 \mathrm{fps}\end{array}$} & Wash Solution & $0.02 \mathrm{M} \mathrm{NaOH}$ \\
\hline & Permeate Conc. & $\begin{array}{l}{[\mathrm{Na}]: 0.50 \mathrm{M}} \\
{[\mathrm{OH}]: 0.38 \mathrm{M}}\end{array}$ \\
\hline & Filter Flux & $0.09 \mathrm{gpm} / \mathrm{ft}^{2}$ \\
\hline \multirow{3}{*}{$\begin{array}{l}\text { Caustic Wash } 6 \\
\text { Filtration Conditions } \\
\text { TMP: } 40 \text { psid } \\
A V: 13 \mathrm{fps} \\
\end{array}$} & Wash Solution & $0.01 \mathrm{M} \mathrm{NaOH}$ \\
\hline & Permeate Conc. & $\begin{array}{l}{[\mathrm{Na}]: 0.25 \mathrm{M}} \\
{[\mathrm{OH}]: 0.17 \mathrm{M}}\end{array}$ \\
\hline & Filter Flux & $0.1 \mathrm{gpm} / \mathrm{ft}^{2}$ \\
\hline \multirow{4}{*}{$\begin{array}{l}\text { Washed Caustic Leached } \\
\text { Slurry }\end{array}$} & UDS & $13 \mathrm{wt} \%$ \\
\hline & Final water content in slurry & $85 \mathrm{wt} \%$ \\
\hline & Particle Size & $\begin{array}{l}\mathrm{d}(10): 0.54 \mu \mathrm{m} \\
\mathrm{d}(50): 1.7 \mu \mathrm{m} \\
\mathrm{d}(90): 5.7 \mu \mathrm{m}\end{array}$ \\
\hline & $\begin{array}{l}\text { Rheology } \\
\text { (a) } 25^{\circ} \mathrm{C}-60^{\circ} \mathrm{C}\end{array}$ & $\begin{array}{l}\text { Non-Newtonian } \\
\text { Yield Stress: 21-24 Pa } \\
\text { Consistency: 29-15 } \mathrm{mPa} \cdot \mathrm{s}\end{array}$ \\
\hline \multirow[t]{3}{*}{ Oxidative Leach Slurry } & UDS & $6 \mathrm{wt} \%$ \\
\hline & Final water content in slurry & $91 \mathrm{wt} \%$ \\
\hline & Particle Size & $\begin{array}{l}\mathrm{d}(10): 0.44 \mu \mathrm{m} \\
\mathrm{d}(50): 1.2 \mu \mathrm{m} \\
\mathrm{d}(90): 4.9 \mu \mathrm{m}\end{array}$ \\
\hline \multirow{3}{*}{$\begin{array}{l}\text { Oxidative Wash } 1 \\
\text { Filtration Conditions } \\
T M P: 40 \text { psid } \\
A V: 13 \mathrm{fps}\end{array}$} & Wash Solution & $0.01 \mathrm{M} \mathrm{NaOH}$ \\
\hline & Permeate Conc. & $\begin{array}{l}\mathrm{Na}]: 0.28 \mathrm{M} \\
{[\mathrm{OH}]: 0.05 \mathrm{M}}\end{array}$ \\
\hline & Filter Flux & $0.1 \mathrm{gpm} / \mathrm{ft}^{2}$ \\
\hline \multirow{3}{*}{$\begin{array}{l}\text { Oxidative Wash } 2 \\
\text { Filtration Conditions } \\
T M P: 40 \text { psid } \\
A V: 13 \mathrm{fps}\end{array}$} & Wash Solution & $0.01 \mathrm{M} \mathrm{NaOH}$ \\
\hline & Permeate Conc. & $\begin{array}{l}{[\mathrm{Na}]: 0.19 \mathrm{M}} \\
{[\mathrm{OH}]: 0.03 \mathrm{M}}\end{array}$ \\
\hline & Filter Flux & $0.1 \mathrm{gpm} / \mathrm{ft}^{2}$ \\
\hline Oxidative Wash 3 & Wash Solution & $0.01 \mathrm{NaOH}$ \\
\hline
\end{tabular}


Table 4.3. Summary of Group 6/5 CUF Tests

\begin{tabular}{|c|c|c|}
\hline Filtration Step & Property & Group 6/5 Test \\
\hline \multirow{2}{*}{$\begin{array}{l}\text { Filtration Conditions } \\
T M P: 40 \text { psid } \\
A V: 13 \mathrm{fps}\end{array}$} & Permeate Conc. & $\begin{array}{l}{[\mathrm{Na}]: 0.10 \mathrm{M}} \\
{[\mathrm{OH}]: 0.01 \mathrm{M}}\end{array}$ \\
\hline & Filter Flux & $0.1 \mathrm{gpm} / \mathrm{ft}^{2}$ \\
\hline \multirow{4}{*}{$\begin{array}{l}\text { Washed Oxidative Leached } \\
\text { Slurry }\end{array}$} & UDS & $9.7 \mathrm{wt} \%$ \\
\hline & Final water content in slurry & $88 \mathrm{wt} \%$ \\
\hline & Particle Size & $\begin{array}{l}\mathrm{d}(10): 0.43 \mu \mathrm{m} \\
\mathrm{d}(50): 1.2 \mu \mathrm{m} \\
\mathrm{d}(90): 4.2 \mu \mathrm{m}\end{array}$ \\
\hline & $\begin{array}{l}\text { Rheology } \\
\text { (a) } 25^{\circ} \mathrm{C}-60^{\circ} \mathrm{C}\end{array}$ & $\begin{array}{l}\text { Non-Newtonian } \\
\text { Yield Stress: } 0.7-1.4 \mathrm{~Pa} \\
\text { Consistency: } 5-3 \mathrm{mPa} \cdot \mathrm{s}\end{array}$ \\
\hline \multirow{6}{*}{$\begin{array}{l}\text { Final Filter Testing } \\
\text { Baseline Condition TMP: } 40 \\
\text { psid } \\
\text { AV: } 13 \mathrm{fps}\end{array}$} & Material Description & $\begin{array}{l}\text { Group 6/5 Washed Leached Slurry } \\
\text { Blended with } \\
\text { Group } 5 \text { Slurry Washed Leached Slurry }\end{array}$ \\
\hline & UDS & $8.0 \mathrm{wt} \%$ \\
\hline & Particle Size & $\begin{array}{l}\mathrm{d}(10): 0.44 \mu \mathrm{m} \\
\mathrm{d}(50): 1.3 \mu \mathrm{m} \\
\mathrm{d}(90): 5.1 \mu \mathrm{m}\end{array}$ \\
\hline & $\begin{array}{l}\text { Rheology } \\
\text { (a) } 25^{\circ} \mathrm{C}-60^{\circ} \mathrm{C}\end{array}$ & $\begin{array}{l}\text { Non-Newtonian } \\
\text { Yield Stress: } 1-3-1.6 \mathrm{~Pa} \\
\text { Consistency: } 5-4 \mathrm{mPa} \cdot \mathrm{s}\end{array}$ \\
\hline & Baseline Flux & $0.1 \mathrm{gpm} / \mathrm{ft}^{2}$ \\
\hline & Controlling Parameter & $\begin{array}{l}\text { Both TMP and AV } \\
\text { Stable over Time }\end{array}$ \\
\hline
\end{tabular}

\subsection{Caustic Leach and Wash}

The caustic leach and wash solution analytical results are shown in Table 4.4 along with the measured initial aqueous-phase composition (for comparison). Analyte concentrations changed as predicted; [Al] and $[\mathrm{Na}]$ concentrations increased in the caustic leach, and most analyte concentrations decreased in the subsequent washes. The free-hydroxide concentration $(0.17 \mathrm{M})$ in the sixth and final wash solution was less than the benchmark of $0.25 \mathrm{M}$. The sixth wash was necessary to drop the free hydroxide below $0.25 \mathrm{M}$ since the fifth wash solution was measured at $0.38 \mathrm{M}$ free hydroxide.

Normalization of the concentration data to a "spectator" analyte concentration allows a qualitative assessment of relative analyte concentration changes as a result of the leaching and washing processes. To this end, the supernate, leach, composite wash, and final wash concentrations in Table 4.4 were normalized to the nitrate concentration. This assessment assumes that the nitrate did not precipitate or dissolve to a significant extent relative to the starting matrix composition during any process step. If the ratio of [analyte]/[nitrate] was consistent with that of the initial supernate composition, then the process step was shown to be simple dilution of the analyte in the aqueous phase. Where the [analyte]/[nitrate] concentration ratio increased, then the analyte was shown to dissolve from the solids phase, enriching the 
aqueous phase. Conversely, if the [analyte]/[nitrate] concentration ratio decreased, then the analyte was shown to precipitate.

The normalized ratio for Al, of course, was enriched in the caustic leach solution (normalized factors of 50.1 vs 245). The normalized $\mathrm{Cr}$ concentrations continued to increase through leaching and washing, indicating that a fraction of the $\mathrm{Cr}$ in the solids was dissolving under the caustic leach and wash conditions (probably associated with oxidation by dissolved oxygen). The normalized $\mathrm{P}$ and phosphate ratios decreased in the caustic leach but increased in the wash. Therefore $\mathrm{P}$ was shown to migrate to the solids phase during the leach process, possibly as sodium phosphate salt, and then dissolve as washing progressed. Similarly, oxalate was depleted in the aqueous phase during the leach processing and dissolved as washing progressed. Both phosphate and oxalate concentration trends were consistent with reduced solubility in high $\mathrm{NaOH}$ matrices. The $\mathrm{U}$ (KPA) result showed a weak tendency to enrich in the aqueous phase with each process step. Inferences about $\mathrm{Na}$ and free hydroxide cannot be made since these components were added as part of the leach and wash processing. 
Table 4.4. Caustic Leach and Wash Solution Composition

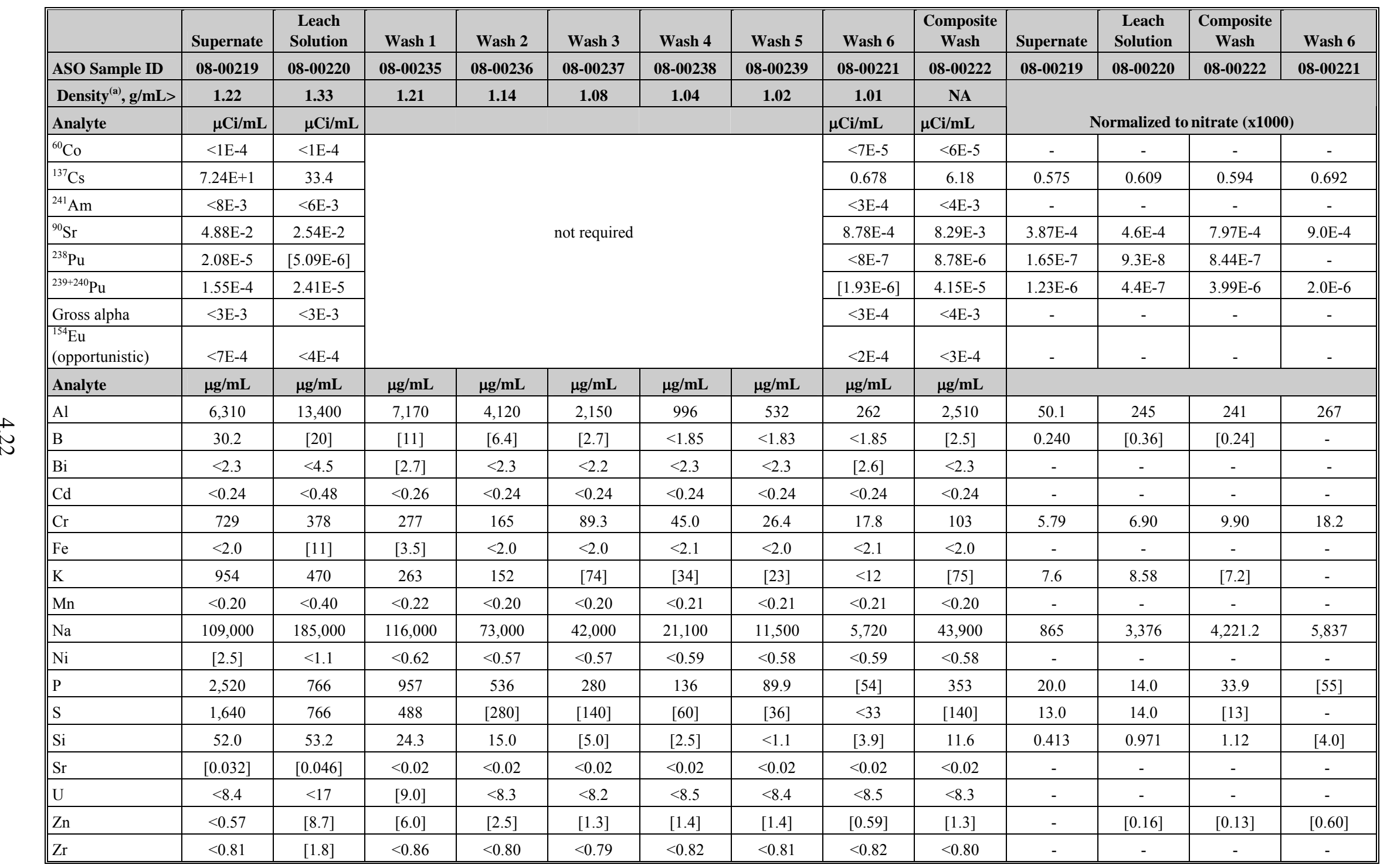


Table 4.4 (contd)

\begin{tabular}{|c|c|c|c|c|c|c|c|c|c|c|c|c|c|}
\hline & Supernate & $\begin{array}{c}\text { Leach } \\
\text { Solution } \\
\end{array}$ & Wash 1 & Wash 2 & Wash 3 & Wash 4 & Wash 5 & Wash 6 & $\begin{array}{c}\text { Composite } \\
\text { Wash }\end{array}$ & Supernate & $\begin{array}{c}\text { Leach } \\
\text { Solution } \\
\end{array}$ & $\begin{array}{c}\text { Composite } \\
\text { Wash }\end{array}$ & Wash 6 \\
\hline ASO Sample ID & 08-00219 & 08-00220 & 08-00235 & 08-00236 & 08-00237 & 08-00238 & 08-00239 & 08-00221 & 08-00222 & 08-00219 & 08-00220 & 08-00222 & 08-00221 \\
\hline Density $^{(\mathrm{a})}, \mathrm{g} / \mathrm{mL}>$ & 1.22 & 1.33 & 1.21 & 1.14 & 1.08 & 1.04 & 1.02 & 1.01 & NA & \multirow{2}{*}{\multicolumn{4}{|c|}{ Normalized to nitrate $(\mathbf{x 1 0 0 0 )}$}} \\
\hline Analyte & $\mu \mathrm{g} / \mathrm{mL}$ & $\mu \mathrm{g} / \mathrm{mL}$ & & & & & & $\mu \mathrm{g} / \mathrm{mL}$ & $\mu \mathrm{g} / \mathrm{mL}$ & & & & \\
\hline $\mathrm{U}(\mathrm{KPA})$ & 5.22 & 6.41 & & & not required & & & 0.752 & 2.94 & 0.0414 & 0.117 & 0.283 & 0.767 \\
\hline nitrite & 37,200 & 16,600 & \multirow{5}{*}{\multicolumn{5}{|c|}{ not analyzed }} & 285 & 3,150 & 295 & 303 & 303 & 291 \\
\hline nitrate & 126,000 & 54,800 & & & & & & 980 & 10,400 & 1000 & 1000 & 1000 & 1000 \\
\hline phosphate & 8,310 & 1,740 & & & & & & 180 & 575 & 66.0 & 31.8 & 55.3 & 184 \\
\hline sulfate & 6,690 & 3,020 & & & & & & 54.8 & 1,180 & 53.1 & 55.1 & 113 & 55.9 \\
\hline oxalate & 894 & 118 & & & & & & 541 & 1,670 & 7.10 & 2.15 & 161 & 552 \\
\hline free $\mathrm{OH}, \mathrm{M}$ & $0.625 \mathrm{M}$ & $6.16 \mathrm{M}$ & $3.95 \mathrm{M}$ & $2.41 \mathrm{M}$ & $1.36 \mathrm{M}$ & $0.73 \mathrm{M}$ & $0.38 \mathrm{M}$ & $0.17 \mathrm{M}$ & $1.57 \mathrm{M}$ & 0.00496 & 0.112 & 0.151 & 0.173 \\
\hline \multicolumn{14}{|c|}{ Opportunistic Analytes } \\
\hline Analyte & $\mu \mathrm{g} / \mathrm{mL}$ & $\mu \mathrm{g} / \mathrm{mL}$ & $\mu \mathrm{g} / \mathrm{mL}$ & $\mu \mathrm{g} / \mathrm{mL}$ & $\mu \mathrm{g} / \mathrm{mL}$ & $\mu \mathrm{g} / \mathrm{mL}$ & $\mu \mathrm{g} / \mathrm{mL}$ & $\mu \mathrm{g} / \mathrm{mL}$ & $\mu \mathrm{g} / \mathrm{mL}$ & & & & \\
\hline fluoride & 273 & 27 & \multicolumn{5}{|c|}{ not analyzed } & 5.4 & 25.1 & 2.17 & 0.493 & 2.41 & 5.51 \\
\hline $\mathrm{Ag}$ & $<0.42$ & $<0.83$ & $<0.45$ & $<0.42$ & $<0.41$ & $<0.43$ & $<0.42$ & $<0.43$ & $<0.42$ & - & - & - & - \\
\hline As & $<7.0$ & $<14$ & {$[10.5]$} & $<6.9$ & $<6.8$ & $<7.1$ & $<7.0$ & $<7.1$ & $<6.9$ & - & - & - & - \\
\hline $\mathrm{Ba}$ & $<0.34$ & $<0.67$ & {$[0.37]$} & $<0.33$ & $<0.33$ & $<0.34$ & $<0.34$ & $<0.34$ & $<0.34$ & - & - & - & - \\
\hline $\mathrm{Be}$ & $<0.01$ & {$[0.086]$} & {$[0.022]$} & {$[0.022]$} & $<0.01$ & $<0.01$ & $<0.01$ & $<0.01$ & {$[0.018]$} & - & - & - & - \\
\hline $\mathrm{Ca}$ & [20] & [17] & [4.25] & {$[2.5]$} & {$[2.7]$} & $<2.1$ & $<2.1$ & [3.3] & [5.2] & {$[0.16]$} & {$[0.31]$} & {$[0.50]$} & [3.4] \\
\hline $\mathrm{Ce}$ & $<1.2$ & $<2.4$ & $<1.3$ & $<1.2$ & $<1.2$ & $<1.2$ & $<1.2$ & $<1.2$ & $<1.2$ & - & - & - & - \\
\hline Co & $<0.39$ & $<0.76$ & $<0.41$ & $<0.38$ & {$[0.42]$} & {$[0.42]$} & $<0.39$ & $<0.39$ & $<0.38$ & - & - & - & - \\
\hline $\mathrm{Cu}$ & $<0.48$ & $<0.95$ & $<0.51$ & $<0.48$ & $<0.47$ & $<0.49$ & $<0.48$ & $<0.49$ & $<0.48$ & - & - & - & - \\
\hline Dy & $<0.35$ & $<0.69$ & $<0.37$ & $<0.35$ & $<0.34$ & $<0.36$ & $<0.35$ & $<0.35$ & $<0.35$ & - & - & - & - \\
\hline $\mathrm{Eu}$ & $<0.11$ & $<0.21$ & $<0.12$ & $<0.11$ & $<0.11$ & $<0.11$ & $<0.11$ & $<0.11$ & $<0.11$ & - & - & - & - \\
\hline $\mathrm{La}$ & {$[0.20]$} & $<0.26$ & $<0.14$ & $<0.13$ & $<0.13$ & $<0.13$ & $<0.13$ & $<0.13$ & {$[0.17]$} & - & - & - & - \\
\hline $\mathrm{Li}$ & $<0.54$ & {$[1.7]$} & {$[2.0]$} & [1.5] & {$[1.3]$} & {$[0.61]$} & $<0.54$ & $<0.55$ & $<0.54$ & - & - & - & - \\
\hline $\mathrm{Mg}$ & $<0.70$ & $<1.38$ & $<0.75$ & $<0.69$ & $<0.69$ & $<0.71$ & $<0.70$ & $<0.71$ & $<0.70$ & - & - & - & - \\
\hline Mo & 30.5 & 16.3 & 8.21 & [4.5] & {$[2.8]$} & [1.4] & [1.3] & {$[0.83]$} & [3.1] & 0.242 & 0.297 & {$[0.30]$} & {$[0.85]$} \\
\hline $\mathrm{Nd}$ & $<1.7$ & $<3.4$ & $<1.8$ & $<1.7$ & $<1.7$ & $<1.7$ & $<1.7$ & $<1.7$ & $<1.7$ & - & - & - & - \\
\hline $\mathrm{Pb}$ & $<3.7$ & {$[25]$} & [4.94] & $<3.7$ & $<3.6$ & $<3.7$ & $<3.7$ & $<3.7$ & $<3.7$ & - & - & - & - \\
\hline $\mathrm{Pd}$ & [1.7] & $<2.48$ & {$[1.38]$} & $<1.2$ & $<1.2$ & $<1.3$ & $<1.3$ & $<1.3$ & $<1.2$ & - & - & - & - \\
\hline $\mathrm{Rh}$ & $<2.5$ & $<5.0$ & $<2.7$ & $<2.5$ & $<2.5$ & $<2.6$ & $<2.5$ & $<2.6$ & $<2.5$ & - & - & - & - \\
\hline
\end{tabular}


Table 4.4 (contd)

\begin{tabular}{|c|c|c|c|c|c|c|c|c|c|c|c|c|c|}
\hline & Supernate & $\begin{array}{c}\text { Leach } \\
\text { Solution } \\
\end{array}$ & Wash 1 & Wash 2 & Wash 3 & Wash 4 & Wash 5 & Wash 6 & $\begin{array}{c}\text { Composite } \\
\text { Wash } \\
\end{array}$ & Supernate & $\begin{array}{c}\text { Leach } \\
\text { Solution } \\
\end{array}$ & \begin{tabular}{|c|}
$\begin{array}{c}\text { Composite } \\
\text { Wash }\end{array}$ \\
\end{tabular} & Wash 6 \\
\hline ASO Sample ID & 08-00219 & 08-00220 & 08-00235 & 08-00236 & 08-00237 & 08-00238 & 08-00239 & 08-00221 & 08-00222 & 08-00219 & 08-00220 & 08-00222 & 08-00221 \\
\hline Density $^{(a)}, g / m L>$ & 1.22 & 1.33 & 1.21 & 1.14 & 1.08 & 1.04 & 1.02 & 1.01 & NA & \multirow{2}{*}{\multicolumn{4}{|c|}{ Normalized to nitrate $(\mathbf{x} 1000)$}} \\
\hline Analyte & $\mu \mathrm{g} / \mathrm{mL}$ & $\mu \mathrm{g} / \mathrm{mL}$ & & & & & & $\mu \mathrm{g} / \mathrm{mL}$ & $\mu \mathrm{g} / \mathrm{mL}$ & & & & \\
\hline $\mathrm{Ru}$ & [3.8] & [3.5] & $<0.96$ & $<0.81$ & $<0.80$ & $<0.83$ & $<0.82$ & $<0.83$ & $<0.82$ & {$[0.030]$} & {$[0.064]$} & - & - \\
\hline $\mathrm{Sb}$ & $<3.1$ & $<6.2$ & $<3.4$ & $<3.1$ & $<3.1$ & $<3.2$ & $<3.1$ & $<3.2$ & $<3.1$ & - & - & - & - \\
\hline Se & {$[8.0]$} & [9.9] & $<5.2$ & {$[12]$} & $<4.8$ & $<5.0$ & $<4.9$ & [27] & [29] & {$[0.063]$} & {$[0.18]$} & {$[2.8]$} & [28] \\
\hline Sn & [3.2] & $<3.9$ & [3.6] & [4.9] & $<2.0$ & $<2.0$ & [4.2] & $<2.0$ & $<2.0$ & - & - & - & - \\
\hline $\mathrm{Ta}$ & $<1.3$ & $<2.6$ & $<1.4$ & $<1.3$ & $<1.3$ & $<1.3$ & $<1.3$ & $<1.3$ & $<1.3$ & - & - & - & - \\
\hline $\mathrm{Te}$ & $<3.1$ & $<6.2$ & $<3.3$ & $<3.1$ & $<3.1$ & $<3.2$ & $<3.2$ & $<3.2$ & $<3.1$ & - & - & - & - \\
\hline Th & $<1.2$ & $<2.3$ & $<1.3$ & $<1.2$ & $<1.2$ & $<1.2$ & $<1.2$ & $<1.2$ & $<1.2$ & - & - & - & - \\
\hline $\mathrm{Ti}$ & $<0.10$ & $<0.19$ & $<0.10$ & $<0.10$ & $<0.09$ & $<0.10$ & $<0.10$ & $<0.10$ & $<0.10$ & - & - & - & - \\
\hline $\mathrm{Tl}$ & $<6.5$ & $<13$ & {$[9.0]$} & $<6.4$ & $<6.4$ & $<6.6$ & $<6.5$ & $<6.6$ & {$[8.2]$} & - & - & & - \\
\hline $\mathrm{V}$ & {$[1.6]$} & {$[0.75]$} & {$[0.65]$} & {$[0.51]$} & $<0.31$ & $<0.32$ & $<0.31$ & {$[0.36]$} & {$[0.40]$} & {$[0.013]$} & {$[0.014]$} & {$[0.038]$} & {$[0.37]$} \\
\hline W & 52.9 & {$[28]$} & [13] & {$[7.6]$} & {$[5.5]$} & {$[2.1]$} & $<1.5$ & $<1.5$ & {$[6.5]$} & 0.420 & {$[0.51]$} & {$[0.63]$} & - \\
\hline $\mathrm{Y}$ & $<0.08$ & $<0.17$ & $<0.09$ & $<0.08$ & $<0.08$ & $<0.09$ & $<0.08$ & $<0.09$ & $<0.08$ & - & - & - & - \\
\hline $\begin{array}{l}\text { (a) Density val } \\
\text { ASR } 8055 \\
\text { Reference date: } \\
\text { Analyte uncerta } \\
\text { and less than th } \\
\text { Opportunistic a }\end{array}$ & $\begin{array}{l}\text { des were ob } \\
\text { November } \\
\text { inties were } \\
\text { estimated } \\
\text { halytes are }\end{array}$ & \multicolumn{6}{|c|}{$\begin{array}{l}\text { (a) Density values were obtained from the mass flow meter, which had not been calibrated to NQA-1 standards; they are reported for information only. } \\
\text { ASR } 8055 \\
\text { Reference date: November } 5,2007 \text {. }\end{array}$} & $\begin{array}{l}\text { JQA-1 star } \\
\text { oncentrati } \\
\text { se analytes }\end{array}$ & idards; the & are report & & mation only & nit (MDL) \\
\hline
\end{tabular}


Figure 4.10 shows the relative concentrations of selected analytes in the initial supernatant, leach composite, wash composite, and final wash solutions. Nitrate and ${ }^{137} \mathrm{Cs}$ concentrations provide good benchmarks to understanding compositional changes from simple dilutions. The Al concentration characteristically increased in the caustic leach. The oxalate concentration showed a marked decrease in the caustic leach solution and increase in the wash composite, unrelated to normal dilution; concentration changes were associated with variation of sodium oxalate solubility in the given matrix. The P (present as phosphate) and fluoride concentration trends were similar to those of oxalate but much less pronounced. Changes in the ${ }^{239+240} \mathrm{Pu}$ concentrations did not follow the characteristic dilution sequences; in fact, its solubility trends appeared to reflect those of oxalate and fluoride. Both oxalate and fluoride are good complexing agents for actinides; the oxalate, fluoride, and/or phosphate-enhanced dissolutions during the washing processes may contribute to increased $\mathrm{Pu}$ solubility.

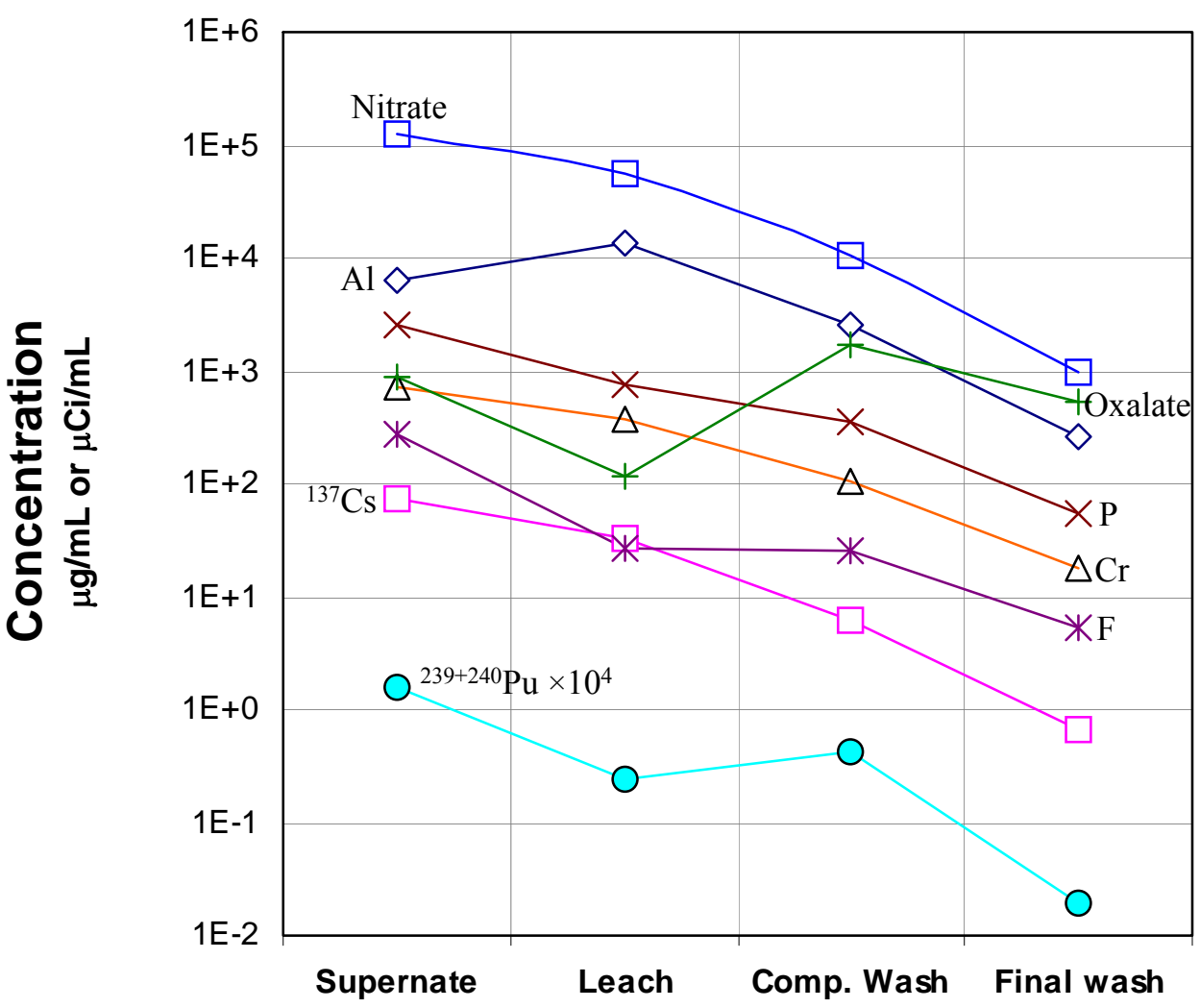

Figure 4.10. Analyte Concentration Changes during Caustic Leach and Solids Wash

Table 4.5 provides the key analyte concentrations in the caustic leached and washed solids with comparison to the measured initial washed-solids composition. Also shown are the analyte concentration factors (CFs) in the leached solids (simple ratio of leached solids composition divided by initial washed solids composition). The higher the $\mathrm{CF}$, the more the analyte is shown to be enriched in the solids phase. In this case, the $\mathrm{Fe}, \mathrm{Mn}, \mathrm{Sr}, \mathrm{U},{ }^{239+240} \mathrm{Pu}$, and ${ }^{90} \mathrm{Sr}$ had the highest $\mathrm{CF}$ s averaging 1.54, indicating that the initial mass was $1.54 \times$ higher than the final mass. Equation 4.1 was modified to incorporate the $\mathrm{CF}$ and measured analyte concentrations to determine the leach factor as shown in Equation 4.2. 


$$
L F=1-\left(\frac{C_{F}}{C_{I} \times 1.54}\right)
$$

where LF is the leach factor, $\mathrm{C}_{\mathrm{F}}$ is the analyte concentration in the caustic leached and washed solids, and $\mathrm{C}_{\mathrm{I}}$ is the calculated washed solids starting analyte concentration. Table 4.5 shows the calculated leach factors for the key analytes.

Table 4.5. Solids Composition Before and After Caustic Leach and Wash

\begin{tabular}{|c|c|c|c|c|c|}
\hline & $\begin{array}{c}\text { Initial Washed } \\
\text { Solids }\end{array}$ & $\begin{array}{c}\text { Caustic Leached and } \\
\text { Washed Solids }\end{array}$ & \multirow{3}{*}{$\begin{array}{c}\text { Conc. } \\
\text { Factor }^{(e)}\end{array}$} & \multicolumn{2}{|c|}{ Leached (\%) } \\
\hline ASO Sample ID & NA & 08-00244 & & \multirow{2}{*}{$\begin{array}{c}\text { Solids } \\
\text { Analysis }\end{array}$} & \multirow{2}{*}{$\begin{array}{l}\text { Solution } \\
\text { Analysis }\end{array}$} \\
\hline Analyte & $\mu \mathrm{Ci} / \mathrm{g}^{(\mathrm{a}, \mathrm{b})}$ & $\mu \mathrm{Ci} / \mathrm{g}^{(\mathrm{a}, \mathrm{c})}$ & & & \\
\hline${ }^{137} \mathrm{Cs}$ & $6.61 \mathrm{E}+1$ & $8.42 \mathrm{E}+1$ & 1.28 & $17 \%$ & (g) \\
\hline${ }^{60} \mathrm{Co}$ & $2.61 \mathrm{E}-2$ & $4.19 \mathrm{E}-2$ & 1.61 & $-4.2 \%$ & $<7 \%$ \\
\hline${ }^{241} \mathrm{Am}$ & $1.63 \mathrm{E}+0$ & $2.12 \mathrm{E}+0$ & 1.30 & $16 \%^{(\mathrm{d})}$ & $<10 \%$ \\
\hline${ }^{238} \mathrm{Pu}$ & $5.06 \mathrm{E}-2$ & $7.70 \mathrm{E}-2$ & 1.52 & $1.2 \%{ }^{(\mathrm{d})}$ & $0.17 \%$ \\
\hline${ }^{239+240} \mathrm{Pu}$ & $8.90 \mathrm{E}-1$ & $1.31 \mathrm{E}+0$ & 1.48 & $4.2 \%{ }^{(\mathrm{d})}$ & $0.02 \%$ \\
\hline Gross alpha & $2.71 \mathrm{E}+0$ & $3.68 \mathrm{E}+0$ & 1.36 & $12 \%^{(\mathrm{d})}$ & $<5 \%$ \\
\hline Gross beta & $1.23 \mathrm{E}+3$ & $1.94 \mathrm{E}+3$ & 1.58 & $-2.2 \%$ & (g) \\
\hline${ }^{90} \mathrm{Sr}$ & $5.72 \mathrm{E}+2$ & $8.71 \mathrm{E}+2$ & 1.52 & $1.2 \%^{(\mathrm{d})}$ & $0.01 \%$ \\
\hline${ }^{154} \mathrm{Eu}$ (opportunistic) & $4.24 \mathrm{E}-1$ & $6.42 \mathrm{E}-1$ & 1.51 & $1.8 \%$ & $<2 \%$ \\
\hline Analyte & $\mu \mathrm{g} / \mathrm{g}$ & $\mu \mathrm{g} / \mathrm{g}$ & & & \\
\hline $\mathrm{Al}$ & 335,500 & 278,000 & 0.83 & $46 \%$ & $39 \%$ \\
\hline $\mathrm{B}$ & [210] & $<88$ & - & - & {$[1.2 \%]$} \\
\hline $\mathrm{Bi}$ & {$[880]$} & [350] & {$[0.40]$} & {$[74 \%]$} & - \\
\hline $\mathrm{Cd}$ & [18] & {$[60]$} & {$[3.4]$} & {$[-122 \%]$} & $<23 \%$ \\
\hline $\mathrm{Cr}$ & $26,250^{(\mathrm{f})}$ & 38,000 & 1.45 & $6.2 \%{ }^{(\mathrm{f})}$ & {$[1.5 \%]$} \\
\hline $\mathrm{Fe}$ & 11,250 & 15,800 & 1.40 & $8.9 \%^{(\mathrm{d})}$ & {$[0.83 \%]$} \\
\hline $\mathrm{K}$ & na & na & - & - & (g) \\
\hline $\mathrm{Mn}$ & 4,970 & 7,360 & 1.48 & $4.0 \%$ & $<0.1 \%$ \\
\hline $\mathrm{Na}$ & {$[25,500]$} & {$[69,000]$} & na & na & na \\
\hline $\mathrm{Ni}$ & na & na & - & - & $<1.6 \%$ \\
\hline$P$ & {$[1,400]$} & [980] & {$[0.70]$} & {$[55 \%]$} & (g) \\
\hline $\mathrm{S}$ & {$[1,650]$} & [990] & {$[0.60]$} & {$[61 \%]$} & (g) \\
\hline $\mathrm{Si}$ & 14,350 & 19,900 & 1.39 & $10 \%$ & $2.3 \%$ \\
\hline $\mathrm{Sr}$ & 943 & 1,360 & 1.44 & $6.5 \%^{(\mathrm{d})}$ & {$[0.02 \%]$} \\
\hline $\mathrm{U}$ & 17,600 & 27,100 & 1.54 & $0.18 \%$ & $<1.9 \%$ \\
\hline $\mathrm{Zn}$ & 199 & {$[150]$} & 0.75 & $51 \%$ & {$[28 \%]$} \\
\hline $\mathrm{Zr}$ & {$[140]$} & [210] & {$[1.5]$} & {$[2.8 \%]$} & {$[6.2 \%]$} \\
\hline $\mathrm{U}(\mathrm{KPA})$ & 15,300 & 26,300 & 1.72 & $-12 \%$ & $0.55 \%$ \\
\hline \multicolumn{6}{|c|}{ Opportunistic Analytes } \\
\hline $\mathrm{Ag}$ & {$[15]$} & $<17$ & - & - & - \\
\hline As & $<160$ & $<270$ & - & - & - \\
\hline $\mathrm{Ba}$ & 118 & [160] & {$[1.4]$} & {$[12 \%]$} & - \\
\hline $\mathrm{Be}$ & {$[0.75]$} & $<1.0$ & - & - & - \\
\hline
\end{tabular}


Table 4.5 (contd)

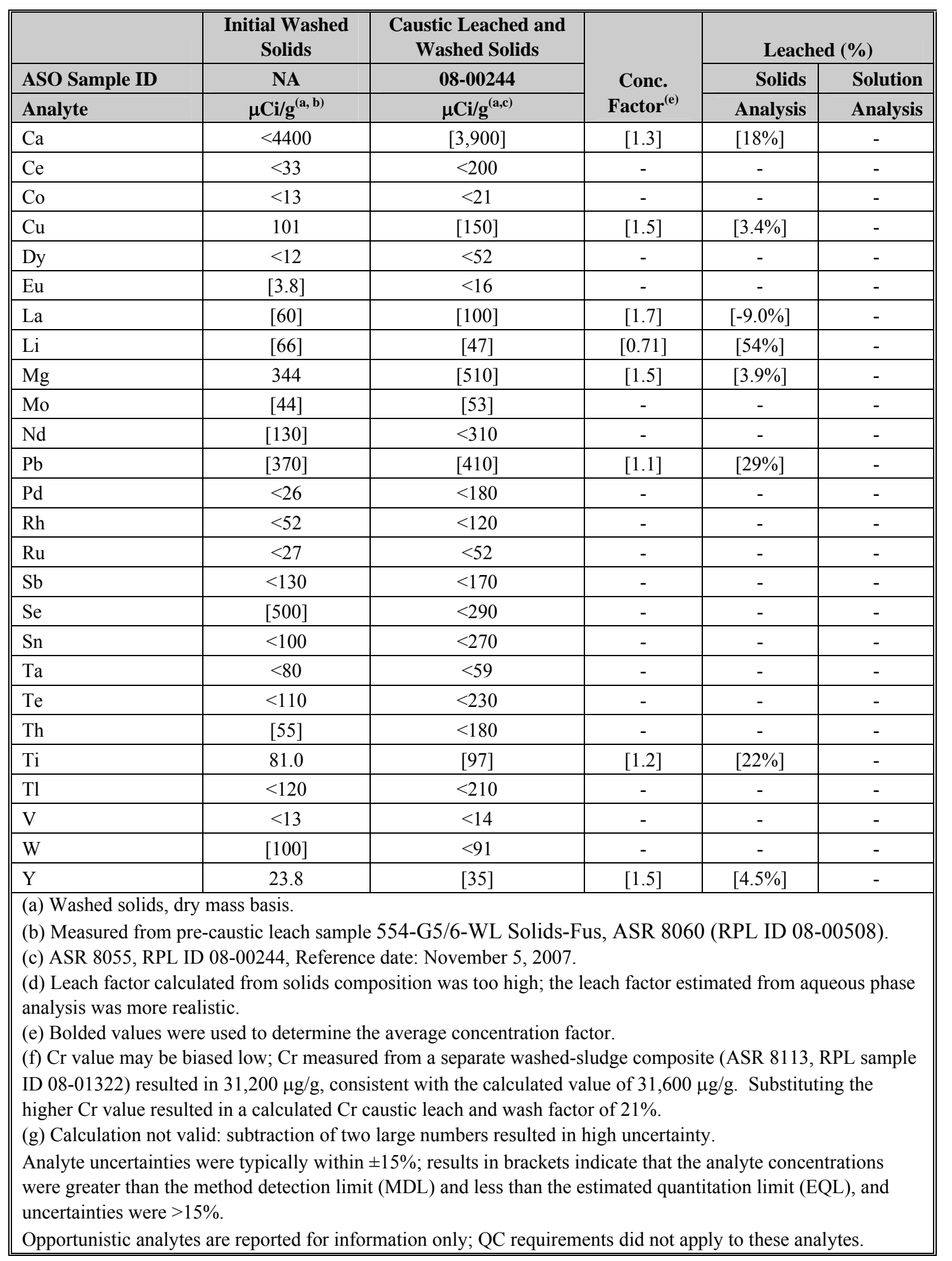


The analyte concentrations in the aqueous phases were also evaluated for total analyte recovery. A leach factor was estimated based on the increased analyte mass or activity recovered in the aqueous phases (leach and wash solutions) relative to the total analyte mass or activity in the initial solids. This approach was based on evaluating the analyte mass balance in the liquid permeate before and after leaching.

It is clear that the leach factors are inexact based on the discrepancies between the factors determined from solids examination and those determined from solution examination. Aluminum was calculated to have a leach factor of $46 \%$ based on evaluating the solids composition. This was higher than the leach factor of 39\% determined from the net increased Al mass found in the combined aqueous phases, but within the overall experimental uncertainty. The leach factors for $\mathrm{Am}, \mathrm{Pu}, \mathrm{Fe}, \mathrm{Sr}$, and ${ }^{90} \mathrm{Sr}$ calculated from the solids phase, appeared unrealistically high. The measured concentrations of these analytes in the leach and wash solutions indicated that much lower leach factors were achieved. Their incongruence indicated that the solids analytical sample might not have been completely representative with respect to the actinide, $\mathrm{Fe}$, and $\mathrm{Sr}$ concentrations of the whole sludge material in the CUF. The $\mathrm{Cr}$ leach factor was more difficult to determine. The measured starting material concentration $(26,250 \mu \mathrm{g} / \mathrm{g})$ was significantly lower than that of a separate analytical sample $(31,200 \mu \mathrm{g} / \mathrm{g})$, further attesting to the difficulty in obtaining representative sub-samples from the large slurry. Using the higher initial Cr concentration in the calculation resulted in a caustic leach and wash factor of $21 \%$. Evaluating the aqueous phase for the $\mathrm{Cr}$ leaching factor was confounded because the net mass increase was lost within the $\pm 15 \%$ reported analytical uncertainties of the starting and ending compositions.

\subsection{Oxidative Leach and Wash}

The final rinse of the caustic-leached solids resulted in a free-hydroxide concentration of $0.17 \mathrm{M}$. This concentration met the target requirement defined in the concurrence request of $<0.25 \mathrm{M}$ free hydroxide. The sample matrix was not amended with additional $\mathrm{NaOH}$ to increase the free-hydroxide concentration to $0.25 \mathrm{M}$. The 1-M sodium permanganate solution was added directly to the sample matrix, resulting in a final $[\mathrm{OH}]$ concentration of $0.09 \mathrm{M}$.

Figure 4.11 shows the Cr oxidative leaching performance as a function of time in the CUF (data points are provided in Table 4.6). The $\mathrm{NaMnO}_{4}$ was added at time $=0$. The $\mathrm{Pu}$ (combined ${ }^{239+240} \mathrm{Pu}$ and ${ }^{238} \mathrm{Pu}$ ) concentrations are also shown along with those of $\mathrm{Na}, \mathrm{Al}$, and $\mathrm{Mn}$ as reference points. Except for $\mathrm{Mn}$, all analytes showed a concentration decrease from $0.5 \mathrm{~h}$ to $1 \mathrm{~h}$, followed by a concentration increase from $1 \mathrm{~h}$ to $2 \mathrm{~h}$. Since the $[\mathrm{Na}]$ and $[\mathrm{Al}]$ were expected to be constant, the undulations were attributed to slight variability in sample evaporation following the sampling activity. The $\mathrm{Cr}$ reached equilibrium concentration within $0.5 \mathrm{~h}$ of permanganate addition, indicating that oxidation to the reactive $\mathrm{Cr}$ compound was extremely rapid under the process conditions. 


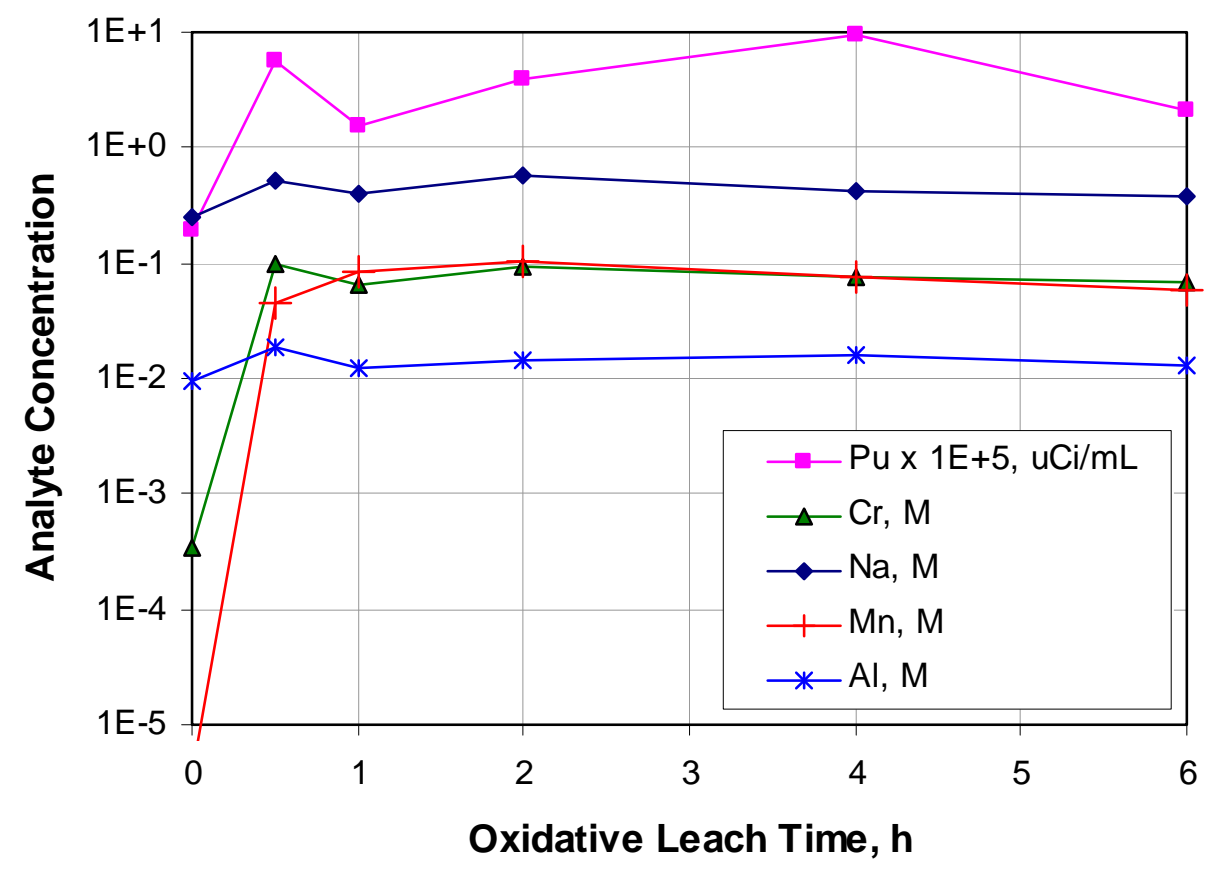

Figure 4.11. $\mathrm{Cr}$ and $\mathrm{Pu}$ Leachate Concentrations as a Function of Time during CUF Oxidative Leaching Notes: $\mathrm{T}=27 \pm 3^{\circ} \mathrm{C}, 1.7 \mathrm{Mn} / \mathrm{Cr}$ mole ratio

Table 4.6. Analyte Concentrations in Leachate as a Function of Time during Oxidative Leaching

\begin{tabular}{|c|c|c|c|c|c|c|}
\hline \multirow[b]{2}{*}{ Analyte } & \multicolumn{6}{|c|}{ " Sample Time, h } \\
\hline & 0 & 0.5 & 1 & 2 & 4 & 6 \\
\hline $\mathrm{Pu}, \mu \mathrm{Ci} / \mathrm{mL}$ & {$[2.7 \mathrm{E}-6]$} & $6.02 \mathrm{E}-5$ & $1.69 \mathrm{E}-5$ & $4.33 \mathrm{E}-5$ & $1.09 \mathrm{E}-4$ & $2.29 \mathrm{E}-5$ \\
\hline $\mathrm{Na}, \mathrm{M}$ & 0.249 & 0.526 & 0.392 & 0.570 & 0.421 & 0.378 \\
\hline $\mathrm{Cr}, \mathrm{M}$ & $3.42 \mathrm{E}-4$ & 0.0973 & 0.0652 & 0.0956 & 0.0762 & 0.0677 \\
\hline $\mathrm{Mn}, \mathrm{M}$ & $<3.8 \mathrm{E}-6$ & 0.0455 & 0.0857 & 0.1028 & 0.0777 & 0.0592 \\
\hline $\mathrm{Al}, \mathrm{M}$ & 0.0097 & 0.0182 & 0.0123 & 0.0146 & 0.0157 & 0.0132 \\
\hline \multicolumn{7}{|c|}{$\begin{array}{l}\text { Temperature }=27 \pm 3^{\circ} \mathrm{C} \text {. } \\
\text { Free-hydroxide concentration during leach }=0.09 \mathrm{M} \text {. } \\
\text { Data are plotted in Figure } 4.11 \text {. } \\
\text { Analyte uncertainties were typically within } \pm 15 \% \text {; the bracketed Pu result indicates that its } \\
\text { concentration was }>\mathrm{MDL} \text { and }<\mathrm{EQL} \text {, and uncertainty was }>15 \% \text {. }\end{array}$} \\
\hline
\end{tabular}

A small fraction of the total $\mathrm{Pu}$ dissolved during the $\mathrm{Cr}$ oxidative leaching step, which is consistent with the parametric test results. The combined ${ }^{239+240} \mathrm{Pu}$ and ${ }^{238} \mathrm{Pu}$ reached an average $5.0 \mathrm{E}-5 \mu \mathrm{Ci} / \mathrm{mL}$ in solution (average of samples taken at time $=0.5 \mathrm{~h}$ through $6 \mathrm{~h}$ ). This concentration was $\sim 20 \times$ higher than the $\mathrm{Pu}$ concentration in the aqueous phase before adding the sodium permanganate; the amount of $\mathrm{Pu}$ mobilized represented a very small fraction $(0.03 \%)$ of the whole Pu content in the CUF. The measured $\mathrm{Pu}$ concentration was compared to that expected based on the Pu solubility as a function of the equilibrium free-hydroxide concentration (Figure 4.12). Again, because the isotopic distribution was not known, the possible range of $\mathrm{Pu}$ concentrations associated with the differences in ${ }^{239} \mathrm{Pu}$ and ${ }^{240} \mathrm{Pu}$ specific activities is shown. The dissolved $\mathrm{Pu}$ in the CUF test appeared to conform to the extrapolated curve 
defined by the published and parametric leaching data. Increasing Pu dissolution appears to be directly related to increasing hydroxide concentration.

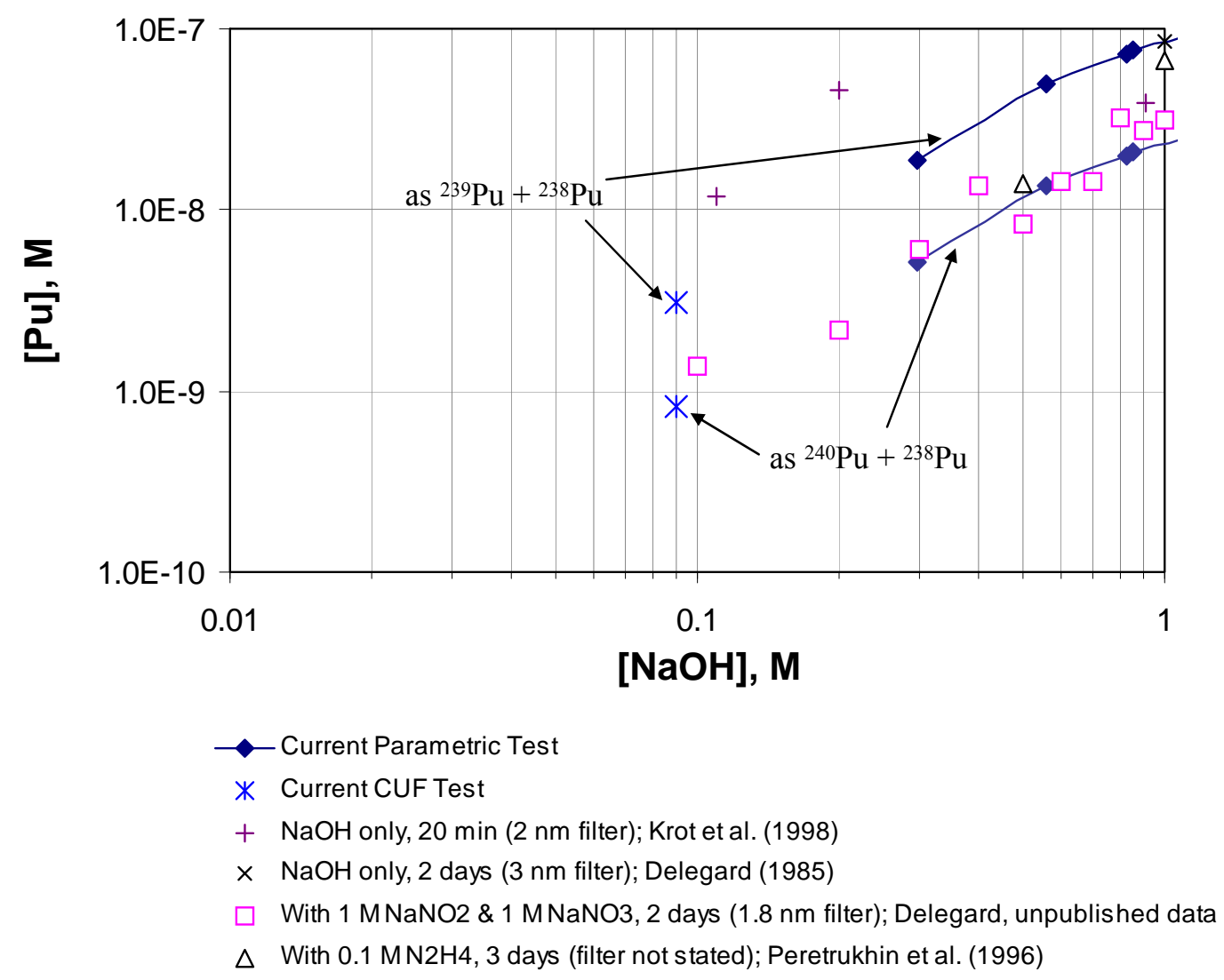

Figure 4.12. Comparison of CUF Pu Dissolution During Oxidative Leaching to Parametric Testing and Previously Published Results (Delegard 2006)

The compositions of the slurry contact solution before adding the $1 \mathrm{M} \mathrm{NaMnO}_{4}$, the final oxidative leach solution, and each water wash are shown in Table 4.7. Aside from $\mathrm{Cr}, \mathrm{Mn}$, and $\mathrm{Na}$, metal concentrations in the aqueous phases are very low. The analyte concentration in the wash 1-3 composite should represent the average concentration of washes 1-3. The composite wash result for several analytes (Al, $\mathrm{Pu}$, and ${ }^{90} \mathrm{Sr}$ ) were significantly less than the calculated average result; the variation may be associated with continued co-precipitation of the analyte with the Mn-precipitated compound or analytical error.

Selected analyte concentrations (from Table 4.7) are plotted in Figure 4.13, so that trends in concentration changes can be evaluated for the various process steps. Simple dilution effects can be tracked from $\left[{ }^{137} \mathrm{Cs}\right]$ changes (all steps) and $[\mathrm{Na}]$ changes (after addition of $\mathrm{NaMnO}_{4}$ ). After the initial increase of $\mathrm{Na}, \mathrm{Cr}$, and $\mathrm{Mn}$ concentrations from the oxidative leach step, these analyte concentrations steadily decreased as a function of washing. The ${ }^{239+240} \mathrm{Pu}$ concentration behavior stood in marked contrast as its concentration increased on the first wash whereas all other analyte concentrations were decreasing. The Al concentration appeared to have reached a quasi-steady state. 
Table 4.7. Oxidative Leach and Wash Solutions

\begin{tabular}{|c|c|c|c|c|c|c|}
\hline $\begin{array}{r}\text { Sample } \\
\text { Description: }\end{array}$ & $\begin{array}{c}\text { Before Ox. } \\
\text { Leach }\end{array}$ & $\begin{array}{c}\text { Final Ox. } \\
\text { Leach } \\
\mathbf{T}=\mathbf{6} \mathrm{h} \\
\end{array}$ & Wash 1 & Wash 2 & Wash 3 & $\begin{array}{l}\text { Composite } \\
\text { Wash } 1 \text { - } 3 \\
\end{array}$ \\
\hline Sample ID: & 08-00221 & 08-00229 & 08-00240 & 08-00241 & 08-00223 & 08-00224 \\
\hline Density $^{(a)}, \mathrm{g} / \mathrm{mL}$ : & 1.01 & 1.02 & 1.02 & 1.01 & 1.01 & 1.01 \\
\hline Analyte & $\mu \mathrm{Ci} / \mathrm{mL}$ & $\mu \mathrm{Ci} / \mathbf{m L}$ & $\mu \mathrm{Ci} / \mathrm{mL}$ & $\mu \mathrm{Ci} / \mathrm{mL}$ & $\mu \mathrm{Ci} / \mathbf{m L}$ & $\mu \mathrm{Ci} / \mathbf{m L}$ \\
\hline${ }^{137} \mathrm{Cs}$ & $6.78 \mathrm{E}-1$ & $1.07 \mathrm{E}+0$ & $7.73 \mathrm{E}-1$ & $5.21 \mathrm{E}-1$ & $3.26 \mathrm{E}-1$ & $4.72 \mathrm{E}-1$ \\
\hline${ }^{60} \mathrm{Co}$ & $<7 . \mathrm{E}-5$ & $<1 . \mathrm{E}-4$ & $<7 . \mathrm{E}-5$ & $<7 \mathrm{E}-5$ & $<6$.E-5 & $<5$.E-5 \\
\hline${ }^{241} \mathrm{Am}$ & $<3$. E-4 & $<3 . \mathrm{E}-3$ & $<1 \mathrm{E}-3$ & $<1 \mathrm{E}-3$ & $<8$. E-4 & $<2$. E-3 \\
\hline${ }^{90} \mathrm{Sr}$ & $8.78 \mathrm{E}-4$ & {$[7.6 \mathrm{E}-5]$} & $8.98 \mathrm{E}-3$ & $8.94 \mathrm{E}-4$ & $2.44 \mathrm{E}-2$ & $2.81 \mathrm{E}-3$ \\
\hline${ }^{238} \mathrm{Pu}$ & $<8 . \mathrm{E}-7$ & $<2 \mathrm{E}-6$ & $9.45 \mathrm{E}-6$ & $9.75 \mathrm{E}-6$ & $3.82 \mathrm{E}-6$ & [2.1E-6] \\
\hline${ }^{239+240} \mathrm{Pu}$ & [1.9E-6] & $2.11 \mathrm{E}-5$ & $3.91 \mathrm{E}-5$ & $2.76 \mathrm{E}-5$ & $1.75 \mathrm{E}-5$ & [3.2E-6] \\
\hline Gross alpha & $<3 . \mathrm{E}-4$ & $<3 . \mathrm{E}-4$ & $<3 . \mathrm{E}-4$ & $<3 . \mathrm{E}-4$ & $<3 . \mathrm{E}-4$ & $<4$.E-4 \\
\hline Gross beta & $6.36 \mathrm{E}-1$ & $9.78 \mathrm{E}-1$ & $8.03 \mathrm{E}-1$ & $5.31 \mathrm{E}-1$ & $3.48 \mathrm{E}-1$ & $4.20 \mathrm{E}-1$ \\
\hline${ }^{154} \mathrm{Eu}$ & $<2 \mathrm{E}-4$ & $<3 \mathrm{E}-4$ & $<2 \mathrm{E}-4$ & $<2 \mathrm{E}-4$ & $<2 \mathrm{E}-4$ & $<1 \mathrm{E}-4$ \\
\hline Analyte & $\mu \mathrm{g} / \mathrm{mL}$ & $\mu \mathrm{g} / \mathrm{mL}$ & $\mu \mathrm{g} / \mathrm{mL}$ & $\mu \mathrm{g} / \mathrm{mL}$ & $\mu \mathrm{g} / \mathrm{mL}$ & $\mu \mathrm{g} / \mathrm{mL}$ \\
\hline $\mathrm{Al}$ & 262 & 357 & 219 & 196 & 253 & 60.7 \\
\hline $\mathrm{B}$ & $<1.8$ & $<3.6$ & $<1.8$ & $<1.8$ & $<1.8$ & $<1.8$ \\
\hline $\mathrm{Bi}$ & {$[2.6]$} & $<4.6$ & {$[4.4]$} & $<2.3$ & $<2.2$ & $<2.2$ \\
\hline $\mathrm{Cd}$ & $<0.24$ & $<0.5$ & $<0.23$ & $<0.24$ & {$[0.24]$} & $<0.23$ \\
\hline $\mathrm{Cr}$ & 17.8 & 3,520 & 2,340 & 1,470 & 727 & 1,380 \\
\hline $\mathrm{Fe}$ & $<2.1$ & $<4.1$ & $<2.0$ & $<2.0$ & $<2.0$ & $<2.0$ \\
\hline $\mathrm{K}$ & $<12.32$ & {$[100]$} & {$[58]$} & [49] & [19] & {$[42]$} \\
\hline $\mathrm{Mn}$ & $<0.21$ & 3,250 & 2,580 & 1,630 & 902 & 1,220 \\
\hline $\mathrm{Na}$ & 5,720 & 8,680 & 6,490 & 4,270 & 2,380 & 3,920 \\
\hline $\mathrm{Ni}$ & $<0.59$ & $<1.2$ & $<0.56$ & $<0.58$ & $<0.57$ & $<0.56$ \\
\hline $\mathrm{P}$ & {$[54]$} & [64] & [46] & [39] & {$[36]$} & [23] \\
\hline $\mathrm{S}$ & $<33$ & $<65$ & $<32$ & $<33$ & $<32$ & $<31$ \\
\hline $\mathrm{Si}$ & [3.9] & $<2.3$ & $<1.1$ & $<1.1$ & [6.4] & $<1.1$ \\
\hline $\mathrm{Sr}$ & $<0.02$ & $<0.03$ & $<0.02$ & $<0.02$ & $<0.02$ & $<0.02$ \\
\hline $\mathrm{U}$ & $<8.5$ & $<17$ & $<8.1$ & $<8.4$ & $<8.2$ & $<8.1$ \\
\hline $\mathrm{Zn}$ & {$[0.59]$} & $<1.1$ & $<0.55$ & $<0.57$ & $<0.56$ & $<0.55$ \\
\hline $\mathrm{Zr}$ & $<0.82$ & $<1.6$ & $<0.78$ & $<0.81$ & $<0.80$ & $<0.78$ \\
\hline $\mathrm{U}$ (KPA) & 0.75 & 0.196 & \multirow{6}{*}{\multicolumn{2}{|c|}{ not analyzed }} & 0.199 & 0.0859 \\
\hline Nitrite & 285 & & & & $<0.05$ & $<0.05$ \\
\hline Nitrate & 980 & & & & 440 & 795 \\
\hline Phosphate & 180 & & & & 77.9 & {$[80]$} \\
\hline Sulfate & 55 & & & & 6.99 & {$[42]$} \\
\hline Oxalate & 541 & & & & 152 & 301 \\
\hline free $\mathrm{OH}, \mathrm{M}$ & $0.17 \mathrm{M}$ & $0.085 \mathrm{M}$ & $0.050 \mathrm{M}$ & $0.028 \mathrm{M}$ & $0.010 \mathrm{M}$ & $0.028 \mathrm{M}$ \\
\hline \multicolumn{7}{|l|}{$\begin{array}{l}\text { Opportunistic } \\
\text { Analytes }\end{array}$} \\
\hline Analyte & $\mu \mathrm{g} / \mathrm{mL}$ & $\mu \mathrm{g} / \mathrm{mL}$ & $\mu \mathrm{g} / \mathrm{mL}$ & $\mu \mathrm{g} / \mathrm{mL}$ & $\mu \mathrm{g} / \mathrm{mL}$ & $\mu \mathrm{g} / \mathrm{mL}$ \\
\hline Fluoride & 5.4 & \multicolumn{3}{|c|}{ not analyzed } & 3.03 & {$[15]$} \\
\hline $\mathrm{Ag}$ & $<0.43$ & $<0.84$ & $<0.41$ & $<0.42$ & $<0.42$ & $<0.41$ \\
\hline As & $<7.1$ & $<14$ & $<6.7$ & $<7.0$ & $<6.8$ & $<6.7$ \\
\hline
\end{tabular}


Table 4.7 (contd)

\begin{tabular}{|c|c|c|c|c|c|c|}
\hline $\begin{array}{r}\text { Sample } \\
\text { Description: }\end{array}$ & $\begin{array}{c}\text { Before Ox. } \\
\text { Leach }\end{array}$ & $\begin{array}{c}\text { Final Ox. } \\
\text { Leach } \\
\mathrm{T}=6 \mathrm{~h}\end{array}$ & Wash 1 & Wash 2 & Wash 3 & $\begin{array}{l}\text { Composite } \\
\text { Wash } 1 \text { - } 3\end{array}$ \\
\hline Sample ID: & 08-00221 & 08-00229 & 08-00240 & 08-00241 & 08-00223 & 08-00224 \\
\hline Density $^{(a)}, \mathrm{g} / \mathrm{mL}$ : & 1.01 & 1.02 & 1.02 & 1.01 & 1.01 & 1.01 \\
\hline Analyte & $\mu \mathrm{Ci} / \mathrm{mL}$ & $\mu \mathrm{Ci} / \mathbf{m L}$ & $\mu \mathrm{Ci} / \mathrm{mL}$ & $\mu \mathrm{Ci} / \mathrm{mL}$ & $\mu \mathrm{Ci} / \mathrm{mL}$ & $\mu \mathrm{Ci} / \mathrm{mL}$ \\
\hline $\mathrm{Ba}$ & $<0.34$ & $<0.68$ & $<0.33$ & $<0.34$ & $<0.33$ & $<0.33$ \\
\hline $\mathrm{Be}$ & $<0.01$ & $<0.02$ & $<0.01$ & $<0.01$ & $<0.01$ & $<0.01$ \\
\hline $\mathrm{Ca}$ & {$[3.3]$} & {$[5.8]$} & [3.1] & {$[2.3]$} & {$[4.0]$} & {$[2.3]$} \\
\hline $\mathrm{Ce}$ & $<1.2$ & $<2.4$ & $<1.2$ & $<1.2$ & $<1.2$ & $<1.2$ \\
\hline $\mathrm{Co}$ & $<0.39$ & $<0.77$ & $<0.37$ & $<0.39$ & $<0.38$ & $<0.37$ \\
\hline $\mathrm{Cu}$ & $<0.49$ & $<0.97$ & $<0.47$ & $<0.48$ & $<0.47$ & $<0.47$ \\
\hline Dy & $<0.35$ & $<0.70$ & $<0.34$ & $<0.35$ & $<0.34$ & $<0.34$ \\
\hline $\mathrm{Eu}$ & $<0.11$ & $<0.22$ & $<0.11$ & $<0.11$ & $<0.11$ & $<0.10$ \\
\hline $\mathrm{La}$ & $<0.13$ & $<0.27$ & {$[0.20]$} & $<0.13$ & $<0.13$ & $<0.13$ \\
\hline $\mathrm{Li}$ & $<0.55$ & $<1.1$ & {$[0.80]$} & $<0.55$ & $<0.53$ & $<0.52$ \\
\hline $\mathrm{Mg}$ & $<0.71$ & $<1.4$ & $<0.68$ & $<0.70$ & $<0.69$ & $<0.68$ \\
\hline Mo & {$[0.83]$} & $<1.3$ & {$[0.87]$} & $<0.65$ & {$[0.94]$} & {$[1.5]$} \\
\hline $\mathrm{Nd}$ & $<1.7$ & $<3.4$ & $<1.7$ & $<1.7$ & $<1.7$ & $<1.7$ \\
\hline $\mathrm{Pb}$ & $<3.7$ & $<7.4$ & $<3.6$ & $<3.7$ & $<3.6$ & $<3.6$ \\
\hline $\mathrm{Pd}$ & $<1.3$ & $<2.5$ & $<1.2$ & $<1.3$ & $<1.2$ & $<1.2$ \\
\hline $\mathrm{Rh}$ & $<2.6$ & $<5.0$ & $<2.4$ & $<2.5$ & $<2.5$ & $<2.4$ \\
\hline $\mathrm{Ru}$ & $<0.83$ & $<1.6$ & $<0.80$ & $<0.82$ & $<0.81$ & $<0.79$ \\
\hline $\mathrm{Sb}$ & $<3.2$ & $<6.3$ & [10] & {$[7.6]$} & $<3.1$ & $<3.0$ \\
\hline $\mathrm{Se}$ & [27] & {$[58]$} & $<4.74$ & {$[6.1]$} & {$[21]$} & {$[22]$} \\
\hline $\mathrm{Sn}$ & $<2.0$ & $<4.0$ & [4.1] & [3.1] & $<2.0$ & $<1.9$ \\
\hline $\mathrm{Ta}$ & $<1.3$ & $<2.7$ & $<1.3$ & $<1.3$ & {$[1.5]$} & $<1.3$ \\
\hline $\mathrm{Te}$ & $<3.2$ & $<6.3$ & $<3.1$ & $<3.2$ & $<3.1$ & $<3.0$ \\
\hline $\mathrm{Th}$ & $<1.2$ & $<2.4$ & $<1.1$ & $<1.2$ & $<1.2$ & $<1.1$ \\
\hline $\mathrm{Ti}$ & $<0.10$ & $<0.19$ & $<0.09$ & $<0.10$ & $<0.09$ & $<0.09$ \\
\hline $\mathrm{Tl}$ & $<6.6$ & $<13.0$ & $<6.3$ & $<6.5$ & $<6.4$ & $<6.3$ \\
\hline $\mathrm{V}$ & {$[0.36]$} & $<0.63$ & $<0.30$ & $<0.32$ & {$[0.37]$} & {$[0.33]$} \\
\hline W & $<1.5$ & $<3.0$ & $<1.5$ & $<1.5$ & $<1.5$ & $<1.4$ \\
\hline $\mathrm{Y}$ & $<0.09$ & $<0.17$ & $<0.08$ & $<0.08$ & $<0.08$ & $<0.08$ \\
\hline
\end{tabular}

(a) Density values were obtained from the mass flow meter, which had not been calibrated to NQA-1 standards; they are reported for information only.

ASR 8055, 8108

Reference Date November 5, 2007.

Analyte uncertainties were typically within $\pm 15 \%$; results in brackets indicate that the analyte concentrations were greater than the method detection limit (MDL) and less than the estimated quantitation limit (EQL), and uncertainties were $>15 \%$.

Opportunistic analytes are reported for information only; QC requirements did not apply to these analytes. 


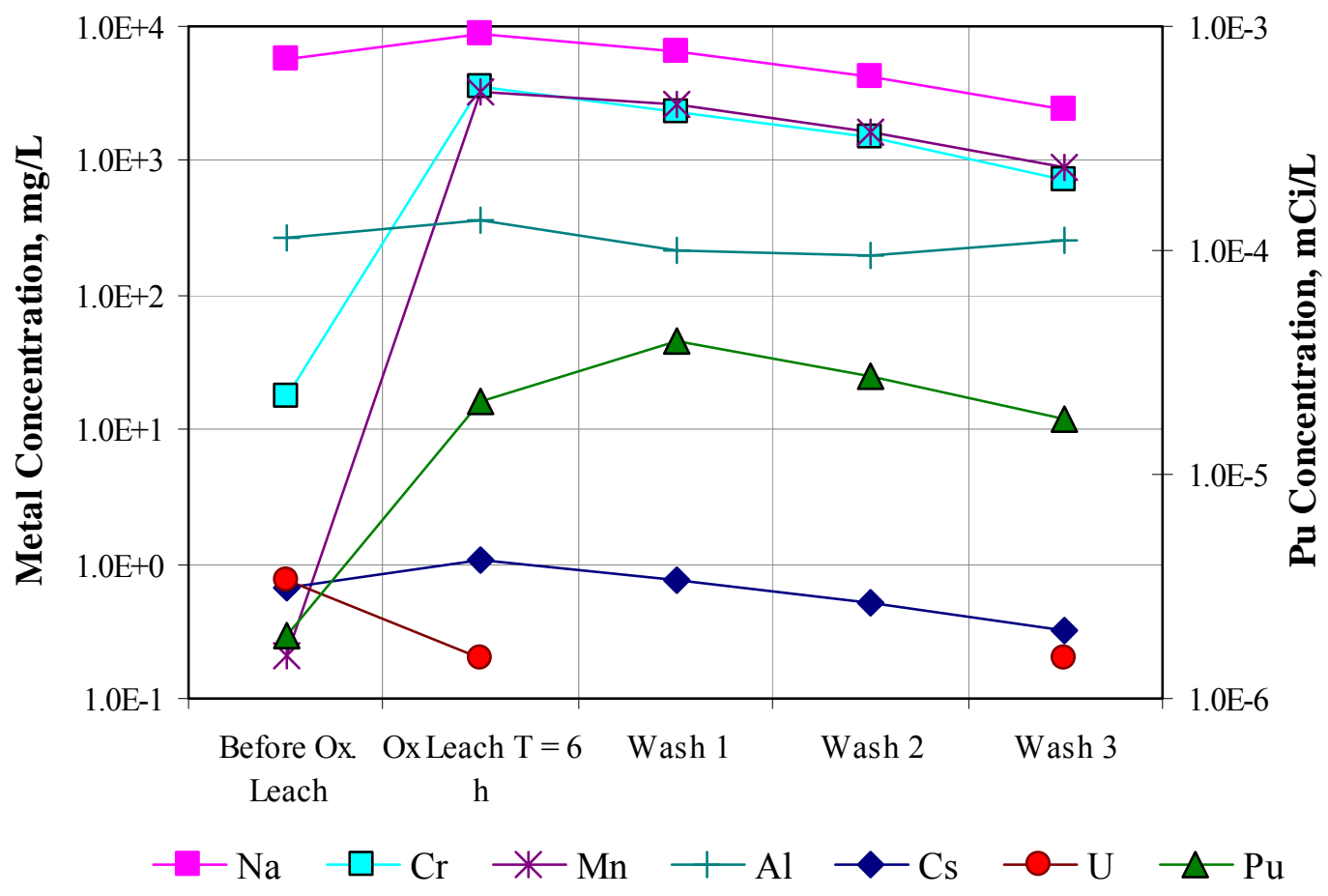

Figure 4.13. Analyte Concentration as a Function of Oxidative Leach and Wash Step (Note: Data values are provided in Table 4.7)

Table 4.8 shows the analyte concentrations in the final oxidatively leached and washed solids. The CFs associated with the oxidative leach and wash step are also shown (starting composition basis was from the caustic leached and washed solids shown in Table 4.5). The average CF for insoluble components $\mathrm{Fe}, \mathrm{U},{ }^{90} \mathrm{Sr}$, and $\mathrm{Sr}(1.53)$ was used to normalize the data and calculate the oxidative leach factors per Equation 4.2. According to this calculation, an additional $46 \%$ of the $\mathrm{Al}$ was removed from the solids phase during oxidative leaching. Additional Al leaching was not expected under these processing conditions. As discussed in the next paragraph, it is likely that the additional Al removal suggested by the solids analysis is in error since measurements of the oxidative leaching and washing solutions did not suggest significant additional Al removal.

The oxidative leaching and washing solutions were evaluated for analyte recoveries to estimate what mass fraction of the components leached from the solids. The results of this analysis are also provided in Table 4.8. There are dramatic differences between the fractions of each component leached when calculated by the analysis of the solids versus that determined by analysis of the liquid phases. The values obtained by the latter method are likely more reliable because of the apparent difficulty in obtaining representative sub-samples of the slurried solids along with the confounding contributions from entrained supernatant liquid to the solids analysis. The $\mathrm{Cr}$ leach factor obtained from the solution analysis was biased low because not all of the dissolved $\mathrm{Cr}$ had been removed from the CUF. 
Table 4.8. Solids Composition after Oxidative Leach and Wash with Leach Factors

\begin{tabular}{|c|c|c|c|c|}
\hline \multirow[b]{2}{*}{ Analyte } & \multirow{2}{*}{$\begin{array}{c}\text { Sample } \\
\mu \mathrm{Ci} / \mathbf{g}^{(\mathbf{a})}\end{array}$} & \multirow{2}{*}{$\begin{array}{c}\text { Concentration } \\
\text { Factor }\end{array}$} & \multicolumn{2}{|c|}{ Leached (\%) } \\
\hline & & & $\begin{array}{c}\text { Solids } \\
\text { Analysis }^{(\mathbf{b})}\end{array}$ & $\begin{array}{l}\text { Solution } \\
\text { Analysis }\end{array}$ \\
\hline${ }^{137} \mathrm{Cs}$ & $8.34 \mathrm{E}+1$ & 0.990 & $35 \%$ & $6.3 \%$ \\
\hline${ }^{60} \mathrm{Co}$ & $3.98 \mathrm{E}-2$ & 0.951 & $38 \%$ & $<2.7 \%$ \\
\hline${ }^{241} \mathrm{Am}$ & $1.62 \mathrm{E}+0$ & 0.766 & $50 \%$ & $<0.9 \%$ \\
\hline${ }^{238} \mathrm{Pu}$ & $6.36 \mathrm{E}-2$ & 0.826 & $46 \%$ & $0.16 \%$ \\
\hline${ }^{239+240} \mathrm{Pu}$ & $1.65 \mathrm{E}+0$ & 1.25 & $18 \%$ & $0.043 \%$ \\
\hline Gross alpha & $3.69 \mathrm{E}+0$ & 1.00 & $35 \%$ & $<0.16 \%$ \\
\hline Gross beta & $2.78 \mathrm{E}+3$ & 1.43 & $6.7 \%$ & $0.59 \%$ \\
\hline${ }^{90} \mathrm{Sr}$ & $1.27 \mathrm{E}+3$ & 1.46 & $4.7 \%$ & $0.026 \%$ \\
\hline${ }^{154} \mathrm{Eu}$ (opportunistic) & $5.76 \mathrm{E}-1$ & 0.898 & $41 \%$ & $<0.56 \%$ \\
\hline Analyte & $\mu \mathrm{g} / \mathrm{g}$ & & & \\
\hline $\mathrm{Al}$ & 230,000 & 0.827 & $46 \%$ & $1.7 \%$ \\
\hline $\mathrm{B}$ & $<84$ & -- & -- & -- \\
\hline $\mathrm{Bi}$ & {$[300]$} & -- & -- & -- \\
\hline $\mathrm{Cd}$ & {$[36]$} & -- & -- & $<0.01 \%$ \\
\hline $\mathrm{Cr}$ & $5,890^{\text {(c) }}$ & $0.155^{(\mathrm{c})}$ & $90 \%{ }^{(\mathrm{c})}$ & $>85 \%{ }^{(\mathrm{c})}$ \\
\hline $\mathrm{Fe}$ & 23,900 & 1.51 & $1.3 \%$ & $<0.29 \%$ \\
\hline $\mathrm{K}$ & $\mathrm{n} / \mathrm{m}$ & na & na & -- \\
\hline $\mathrm{Mn}$ & 34,400 & na & na & na \\
\hline $\mathrm{Na}$ & {$[110,000]$} & na & na & na \\
\hline $\mathrm{Ni}$ & $\mathrm{n} / \mathrm{m}$ & na & na & $<2.2 \%$ \\
\hline $\mathrm{P}$ & [500] & 0.510 & $67 \%$ & $30 \%$ \\
\hline $\mathrm{S}$ & [970] & 0.980 & $36 \%$ & -- \\
\hline $\mathrm{Si}$ & 22,300 & 1.12 & $27 \%$ & $<0.27 \%$ \\
\hline $\mathrm{Sr}$ & 2,390 & 1.76 & $-15 \%$ & -- \\
\hline $\mathrm{U}$ & 40,700 & 1.50 & $2.1 \%$ & -- \\
\hline $\mathrm{Zn}$ & {$[150]$} & 1.00 & $35 \%$ & -- \\
\hline $\mathrm{Zr}$ & {$[300]$} & -- & -- & -- \\
\hline $\mathrm{U}(\mathrm{KPA})$ & 37,700 & 1.43 & $6.5 \%$ & $0.016 \%$ \\
\hline \multicolumn{5}{|c|}{ Opportunistic Analytes } \\
\hline $\mathrm{Ag}$ & $<16$ & -- & -- & -- \\
\hline As & $<260$ & -- & -- & -- \\
\hline $\mathrm{Ba}$ & [240] & -- & -- & -- \\
\hline $\mathrm{Be}$ & $<1$ & -- & -- & -- \\
\hline $\mathrm{Ca}$ & {$[3,900]$} & 1.00 & $35 \%$ & -- \\
\hline $\mathrm{Ce}$ & $<190$ & -- & -- & -- \\
\hline $\mathrm{Co}$ & {$[28]$} & -- & -- & -- \\
\hline $\mathrm{Cu}$ & {$[120]$} & -- & -- & -- \\
\hline Dy & $<49$ & -- & -- & -- \\
\hline $\mathrm{Eu}$ & $<16$ & -- & -- & -- \\
\hline $\mathrm{La}$ & 111 & 1.11 & $28 \%$ & -- \\
\hline $\mathrm{Li}$ & [59] & 1.26 & $18 \%$ & -- \\
\hline $\mathrm{Mg}$ & [610] & 1.20 & $22 \%$ & -- \\
\hline
\end{tabular}


Table 4.8 (contd)

\begin{tabular}{|c|c|c|c|c|}
\hline \multirow[b]{2}{*}{ Analyte } & \multirow[b]{2}{*}{$\begin{array}{l}\text { Sample } \\
\mu \mathrm{Ci} / \mathbf{g}^{(\mathbf{a})}\end{array}$} & \multirow[b]{2}{*}{$\begin{array}{c}\text { Concentration } \\
\text { Factor }\end{array}$} & \multicolumn{2}{|c|}{ Leached (\%) } \\
\hline & & & $\begin{array}{c}\text { Solids } \\
\text { Analysis }^{(b)}\end{array}$ & $\begin{array}{l}\text { Solution } \\
\text { Analysis }\end{array}$ \\
\hline Mo & {$[38]$} & 0.717 & $53 \%$ & -- \\
\hline $\mathrm{Nd}$ & $<297$ & -- & -- & -- \\
\hline $\mathrm{Pb}$ & [270] & 0.659 & $57 \%$ & -- \\
\hline $\mathrm{Pd}$ & $<175$ & -- & -- & -- \\
\hline $\mathrm{Rh}$ & $<115$ & -- & -- & -- \\
\hline $\mathrm{Ru}$ & $<49$ & -- & -- & -- \\
\hline $\mathrm{Sb}$ & $<163$ & -- & -- & -- \\
\hline $\mathrm{Se}$ & $<278$ & -- & -- & -- \\
\hline $\mathrm{Sn}$ & $<260$ & -- & -- & -- \\
\hline $\mathrm{Ta}$ & $<56$ & -- & -- & -- \\
\hline $\mathrm{Te}$ & $<221$ & -- & -- & -- \\
\hline Th & $<172$ & -- & -- & -- \\
\hline $\mathrm{Ti}$ & [110] & 1.13 & $26 \%$ & -- \\
\hline $\mathrm{Tl}$ & $<200$ & -- & -- & -- \\
\hline $\mathrm{V}$ & $<13$ & -- & -- & -- \\
\hline $\mathrm{W}$ & $<88$ & -- & -- & -- \\
\hline $\mathrm{Y}$ & {$[38]$} & -- & -- & -- \\
\hline
\end{tabular}

(a) Solids washed in CUF, dry mass basis.

(b) Leach factor calculated from solids composition was too high because in part, the analytical aliquot was dried with entrained supernatant; the leach factor estimated from aqueous-phase analysis was more realistic. (c) The $\mathrm{Cr}$ concentration in the solids phase likely included dissolved $\mathrm{Cr}$ from supernatant entrainment. At the conclusion of testing, the aqueous phase still in the CUF contained some of the leached $\mathrm{Cr}$, which was not included in the calculation. Both situations would cause the leach factors to be biased low.

Reference date: November 5, 2007.

ASR 8055, Sample 08-00246, oxidatively leached and washed solids.

Analyte uncertainties were typically within $\pm 15 \%$; results in brackets indicate that the analyte concentrations were greater than the method detection limit (MDL) and less than the estimated quantitation limit (EQL), and uncertainties were $>15 \%$.

Opportunistic analytes are reported for information only; QC requirements did not apply to these analytes. na $=$ not applicable

$\mathrm{n} / \mathrm{m}=$ not measured

\subsection{Comparison of CUF Testing to Oxidant Dosage (Parametric) Testing}

The $\mathrm{Cr}$ dissolution predicted by batch leach (parametric oxidant dosage) testing was reflected in the $\mathrm{Cr}$ dissolution behavior in the CUF. The $\mathrm{Cr}$ dissolution rate was rapid in both cases, reaching equilibrium conditions before the first time-test sample was taken. The extent of dissolution in the demonstration test paralleled the parametric leach test results where excess permanganate $(\mathrm{Mn} / \mathrm{Cr}$ mole ratio $\geq 1)$ is used. In both cases, the total amount of $\mathrm{Cr}$ removed during the combined caustic and oxidative leaching from the initial solids phase was $>90 \%$, indicating that $\leq 10 \%$ of the $\mathrm{Cr}$ in this waste form was not amenable to oxidative leaching. Furthermore, the Pu mobilization predicted during the oxidant dosage testing was 
reflected in the CUF testing as seen in Figure 4.12, supporting its mobilization as a function of the leach solution hydroxide concentration.

However, there is some uncertainty associated with the amount of $\mathrm{Cr}$ that will dissolve during caustic leaching. As indicated in Table 4.5, between 1.5 and 21\% (see footnote in Table 4.5), and in Table 3.2, $\sim 8$ to $16 \%$ of the $\mathrm{Cr}$ dissolved during caustic leaching. Thus, it is recommended that the permanganate dosage derived from the batch leach test be used as a guide. It is expected that the batch leaching tests will result in an upper bound on the permanganate dosage by predicting lower $\mathrm{Cr}$ solubility during the caustic leaching process. The batch leaching tests will likely have less air oxidation (from dissolved $\mathrm{O}_{2}$ ) during the caustic leach processing relative to the plant conditions because the small-scale batch tests have less air entrainment relative to the use of spargers and PJM mixers, both of which are expected to increase the mass transfer of dissolved oxygen to the system.

\subsection{Surface Area and Crystal Habit of the Product Solids}

The surface area of the oxidatively leached and washed solids was $42.7 \mathrm{~m}^{2} / \mathrm{g}$. In comparison, the Group 5 washed solids surface area was $26 \mathrm{~m}^{2} / \mathrm{g}$, and the Group 6 caustic leached solids (Cr-rich fraction) surface area was $154 \mathrm{~m}^{2} / \mathrm{g}$. The surface area of the final leached solids was consistent with removing most of the high-surface-area Cr component.

Characterization of the caustic- and oxidatively-leached and washed Group 5/6 solids with XRD (Figure 4.14) indicated that the primary crystalline phase was boehmite $[\mathrm{AlO}(\mathrm{OH})]$. Secondary crystalline phases included clarkeite $\left\{\mathrm{Na}\left[\left(\mathrm{UO}_{2}\right) \mathrm{O}(\mathrm{OH})\right]\right\}$ and cancrinite $\left[\mathrm{Na}_{7.14}\left(\mathrm{Al}_{6} \mathrm{Si}_{7.08} \mathrm{O}_{26.73}\right)\left(\mathrm{H}_{2} \mathrm{O}\right)_{4.87}\right]$. A minor component of nitratine $\left(\mathrm{NaNO}_{3}\right)$ was found that represented incompletely washed-out supernatant. Phases that were possibly present but not confirmed were anorthite $\left[(\mathrm{Ca}, \mathrm{Na})(\mathrm{Si}, \mathrm{Al})_{4} \mathrm{O}_{8}\right]$, sodium uranium oxide $\left[\mathrm{Na}_{6} \mathrm{U}_{7} \mathrm{O}_{24}\right]$, stishovite $\left[\mathrm{SiO}_{2}\right]$, and calcite $\left[\mathrm{CaCO}_{3}\right]$. Notably, gibbsite was not present in the XRD pattern. This indicated that gibbsite (a major Al phase in Group 6 solids) was successfully leached and that Al did not re-precipitate (as gibbsite) during the washing sequence (a likely occurrence if the wash solution free hydroxide concentration was too low to maintain $\mathrm{Al}$ in solution). If $\mathrm{Al}$ precipitation did occur during the wash sequence, the resulting gibbsite would have to be microcrystalline to avoid detection by XRD.

Specific crystalline phases associated with $\mathrm{Cr}, \mathrm{Fe}$, and $\mathrm{Mn}$ were not identified; either insufficient mass fractions of these components were present, or their phases were amorphous. The large hump between 12 and $25^{\circ}$ 2- $-\theta$ observed in Figure 4.14a (raw XRD pattern) was evidence of a significant amorphous component. 
a)

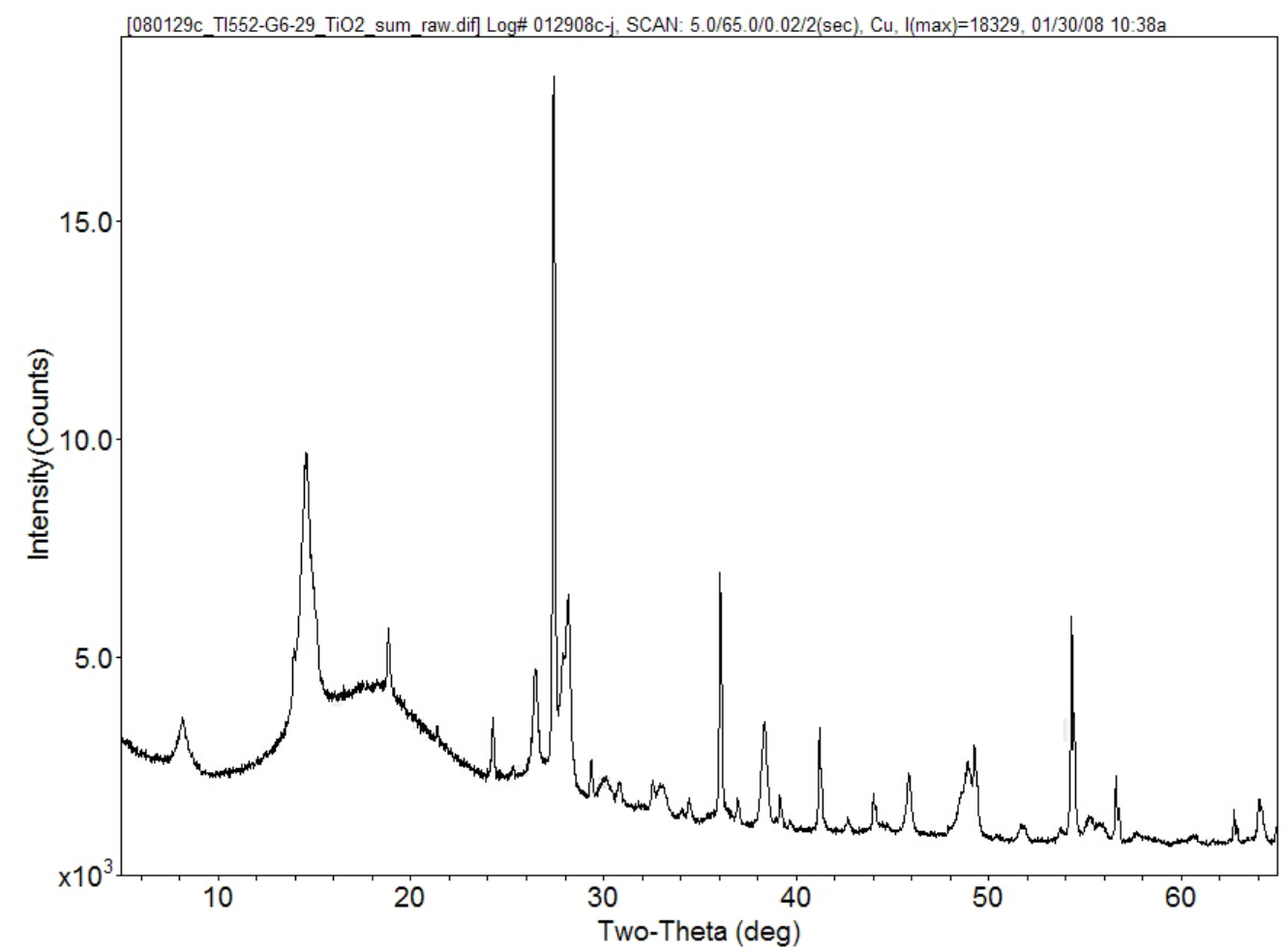

b)

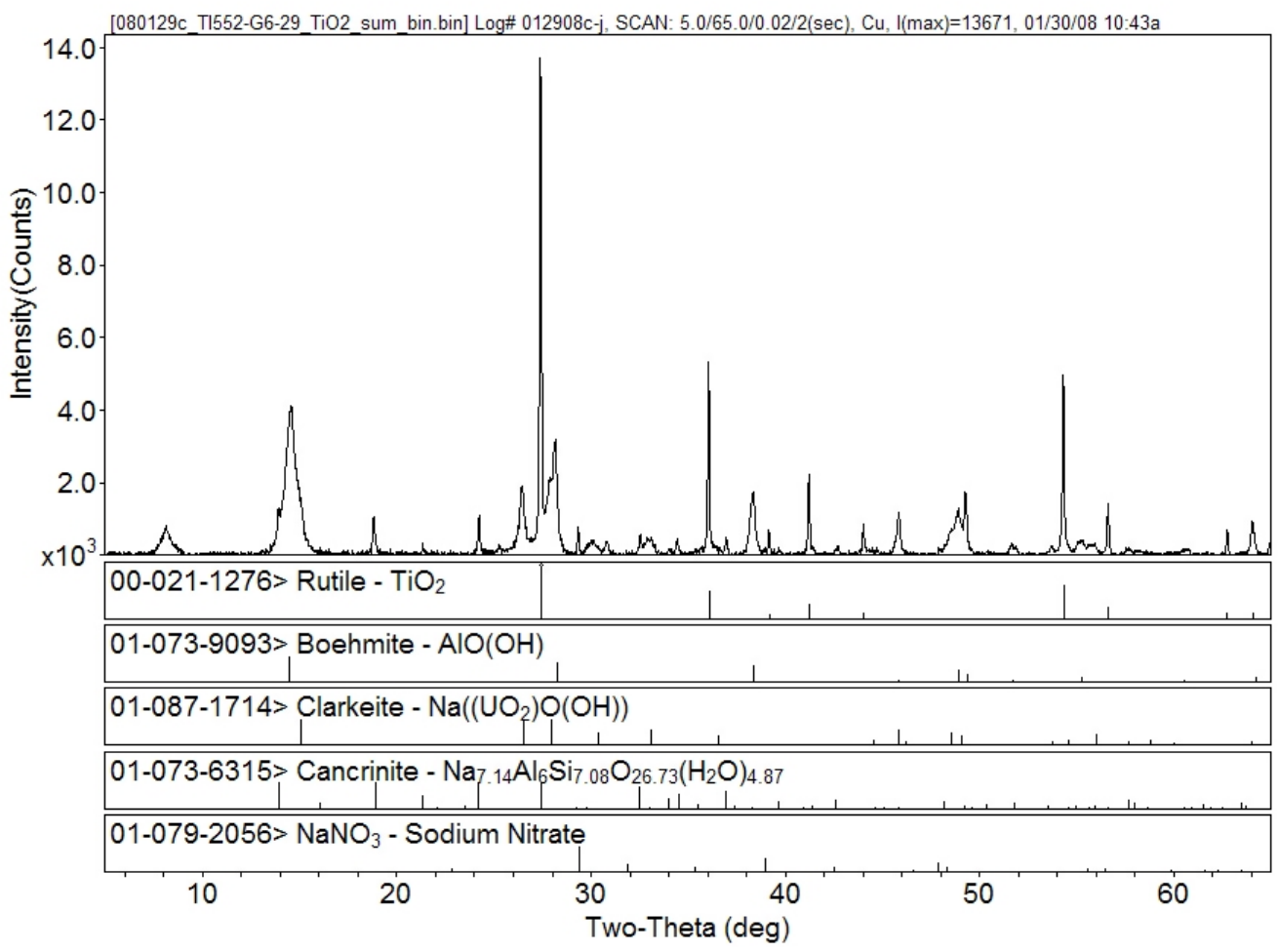

Figure 4.14. XRD Pattern of the Caustic and Oxidatively Leached and Washed Group 5/6 Solids a) Raw Diffraction Pattern, b) Background-Subtracted Diffraction Pattern with StickFigure Phase Identification (Rutile is the internal standard) 
The boehmite crystallite size was determined to be $230 \AA$ based on the evaluation of the $14^{\circ} 2-\theta$ peak (after subtracting contributions of clarkeite and cancrinite) and using a simplistic crystallite size evaluation. ${ }^{\text {(a) }}$ The boehmite crystallite size was determined to be $203 \AA$ on the starting material (unleached and not sheared in the CUF operation, Fiskum et al. 2008). Within the uncertainty of the analysis, the difference between the input $(203 \AA)$ and final $(230 \AA)$ boehmite crystallite sizes was not significant.

Whole-pattern fitting conducted with the JADE software indicated that the boehmite:clarkeite phase ratio was 11:1, and the boehmite:cancrinite phase ratio was 5.6:1 (uncertainty in this analysis is typically $\sim 10$ to $20 \%$; thus, the phase ratios should be considered an approximation).

The best estimate of the composition of the caustic and oxidatively leached and washed Group 5/6 solids is provided in Figure 4.15. The estimate incorporated the XRD phase identification with the phase ratios and chemical characterization (Table 4.8). Boehmite was estimated to comprise $\sim 48 \mathrm{wt} \%$ of the mass fraction, assuming that all $\mathrm{Al}$ in the solids was assigned to boehmite and cancrinite given the phase ratio of 5.6:1. All $\mathrm{U}$ was assigned to clarkeite. The unassigned Na represented the total Na concentration less the mass associated with cancrinite and clarkeite. The balance of the mass fraction ( $24 \mathrm{wt} \%)$ was assumed to be composed primarily of anions associated with sodium (e.g., hydroxide, nitrate, and nitrite) as well as oxides, hydroxides, and waters of hydration associated with the metals.

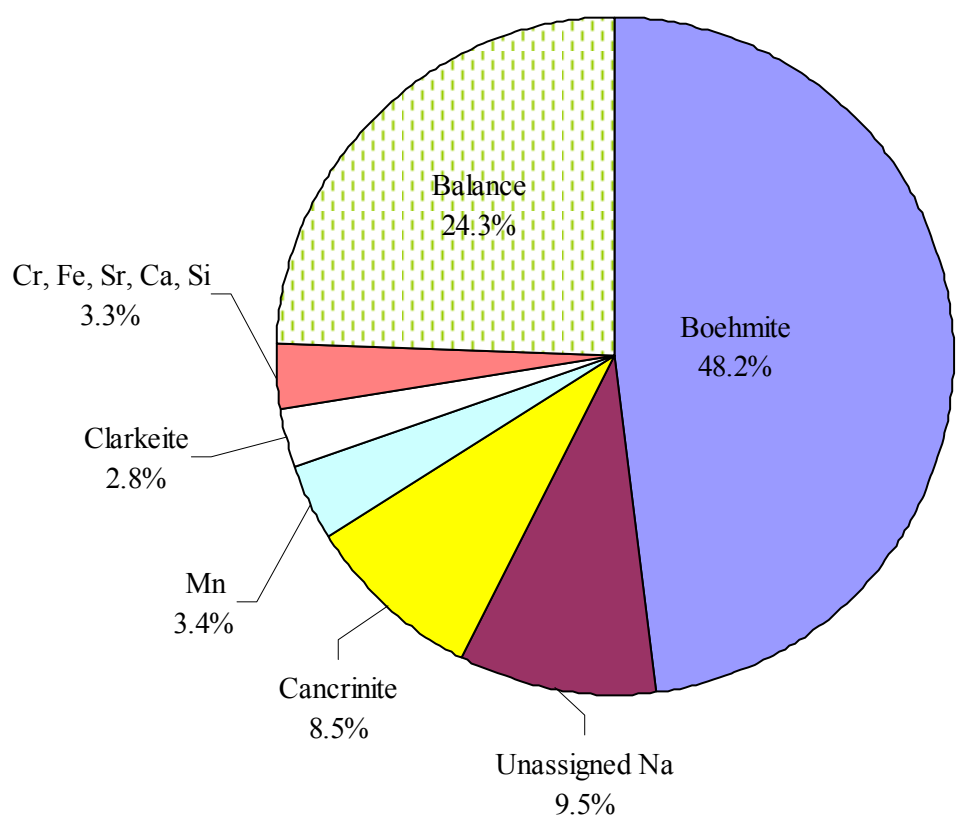

Figure 4.15. Best Estimate of Product Phase Identification

SEM imaging of the oxidatively leached and washed Group 5/6 solids product is shown in Figure 4.16. Two curious morphological features are shown. One appeared to be a rod and could easily be an artifact introduced from the preparation process. The other feature appears with definite ridges and

(a) The JADE operating software applied the Scherrer equation to estimate the crystallite size (Klug and Alexander) 1974, pp 687-690. 
pitted pattern, indicative of chemical attack. Surprisingly, the EDS evaluation of this feature resulted in identification of $\mathrm{C}$ and $\mathrm{O}$, which might indicate it could be an artifact from the SEM sample preparation procedure. Phases containing $\mathrm{Al}$ and $\mathrm{O}$ dominated much of the sample, consistent with boehmite composition. Minor components of $\mathrm{Mn}, \mathrm{Fe}, \mathrm{Cr}, \mathrm{U}, \mathrm{Ca}$, and $\mathrm{Na}$ were also identified. One phase showing exceptionally high Si was identified. Specific morphological features were too small for definitive SEM imaging.


Figure 4.16. SEM Images with EDS Evaluation of Oxidatively Leached and Washed Solids (EDS evaluation of spots 1 and 2 resulted in identification of only $\mathrm{C}$ and $\mathrm{O}$ suggesting that this is an artifact) 
STEM images using the HAADF detector combined with EDS analysis are shown in Figure 4.17 and Figure 4.18. In the STEM-HAADF images, the contrast is proportional to the atomic number, and the high $\mathrm{Z}$ phases, such as uranium-bearing phases, show up brighter. Aluminum dominated much of the phase chemistry, which is consistent with boehmite composition. A calcite phase was tentatively identified. Uranium was identified with an alumino-silicate phase as well as the Al-oxide material. The uranium phase was acicular in form.

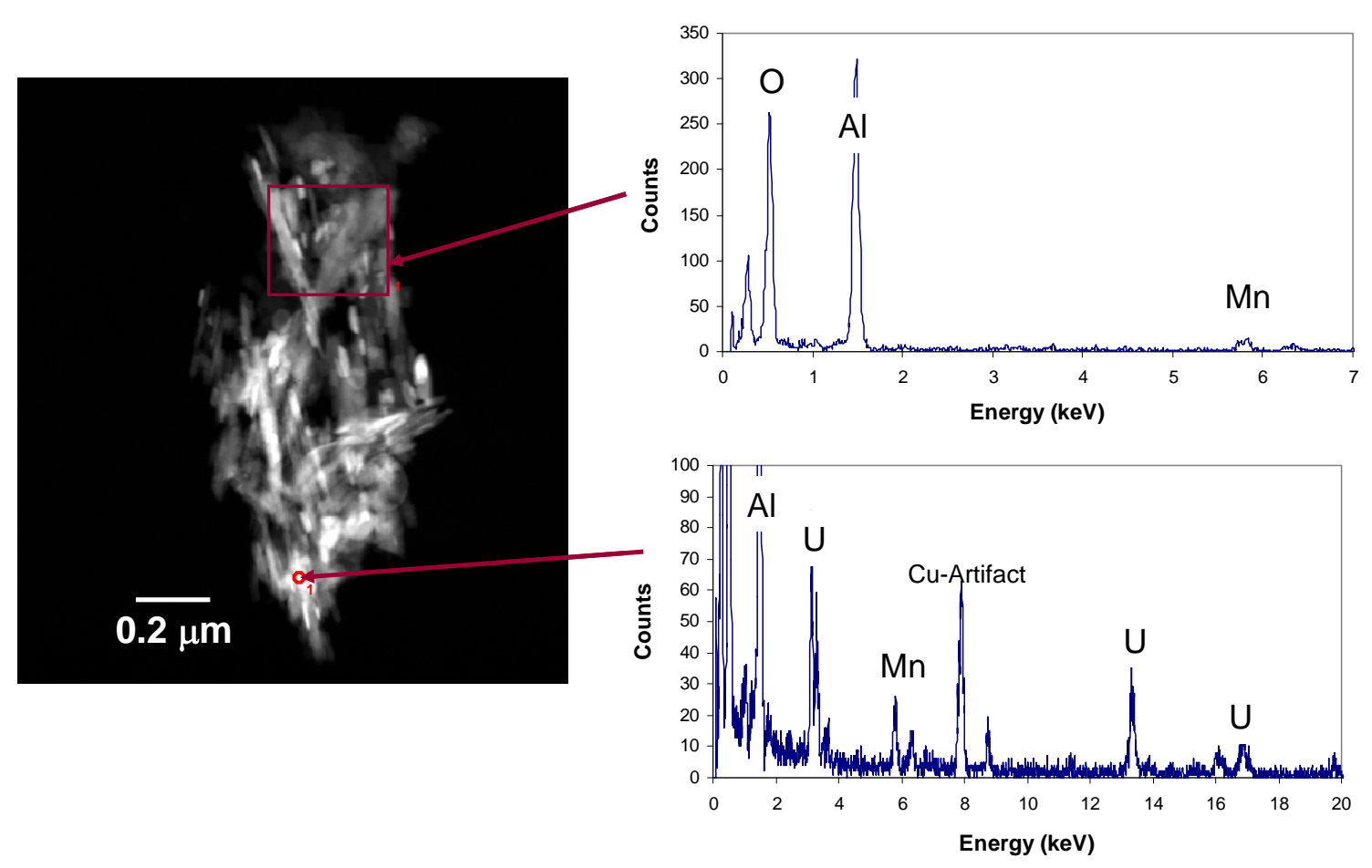

Figure 4.17. Uranium Phase Associated with Aluminum Phase 
a)

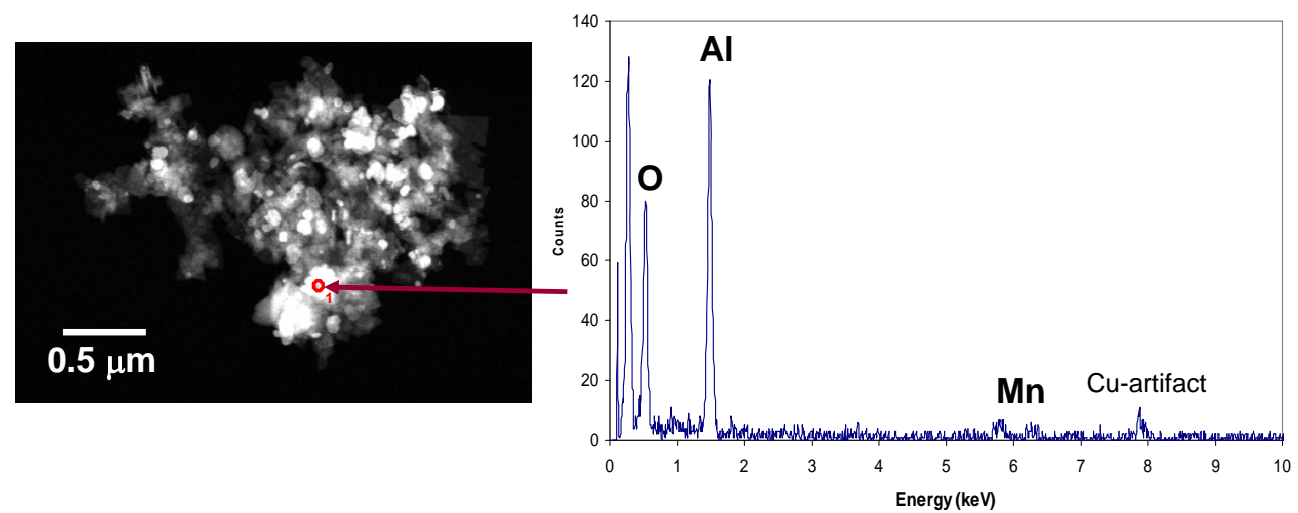

b)
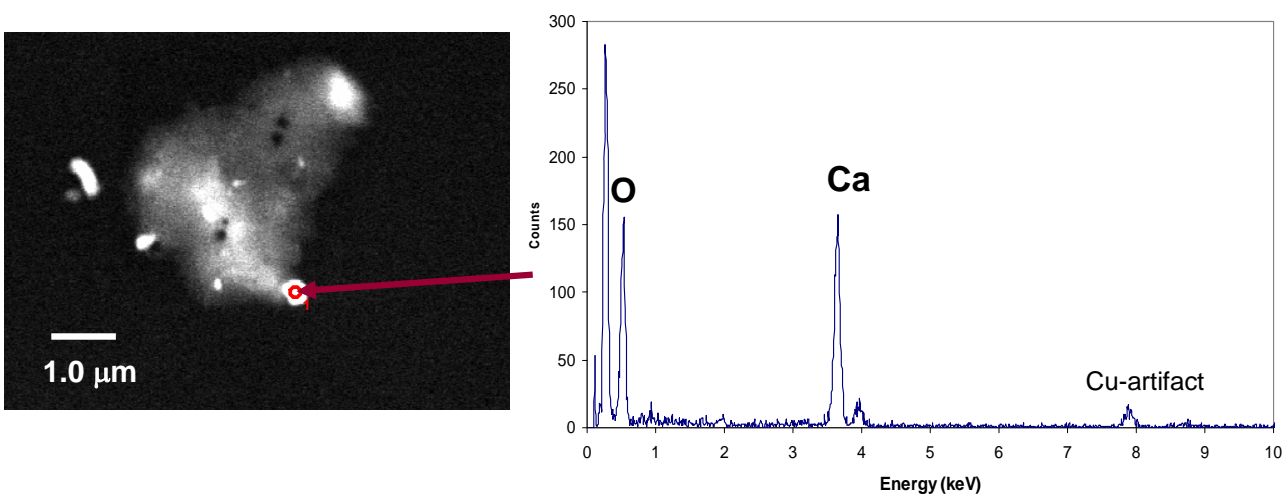

c)

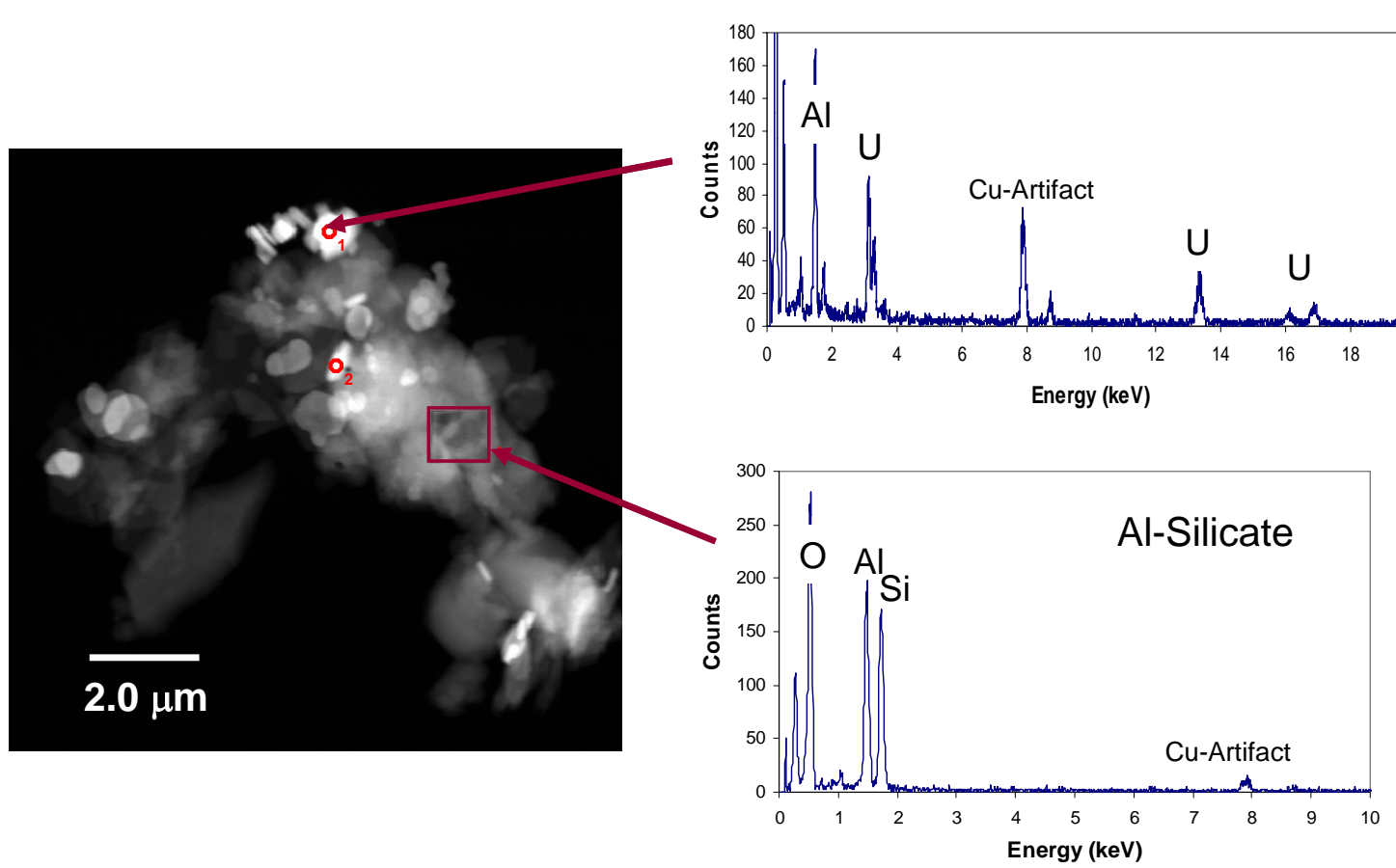

Figure 4.18. TEM Images with EDS Evaluation a) Particle Agglomerates Dominated by $\mathrm{Al}$ and O b) Calcite Particle c) Uranium Associated with an Alumino-Silicate Phase, Possibly Cancrinite 


\subsection{Filtration, Rheological, and PSD Results}

The filtration, rheological, and PSD characterization data were obtained during the demonstration test as indicated in Table 4.9. These were reported and discussed separately and are not repeated here. ${ }^{(a)}$

Table 4.9. Rheology, PSD, and Filtration Testing Supporting the Demonstration Test

\begin{tabular}{||l|c|c|c||}
\hline Test Step & Rheology & PSD & $\begin{array}{c}\text { Filter Test } \\
\text { Matrix }\end{array}$ \\
\hline Initial condition at $13.2 \mathrm{wt} \%$ UDS & $\mathrm{x}$ & $\mathrm{x}$ & $\mathrm{x}$ \\
\hline Caustic leached slurry at $8.9 \mathrm{wt} \%$ UDS & $\mathrm{x}$ & $\mathrm{x}$ & \\
\hline Caustic leached and washed slurry at $12.8 \mathrm{wt} \%$ UDS & $\mathrm{x}$ & $\mathrm{x}$ & \\
\hline Oxidatively leached slurry at $6.0 \mathrm{wt} \%$ UDS & $\mathrm{x}$ & $\mathrm{x}$ & \\
\hline Oxidatively leached and washed slurry at $9.7 \mathrm{wt} \%$ UDS & $\mathrm{x}$ & $\mathrm{x}$ & $\mathrm{x}$ \\
\hline
\end{tabular}

\subsection{Assessment of CUF Surfaces for Pu Accumulation}

The 2-M nitric acid leach solution circulating in the CUF assembly was intended to leach Pu that might have plated on the CUF component surfaces during prototypic leach operations. The leach solution was measured for radionuclides and metals; key component results are provided in Table 4.10.

Table 4.10. 2 M Nitric Acid CUF Leach Solution

\begin{tabular}{|c|c|c|c|}
\hline Analyte & $\begin{array}{l}\text { Sample } \\
\mu \mathrm{Ci} / \mathrm{mL}\end{array}$ & Analyte & $\begin{array}{l}\text { Sample } \\
\mu \mathrm{Ci} / \mathrm{mL}\end{array}$ \\
\hline${ }^{137} \mathrm{Cs}$ & $1.52 \mathrm{E}-1$ & Gross alpha & $1.78 \mathrm{E}-3$ \\
\hline${ }^{60} \mathrm{Co}$ & $<3 \mathrm{E}-5$ & Gross beta & $8.36 \mathrm{E}-1$ \\
\hline${ }^{241} \mathrm{Am}$ & $8.13 \mathrm{E}-4$ & ${ }^{90} \mathrm{Sr}$ & $3.80 \mathrm{E}-1$ \\
\hline${ }^{238} \mathrm{Pu}$ & $3.89 \mathrm{E}-5$ & ${ }^{154} \mathrm{Eu}$ (opportunistic) & $<8 \mathrm{E}-5$ \\
\hline${ }^{239+240} \mathrm{Pu}$ & $9.75 \mathrm{E}-4$ & -- & -- \\
\hline Analyte & $\mu \mathrm{g} / \mathrm{mL}$ & Analyte & $\mu \mathrm{g} / \mathrm{mL}$ \\
\hline $\mathrm{Al}$ & 111 & $\mathrm{Ni}$ & 8.29 \\
\hline $\mathrm{B}$ & {$[0.26]$} & $\mathrm{P}$ & 59.3 \\
\hline $\mathrm{Bi}$ & 149 & $\mathrm{~S}$ & [3.9] \\
\hline $\mathrm{Cd}$ & {$[0.16]$} & $\mathrm{Si}$ & 59.6 \\
\hline $\mathrm{Cr}$ & 14.3 & $\mathrm{Sr}$ & 8.56 \\
\hline $\mathrm{Fe}$ & 142 & $\mathrm{U}$ & 38.0 \\
\hline $\mathrm{K}$ & {$[2.0]$} & $\mathrm{Zn}$ & 1.66 \\
\hline $\mathrm{Mn}$ & 7.59 & $\mathrm{Zr}$ & 0.632 \\
\hline $\mathrm{Na}$ & 383 & $\mathrm{U}(\mathrm{KPA})$ & 36.3 \\
\hline \multicolumn{4}{|c|}{$\begin{array}{l}\text { Reference date: November 5, } 2007 \\
\text { ASR 8113, Sample 08-01303 }\end{array}$} \\
\hline \multicolumn{4}{|c|}{$\begin{array}{l}\text { Analyte uncertainties were typically within } \pm 15 \% \text {; results in brackets indicate that the analyte } \\
\text { concentrations were greater than the method detection limit (MDL) and less than the } \\
\text { estimated quantitation limit (EQL), and uncertainties were }>15 \% \text {. }\end{array}$} \\
\hline
\end{tabular}

(a) Shimskey et al. in press.. 
The concentration of $\mathrm{Pu}$ onto the component surfaces cannot be discerned from the analytical data directly. Therefore, the data were evaluated relative to the final oxidatively leached Group 5/6 product after normalizing the concentrations to the ${ }^{137} \mathrm{Cs}$ concentration. The ${ }^{137} \mathrm{Cs}$ was selected for normalization since it was not expected to plate onto component surfaces and is largely a spectator ion to all processing steps. Relative concentrations of selected analytes are shown in Figure 4.19. Relative Al, Am, Pu (sum of ${ }^{239+240} \mathrm{Pu}$ and ${ }^{238} \mathrm{Pu}$ ), and $\mathrm{U}$ concentrations in the nitric acid leach solution were slightly lower than those of the oxidatively leached Group 5/6 solids. Relative Al, $\mathrm{Fe}, \mathrm{Na}$, and $\mathrm{Sr}$ concentrations in the nitric acid leach solution were slightly higher than those of the oxidatively leached Group 5/6 solids. Had Pu shown a preferential tendency to plate onto the CUF component surfaces, the relative $\mathrm{Pu}$ in the $2 \mathrm{M}$ nitric acid leach solution would be expected to be higher than that of the oxidatively leached Group 5/6 solids. Its trend was opposite that of Fe and corresponded to other bulk components ( $\mathrm{U}, \mathrm{Am}$, and $\mathrm{Al}$ ). Thus, within the uncertainty of the test, the presence of $\mathrm{Pu}$ in the $2 \mathrm{M}$ nitric acid leach solution was attributed solely to residual solids holdup.

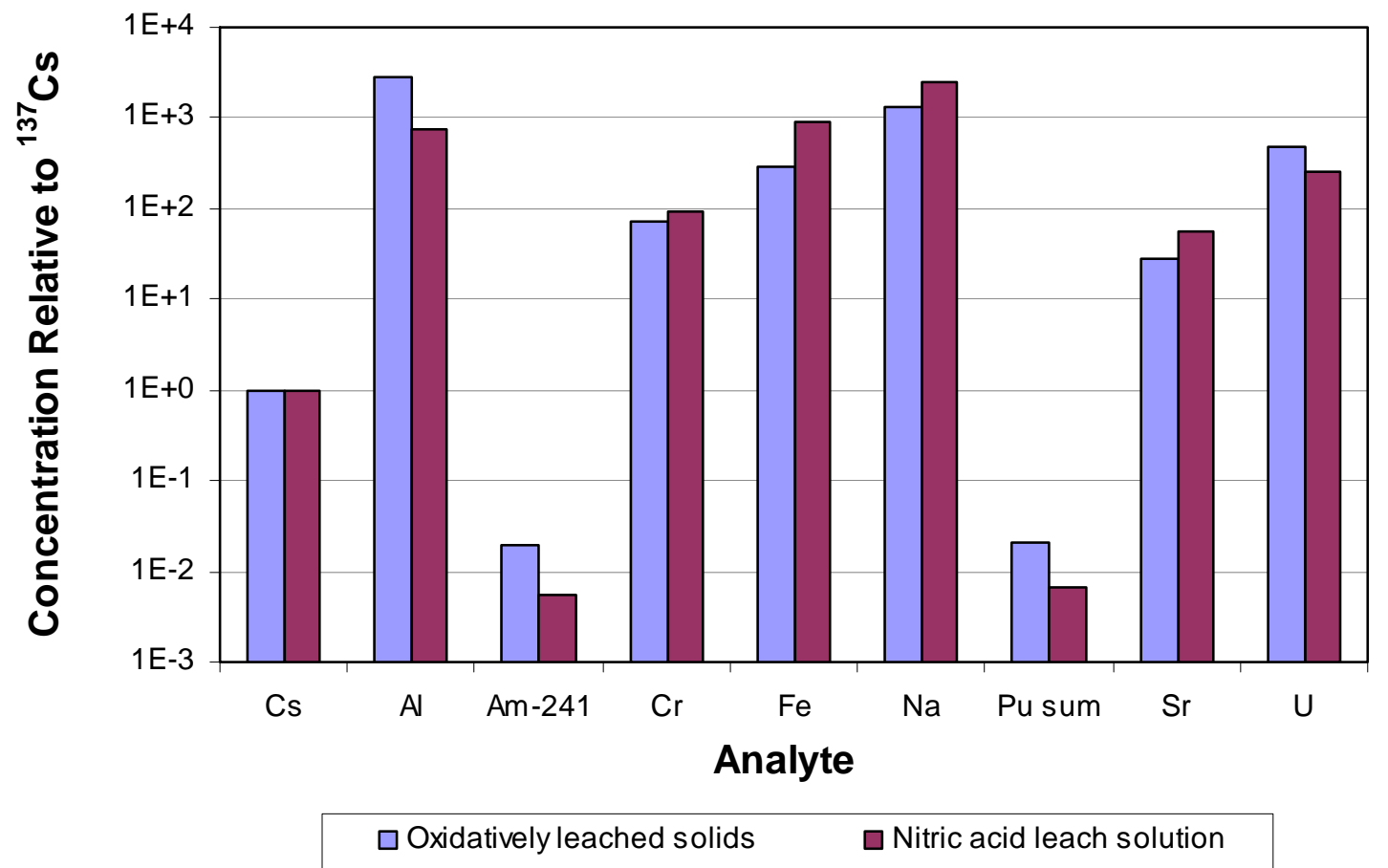

Figure 4.19. Analyte Concentrations Normalized to ${ }^{137} \mathrm{Cs}$ Concentration for the Oxidatively Leached Solids and the $2 \mathrm{M} \mathrm{HNO}_{3}$ CUF Surfaces Leach Solution

The $2 \mathrm{M} \mathrm{HNO}_{3}$ solution at $\sim 27^{\circ} \mathrm{C}$ is not a strong dissolving agent for Pu oxides and as such, may not have removed all of the Pu from component surfaces; however, it was the strongest nitric acid solution that was desired to run through the CUF system without the risk of damage and was delineated for use in the test plan. As such, the conclusions must be considered as possible but not definitive. A Ce(IV) solution has been reported to be an effective decontaminating solution for stainless steel surfaces (Bray et al. 1992). 


\subsection{Cesium Ion Exchange}

This section describes the ion exchange feed preparation, ion exchange process conditions, and processing results, including cesium loading behavior, effluent compositions, and analyte fractionation through the ion exchange process. The ion exchange column testing was conducted according to test instruction TI-RPP-WTP-548. ${ }^{\text {(a) }}$ The processes covered in this section, in relation to the whole demonstration test, are shown in bold in Figure 5.1.

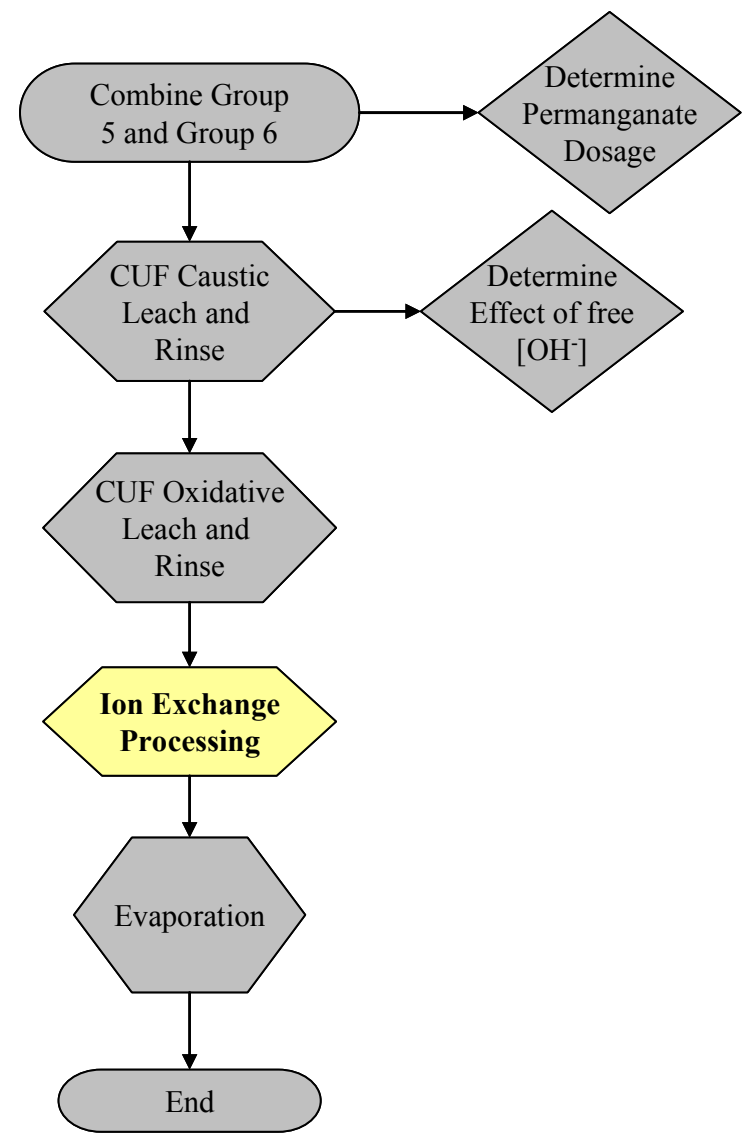

Figure 5.1. Pretreatment Operations with Ion Exchange Supporting the Demonstration Test

Figure 5.2 summarizes the specific ion exchange process steps. Characterization testing is shown to the right. Linkages between this and other demonstration test processes are also shown (feed components from the CUF processing and fractions of the feed displacement and water rinse solutions that feed the evaporator).

(a) Testing was conducting according to TI-RPP-WTP-548, Cesium Removal from Group 5/6 Actual Tank Waste Using Spherical Resorcinol-Formaldehyde Resin, SK Fiskum, 11/7/2007. 


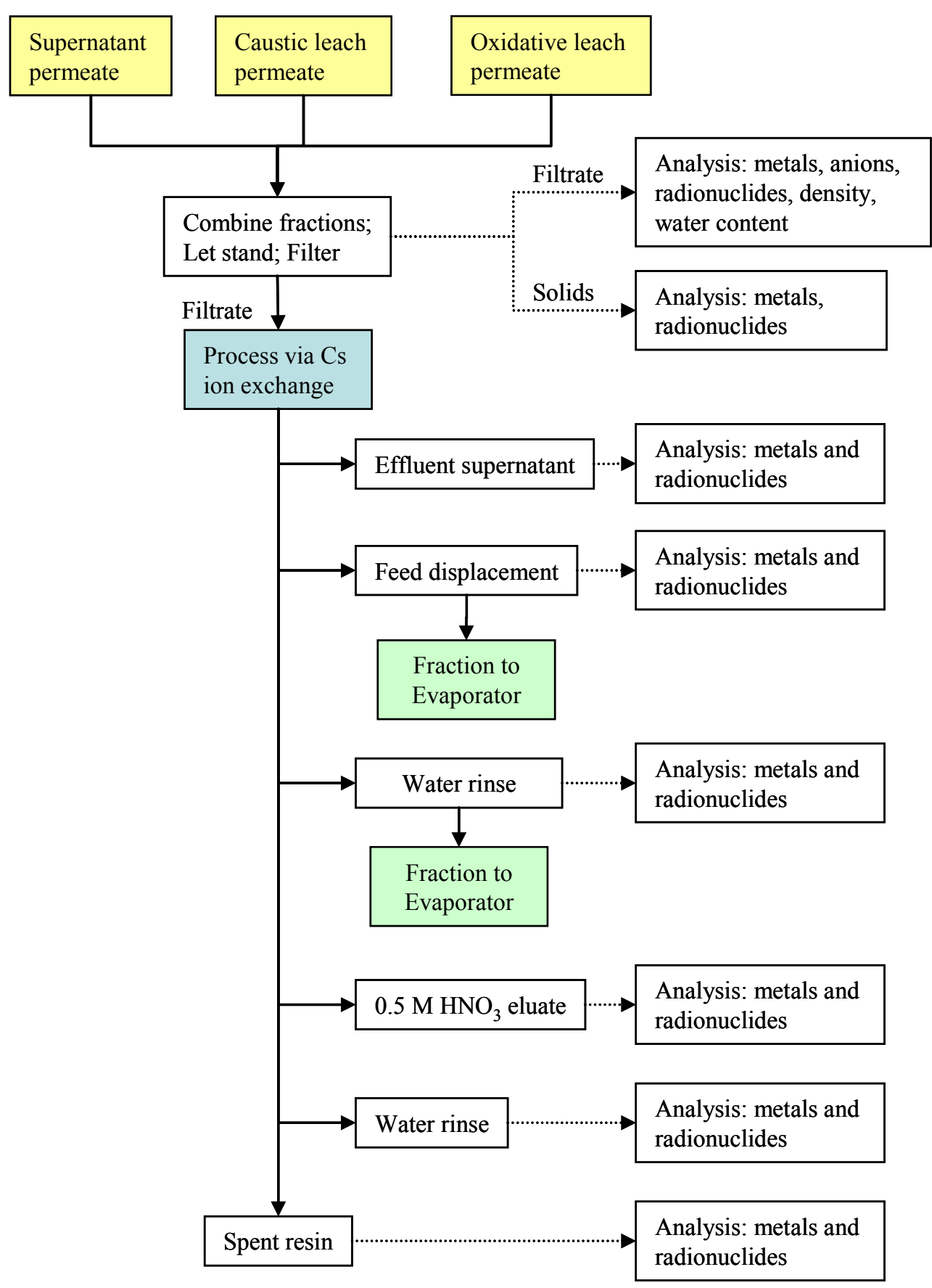

Figure 5.2. Ion Exchange Process Steps Supporting the Demonstration Test

\subsection{Feed Preparation}

Ion exchange feed was prepared with actual tank waste process streams obtained from the CUF process permeates. The components, sample identification, and volumes that were combined to create the feed are delineated in Table 5.1. Note that the feed was not prototypic of expected feed to ion exchange in that the oxidative leach solution was added in an effort to increase the Pu exposure to the resin. The 
addition of the final filtration test permeate (see Table 5.1) was also not prototypic; this had the effect of diluting the sodium concentration.

Table 5.1. Ion Exchange Feed Component Inputs

\begin{tabular}{|c|c|c|c|c|}
\hline Source $^{(a)}$ & $\begin{array}{c}\text { Sample } \\
\text { Identification }\end{array}$ & $\begin{array}{c}\text { Volume, } \\
\text { mL }\end{array}$ & $\begin{array}{l}\text { Density, } \\
\text { g/mL }\end{array}$ & $\begin{array}{c}\text { Dissolved } \\
\text { Solids, wt \% }\end{array}$ \\
\hline $\begin{array}{l}\text { Initial permeate (essentially combined } \\
\text { Group } 5 \text { and Group } 6 \text { supernatant) }\end{array}$ & G6-Dewater1 & 941 & 1.24 & 35.2 \\
\hline \multirow{3}{*}{ Caustic leach permeate } & G6-CtLeach1 & 708 & 1.33 & 28.2 \\
\hline & G6-CtLeach2 & 668 & 1.33 & 28.2 \\
\hline & G6-CtLeach3 & 622 & 1.33 & 28.2 \\
\hline Oxidative leach permeate & G6-OxWash1 & 898 & 1.01 & $\mathrm{n} / \mathrm{a}$ \\
\hline Final filtration test permeate ${ }^{(b)}$ & G6-FDewater1 & 933 & $1.02^{(\mathrm{c})}$ & $\mathrm{n} / \mathrm{a}$ \\
\hline \multicolumn{5}{|c|}{$\begin{array}{l}\text { (a) All sources were obtained from the CUF processing described in Section } 4.0 \text { and by Shimskey et al. (in } \\
\text { press). } \\
\text { (b) The final filtration test permeate was added by mistake and was reported under CAR } 28781.12 \text {; no } \\
\text { negative impacts to the test or interpretations are expected; in fact, the additional feed component } \\
\text { increased the dissolved Pu concentration, providing a better opportunity to evaluate potential Pu effects } \\
\text { on the ion exchanger. Refer to Figure } 4.8 \text { for reference to the CUF processing step. } \\
\text { (c) Estimated density: density was not measured. } \\
\text { Note: } \mathrm{n} / \mathrm{a}=\text { not analyzed. }\end{array}$} \\
\hline
\end{tabular}

The compositions of the various source solutions along with the calculated composition of the mixture are shown in Table 5.2 (radionuclides) and Table 5.3 (metals and anions). The fate of Pu was of specific interest, and its concentration was highest in the final filtration test permeate (G6-FDewater1), which had been added by mistake. Adding G6-FDewater1 doubled the calculated $\mathrm{Pu}$ concentration, and reduced the $\mathrm{Na}$ concentration by $\sim 19 \%$ (from an expected $5.45 \mathrm{M}$ to $4.43 \mathrm{M}$ ). The increase in $\mathrm{Pu}$ concentration was helpful in defining the fate of $\mathrm{Pu}$ through the subsequent process steps (less constraint relative to the $\mathrm{Pu}$ detection limit). The reduction of $\mathrm{Na}$ concentration was still within the normal operating bounds for $\mathrm{Cs}$ ion exchange processing. The overall process chemistry and related conclusions were not adversely affected by adding the final filtration test permeate.

The combination of the supernatant and caustic leach permeates with the oxidative leach permeate (containing permanganate in solution) resulted in the formation of a dark brown precipitate and clarified the aqueous phase within $16 \mathrm{~h}$ of combination. ${ }^{(a)}$ The feed was filtered through one of two 0.45 - $\mu \mathrm{m}$ poresize nylon filters to remove the solids so as not to foul the resin bed. The filtrate (ion exchanger feed) was collected in three $\sim 1.5$-L fractions (identified as Feed A, B, and C); each was analyzed for ICP-OES metals, anions, free hydroxide, and radionuclides.

(a) The precipitate formed from a solution geometry of nominally $15 \mathrm{~cm}$ wide by $8 \mathrm{~cm}$ deep by $14 \mathrm{~cm}$ high (in a rectangular high-density polyethylene bottle [Nalgene 2007-0064]). 
Table 5.2. Radionuclide Analysis of the Ion Exchange Feed Components

\begin{tabular}{|c|c|c|c|c|c|}
\hline Sample ID> & G6-Dewater1 & $\begin{array}{c}\text { G6-CtLeach1- } \\
\text { G6-CtLeach3 }\end{array}$ & G6-OxWash1 & $\begin{array}{c}\text { G6- } \\
\text { FDewater1 }\end{array}$ & \multirow{4}{*}{$\begin{array}{c}\text { Calculated } \\
\text { Composite } \\
\text { Composition }\end{array}$} \\
\hline Volume> & $769 \mathrm{~mL}$ & $1998 \mathrm{~mL}$ & $898 \mathrm{~mL}$ & $941 \mathrm{~mL}$ & \\
\hline ASR ID> & 8055 & 8055 & $8055 / 8108$ & 8113 & \\
\hline ASO ID> & 08-00219 & 08-00220 & 08-00240 & 08-01296 & \\
\hline Analyte & $\mu \mathrm{Ci} / \mathrm{mL}$ & $\mu \mathrm{Ci} / \mathbf{m L}$ & $\mu \mathrm{Ci} / \mathrm{mL}$ & $\mu \mathrm{Ci} / \mathrm{mL}$ & $\mu \mathrm{Ci} / \mathrm{mL}$ \\
\hline${ }^{137} \mathrm{Cs}$ & $7.24 \mathrm{E}+1$ & $3.34 \mathrm{E}+1$ & $7.73 \mathrm{E}-1$ & $7.41 \mathrm{E}-1$ & $2.69 \mathrm{E}+1$ \\
\hline${ }^{60} \mathrm{Co}$ & $<1 . \mathrm{E}-4$ & $<1 . \mathrm{E}-4$ & $<7 . \mathrm{E}-5$ & $<2 . \mathrm{E}-5$ & $<8 . \mathrm{E}-5$ \\
\hline${ }^{241} \mathrm{Am}$ & $<8 . \mathrm{E}-3$ & $<6 . \mathrm{E}-3$ & $<1 . \mathrm{E}-3$ & $<1 . \mathrm{E}-3$ & $<4 . \mathrm{E}-3$ \\
\hline${ }^{238} \mathrm{Pu}$ & $2.08 \mathrm{E}-5$ & $5.09 \mathrm{E}-6$ & $9.45 \mathrm{E}-6$ & $4.87 \mathrm{E}-5$ & $1.75 \mathrm{E}-5$ \\
\hline${ }^{239+240} \mathrm{Pu}$ & $1.55 \mathrm{E}-4$ & $2.41 \mathrm{E}-5$ & $3.91 \mathrm{E}-5$ & $3.24 \mathrm{E}-4$ & $1.10 \mathrm{E}-4$ \\
\hline Gross alpha & $<3 . \mathrm{E}-3$ & $<3 . \mathrm{E}-3$ & $<3 . \mathrm{E}-4$ & $<8 . \mathrm{E}-4$ & $<2 . \mathrm{E}-3$ \\
\hline Gross beta & $7.44 \mathrm{E}+1$ & $3.55 \mathrm{E}+1$ & $8.03 \mathrm{E}-1$ & $6.30 \mathrm{E}-1$ & $2.81 \mathrm{E}+1$ \\
\hline${ }^{90} \mathrm{Sr}$ & $4.88 \mathrm{E}-2$ & $2.54 \mathrm{E}-2$ & $8.98 \mathrm{E}-3$ & $1.09 \mathrm{E}-4$ & $2.09 \mathrm{E}-2$ \\
\hline Sum of alpha ${ }^{(a)}$ & $1.76 \mathrm{E}-4$ & $2.92 \mathrm{E}-5$ & $4.86 \mathrm{E}-5$ & $3.73 \mathrm{E}-4$ & $1.28 \mathrm{E}-4$ \\
\hline$\alpha$ gross/sum & na & na & na & na & na \\
\hline $\begin{array}{l}\text { Isotopic ratio of } \\
{ }^{239+240} \mathrm{Pu} /{ }^{238} \mathrm{Pu}\end{array}$ & 7.45 & 4.73 & 4.14 & 6.65 & 6.30 \\
\hline Sum of beta ${ }^{(b)}$ & $7.25 \mathrm{E}+1$ & $3.35 \mathrm{E}+1$ & $7.91 \mathrm{E}-1$ & $7.41 \mathrm{E}-1$ & $2.69 \mathrm{E}+1$ \\
\hline$\beta$ gross/sum & 1.03 & 1.06 & 1.02 & 0.85 & 1.04 \\
\hline \multicolumn{6}{|l|}{ Opportunistic } \\
\hline${ }^{154} \mathrm{Eu}$ & $<7 . \mathrm{E}-4$ & $<4 . \mathrm{E}-4$ & $<2 . \mathrm{E}-4$ & $<6 . \mathrm{E}-5$ & $<3 . \mathrm{E}-4$ \\
\hline${ }^{155} \mathrm{Eu}$ & $<9 . \mathrm{E}-3$ & $<6 . \mathrm{E}-3$ & $<8 . \mathrm{E}-4$ & $<5 . \mathrm{E}-4$ & $<4$. E-3 \\
\hline \multicolumn{6}{|c|}{$\begin{array}{l}\text { (a) Sum of alpha is the sum of detected }{ }^{241} \mathrm{Am},{ }^{238} \mathrm{Pu} \text {, and }{ }^{239+240} \mathrm{Pu} \text {; if }{ }^{241} \mathrm{Am} \text { was not detected, then it was not } \\
\text { included in the alpha sum. } \\
\text { (b) Sum of beta is the sum of all detected beta-emitting isotopes; }{ }^{90} \mathrm{Sr} \text { concentration is doubled to account for the } \\
\text { secular equilibrium of }{ }^{90} \mathrm{Y} \text {. } \\
\text { Notes: } \\
\text { Reference date is November } 5,2007 \text {. } \\
\text { na = not applicable }\end{array}$} \\
\hline
\end{tabular}


Table 5.3. Chemical Composition of the Ion Exchange Feed Components

\begin{tabular}{|c|c|c|c|c|c|c|c|c|c|c|}
\hline Sample ID> & \multicolumn{2}{|c|}{ G6-Dewater1 } & \multicolumn{2}{|c|}{ G6-CtLeach1-3 } & \multicolumn{2}{|c|}{ G6-OxWash1 } & \multicolumn{2}{|c|}{ G6-FDewater1 } & & \\
\hline Volume $>$ & \multicolumn{2}{|c|}{$769 \mathrm{~mL}$} & \multicolumn{2}{|c|}{$1998 \mathrm{~mL}$} & \multicolumn{2}{|c|}{$898 \mathrm{~mL}$} & \multicolumn{2}{|c|}{$941 \mathrm{~mL}$} & & \\
\hline ASR ID $>$ & \multicolumn{2}{|c|}{8055} & \multicolumn{2}{|c|}{8055} & \multicolumn{2}{|c|}{$8055 / 8108$} & \multicolumn{2}{|c|}{8113} & \multirow{2}{*}{\multicolumn{2}{|c|}{$\begin{array}{c}\text { Calculated Composite } \\
\text { Composition } \\
\end{array}$}} \\
\hline ASO ID> & \multicolumn{2}{|c|}{ 08-00219 } & \multicolumn{2}{|c|}{ 08-00220 } & \multicolumn{2}{|c|}{ 08-00240 } & \multicolumn{2}{|c|}{ 08-01296 } & & \\
\hline Analyte & $\mu \mathrm{g} / \mathrm{mL}$ & $\mathbf{M}$ & $\mu \mathrm{g} / \mathrm{mL}$ & $\mathbf{M}$ & $\mu \mathrm{g} / \mathrm{mL}$ & $\mathbf{M}$ & $\mu \mathrm{g} / \mathrm{mL}$ & $\mathbf{M}$ & $\mu \mathrm{g} / \mathrm{mL}$ & $\mathbf{M}$ \\
\hline $\mathrm{Al}$ & 6,310 & $2.34 \mathrm{E}-1$ & 13,400 & 4.97E-1 & 219 & $8.12 \mathrm{E}-3$ & 1,170 & $4.34 \mathrm{E}-2$ & 7,147 & $2.65 \mathrm{E}-1$ \\
\hline $\mathrm{B}$ & 30.2 & $2.79 \mathrm{E}-3$ & {$[20]$} & [1.9E-3] & $<1.77$ & $<1.6 \mathrm{E}-4$ & {$[1.7]$} & {$[1.6 \mathrm{E}-4]$} & 14 & $1.33 \mathrm{E}-3$ \\
\hline $\mathrm{Bi}$ & $<2.28$ & $<1.1 \mathrm{E}-5$ & $<4.50$ & $<2.2 \mathrm{E}-5$ & {$[4.4]$} & [2.1E-5] & $<0.75$ & $<3.6 \mathrm{E}-6$ & $<3.3$ & $<1.6 \mathrm{E}-5$ \\
\hline $\mathrm{Cd}$ & $<0.24$ & $<2.1 \mathrm{E}-6$ & $<0.48$ & $<4.2 \mathrm{E}-6$ & $<0.23$ & $<2.1 \mathrm{E}-6$ & $<0.085$ & $<7.5 \mathrm{E}-7$ & $<0.31$ & $<2.8 \mathrm{E}-6$ \\
\hline $\mathrm{Cr}$ & 729 & $1.40 \mathrm{E}-2$ & 378 & $7.27 \mathrm{E}-3$ & 2,340 & $4.50 \mathrm{E}-2$ & 284 & $5.46 \mathrm{E}-3$ & 800 & $1.54 \mathrm{E}-2$ \\
\hline $\mathrm{Fe}$ & $<2.04$ & $<3.6 \mathrm{E}-5$ & {$[11]$} & {$[2.0 \mathrm{E}-4]$} & $<1.98$ & $<3.5 \mathrm{E}-5$ & {$[0.082]$} & [1.5E-6] & $<5.5$ & $<9.9 \mathrm{E}-5$ \\
\hline $\mathrm{K}$ & 954 & $2.44 \mathrm{E}-2$ & 470 & $1.20 \mathrm{E}-2$ & {$[58]$} & {$[1.5 \mathrm{E}-3]$} & 32.0 & $8.18 \mathrm{E}-4$ & 381 & $9.74 \mathrm{E}-3$ \\
\hline $\mathrm{Mn}$ & $<0.20$ & $<3.7 \mathrm{E}-6$ & $<0.40$ & $<7.4 \mathrm{E}-6$ & 2,580 & $4.70 \mathrm{E}-2$ & 3.98 & $7.24 \mathrm{E}-5$ & 504 & $9.18 \mathrm{E}-3$ \\
\hline $\mathrm{Na}$ & 109,000 & $4.74 \mathrm{E}+0$ & 185,000 & $8.05 \mathrm{E}+0$ & 6,490 & $2.82 \mathrm{E}-1$ & 10,300 & $4.48 \mathrm{E}-1$ & 101,805 & $4.43 \mathrm{E}+0$ \\
\hline $\mathrm{Ni}$ & {$[2.5]$} & {$[4.6 \mathrm{E}-5]$} & $<1.14$ & $<1.9 \mathrm{E}-5$ & $<0.56$ & $<9.6 \mathrm{E}-6$ & $<0.060$ & $<1.0 \mathrm{E}-6$ & {$[1.0]$} & [1.8E-5] \\
\hline $\mathrm{P}$ & 2,520 & $8.14 \mathrm{E}-2$ & 766 & $2.47 \mathrm{E}-2$ & {$[46]$} & [1.5E-3] & 28.0 & $9.04 \mathrm{E}-4$ & 768 & $2.48 \mathrm{E}-2$ \\
\hline $\mathrm{S}$ & 1,640 & $5.12 \mathrm{E}-2$ & 766 & $2.39 \mathrm{E}-2$ & $<31.61$ & $<9.9 \mathrm{E}-4$ & [12] & [3.7E-4] & 615 & $1.92 \mathrm{E}-2$ \\
\hline $\mathrm{Si}$ & 52.0 & $1.85 \mathrm{E}-3$ & 53.2 & $1.89 \mathrm{E}-3$ & $<1.10$ & $<3.9 \mathrm{E}-5$ & 5.86 & $2.09 \mathrm{E}-4$ & 33.2 & $1.18 \mathrm{E}-3$ \\
\hline $\mathrm{Sr}$ & [0.032] & [1.0E-6] & {$[0.046]$} & [5.2E-7] & $<0.02$ & $<1.9 \mathrm{E}-7$ & [0.0043] & [4.9E-8] & [0.029] & [3.4E-7] \\
\hline $\mathrm{U}$ & $<8.36$ & $<3.5 \mathrm{E}-5$ & $<16.51$ & $<6.9 \mathrm{E}-5$ & $<8.11$ & $<3.4 \mathrm{E}-5$ & $<0.80$ & $<3.3 \mathrm{E}-6$ & $<10$ & $<4.3 \mathrm{E}-5$ \\
\hline $\mathrm{Zn}$ & $<0.57$ & $<8.7 \mathrm{E}-6$ & {$[8.7]$} & [1.3E-4] & $<0.55$ & $<8.4 \mathrm{E}-6$ & {$[0.62]$} & [9.5E-6] & $<4.1$ & $<6.3 \mathrm{E}-5$ \\
\hline $\mathrm{Zr}$ & $<0.81$ & $<8.9 \mathrm{E}-6$ & {$[1.8]$} & {$[2.0 \mathrm{E}-5]$} & $<0.78$ & $<8.6 \mathrm{E}-6$ & {$[0.047]$} & [5.2E-7] & $<1.1$ & $<1.2 \mathrm{E}-5$ \\
\hline U KPA & 5.22 & $2.19 \mathrm{E}-5$ & 6.4 & $2.69 \mathrm{E}-5$ & \multicolumn{2}{|c|}{$\mathrm{n} / \mathrm{a}$} & \multicolumn{2}{|c|}{$\mathrm{n} / \mathrm{a}$} & 3.65 & $1.53 \mathrm{E}-5$ \\
\hline nitrite & 37,200 & $8.09 \mathrm{E}-1$ & 16,600 & $3.61 \mathrm{E}-1$ & \multicolumn{2}{|c|}{$\mathrm{n} / \mathrm{a}$} & \multicolumn{2}{|c|}{$\mathrm{n} / \mathrm{a}$} & 13,409 & $2.92 \mathrm{E}-1$ \\
\hline nitrate & 126,000 & $2.03 \mathrm{E}+0$ & 54,800 & $8.84 \mathrm{E}-1$ & \multicolumn{2}{|c|}{$\mathrm{n} / \mathrm{a}$} & \multicolumn{2}{|c|}{$\mathrm{n} / \mathrm{a}$} & 44,800 & 7.23E-1 \\
\hline phosphate & 8,310 & $8.75 \mathrm{E}-2$ & 1,740 & $1.83 \mathrm{E}-2$ & \multicolumn{2}{|c|}{$\mathrm{n} / \mathrm{a}$} & \multicolumn{2}{|c|}{$\mathrm{n} / \mathrm{a}$} & 2,142 & $2.26 \mathrm{E}-2$ \\
\hline sulfate & 6,690 & $6.96 \mathrm{E}-2$ & 3,020 & $3.14 \mathrm{E}-2$ & \multicolumn{2}{|c|}{$\mathrm{n} / \mathrm{a}$} & \multicolumn{2}{|c|}{$\mathrm{n} / \mathrm{a}$} & 2,427 & $2.53 \mathrm{E}-2$ \\
\hline
\end{tabular}


Table 5.3 (contd)

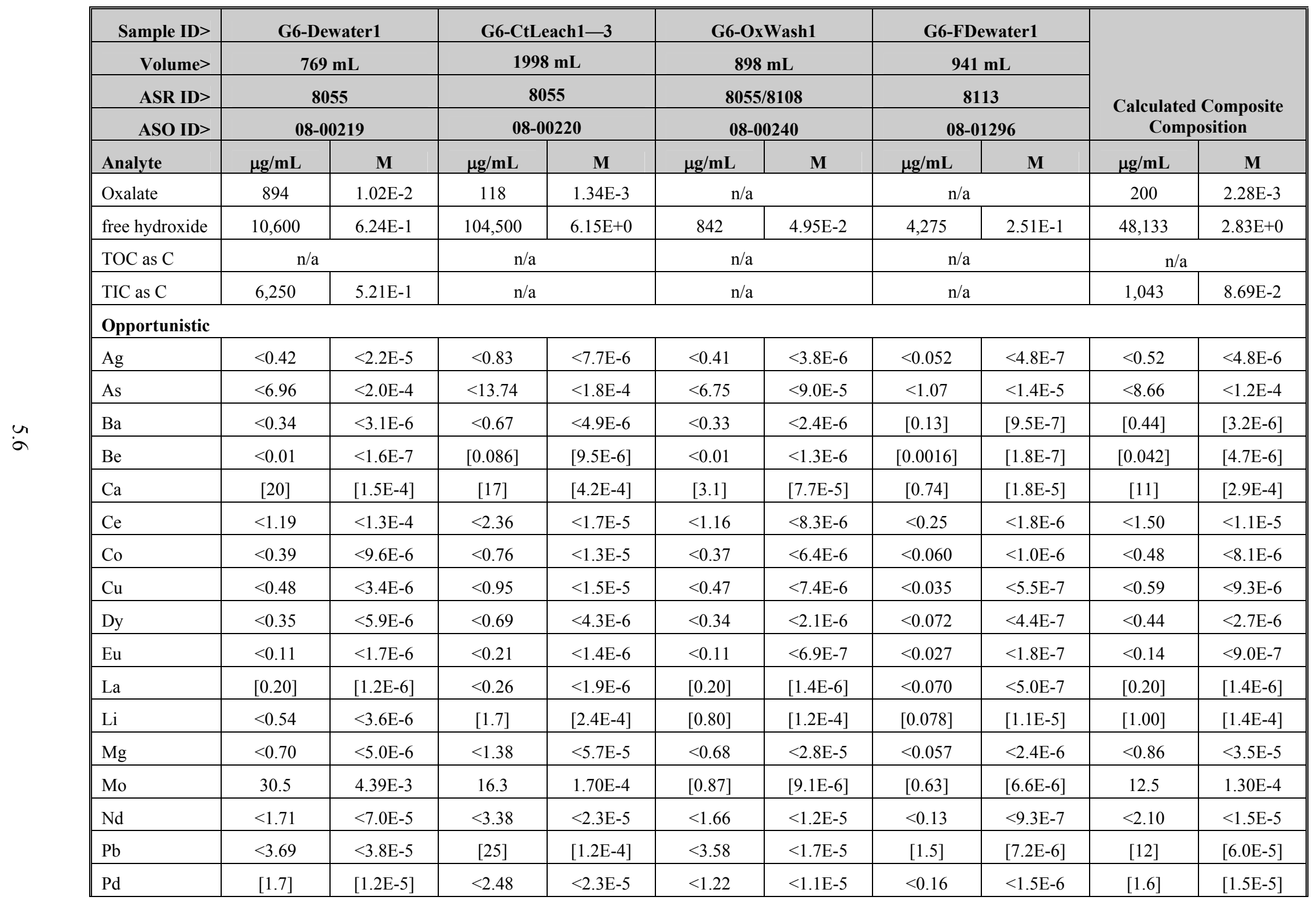


Table 5.3 (contd)

\begin{tabular}{|c|c|c|c|c|c|c|c|c|c|c|}
\hline Sample ID> & \multicolumn{2}{|c|}{ G6-Dewater1 } & \multicolumn{2}{|c|}{ G6-CtLeach1-3 } & \multicolumn{2}{|c|}{ G6-OxWash1 } & \multicolumn{2}{|c|}{ G6-FDewater1 } & & \\
\hline Volume> & \multicolumn{2}{|c|}{$769 \mathrm{~mL}$} & \multicolumn{2}{|c|}{$1998 \mathrm{~mL}$} & \multicolumn{2}{|c|}{$898 \mathrm{~mL}$} & \multicolumn{2}{|c|}{$941 \mathrm{~mL}$} & \multirow{3}{*}{\multicolumn{2}{|c|}{$\begin{array}{c}\text { Calculated Composite } \\
\text { Composition }\end{array}$}} \\
\hline ASR ID> & \multicolumn{2}{|c|}{8055} & \multicolumn{2}{|c|}{8055} & \multicolumn{2}{|c|}{$8055 / 8108$} & \multicolumn{2}{|c|}{8113} & & \\
\hline ASO ID> & \multicolumn{2}{|c|}{ 08-00219 } & \multicolumn{2}{|c|}{ 08-00220 } & \multicolumn{2}{|c|}{ 08-00240 } & \multicolumn{2}{|c|}{$08-01296$} & & \\
\hline Analyte & $\mu \mathrm{g} / \mathrm{mL}$ & $\mathbf{M}$ & $\mu \mathrm{g} / \mathrm{mL}$ & M & $\mu \mathrm{g} / \mathrm{mL}$ & $\mathbf{M}$ & $\mu \mathrm{g} / \mathrm{mL}$ & $\mathbf{M}$ & $\mu \mathrm{g} / \mathrm{mL}$ & $\mathbf{M}$ \\
\hline $\mathrm{Rh}$ & $<2.52$ & $<1.2 \mathrm{E}-5$ & $<4.98$ & $<4.8 \mathrm{E}-5$ & $<2.44$ & $<2.4 \mathrm{E}-5$ & $<0.30$ & $<2.9 \mathrm{E}-6$ & $<3.12$ & $<3.0 \mathrm{E}-5$ \\
\hline $\mathrm{Ru}$ & {$[3.8]$} & [3.6E-5] & {$[3.5]$} & {$[3.5 \mathrm{E}-5]$} & $<0.80$ & $<7.9 \mathrm{E}-6$ & {$[0.31]$} & [3.1E-6] & {$[2.4]$} & [2.3E-5] \\
\hline $\mathrm{Sb}$ & $<3.13$ & $<3.0 \mathrm{E}-5$ & $<6.19$ & $<5.1 \mathrm{E}-5$ & [10] & [8.2E-5] & $<0.50$ & $<4.1 \mathrm{E}-6$ & $<5.26$ & $<4.3 \mathrm{E}-5$ \\
\hline $\mathrm{Se}$ & {$[8.0]$} & [7.9E-5] & {$[9.9]$} & [1.3E-4] & $<4.74$ & $<6.0 \mathrm{E}-5$ & $<1.7$ & $<2.2 \mathrm{E}-5$ & [6.9] & {$[8.7 \mathrm{E}-5]$} \\
\hline $\mathrm{Sn}$ & {$[3.2]$} & {$[2.6 \mathrm{E}-5]$} & $<3.95$ & $<3.3 \mathrm{E}-5$ & {$[4.1]$} & {$[3.5 \mathrm{E}-5]$} & $<0.67$ & $<5.7 \mathrm{E}-6$ & {$[3.2]$} & {$[2.7 \mathrm{E}-5]$} \\
\hline $\mathrm{Ta}$ & $<1.33$ & $<1.7 \mathrm{E}-5$ & $<2.62$ & $<1.4 \mathrm{E}-5$ & $<1.29$ & $<7.1 \mathrm{E}-6$ & $<0.42$ & $<2.3 \mathrm{E}-6$ & $<1.70$ & $<9.4 \mathrm{E}-6$ \\
\hline $\mathrm{Te}$ & $<3.15$ & $<2.7 \mathrm{E}-5$ & $<6.22$ & $<4.9 \mathrm{E}-5$ & $<3.05$ & $<2.4 \mathrm{E}-5$ & {$[0.83]$} & {$[6.5 \mathrm{E}-6]$} & $<3.99$ & $<3.1 \mathrm{E}-5$ \\
\hline Th & $<1.18$ & $<6.5 \mathrm{E}-6$ & $<2.33$ & $<1.0 \mathrm{E}-5$ & $<1.15$ & $<4.9 \mathrm{E}-6$ & {$[0.41]$} & {$[1.8 \mathrm{E}-6]$} & $<1.52$ & $<6.5 \mathrm{E}-6$ \\
\hline $\mathrm{Ti}$ & $<0.10$ & $<7.6 \mathrm{E}-7$ & $<0.19$ & $<4.0 \mathrm{E}-6$ & $<0.09$ & $<2.0 \mathrm{E}-6$ & {$[0.013]$} & {$[2.7 \mathrm{E}-7]$} & $<0.12$ & $<2.5 \mathrm{E}-6$ \\
\hline $\mathrm{Tl}$ & $<6.47$ & $<2.8 \mathrm{E}-5$ & $<12.79$ & $<6.3 \mathrm{E}-5$ & $<6.28$ & $<3.1 \mathrm{E}-5$ & $<0.95$ & $<4.6 \mathrm{E}-6$ & $<8.05$ & $<3.9 \mathrm{E}-5$ \\
\hline $\mathrm{V}$ & {$[1.6]$} & {$[3.3 \mathrm{E}-5]$} & {$[0.75]$} & {$[1.5 \mathrm{E}-5]$} & $<0.30$ & $<6.0 \mathrm{E}-6$ & {$[0.15]$} & [2.9E-6] & {$[0.68]$} & [1.3E-5] \\
\hline $\mathrm{W}$ & 52.9 & $2.59 \mathrm{E}-4$ & {$[28]$} & [1.5E-4] & $<1.45$ & $<7.9 \mathrm{E}-6$ & $<0.47$ & $<2.6 \mathrm{E}-6$ & 21.4 & $1.16 \mathrm{E}-4$ \\
\hline $\mathrm{Y}$ & $<0.08$ & $<1.7 \mathrm{E}-6$ & $<0.17$ & $<1.9 \mathrm{E}-6$ & $<0.08$ & $<9.2 \mathrm{E}-7$ & $<0.011$ & $<1.2 \mathrm{E}-7$ & $<0.10$ & $<1.2 \mathrm{E}-6$ \\
\hline $\begin{array}{l}\text { Analyte uncer } \\
\text { detection limit } \\
\text { Opportunistic } \\
\mathrm{n} / \mathrm{a}=\text { not anal }\end{array}$ & $\begin{array}{l}\text { ies wer } \\
\text { DL) anc } \\
\text { ytes are } \\
\text { and }\end{array}$ & $\begin{array}{l}\text { cally wit } \\
\text { than the } \\
\text { tted for i }\end{array}$ & $\begin{array}{l}15 \% \text {; re } \\
\text { ated qu } \\
\text { lation o }\end{array}$ & $\begin{array}{l}\text { in brack } \\
\text { tion lim } \\
\text { 2C requi }\end{array}$ & $\begin{array}{l}\text { icate th } \\
\text { L), and } \\
\text { ts did n }\end{array}$ & $\begin{array}{l}\text { e analyt } \\
\text { ertainties } \\
\text { pply to tl }\end{array}$ & $\begin{array}{l}\text { entratio } \\
>15 \% \text {. } \\
\text { nalytes. }\end{array}$ & ere great & in the mi & \\
\hline
\end{tabular}


The filtered feed compositions are shown in Table 5.4 (metals and anions) and Table 5.5 (radionuclides). The slight compositional variations between Feed A, Feed B, and Feed C were within the analytical uncertainty of $\pm 15 \%$ and were thus were not considered significant. The analyte charge balance was evaluated and the cationic charge (primarily $\mathrm{Na}$ at $4.6 \mathrm{M}$ ) agreed within $2 \%$ of the anionic charge (combined $4.7 \mathrm{M}$ ) indicating excellent analytical integrity.

Table 5.4. Ion Exchange Processing Feed Metal and Anion Composition

\begin{tabular}{|c|c|c|c|c|c|c|}
\hline Sample ID> & Feed A & Feed B & Feed C & \multirow{3}{*}{\multicolumn{2}{|c|}{$\begin{array}{c}\text { Average } \\
\text { Feed }\end{array}$}} & \multirow[b]{4}{*}{ RSD } \\
\hline Volume $>$ & $1.51 \mathrm{~L}$ & $1.56 \mathrm{~L}$ & $1.51 \mathrm{~L}$ & & & \\
\hline ASO ID> & 08-00791 & 08-00792 & 08-00793 & & & \\
\hline Analyte & $\mu \mathrm{g} / \mathrm{mL}$ & $\mu \mathrm{g} / \mathrm{mL}$ & $\mu \mathrm{g} / \mathrm{mL}$ & $\mu \mathrm{g} / \mathrm{mL}$ & $\mathbf{M}$ & \\
\hline $\mathrm{Al}$ & 7,270 & 7,700 & 7,000 & 7,323 & $2.71 \mathrm{E}-1$ & $4.8 \%$ \\
\hline $\mathrm{B}$ & 28.7 & 28.9 & 28.7 & 28.8 & $2.66 \mathrm{E}-3$ & $0.4 \%$ \\
\hline $\mathrm{Ba}$ & {$[0.31]$} & {$[0.42]$} & {$[0.53]$} & {$[0.42]$} & [3.1E-6] & [26\%] \\
\hline $\mathrm{Bi}$ & $<3.8$ & [3.9] & [5.4] & {$[4.35]$} & [2.1E-5] & [21\%] \\
\hline $\mathrm{Ca}$ & [1.4] & [2.3] & [1.6] & {$[1.77]$} & [4.4E-5] & {$[27 \%]$} \\
\hline $\mathrm{Cd}$ & $<0.43$ & $<0.42$ & {$[0.46]$} & $<0.43$ & $<3.9 \mathrm{E}-6$ & na \\
\hline $\mathrm{Cr}$ & 720 & 723 & 740 & 728 & $1.40 \mathrm{E}-2$ & $1.5 \%$ \\
\hline $\mathrm{Cu}$ & $<0.18$ & $<0.17$ & $<0.17$ & $<0.17$ & $<2.7 \mathrm{E}-6$ & na \\
\hline $\mathrm{Fe}$ & 7.71 & [3.8] & [4.7] & [5.4] & [9.7E-5] & [38\%] \\
\hline $\mathrm{K}$ & 385 & 413 & 399 & 399 & $1.02 \mathrm{E}-2$ & $3.5 \%$ \\
\hline $\mathrm{Mn}$ & {$[0.46]$} & {$[0.28]$} & {$[0.21]$} & {$[0.32]$} & [5.8E-6] & [41\%] \\
\hline $\mathrm{Na}$ & 103,000 & 108,000 & 99,200 & 103,400 & $4.50 \mathrm{E}+0$ & $4.3 \%$ \\
\hline $\mathrm{Ni}$ & {$[0.42]$} & $<0.30$ & {$[0.38]$} & {$[0.37]$} & [6.2E-6] & {$[17 \%]$} \\
\hline $\mathrm{P}$ & 784 & 824 & 794 & 801 & $2.59 \mathrm{E}-2$ & $2.6 \%$ \\
\hline $\mathrm{S}$ & 837 & 897 & 822 & 852 & $2.66 \mathrm{E}-2$ & $4.7 \%$ \\
\hline $\mathrm{Si}$ & 107 & 108 & 107 & 107 & $3.82 \mathrm{E}-3$ & $0.5 \%$ \\
\hline $\mathrm{Sr}$ & $<0.010$ & $<0.010$ & $<0.010$ & $<0.010$ & $<1.2 \mathrm{E}-7$ & na \\
\hline Th & [2.3] & [1.7] & $<1.2$ & {$[1.74]$} & [7.5E-6] & [31\%] \\
\hline $\mathrm{U}$ & [9.6] & [7.1] & {$[6.0]$} & [7.57] & [3.2E-5] & [24\%] \\
\hline $\mathrm{Zn}$ & [3.8] & {$[4.0]$} & [3.6] & [3.8] & [5.8E-5] & {$[5 \%]$} \\
\hline $\mathrm{Zr}$ & {$[0.38]$} & {$[0.24]$} & {$[0.23]$} & {$[0.28]$} & [3.1E-6] & [30\%] \\
\hline U KPA & 3.59 & 3.82 & 3.53 & 3.65 & $1.53 \mathrm{E}-5$ & $4.2 \%$ \\
\hline nitrite & 13,000 & 13,200 & 13,000 & 13,100 & $2.84 \mathrm{E}-1$ & $0.88 \%$ \\
\hline nitrate & 43,700 & 44,600 & 44,100 & 44,100 & $7.12 \mathrm{E}-1$ & $1.0 \%$ \\
\hline phosphate & 2,450 & 2,480 & 2,460 & 2,460 & $2.59 \mathrm{E}-2$ & $0.62 \%$ \\
\hline sulfate & 2,360 & 2,410 & 2,360 & 2,380 & $2.47 \mathrm{E}-2$ & $1.2 \%$ \\
\hline oxalate & 467 & 441 & 479 & 462 & $5.25 \mathrm{E}-3$ & $4.2 \%$ \\
\hline free hydroxide & 47,200 & 49,400 & 44,100 & 46,900 & $2.76 \mathrm{E}+0$ & $5.7 \%$ \\
\hline TOC as $\mathrm{C}$ & 450 & 360 & 360 & 390 & $3.25 \mathrm{E}-2$ & $13 \%$ \\
\hline TIC as $\mathrm{C}$ & 3,230 & 2,850 & 2,650 & 2,910 & $2.43 \mathrm{E}-1$ & $10 \%$ \\
\hline
\end{tabular}


Table 5.4 (contd)

\begin{tabular}{|c|c|c|c|c|c|c|}
\hline Sample ID> & \multirow{4}{*}{$\begin{array}{c}\text { Feed A } \\
1.51 \mathrm{~L} \\
08-00791 \\
\mu \mathrm{g} / \mathrm{mL} \\
\end{array}$} & \multirow{4}{*}{$\begin{array}{c}\text { Feed B } \\
1.56 \mathrm{~L} \\
08-00792 \\
\mu \mathrm{g} / \mathrm{mL} \\
\end{array}$} & \multirow{4}{*}{\begin{tabular}{|c|} 
Feed C \\
$1.51 \mathrm{~L}$ \\
$08-00793$ \\
$\mu \mathrm{g} / \mathrm{mL}$ \\
\end{tabular}} & \multirow{3}{*}{\multicolumn{2}{|c|}{$\begin{array}{c}\text { Average } \\
\text { Feed }\end{array}$}} & \multirow[b]{4}{*}{ RSD } \\
\hline \multirow{3}{*}{$\begin{array}{l}\text { Volume }> \\
\text { ASO ID }> \\
\text { Analyte } \\
\end{array}$} & & & & & & \\
\hline & & & & & & \\
\hline & & & & $\mu \mathrm{g} / \mathrm{mL}$ & $\mathbf{M}$ & \\
\hline Opportunistic & & & & & & \\
\hline fluoride & 40.5 & 44.2 & 47.7 & 44 & $2.32 \mathrm{E}-3$ & $8.2 \%$ \\
\hline chloride & 1,090 & 1,130 & 1,100 & 1,107 & $3.12 \mathrm{E}-2$ & $1.9 \%$ \\
\hline $\mathrm{Ag}$ & $<0.26$ & $<0.26$ & $<0.26$ & $<0.26$ & $<2.4 \mathrm{E}-6$ & na \\
\hline As & $<5.4$ & $<5.3$ & $<5.3$ & $<5.3$ & $<7.1 \mathrm{E}-5$ & na \\
\hline $\mathrm{Be}$ & {$[0.047]$} & {$[0.031]$} & {$[0.024]$} & {$[0.034]$} & [3.8E-6] & {$[35 \%]$} \\
\hline $\mathrm{Ce}$ & $<1.3$ & $<1.2$ & $<1.2$ & $<1.2$ & $<8.9 \mathrm{E}-6$ & na \\
\hline Co & {$[0.35]$} & $<0.30$ & $<0.30$ & $<0.31$ & $<5.3 \mathrm{E}-6$ & na \\
\hline Dy & $<0.36$ & $<0.36$ & $<0.36$ & $<0.36$ & $<2.2 \mathrm{E}-6$ & na \\
\hline $\mathrm{Eu}$ & $<0.14$ & $<0.14$ & $<0.14$ & $<0.14$ & $<9.0 \mathrm{E}-7$ & na \\
\hline $\mathrm{La}$ & {$[0.85]$} & {$[0.43]$} & $<0.35$ & $<0.54$ & $<3.9 \mathrm{E}-6$ & na \\
\hline $\mathrm{Li}$ & {$[0.70]$} & {$[0.71]$} & {$[0.76]$} & {$[0.72]$} & [1.0E-4] & {$[4 \%]$} \\
\hline $\mathrm{Mg}$ & [1.1] & $<0.28$ & $<0.29$ & $<0.56$ & $<2.3 \mathrm{E}-5$ & na \\
\hline Mo & 11.1 & 11.6 & 10.1 & 10.9 & $1.14 \mathrm{E}-4$ & $4.6 \%$ \\
\hline $\mathrm{Nd}$ & $<0.68$ & $<0.67$ & $<0.67$ & $<0.67$ & $<4.6 \mathrm{E}-6$ & na \\
\hline $\mathrm{Pb}$ & $<4.0$ & $<3.9$ & $<4.0$ & $<4.0$ & $<1.9 \mathrm{E}-5$ & na \\
\hline $\mathrm{Pd}$ & {$[1.5]$} & $<0.78$ & {$[0.83]$} & {$[1.04]$} & [9.7E-6] & {$[65 \%]$} \\
\hline $\mathrm{Rh}$ & {$[2.4]$} & {$[2.5]$} & $<1.49$ & $<2.13$ & $<2.1 \mathrm{E}-5$ & na \\
\hline $\mathrm{Ru}$ & {$[1.6]$} & {$[1.3]$} & {$[1.4]$} & {$[1.43]$} & [1.4E-5] & {$[11 \%]$} \\
\hline $\mathrm{Sb}$ & $<2.5$ & $<2.5$ & $<2.5$ & $<2.5$ & $<2.0 \mathrm{E}-5$ & na \\
\hline $\mathrm{Se}$ & $<8.8$ & $<8.6$ & $<8.7$ & $<8.7$ & $<1.1 \mathrm{E}-4$ & na \\
\hline $\mathrm{Sn}$ & [4.3] & $<3.3$ & [5.7] & {$[4.44]$} & [3.7E-5] & {$[32 \%]$} \\
\hline $\mathrm{Ta}$ & $<2.1$ & $<2.1$ & $<2.1$ & $<2.1$ & $<1.2 \mathrm{E}-5$ & na \\
\hline $\mathrm{Te}$ & $<3.3$ & $<3.2$ & $<3.2$ & $<3.2$ & $<2.5 \mathrm{E}-5$ & na \\
\hline $\mathrm{Ti}$ & [0.19] & {$[0.067]$} & {$[0.072]$} & {$[0.110]$} & [2.3E-6] & {$[63 \%]$} \\
\hline $\mathrm{Tl}$ & $<4.8$ & $<4.7$ & $<4.7$ & $<4.7$ & $<2.3 \mathrm{E}-5$ & na \\
\hline $\mathrm{V}$ & {$[0.64]$} & {$[0.60]$} & {$[0.59]$} & {$[0.61]$} & [1.2E-5] & {$[4.3 \%]$} \\
\hline W & [21] & 23.6 & [21] & [22] & [1.2E-4] & [6.9\%] \\
\hline $\mathrm{Y}$ & $<0.055$ & $<0.054$ & $<0.055$ & $<0.055$ & $<6.1 \mathrm{E}-7$ & na \\
\hline $\begin{array}{l}\text { ASR } 8074 \\
\text { Analyte uncerta } \\
\text { concentrations } \\
\text { estimated quant }\end{array}$ & $\begin{array}{l}\text { inties were } t \\
\text { vere greater } \\
\text { tation limit }\end{array}$ & $\begin{array}{l}\text { ically withi } \\
\text { in the mini } \\
\text { QL), and u }\end{array}$ & $\begin{array}{l} \pm 15 \% \text {; resul } \\
\text { um detectior } \\
\text { ertainties } w\end{array}$ & $\begin{array}{l}\text { in bracke } \\
\text { imit }(\mathrm{MD} \\
>15 \% \text {. }\end{array}$ & $\begin{array}{l}\text { idicate tha } \\
\text { nd less tha }\end{array}$ & analyte \\
\hline $\begin{array}{l}\text { Opportunistic a } \\
\text { these analytes. } \\
\text { na }=\text { not applica }\end{array}$ & $\begin{array}{l}\text { alytes are re } \\
\text { ble }\end{array}$ & orted for in & rmation only & $\mathrm{QC}$ requir & nts did no & ply to \\
\hline
\end{tabular}


Table 5.5. Ion Exchange Processing Feed Radionuclide Composition

\begin{tabular}{|c|c|c|c|c|c|}
\hline Sample ID> & Feed A & Feed B & Feed C & \multirow{3}{*}{$\begin{array}{c}\text { Average } \\
\text { Feed }\end{array}$} & \multirow[b]{4}{*}{ RSD } \\
\hline Volume> & $1.51 \mathrm{~L}$ & $1.56 \mathrm{~L}$ & $1.51 \mathrm{~L}$ & & \\
\hline ASO ID> & $08-00791$ & 08-00792 & 08-00793 & & \\
\hline Analyte & $\mu \mathrm{Ci} / \mathrm{mL}$ & $\mu \mathrm{Ci} / \mathrm{mL}$ & $\mu \mathrm{Ci} / \mathrm{mL}$ & $\mu \mathrm{Ci} / \mathrm{mL}$ & \\
\hline${ }^{137} \mathrm{Cs}$ & $2.74 \mathrm{E}+1$ & $2.86 \mathrm{E}+1$ & $2.79 \mathrm{E}+1$ & $2.80 \mathrm{E}+1$ & $2.2 \%$ \\
\hline${ }^{60} \mathrm{Co}$ & $<1$. E-4 & $<2$.E-4 & $<1$.E-4 & $<1 . \mathrm{E}-4$ & na \\
\hline${ }^{241} \mathrm{Am}$ & $<5 . \mathrm{E}-3$ & $<8 . \mathrm{E}-3$ & $<6 . \mathrm{E}-3$ & $<6 . \mathrm{E}-3$ & na \\
\hline${ }^{238} \mathrm{Pu}$ & $1.13 \mathrm{E}-5$ & $1.78 \mathrm{E}-5$ & $9.59 \mathrm{E}-6$ & $1.29 \mathrm{E}-5$ & $34 \%$ \\
\hline${ }^{239+240} \mathrm{Pu}$ & $7.66 \mathrm{E}-5$ & $9.22 \mathrm{E}-5$ & $7.02 \mathrm{E}-5$ & $7.97 \mathrm{E}-5$ & $14 \%$ \\
\hline Gross alpha & $<2$.E-4 & $<2 . \mathrm{E}-4$ & $<2$.E-4 & $<2 . \mathrm{E}-4$ & na \\
\hline Gross beta & $2.30 \mathrm{E}+1$ & $2.41 \mathrm{E}+1$ & $2.45 \mathrm{E}+1$ & $2.39 \mathrm{E}+1$ & $3.3 \%$ \\
\hline${ }^{90} \mathrm{Sr}$ & $1.36 \mathrm{E}-4$ & $2.04 \mathrm{E}-4$ & $1.99 \mathrm{E}-4$ & $1.80 \mathrm{E}-4$ & $21 \%$ \\
\hline Sum of $\alpha$ & $8.79 \mathrm{E}-5$ & $1.10 \mathrm{E}-4$ & $7.98 \mathrm{E}-5$ & $9.26 \mathrm{E}-5$ & $17 \%$ \\
\hline$\alpha$ gross/sum & na & na & na & na & na \\
\hline $\begin{array}{l}\text { Isotopic ratio of } \\
{ }^{239+240} \mathrm{Pu} /{ }^{238} \mathrm{Pu}\end{array}$ & 6.78 & 5.18 & 7.32 & 6.18 & $18 \%$ \\
\hline Sum of $\beta$ & $2.74 \mathrm{E}+1$ & $2.86 \mathrm{E}+1$ & $2.79 \mathrm{E}+1$ & $2.80 \mathrm{E}+1$ & $2.2 \%$ \\
\hline$\beta$ gross/sum & 0.84 & 0.84 & 0.88 & 0.85 & $2.5 \%$ \\
\hline \multicolumn{6}{|c|}{$\begin{array}{l}\text { Notes: } \\
\text { Reference date: December 17, } 2007 \\
\text { ASR } 8074 \\
\text { na = not applicable }\end{array}$} \\
\hline
\end{tabular}

The total Cs concentration (sum of ${ }^{133} \mathrm{Cs},{ }^{135} \mathrm{Cs}$, and ${ }^{137} \mathrm{Cs}$ ) in the feed was determined to be $1.83 \mu \mathrm{g} / \mathrm{mL}$. The Cs analysis was conducted on the eluate using ICP-MS after ion exchange processing was complete, and the feed concentration was inferred by ratio to the known ${ }^{137} \mathrm{Cs}$ concentration. The mass-to-charge ratio $(\mathrm{m} / \mathrm{z})$ at $133\left({ }^{133} \mathrm{Cs}\right)$ was free of other element interferences and could thus be measured directly. Barium isotopes interfere at the $\mathrm{m} / \mathrm{z}$ at 135 and 137. The Ba inter-element correction was applied to these masses based on evaluation of Ba isotopes 134, 136, and 138 and an assumed natural isotopic distribution (the isotopic distribution of 134, 136, and 138 did reflect natural abundances). The ${ }^{137} \mathrm{Cs}$ concentration determined by ICP-MS agreed within $7 \%$ to the gamma energy analysis (GEA) determination. The isotopic breakdown of the ion exchange process feed was as follows: $63 \%{ }^{133} \mathrm{Cs}$, $19 \%{ }^{135} \mathrm{Cs}$, and $18 \%{ }^{137} \mathrm{Cs}$.

Images of the filtered feed solids are shown in Figure 5.3. After drying for $\sim 1$ day, a sample was collected for ICP-OES metals, radiochemical, XRD, SEM, and TEM analyses. The radiochemical and metals analysis results of the unwashed, precipitated solids and filtrate are provided in Table 5.6 and Table 5.7, respectively. The radionuclides were measured from the hydrofluoric (HF)-assisted acid digestion preparation. The metals were measured from both the HF-assisted acid digestion preparation and the $\mathrm{KOH}$ fusion preparation. As expected, $\mathrm{Mn}$ and $\mathrm{Na}$ dominated the solids composition. 
a)

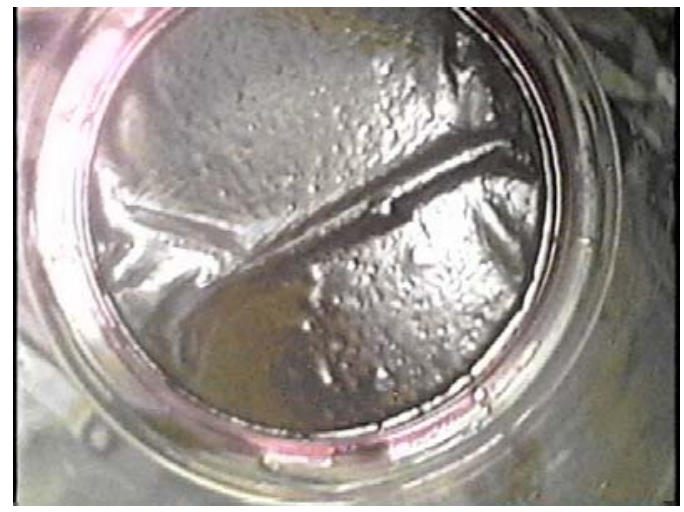

b)

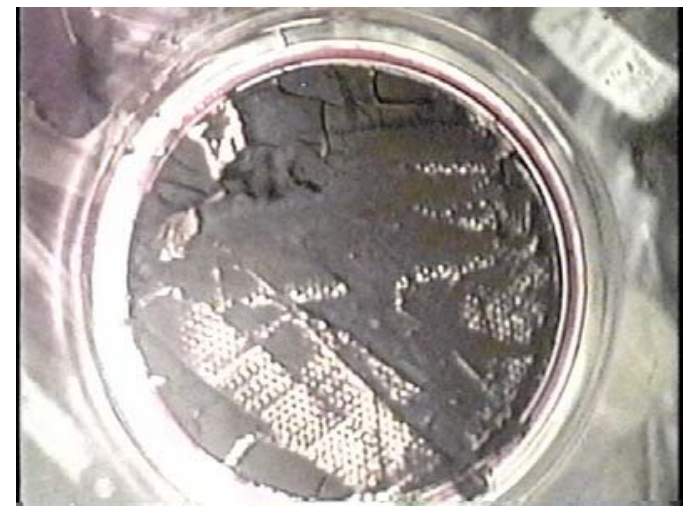

Figure 5.3. Solids Collected on Two Filters from the Ion Exchange Feed Composite Filter diameters are $75 \mathrm{~mm}$. a) not sampled; b) after sub-sampling.

Table 5.6. Radiochemical Composition of the Filtered Feed Solids

\begin{tabular}{|c|c|c|c|c|c|}
\hline Sample ID> & TI548-CsIX-FF-S & Average & Aqueous & \multirow{4}{*}{$\begin{array}{c}\text { Solids }(\mu \mathrm{g} / \mathrm{g}): \\
\text { Filtr. }(\mu \mathrm{g} / \mathrm{mL}) \\
\text { Ratio }\end{array}$} & \multirow{4}{*}{$\begin{array}{c}\text { Normalized } \\
\text { Analyte } \\
\text { Concentration } \\
\text { Factor } \\
\text { Fe }\end{array}$} \\
\hline ASO ID> & 08-00772 & \multirow{2}{*}{$\begin{array}{c}\text { Feed } \\
\text { Filtrate }\end{array}$} & \multirow{3}{*}{$\begin{array}{c}\text { Phase } \\
\text { Concentration } \\
\text { Ratio }^{(\mathbf{b})} \\
\end{array}$} & & \\
\hline & Filtered Solids & & & & \\
\hline Analyte & $\mu \mathrm{Ci} / \mathrm{g}^{(\mathrm{a})}$ & $\mu \mathrm{Ci} / \mathrm{mL}$ & & & \\
\hline${ }^{137} \mathrm{Cs}$ & $4.77 \mathrm{E}+1$ & $2.80 \mathrm{E}+1$ & 1.04 & 1.70 & 0.88 \\
\hline${ }^{60} \mathrm{Co}$ & $2.36 \mathrm{E}-2$ & $<1 . \mathrm{E}-4$ & na & na & na \\
\hline${ }^{241} \mathrm{Am}$ & $7.70 \mathrm{E}-2$ & $<6 . \mathrm{E}-3$ & na & na & na \\
\hline${ }^{238} \mathrm{Pu}$ & $1.99 \mathrm{E}-2^{(\mathrm{d})}$ & $1.29 \mathrm{E}-5$ & 0.74 & $1,543^{(\mathrm{d})}$ & $795^{(\mathrm{d})}$ \\
\hline${ }^{239+240} \mathrm{Pu}$ & $4.46 \mathrm{E}-2$ & $7.97 \mathrm{E}-5$ & 0.72 & 559 & 288 \\
\hline Gross alpha & $1.00 \mathrm{E}-1$ & $<2$.E-4 & na & na & na \\
\hline Gross beta & $8.75 \mathrm{E}+1$ & $2.39 \mathrm{E}+1$ & 0.85 & 3.66 & 1.89 \\
\hline${ }^{90} \mathrm{Sr}$ & $2.51 \mathrm{E}+1$ & $1.80 \mathrm{E}-4$ & 0.0086 & 139,703 & 72,009 \\
\hline Sum of alpha & $1.41 \mathrm{E}-1$ & $9.26 \mathrm{E}-5$ & & & \\
\hline$\alpha$ gross/sum & 0.76 & na & & & \\
\hline $\begin{array}{l}\text { Isotopic ratio of } \\
{ }^{239+240} \mathrm{Pu} /{ }^{238} \mathrm{Pu}\end{array}$ & $2.24^{(\mathrm{c})}$ & 6.18 & & no data & \\
\hline Sum of beta & $9.79 \mathrm{E}+1$ & $2.80 \mathrm{E}+1$ & & & \\
\hline$\beta$ gross/sum & 0.89 & 0.85 & & & \\
\hline
\end{tabular}

(a) Unwashed solids, dry mass basis.

(b) The calculated supernatant composition is shown in Table 5.2 (assumes no analyte precipitation). Where the analyte concentration ratio (measured/calculated concentration) is $<1$, the analyte was lost from the supernatant by co-precipitation.

(c) Where the normalized analyte ratio is $>1$, the analyte was expected to be lost from the supernatant and collected with the precipitate.

(d) The Pu isotopic ratio in the solids phase was inconsistent with the input component and filtrate isotopic ratios. This indicated potential sample contamination with ${ }^{238} \mathrm{Pu}$ or incomplete separation of ${ }^{241} \mathrm{Am}$ in the analytical sample with a corresponding positive interference on the characterization alpha energy peak. The effect was further reflected in the solids:filtrate concentration factor ratios.

Notes:

Highlighted and bolded analyte, ${ }^{137} \mathrm{Cs}$, was factored into the normalization basis.

na $=$ not applicable

ASR 8070 and 8074 
Table 5.7. Metals (ICP-OES) Composition of the Filtered Solids

\begin{tabular}{|c|c|c|c|c|c|c|c|c|c|}
\hline \multirow{4}{*}{$\begin{array}{l}\text { Sample ID> } \\
\text { ASO ID> } \\
\text { Analyte }\end{array}$} & \multirow{2}{*}{\multicolumn{5}{|c|}{$\begin{array}{c}\text { TI548-CsIX-FF-S } \\
\text { 08-00772, Filtered Solids } \\
\end{array}$}} & \multirow{4}{*}{$\begin{array}{c}\text { Average } \\
\text { Feed } \\
\text { Filtrate } \\
\mu \mathrm{g} / \mathrm{mL}\end{array}$} & \multirow{4}{*}{$\begin{array}{c}\text { Aqueous } \\
\text { Phase } \\
\text { Concentration }^{\text {Ratio }}{ }^{(b)} \\
\text { Rat }^{\text {Pat }}\end{array}$} & \multirow{4}{*}{$\begin{array}{c}\text { Solids }(\mu \mathrm{g} / \mathrm{g}) \text { : } \\
\text { Filtr. }(\mu \mathrm{g} / \mathrm{mL}) \\
\text { Ratio }\end{array}$} & \multirow{4}{*}{$\begin{array}{c}\text { Normalized } \\
\text { Analyte } \\
\text { Concentration } \\
\text { Factor }^{(c)}\end{array}$} \\
\hline & & & & & & & & & \\
\hline & \multicolumn{2}{|c|}{ KOH fusion } & \multicolumn{2}{|c|}{ Acid Digest } & \multirow{2}{*}{$\frac{\text { Average }}{\mu \mathrm{g} / \mathrm{g}^{(\mathrm{a})}}$} & & & & \\
\hline & $\mu g / g^{(a)}$ & RPD & $\mu g / g^{(a)}$ & RPD & & & & & \\
\hline $\mathrm{Al}$ & {$[16,500]$} & -- & 14,200 & 1.4 & 15,350 & 7,323 & 1.02 & 2.10 & 1.08 \\
\hline $\mathrm{B}$ & $<79$ & -- & [440] & na & $<79$ & 28.8 & 2.00 & -- & -- \\
\hline $\mathrm{Bi}$ & $<293$ & -- & $<377$ & -- & $<335$ & {$[4.35]$} & {$[>1.3]$} & -- & -- \\
\hline $\mathrm{Cd}$ & $<30$ & -- & $<43$ & -- & $<36$ & $<0.43$ & na & -- & -- \\
\hline $\mathrm{Cr}$ & 1,425 & 13 & 1,355 & 0.74 & 1,390 & 728 & 0.91 & 1.91 & 0.98 \\
\hline $\mathrm{Fe}$ & {$[3,450]$} & -- & 3,860 & 3.1 & 3,655 & {$[5.4]$} & {$[>1.0]$} & [676] & [349] \\
\hline $\mathrm{K}$ & na & na & $<904$ & -- & $<904$ & 399 & 1.05 & -- & -- \\
\hline $\mathrm{Mn}$ & 251,500 & 6.0 & 304,500 & 4.9 & 278,000 & {$[0.32]$} & 0.0006 & 794,211 & na \\
\hline $\mathrm{Na}$ & 212,000 & 1.9 & 229,000 & 2.6 & 220,500 & 103,400 & 1.02 & 2.05 & 1.06 \\
\hline $\mathrm{Ni}$ & na & na & [135] & -- & {$[135]$} & {$[0.37]$} & {$[0.35]$} & [370] & [190] \\
\hline $\mathrm{P}$ & {$[1,450]$} & -- & {$[1,800]$} & -- & {$[1,625]$} & 801 & 1.04 & {$[2.03]$} & {$[1.05]$} \\
\hline $\mathrm{S}$ & {$[1,735]$} & -- & {$[4,900]$} & -- & {$[3,318]$} & 852 & 1.39 & [3.89] & {$[2.01]$} \\
\hline $\mathrm{Si}$ & $<2400^{(\mathrm{d})}$ & -- & na & -- & na & 107 & 3.24 & -- & -- \\
\hline $\mathrm{Sr}$ & {$[36]$} & -- & 20.5 & 4.9 & 28 & $<0.010$ & na & $>2,749$ & $>1,417$ \\
\hline $\mathrm{U}$ & [505] & -- & [620] & -- & {$[563]$} & {$[7.57]$} & {$[>0.73]$} & {$[74]$} & {$[38]$} \\
\hline $\mathrm{Zn}$ & [205] & -- & [220] & -- & [213] & {$[3.8]$} & {$[>0.9]$} & {$[56]$} & [29] \\
\hline $\mathrm{Zr}$ & {$[62]$} & -- & 368 & 0.5 & 368 & {$[0.28]$} & {$[>0.26]$} & {$[1,299]$} & [669] \\
\hline U KPA & na & -- & 208 & 14 & 208 & 3.65 & 1.00 & 57 & 29 \\
\hline \multicolumn{10}{|l|}{ Opportunistic } \\
\hline $\mathrm{Ag}$ & $<15$ & -- & $<26$ & -- & $<21$ & $<0.26$ & na & -- & -- \\
\hline As & $<401$ & -- & $<540$ & -- & $<470$ & $<5.3$ & na & -- & -- \\
\hline $\mathrm{Ba}$ & [14] & -- & {$[8.45]$} & -- & [11] & {$[0.42]$} & {$[0.96]$} & {$[26]$} & {$[13]$} \\
\hline $\mathrm{Be}$ & $<0.5$ & -- & {$[0.81]$} & -- & {$[0.65]$} & {$[0.034]$} & [0.81] & -- & -- \\
\hline $\mathrm{Ca}$ & $<12,000$ & -- & 2,975 & 1.0 & 2,975 & {$[1.77]$} & {$[0.15]$} & {$[1,684]$} & [868] \\
\hline $\mathrm{Ce}$ & $<85$ & -- & $<126$ & -- & $<105$ & $<1.2$ & na & -- & -- \\
\hline $\mathrm{Co}$ & $<28$ & -- & $<30$ & -- & $<29$ & $<0.31$ & na & -- & -- \\
\hline $\mathrm{Cu}$ & 923 & 21 & 1,095 & 2.7 & 1,009 & $<0.17$ & na & $>5,803$ & $>2,991$ \\
\hline Dy & $<30$ & -- & $<36$ & -- & $<33$ & $<0.36$ & na & -- & -- \\
\hline $\mathrm{Eu}$ & $<4$ & -- & $<6$ & -- & $<5$ & $<0.14$ & na & -- & -- \\
\hline $\mathrm{La}$ & $<28$ & -- & $<35$ & -- & $<31$ & $<0.54$ & $<2.7$ & -- & -- \\
\hline
\end{tabular}


Table 5.7 (contd)




Supernatant entrainment was expected in the filtered solids since the solids were not washed. The supernatant entrainment in the solids was estimated from the relative $\mathrm{Al}, \mathrm{Na},{ }^{137} \mathrm{Cs}$, and $\mathrm{Cr}$ concentrations in the solids and liquid phases (highlighted and bolded in Table 5.6 and Table 5.7). The ratio of these analytes (solid:liquid concentrations) averaged 1.94. All analyte ratios were normalized to this factor in an effort to estimate specific analyte concentration factors in the solids, i.e., determine what components co-precipitated with the $\mathrm{Mn}$ compound. Strontium, and to a lesser extent $\mathrm{Pu}$, was shown to partition to the solids phase.

The composition of the aqueous fraction was further examined to confirm loss of components to the solids phase. The calculated composition of the aqueous phase (based on the combined composition of the input components, see Table 5.2 and Table 5.3) was compared to the filtrate composition. The analyte concentration ratios are shown in Table 5.6 and Table 5.7. Where the ratio equals 1.0, no analyte loss to the solid phase was observed; analyte loss to the solid phase was indicated if the ratio is $<1.0$. Analytes B and $\mathrm{Si}$ resulted in ratios $>1.2$; the high ratio was attributed to analytical method uncertainty. These analytes are often associated with glassware leaching. The analyte ratios for ${ }^{137} \mathrm{Cs}, \mathrm{Al}, \mathrm{Cr}, \mathrm{K}, \mathrm{Na}$, and $\mathrm{P}$ (none of which were likely candidates in the precipitation reaction) were $1.0 \pm 10 \%$, indicating excellent comparability between the calculated and measured composition. In this analysis, $\mathrm{U}$ was shown to remain in solution. Approximately $25 \%$ of the $\mathrm{Pu}$, most of the $\mathrm{Ca}$ and $\mathrm{Pb}$, and virtually all of the $\mathrm{Sr}$ (and ${ }^{90} \mathrm{Sr}$ ) and Mn were removed.

The feed component Mn concentrations indicated that the aqueous composite should contain $\sim 504 \mu \mathrm{g} / \mathrm{mL}$. The filtrate contained $\sim 0.32 \mu \mathrm{g} / \mathrm{mL} \mathrm{Mn}$. Based on the difference between these concentrations and a solution volume of $4.61 \mathrm{~L}$, the total Mn mass loss from solution was calculated to be $2.32 \mathrm{~g}$. The solids contained $25.15 \mathrm{wt} \% \mathrm{Mn}$ (dry mass basis); therefore, the total dry solids mass collected can be inferred to be $9.22 \mathrm{~g}$. The supernatant entrainment calculation was previously described and represented a mass fraction of $\sim 51 \mathrm{wt} \%$ in the dried solids sample. Thus, the precipitated solids mass (free of supernatant entrainment) approximated $\sim 4.56 \mathrm{~g}$. Since the Mn recovered in the precipitate was $2.32 \mathrm{~g}$, the Mn fraction in the precipitated solids was $51 \mathrm{wt} \%$. This concentration is significantly less than that found in $\mathrm{MnO}_{2}(63 \mathrm{wt} \%)$ and $\mathrm{Mn}_{2} \mathrm{O}_{3}(70 \mathrm{wt} \%)$. Furthermore, it can be inferred that $1 \mathrm{~g}$ of Mncompound precipitated per $1 \mathrm{~L}$ of blended feed. Permanganate reduction and precipitation is further discussed in Section 6.3.5.

The SEM micrographs of the dried filtered solids are shown in Figure 5.4 and Figure 5.5. The particles or particle agglomerates are $<1$ micron in diameter and appear to be generally platy with angular sides. The SEM-EDS examination shows that manganese dominated the material composition, accompanied by oxygen, sodium, and aluminum. Aluminum and sodium were the major metal components in the supernatant $(7,323$ and $103,400 \mu \mathrm{g} / \mathrm{mL}$, respectively) and were likely coating the Mnrich phase since the solids were not washed. 

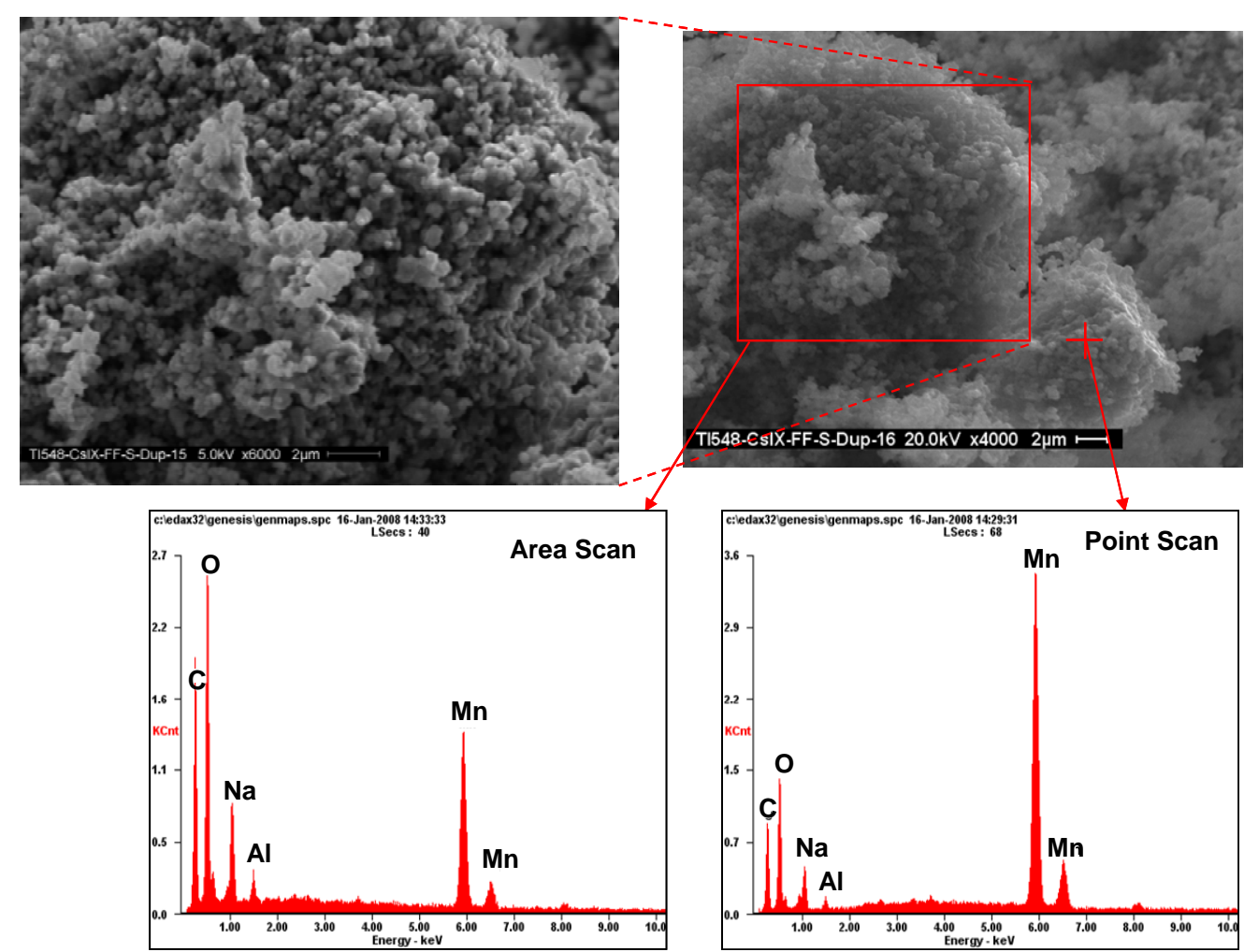

Figure 5.4. SEM Micrographs with EDS Evaluation of the Filtered Solids
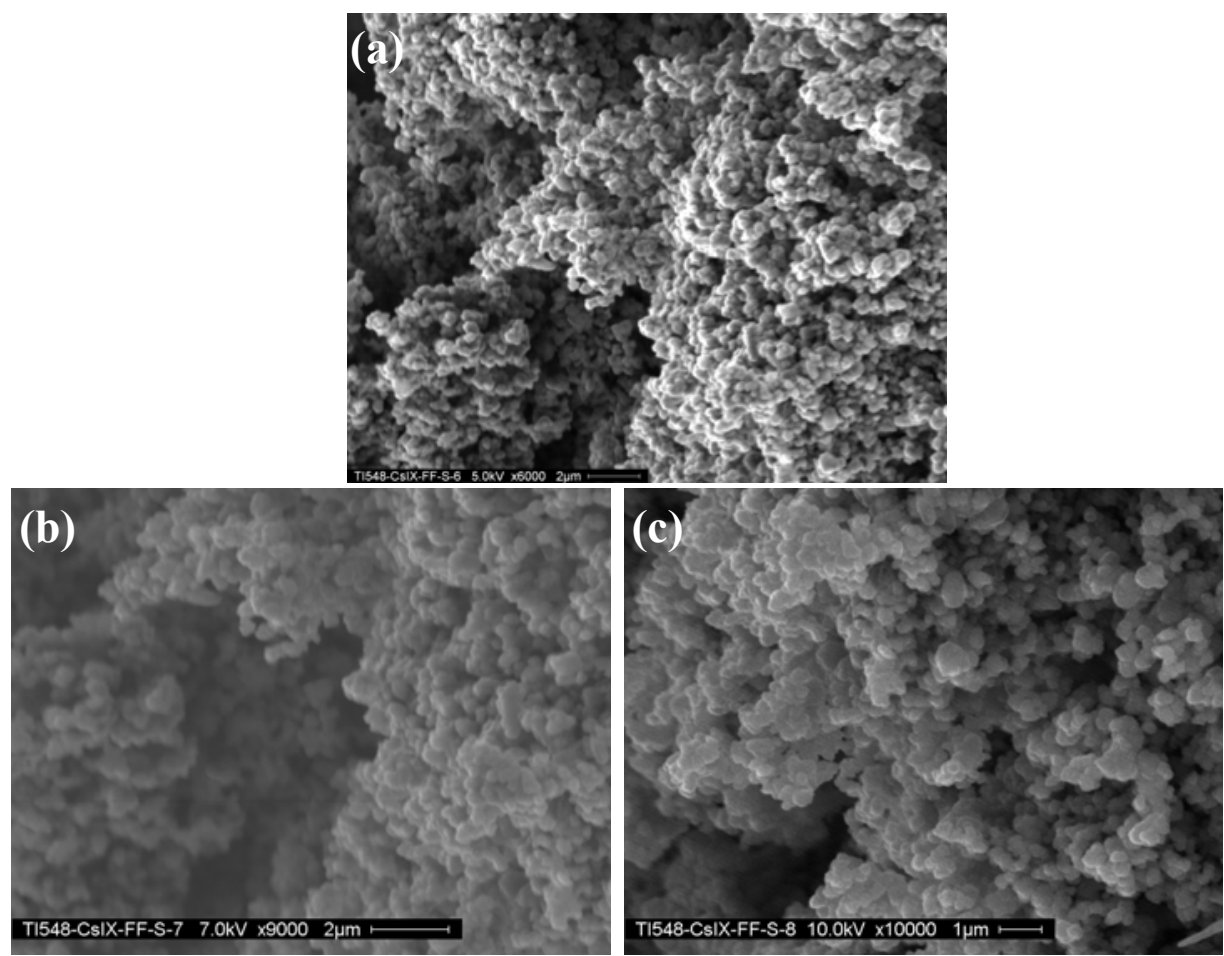

Figure 5.5. SEM Micrographs of the Cesium Ion Exchange Filtered Solids (a) $6000 \times$, (b) $9000 \times$, (c) $10,000 \times$ 
Figure 5.6 shows the raw and background-subtracted powder XRD patterns of the dried precipitated solids. The background-subtracted spectrum also shows stick-figure phase identifications listed in order of internal standard followed by phases with decreasing peak intensity. The observed peak intensity (area) for sodium carbonate is less than that for boehmite, but the efficiency of sodium carbonate at diffracting the X-ray beam is considerably less than the efficiency for boehmite. Thus, the sodium carbonate is higher in concentration than the boehmite. A small amount of silicon dioxide may be present, showing a peak intensity of about $5 \%$ of that for the major peak of sodium nitrate. Confirming lines for this phase were too low intensity to be detected; therefore, this phase must be considered possible but not confirmed. A broad peak at about 30.5 degrees 2-theta appears to be two overlapped peaks. These could not be identified subject to the applied chemistry restrictions ( $\mathrm{Al}, \mathrm{Na}, \mathrm{Mn}, \mathrm{Cr}, \mathrm{Fe}, \mathrm{Ca}$, and $\mathrm{Pb}$ ) used in the JADE search routines. The raw data show a pronounced amorphous peak, indicating that a significant portion of amorphous material is present. This material could not be identified by XRD. Phases containing $\mathrm{Mn}$, especially $\mathrm{MnO}_{2}$, were specifically searched for, but none were identified. The major crystalline phases that were identified were related to the entrained supernatant coating the filtered solids, i.e., $\mathrm{NaNO}_{3}$ and $\mathrm{Na}_{2} \mathrm{CO}_{3}$.

Dark precipitated solids formation has been previously observed in similar combinations of supernatant and permanganate solutions. Duff et al. (2002) reported the formation of a colloidal tetravalent Mn-rich sodium birnessite-type $\left[\mathrm{Na}_{4} \mathrm{Mn}_{14} \mathrm{O}_{27} \bullet 9 \mathrm{H}_{2} \mathrm{O}(\mathrm{s})\right]$ phase with the addition of $0.01 \mathrm{M}$ permanganate and reductant (either hydrogen peroxide or sodium formate) to a HLW salt simulant solution. The possible phase identification was based on the SEM and TEM evaluations by Dietz et al. (2002). Similar to the current test results, Duff et al. also reported no crystallinity of the precipitated Mn phase based on XRD analysis. However, with high resolution TEM imaging of the current precipitated phase, it was possible to see clear evidence of crystallinity in the particles. 
a)



b)

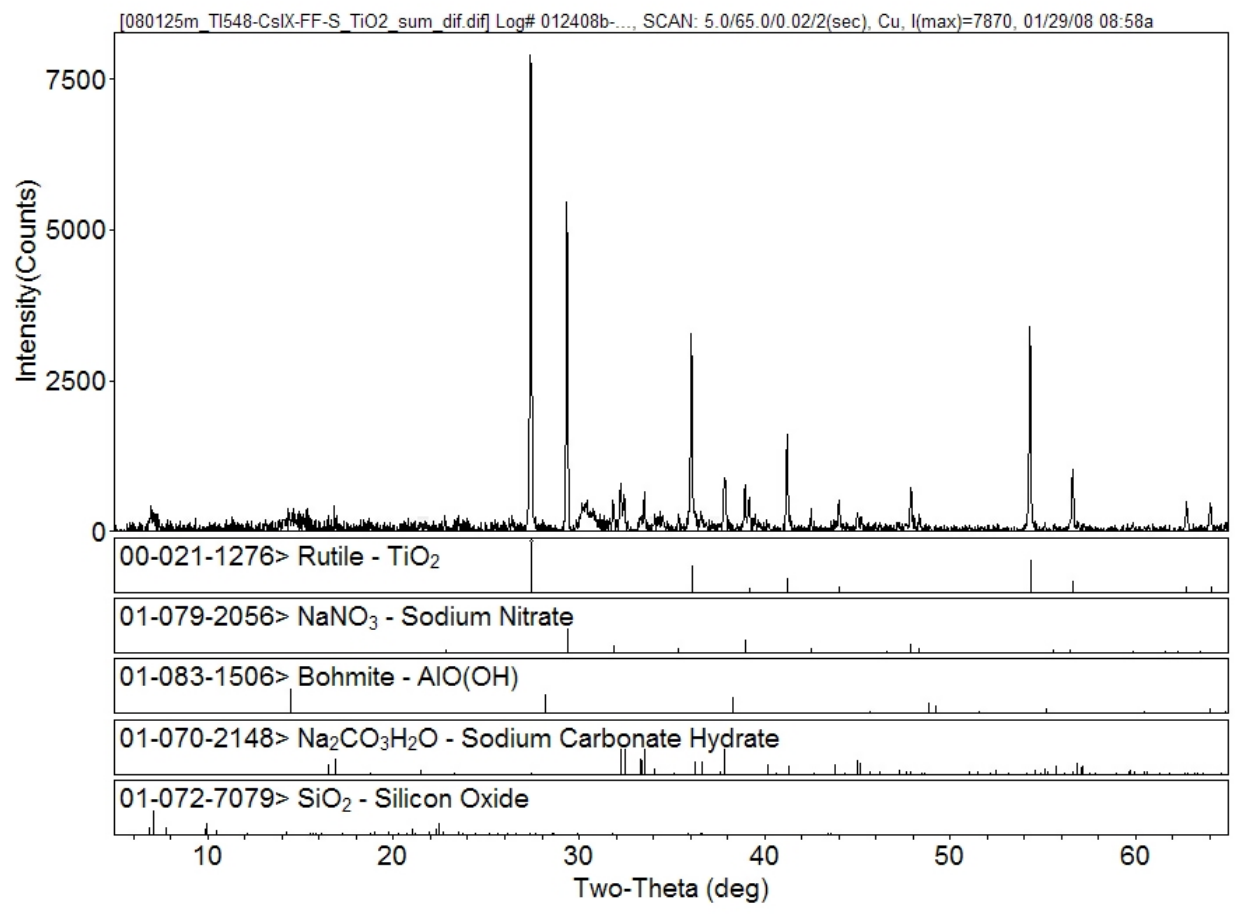

Figure 5.6. $\mathrm{X}$-Ray Powder Diffraction Pattern of Filtered Solids with Rutile $\left(\mathrm{TiO}_{2}\right)$ Internal Standard a) Raw Spectral Pattern b) Background-Subtracted Spectral Pattern 
Figure 5.7 shows the TEM micrographs of the precipitated solids. The Mn agglomerates are shown as dark blotches on the lacy carbon grid. No distinct morphological features were identified at low magnification. High resolution TEM imaging in this study clearly shows evidence for crystallinity (see Figure 5.8). The particles were small enough to appear amorphous in the XRD analysis.
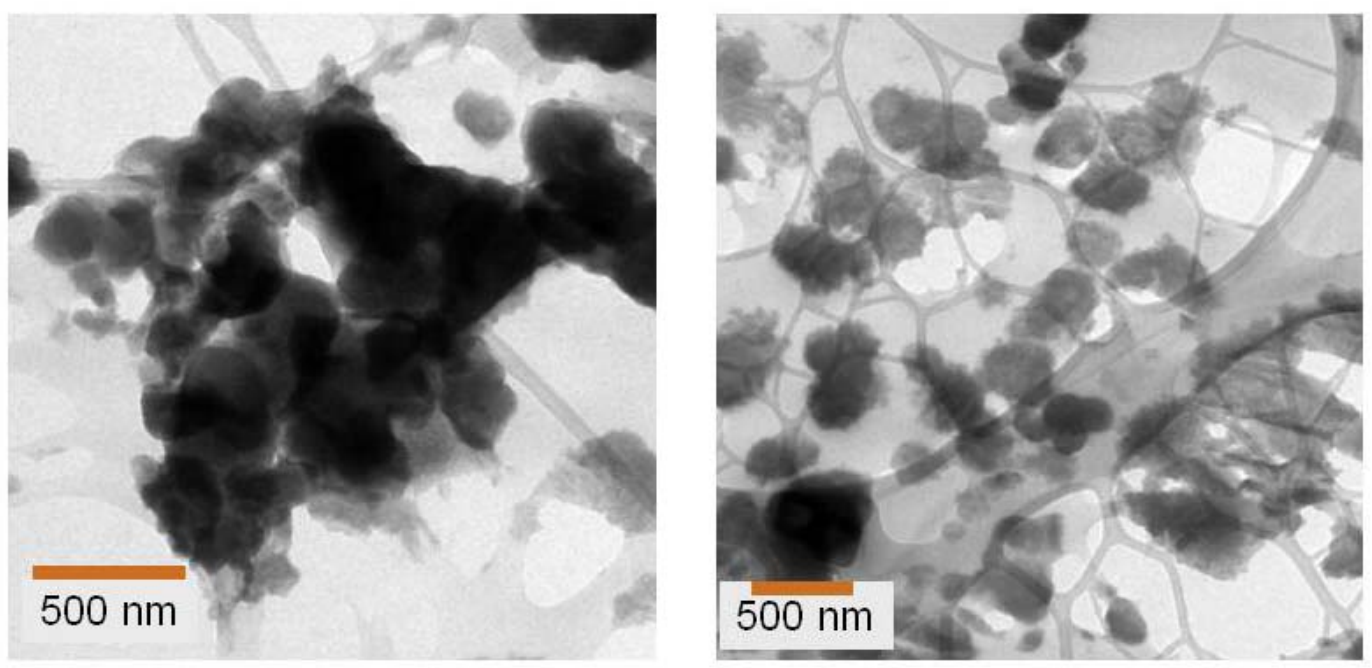

Figure 5.7. TEM Micrographs of the Cesium Ion Exchange Filtered Solids 


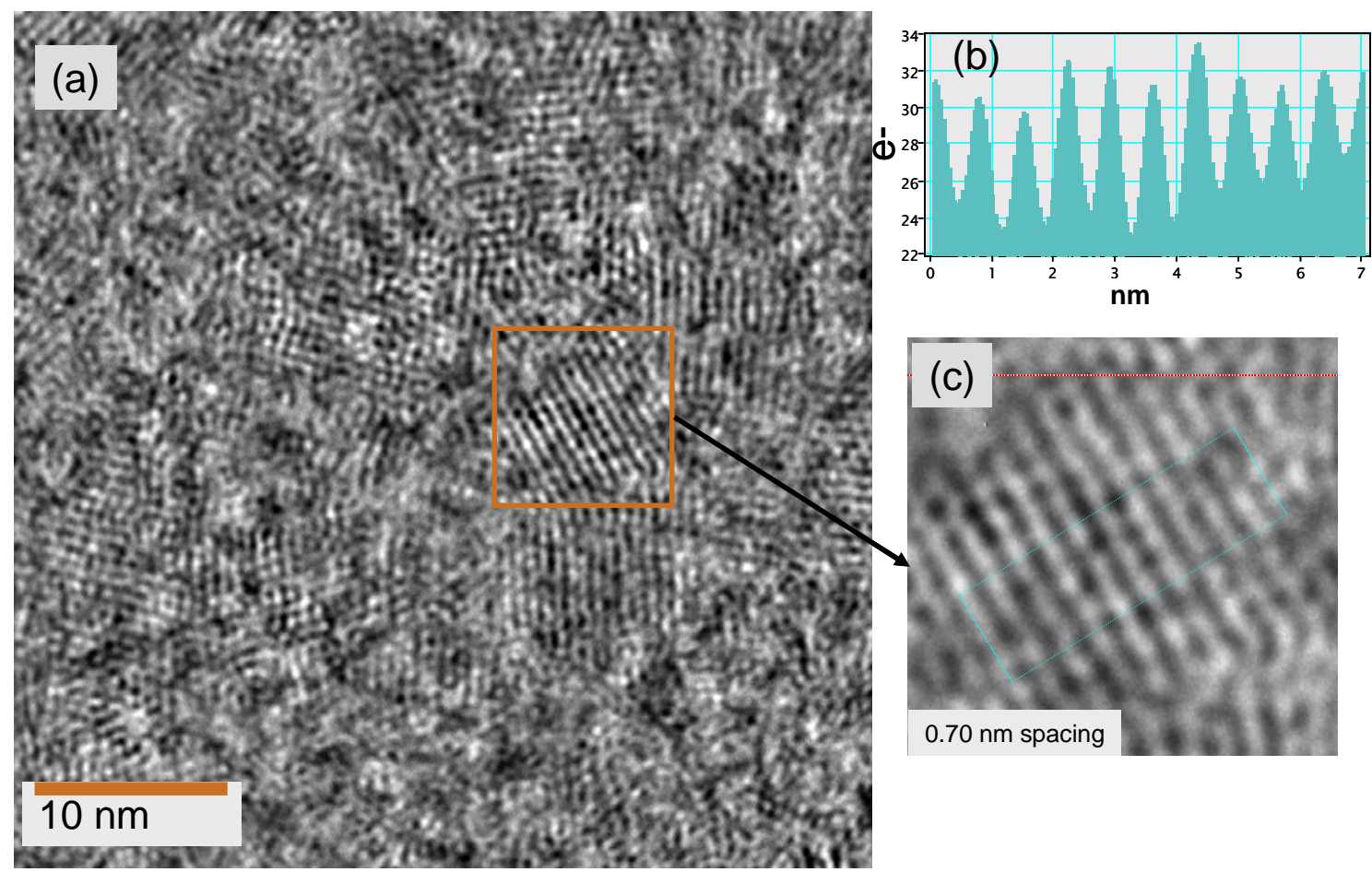

Figure 5.8. (a) Evidence for the Nano-Crystalline Nature of the Manganese Phases (b) Histogram over Selected Region, and (c) Enlarged Region Showing a 0.7-nm Lattice Spacing

The high-resolution images have been background subtracted and in some instances, Fourier filtered, to improve the visibility of features. The individual crystallites appear to be $<10 \mathrm{~nm}$ in diameter based on the high resolution images (see Figure 5.9).
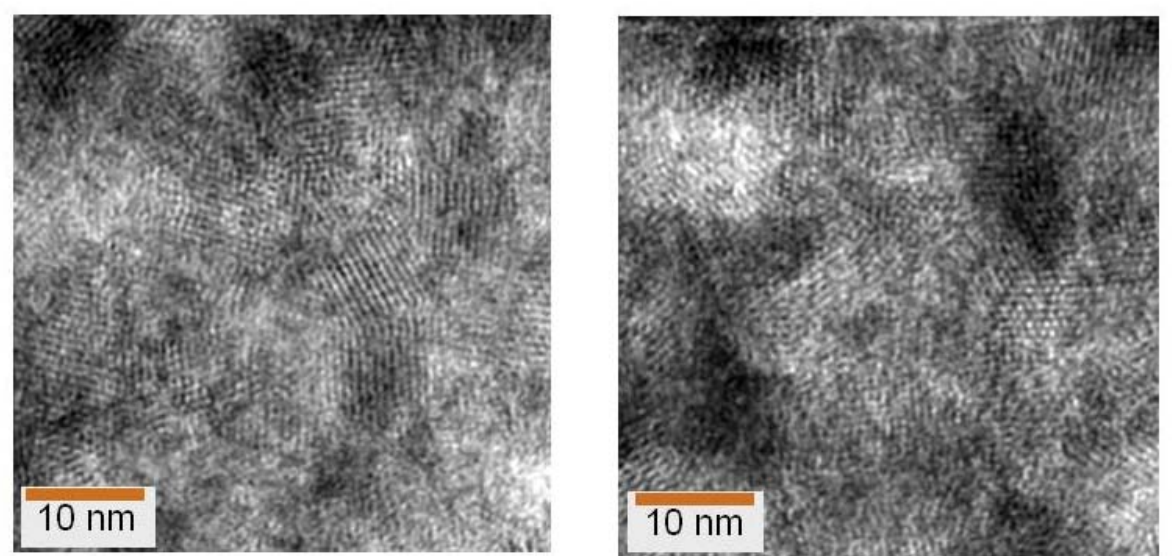

Figure 5.9. High Resolution TEM Images of Manganese Particles 
The composition of the phase is manganese rich but not consistent with pure birnessite as sodium is not a major component in the material (see Figure 5.10). Sodium nitrate was reported in the XRD results and sodium was detected during SEM-EDS analysis; however, in both of these cases the observed sodium was probably not associated with the manganese phase.

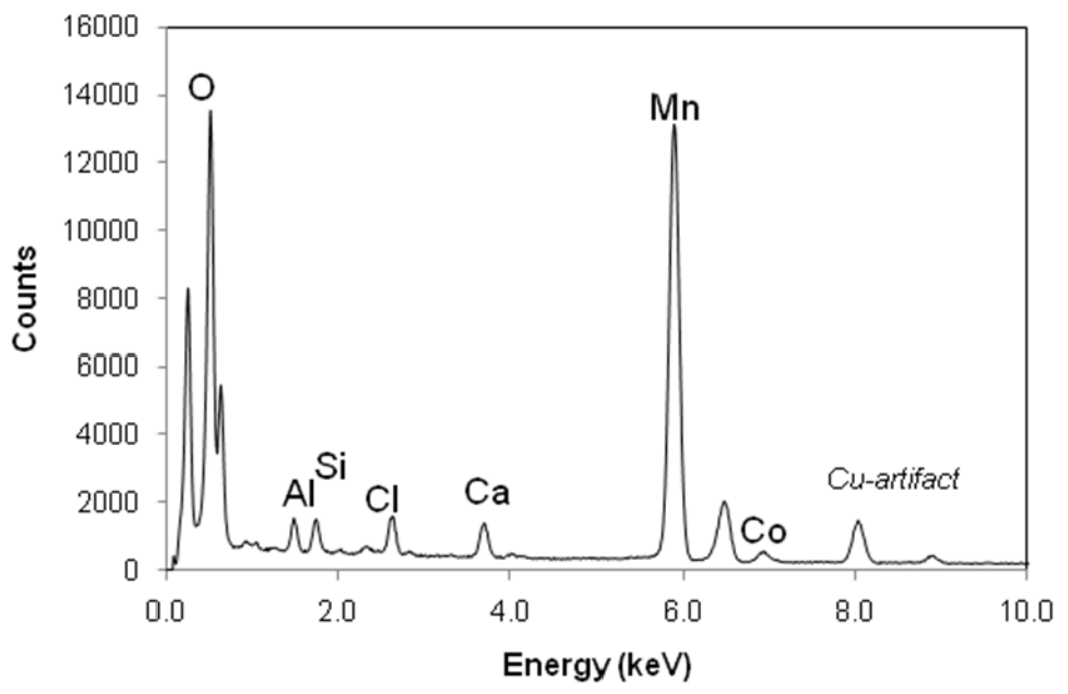

Figure 5.10. X-Ray Energy Dispersive Analysis of the Mn Phase

Electron energy-loss spectroscopy (EELS) of the manganese phase was used to evaluate the manganese oxidation state. Using both the branching ratio at 0.75 and the near-edge structure compared to previous work, the Mn was estimated to be present in a mixed $2+, 3+$ oxidation state. Typically, a branching ratio of 0.66 is found for $\mathrm{Mn}^{4+}$ and 0.84 for $\mathrm{Mn}^{2+}$. In this instance, branching ratio values of 0.77 and 0.75 were obtained from the EELS analyses. The near-edge structure has a distinctive peak splitting in the $\mathrm{L}_{3}$ edge that is consistent with a mixed $\mathrm{Mn}^{2+} / \mathrm{Mn}^{3+}$ oxidation state (Figure 5.11). The assignments are indicated on the figure; however, results indicate the phase is dominated by Mn(III). The $\mathrm{O} \mathrm{K}$-edge pre-peak can be assigned to transitions of $\mathrm{O} 1 \mathrm{~s}$ electrons to $\mathrm{O} 2 p$-states strongly hybridized with Mn $3 d$-states (see Figure 5.11). The pre-peak structure is present in all Mn oxides but is weakest where oxygen is in 8 fold co-ordination with $\mathrm{Mn}$. In this case, the pre-edge peak is only barely visible. 


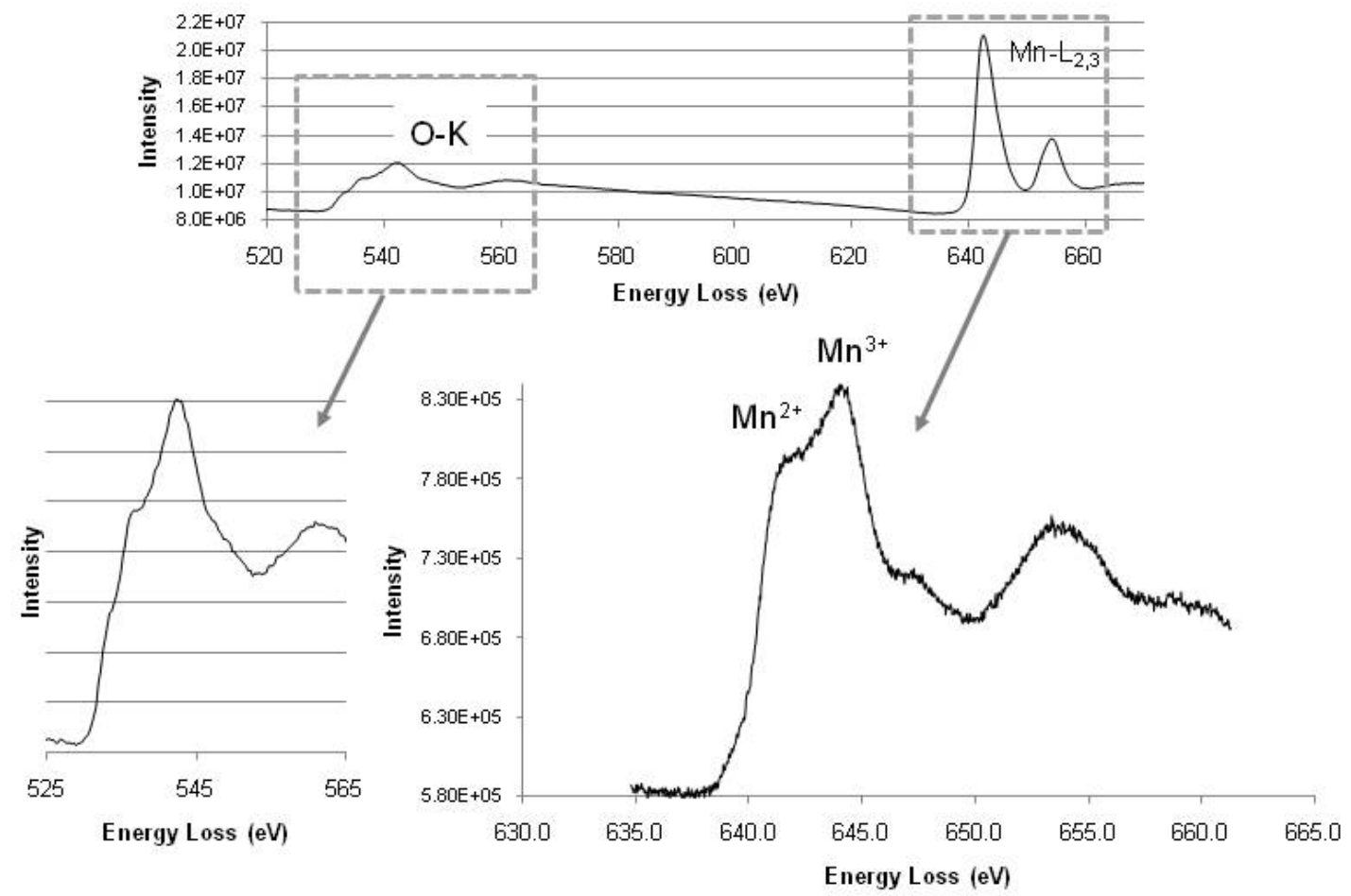

Figure 5.11. Electron Energy-Loss Analysis of Mn Phase. The top spectrum shows both the oxygen and manganese edges; the lower right spectrum shows a Mn-edge taken under different experimental conditions to reveal the fine-structure and the lower left spectrum shows an enlarged O-K edge.

The overall particle size was extremely small. In the SEM images (see Figure 5.5), the individual particles cannot be observed. Under low magnification imaging in the TEM, the particles appear to have an average size of $\sim 200 \mathrm{~nm}$ (note that these particles consist of even smaller crystallites). The cumulative particle size distribution plot is shown in Figure 5.12. A mathematical fit to the data is also shown on the graph. 


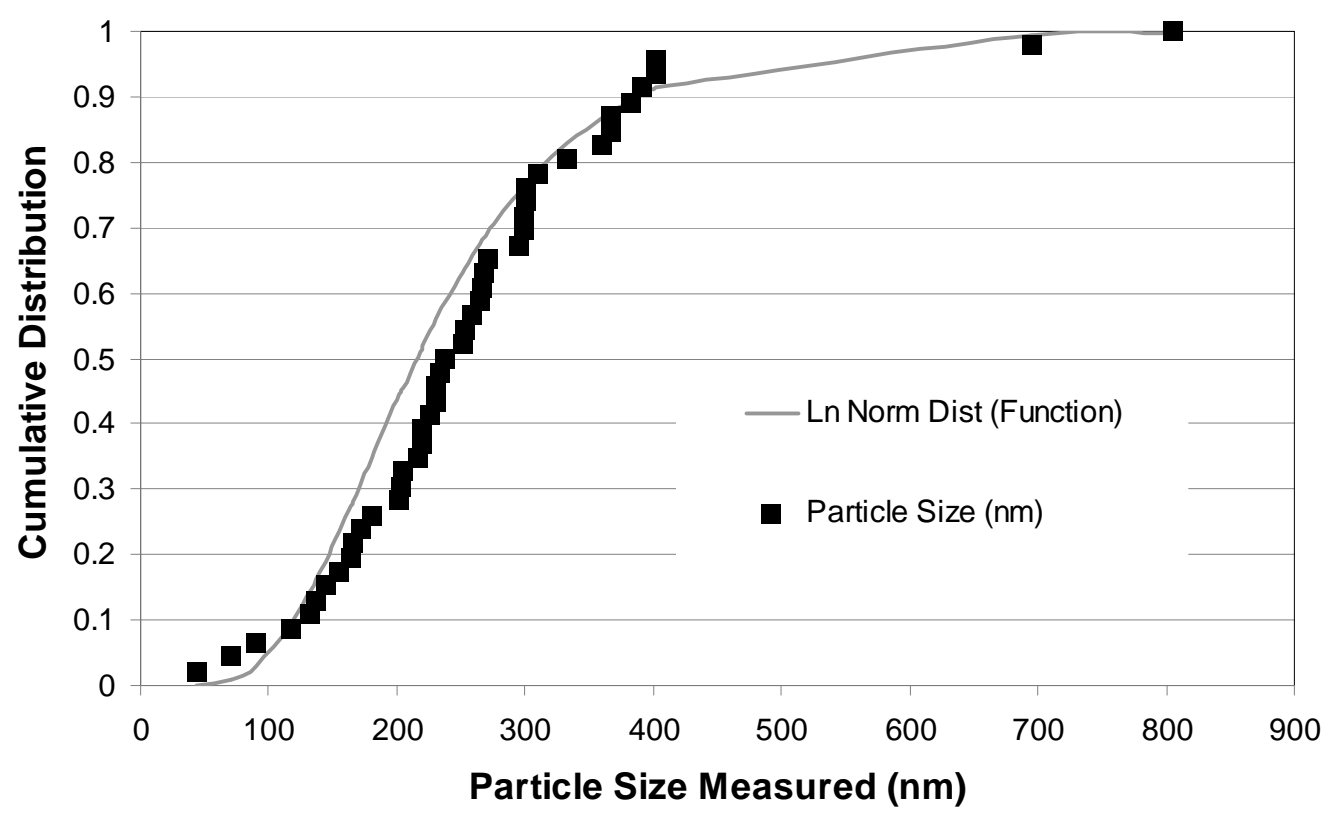

Figure 5.12. Cumulative Distribution Plot of Manganese Particle Sizes Observed in the TEM

The high-resolution TEM images shown in Figure 5.8 and Figure 5.9 indicate that the actual crystallite size is significantly smaller than the individual particles and larger particle agglomerates. This accounts for the inability to see evidence of crystallinity in this study or the one by Duff et al. (2002).

The observed precipitation is not expected to confound Cs ion exchange in the nominal WTP pretreatment process. Permeate from the oxidative leaching process and recycles is expected to be returned to the system upstream of filtration. Associated precipitation would likely occur in vessels containing feed slurries as indicated in Figure 5.13. 




Figure 5.13. Schematic Representation of the Key Processes to be Performed in the PTF (Note: This is for illustrative purposes only; it is not meant to be a comprehensive view of the functions performed within the WTP.)

\subsection{Resorcinol-Formaldehyde Test Resin}

The ion exchange material was spherical resorcinol-formaldehyde (RF) resin manufactured by Microbeads (Skedsmokorset, Norway) in a nominal 60-gal production lot in April 2006, lot number 6C-360-745. (a) The resin had been stored in the as-received condition: H-form at ambient temperature in water with a nitrogen cover gas. The resin was sub-sampled on 12/4/07 to support this test. The storage conditions (time and temperature) were not expected to result in adverse effectiveness of the ion exchanger based on results from a storage and aging study (Fiskum et al. 2007).

The ion exchange resin was pretreated according standard conditions ${ }^{(\mathrm{b})}$ and has been previously described (Fiskum et al. 2006a). In brief, the resin was converted to the sodium form then back to the hydrogen form (swell-shrink cycle) in an open-beaker format and a second sodium form to hydrogen form conversion cycle in the column.

(a) A 60-gal production lot in the as-received condition is equivalent to 100 -gal Na-form resin.

(b) WTP document number 097893. CA Nash and CE Duffey, August 17, 2004, Hanford RPP-WTP Alternate Resin Program-Protocol P1-RF: Spherical Resin Sampling from Containers, Resin Pretreatment, F-Factor, and Resin Loading to Column. 


\subsection{Ion Exchange Process Testing}

The system configuration and processing conditions are summarized in this section.

\subsubsection{Ion Exchange System}

Figure 5.14 shows a schematic of the ion exchange column assembly. The system consisted of one glass column containing the ion exchange resin, a small metering pump, two valves, a pressure gauge, and a pressure-relief valve. Valve 1 could be turned to the column-flow position or an exhaust position to expel trapped air or fluids from the column input/output lines. Valve 2 was primarily used to obtain samples. The column (Spectra/Chrom ${ }^{\circledR}$ Organic Chromatrography Column) obtained from Spectrum Chromatography (Houston, TX) was composed of borosilicate glass with standard Teflon ${ }^{\circledR}$ fittings. The column was $20-\mathrm{cm}$ tall with an inside diameter of $2.65 \mathrm{~cm}$. The resin bed was supported on a stainless steel, 200-mesh screen, positioned above the column fitting, allowing full view of the entire resin bed. The screen was stabilized in place with a snug-fitting O-ring. The cavity below the screen support was filled with 3-mm-diameter glass beads, reducing the fluid-filled volume from $19 \mathrm{~mL}$ to $13 \mathrm{~mL}$. The polyethylene connecting tubing was $1 / 8$-in. OD and $1 / 16$-in. ID. The column assembly contained an in-line Swagelok Poppet pressure relief check valve with a 10-psi trigger (Solon, $\mathrm{OH}$ ) and a 15-psi pressure gage (Omega Engineering, Ltd Manchester, UK; for indication-only). Valved quick-disconnects (Cole Parmer, Vernon Hills, IL) were installed in-line to allow for ease of column and resin removal. Fluid Metering, Incorporated (FMI) QVG50 pumps (Syosset, NY) equipped with ceramic and Kynar ${ }^{\mathbb{R}}$ coated low-flow piston pump heads were used to introduce all fluids. The flowrate was controlled with a remotely operated FMI stroke-rate controller. The pump was set up to deliver flowrates from $0.4-$ to $1.0-\mathrm{mL} / \mathrm{min}$. The volume actually pumped was determined using the mass of the collected fluid divided by the fluid density. The apparatus volume (AV) was the summed volume of all fluid-filled parts and was $\sim 59 \mathrm{~mL}$.

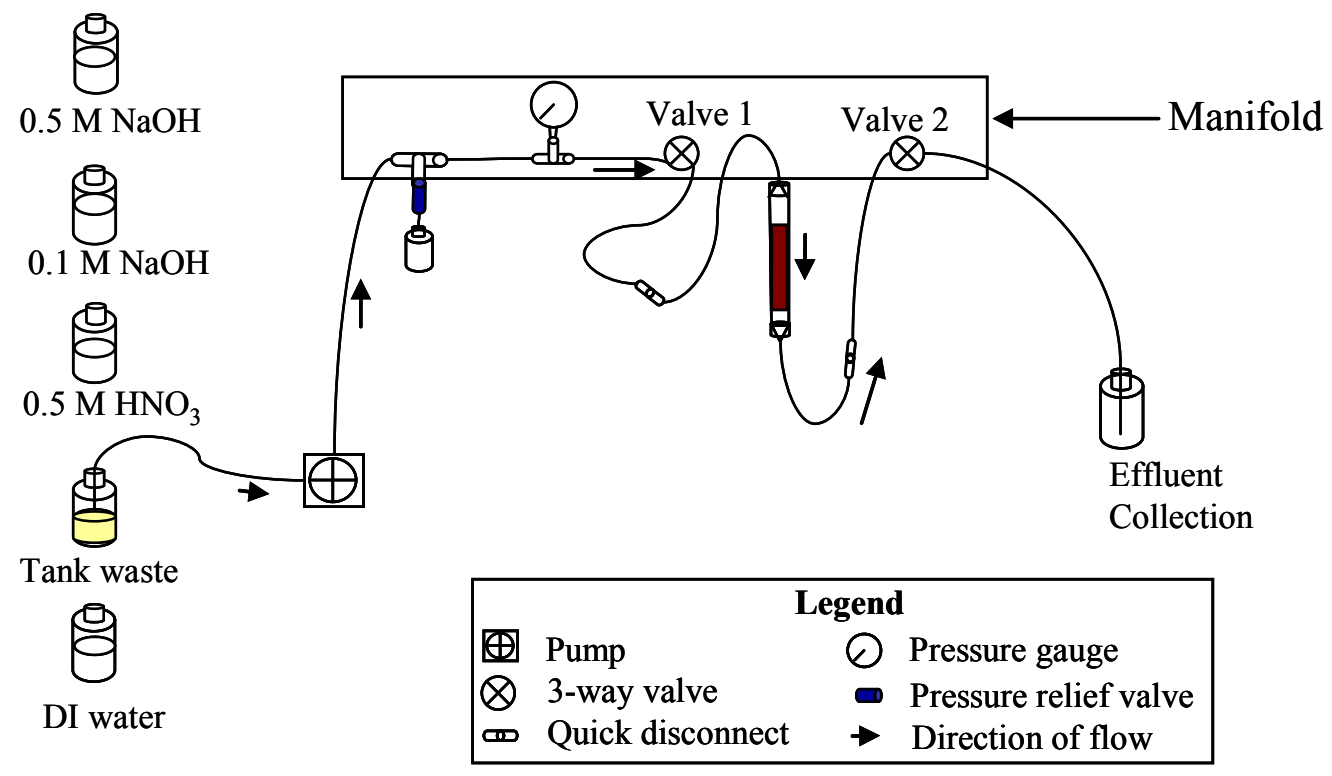

Figure 5.14. Ion Exchange Column Processing System Schematic 
The height of the resin bed (and thus shrinkage and swelling) was measured with a millimeter-scale ruler adhesively placed on the column (the associated measurement error was estimated to be $\pm 2 \mathrm{~mm}$ ). The fluid level in the column was maintained at nominally the 7.6- $\mathrm{cm}$ height. Depending on whether the resin was expanded in the $\mathrm{Na}$-form $(\sim 4.1 \mathrm{~cm}$ tall) or contracted in the $\mathrm{H}$-form $(\sim 3.2 \mathrm{~cm}$ tall $)$, the fluid volume in the column above the resin bed varied between $\sim 20 \mathrm{~mL}$ and $\sim 24 \mathrm{~mL}$, respectively ( $\sim$ one bed volume [BV]). There was a substantial air gap of $\sim 30 \mathrm{~mL}(\sim 5.4 \mathrm{~cm})$ above the fluid head. Figure 5.15 shows the system before it was installed in the hot cells (the resin bed was in the sodium form).

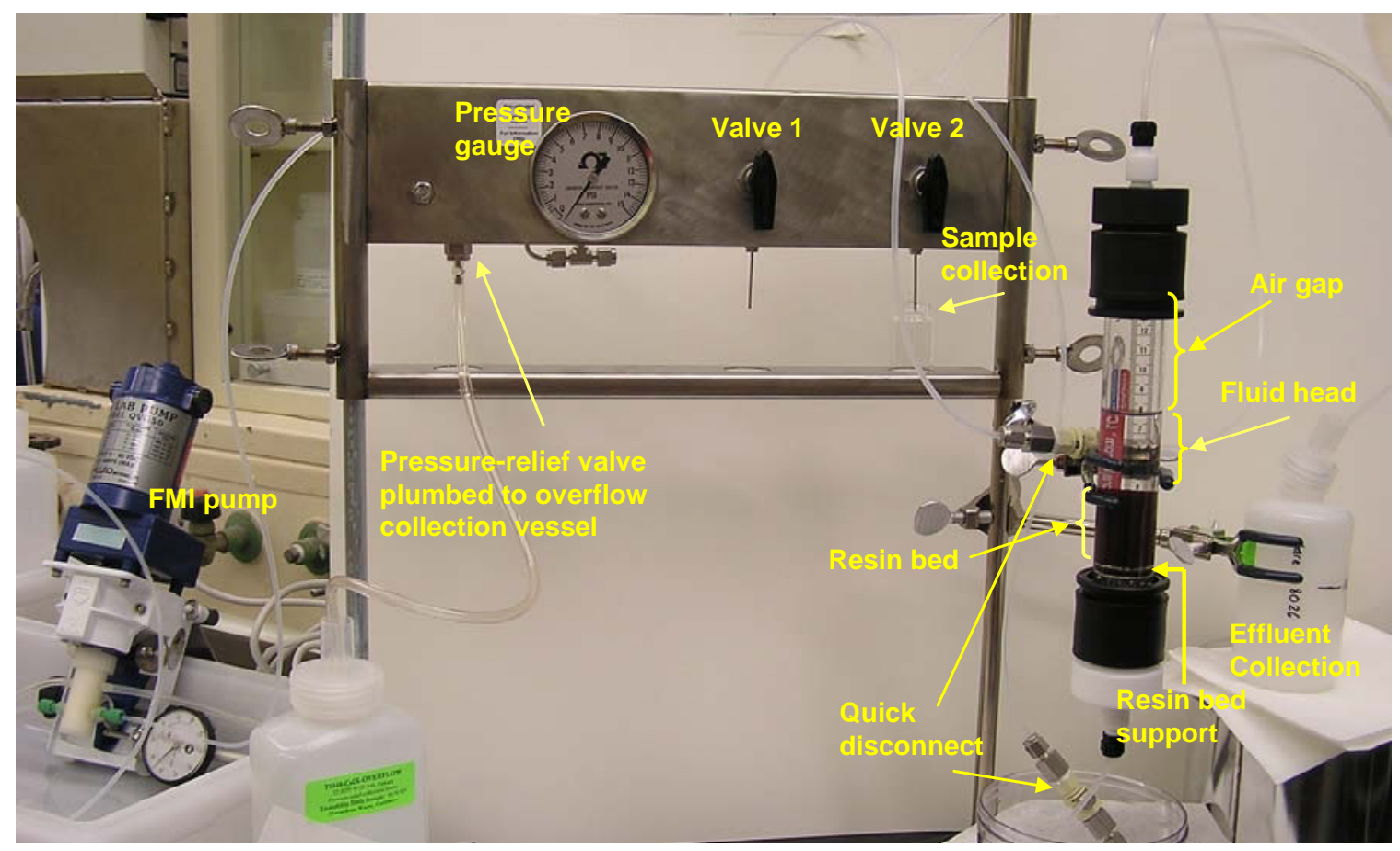

Figure 5.15. Photograph of the Ion Exchange Column Processing System (During In-Column Resin Conditioning)

\subsubsection{Resin Mass in Column}

The dry H-form resin mass loaded into the ion exchange columns was determined indirectly. The open-beaker pretreated wetted resin was split such that a $17.1-\mathrm{mL}$ settled volume of $\mathrm{H}$-form resin was prepared for the column processing, and a second $9.8-\mathrm{mL}$ aliquot was taken to determine the dry mass. Excess water was removed from the second sample, which was then taken to dryness under vacuum at $50^{\circ} \mathrm{C}$. Dryness was defined as a resin mass change of $<0.5 \%$ over a 7 -h period. The dry mass of $9.8 \mathrm{~mL}$ wet resin was $3.42 \mathrm{~g}$. The dry H-form resin mass in the ion exchange column $(5.97 \mathrm{~g})$ was calculated relative to the measured volume splits and the dry mass of the dried split according to Equation 5.1. The mass uncertainty was estimated to be $\pm 2 \%$.

$$
\mathrm{M}_{\mathrm{c}}=\frac{\mathrm{V}_{\mathrm{c}} * \mathrm{M}_{\mathrm{d}}}{\mathrm{V}_{\mathrm{d}}}
$$


where $\mathrm{M}_{\mathrm{c}}=$ mass of dry $\mathrm{H}$-form resin loaded in the column

$\mathrm{V}_{\mathrm{c}}=$ volume of wet $\mathrm{H}$-form resin transferred to the column

$\mathrm{V}_{\mathrm{d}}=$ volume of wet $\mathrm{H}$-form split resin used for dry mass determination

$\mathrm{M}_{\mathrm{d}}=$ mass of dry $\mathrm{H}$-form split resin used for dry mass determination.

The dry bed density $\left(\delta_{\mathrm{DRB}}\right)$ was calculated to be $0.28 \mathrm{~g} / \mathrm{mL}$ according to Equation 5.2 where the dry $\mathrm{H}$-form resin mass divided by the expanded wetted Na-form resin volume is

$$
\delta_{D R B}=\frac{M_{c}}{B V}
$$

\subsubsection{Bed Volume}

In all cases, one BV was defined as the Na-form resin BV calculated after initial pretreatment cycling in the column. The BV was determined after completing the in-column $0.5 \mathrm{M} \mathrm{NaOH}$ preconditioning rinse. The BV is an arbitrary value; the volume of the resin bed in the H-form was typically $20 \%$ smaller than the Na-form resin BV, consistent with previously observed RF resin expansions and contractions (Fiskum et al. 2006a).

\subsubsection{Ion Exchange Processing Conditions}

The ion exchange processing parameters are summarized in Table 5.8. All solutions were processed downflow. These parameters were established in the test plan and generally mimic expected plant operating conditions. The cumulative, pumped BV was calculated based on the effluent collection mass and density. The solution density changed rapidly during transition and mixing from regeneration solution to the simulant feed $(1.02 \mathrm{~g} / \mathrm{mL}$ to $1.19 \mathrm{~g} / \mathrm{mL}$, respectively); the transition was essentially complete after processing one apparatus volume. A nominal density of $1.13 \mathrm{~g} / \mathrm{mL}$ was applied to the net mass measurement associated with the first sampling event. This represented an absolute volume uncertainty of $\sim 6 \mathrm{~mL}$ or $0.3 \mathrm{BVs}$. This uncertainty was considered negligible in the overall process. The time interval was measured with a standard clock. The process temperature was determined with an incell thermocouple measuring the ambient condition.

Elution processing was conducted at two flowrates where the first $9.35 \mathrm{BVs}$ were processed at $1.06 \mathrm{BV} / \mathrm{h}$, slower than the targeted $1.4 \mathrm{BV} / \mathrm{h}$. The slower flowrate is expected to improve the sharpness of the Cs elution profile. The flowrate of the last $4.93 \mathrm{BVs}$ was processed at a slightly higher flowrate of $1.64 \mathrm{BV} / \mathrm{h}$.

Samples were collected periodically during the feed processing to evaluate Cs breakthrough profiles. Feed effluent samples were collected three to four times per day in 3- to 5-mL aliquots; between sampling events, the bulk of the effluent was collected as a series of six composites. The feed displacement was collected as a composite as were the water rinses and eluate. The temperature was recorded with each sampling event. The Cs loading behavior was monitored from the ${ }^{137} \mathrm{Cs}$ activity in the collected sample using gamma spectrometry.

Each of the six feed effluent composites was measured for metals (ICP-OES), U (KPA), and radionuclides (gamma emitters, gross alpha, gross beta, ${ }^{238} \mathrm{Pu},{ }^{239+240} \mathrm{Pu}$, and ${ }^{90} \mathrm{Sr}$ ). Only the final effluent 
composite was additionally measured for anions, free hydroxide, total inorganic carbon (TIC), and total organic carbon (TOC). The other process effluents (feed displacement, water rinse, eluate, and final rinse) were analyzed as composites. Anions, free hydroxide, TIC, and TOC analyses were not relevant to the eluate and subsequent water rinse, so they were not conducted on these process streams.

The ion exchange resin was removed from the column. The contact fluid was removed and analyzed for radionuclides and metals. The damp resin was dried at room temperature under nitrogen. It was then sub-sampled for acid digestion and follow-on metals and radionuclide analysis.

Table 5.8. Ion Exchange Process Steps and Conditions

\begin{tabular}{|c|c|c|c|c|c|c|c|c|}
\hline \multirow[b]{2}{*}{ Process step } & \multirow[b]{2}{*}{ Solution } & \multicolumn{3}{|c|}{ Total Volume } & \multicolumn{2}{|c|}{ Flowrate } & \multirow{2}{*}{$\begin{array}{c}\text { Time } \\
\mathrm{h}\end{array}$} & \multirow{2}{*}{$\begin{array}{c}\mathrm{T} \\
{ }^{\circ} \mathrm{C}\end{array}$} \\
\hline & & $\mathbf{B V}^{(\mathrm{a})}$ & $\mathbf{A \mathbf { V } ^ { ( \mathbf { b } ) }}$ & $\mathbf{m L}$ & BV/h & $\mathrm{mL} / \mathrm{min}$ & & \\
\hline \multicolumn{9}{|c|}{ In-situ Preconditioning (12/11/07) } \\
\hline Water rinse & DI water & 7.82 & 3.06 & 168.2 & 2.83 & 1.013 & 2.77 & 21 \\
\hline Acid wash & $0.5 \mathrm{M} \mathrm{HNO}_{3}$ & 7.87 & 3.08 & 169.4 & 2.99 & 1.072 & 2.63 & 21 \\
\hline Water rinse & DI water & 2.73 & 1.07 & 58.8 & 1.34 & 0.482 & 2.03 & 22 \\
\hline \multicolumn{9}{|c|}{ (Start 12/17/07) } \\
\hline Regeneration & $0.5 \mathrm{M} \mathrm{NaOH}$ & 5.43 & 2.12 & 116.7 & 2.71 & 0.972 & 2.00 & 24 \\
\hline Loading column & Tank waste & 209 & na & 4,497 & 2.81 & 1.01 & 74.0 & $24-26$ \\
\hline Feed displacement & $0.1 \mathrm{M} \mathrm{NaOH}$ & 5.13 & 2.01 & 110.4 & 2.52 & 0.905 & 2.03 & 26 \\
\hline Rinse & DI water & 5.54 & 2.17 & 119.1 & 2.68 & 0.961 & 2.07 & 26 \\
\hline \multirow{2}{*}{ Elution } & \multirow{2}{*}{$0.5 \mathrm{M} \mathrm{HNO}_{3}$} & 9.35 & 3.66 & 201.2 & 1.06 & 0.381 & 8.80 & 25 \\
\hline & & 4.93 & 1.93 & 106.1 & 1.64 & 0.586 & 3.02 & 25 \\
\hline Rinse & DI water & 2.94 & 1.15 & 63.2 & 1.37 & 0.490 & 2.15 & 26 \\
\hline
\end{tabular}

\subsection{Ion Exchange Processing Data Analysis}

The ion exchange process results are defined in this section.

\subsubsection{Loading Profile}

Figure 5.16 shows the Cs loading profile plotted as percent analyte concentration in column effluent divided by analyte concentration in feed $\left(\% \mathrm{C} / \mathrm{C}_{\mathrm{o}}\right)$ vs. the $\mathrm{BVs}$ of feed processed through each column; plotted data points are shown in Table 5.9. The $\mathrm{C}_{\mathrm{o}}$ reference value was the ${ }^{137} \mathrm{Cs}$ measured in the process feed $(27.8 \mu \mathrm{Ci} / \mathrm{mL})$, and the $\mathrm{C}$ value was measured on the effluent sample. The $\% \mathrm{C} / \mathrm{C}_{\mathrm{o}}$ is plotted on a probability scale ${ }^{(a)}$ allowing direct comparison to previously reported breakthrough plots (Fiskum et al. 2006a and Fiskum et al. 2006b). In this case, no Cs breakthrough (not even the onset) was measured after

(a) A probability scale is the inverse of the Gaussian cumulative distribution function (characteristic of ideal ion exchange theory) such that a graph of the sigmoidally shaped Gaussian cumulative distribution function versus the $\log$ BV appears as a straight line (Buckingham 1967). The probability scale has two advantages: 1) making low $\mathrm{C} / \mathrm{C}_{\mathrm{o}}$ data easily readable such that the initial load performance is discernable and 2) easily estimating extrapolation (or interpolation) to $50 \%$ breakthrough from a discernable breakthrough profile. 
processing $209 \mathrm{BVs}$ of feed. The undulating nature of the load curve was not considered experimentally significant.

Figure 5.16 also shows the six effluent composite segments. Analyzing the first five composite effluents resulted in non-detectable ${ }^{137} \mathrm{Cs}$, corresponding to Cs decontamination factors (DFs) of $>1.0 \mathrm{E}+6$; the final effluent composite resulted in $5.5 \mathrm{E}-5 \mu \mathrm{Ci} / \mathrm{mL}^{137} \mathrm{Cs}$ or a Cs DF of $5.0 \mathrm{E}+5$.

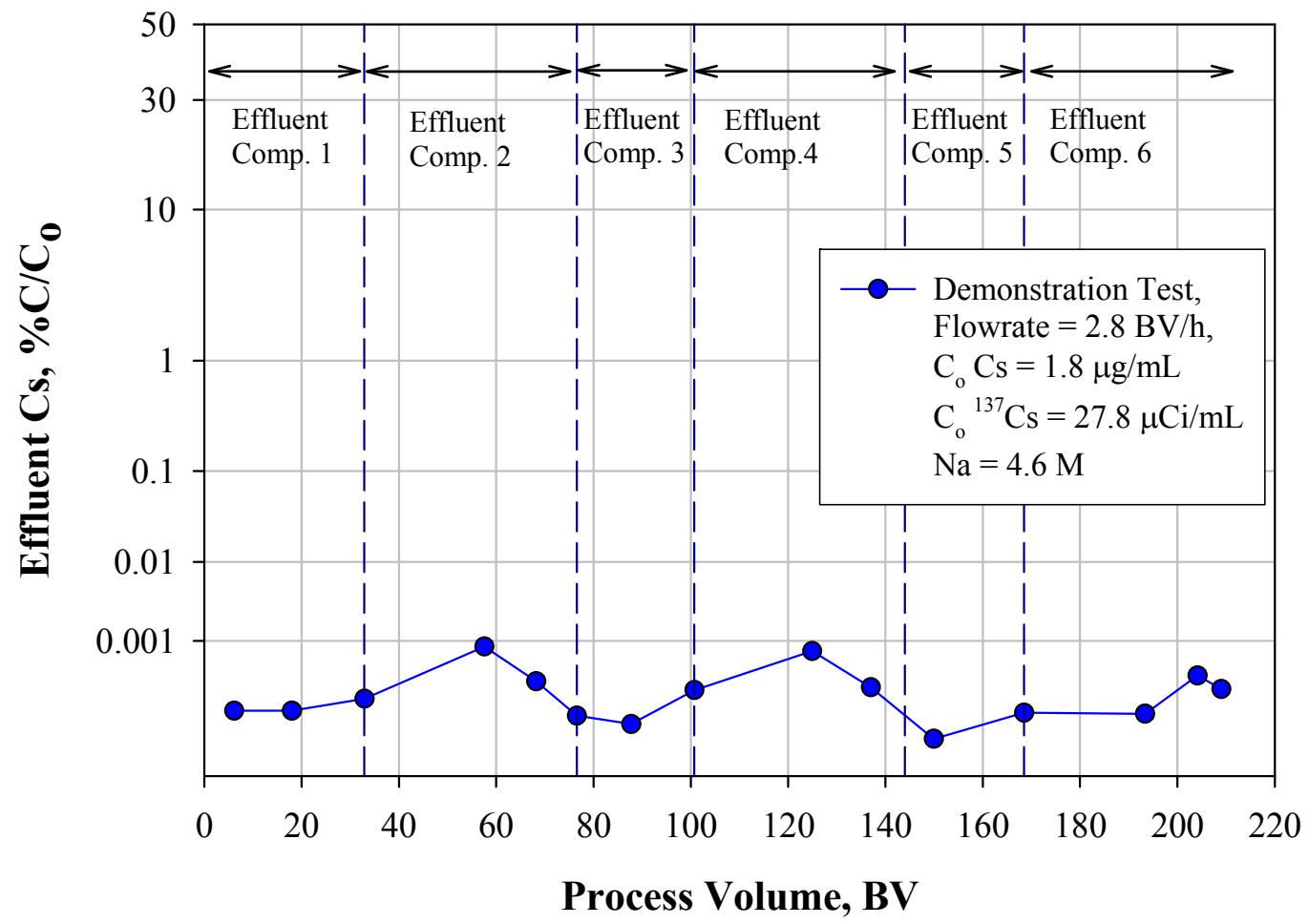

Figure 5.16. Cesium Load Profile

Table 5.9. Cs Ion Exchange Effluent Sample Results

\begin{tabular}{|r|c|c|c||}
\hline \multicolumn{1}{|c|}{$\mathbf{B V}$} & ${ }^{\mathbf{1 3 7}} \mathbf{C s} \boldsymbol{\mu \mathbf { C i } / \mathbf { m L }}$ & $\mathbf{\% \mathbf { C } / \mathbf { C } _ { \mathbf { o } }}$ & $\mathbf{C s} \mathbf{D F}$ \\
\hline 6.2 & $2.85 \mathrm{E}-5$ & $1.02 \mathrm{E}-4$ & $9.77 \mathrm{E}+5$ \\
\hline 18.0 & $2.85 \mathrm{E}-5$ & $1.02 \mathrm{E}-4$ & $9.76 \mathrm{E}+5$ \\
\hline 32.9 & $4.29 \mathrm{E}-5$ & $1.54 \mathrm{E}-4$ & $6.49 \mathrm{E}+5$ \\
\hline 57.6 & $2.34 \mathrm{E}-4$ & $8.40 \mathrm{E}-4$ & $1.19 \mathrm{E}+5$ \\
\hline 68.2 & $7.67 \mathrm{E}-5$ & $2.76 \mathrm{E}-4$ & $3.63 \mathrm{E}+5$ \\
\hline 76.6 & $2.41 \mathrm{E}-5$ & $8.65 \mathrm{E}-5$ & $1.16 \mathrm{E}+6$ \\
\hline 87.8 & $1.81 \mathrm{E}-5$ & $6.49 \mathrm{E}-5$ & $1.54 \mathrm{E}+6$ \\
\hline 100.7 & $5.70 \mathrm{E}-5$ & $2.05 \mathrm{E}-4$ & $4.88 \mathrm{E}+5$ \\
\hline 124.9 & $2.02 \mathrm{E}-4$ & $7.26 \mathrm{E}-4$ & $1.38 \mathrm{E}+5$ \\
\hline 137.0 & $6.26 \mathrm{E}-5$ & $2.25 \mathrm{E}-4$ & $4.45 \mathrm{E}+5$ \\
\hline 149.9 & $<1.07 \mathrm{E}-5$ & $<3.83 \mathrm{E}-5$ & $>2.61 \mathrm{E}+6$ \\
\hline 168.5 & $2.68 \mathrm{E}-5$ & $9.63 \mathrm{E}-5$ & $1.04 \mathrm{E}+6$ \\
\hline 193.4 & $2.58 \mathrm{E}-5$ & $9.28 \mathrm{E}-5$ & $1.08 \mathrm{E}+6$ \\
\hline 204.1 & $9.24 \mathrm{E}-5$ & $3.32 \mathrm{E}-4$ & $3.01 \mathrm{E}+5$ \\
\hline 209.0 & $5.91 \mathrm{E}-5$ & $2.12 \mathrm{E}-4$ & $4.71 \mathrm{E}+5$ \\
\hline
\end{tabular}


Normally, ${ }^{137} \mathrm{Cs}$ is measured at increasing concentration as the process volume increases. This breakthrough profile would provide engineering information such as capacity and process volume at $50 \%$ Cs breakthrough. However, the total Cs concentration in the feed was rather low at $1.83 \mu \mathrm{g} / \mathrm{mL}$ (typical Envelope A feeds have Cs concentrations closer to $6 \mu \mathrm{g} / \mathrm{mL}$ ), and the $\mathrm{K}$ concentration (competitor for ion exchange sites) was also at the low end at $0.01 \mathrm{M}$; both circumstances would contribute to delayed Cs breakthrough. Over the 209-BV loading, a total of $8.21 \mathrm{mg}$ Cs were loaded on the bed corresponding to $1.38 \mathrm{mg}$ Cs per g of dry H-form resin. In comparison, testing with AP-101 actual waste $(6.0 \mu \mathrm{g} / \mathrm{mL} \mathrm{Cs}$ and $0.74 \mathrm{M} \mathrm{K}$ ) resulted in Cs loading of $\sim 2.3 \mathrm{mg}$ Cs per g dry $\mathrm{H}$-form resin at $\sim 90 \% \mathrm{Cs}$ breakthrough (Fiskum et al. 2006b).

The apparent lack of Cs breakthrough in this test was not expected to influence Pu processing-related effects and interpretations. In fact, the large feed volume should highlight potential Pu processing effects such as in-column precipitation or exchange. Should either of these events be occurring, increasing the feed mass would result in correspondingly increased $\mathrm{Pu}$ mass diversion. In turn, this would result in enhanced detection in the eluate or spent resin.

\subsubsection{Mass and Activity Balance}

Table 5.10 and Table 5.11 summarize the chemical and radiochemical compositions of the various processing solutions and spent resin. The spent resin results are shown on a dry-mass basis after the elution and water rinse such that the resin is primarily in the H-form. For reference, the composite feed composition is also shown. Analyte concentrations in the six composite effluents did not vary significantly outside of the measurement uncertainties, and the average is reported with the RSD for the six different measurements.

The analyte recovery relative to each process stream was calculated and shown as weight-percent recovery (activity \% recovery in the case of radioisotopes). The final column shows the total weightpercent recovery for the analyte. Ideally, the sum will equal $100 \%$, indicating mass/activity balance. Typically, $85 \%$ to $115 \%$ total analyte recovery was obtained, well within the overall analytical uncertainty. Bracketed results are shown for information only and are potentially associated with relative analytical uncertainty exceeding $15 \%$. The mass-balance closure for $\mathrm{Si}$ was low at $33 \%$; the source of this discrepancy is not understood; however, it is a trace-level analyte and may be subject to more uncertainty relative to the handling and analysis.

Approximately 90 to $95 \%$ of the Pu presented to the ion exchanger passed through it with no apparent retention; it was collected in the effluent and feed displacement. There was no apparent upward or downward change in the effluent $\mathrm{Pu}$ concentration as a function of process volume determined from evaluating the concentration in the six effluent composites. Approximately $4.30 \%$ of the Pu appeared to be associated with the eluate and water rinse and $0.18 \%$ associated with the spent resin. Thus, the resin demonstrated the affinity to hold up $4.5 \%$ of the $\mathrm{Pu}$ activity during the feed, feed displacement, and water rinse processing. The mechanism for Pu hold-up was not determined in this study. 
Table 5.10. Process Solution Compositions and Analyte Recoveries: ICP-OES Metals, Anions, Free Hydroxide, TOC, and TIC

\begin{tabular}{|c|c|c|c|c|c|c|c|c|c|c|c|c|c|c|c|}
\hline \multirow{4}{*}{$\begin{array}{r}\begin{array}{r}\text { Sample } \\
\text { ID }>\end{array} \\
\text { ASR }> \\
\text { ASO ID }> \\
\end{array}$} & \multirow{3}{*}{\begin{tabular}{|c|}
$\begin{array}{c}\text { Comp. } \\
\text { Feed }\end{array}$ \\
8074 \\
$\mathbf{0 8 - 0 0 7 9 1}$ \\
$-\mathbf{0 0 7 9 3}$ \\
\end{tabular}} & \multicolumn{3}{|c|}{ Composite Effluent } & \multicolumn{2}{|c|}{ Feed Displacement } & \multicolumn{2}{|c|}{ DI Water Rinse } & \multicolumn{2}{|c|}{ Eluate } & \multicolumn{2}{|c|}{ DI Water Rinse } & \multicolumn{2}{|c|}{ Spent Resin } & \multirow{3}{*}{$\begin{array}{c}\text { Sum of } \\
\text { Analyte } \\
\text { Fractions } \\
\end{array}$} \\
\hline & & & & \multirow{3}{*}{$\begin{array}{c}\begin{array}{c}\text { Analyte } \\
\text { Fraction }\end{array} \\
\text { Wt } \%\end{array}$} & 8074 & \multirow{3}{*}{$\begin{array}{c}\begin{array}{c}\text { Analyte } \\
\text { Fraction }\end{array} \\
\text { Wt \% } \\
\end{array}$} & 8074 & \multirow{3}{*}{$\begin{array}{c}\begin{array}{c}\text { Analyte } \\
\text { Fraction }\end{array} \\
\text { Wt \% } \\
\end{array}$} & 8074 & \multirow{3}{*}{$\begin{array}{c}\begin{array}{c}\text { Analyte } \\
\text { Fraction }\end{array} \\
\text { Wt \% } \\
\end{array}$} & 8074 & \multirow[b]{2}{*}{$\begin{array}{c}\text { Analyte } \\
\text { Fraction } \\
\end{array}$} & 8082 & \multirow{3}{*}{$\begin{array}{c}\begin{array}{c}\text { Analyte } \\
\text { Fraction }\end{array} \\
\text { Wt \% }\end{array}$} & \\
\hline & & \multicolumn{2}{|c|}{$\begin{array}{c}08-00794, \\
08-00798-00802 \\
\end{array}$} & & 08-00795 & & 08-00796 & & 08-00804 & & 08-00803 & & 08-00835 & & \\
\hline & $\mu \mathrm{g} / \mathrm{mL}$ & $\mu \mathrm{g} / \mathrm{mL}$ & RSD & & $\mu \mathrm{g} / \mathrm{mL}$ & & $\mu \mathrm{g} / \mathrm{mL}$ & & $\mu \mathrm{g} / \mathrm{mL}$ & & $\mu \mathrm{g} / \mathrm{mL}$ & Wt \% & $\mu \mathrm{g} / \mathbf{g}^{(\mathrm{f})}$ & & Wt \% \\
\hline $\mathrm{Al}$ & 7,323 & 7,294 & $4.8 \%$ & 99.5 & 4,870 & 1.63 & 127 & 0.046 & 16.3 & 0.015 & {$[0.86]$} & [1.7E-4] & 51.1 & 0.00093 & 101 \\
\hline $\mathrm{B}$ & 28.8 & 16.3 & $6.7 \%$ & 56.7 & 10.9 & 0.93 & $<0.12$ & $<0.01$ & 178 & 42.2 & 3.29 & 0.16 & [2.2] & {$[0.010]$} & 100 \\
\hline $\mathrm{Ba}$ & {$[0.42]$} & {$[0.29]$} & [34\%] & [70] & {$[0.27]$} & {$[1.6]$} & {$[0.091]$} & {$[0.57]$} & 0.591 & 9.6 & {$[0.081]$} & {$[0.27]$} & {$[0.21]$} & {$[0.065]$} & [82] \\
\hline $\mathrm{Bi}$ & [4.35] & {$[4.01]$} & {$[8 \%]$} & [92] & $<3.8$ & $<2.1$ & $<0.74$ & $<0.45$ & $<3.1$ & $<4.9$ & $<0.75$ & $<0.2$ & $<1.48$ & $<0.045$ & {$[100]$} \\
\hline $\mathrm{Ca}$ & [1.77] & {$[5.33]^{(b)}$} & {$[82 \%]$} & [258] & {$[7.1]^{(b)}$} & [9.9] & $2.84^{(\mathrm{b})}$ & na & {$[2.8]^{(b)}$} & [11] & $2.79^{(\mathrm{b})}$ & na & $13.1^{(\mathrm{b})}$ & 0.98 & na \\
\hline $\mathrm{Cd}$ & $<0.43$ & $<0.42$ & na & na & $<0.43$ & na & $<0.084$ & na & $<0.36$ & na & $<0.085$ & na & $<0.17$ & $<0.051$ & na \\
\hline $\mathrm{Cr}$ & 728 & 726 & $5.6 \%$ & 99.3 & 482 & 1.63 & 1.62 & 0.0059 & [0.95] & {$[0.009]$} & {$[0.24]$} & [4.6E-4] & 260 & 0.047 & 101 \\
\hline $\mathrm{Cu}$ & $<0.17$ & $<0.19$ & na & na & {$[0.36]$} & {$[>5.1]$} & $<0.03$ & na & {$[0.25]$} & {$[>10]$} & {$[0.037]$} & {$[0.30]$} & {$[0.21]$} & {$[0.16]$} & $>16$ \\
\hline $\mathrm{Fe}$ & {$[5.4]$} & [1.37] & {$[62 \%]$} & [27] & [3.8] & [1.7] & {$[0.31]$} & [0.15] & {$[1.3]$} & [1.6] & 1.31 & 0.34 & 4.44 & 0.109 & [32] \\
\hline $\mathrm{K}$ & 399 & 390 & $10.6 \%$ & 97.7 & 260 & 1.60 & 26.3 & 0.175 & 91.5 & 1.6 & {$[0.73]$} & {$[0.00257]$} & $<0.99$ & $<0.00033$ & 101 \\
\hline $\mathrm{Mn}$ & {$[0.32]$} & {$[0.23]$} & {$[37 \%]$} & [72] & {$[0.30]$} & [2.3] & {$[0.013]$} & {$[0.11]$} & {$[0.36]$} & {$[7.8]$} & 0.169 & $0.75 \%$ & 10.7 & 4.46 & [88] \\
\hline $\mathrm{Na}$ & 103,400 & 103,033 & $4.6 \%$ & 99.6 & 70,500 & 1.67 & 2,770 & 0.071 & 2,230 & 0.15 & 10.6 & $0.0001 \%$ & 23.7 & 0.00003 & 102 \\
\hline $\mathrm{Ni}$ & {$[0.37]$} & $<0.36$ & na & $<99$ & $<0.30$ & $<2.0$ & $<0.06$ & $<0.43$ & {$[0.82]$} & {$[15]$} & {$[0.22]$} & {$[0.85]$} & 12.2 & 4.43 & na \\
\hline $\mathrm{P}$ & 801 & 796 & $3.8 \%$ & 99.3 & 520 & 1.59 & {$[1.8]$} & {$[0.01]$} & $<5.2$ & $<0.045$ & [2.7] & [0.00474] & [3.5] & {$[0.00058]$} & 101 \\
\hline $\mathrm{S}$ & 852 & 856 & $4.6 \%$ & 100 & 588 & 1.69 & [9.7] & {$[0.03]$} & {$[10]$} & {$[0.081]$} & {$[3.8]$} & {$[0.00627]$} & 1,270 & 0.20 & 102 \\
\hline $\mathrm{Si}$ & 107 & 31.4 & $6.5 \%$ & 29.1 & 21.6 & 0.49 & 1.41 & 0.035 & 62.3 & 4.0 & 2.08 & 0.027 & 57.3 & 0.071 & 34 \\
\hline $\mathrm{Sr}$ & $<0.010$ & $<0.010$ & na & na & {$[0.020]$} & {$[>4.8]$} & $<0.002$ & na & {$[0.058]$} & [>39] & {$[0.008]$} & [1.05] & {$[0.045]$} & {$[0.587]$} & $>46$ \\
\hline Th & {$[1.74]^{(\mathrm{c})}$} & $<1.37^{(\mathrm{c})}$ & na & $<77$ & $<1.23^{(\mathrm{c})}$ & $<1.7$ & $<0.24^{(\mathrm{c})}$ & $<0.37$ & $<1.0$ & $<4.0$ & $<0.25^{(\mathrm{c})}$ & $<0.2$ & $<0.48^{(\mathrm{c})}$ & $<0.037$ & na \\
\hline U & [7.57] & $<4.5$ & na & $<59$ & [7.2] & [2.3] & $<0.79$ & $<0.28$ & $<3.3$ & $<3.0$ & $<0.80$ & $<0.1$ & $<1.66$ & $<0.029$ & na \\
\hline $\mathrm{Zn}$ & {$[3.8]$} & {$[3.83]$} & {$[11 \%]$} & [99] & {$[3.0]$} & [1.9] & {$[0.83]$} & {$[0.58]$} & [5.1] & {$[9.2]$} & {$[0.79]$} & {$[0.29]$} & 6.70 & 0.234 & [112] \\
\hline $\mathrm{Zr}$ & {$[0.28]$} & $<0.17$ & na & $<62$ & {$[0.15]$} & [1.3] & $<0.027$ & $<0.25$ & $<0.11$ & $<2.8$ & $<0.028$ & $<0.1$ & {$[0.45]$} & {$[0.21]$} & na \\
\hline U KPA & 3.65 & 3.47 & $5.5 \%$ & 95.0 & 2.43 & 1.64 & 0.293 & 0.213 & $1.18 \mathrm{E}+0$ & 2.2 & 0.196 & 0.076 & 0.232 & 0.0084 & 99 \\
\hline nitrite & 13,067 & 12,700 & (a) & 97.2 & 8,670 & 1.63 & 21.6 & 0.0044 & $\mathrm{n} / \mathrm{a}$ & & $\mathrm{n} / \mathrm{a}$ & & $\mathrm{n} / \mathrm{a}$ & & 99 \\
\hline nitrate & 44,133 & 43,200 & (a) & 97.9 & 29,100 & 1.62 & 74.0 & 0.0044 & $\mathrm{n} / \mathrm{a}$ & & $\mathrm{n} / \mathrm{a}$ & & $\mathrm{n} / \mathrm{a}$ & & 100 \\
\hline phosphate & 2,463 & 2,410 & (a) & 97.8 & 1,570 & 1.56 & 4.80 & 0.0052 & $\mathrm{n} / \mathrm{a}$ & & $\mathrm{n} / \mathrm{a}$ & & $\mathrm{n} / \mathrm{a}$ & & 99 \\
\hline sulfate & 2,377 & 2,310 & (a) & 97.2 & 1,520 & 1.57 & 8.73 & 0.010 & $\mathrm{n} / \mathrm{a}$ & & $\mathrm{n} / \mathrm{a}$ & & $\mathrm{n} / \mathrm{a}$ & & 99 \\
\hline
\end{tabular}


Table 5.10 (contd)

\begin{tabular}{|c|c|c|c|c|c|c|c|c|c|c|c|c|c|c|c|}
\hline \multirow{3}{*}{$\begin{array}{r}\begin{array}{r}\text { Sample } \\
\text { ID }>\end{array} \\
\text { ASR }> \\
\text { ASO ID }> \\
\end{array}$} & \multirow{3}{*}{$\begin{array}{c}\begin{array}{c}\text { Comp. } \\
\text { Feed }\end{array} \\
8074 \\
08-00791 \\
-00793 \\
\end{array}$} & \multicolumn{3}{|c|}{ Composite Effluent } & \multicolumn{2}{|c|}{ Feed Displacement } & \multicolumn{2}{|c|}{ DI Water Rinse } & \multicolumn{2}{|c|}{ Eluate } & \multicolumn{2}{|c|}{ DI Water Rinse } & \multicolumn{2}{|c|}{ Spent Resin } & \multirow{4}{*}{$\begin{array}{c}\begin{array}{c}\text { Sum of } \\
\text { Analyte } \\
\text { Fractions }\end{array} \\
\text { Wt \% } \\
\end{array}$} \\
\hline & & \multirow{2}{*}{\multicolumn{2}{|c|}{$\begin{array}{c}8074 \\
08-00794 \\
\text { 08-00798- 00802 } \\
\end{array}$}} & \multirow{3}{*}{$\begin{array}{c}\begin{array}{c}\text { Analyte } \\
\text { Fraction }\end{array} \\
\text { Wt \% } \\
\end{array}$} & \multirow{3}{*}{$\begin{array}{c}8074 \\
08-00795 \\
\mu \mathrm{g} / \mathrm{mL} \\
\end{array}$} & \multirow{3}{*}{$\begin{array}{c}\begin{array}{c}\text { Analyte } \\
\text { Fraction }\end{array} \\
\text { Wt \% } \\
\end{array}$} & \multirow{3}{*}{$\begin{array}{c}8074 \\
08-00796 \\
\mu \mathrm{g} / \mathrm{mL} \\
\end{array}$} & \multirow{3}{*}{$\begin{array}{c}\begin{array}{c}\text { Analyte } \\
\text { Fraction }\end{array} \\
\text { Wt \% } \\
\end{array}$} & \multirow{3}{*}{$\begin{array}{c}8074 \\
08-00804 \\
\mu \mathrm{g} / \mathrm{mL}\end{array}$} & \multirow{3}{*}{$\begin{array}{c}\begin{array}{c}\text { Analyte } \\
\text { Fraction }\end{array} \\
\text { Wt \% } \\
\end{array}$} & \multirow{3}{*}{$\begin{array}{c}8074 \\
08-00803 \\
\mu \mathrm{g} / \mathrm{mL} \\
\end{array}$} & \multirow{3}{*}{$\begin{array}{c}\begin{array}{c}\text { Analyte } \\
\text { Fraction }\end{array} \\
\text { Wt } \% \\
\end{array}$} & \multirow{3}{*}{$\begin{array}{c}8082 \\
08-00835 \\
\mu g / g^{(f)} \\
\end{array}$} & \multirow{3}{*}{$\begin{array}{c}\begin{array}{c}\text { Analyte } \\
\text { Fraction }\end{array} \\
\text { Wt } \% \\
\end{array}$} & \\
\hline & & & & & & & & & & & & & & & \\
\hline Analyte & $\mu \mathrm{g} / \mathrm{mL}$ & $\mu \mathrm{g} / \mathrm{mL}$ & RSD & & & & & & & & & & & & \\
\hline Oxalate & 462 & 479 & (a) & 103.6 & 313 & 1.66 & $<0.03$ & $<0.0002$ & \multicolumn{2}{|l|}{$\frac{\mu \mathbf{g} / \mathbf{m L}}{\mathrm{n} / \mathrm{a}}$} & \multicolumn{2}{|l|}{$\mathrm{n} / \mathrm{a}$} & \multicolumn{2}{|l|}{$\mathrm{n} / \mathrm{a}$} & 105 \\
\hline free $\mathrm{OH}^{(\mathrm{e})}$ & $2.76 \mathrm{M}$ & $2.56 \mathrm{M}$ & (a) & 92.8 & $1.85 \mathrm{M}$ & 1.65 & $0.11 \mathrm{M}$ & 0.101 & \multicolumn{2}{|l|}{$\mathrm{n} / \mathrm{a}$} & \multicolumn{2}{|l|}{$\mathrm{n} / \mathrm{a}$} & $\mathrm{n} / \mathrm{a}$ & & 94 \\
\hline TOC--C & 390 & 370 & (a) & 94.9 & 240 & 1.51 & $<60$ & $<0.41$ & $\mathrm{n} / \mathrm{a}$ & & $\mathrm{n} / \mathrm{a}$ & & $\mathrm{n} / \mathrm{a}$ & & 97 \\
\hline TIC--C & 2,910 & 2,650 & (a) & 91.1 & 1,770 & 1.49 & 68 & 0.061 & $\mathrm{n} / \mathrm{a}$ & & $\mathrm{n} / \mathrm{a}$ & & $\mathrm{n} / \mathrm{a}$ & & 93 \\
\hline Opportunis & & & & & & & & & & & & & & & \\
\hline fluoride & 44 & 45.6 & (a) & 103.3 & 39.5 & 2.20 & $<0.16$ & $<0.01$ & $\mathrm{n} / \mathrm{a}$ & & $\mathrm{n} / \mathrm{a}$ & & $\mathrm{n} / \mathrm{a}$ & & 106 \\
\hline chloride & 1,107 & 1,070 & (a) & 96.7 & 721 & 1.60 & 1.93 & 0.0046 & $\mathrm{n} / \mathrm{a}$ & & $\mathrm{n} / \mathrm{a}$ & & $\mathrm{n} / \mathrm{a}$ & & 98 \\
\hline $\mathrm{Ag}$ & $<0.26$ & $<0.27$ & na & na & $<0.26$ & na & $<0.052$ & na & {$[0.33]$} & {$[>9]$} & 0.816 & $>4.4$ & 12.7 & $>6.46$ & $>20$ \\
\hline As & $<5.3$ & $<5.82$ & na & na & $<5.4$ & na & $<1.1$ & na & {$[7.5]$} & {$[>10]$} & $<1.1$ & na & $<2.12$ & na & {$[>10]$} \\
\hline $\mathrm{Be}$ & {$[0.034]$} & {$[0.028]$} & {$[13 \%]$} & [83] & {$[0.015]$} & [1.1] & $<0.001$ & $<0.10$ & {$[0.005]$} & [1.09] & {$[0.001]$} & {$[0.058]$} & {$[0.025]$} & {$[0.098]$} & {$[86]$} \\
\hline $\mathrm{Ce}$ & $<1.2$ & $<1.25$ & na & na & $<1.3$ & na & {$[0.26]$} & {$[>0.55]$} & $<1.0$ & na & $<0.25$ & $<0.3$ & $<0.49$ & na & na \\
\hline Co & $<0.31$ & $<0.35$ & na & na & $<0.30$ & na & {$[0.092]$} & {$[>0.77]$} & $<0.25$ & na & {$[0.067]$} & {$[>0.30]$} & {$[0.23]$} & {$[0.095]$} & na \\
\hline Dy & $<0.36$ & $<0.37$ & na & na & {$[0.38]$} & [2.6] & $<0.072$ & na & {$[0.45]$} & {$[>8]$} & $<0.073$ & na & $<0.14$ & na & {$[>11]$} \\
\hline $\mathrm{Eu}$ & $<0.14$ & $<0.14$ & na & na & $<0.14$ & na & $<0.027$ & na & $<0.11$ & na & $<0.028$ & na & $<0.05$ & na & na \\
\hline $\mathrm{La}$ & $<0.54$ & {$[0.39]$} & {$[13 \%]$} & {$[>71]$} & $<0.35$ & na & {$[0.075]$} & {$[>0.37]$} & $<0.29$ & na & {$[0.11]$} & {$[>0.28]$} & $<0.14$ & na & {$[>71]$} \\
\hline $\mathrm{Li}$ & {$[0.72]$} & {$[0.65]$} & {$[17 \%]$} & [89] & {$[1.00]$} & {$[3.4]$} & {$[0.021]$} & {$[0.077]$} & {$[0.42]$} & [3.9] & $<0.015$ & $<0.029$ & $<0.03$ & $<0.006$ & [96] \\
\hline $\mathrm{Mg}$ & $<0.56$ & $<0.29$ & na & na & $<0.29$ & na & $<0.057$ & na & {$[0.42]$} & {$[>5]$} & $<0.058$ & na & {$[0.98]$} & {$[>0.23]$} & {$[>6]$} \\
\hline Mo & 10.9 & 11.13 & $5.0 \%$ & 102 & 6.89 & 1.55 & $<0.13$ & $<0.004$ & $<0.54$ & $<0.3$ & $<0.13$ & $<0.017$ & {$[1.25]$} & {$[0.015]$} & 104 \\
\hline $\mathrm{Nd}$ & $<0.67$ & $<0.67$ & na & na & $<0.68$ & na & $<0.13$ & na & $<0.56$ & na & $<0.14$ & na & $<0.27$ & na & na \\
\hline $\mathrm{Pb}$ & $<4.0$ & $<3.99$ & na & na & $<4.0$ & na & $<0.79$ & na & {$[9.8]$} & $>17$ & $<0.80$ & na & $<1.71$ & na & {$[>17]$} \\
\hline $\mathrm{Pd}$ & [1.04] & $<0.87$ & na & $<86$ & {$[0.94]$} & {$[2.2]$} & $<0.16$ & $<0.40$ & $<0.66$ & $<4.3$ & $<0.16$ & $<0.21$ & $<0.31$ & $<0.040$ & na \\
\hline $\mathrm{Rh}$ & $<2.13$ & {$[1.8]$} & [22\%] & {$[>87]$} & [1.7] & {$[2.0]$} & $<0.30$ & na & $<1.3$ & na & $<0.30$ & na & $<0.63$ & na & {$[>89]$} \\
\hline $\mathrm{Ru}$ & [1.43] & [1.9] & [15\%] & [137] & {$[1.5]$} & {$[2.6]$} & $<0.21$ & $<0.39$ & $<0.89$ & $<4.2$ & $<0.21$ & $<0.21$ & $<0.42$ & $<0.039$ & {$[145]$} \\
\hline $\mathrm{Sb}$ & $<2.5$ & {$[2.7]$} & [18\%] & {$[>110]$} & $<2.5$ & na & {$[0.52]$} & {$[>0.55]$} & {$[3.8]$} & {$[>10]$} & $<0.50$ & na & $<0.99$ & na & {$[>121]$} \\
\hline $\mathrm{Se}$ & $<8.7$ & $<8.72$ & na & na & $<8.8$ & na & $<1.7$ & na & [9] & {$[>7]$} & $<1.8$ & na & [4.29] & {$[>0.065]$} & {$[>8]$} \\
\hline $\mathrm{Sn}$ & [4.44] & $<3.52$ & na & $<80$ & $<3.4$ & $<1.9$ & $<0.67$ & $<0.40$ & $<2.8$ & $<4.3$ & $<0.68$ & $<0.21$ & {$[2.25]$} & {$[0.067]$} & na \\
\hline
\end{tabular}


Table 5.10 (contd)

\begin{tabular}{|c|c|c|c|c|c|c|c|c|c|c|c|c|c|c|c|}
\hline \multirow{3}{*}{$\begin{array}{r}\begin{array}{r}\text { Sample } \\
\text { ID }>\end{array} \\
\text { ASR }> \\
\text { ASO ID> } \\
\end{array}$} & \multirow{3}{*}{$\begin{array}{c}\begin{array}{c}\text { Comp. } \\
\text { Feed }\end{array} \\
8074 \\
08-00791 \\
-\mathbf{0 0 7 9 3} \\
\end{array}$} & \multicolumn{3}{|c|}{ Composite Effluent } & \multicolumn{2}{|c|}{ Feed Displacement } & \multicolumn{2}{|c|}{ DI Water Rinse } & \multicolumn{2}{|c|}{ Eluate } & \multicolumn{2}{|c|}{ DI Water Rinse } & \multicolumn{2}{|c|}{ Spent Resin } & \multirow{3}{*}{$\begin{array}{c}\text { Sum of } \\
\text { Analyte } \\
\text { Fractions } \\
\end{array}$} \\
\hline & & & & \multirow[b]{2}{*}{$\begin{array}{c}\text { Analyte } \\
\text { Fraction } \\
\end{array}$} & 8074 & & 8074 & & 8074 & & 8074 & & 8082 & & \\
\hline & & \multicolumn{2}{|c|}{$\begin{array}{c}08-00794, \\
08-00798-00802 \\
\end{array}$} & & 08-00795 & $\begin{array}{r}\text { Analyte } \\
\text { Fraction } \\
\end{array}$ & 08-00796 & $\begin{array}{c}\text { Analyte } \\
\text { Fraction } \\
\end{array}$ & 08-00804 & $\begin{array}{c}\text { Analyte } \\
\text { Fraction } \\
\end{array}$ & 08-00803 & $\begin{array}{c}\text { Analyte } \\
\text { Fraction } \\
\end{array}$ & 08-00835 & $\begin{array}{c}\text { Analyte } \\
\text { Fraction } \\
\end{array}$ & \\
\hline Analyte & $\mu \mathrm{g} / \mathrm{mL}$ & $\mu \mathrm{g} / \mathrm{mL}$ & RSD & Wt $\%$ & $\mu \mathrm{g} / \mathrm{mL}$ & Wt \% & $\mu \mathrm{g} / \mathrm{mL}$ & Wt \% & $\mu \mathrm{g} / \mathrm{mL}$ & Wt \% & $\mu \mathrm{g} / \mathrm{mL}$ & Wt \% & $\mu g / g^{(f)}$ & Wt \% & Wt \% \\
\hline $\mathrm{Ta}$ & $<2.1$ & $<2.12$ & na & na & $<2.1$ & na & $<0.42$ & na & $<1.9$ & na & $<0.43$ & na & $<0.84$ & na & na \\
\hline $\mathrm{Te}$ & $<3.2$ & $<3.24$ & na & na & $<3.3$ & na & $<0.64$ & na & $<2.7$ & na & $<0.65$ & na & [1.6] & {$[>0.066]$} & na \\
\hline $\mathrm{Ti}$ & {$[0.110]$} & $<0.05$ & na & $<50$ & $<0.054$ & $<1.2$ & $<0.011$ & $<0.26$ & {$[0.10]$} & {$[6.2]$} & $<0.011$ & $<0.14$ & {$[0.039]$} & {$[0.047]$} & $<58$ \\
\hline $\mathrm{Tl}$ & $<4.7$ & $<4.94$ & na & na & $<4.8$ & na & $<0.94$ & na & {$[5.7]$} & {$[>8]$} & [1.7] & {$[>0.51]$} & $<1.87$ & na & {$[>9.2]$} \\
\hline $\mathrm{V}$ & {$[0.61]$} & {$[0.54]$} & {$[8 \%]$} & [89] & {$[0.27]$} & [1.1] & $<0.018$ & $<0.08$ & $<0.077$ & $<0.9$ & {$[0.043]$} & {$[0.10]$} & {$[0.071]$} & {$[0.015]$} & [92] \\
\hline $\mathrm{W}$ & [22] & [22] & {$[2 \%]$} & [101] & [13] & [1.5] & $<0.47$ & $<0.06$ & {$[2.2]$} & {$[0.69]$} & $<0.48$ & $<0.031$ & {$[1.5]$} & {$[0.0091]$} & [103] \\
\hline Y & $<0.055$ & $<0.05$ & na & na & $<0.055$ & na & $<0.011$ & na & $<0.046$ & na & $<0.011$ & na & $<0.02$ & na & na \\
\hline
\end{tabular}

(a) Only the final of six effluent composites was measured for anions, free hydroxide, TIC and TOC.



(c) The thorium QC failed: ASR 8074 BS recovery was 20\% and ASR 8082 MS and BS recoveries were $27 \%$. The eluate was measured directly after dilution so the BS and MS QC do not apply to this analysis.

N (d) Opportunistic analytes are shown for information only; data were not necessarily evaluated against QC criteria.

(e) Free hydroxide, reported in terms of molarity.

(f) Dry mass basis.

Notes: $n a=$ not applicable; $\mathrm{n} / \mathrm{a}=$ not analyzed

Analyte uncertainties were typically within $\pm 15 \%$; results in brackets indicate that the analyte concentrations were greater than the minimum detection limit (MDL) and less than the

estimated quantitation limit (EQL), and uncertainties were $>15 \%$.

ASR $=$ analytical services request 
Table 5.11. Process Solution Compositions and Analyte Recoveries: Radionuclides

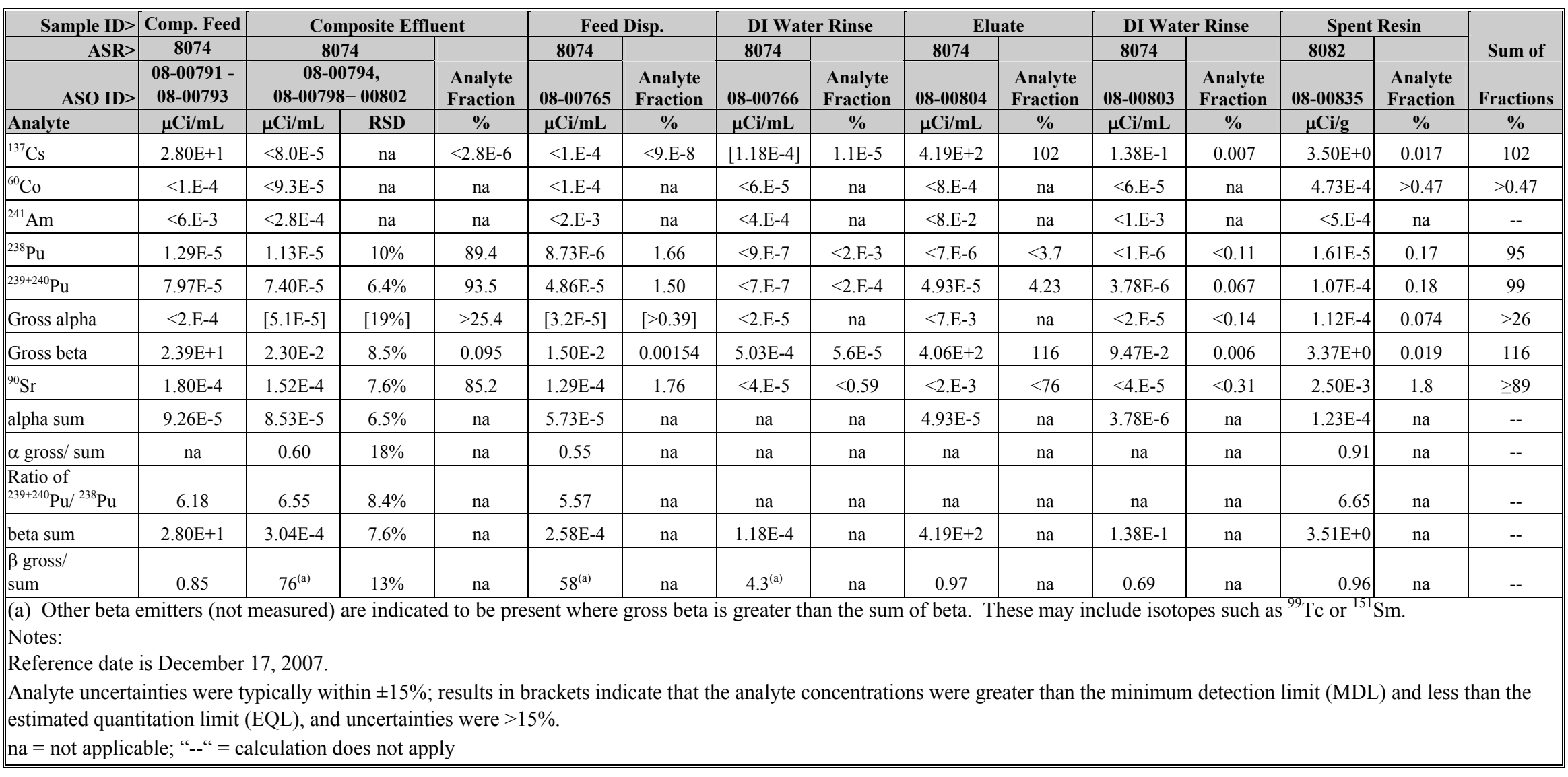


The WTP design-basis residual Cs content in spent resin was determined to be $4.2 \mu \mathrm{g} / \mathrm{g}$ in the spherical RF, allowing for safe handling of the spent resin (Burgeson et al. 2004). The total Cs concentration on the resin following the elution with $14.3 \mathrm{BVs}$ of $0.5 \mathrm{M} \mathrm{HNO}_{3}$ and the rinse with $2.9 \mathrm{BV}$ of DI water was $0.23 \mathrm{~g}$ Cs per $\mathrm{g}$ dry $\mathrm{H}$-form resin, $\sim 5 \%$ of the design-basis limit.

The total spent-resin $\mathrm{Pu}$ activity was $0.12 \mathrm{nCi} / \mathrm{g}$, and the ${ }^{241} \mathrm{Am}$ activity was $<0.6 \mathrm{nCi} / \mathrm{g}$ (dry mass basis). The activity sum of alpha emitters was well below the $100-\mathrm{nCi} / \mathrm{g}$ threshold that defines TRU waste.

Chromium was found on the spent resin at $260 \mu \mathrm{g} / \mathrm{g}$, lower than the $338 \mu \mathrm{g} / \mathrm{g}$ found in previous testing (Fiskum et al. 2006c). This analyte is significant since it is listed under the Resource Conservation and Recovery Act (RCRA) as an analyte of concern (along with $\mathrm{Ag}, \mathrm{As}, \mathrm{Ba}, \mathrm{Cd}, \mathrm{Pb}, \mathrm{Se}$, and $\mathrm{Hg}$ ). Should the entire $\mathrm{Cr}$ quantity be successfully leached from the resin into the aqueous phase under a standard toxicity characteristics leach procedure (TCLP) (EPA SW-846, Method 1311), the spent resin would fail the land-disposal regulation requirement. Note that a properly conducted TCLP test requires $\sim 100 \mathrm{~g}$ resin to provide a definitive evaluation basis and would not be well-accommodated in small-scale laboratory testing with actual tank waste.

Silver (opportunistic analyte) was not detected in the feed but was detected in the eluate and resin. ${ }^{(a)}$ It appeared to have some affinity for the resin; $\geq 20 \%$ was found in the combined eluate, water rinse, and resin. Like $\mathrm{Cs}$, it also exists in the +1 oxidation state and thus may exchange onto the resin similarly to Cs. An evaluation of the Ag concentration on the resin $(12.7 \mu \mathrm{g} / \mathrm{g})$ showed that even if all of it leached in the TCLP test, it would remain below the threshold concentration for land-disposal regulatory limit.

\subsubsection{Total Dissolved Solids}

Table 5.12 shows the total dissolved solids (TDS) content in the feed, the sixth (final) effluent composite, feed displacement, and water rinse following feed displacement. The water content in the process solutions can be derived from the TDS (100\% - TDS) and can be used to support engineering calculations. There was no statistically significant difference between the composite feeds and the effluent composite results. The step-wise difference in the feed displacement and water rinse was consistent with the process considerations.

Table 5.12. Total Dissolved Solids Content in Process Solutions

\begin{tabular}{||l|l|c|c||}
\hline Sample Description & Sample ID & $\begin{array}{c}\text { TDS } \\
\text { wt \% }\end{array}$ & $\begin{array}{c}\text { Density, g/mL } \\
\left.\text { (T= 24 }{ }^{\circ} \mathbf{C}\right)\end{array}$ \\
\hline Feed Composite A & $08-00791$ & 20.8 & 1.192 \\
\hline Feed Composite B & $08-00792$ & 21.5 & 1.197 \\
\hline Feed Composite C & $08-00793$ & 20.2 & 1.179 \\
\hline Final effluent composite & $08-00794$ & 20.4 & 1.201 \\
\hline Feed displacement & $08-00795$ & 14.5 & 1.141 \\
\hline $\begin{array}{l}\text { Water rinse after feed } \\
\text { displacement }\end{array}$ & $08-00796$ & 0.16 & 1.005 \\
\hline \hline
\end{tabular}

(a) Silver is a ${ }^{235} \mathrm{U}$ fission product; ${ }^{107} \mathrm{Ag}$ fission yield is $0.146 \%$ and ${ }^{109} \mathrm{Ag}$ fission yield is $0.031 \%$. 


\subsection{Evaporation and Concentration}

This section describes the evaporator feeds, the evaporation processing, and the postevaporation solid and liquid compositions. ${ }^{\text {(a) }}$ The processes covered in this section in relation to the whole demonstration test are shown in bold in Figure 6.1.



Figure 6.1. Pretreatment Operations with Evaporation Supporting the Demonstration Test

Figure 6.2 summarizes the specific evaporation and post-evaporation processing steps. Characterization testing is shown to the right in the figure. Linkages between this test sequence and previous process steps (CUF and ion exchange) are also shown. These process steps are discussed in detail in the following sections.

(a) Processing was conducted according to TI-RPP-WTP-525, Evaporation Testing for the Pretreatment Demonstration, SK Fiskum, 1/29/08. 


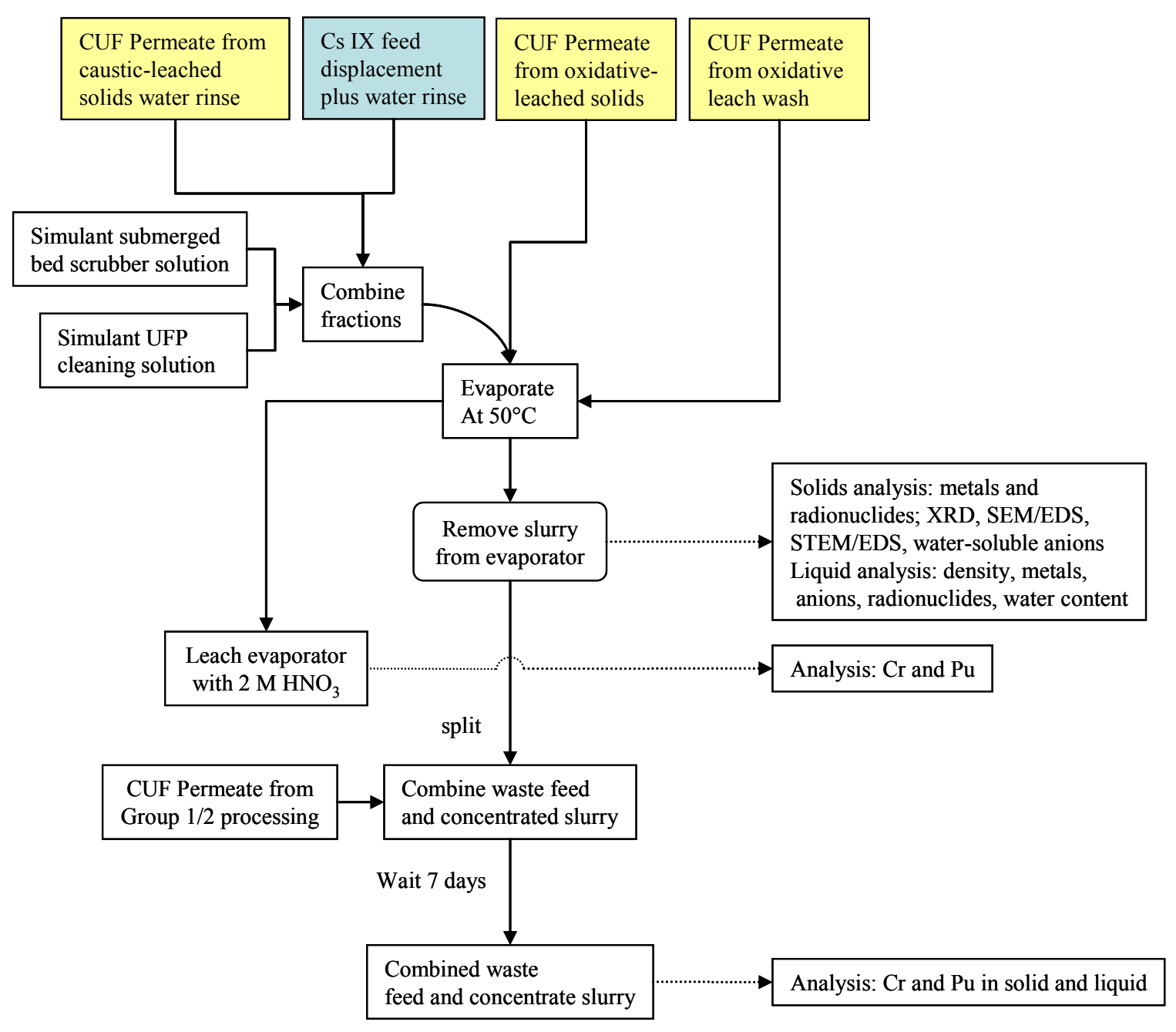

Figure 6.2. Evaporation Process Steps Supporting the Demonstration Test

\subsection{Evaporator Feeds}

Table 6.1 shows the targeted process streams that will be submitted to the FEP. Only selected process feeds were included for the current testing, and these are indicated by numerical fractional volumes in Table 6.1. Several WTP evaporator feeds were specifically omitted from the current test because they were not available as part of the demonstration test, not available as simulants, and/or are not significant contributors to the evaporation test outcomes; these process streams are shaded in Table 6.1. The ultrafiltration process (UFP) cleaning solution was prepared as a simulant; ${ }^{(a)}$ the submerged bed scrubber (SBS) simulant was prepared by Vitreous State Laboratory (VSL) (obtained via the Savannah River National Laboratory (SRNL) from previous testing campaigns).

(a) UFP cleaning solution simulant concurrence request letter WTP/RPP-MOA-PNNL-00091 from GH Beeman to HR Hazen, 4/4/07. 
Table 6.1. Fractional Feed Process Streams to the Demonstration Test FEP (Evaporator)

\begin{tabular}{|c|c|c|c|}
\hline \multirow[b]{2}{*}{ Process Feed Description } & \multirow[b]{2}{*}{ Source } & \multicolumn{2}{|c|}{ Fractional Volumes to the FEP ${ }^{(a)}$} \\
\hline & & $\begin{array}{c}\text { Acid/Alkaline } \\
\text { Effluent } \\
\text { Vessels }^{(\mathbf{b})}\end{array}$ & $\begin{array}{c}\text { Plant Wash } \\
\text { Vessel }^{(\mathbf{c})}\end{array}$ \\
\hline Cs ion exchange feed displacement & Cs IX & 0.00735 & \\
\hline Cs ion exchange water rinse & Cs IX & 0.00735 & \\
\hline Condenser condensate & $\mathrm{NA}^{(\mathrm{d})}$ & & \\
\hline UFP cleaning solution & Simulant $^{(\mathrm{e})}$ & 0.0492 & \\
\hline Water wash filtrates (caustic leach) & CUF & 0.3714 & \\
\hline Oxidative leach filtrate & CUF & 0.1463 & \\
\hline Water wash filtrates (oxidative leach) & CUF & 0.4018 & \\
\hline Submerged bed scrubber & Simulant ${ }^{(\mathrm{f})}$ & & 0.0166 \\
\hline HLW canister decontamination solution & $\mathrm{NA}^{(\mathrm{d})}$ & & \\
\hline $\begin{array}{l}\text { Pretreatment vessel vents scrubber condensate } \\
\text { Liquid effluent pretreatment high-efficiency mist } \\
\text { eliminator }\end{array}$ & $\begin{array}{l}\mathrm{NA}^{(\mathrm{d})} \\
\mathrm{NA}^{(\mathrm{d})}\end{array}$ & & \\
\hline Liquid effluent from reverse flow diverter & $\mathrm{NA}^{(\mathrm{d})}$ & & \\
\hline Spent resin flush & $\mathrm{NA}^{(\mathrm{d})}$ & & \\
\hline \multicolumn{4}{|c|}{$\begin{array}{l}\text { (a) Fractional volumes were provided by J Reynolds (personal communication to S Fiskum, 3/28/07) and } \\
\text { were based on formulation provided by R Carter and J Bernards, 2007. Steady-State Flowsheet (AES) } \\
\text { Model Version } 4.1 \text { Verification and Validation Report. 24590-WTP-VV-PO-06-001, Rev. 0. Bechtel } \\
\text { National Inc., Richland, WA. } \\
\text { (b) Representative of PWD-VSL-00015/16. } \\
\text { (c) Representative of PWD-VSL-00044. } \\
\text { (d) Not applicable, not added per direction from the test plan. } \\
\text { (e) Simulant solution prepared in-house. } \\
\text { (f) Simulant solution prepared by VSL and provided by SRNL. Formulation and history were reported } \\
\text { previously (WSRC-TR-2004-00478). }\end{array}$} \\
\hline
\end{tabular}

Selected feed components were combined as shown in Figure 6.3 and Figure 6.4 into two sub-composites, TI525-EvFA and TI525-EvFB. Component volumes were determined from transferred masses and solution densities. The sub-composite analyte concentrations were calculated from the individual input component concentrations. 


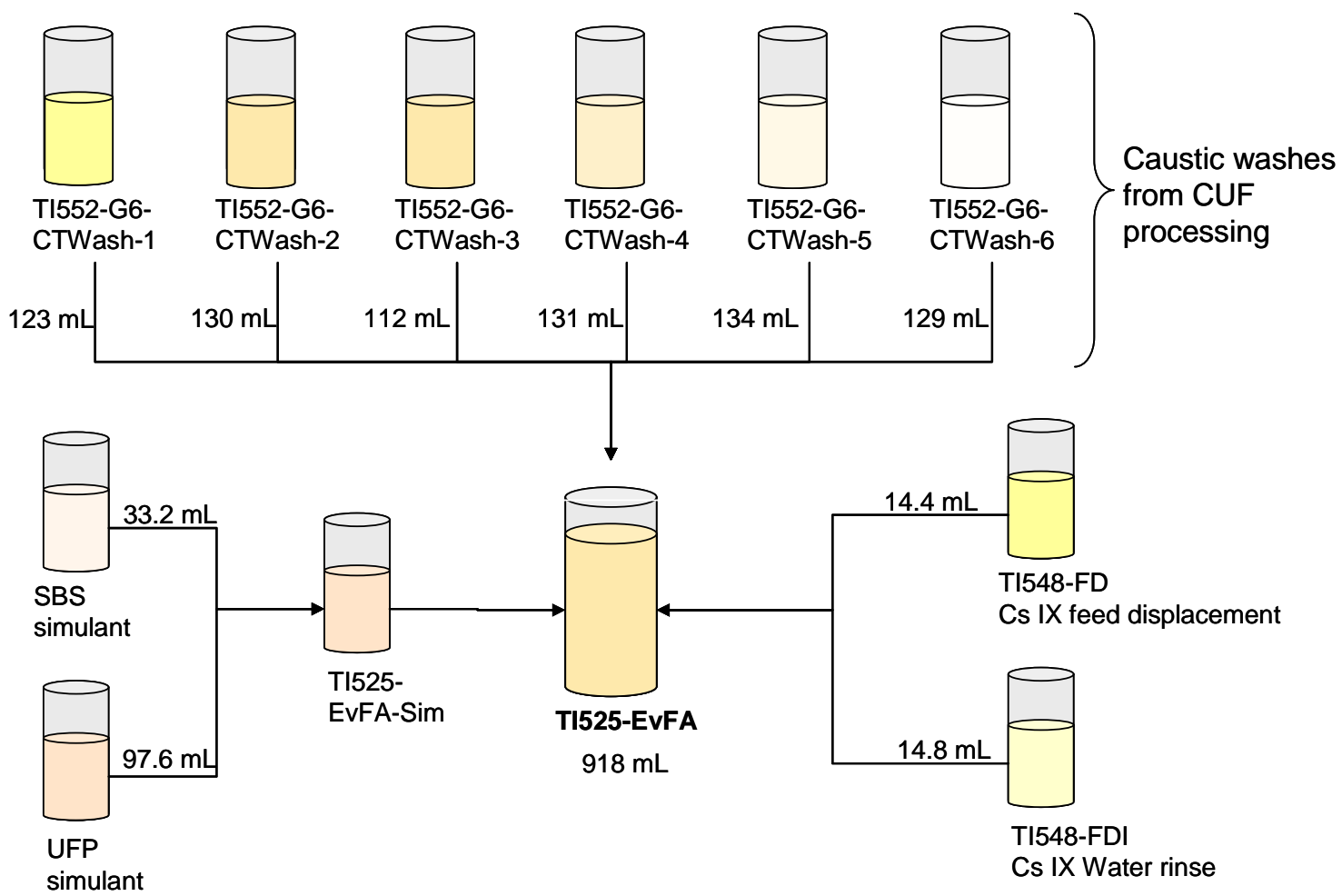

Figure 6.3. Preparation of Composite Feed TI525-EvFA

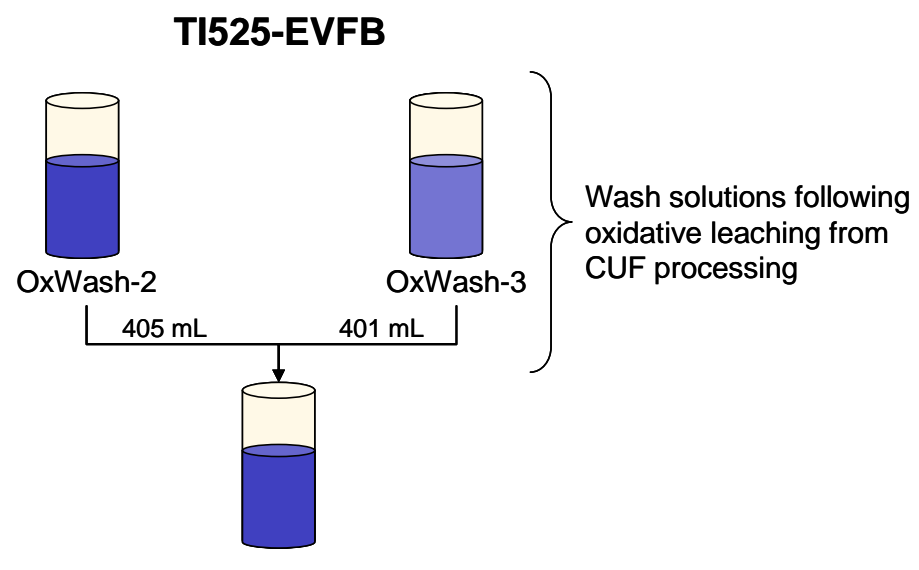

TI525-EvFB

Figure 6.4. Preparation of Composite Feed TI525-EvFB

Table 6.1 defines a variety of evaporator feed sources. In this test, the OxWash-1 represented the oxidative leach filtrate (which contained the first wash solution), TI525-EvFB represented the water wash filtrates from the oxidative leach, and TI525-EvFA represented all other evaporator feed components. Figure 6.5 depicts how these components were transferred to the evaporator. Maintaining these evaporator feeds as separate components was dictated by two paradigms: weight restrictions on the manipulators and avoidance of unwanted potential precipitation reactions outside of the evaporator. 


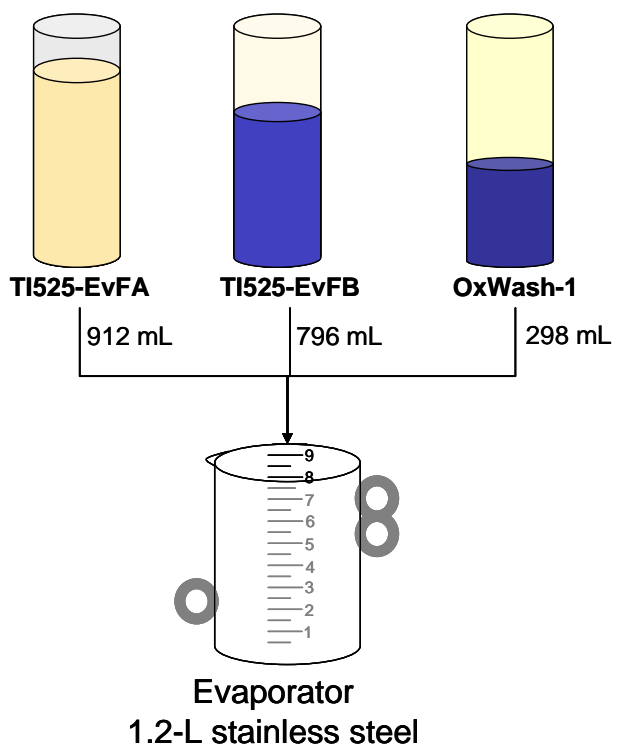

Figure 6.5. Component Evaporator Feeds

The measured and calculated evaporator feed composite compositions are shown in Table 6.2 in terms of total $\mu \mathrm{Ci}$ and $\mu \mathrm{Ci} / \mathrm{mL}$ and Table 6.3 in terms of total micrograms and molarity. Most of the feed bottle contents were successfully transferred to the evaporator as determined by net mass of the emptied bottles.

Table 6.2. Radionuclide Composition of the Evaporator Feed Components

\begin{tabular}{|c|c|c|c|c|c|}
\hline \multirow{4}{*}{$\begin{array}{l}\text { Sample ID> } \\
\text { Wt\% Transferred }> \\
\text { Analyte }\end{array}$} & \multirow{4}{*}{$\begin{array}{c}\text { Calculated } \\
\text { TI525-EvFA } \\
99.3 \\
\mathrm{uCi}\end{array}$} & \multirow{4}{*}{$\begin{array}{c}\text { Calculated } \\
\text { TI525-EvFB } \\
98.7 \\
\mu \mathrm{Ci} \\
\end{array}$} & \multirow{4}{*}{$\begin{array}{c}\text { Measured } \\
\text { OxWash-1 } \\
97.8 \\
\mu \mathrm{Ci} \\
\end{array}$} & \multirow{3}{*}{\multicolumn{2}{|c|}{$\begin{array}{c}\text { Calculated Composite } \\
\text { Composition }\end{array}$}} \\
\hline & & & & & \\
\hline & & & & & \\
\hline & & & & $\mu \mathrm{Ci}$ & $\mu \mathrm{Ci} / \mathrm{mL}$ \\
\hline${ }^{137} \mathrm{Cs}$ & $4.69 \mathrm{E}+3$ & $3.42 \mathrm{E}+2$ & $2.35 \mathrm{E}+2$ & $5.16 \mathrm{E}+3$ & $2.57 \mathrm{E}+0$ \\
\hline${ }^{60} \mathrm{Co}$ & $<5$.E-2 & $<5$.E-2 & $<2$.E-2 & $<1 . \mathrm{E}-1$ & $<6$.E-5 \\
\hline${ }^{241} \mathrm{Am}$ & $<3 . \mathrm{E}+0$ & $<7$. E-1 & $<3$. E-1 & $<4 . \mathrm{E}+0$ & $<2$.E-3 \\
\hline${ }^{238} \mathrm{Pu}$ & $6.78 \mathrm{E}-3$ & $5.48 \mathrm{E}-3$ & $2.88 \mathrm{E}-3$ & $1.49 \mathrm{E}-2$ & $7.45 \mathrm{E}-6$ \\
\hline${ }^{239+240} \mathrm{Pu}$ & $3.22 \mathrm{E}-2$ & $1.82 \mathrm{E}-2$ & $1.19 \mathrm{E}-2$ & $6.13 \mathrm{E}-2$ & $3.06 \mathrm{E}-5$ \\
\hline Gross alpha & $<3 . \mathrm{E}+0$ & $<2$.E-1 & $<9 . \mathrm{E}-2$ & $<3 . \mathrm{E}+0$ & $<2$.E-3 \\
\hline Gross beta & $4.35 \mathrm{E}+3$ & $3.55 \mathrm{E}+2$ & $2.44 \mathrm{E}+2$ & $4.85 \mathrm{E}+3$ & $2.42 \mathrm{E}+0$ \\
\hline${ }^{90} \mathrm{Sr}$ & $6.29 \mathrm{E}+0$ & $1.02 \mathrm{E}+1$ & $2.73 \mathrm{E}+0$ & $1.90 \mathrm{E}+1$ & $9.45 \mathrm{E}-3$ \\
\hline Sum of alpha & $3.90 \mathrm{E}-2$ & $2.37 \mathrm{E}-2$ & $1.48 \mathrm{E}-2$ & $7.62 \mathrm{E}-2$ & $3.80 \mathrm{E}-5$ \\
\hline $\begin{array}{l}\text { Isotopic ratio of } \\
{ }^{239+240} \mathrm{Pu} /{ }^{238} \mathrm{Pu} \\
\end{array}$ & 4.74 & 3.32 & 4.14 & 4.11 & 4.11 \\
\hline Sum of beta & $5.12 \mathrm{E}+0$ & 4.49E-1 & $7.91 \mathrm{E}-1$ & $5.19 \mathrm{E}+3$ & $2.59 \mathrm{E}+0$ \\
\hline$\beta$ gross/sum & 0.93 & 0.98 & 1.02 & 0.93 & 0.93 \\
\hline
\end{tabular}


Table 6.3. Chemical Composition of the Evaporator Feed Components

\begin{tabular}{|c|c|c|c|c|c|}
\hline \multirow{4}{*}{$\begin{array}{l}\text { Sample ID }> \\
\text { Wt\% transferred }> \\
\text { Analyte }\end{array}$} & \multirow{4}{*}{\begin{tabular}{|c|} 
Calculated \\
TI525-EvFA \\
99.3 \\
$\mu \mathrm{g}$ \\
\end{tabular}} & \multirow{4}{*}{$\begin{array}{c}\text { Calculated } \\
\text { TI525-EvFB } \\
98.7 \\
\mu \mathrm{g}\end{array}$} & \multirow{4}{*}{$\begin{array}{c}\text { Measured } \\
\text { OxWash-1 } \\
97.8 \\
\mu \mathrm{g} \\
\end{array}$} & \multirow{3}{*}{\multicolumn{2}{|c|}{$\begin{array}{l}\text { Calculated } \\
\text { Composite } \\
\text { Composition } \\
\end{array}$}} \\
\hline & & & & & \\
\hline & & & & & \\
\hline & & & & $\mu \mathrm{g}$ & $\mathbf{M}$ \\
\hline $\mathrm{Al}$ & $2.05 \mathrm{E}+6$ & $1.81 \mathrm{E}+5$ & $6.67 \mathrm{E}+4$ & $2.26 \mathrm{E}+6$ & 4.17E-2 \\
\hline $\mathrm{B}$ & {$[2.1 \mathrm{E}+4]$} & $<1.5 \mathrm{E}+3$ & $<5.4 \mathrm{E}+2$ & {$[2.0 \mathrm{E}+4]$} & [9.3E-4] \\
\hline $\mathrm{Bi}$ & $1.83 \mathrm{E}+4$ & $<1.8 \mathrm{E}+3$ & {$[1.3 \mathrm{E}+3]$} & $1.92 \mathrm{E}+4$ & 4.59E-5 \\
\hline $\mathrm{Cd}$ & $4.28 \mathrm{E}+3$ & {$[1.9 \mathrm{E}+2]$} & $<7.1 \mathrm{E}+1$ & $4.38 \mathrm{E}+3$ & $1.94 \mathrm{E}-5$ \\
\hline $\mathrm{Cr}$ & $9.02 \mathrm{E}+4$ & $8.87 \mathrm{E}+5$ & $7.12 \mathrm{E}+5$ & $1.67 \mathrm{E}+6$ & $1.60 \mathrm{E}-2$ \\
\hline $\mathrm{Fe}$ & $2.76 \mathrm{E}+5$ & $<1.6 \mathrm{E}+3$ & $<6.0 \mathrm{E}+2$ & $2.70 \mathrm{E}+5$ & $2.41 \mathrm{E}-3$ \\
\hline $\mathrm{K}$ & $6.10 \mathrm{E}+4$ & {$[2.7 \mathrm{E}+4]$} & {$[1.8 \mathrm{E}+4]$} & {$[1.0 \mathrm{E}+5]$} & [1.3E-3] \\
\hline $\mathrm{Mn}$ & $7.71 \mathrm{E}+4$ & $1.02 \mathrm{E}+6$ & $7.86 \mathrm{E}+5$ & $1.87 \mathrm{E}+6$ & $1.69 \mathrm{E}-2$ \\
\hline $\mathrm{Na}$ & $3.49 \mathrm{E}+7$ & $2.68 \mathrm{E}+6$ & $1.98 \mathrm{E}+6$ & $3.88 \mathrm{E}+7$ & $8.41 \mathrm{E}-1$ \\
\hline $\mathrm{Ni}$ & $4.81 \mathrm{E}+3$ & $<4.6 \mathrm{E}+2$ & $<1.7 \mathrm{E}+2$ & $4.71 \mathrm{E}+3$ & $4.00 \mathrm{E}-5$ \\
\hline $\mathrm{P}$ & $2.84 \mathrm{E}+5$ & {$[3.0 \mathrm{E}+4]$} & {$[1.4 \mathrm{E}+4]$} & $3.22 \mathrm{E}+5$ & $5.19 \mathrm{E}-3$ \\
\hline $\mathrm{S}$ & {$[1.1 \mathrm{E}+5]$} & $<2.6 \mathrm{E}+4$ & $<9.6 \mathrm{E}+3$ & {$[1.1 \mathrm{E}+5]$} & [1.7E-3] \\
\hline $\mathrm{Si}$ & $6.84 \mathrm{E}+4$ & {$[3.0 \mathrm{E}+3]$} & $<3.3 \mathrm{E}+2$ & $7.00 \mathrm{E}+4$ & $1.24 \mathrm{E}-3$ \\
\hline $\mathrm{Sr}$ & $3.36 \mathrm{E}+2$ & $<1.4 \mathrm{E}+1$ & $<5.0 \mathrm{E}+0$ & $3.29 \mathrm{E}+2$ & $1.87 \mathrm{E}-6$ \\
\hline $\mathrm{U}$ & $<7.0 \mathrm{E}+3$ & $<6.7 \mathrm{E}+3$ & $<2.5 \mathrm{E}+3$ & $<1.6 \mathrm{E}+4$ & $<3.3 \mathrm{E}-5$ \\
\hline $\mathrm{Zn}$ & $5.63 \mathrm{E}+3$ & $<4.5 \mathrm{E}+2$ & $<1.7 \mathrm{E}+2$ & $5.51 \mathrm{E}+3$ & $4.20 \mathrm{E}-5$ \\
\hline $\mathrm{Zr}$ & $1.93 \mathrm{E}+3$ & $<6.5 \mathrm{E}+2$ & $<2.4 \mathrm{E}+2$ & $1.88 \mathrm{E}+3$ & $1.03 \mathrm{E}-5$ \\
\hline U KPA & $2.27 \mathrm{E}+3$ & $9.54 \mathrm{E}+1$ & mbined & $2.35 \mathrm{E}+3$ & $4.92 \mathrm{E}-6$ \\
\hline nitrite & $2.52 \mathrm{E}+6$ & $<5.6 \mathrm{E}+1$ & mbined & $2.50 \mathrm{E}+6$ & $2.71 \mathrm{E}-2$ \\
\hline nitrate & $8.32 \mathrm{E}+6$ & $8.83 \mathrm{E}+5$ & mbined & $9.13 \mathrm{E}+6$ & $7.34 \mathrm{E}-2$ \\
\hline phosphate & $9.18 \mathrm{E}+5$ & {$[8.88+4$} & mbined & $1.00 \mathrm{E}+6$ & $5.25 \mathrm{E}-3$ \\
\hline sulfate & $4.72 \mathrm{E}+5$ & {$[4.66 \mathrm{E}+4$} & mbined & $5.14 \mathrm{E}+5$ & $2.67 \mathrm{E}-3$ \\
\hline oxalate & $1.27 \mathrm{E}+6$ & $3.34 \mathrm{E}+5$ & mbined & $1.59 \mathrm{E}+6$ & $9.01 \mathrm{E}-3$ \\
\hline free hydroxide & $2.08 \mathrm{E}+7$ & & $/ \mathrm{a}$ & $2.04 \mathrm{E}+7$ & $5.98 \mathrm{E}-1$ \\
\hline TOC as $\mathrm{C}$ & & & $1 / \mathrm{a}$ & & \\
\hline TIC as C & & & $/ \mathrm{a}$ & & \\
\hline Opportunistic Anal & & & & & \\
\hline $\mathrm{F}$ & $1.96 \mathrm{E}+4$ & $1.64 \mathrm{E}+4$ & mbined & $3.58 \mathrm{E}+4$ & $9.40 \mathrm{E}-4$ \\
\hline $\mathrm{Ag}$ & $<3.5 \mathrm{E}+2$ & $<3.4 \mathrm{E}+2$ & $<1.2 \mathrm{E}+2$ & $<8.0 \mathrm{E}+2$ & $<3.7 \mathrm{E}-6$ \\
\hline As & $<6.4 \mathrm{E}+3$ & $<5.6 \mathrm{E}+3$ & $<2.1 \mathrm{E}+3$ & $<1.4 \mathrm{E}+4$ & $<9.2 \mathrm{E}-5$ \\
\hline $\mathrm{Ba}$ & $<2.7 \mathrm{E}+2$ & $<2.7 \mathrm{E}+2$ & $<1.0 \mathrm{E}+2$ & $<6.4 \mathrm{E}+2$ & $<2.3 \mathrm{E}-6$ \\
\hline $\mathrm{Be}$ & {$[1.4 \mathrm{E}+1]$} & $<9.7 \mathrm{E}+0$ & $<3.6 \mathrm{E}+0$ & {$[1.4 \mathrm{E}+1]$} & [7.5E-7] \\
\hline $\mathrm{Ca}$ & $2.67 \mathrm{E}+4$ & {$[2.5 \mathrm{E}+3]$} & {$[9.4 \mathrm{E}+2]$} & $2.96 \mathrm{E}+4$ & $3.68 \mathrm{E}-4$ \\
\hline $\mathrm{Ce}$ & $<1.0 \mathrm{E}+3$ & $<9.6 \mathrm{E}+2$ & $<3.5 \mathrm{E}+2$ & $<2.3 \mathrm{E}+3$ & $<8.1 \mathrm{E}-6$ \\
\hline $\mathrm{Co}$ & $<3.3 \mathrm{E}+2$ & $<3.1 \mathrm{E}+2$ & $<1.1 \mathrm{E}+2$ & $<7.4 \mathrm{E}+2$ & $<6.3 \mathrm{E}-6$ \\
\hline $\mathrm{Cu}$ & $<7.1 \mathrm{E}+2$ & $<3.9 \mathrm{E}+2$ & $<1.4 \mathrm{E}+2$ & $<1.2 \mathrm{E}+3$ & $<9.5 \mathrm{E}-6$ \\
\hline Dy & $<2.9 \mathrm{E}+2$ & $<2.8 \mathrm{E}+2$ & $<1.0 \mathrm{E}+2$ & $<6.7 \mathrm{E}+2$ & $<2.0 \mathrm{E}-6$ \\
\hline $\mathrm{Eu}$ & $<9.2 \mathrm{E}+1$ & $<8.7 \mathrm{E}+1$ & $<3.2 \mathrm{E}+1$ & $<2.1 \mathrm{E}+2$ & $<6.8 \mathrm{E}-7$ \\
\hline
\end{tabular}


Table 6.3 (contd)

\begin{tabular}{|c|c|c|c|c|c|}
\hline \multirow{4}{*}{\begin{tabular}{l}
\multicolumn{1}{c}{ Sample ID> } \\
Wt\% transferred $>$ \\
Analyte
\end{tabular}} & \multirow{4}{*}{$\begin{array}{c}\text { Calculated } \\
\text { TI525-EvFA } \\
99.3 \\
\mu \mathrm{g} \\
\end{array}$} & \multirow{4}{*}{$\begin{array}{c}\text { Calculated } \\
\text { TI525-EvFB } \\
98.7 \\
\mu \mathrm{g} \\
\end{array}$} & \multirow{4}{*}{$\begin{array}{c}\text { Measured } \\
\text { OxWash-1 } \\
97.8 \\
\mu \mathrm{g}\end{array}$} & \multirow{3}{*}{\multicolumn{2}{|c|}{$\begin{array}{l}\text { Calculated } \\
\text { Composite } \\
\text { Composition } \\
\end{array}$}} \\
\hline & & & & & \\
\hline & & & & & \\
\hline & & & & $\mu \mathrm{g}$ & $\mathbf{M}$ \\
\hline $\mathrm{La}$ & {$[1.5 \mathrm{E}+2]$} & $<1.1 \mathrm{E}+2$ & {$[6.1 \mathrm{E}+1]$} & $<3.1 \mathrm{E}+2$ & $<1.1 \mathrm{E}-6$ \\
\hline $\mathrm{Li}$ & {$[4.2 \mathrm{E}+2]$} & $<4.4 \mathrm{E}+2$ & {$[2.4 \mathrm{E}+2]$} & {$[6.6 \mathrm{E}+2]$} & [4.7E-5] \\
\hline $\mathrm{Mg}$ & $1.90 \mathrm{E}+3$ & $<5.6 \mathrm{E}+2$ & $<2.1 \mathrm{E}+2$ & {$[1.9 \mathrm{E}+3]$} & {$[3.8 \mathrm{E}-5]$} \\
\hline Mo & $2.45 \mathrm{E}+3$ & {$[6.4 \mathrm{E}+2]$} & {$[2.6 \mathrm{E}+2]$} & $4.07 \mathrm{E}+3$ & $2.12 \mathrm{E}-5$ \\
\hline $\mathrm{Nd}$ & $<3.1 \mathrm{E}+3$ & $<1.4 \mathrm{E}+3$ & $<5.1 \mathrm{E}+2$ & $<4.9 \mathrm{E}+3$ & $<1.7 \mathrm{E}-5$ \\
\hline $\mathrm{Pb}$ & $<3.1 \mathrm{E}+3$ & $<3.0 \mathrm{E}+3$ & $<1.1 \mathrm{E}+3$ & $<7.1 \mathrm{E}+3$ & $<1.7 \mathrm{E}-5$ \\
\hline $\mathrm{Pd}$ & $<1.0 \mathrm{E}+3$ & $<1.0 \mathrm{E}+3$ & $<3.7 \mathrm{E}+2$ & $<2.4 \mathrm{E}+3$ & $<1.1 \mathrm{E}-5$ \\
\hline $\mathrm{Rh}$ & $<2.1 \mathrm{E}+3$ & $<2.0 \mathrm{E}+3$ & $<7.4 \mathrm{E}+2$ & $<4.8 \mathrm{E}+3$ & $<2.3 \mathrm{E}-5$ \\
\hline $\mathrm{Ru}$ & $<7.0 \mathrm{E}+2$ & $<6.6 \mathrm{E}+2$ & $<2.4 \mathrm{E}+2$ & $<1.6 \mathrm{E}+3$ & $<7.8 \mathrm{E}-6$ \\
\hline $\mathrm{Sb}$ & $<2.7 \mathrm{E}+3$ & $<4.3 \mathrm{E}+3$ & {$[3.0 \mathrm{E}+3]$} & $<9.9 \mathrm{E}+3$ & $<4.1 \mathrm{E}-5$ \\
\hline $\mathrm{Se}$ & $<5.4 \mathrm{E}+4$ & {$[1.1 \mathrm{E}+4]$} & $<1.4 \mathrm{E}+3$ & $<6.5 \mathrm{E}+4$ & $<4.1 \mathrm{E}-4$ \\
\hline $\mathrm{Sn}$ & $<1.7 \mathrm{E}+3$ & $<2.0 \mathrm{E}+3$ & {$[1.2 \mathrm{E}+3]$} & $<4.9 \mathrm{E}+3$ & $<2.1 \mathrm{E}-5$ \\
\hline $\mathrm{Ta}$ & $<1.1 \mathrm{E}+3$ & {$[1.1 \mathrm{E}+3]$} & $<3.9 \mathrm{E}+2$ & $<2.6 \mathrm{E}+3$ & $<7.2 \mathrm{E}-6$ \\
\hline $\mathrm{Te}$ & $<3.4 \mathrm{E}+3$ & $<2.5 \mathrm{E}+3$ & $<9.3 \mathrm{E}+2$ & $<6.7 \mathrm{E}+3$ & $<2.6 \mathrm{E}-5$ \\
\hline Th & $<9.8 \mathrm{E}+2$ & $<9.5 \mathrm{E}+2$ & $<3.5 \mathrm{E}+2$ & $<2.2 \mathrm{E}+3$ & $<4.8 \mathrm{E}-6$ \\
\hline $\mathrm{Ti}$ & {$[1.4 \mathrm{E}+2]$} & $<7.7 \mathrm{E}+1$ & $<2.8 \mathrm{E}+1$ & {$[1.4 \mathrm{E}+2]$} & [1.4E-6] \\
\hline $\mathrm{Tl}$ & {$[6.2 \mathrm{E}+3]$} & $<5.2 \mathrm{E}+3$ & $<1.9 \mathrm{E}+3$ & $<1.3 \mathrm{E}+4$ & $<3.2 \mathrm{E}-5$ \\
\hline $\mathrm{V}$ & {$[3.2 \mathrm{E}+2]$} & {$[2.8 \mathrm{E}+2]$} & $<9.3 \mathrm{E}+1$ & {$[5.8 \mathrm{E}+2]$} & [5.7E-6] \\
\hline $\mathrm{W}$ & {$[5.1 \mathrm{E}+3]$} & $<1.2 \mathrm{E}+3$ & $<4.4 \mathrm{E}+2$ & {$[5.0 \mathrm{E}+3]$} & [1.4E-5] \\
\hline $\mathrm{Y}$ & $<7.0 \mathrm{E}+1$ & $<6.8 \mathrm{E}+1$ & $<2.5 \mathrm{E}+1$ & $<1.6 \mathrm{E}+2$ & $<9.0 \mathrm{E}-7$ \\
\hline \multicolumn{6}{|c|}{$\begin{array}{l}\text { Analyte uncertainties were typically within } \pm 15 \% \text {; results in brackets indicate that the analyte } \\
\text { concentrations were greater than the minimum detection limit }(\mathrm{MDL}) \text { and less than the estimated } \\
\text { quantitation limit }(\mathrm{EQL}) \text {, and uncertainties were }>15 \% \text {. } \\
\text { Opportunistic analytes are reported for information only; QC requirements did not apply to these } \\
\text { analytes. } \\
\mathrm{n} / \mathrm{a}=\text { not analyzed }\end{array}$} \\
\hline
\end{tabular}

\subsection{Experimental}

The evaporation vessel, pictured in Figure 6.6, was a 1.2-L stainless steel beaker (modified for use with manipulators by welding finger rings on the exterior). It was equipped with a removable stainless steel ruler such that volume as a function of fluid level could be determined. The beaker was also equipped with a form-fitted, slotted lid used to protect the contents during non-evaporation times (overnight) while allowing the stirrer and thermocouple to remain in place. The solution was stirred with a 2-in stainless steel triple-bladed impeller mounted on a stainless steel shaft, which in turn was mounted to an overhead motor. The chemically resistant (PTFE) type-K thermocouple (Digi-Sense from Cole-Parmer, Vernon Hills, IL) was calibrated to an 
accuracy of $\pm 2^{\circ} \mathrm{C}$. The thermocouple and hot plate were connected to a Digi-Sense temperature controller to maintain a solution temperature of $50 \pm 2^{\circ} \mathrm{C}$.

The combined volume of the three feeds $(2.03 \mathrm{~L})$ was too large to be added at once to the evaporator. The three evaporator feeds (TI525-EvFA, TI525-EvFB, and OxWash 1) were poured into the evaporator in pro-rated quantities (by volume). As the volume decreased from evaporation, additional feed from each stock source was added again in pro-rated volume quantities.

a)

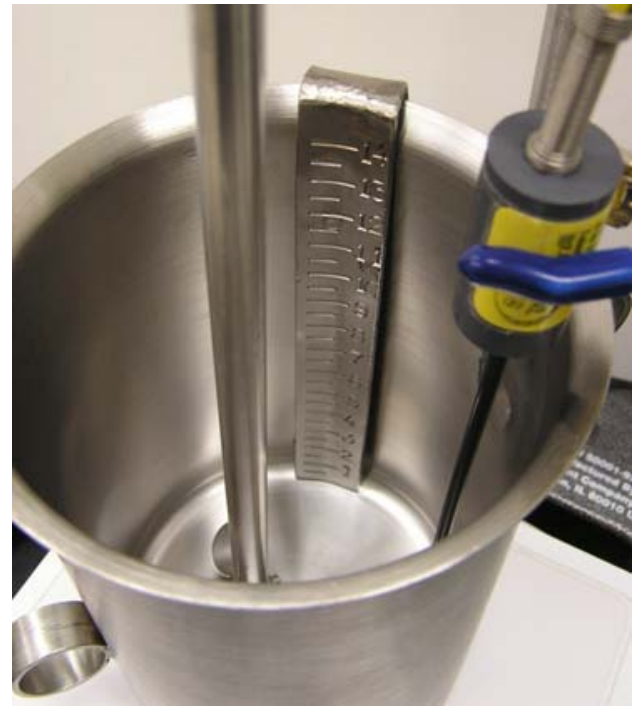

b)

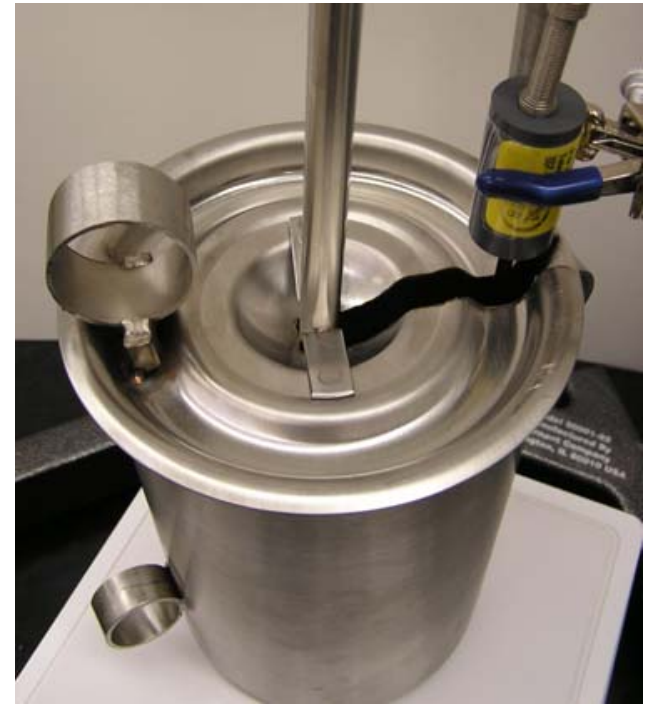

Figure 6.6. Evaporation Vessel Before Test a) with ruler in place, b) with cover in place

The heat/evaporation was initiated during the morning shift and continued through the day shift. The system was turned off and covered at night to mitigate the risk of the system going dry. The solution was mixed with the impeller during the evaporation process (day shift). Evaporation started on $3 / 25 / 08$ and continued through $4 / 7 / 08$, nominally an 80 -h total evaporation time. The target evaporated slurry volume was $340 \mathrm{~mL}$ to produce a $5 \mathrm{M} \mathrm{Na}$ supernatant solution.

The evaporated slurry (sample ID = TI525-EvConc) was transferred to a volume-graduated bottle to assess the total-slurry and settled-solids volumes. Efforts were made to quantitatively transfer the solids from the evaporator with the aqueous fraction. Despite repeated rinsing attempts with the aqueous fraction, some sludge residue remained in the evaporator and on the impeller. The aqueous component was still highly colored from permanganate, and thus, the interface with the settled-solids layer was difficult to discern. The total slurry volume of $296 \mathrm{~mL}$ $(359 \mathrm{~g})$ was recovered from the evaporator. The 5-day settled-solids volume was $<50 \mathrm{~mL}$.

The evaporator and impeller were irregularly coated with a dark sludge material as shown in Figure 6.7. The impeller shaft manifested rings associated with the repeated feed additions and evaporative concentrations. 

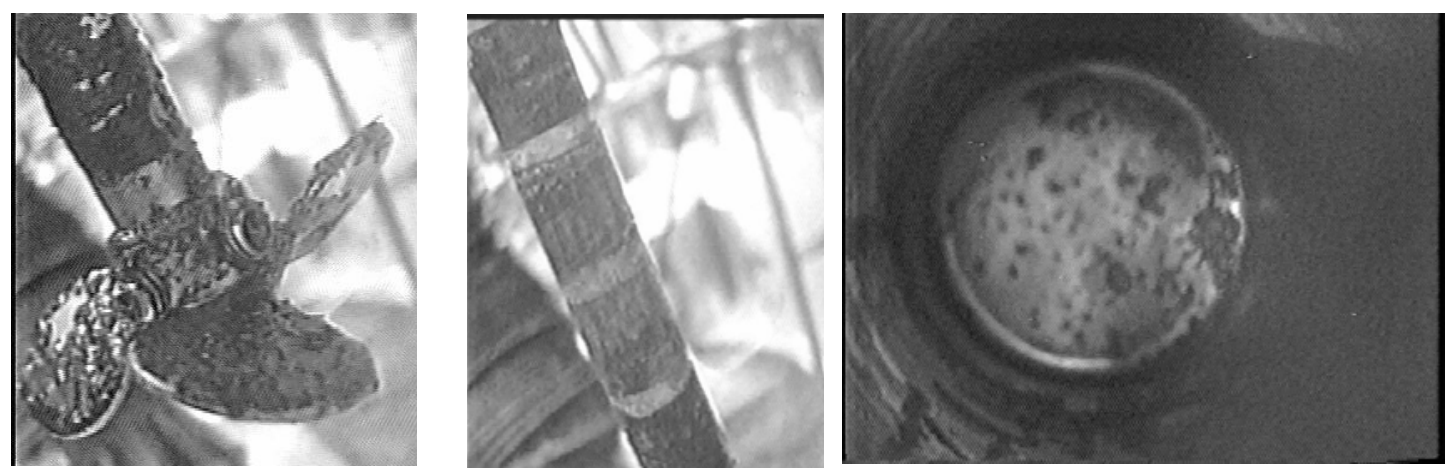

Figure 6.7. Sludge Coating the Impeller, Shaft, and Evaporator Post-Evaporation (Best available photographs)

A $600-\mathrm{mL}$ volume of $2 \mathrm{M} \mathrm{HNO}_{3}$ was added to the evaporator with the impeller in place. The contents were then heated to a sub-boiling temperature for $4 \mathrm{~h}$ in an effort to dissolve the residual sludge and any $\mathrm{Pu}$ that might have preferentially plated onto the stainless steel. The slotted cover was left in place to encourage refluxing. The acid leaching mixture was cooled, and the final volume of $471 \mathrm{~mL}(512 \mathrm{~g}$ ) was collected for analysis (sample ID = TI525-EL). The evaporator components were physically well cleaned as a result of the acid leach leaving very little residue (see Figure 6.8). The acidic leaching solution was colored light tan.

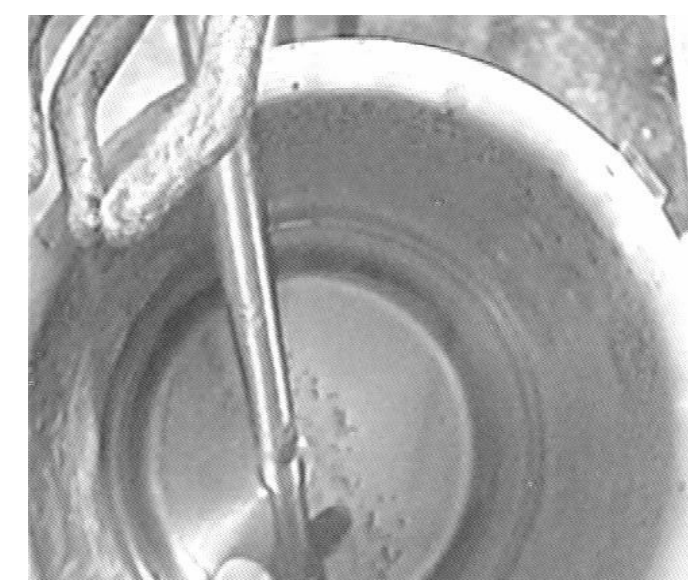

Figure 6.8. Acid-Leached Evaporator

The evaporator concentrate slurry (TI525-EvConc) was mixed with an overhead mixer to suspend solids and allow for subsampling. The material was split into six analytical fractions as shown in Figure 6.9. The initial analytical samples (1 and 2) each consisted of $13 \mathrm{~mL}$ of slurry, which ultimately did not provide sufficient solids for complete characterization. These washed solids were submitted for XRD and SEM analysis. Larger 25-mL slurry samples were taken to support the chemical characterization of the solids. An additional 20 -mL sample was filtered for direct solids analysis by XRD. 


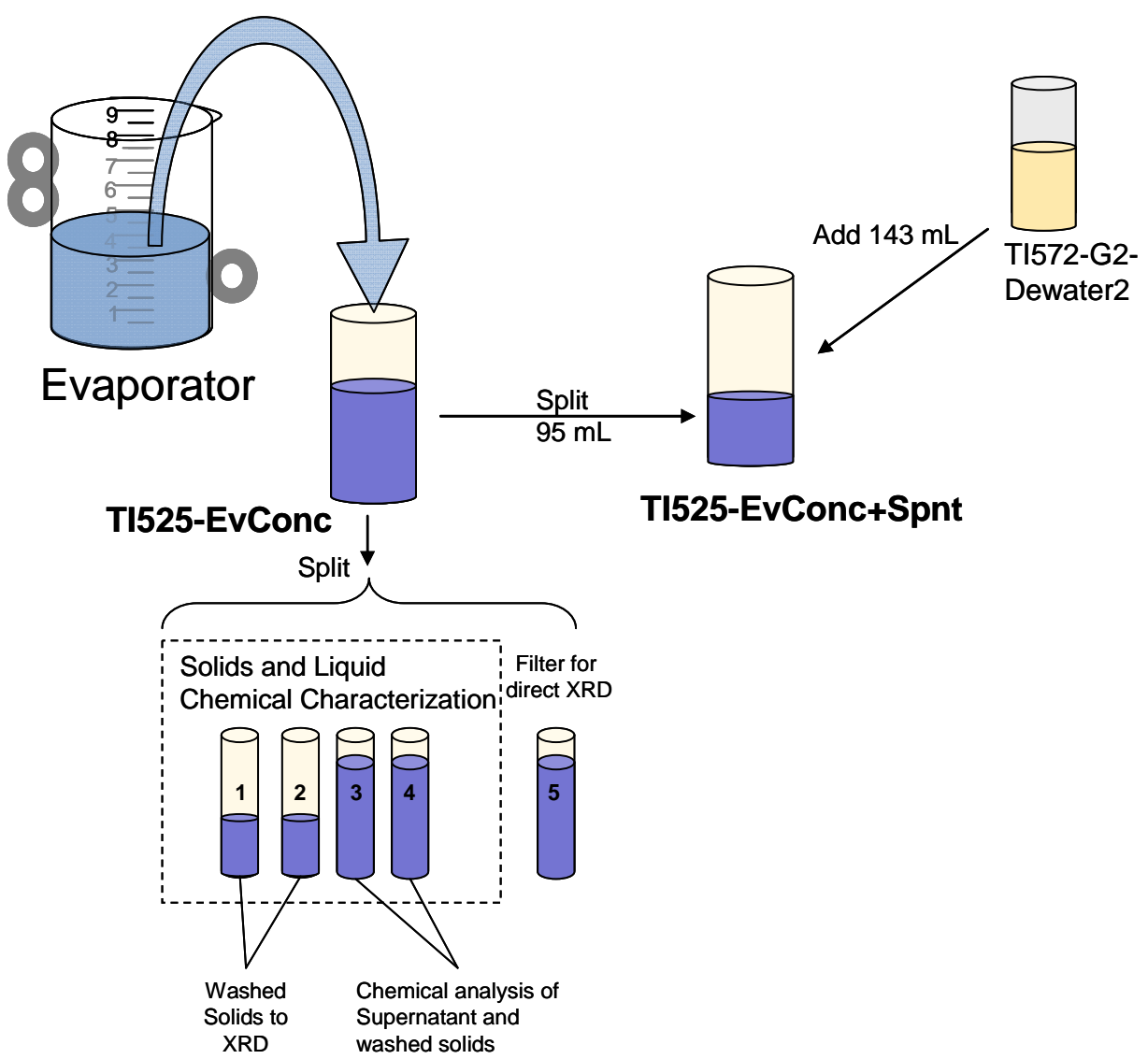

Figure 6.9. Processing and Splits of the Evaporator Concentrate, TI525-EvConc

A $95-\mathrm{mL}$ or $31 \mathrm{wt} \%$ split from TI525-EvConc was combined with $143 \mathrm{~mL}$ of Group 1 plus Group 2 (bismuth phosphate sludge and saltcake) supernatant (sample ID TI572-G2-Dewater2). ${ }^{(a)}$ This supernatant was produced as a result of CUF processing activity. ${ }^{(b)}$ The resulting slurry (labeled TI525-EvConc+Spnt) was mixed by shaking and allowed to stand for 7 days for observation. During the aging period, no additional color change in the supernatant was observed, and no additional precipitation could be discerned (see Figure 6.10). Processing of the aged TI525-EvConc+Spnt is shown in Figure 6.11.

(a) G.L. Lumetta. 2008. Group 1 and Group 2 draft report-WTP-RPT-166.

(b) R.Shimskey, private communication. 


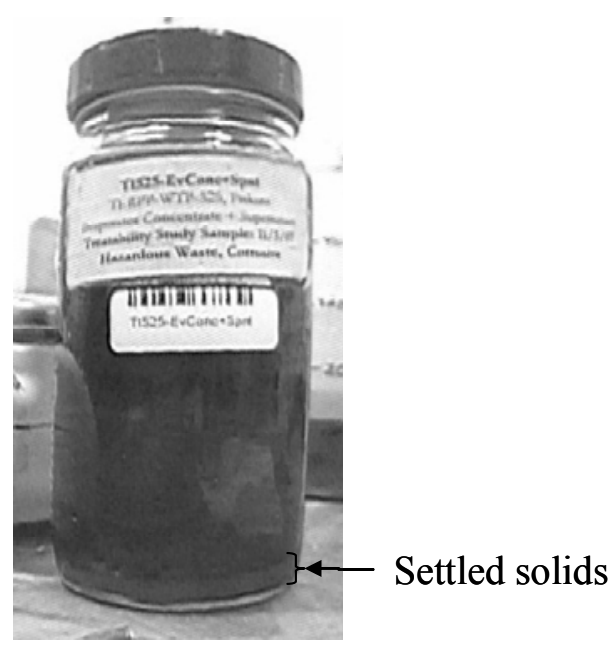

Figure 6.10. Aged (7-Day) Evaporator Concentrate Mixed with Supernatant (TI525-EvConc+Spnt)

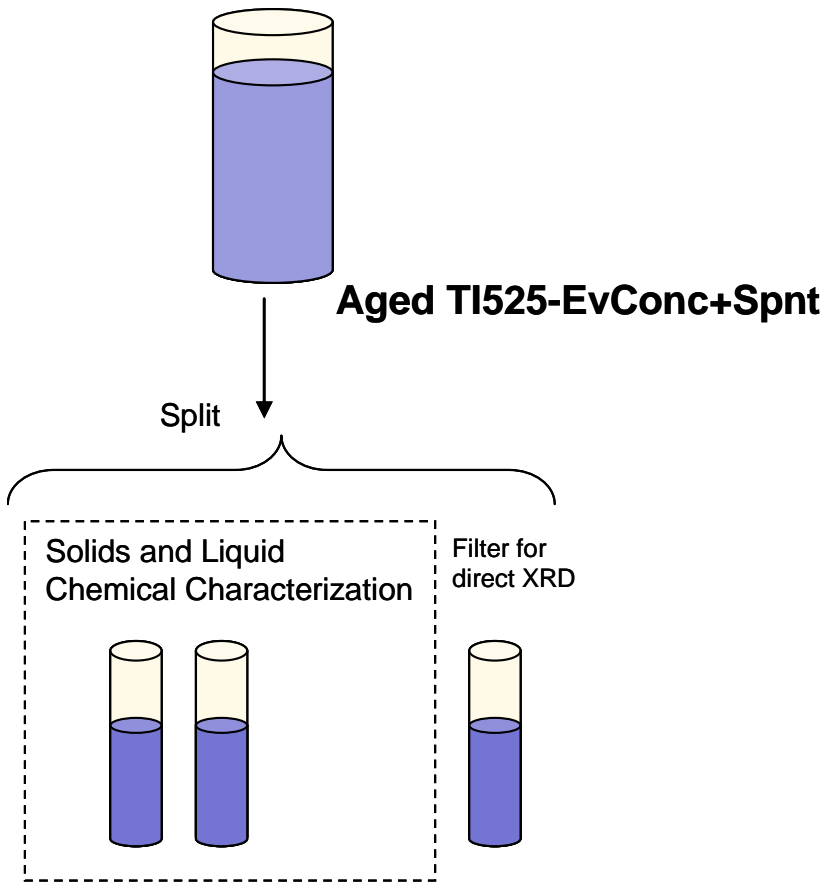

Figure 6.11. Processing of the Evaporator Concentrate Plus Supernatant

Figure 6.12 shows the analytical processing scheme applied to the slurry characterization samples. Extensive characterization was conducted in an effort to determine the supernatant and solids composition and close the material balance. Specific analytical methodologies are provided in Appendix A. 


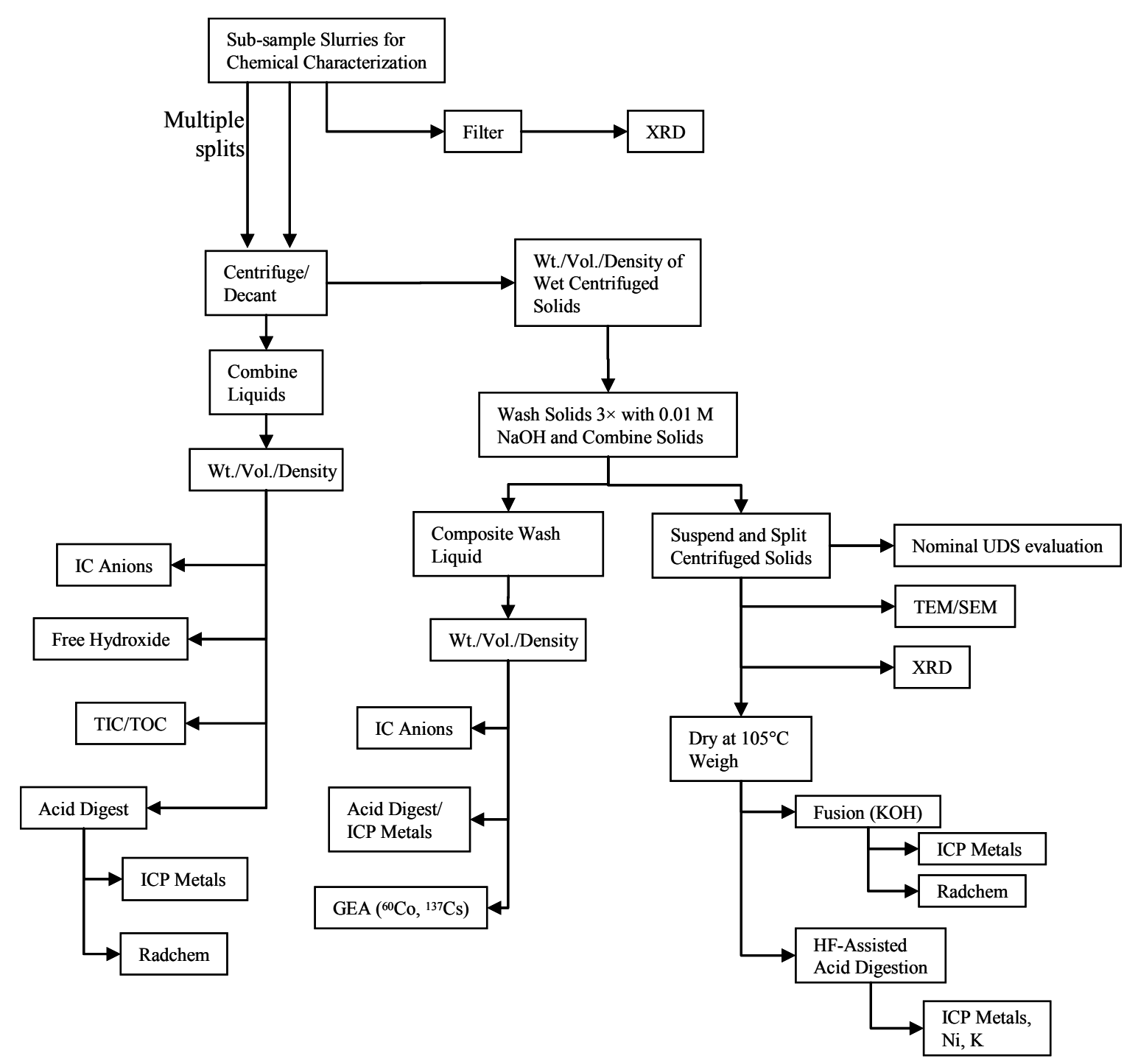

Figure 6.12. Analytical Processing Scheme for Slurry Characterization

\subsection{Results}

This section describes the characterization results and mass balances obtained for analytes through the evaporation process, evaporator leach process, and the combination of evaporator bottoms with tank waste supernatant.

\subsubsection{Physical Properties of Slurries}

Table 6.4 summarizes the measured physical properties and absolute uncertainties as well as the best estimate of total dry washed solids for two slurries: 1) the post-evaporation slurry, and 2) the slurry resulting from the combined evaporator slurry plus Group 1/2 supernate. Both slurries contained a relatively small amount of undissolved solids. The small volumes could not be measured accurately and thus were associated with high relative uncertainties. The dry washed solids mass represented in Table 6.4 will not include sodium oxalate, a likely component of the 
unwashed solids. The sodium oxalate component, that is normally insoluble in the aqueous portion, can be inferred from the anion analysis results of the solids rinse solution.

Table 6.4. Physical Properties of Slurries

\begin{tabular}{|l|l|c|c||}
\hline Property & Units & TI525-EvConc & TI525-EvConc+Spnt $^{(\mathbf{( a )}}$ \\
\hline Reference temperature & ${ }^{\circ} \mathrm{C}$ & 26 & 29 \\
\hline Slurry density & $\mathrm{g} / \mathrm{mL}$ & $1.21 \pm 0.02$ & $1.22 \pm 0.02$ \\
\hline Slurry volume & $\mathrm{mL}$ & $296 \pm 4$ & $238 \pm 5$ \\
\hline Slurry mass & $\mathrm{g}$ & $359.322 \pm 0.003$ & $290.73 \pm 0.03$ \\
\hline Supernate density & $\mathrm{g} / \mathrm{mL}$ & $1.237 \pm 0.015$ & $1.247 \pm 0.013$ \\
\hline \multirow{2}{*}{ Wet centrifuged solids } & $\mathrm{vol} \%$ & $4.2 \pm 1.4$ & $2.3 \pm 1.2$ \\
\cline { 2 - 5 } & $\mathrm{wt} \%$ & $4.08 \pm 0.75$ & $2.17 \pm 0.10$ \\
\hline Dry washed solids mass & $\mathrm{g}$ & $2.05 \pm 0.25$ & $0.84 \pm 0.09$ \\
\hline $\begin{array}{l}\text { (a) Post-evaporation slurry } \\
\text { (b) Evaporator slurry mixed with Group 1/2 supernatant. }\end{array}$ \\
\hline
\end{tabular}

\subsubsection{Evaporator Concentrate}

The compositions of supernate, washed-solids, solids wash-solution, and evaporator vessel nitric acid leach-solution are shown Table 6.5 and Table 6.7. The mass fraction recovered from each of the solutions is provided adjacent to the sample concentration. The last column provides the total activity and mass balances. These compositions and analyte recoveries represent just the evaporation processing.

Many analytes (Cs, Na, Al, phosphate, sulfate, and fluoride) remained in the aqueous portion. Oxalate was found primarily in the wash solution indicating that $\sim 74 \%$ had precipitated as a result of the concentration. This behavior is consistent with the reduced solubility of sodium oxalate in a high-sodium matrix and high solubility in the $0.01 \mathrm{M} \mathrm{NaOH}$ wash solution. The $\mathrm{Mn}$ component was about evenly split between the aqueous and solid phase. In fact, the solids were dominated by $\mathrm{Mn}$ at $36 \mathrm{wt} \%$.

The criticality safety-related elements ( $\mathrm{B}, \mathrm{Cd}, \mathrm{Cr}, \mathrm{Fe}, \mathrm{Ni}$, and $\mathrm{Pu}$ ) were included in the overall data evaluation. Boron was not detected in the evaporator feeds but was detected in the concentrate; examination of its fractionation showed it resided in the aqueous fraction. The elements $\mathrm{Cd}, \mathrm{Fe}$, and $\mathrm{Ni}$ partitioned primarily to the solids phase during evaporation. Chromium primarily stayed in the aqueous phase. 
Table 6.5. FEP Evaporation Products, Radionuclides

\begin{tabular}{|c|c|c|c|c|c|c|c|c|c|c|}
\hline \multirow[b]{2}{*}{ Description } & \multirow{2}{*}{$\begin{array}{c}\text { Input } \\
\text { Composition } \\
\end{array}$} & \multicolumn{2}{|c|}{ Aqueous Phase } & \multicolumn{2}{|c|}{ Wash Solution } & \multicolumn{2}{|c|}{ Washed Solids } & \multicolumn{2}{|c|}{ Acid Leach } & \multirow{3}{*}{$\begin{array}{c}\text { Total } \\
\text { Mass or }\end{array}$} \\
\hline & & \multicolumn{2}{|c|}{ TI525-EvConc-C } & \multicolumn{2}{|c|}{ TI525-EvConc-A-WL-C } & \multicolumn{2}{|c|}{ TI525-Ev-S-WL } & \multicolumn{2}{|c|}{ TI525-EL } & \\
\hline Vol. or mass> & $2006 \mathrm{~mL}$ & \multicolumn{2}{|c|}{$296 \mathrm{~mL}$} & \multicolumn{2}{|c|}{$243 \mathrm{~mL}$} & \multicolumn{2}{|c|}{$2.05 \mathrm{~g}$} & \multicolumn{2}{|c|}{$471 \mathrm{~mL}$} & \\
\hline Sample ID> & NA & 08-01987 & $\begin{array}{c}\text { Recovered } \\
\text { Fraction }\end{array}$ & 08-01988 & Recovered & 08-01989 & Recovered & 08-01993 & Recovered & Activity \\
\hline${ }^{137} \mathrm{Cs}$ & $5.16 \mathrm{E}+3$ & $1.87 \mathrm{E}+1$ & $107 \%$ & $6.08 \mathrm{E}-1$ & $2.9 \%$ & $2.97 \mathrm{E}+1$ & $1.18 \%$ & $1.99 \mathrm{E}-1$ & $1.8 \%$ & $113 \%$ \\
\hline${ }^{60} \mathrm{Co}$ & $<1 . \mathrm{E}-1$ & $<9 . \mathrm{E}-5$ & -- & $<1 . \mathrm{E}-4$ & $<20 \%$ & $7.89 \mathrm{E}-2$ & $>135 \%$ & $<7 . \mathrm{E}-5$ & -- & $>135 \%$ \\
\hline${ }^{241} \mathrm{Am}$ & $<4 . \mathrm{E}+0$ & $<2 . \mathrm{E}-3$ & -- & $<8$.E-4 & $<4.8 \%$ & $2.70 \mathrm{E}-1$ & $>14 \%$ & $<9 . \mathrm{E}-4$ & -- & $>14 \%$ \\
\hline${ }^{239+240} \mathrm{Pu}$ & $6.13 \mathrm{E}-2$ & $1.40 \mathrm{E}-4$ & $67.6 \%$ & $2.51 \mathrm{E}-5$ & $9.9 \%$ & $9.52 \mathrm{E}-2^{(\mathrm{b})}$ & $318 \%{ }^{(\mathrm{b})}$ & {$[4.5 \mathrm{E}-6]$} & {$[3.4 \%]$} & $399 \%^{(\mathrm{b})}$ \\
\hline Gross alpha & $<3 . \mathrm{E}+0$ & $<4$.E-4 & -- & $<5$.E-4 & $<3.7 \%$ & {$[5.8 \mathrm{E}-1]$} & {$[>36 \%]$} & $<5$. E-4 & -- & {$[>36 \%]$} \\
\hline Gross beta & $4.85 \mathrm{E}+3$ & $1.63 \mathrm{E}+1$ & $99.4 \%$ & $5.82 \mathrm{E}-1$ & $2.9 \%$ & $7.77 \mathrm{E}+2$ & $33 \%$ & $1.95 \mathrm{E}-1$ & $1.9 \%$ & $137 \%$ \\
\hline${ }^{90} \mathrm{Sr}$ & $1.90 \mathrm{E}+1$ & $1.90 \mathrm{E}-4$ & $0.30 \%$ & $1.03 \mathrm{E}-3$ & $1.3 \%$ & $3.54 \mathrm{E}+2^{(\mathrm{c})}$ & $3827 \%^{(\mathrm{c})}$ & $9.06 \mathrm{E}-4$ & $2.3 \%$ & $3831 \%^{(\mathrm{c})}$ \\
\hline Sum of alpha & $7.62 \mathrm{E}-2$ & $1.66 \mathrm{E}-4$ & -- & $3.05 \mathrm{E}-5$ & -- & $1.11 \mathrm{E}-1$ & -- & $<9$.E-4 & -- & -- \\
\hline$\alpha$ gross/sum & na & na & -- & na & -- & na & -- & na & -- & -- \\
\hline $\begin{array}{l}\text { Ratio of } \\
{ }^{239+240} \mathrm{Pu} /{ }^{238} \mathrm{Pu}\end{array}$ & 4.11 & 5.34 & -- & [4.62] & -- & 5.84 & -- & na & -- & -- \\
\hline Sum of beta & $5.19 \mathrm{E}+3$ & $1.87 \mathrm{E}+1$ & -- & $6.10 \mathrm{E}-1$ & -- & $7.38 \mathrm{E}+2$ & -- & $2.01 \mathrm{E}-1$ & -- & -- \\
\hline$\beta$ gross/sum & 0.93 & 0.87 & -- & 0.95 & -- & 1.05 & -- & 0.97 & -- & -- \\
\hline $\begin{array}{l}\text { (a) Washed, } \\
\text { (b) The Pu rec } \\
\text { (c) The }{ }^{90} \mathrm{Sr} \text { re } \\
\text { ASR }=8159 \\
\text { Reference date } \\
\text { Analyte uncert } \\
\text { (MDL) and les } \\
\text { na = not applic }\end{array}$ & $\begin{array}{l}\text { nass basis. } \\
\text { eries in the so } \\
\text { very is too hig } \\
5 / 1 / 2008 \\
\text { ties were typi } \\
\text { tan the estima } \\
\text { e; "--." calcula }\end{array}$ & $\begin{array}{l}\text { are too hig } \\
\text { The high r } \\
\text { y within } \pm \\
\text { quantitatio } \\
\text { n does not }\end{array}$ & $\begin{array}{l}\text { See text for } \\
\text { very may be } \\
\text {; results in } \\
\text { mit (EQL), } \\
\text { ly }\end{array}$ & $\begin{array}{l}\text { cussion. } \\
\text { result of } \\
\text { ckets indic } \\
\text { uncertaint }\end{array}$ & $\begin{array}{l}\text { amination } \mathrm{i} \\
\text { that the ana } \\
\text { were }>15 \%\end{array}$ & concentrat & spling error, & $\begin{array}{l}\text { analytical } \\
\text { than the } \mathrm{m}\end{array}$ & nimum detec & on limit. \\
\hline
\end{tabular}


Table 6.6. FEP Evaporation Products, Metals and Anions

\begin{tabular}{|c|c|c|c|c|c|c|c|c|c|c|}
\hline \multirow{4}{*}{$\begin{array}{l}\text { Description } \\
\text { Vol. or mass }> \\
\text { Sample ID> } \\
\end{array}$} & \multirow{4}{*}{$\begin{array}{c}\begin{array}{c}\text { Input } \\
\text { Composition }\end{array} \\
2006 \mathrm{~mL} \\
\text { NA } \\
\end{array}$} & \multirow{2}{*}{\multicolumn{2}{|c|}{$\begin{array}{c}\text { Aqueous Phase } \\
\text { TI525-EvConc-C } \\
\end{array}$}} & \multirow{2}{*}{\multicolumn{2}{|c|}{$\begin{array}{c}\text { Wash Solution } \\
\text { TI525-EvConc-A-WL-C }\end{array}$}} & \multirow{2}{*}{\multicolumn{2}{|c|}{$\begin{array}{c}\text { Washed Solids } \\
\text { TI525-Ev-S-WL }\end{array}$}} & \multirow{2}{*}{\multicolumn{2}{|c|}{$\begin{array}{c}\text { Acid Leach } \\
\text { TI525-EL } \\
\end{array}$}} & \multirow{4}{*}{$\begin{array}{c}\text { Total } \\
\text { Mass or } \\
\text { Activity } \\
\text { Balance }\end{array}$} \\
\hline & & & & & & & & & & \\
\hline & & \multicolumn{2}{|c|}{$296 \mathrm{~mL}$} & \multicolumn{2}{|c|}{$243 \mathrm{~mL}$} & \multicolumn{2}{|c|}{$2.05 \mathrm{~g}$} & \multicolumn{2}{|c|}{$471 \mathrm{~mL}$} & \\
\hline & & 08-01987 & Recovered & 08-01988 & Recovered & 08-01989 & Recovered & 08-01993 & Recovered & \\
\hline $\mathrm{Al}$ & $2.26 \mathrm{E}+6$ & 7,180 & $94.2 \%$ & 217 & $2.3 \%$ & 33,725 & $3.1 \%$ & 99.4 & $2.1 \%$ & $102 \%$ \\
\hline $\mathrm{B}$ & {$[2.0 \mathrm{E}+4]$} & 73.5 & {$[107 \%]$} & 3.01 & {$[3.6 \%]$} & [57] & {$[0.57 \%]$} & [1.5] & {$[3.5 \%]$} & [115\%] \\
\hline $\mathrm{Ba}$ & $<6.4 \mathrm{E}+2$ & {$[0.45]$} & {$[>21 \%]$} & 0.133 & $>5.1 \%$ & 76.5 & $>25 \%$ & 0.191 & $>14 \%$ & $>65 \%$ \\
\hline $\mathrm{Bi}$ & $1.92 \mathrm{E}+4$ & $<3.7$ & $<5.7 \%$ & {$[2.5]$} & {$[3.2 \%]$} & 5,018 & $53 \%$ & {$[4.6]$} & [11\%] & $68 \%$ \\
\hline $\mathrm{Ca}$ & $2.96 \mathrm{E}+4$ & $<0.75$ & $<0.75 \%$ & 1.86 & $1.5 \%$ & 8,668 & $60 \%$ & 5.57 & $8.9 \%$ & $70 \%$ \\
\hline $\mathrm{Cd}$ & $4.38 \mathrm{E}+3$ & [1.3] & {$[8.8 \%]$} & {$[0.20]$} & {$[1.1 \%]$} & 1,548 & $72 \%$ & {$[0.72]$} & {$[7.7 \%]$} & [90\%] \\
\hline $\mathrm{Cr}$ & $1.67 \mathrm{E}+6$ & 4,330 & $76.6 \%$ & 141 & $2.0 \%$ & [53] & {$[0.006 \%]$} & 52.7 & $1.5 \%$ & $80 \%$ \\
\hline $\mathrm{Cu}$ & $<1.2 \mathrm{E}+3$ & $<0.17$ & -- & $<0.034$ & -- & 179 & {$[>30 \%]$} & {$[0.034]$} & {$[>1.3 \%]$} & $>31 \%$ \\
\hline $\mathrm{Fe}$ & $2.70 \mathrm{E}+5$ & {$[0.42]$} & {$[0.05 \%]$} & 2.01 & $0.18 \%$ & 80,725 & $>61 \%$ & 5.05 & $0.88 \%$ & $62 \%$ \\
\hline $\mathrm{Mn}$ & $1.87 \mathrm{E}+6$ & 2,190 & $34.7 \%$ & 21.0 & $0.27 \%$ & 356,750 & $39 \%$ & 119 & $3.0 \%$ & $77 \%$ \\
\hline $\mathrm{Na}$ & $3.88 \mathrm{E}+7$ & 131,000 & $100 \%$ & 6,140 & $3.8 \%$ & 89,800 & $0.47 \%$ & 1,980 & $2.4 \%$ & $107 \%$ \\
\hline $\mathrm{Ni}$ & $4.71 \mathrm{E}+3$ & $<0.296$ & $<1.9 \%$ & $<0.059$ & $<0.3 \%$ & 1,855 & $81 \%$ & 1.10 & $11 \%$ & $92 \%$ \\
\hline $\mathrm{P}$ & $3.22 \mathrm{E}+5$ & 1,030 & $94.6 \%$ & 37.8 & $2.8 \%$ & {$[1,950]$} & {$[1.2 \%]$} & 13.3 & $1.9 \%$ & $101 \%$ \\
\hline $\mathrm{S}$ & {$[1.1 \mathrm{E}+5]$} & 542 & [143\%] & {$[20]$} & {$[4.3 \%]$} & $<1716$ & $<3.1 \%$ & {$[9.0]$} & [3.8\%] & [151\%] \\
\hline $\mathrm{Si}$ & $7.00 \mathrm{E}+4$ & 261 & $110 \%$ & 6.49 & $2.3 \%$ & {$[12,000]$} & [35\%] & 4.57 & $3.1 \%$ & {$[151 \%]$} \\
\hline $\mathrm{Sr}$ & $3.29 \mathrm{E}+2$ & $<0.01$ & $<0.91 \%$ & {$[0.0042]$} & {$[0.31 \%]$} & 124 & $77 \%$ & {$[0.038]$} & {$[5.4 \%]$} & $83 \%$ \\
\hline $\mathrm{Th}$ & $<2.2 \mathrm{E}+3$ & {$[9.0]$} & {$[>119 \%]$} & {$[0.37]$} & {$[>4.0 \%]$} & {$[140]$} & {$[>13 \%]$} & $<0.24$ & -- & {$[>135 \%]$} \\
\hline $\mathrm{U}$ & $<1.6 \mathrm{E}+4$ & {$[6.0]$} & {$[>11 \%]$} & $<0.78$ & -- & $<285$ & -- & $<0.77$ & -- & {$[>11 \%]$} \\
\hline $\mathrm{Zn}$ & $5.51 \mathrm{E}+3$ & 11.0 & $59 \%$ & {$[1.4]$} & {$[6.2 \%]$} & 1,203 & $45 \%$ & 1.42 & $12 \%$ & $122 \%$ \\
\hline $\mathrm{Zr}$ & $1.88 \mathrm{E}+3$ & $<0.14$ & -- & $<0.03$ & $<0.3 \%$ & 293 & [32\%] & {$[0.028]$} & {$[0.7 \%]$} & [33\%] \\
\hline
\end{tabular}


Table 6.6 (contd)

\begin{tabular}{|c|c|c|c|c|c|c|c|c|c|c|}
\hline \multirow{4}{*}{$\begin{array}{l}\text { Description } \\
\text { Vol. or mass }> \\
\text { Sample ID> }\end{array}$} & \multirow{4}{*}{$\begin{array}{c}\begin{array}{c}\text { Input } \\
\text { Composition }\end{array} \\
2006 \mathrm{~mL} \\
\text { NA } \\
\end{array}$} & \multirow{2}{*}{\multicolumn{2}{|c|}{$\begin{array}{c}\text { Aqueous Phase } \\
\text { TI525-EvConc-C }\end{array}$}} & \multirow{2}{*}{\multicolumn{2}{|c|}{$\begin{array}{c}\text { Wash Solution } \\
\text { TI525-EvConc-A-WL-C }\end{array}$}} & \multirow{2}{*}{\multicolumn{2}{|c|}{$\begin{array}{c}\text { Washed Solids } \\
\text { TI525-Ev-S-WL }\end{array}$}} & \multirow{2}{*}{\multicolumn{2}{|c|}{$\begin{array}{c}\text { Acid Leach } \\
\text { TI525-EL }\end{array}$}} & \multirow{5}{*}{$\begin{array}{c}\text { Total } \\
\text { Mass or } \\
\text { Activity } \\
\text { Balance }\end{array}$} \\
\hline & & & & & & & & & & \\
\hline & & \multicolumn{2}{|c|}{$296 \mathrm{~mL}$} & \multicolumn{2}{|c|}{$243 \mathrm{~mL}$} & \multicolumn{2}{|c|}{$2.05 \mathrm{~g}$} & \multicolumn{2}{|c|}{$471 \mathrm{~mL}$} & \\
\hline & & 08-01987 & Recovered & 08-01988 & Recovered & 08-01989 & Recovered & 08-01993 & \multirow{2}{*}{$\begin{array}{c}\text { Recovered } \\
\text { Fraction }\end{array}$} & \\
\hline Analyte & $\mu \mathrm{g}$ & $\mu \mathrm{g} / \mathrm{mL}$ & Fraction & $\mu \mathrm{g} / \mathrm{mL}$ & Fraction & $\mu \mathrm{g} / \mathrm{g}$ & Fraction & $\mu \mathrm{g} / \mathrm{mL}$ & & \\
\hline U KPA & $2.35 \mathrm{E}+3$ & \multicolumn{2}{|l|}{$\mathrm{n} / \mathrm{a}$} & \multicolumn{2}{|l|}{$\mathrm{n} / \mathrm{a}$} & 140 & $12 \%$ & \multicolumn{2}{|l|}{$\mathrm{n} / \mathrm{a}$} & -- \\
\hline \multicolumn{11}{|l|}{ Anions } \\
\hline nitrite & $2.50 \mathrm{E}+6$ & 5,630 & $67 \%$ & 185 & $1.8 \%$ & \multirow{5}{*}{$\mathrm{n} / \mathrm{a}$} & \multirow{5}{*}{--} & \multirow{5}{*}{$\mathrm{n} / \mathrm{a}$} & \multirow{5}{*}{--} & $68 \%$ \\
\hline nitrate & $9.13 \mathrm{E}+6$ & 33,400 & $108 \%$ & 980 & $2.6 \%$ & & & & & $111 \%$ \\
\hline phosphate & $1.00 \mathrm{E}+6$ & 3,440 & $102 \%$ & 121 & $2.9 \%$ & & & & & $105 \%$ \\
\hline sulfate & $5.14 \mathrm{E}+5$ & 1,590 & $92 \%$ & 48.6 & $2.3 \%$ & & & & & $94 \%$ \\
\hline oxalate & $1.59 \mathrm{E}+6$ & 932 & $17 \%$ & 3,790 & $57.8 \%$ & & & & & $75 \%$ \\
\hline free hydroxide & $2.04 \mathrm{E}+7$ & $37,850^{(\mathrm{b})}$ & $55 \%{ }^{(\mathrm{b})}$ & $1,043^{(\mathrm{b})}$ & $1.2 \%{ }^{(\mathrm{b})}$ & na & - & na & - & $56 \%{ }^{(\mathrm{b})}$ \\
\hline \multicolumn{11}{|c|}{ Opportunistic Analytes } \\
\hline $\mathrm{F}$ & $\sim 3.58 \mathrm{E}+4$ & 113 & $93.4 \%$ & 5.62 & $3.8 \%$ & $\mathrm{n} / \mathrm{a}$ & -- & $\mathrm{n} / \mathrm{a}$ & -- & $97 \%$ \\
\hline $\mathrm{Cl}$ & na & 830 & - & 25.1 & -- & $\mathrm{n} / \mathrm{a}$ & -- & $\mathrm{n} / \mathrm{a}$ & - & -- \\
\hline $\mathrm{Ag}$ & $<8.0 \mathrm{E}+2$ & $<0.26$ & -- & $<0.05$ & -- & {$[62]$} & {$[>16 \%]$} & $<0.05$ & -- & {$[>16 \%]$} \\
\hline As & $<1.4 \mathrm{E}+4$ & $<5.3$ & - & $<1.1$ & - & $<290$ & -- & $<1.0$ & - & - \\
\hline $\mathrm{Be}$ & {$[1.4 \mathrm{E}+1]$} & {$[0.030]$} & {$[65 \%]$} & $<0.001$ & $<2.3 \%$ & {$[0.47]$} & {$[7.1 \%]$} & $<0.001$ & -- & {$[73 \%]$} \\
\hline $\mathrm{Ce}$ & $<2.3 \mathrm{E}+3$ & $<1.2$ & -- & $<0.24$ & -- & $<65$ & -- & $<0.24$ & -- & -- \\
\hline $\mathrm{Co}$ & $<7.4 \mathrm{E}+2$ & $<0.30$ & -- & $<0.06$ & -- & $<13$ & -- & [0.079] & {$[>5.0 \%]$} & {$[>5.0 \%]$} \\
\hline Dy & $<6.7 \mathrm{E}+2$ & $<0.36$ & -- & $<0.071$ & -- & $<20$ & -- & $<0.070$ & -- & -- \\
\hline $\mathrm{Eu}$ & $<2.1 \mathrm{E}+2$ & $<0.14$ & -- & $<0.027$ & -- & $<5.3$ & -- & $<0.027$ & -- & -- \\
\hline $\mathrm{La}$ & $<3.1 \mathrm{E}+2$ & {$[0.36]$} & {$[>34 \%]$} & $<0.07$ & $<5.3 \%$ & [54] & {$[>36 \%]$} & $<0.07$ & -- & {$[>70 \%]$} \\
\hline $\mathrm{Li}$ & {$[6.6 \mathrm{E}+2]$} & 3.26 & [147\%] & 1.12 & {$[41 \%]$} & 1,210 & [379\%] & 0.472 & {$[34 \%]$} & [567\%] \\
\hline $\mathrm{Mg}$ & {$[1.9 \mathrm{E}+3]$} & $<0.28$ & $<4.5 \%$ & $<0.06$ & $<0.74 \%$ & 748 & $83 \%$ & $<0.06$ & $<1.4 \%$ & {$[83 \%]$} \\
\hline Mo & $4.07 \mathrm{E}+3$ & 9.42 & $69 \%$ & {$[0.24]$} & {$[1.4 \%]$} & $<44$ & $<2.2 \%$ & $<0.13$ & $<1.5 \%$ & $70 \%$ \\
\hline
\end{tabular}


Table 6.6 (contd)

\begin{tabular}{|c|c|c|c|c|c|c|c|c|c|c|}
\hline \multirow[b]{2}{*}{ Description } & \multirow{2}{*}{$\begin{array}{c}\text { Input } \\
\text { Composition } \\
\end{array}$} & \multicolumn{2}{|c|}{ Aqueous Phase } & \multicolumn{2}{|c|}{ Wash Solution } & \multicolumn{2}{|c|}{ Washed Solids } & \multicolumn{2}{|c|}{ Acid Leach } & \multirow{3}{*}{$\begin{array}{c}\text { Total } \\
\text { Mass or }\end{array}$} \\
\hline & & \multicolumn{2}{|c|}{ TI525-EvConc-C } & \multicolumn{2}{|c|}{ TI525-EvConc-A-WL-C } & \multicolumn{2}{|c|}{ TI525-Ev-S-WL } & \multicolumn{2}{|c|}{ TI525-EL } & \\
\hline Vol. or mass> & $2006 \mathrm{~mL}$ & \multicolumn{2}{|c|}{$296 \mathrm{~mL}$} & \multicolumn{2}{|c|}{$243 \mathrm{~mL}$} & \multicolumn{2}{|c|}{$2.05 \mathrm{~g}$} & \multicolumn{2}{|c|}{$471 \mathrm{~mL}$} & \\
\hline Sample ID> & NA & 08-01987 & Recovered & 08-01988 & Recovered & 08-01989 & Recovered & 08-01993 & Recovered & Activity \\
\hline $\mathrm{Nd}$ & $<4.9 \mathrm{E}+3$ & $<0.67$ & -- & $<0.13$ & -- & 660 & $>28 \%$ & {$[0.25]$} & {$[>2.4 \%]$} & $>30 \%$ \\
\hline $\mathrm{Pb}$ & $<7.1 \mathrm{E}+3$ & $<3.9$ & -- & {$[1.1]$} & {$[>3.8 \%]$} & [700] & {$[>20 \%]$} & {$[1.3]$} & {$[>8.7 \%]$} & {$[>33 \%]$} \\
\hline $\mathrm{Pd}$ & $<2.4 \mathrm{E}+3$ & $<0.78$ & -- & $<0.15$ & -- & $<45$ & -- & $<0.15$ & -- & -- \\
\hline $\mathrm{Ru}$ & $<1.6 \mathrm{E}+3$ & {$[2.3]$} & {$[>43 \%]$} & $<0.21$ & -- & $<63$ & -- & $<0.21$ & -- & {$[>43 \%]$} \\
\hline $\mathrm{Sb}$ & $<9.9 \mathrm{E}+3$ & $<2.5$ & -- & $<0.49$ & -- & $<190$ & -- & $<0.48$ & -- & -- \\
\hline $\mathrm{Se}$ & $<6.5 \mathrm{E}+4$ & 111 & $>50 \%$ & {$[3.5]$} & {$[>1.3 \%]$} & $<632$ & -- & [1.9] & {$[>1.4 \%]$} & $>53 \%$ \\
\hline $\mathrm{Sn}$ & $<4.9 \mathrm{E}+3$ & {$[3.8]$} & {$[>23 \%]$} & $<0.66$ & -- & $<184$ & -- & $<0.65$ & -- & {$[>23 \%]$} \\
\hline $\mathrm{Ta}$ & $<2.6 \mathrm{E}+3$ & $<2.1$ & -- & $<0.42$ & -- & $<130$ & -- & $<0.41$ & -- & -- \\
\hline $\mathrm{Te}$ & $<6.7 \mathrm{E}+3$ & $<3.2$ & -- & $<0.64$ & -- & $<184$ & -- & $<0.63$ & -- & -- \\
\hline $\mathrm{W}$ & {$[5.0 \mathrm{E}+3]$} & [17] & [101\%] & {$[0.58]$} & [2.8\%] & $<141$ & -- & {$[0.61]$} & [5.7\%] & {$[109 \%]$} \\
\hline $\mathrm{Y}$ & $<1.6 \mathrm{E}+2$ & $<0.054$ & -- & $<0.011$ & -- & [7.1] & {$[>9.1 \%]$} & $<0.011$ & -- & {$[>9.1 \%]$} \\
\hline $\begin{array}{l}\text { ASR }=8159 \\
\text { Analyte uncer } \\
\text { (MDL) and les } \\
\text { Opportunistic } \\
\text { na = not applic }\end{array}$ & $\begin{array}{l}\text { ties were typi } \\
\text { han the estima } \\
\text { lytes are repor } \\
\text { le; } \mathrm{n} / \mathrm{a}=\text { not an }\end{array}$ & \multicolumn{9}{|c|}{$\begin{array}{l}\text { (a) Washed, dry mass basis. } \\
\text { (b) The free hydroxide may be biased low by a factor of } 2 \text {. The anion and cation charges do not balance with the composition as shown. Furthermore, direct }\end{array}$} \\
\hline
\end{tabular}


Plutonium fractionation was more difficult to discern. Analysis of the aqueous portion showed that $\sim 52$ to $68 \%$ remained soluble (evaluation of ${ }^{238} \mathrm{Pu}$ and ${ }^{239+240} \mathrm{Pu}$, respectively), therefore indicating $\sim 32$ to $48 \%$ had precipitated. The solids wash process mobilized $\sim 9 \%$ of the $\mathrm{Pu}$. The solid-phase evaluation showed 200 to $300 \% \mathrm{Pu}$ recovery, indicative of contamination, analytical error, or sampling error. (A similar circumstance was noted with the precipitated $\mathrm{Mn}$ associated with the ion exchange feed processing, where $\sim 25 \%$ of the $\mathrm{Pu}$ was removed from solution based on solution analysis, yet the solids analysis indicated significantly more $\mathrm{Pu}$ was precipitated.) The solution analysis is considered more definitive because sub-sampling and total mass determination are more accurate, and the ${ }^{238} \mathrm{Pu}$ radiochemical analysis has less potential for ${ }^{241} \mathrm{Am}$ interference.

The nitrite and nitrate were further evaluated to understand the discrepancy in recoveries ( $68 \%$ vs $111 \%$, respectively). The recovery discrepancies indicated that $\sim 32 \mathrm{wt} \%$ nitrite was oxidized to nitrate according to the Equation 6.1.

$$
\mathrm{NO}_{2}^{-}+2 \mathrm{OH}^{-} \rightarrow \mathrm{NO}_{3}^{-}+\mathrm{H}_{2} \mathrm{O}+2 e^{-}
$$

Incorporating this conversion process in the mass balance calculation, the nitrite and nitrate recoveries would become $101 \%$ and $99 \%$, respectively. The corresponding hydroxide consumption as a result of the nitrite oxidation was $\sim 1.4 \%$ of the total available hydroxide.

Other anomalies in the mass and activity balances are apparent. The anion and cation charges did not balance; the anionic charge composition was significantly less than the cation charge.

Although carbonate, which was not measured, would account for some of the imbalance, it is not expected to be the sole source. The free-hydroxide concentrations (calculated initial concentration at $0.60 \mathrm{M}$ and measured final concentration at $2.23 \mathrm{M}$ ) corresponded to a concentration factor of 3.7. The Na concentration factor was 6.8 (calculated initial concentration at $0.84 \mathrm{M}$ and measured final concentration at $5.7 \mathrm{M}$ ). The ${ }^{90} \mathrm{Sr}$ recovery in the solids was calculated at 3,800\%, indicative of contamination, sampling error, or analytical error. The ICPOES determination of Sr indicated that it fractionated virtually entirely to the solids phase; since the feed component $\mathrm{Sr}$ concentrations were $<\mathrm{MDL}$, the total Sr recovery could only be determined as $>76 \%$ ( $>71 \%$ in the solids).

The SEM imaging showed solids similar in character to those that were produced from the Cs ion exchange feed preparations. The solids were generally small $(<500 \mathrm{~nm})$ platy or spherical particle agglomerates. EDS analysis showed the material was dominated by $\mathrm{Mn}$ with some $\mathrm{Na}$, $\mathrm{Al}, \mathrm{Si}, \mathrm{Ca}$, and Fe components. The latter components could simply be associated with entrainment of the solid species in the Mn precipitate, and not associated with the specific Mn precipitate chemical structure. All morphological features were masked by the Mn-rich phase. Therefore, no specific non-Mn phase was identified. 



Figure 6.13. SEM Images of Washed Evaporator Solids

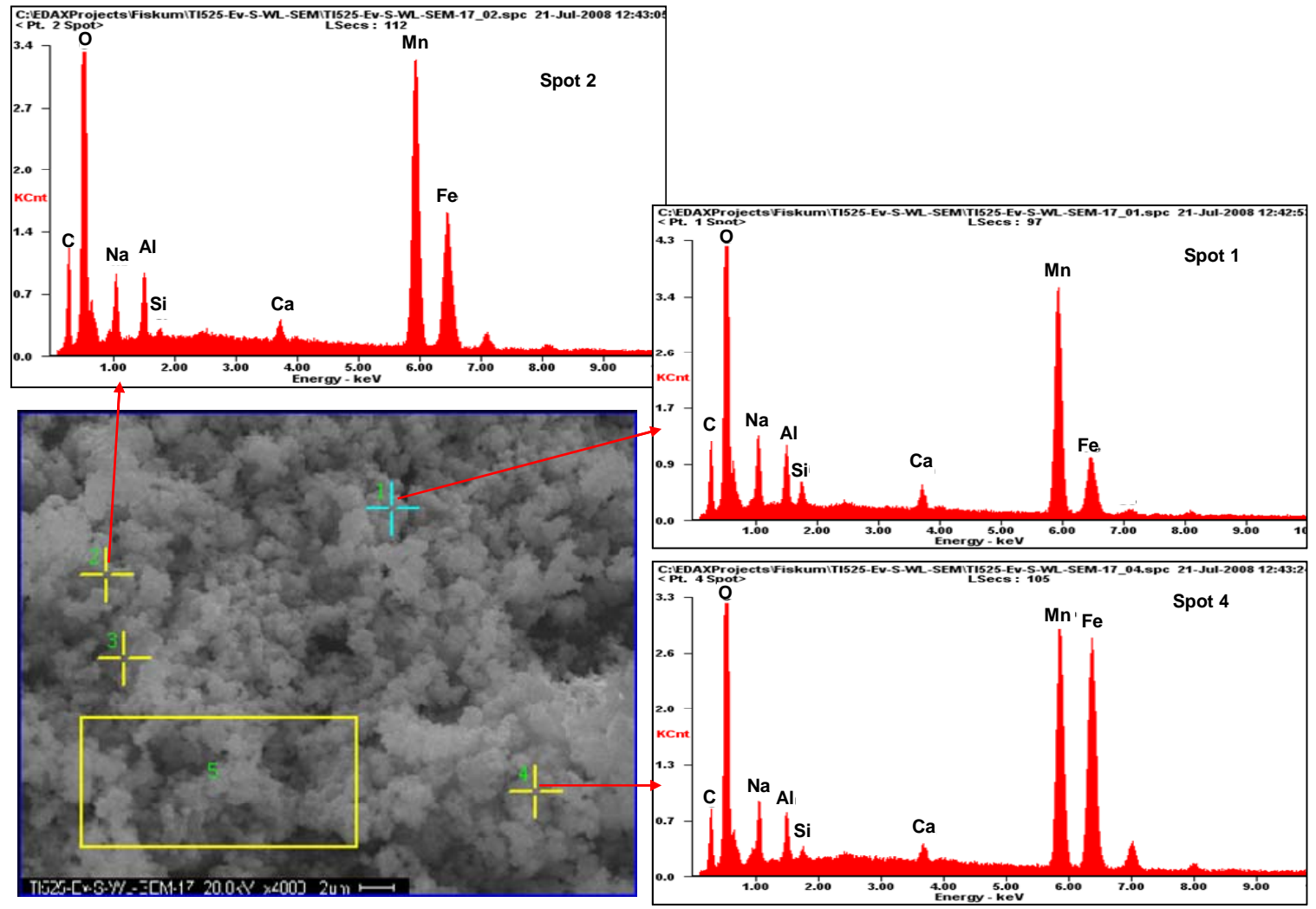

Figure 6.14. SEM Imaging with EDS Evaluation of Evaporator Product Washed Solids (Spot 3 and Area 5 EDS results not shown; they are similar to Spots 1, 2, and 4.) 
Transmission electron microscopy analysis of the washed evaporator solids confirmed that the evaporator sample was dominated by a mixed manganese-iron oxide phase. The diameter of the individual particles was 5 to $10 \mathrm{~nm}$, but these were agglomerated together into slightly larger particles. In Figure 6.15, scanning transmission electron microscope (STEM) high-angle annular dark-field (HAADF) images of the particles are shown. The average (agglomerated) particle diameter was around $200 \mathrm{~nm}$. A cumulative distribution plot of the agglomerated particle sizes from a STEM image is shown in Figure 6.16.

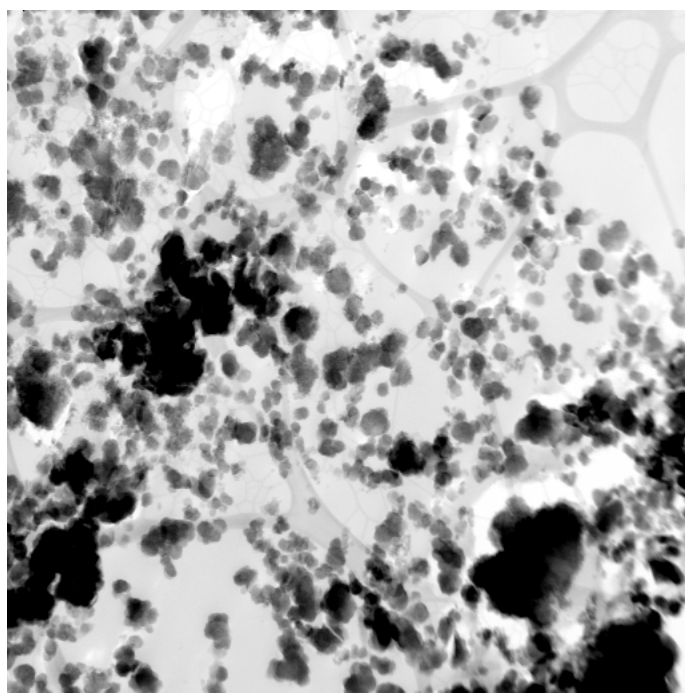

$1 \mu \mathrm{m}$



$20 \mathrm{~nm}$

Figure 6.15. STEM Image (inverted contrast) Showing Particles from the Evaporator Product

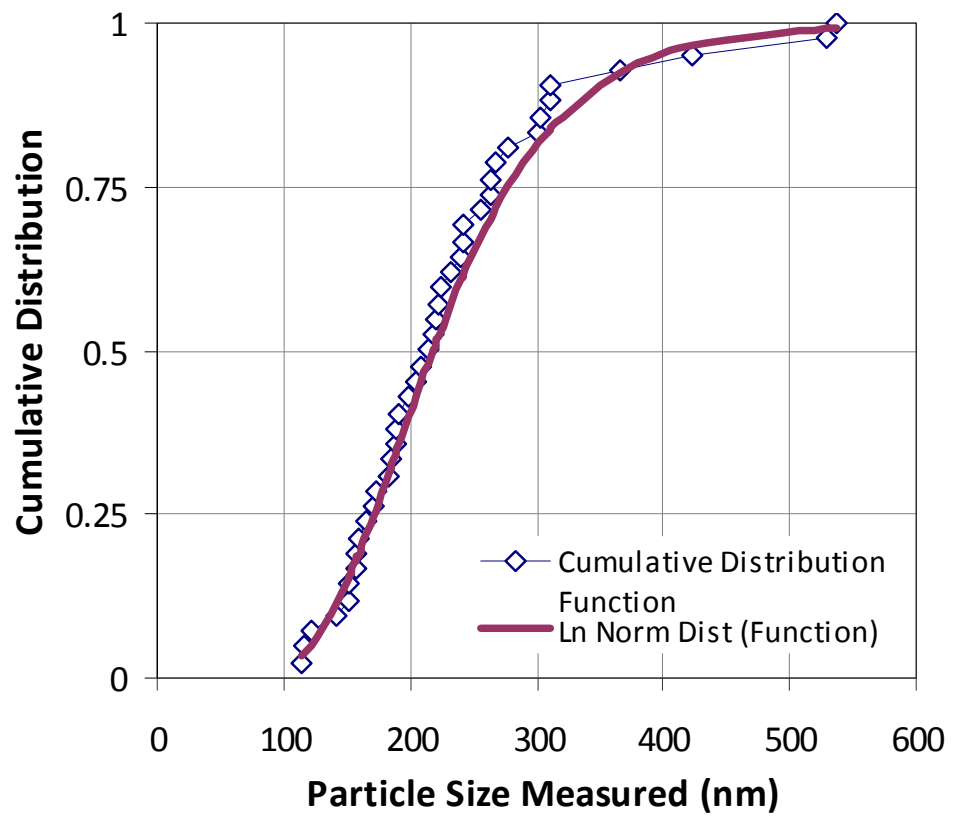

Figure 6.16. Cumulative Distribution Plot of Particle Sizes and a Mathematical (Log Normal) Fit to the Data 
High-resolution imaging of the phases showed that they were nano-crystalline. These data are presented in Figure 6.17. The EDS analysis shows that the manganese phase contains iron and calcium.
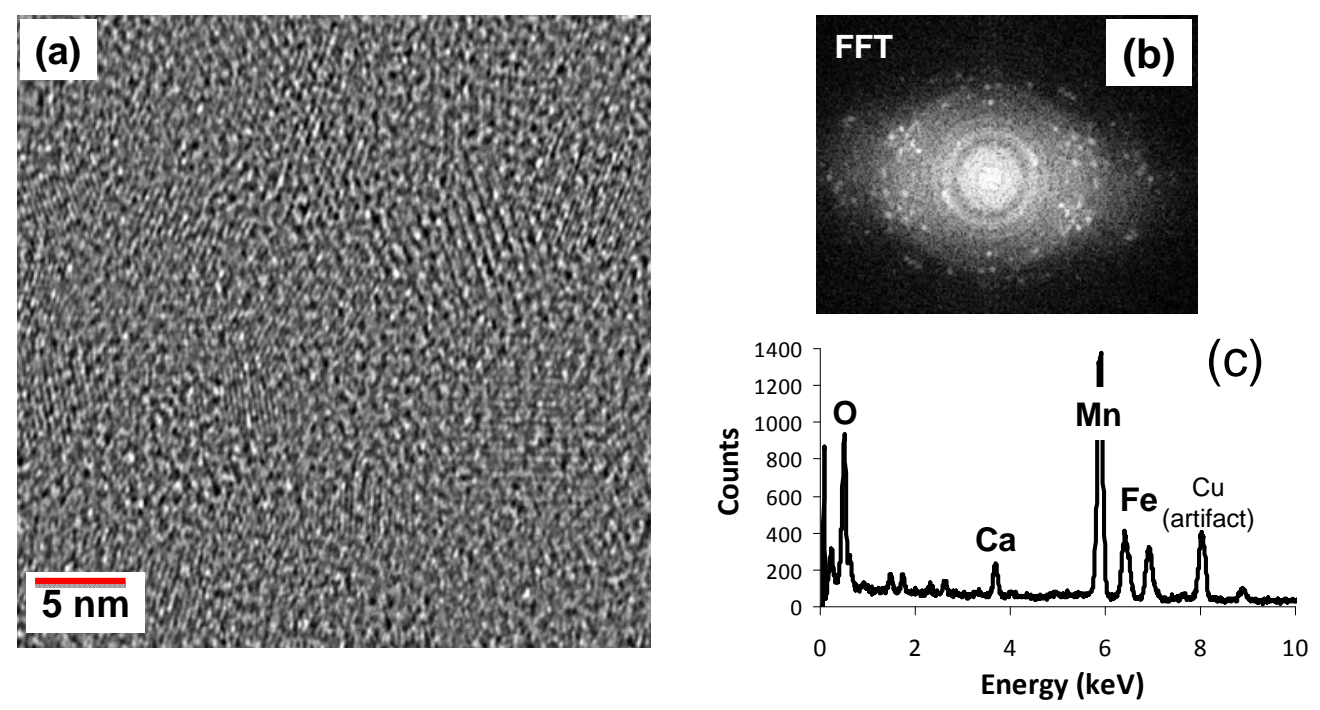

Figure 6.17. (a) High Resolution Filtered Image of a Mixed Mn-Fe Phase, (b) Diffraction Pattern, and (c) X-ray Energy Dispersive Analysis of the Material

The nature of the crystallinity in the major phase in the evaporator sample is shown in Figure 6.18, where the periodic structure of the material can be seen. The crystalline faces are small enough that the material would appear to be X-ray amorphous.

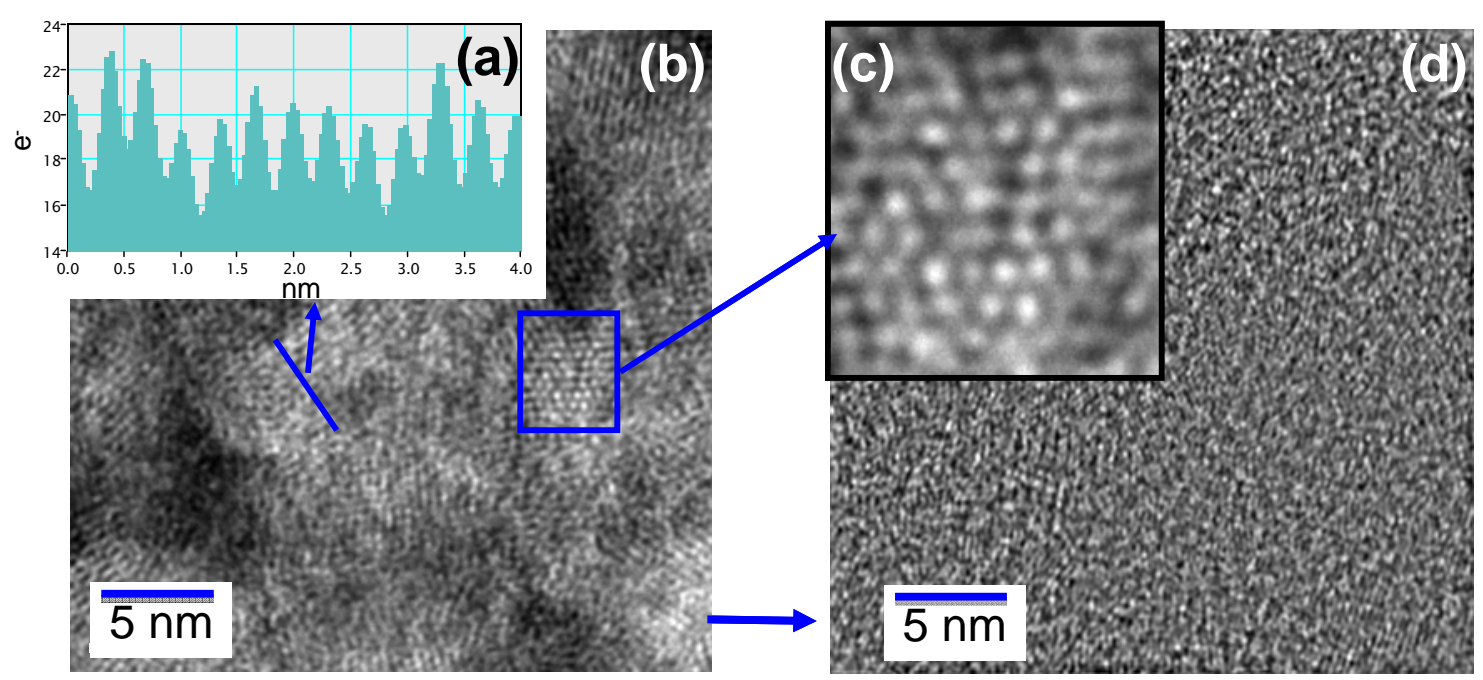

Figure 6.18. (a) Histogram of Lattice Spacings (Intensity vs distance in nm), (b) High Resolution TEM Image of Mn-Fe Phase, (c) Enlarged region taken along a Zone Axis, and (d) A Filtered High Resolution Image 
Figure 6.19 shows the raw XRD pattern for the washed precipitated solids that formed during evaporative concentration. The raw data show a pronounced amorphous peak from 12 to $30^{\circ} 2-\theta$, indicating that a significant portion of amorphous material was present. The amorphous material cannot be identified by XRD.

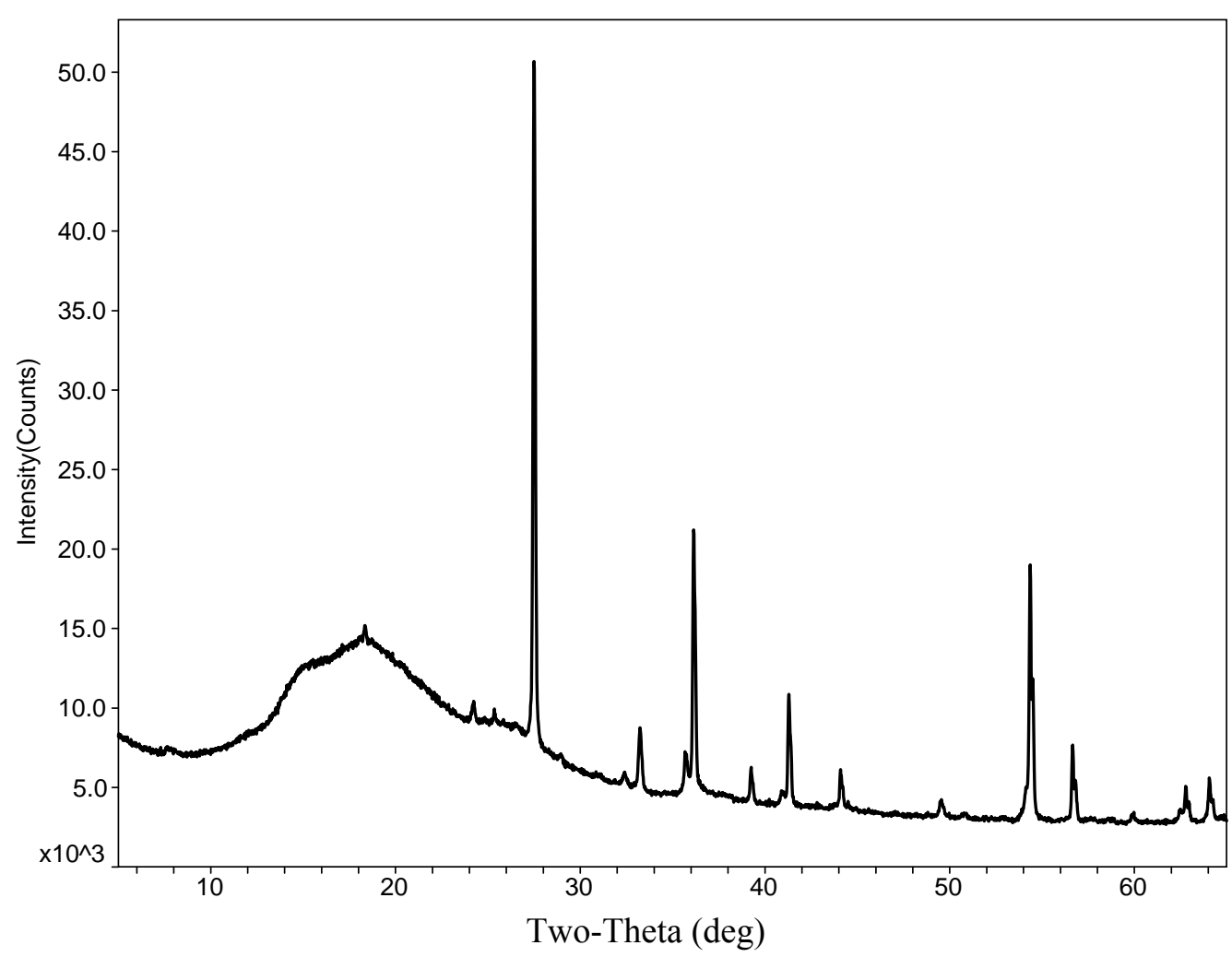

Figure 6.19. Raw X-Ray Powder Diffraction Pattern of the Evaporator Product Washed Precipitated Solids with Rutile $\left(\mathrm{TiO}_{2}\right)$ Internal Standard

Several crystalline phases were identified. Hematite, $\mathrm{Fe}_{2} \mathrm{O}_{3}$, card 61-0289, demonstrated an excellent fit to all diffraction lines. The major peak for hausmannite, syn., $\mathrm{Mn}_{3} \mathrm{O}_{4}$, card 24-0734, demonstrated a good fit to minor peaks; the major peak at $36.1^{\circ} 2-\theta$ was obscured by the rutile peak. Possible phases included manganese oxalate, $\mathrm{MnC}_{2} \mathrm{O}_{4}$, card 32-0646, fitting the broad peaks at $14.6^{\circ}, 18.1^{\circ}$, and $25.2^{\circ} 2-\theta$, boehmite, $\mathrm{AlO}(\mathrm{OH})$, card $65-4638$, fitting one broad peak at $14.6^{\circ} 2-\theta$, manganite, $\mathrm{MnO}(\mathrm{OH})$, card $64-8893$, fitting one broad peak at $26.1^{\circ} 2-\theta$, and iron oxide hydroxide, $\mathrm{FeO}(\mathrm{OH})$, card $60-1050$, may be present based on the fit to $14.6^{\circ} 2-\theta$ peak. Gibbsite, $\mathrm{Al}(\mathrm{OH})_{3}$, card $74-1775$, demonstrated a good fit for one peak at $18.3^{\circ} 2-\theta$; no confirming lines could be fitted since they were too low in intensity. Sodium hexacyanomanganate(II) decahydrate, $\mathrm{Na}_{4}\left(\mathrm{Mn}(\mathrm{CN})_{6}\right)\left(\mathrm{H}_{2} \mathrm{O}\right)_{10}$, card 60-2637, was the only phase identified that accounts for the small but sharp peak at $25.3^{\circ} 2-\theta$. The cyanide anion was not plausible for the waste form but this compound may provide clues to the actual material crystalline structure.

Hematite, hausmannite, and gibbsite are phases fitted to sharp peak reflections in the diffraction pattern. On the other hand, manganese oxalate, boehmite, manganite, and iron oxide 
hydroxide were fitted to the broad peaks in the pattern. There is a much higher degree of uncertainty in identifying broad peaks due to their diffuse nature which in turn affects the accuracy of peak height (relative peak intensity) and peak location $\left({ }^{\circ} 2-\theta\right)$.

The identification of hausmannite, $\mathrm{Mn}_{3} \mathrm{O}_{4}$, as the predominant crystalline Mn-containing species present is somewhat surprising given the results of Rapko et al. (2007) which indicated Mn was predominantly present in the +4 oxidation state following permanganate reaction with chromium(III) hydroxide. Either the conditions in the actual waste result in further reduction of the Mn, or the bulk of the Mn(IV) is in an amorphous form, not revealed by the XRD analysis. 


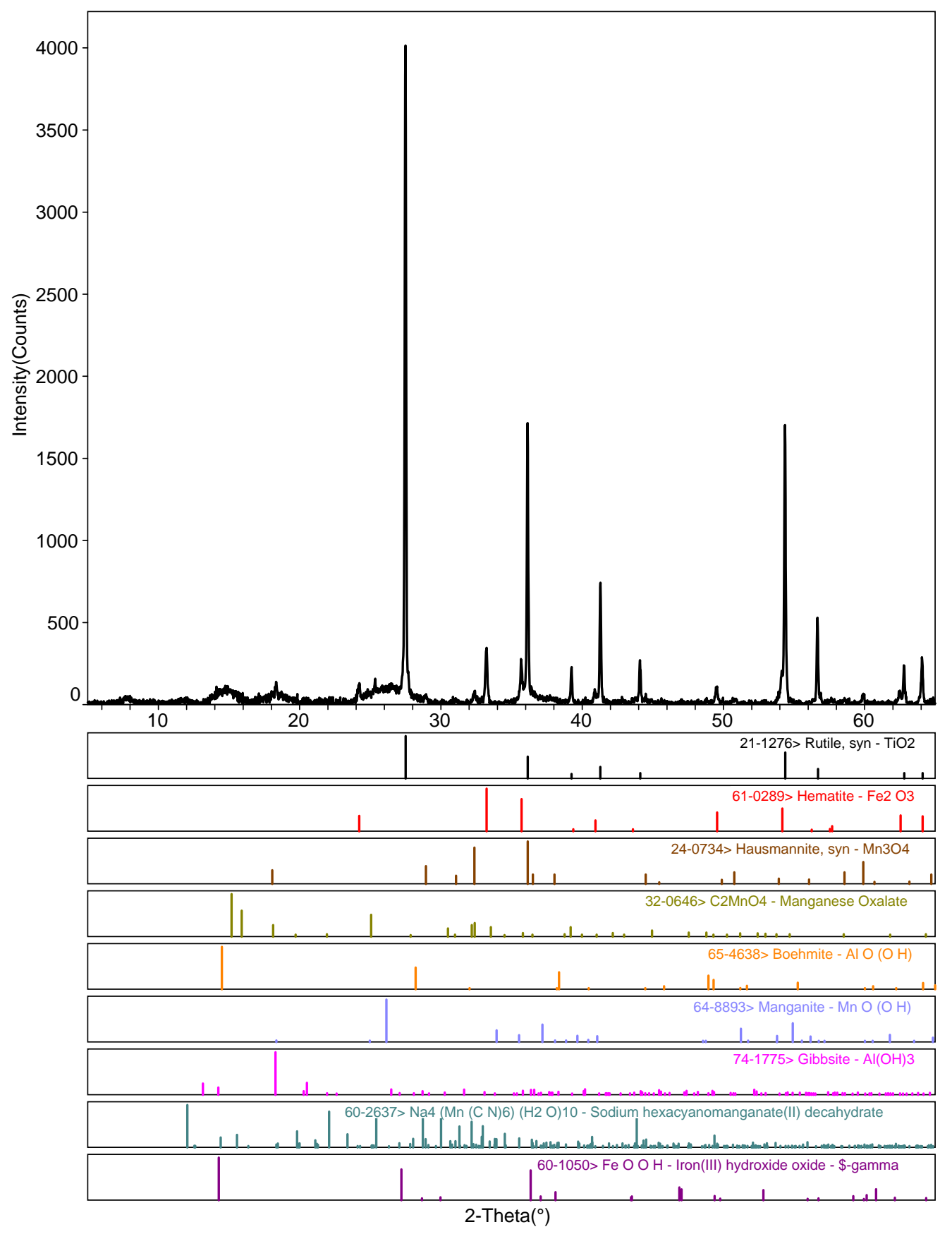

Figure 6.20. Background-Subtracted X-Ray Powder Diffraction Pattern of the Evaporator Product Washed Precipitated Solids with Rutile $\left(\mathrm{TiO}_{2}\right)$ Internal Standard and Stick-Figure Phase Identifications

(Note: The presence of sodium hexacyanomanganate(II) decahydrate, was not considered plausible, see text.) 
Figure 6.21 shows the raw powder XRD pattern of the unwashed dried precipitated solids. It can be compared to the washed solids XRD pattern to provide an idea of what water soluble phases might be present in the precipitated solids. Since the sample had been filtered and dried, some supernatant components could also be present. The raw data show a pronounced amorphous peak from 12 to $30^{\circ} 2-\theta$, indicating that a significant portion of amorphous material was present. The amorphous material cannot be identified by XRD.

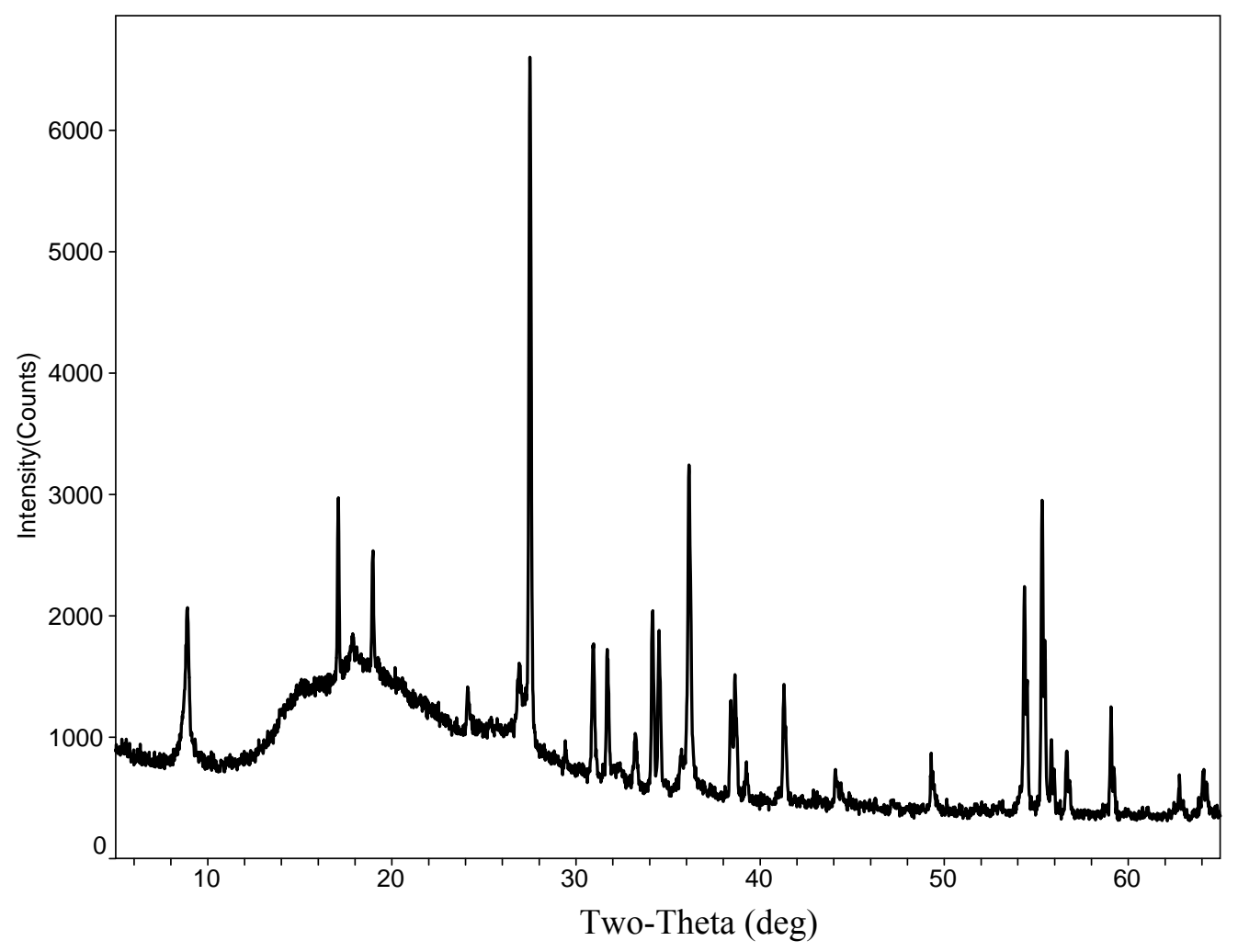

Figure 6.21. Raw X-Ray Powder Diffraction Pattern of the Evaporator Product Unwashed Precipitated Solids with Rutile $\left(\mathrm{TiO}_{2}\right)$ Internal Standard

The background-subtracted spectrum, shown in Figure 6.22, provides the stick-figure phase identifications listed in order of internal standard followed by phases with decreasing peak intensity. Natroxalate, $\mathrm{Na}_{2} \mathrm{C}_{2} \mathrm{O}_{4}$, card 49-1816 presented an overall good fit to peak locations with some large differences in relative peak heights at high angles (55.3, 55.8, and 59.1 $2-\theta)$. Koktaite, $\left(\mathrm{NH}_{4}\right)_{2} \mathrm{Ca}\left(\mathrm{SO}_{4}\right)-2 \mathrm{H}_{2} \mathrm{O}$, card 11-0475, resulted in a good fit to the data, however the presence of the ammonium ion seems dubious in this matrix. Sodium acetate, $\mathrm{C}_{2} \mathrm{H}_{3} \mathrm{NaO}_{2}$, card 29-1158, fit the peak at $8.88^{\circ} 2-\theta$; this major peak and minor peaks also were accounted for by koktaite so its presence could not be confirmed. Manganese hexacyanocobaltate 13-hydrate, $\left(\mathrm{Mn}_{3}\left(\mathrm{Co}(\mathrm{CN})_{6}\right)_{2}\left(\mathrm{H}_{2} \mathrm{O}\right)_{13}\right)_{1.33}$, card 60-0819, demonstrated good structural fit to the peak at $16.98^{\circ}$ $2-\theta$ and $24.1^{\circ} 2-\theta$; other confirming lines overlapped with other phases. The chemistry of $\left.\mathrm{Mn}_{3}\left(\mathrm{Co}(\mathrm{CN})_{6}\right)_{2}\left(\mathrm{H}_{2} \mathrm{O}\right)_{13}\right)_{1.33}$ was not considered plausible (Co was not detected in the solids and $\mathrm{CN}^{-}$was not a likely constituent of the tank waste) but may provide clues as to the component mineral structure. The chemistry of this phase could possibly be $\left.\mathrm{Mn}_{3}\left((\mathrm{Mn}, \mathrm{Fe})(\mathrm{CN})_{6}\right)_{2}\left(\mathrm{H}_{2} \mathrm{O}\right)_{13}\right)_{1.33}$. Other phases containing $\mathrm{Mn}$, especially $\mathrm{MnO}_{2}$, were specifically searched for, but none were 
identified. Silicon dioxide, $\mathrm{SiO}_{2}$, card 64-0666, was identified from the major peak at $18.99^{\circ} 2-\theta$. One major peak at $17.65^{\circ} 2-\theta$ was missing from the scan; since $\mathrm{SiO}_{2}$ is monoclinic, the missing peak did not negate its presence. Good fits to the diffraction pattern were obtained with imandrite, $\mathrm{Na}_{12} \mathrm{Ca}_{3} \mathrm{Fe}_{2}\left(\mathrm{Si}_{6} \mathrm{O}_{18}\right)_{2}$, card 39-0403, and hematite, $\mathrm{Fe}_{2} \mathrm{O}_{3}$, card 61-0289. Boehmite, $\mathrm{AlO}(\mathrm{OH})$, card $65-4638$, fit the broad peak at $15^{\circ} 2-\theta$. The intensities of diffraction peaks 55.3, 55.8 , and $59.1^{\circ} 2-\theta$ were not well matched by the identified phases indicating another phase(s) may be present.

Sodium oxalate clearly was present as part of the precipitated solids (but were removed with water washing). Other phases possibly removed from water washing were those representing the peak at $8.88^{\circ} 2-\theta$ (sodium acetate and koktaite). 


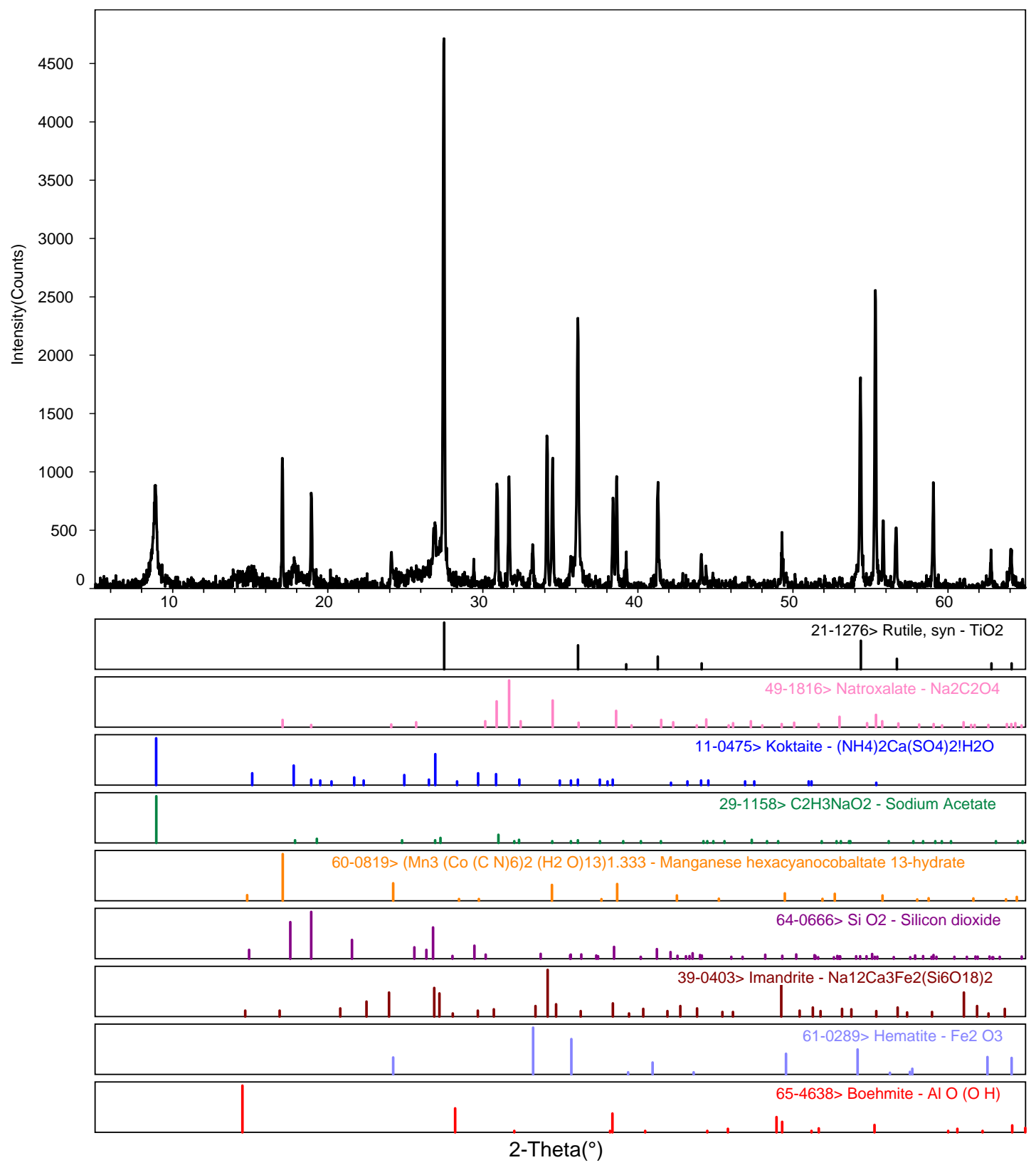

Figure 6.22. Background-Subtracted X-Ray Powder Diffraction Pattern of the Evaporator Product Unwashed Precipitated Solids with Rutile $\left(\mathrm{TiO}_{2}\right)$ Internal Standard and Stick-Figure Phase Identifications

Note: The presence of manganese hexacyanocobaltate 13-hydrate phase was not considered plausible, see text.

\subsubsection{Post-Evaporation Container Leaching}

The evaporator vessel was leached with nitric acid leach solution to evaluate the tendency for $\mathrm{Pu}$ to adhere to or plate on the evaporator walls and to close the material balance associated with the evaporation process. The leached analyte results and percent recoveries are shown in 
Table 6.5. The evaporator concentrate aqueous phase components, represented by $\mathrm{Na},{ }^{137} \mathrm{Cs}, \mathrm{Al}$, and $\mathrm{P}$, recovered an average of $\sim 1.9 \%$ in the acid leach solution. The evaporator-concentrate precipitated metals, represented by $\mathrm{Bi}, \mathrm{Ca}, \mathrm{Ni}, \mathrm{Sr}$, and $\mathrm{Zn}$, recovered an average of $9.7 \%$ in the acid leach solution. However, Fe recovery in the leach solution was low at $0.88 \%$. The residual $\mathrm{Pu}$ recovered in the acid leach solution was $\sim 3.4 \%$. This amount accurately reflects a $\mathrm{Pu}$ fractionation of $77 \%$ in the aqueous phase and $23 \%$ in the solid phase. Thus, $\mathrm{Pu}$ was shown not to selectively plate onto the evaporator walls.

\subsubsection{Evaporator Concentrate Combined with Tank Waste Supernate}

The equilibrated product of the tank waste supernatant (represented by combined Groups 1 and 2 bismuth phosphate sludge and saltcake) combined with the evaporator slurry was evaluated. The calculated composition was based on the mathematical combination of

1) the measured aqueous phase composition of evaporator concentrate (TI525-EvConc-C) multiplied by the calculated volume in the added slurry

2) the measured solids phase composition (dry mass basis) multiplied by the calculated mass in the added evaporator concentrate slurry

3) the measured aqueous phase composition of the added Group 2 dewatered filtrate (obtained from the Group 1/2 CUF processing) multiplied by the added volume

4) the measured oxalate composition in the evaporator concentrate and the solids wash solution; oxalate in the solids was estimated by dividing the evaporator concentrate oxalate mass in the aqueous phase by the relative fraction of oxalate recovered in the concentrate aqueous phase (17\%, see Table 6.6).

The calculated initial composition, equilibrated aqueous phase composition, solids-washsolution composition, and washed-solids composition are provided in Table 6.7 and Table 6.8 along with fractional recoveries. The initial splits of analytes between the solids phase and aqueous phase are also shown. In this case, for example, virtually all of the ${ }^{137} \mathrm{Cs}$ was in the aqueous phase whereas all of the ${ }^{90} \mathrm{Sr}$ was located in the solids phase. Comparison of the initial analyte split to the equilibrated analyte split will provide an indication of analyte movement to or from the solids phase.

Any errors in the input compositions and wt\% UDS would be reflected in the calculated final analyte recovery. Of particular concern is the Pu analysis. The high analyte concentrations found for ${ }^{238} \mathrm{Pu}$ and ${ }^{239+240} \mathrm{Pu}$ in the washed solids after the concentration processing (287\% and 393\% recoveries, respectively) had repercussions with the calculated recoveries in the FEP evaporator combined with supernatant. As can be seen in this case, the total Pu activity balance is low at $\sim 48 \%$. A similar situation was evident for ${ }^{90} \mathrm{Sr}$ determination. Both of these circumstances indicated that the evaporator concentrate analytical sample (TI525-Ev-S-WL) was contaminated with $\mathrm{Pu}$ and ${ }^{90} \mathrm{Sr}$ from another source.

For most elements, the fractionation of evaporator products combined with supernatant waste feed was not much different than that observed for the starting evaporator products. Additional $\mathrm{Mn}$ appeared to precipitate as its fractionation to the solids phase increased and the aqueous phase fraction decreased. The Mn precipitation appeared to co-precipitate additional ${ }^{90} \mathrm{Sr}$ and $\mathrm{Sr}$ out of 
the aqueous phase but had no impact on Th or U. The Pu did not appear to substantially change in the aqueous phase fractionation. The calculated aqueous phase ${ }^{239+240} \mathrm{Pu}$ concentration would have been $7.53 \mathrm{E}-5 \mu \mathrm{Ci} / \mathrm{mL}$ if no Pu precipitated; the observed concentration was $15 \%$ higher at $8.70 \mathrm{E}-5 \mu \mathrm{Ci} / \mathrm{mL}$. Boron remained in the aqueous phase, and $\mathrm{Fe}, \mathrm{Ni}$, and $\mathrm{Cd}$ remained primarily in the solids phase. 
Table 6.7. FEP Concentrate with Group 1/2, Bismuth Phosphate Supernatant, Radionuclides

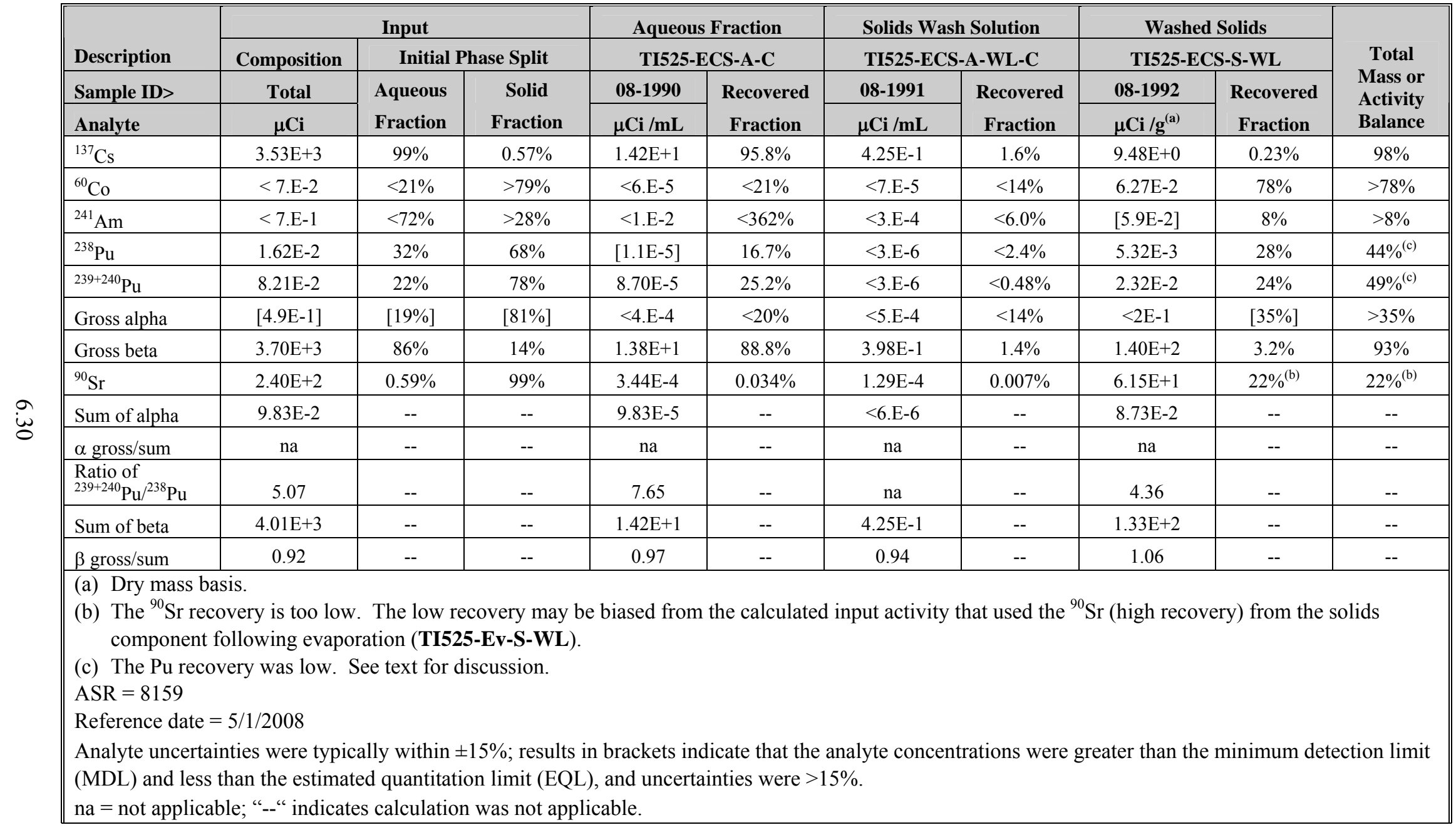


Table 6.8. FEP Concentrate with Group 1/2, Bismuth Phosphate Supernatant, Metals and Anions

\begin{tabular}{|c|c|c|c|c|c|c|c|c|c|c|}
\hline \multirow{4}{*}{$\begin{array}{l}\text { Description } \\
\text { Sample ID> } \\
\text { Analyte }\end{array}$} & \multicolumn{3}{|c|}{ Input } & \multirow{2}{*}{\multicolumn{2}{|c|}{$\begin{array}{c}\text { Aqueous Fraction } \\
\text { TI525-ECS-A-C } \\
\end{array}$}} & \multirow{2}{*}{\multicolumn{2}{|c|}{$\begin{array}{l}\text { Solids Wash Solution } \\
\text { TI525-ECS-A-WL-C }\end{array}$}} & \multirow{2}{*}{\multicolumn{2}{|c|}{$\begin{array}{c}\text { Washed Solids } \\
\text { TI525-ECS-S-WL }\end{array}$}} & \multirow{4}{*}{$\begin{array}{c}\text { Total } \\
\text { Mass or } \\
\text { Activity } \\
\text { Balance }\end{array}$} \\
\hline & \multirow{3}{*}{$\begin{array}{c}\text { Composition } \\
\text { Total } \\
\mu \mathrm{g} \\
\end{array}$} & \multicolumn{2}{|c|}{ Initial Phase Split } & & & & & & & \\
\hline & & Aqueous & Solid & 08-1990 & Recovered & 08-1991 & Recovered & 08-1992 & Recovered & \\
\hline & & Fraction & Fraction & $\mu \mathrm{g} / \mathrm{mL}$ & Fraction & $\mu \mathrm{g} / \mathrm{mL}$ & Fraction & $\mu \mathrm{g} / \mathrm{g}^{(\mathrm{a})}$ & Fraction & \\
\hline $\mathrm{Al}$ & 839,764 & $97 \%$ & $2.7 \%$ & 3,335 & $94.6 \%$ & 80.3 & $1.3 \%$ & 27,100 & $2.7 \%$ & $99 \%$ \\
\hline $\mathrm{B}$ & 16,235 & $100 \%$ & {$[0.23 \%]$} & 67.9 & $99.7 \%$ & 2.69 & $2.2 \%$ & {$[84]$} & {$[0.44 \%]$} & $102 \%$ \\
\hline $\mathrm{Ba}$ & 138.0 & {$[63 \%]$} & $37 \%$ & {$[0.26]$} & {$[45 \%]$} & 0.147 & $14 \%$ & {$[32]$} & {$[19 \%]$} & {$[78 \%]$} \\
\hline $\mathrm{Bi}$ & 3,384 & na & $100 \%$ & $<3.6$ & $<26 \%$ & {$[2.7]$} & {$[11 \%]$} & 3,585 & $89 \%$ & $100 \%$ \\
\hline $\mathrm{Ca}$ & 6,099 & $4 \%$ & $96 \%$ & $<0.74$ & $<2.9 \%$ & [1.1] & {$[2.4 \%]$} & 6,604 & $91 \%$ & $93 \%$ \\
\hline $\mathrm{Cd}$ & 1,167 & [11\%] & $89 \%$ & [1.45] & {$[30 \%]$} & {$[0.24]$} & {$[2.7 \%]$} & 1,080 & $78 \%$ & $110 \%$ \\
\hline $\mathrm{Cr}$ & 480,098 & $100 \%$ & {$[0.01 \%]$} & 1,970 & $97.8 \%$ & 58.3 & $1.6 \%$ & $<13$ & $<0.0023 \%$ & $99 \%$ \\
\hline $\mathrm{Cu}$ & 121 & na & $100 \%$ & $<0.17$ & $<33 \%$ & $<0.03$ & $<3.6 \%$ & 117 & $82 \%$ & $82 \%$ \\
\hline $\mathrm{Fe}$ & 55,248 & {$[1 \%]$} & $99 \%$ & {$[3.75]$} & {$[1.6 \%]$} & {$[0.23]$} & {$[0.06 \%]$} & 50,900 & $77 \%$ & $79 \%$ \\
\hline $\mathrm{K}$ & 124,797 & $100 \%$ & $<0.3 \%$ & 631 & $120 \%$ & 27.7 & $2.9 \%$ & $<455$ & $<0.31 \%$ & $123 \%$ \\
\hline $\mathrm{Mn}$ & 448,691 & $46 \%$ & $54 \%$ & 192 & $10.2 \%$ & {$[0.023]$} & {$[0.0007 \%]$} & 363,000 & $68 \%$ & $78 \%$ \\
\hline $\mathrm{Na}$ & $26,835,570$ & $100 \%$ & $0.23 \%$ & 107,500 & $95.5 \%$ & 5,030 & $2.5 \%$ & 99,500 & $0.31 \%$ & $98 \%$ \\
\hline $\mathrm{Ni}$ & 1,251 & na & $100 \%$ & $<0.29$ & $<5.5 \%$ & $<0.06$ & $<0.60 \%$ & 1,120 & $75 \%$ & $75 \%$ \\
\hline $\mathrm{P}$ & 246,048 & $99 \%$ & {$[0.53 \%]$} & 902 & $87.3 \%$ & 32.5 & $1.7 \%$ & {$[1,400]$} & {$[0.48 \%]$} & $90 \%$ \\
\hline $\mathrm{S}$ & 810,980 & $100 \%$ & $<0.1 \%$ & 3,355 & $98.6 \%$ & 98.1 & $1.6 \%$ & $<1543$ & $<0.16 \%$ & $100 \%$ \\
\hline $\mathrm{Si}$ & 34,408 & $76 \%$ & {$[24 \%]$} & 89.5 & $62.0 \%$ & 3.95 & $1.5 \%$ & 8,300 & $20 \%$ & $84 \%$ \\
\hline $\mathrm{Sr}$ & 116 & $28 \%$ & $72 \%$ & $<0.01$ & $<2.0 \%$ & {$[0.0038]$} & {$[0.43 \%]$} & 111 & $80 \%$ & $80 \%$ \\
\hline $\mathrm{Th}$ & [949] & {$[90 \%]$} & {$[9.9 \%]$} & {$[3.6]$} & {$[90 \%]$} & $<0.23$ & {$[<3.2 \%]$} & {$[87]$} & {$[7.7 \%]$} & $98 \%$ \\
\hline $\mathrm{U}$ & 16,046 & $100 \%$ & $<1.2 \%$ & 66.2 & $98.3 \%$ & {$[0.76]$} & [0.63\%] & [995] & {$[5.2 \%]$} & $104 \%$ \\
\hline $\mathrm{Zn}$ & 1,933 & $58 \%$ & $42 \%$ & [2.35] & {$[29 \%]$} & {$[0.97]$} & {$[6.6 \%]$} & 1,390 & $60 \%$ & $96 \%$ \\
\hline $\mathrm{Zr}$ & 197 & na & $100 \%$ & $<0.13$ & $<16 \%$ & $<0.03$ & $<1.7 \%$ & [89] & $38 \%$ & $>38 \%$ \\
\hline U KPA & 210,251 & $100 \%$ & $0.045 \%$ & $\mathrm{n} / \mathrm{a}$ & -- & $\mathrm{n} / \mathrm{a}$ & -- & $1.13 \mathrm{E}+3$ & $0.45 \%$ & -- \\
\hline nitrite & $1,652,590$ & $100 \%$ & na & 7,070 & $102 \%$ & 196 & $1.6 \%$ & $\mathrm{n} / \mathrm{a}$ & -- & $104 \%$ \\
\hline
\end{tabular}


Table 6.8 (contd)

\begin{tabular}{|c|c|c|c|c|c|c|c|c|c|c|}
\hline \multirow{3}{*}{$\begin{array}{l}\text { Description } \\
\text { Sample ID> }\end{array}$} & \multicolumn{3}{|c|}{ Input } & \multirow{2}{*}{\multicolumn{2}{|c|}{$\begin{array}{c}\text { Aqueous Fraction } \\
\text { TI525-ECS-A-C }\end{array}$}} & \multirow{2}{*}{\multicolumn{2}{|c|}{$\begin{array}{l}\text { Solids Wash Solution } \\
\text { TI525-ECS-A-WL-C }\end{array}$}} & \multirow{2}{*}{\multicolumn{2}{|c|}{$\begin{array}{c}\text { Washed Solids } \\
\text { TI525-ECS-S-WL }\end{array}$}} & \multirow{4}{*}{$\begin{array}{c}\text { Total } \\
\text { Mass or } \\
\text { Activity } \\
\text { Balance }\end{array}$} \\
\hline & \multirow{2}{*}{$\begin{array}{c}\text { Composition } \\
\text { Total } \\
\end{array}$} & \multicolumn{2}{|c|}{ Initial Phase Split } & & & & & & & \\
\hline & & Aqueous & Solid & 08-1990 & Recovered & 08-1991 & Recovered & 08-1992 & Recovered & \\
\hline Analyte & $\mu \mathrm{g}$ & Fraction & Fraction & $\mu \mathrm{g} / \mathrm{mL}$ & Fraction & $\mu \mathrm{g} / \mathrm{mL}$ & Fraction & $\mu \mathrm{g} / \mathrm{g}^{(\mathrm{a})}$ & Fraction & \\
\hline nitrate & $30,543,300$ & $100 \%$ & na & 135,000 & $105 \%$ & 3,700 & $1.6 \%$ & $\mathrm{n} / \mathrm{a}$ & -- & $107 \%$ \\
\hline phosphate & 766,731 & $100 \%$ & na & 3,260 & $101 \%$ & 107 & $1.8 \%$ & $\mathrm{n} / \mathrm{a}$ & -- & $103 \%$ \\
\hline sulfate & $2,257,560$ & $100 \%$ & na & 9,920 & $105 \%$ & 279 & $1.6 \%$ & $\mathrm{n} / \mathrm{a}$ & -- & $106 \%$ \\
\hline oxalate & 804,078 & $36 \%$ & $64 \%$ & 1,360 & $40.3 \%$ & 3,200 & $52.7 \%$ & $\mathrm{n} / \mathrm{a}$ & -- & $93 \%$ \\
\hline free hydroxide & $3,761,978^{(\mathrm{b})}$ & $100 \%$ & na & $14,900^{(\mathrm{b})}$ & $94.4 \%$ & $299^{(\mathrm{b})}$ & $1.0 \%$ & $\mathrm{n} / \mathrm{a}$ & -- & $95 \%$ \\
\hline \multicolumn{11}{|c|}{ Opportunistic Analytes } \\
\hline $\mathrm{F}$ & 579,636 & $100 \%$ & na & 2,750 & 113 & 74.1 & $1.7 \%$ & $\mathrm{n} / \mathrm{a}$ & -- & $115 \%$ \\
\hline $\mathrm{Cl}$ & $\mathrm{n} / \mathrm{a}$ & na & na & 997 & -- & 28.6 & -- & $\mathrm{n} / \mathrm{a}$ & -- & -- \\
\hline $\mathrm{Ag}$ & {$[42]$} & na & {$[100 \%]$} & $<0.25$ & {$[<144 \%]$} & $<0.05$ & {$[<16 \%]$} & $<11$ & {$[<23 \%]$} & $<183 \%$ \\
\hline As & $<1446$ & na & na & $<5.2$ & -- & $<1.0$ & -- & $<259$ & -- & -- \\
\hline $\mathrm{Be}$ & {$[3.2]$} & {$[90 \%]$} & {$[10 \%]$} & $<0.006$ & {$[<47 \%]$} & $<0.001$ & {$[<5 \%]$} & {$[0.71]$} & {$[19 \%]$} & {$[19 \%]$} \\
\hline $\mathrm{Ce}$ & $<335$ & na & na & $<1.2$ & -- & $<0.24$ & -- & $<58$ & -- & -- \\
\hline $\mathrm{Co}$ & $<79$ & na & na & {$[0.45]$} & {$[>134 \%]$} & {$[0.073]$} & {$[>12 \%]$} & $<31$ & -- & {$[>147 \%]$} \\
\hline Dy & $<98$ & na & na & $<0.35$ & -- & $<0.069$ & -- & $<18$ & -- & -- \\
\hline $\mathrm{Eu}$ & $<36$ & na & na & $<0.13$ & --- & $<0.026$ & -- & $<4.6$ & -- & -- \\
\hline $\mathrm{La}$ & {$[71]$} & [48\%] & {$[52 \%]$} & $<0.34$ & {$[<114 \%]$} & $<0.07$ & {$[<12 \%]$} & $<17$ & {$[<21 \%]$} & $<147 \%$ \\
\hline $\mathrm{Li}$ & 1,268 & $36 \%$ & $64 \%$ & 1.70 & $31.9 \%$ & 1.01 & $10.5 \%$ & 934 & $62 \%$ & $104 \%$ \\
\hline $\mathrm{Mg}$ & 504 & na & $100 \%$ & $<0.28$ & $<13 \%$ & $<0.05$ & $<1.4 \%$ & 457 & $76 \%$ & $76 \%$ \\
\hline Mo & 1,913 & $100 \%$ & $\mathrm{na}$ & 7.47 & $93.0 \%$ & {$[0.19]$} & {$[1.3 \%]$} & $<39$ & $<1.7 \%$ & $94.3 \%$ \\
\hline $\mathrm{Nd}$ & 445 & na & $100 \%$ & $<0.65$ & $<35 \%$ & $<0.13$ & $<3.8 \%$ & 395 & $74 \%$ & $74 \%$ \\
\hline $\mathrm{Pb}$ & $<1403$ & na & na & $<3.9$ & -- & {$[1.3]$} & {$[>12 \%]$} & [435] & {$[>26 \%]$} & {$[38 \%]$} \\
\hline $\mathrm{Pd}$ & [139] & {$[100 \%]$} & na & $<0.76$ & {$[<130 \%]$} & $<0.15$ & {$[<14 \%]$} & $<40$ & {$[<24 \%]$} & $<168 \%$ \\
\hline $\mathrm{Rh}$ & $<457$ & na & na & $<1.4$ & -- & $<0.28$ & -- & $<79$ & -- & -- \\
\hline
\end{tabular}


Table 6.8 (contd)

\begin{tabular}{|c|c|c|c|c|c|c|c|c|c|c|}
\hline \multirow{3}{*}{$\begin{array}{l}\text { Description } \\
\text { Sample ID> }\end{array}$} & \multicolumn{3}{|c|}{ Input } & \multirow{2}{*}{\multicolumn{2}{|c|}{$\begin{array}{c}\text { Aqueous Fraction } \\
\text { TI525-ECS-A-C }\end{array}$}} & \multirow{2}{*}{\multicolumn{2}{|c|}{$\begin{array}{l}\text { Solids Wash Solution } \\
\text { TI525-ECS-A-WL-C }\end{array}$}} & \multirow{2}{*}{\multicolumn{2}{|c|}{$\begin{array}{c}\text { Washed Solids } \\
\text { TI525-ECS-S-WL }\end{array}$}} & \multirow{4}{*}{$\begin{array}{c}\text { Total } \\
\text { Mass or } \\
\text { Activity } \\
\text { Balance } \\
\end{array}$} \\
\hline & \multirow{2}{*}{$\begin{array}{c}\text { Composition } \\
\text { Total } \\
\end{array}$} & \multicolumn{2}{|c|}{ Initial Phase Split } & & & & & & & \\
\hline & & Aqueous & Solid & 08-1990 & Recovered & 08-1991 & Recovered & 08-1992 & Recovered & \\
\hline Analyte & $\mu \mathrm{g}$ & Fraction & Fraction & $\mu \mathrm{g} / \mathrm{mL}$ & Fraction & $\mu \mathrm{g} / \mathrm{mL}$ & Fraction & $\mu \mathrm{g} / \mathrm{g}^{(\mathrm{a})}$ & Fraction & \\
\hline $\mathrm{Sb}$ & [623] & {$[100 \%]$} & na & $<2.4$ & {$[<92 \%]$} & $<0.47$ & {$[<10 \%]$} & $<161$ & {$[<22 \%]$} & $<124 \%$ \\
\hline $\mathrm{Se}$ & 13,196 & $100 \%$ & na & [44] & {$[79 \%]$} & $<1.7$ & $<1.7 \%$ & $<567$ & $<3.6 \%$ & {$[79 \%]$} \\
\hline $\mathrm{Ta}$ & $<582$ & na & na & $<2.1$ & -- & $<0.40$ & -- & $<117$ & -- & -- \\
\hline $\mathrm{Te}$ & [738] & {$[100 \%]$} & na & $<3.1$ & {$[<101 \%]$} & $<0.62$ & {$[<11 \%]$} & $<164$ & {$[<19 \%]$} & $<131 \%$ \\
\hline $\mathrm{Ti}$ & 57.7 & {$[21 \%]$} & {$[79 \%]$} & $<0.052$ & $<21 \%$ & $<0.010$ & $<2.3 \%$ & 42.2 & $61 \%$ & $61 \%$ \\
\hline $\mathrm{Tl}$ & $<1346$ & na & na & $<4.6$ & -- & $<0.90$ & -- & $<380$ & -- & -- \\
\hline V & 122 & $87 \%$ & {$[13 \%]$} & {$[0.43]$} & {$[84 \%]$} & {$[0.044]$} & {$[4.77 \%]$} & [23] & {$[16 \%]$} & {$[105 \%]$} \\
\hline W & {$[3,550]$} & {$[100 \%]$} & na & {$[16]$} & {$[104 \%]$} & {$[0.73]$} & {$[2.72 \%]$} & {$[160]$} & {$[3.8 \%]$} & {$[111 \%]$} \\
\hline Y & $<18$ & na & na & $<0.053$ & -- & $<0.010$ & -- & $<2.3$ & -- & -- \\
\hline
\end{tabular}


Another method for reviewing the stability of an analyte in a given phase is provided in Table 6.9. In this analysis, the calculated combined analyte aqueous concentrations are compared to the measured equilibrated aqueous concentrations. Where the ratio of the calculated composition to the measured composition equals $1( \pm 0.08)$, no change in analyte composition is shown (beyond analytical uncertainty), and thus the analyte neither dissolved nor precipitated. Where the analyte concentration ratio is $<0.92$, some level of dissolution is probable. Where the analyte concentration ratio is $>1.08$, some level of analyte precipitation is probable. The behavior of the two different $\mathrm{Pu}$ isotopes measured in this analysis contradicted each other. Half of the ${ }^{238} \mathrm{Pu}$ was lost from solution whereas the ${ }^{239+240} \mathrm{Pu}$ increased in concentration. The $\mathrm{Cr}$ concentration in solution remained static.

Table 6.9. Evaporator Concentrate Combined with Tank Waste Supernatant, Aqueous Phase Analysis

\begin{tabular}{|c|c|c|c|c|}
\hline Analyte & $\begin{array}{c}\text { Calculated } \\
\text { Aqueous } \\
\text { Composition } \\
\mu \mathrm{Ci} / \mathrm{mL} \\
\end{array}$ & $\begin{array}{c}\text { Measured } \\
\text { Aqueous } \\
\text { Composition } \\
\mu \mathrm{Ci} / \mathrm{mL} \\
\end{array}$ & $\begin{array}{c}\text { Calculated/ } \\
\text { Measured } \\
\text { Ratio }\end{array}$ & Comments \\
\hline${ }^{137} \mathrm{Cs}$ & $1.47 \mathrm{E}+1$ & $1.42 \mathrm{E}+1$ & 1.04 & no change \\
\hline${ }^{238} \mathrm{Pu}$ & $2.19 \mathrm{E}-5$ & {$[1.1 \mathrm{E}-5]$} & 1.93 & $\begin{array}{l}\text { precipitated, contradicts } \\
{ }^{239+240} \mathrm{Pu} \text { result }\end{array}$ \\
\hline${ }^{239+240} \mathrm{Pu}$ & $7.53 \mathrm{E}-5$ & $8.70 \mathrm{E}-5$ & 0.87 & possible slight dissolution \\
\hline Gross beta & $1.33 \mathrm{E}+1$ & $1.38 \mathrm{E}+1$ & 0.97 & no change, reflects ${ }^{137} \mathrm{Cs}$ \\
\hline \multirow[t]{2}{*}{${ }^{90} \mathrm{Sr}$} & $5.90 \mathrm{E}-3$ & $3.44 \mathrm{E}-4$ & 17.2 & precipitated \\
\hline & $\mu \mathrm{g} / \mathrm{mL}$ & $\mu \mathrm{g} / \mathrm{mL}$ & & \\
\hline $\mathrm{Al}$ & 3,429 & 3,335 & 1.03 & no change \\
\hline $\mathrm{B}$ & 68.0 & 67.9 & 1.00 & no change \\
\hline $\mathrm{Ba}$ & {$[0.36]$} & {$[0.26]$} & {$[1.40]$} & possible slight precipitation \\
\hline $\mathrm{Cd}$ & {$[0.52]$} & {$[1.45]$} & {$[0.36]$} & possible slight dissolution \\
\hline $\mathrm{Cr}$ & 2,015 & 1,970 & 1.02 & no change \\
\hline $\mathrm{Fe}$ & [3.35] & [3.75] & {$[0.89]$} & possible slight dissolution \\
\hline $\mathrm{K}$ & 524 & 631 & 0.83 & slight dissolution \\
\hline $\mathrm{Mn}$ & 873 & 192 & 4.56 & precipitated \\
\hline $\mathrm{Na}$ & 112,358 & 107,500 & 1.05 & no change \\
\hline $\mathrm{Ni}$ & $<0.29$ & $<0.29$ & -- & na \\
\hline $\mathrm{P}$ & 1,027 & 902 & 1.14 & slight precipitation \\
\hline $\mathrm{S}$ & 3,403 & 3,355 & 1.01 & no change \\
\hline $\mathrm{Si}$ & 110.4 & 89.5 & 1.23 & slight precipitation \\
\hline Th & {$[3.6]$} & [3.6] & {$[1.0]$} & possible slight precipitation \\
\hline $\mathrm{U}$ & 67.3 & 66.2 & 1.02 & no change \\
\hline $\mathrm{Zn}$ & [4.71] & {$[2.35]$} & {$[2.0]$} & precipitated \\
\hline nitrite & 6,935 & 7,070 & 0.98 & no change \\
\hline nitrate & 128,172 & 135,000 & 0.95 & no change \\
\hline phosphate & 3,218 & 3,260 & 0.99 & no change \\
\hline sulfate & 9,474 & 9,920 & 0.96 & no change \\
\hline
\end{tabular}


Table 6.9 (contd)

\begin{tabular}{|c|c|c|c|c|}
\hline Analyte & $\begin{array}{c}\text { Calculated } \\
\text { Aqueous } \\
\text { Composition } \\
\mu \mathrm{g} / \mathrm{mL} \\
\end{array}$ & $\begin{array}{c}\text { Measured } \\
\text { Aqueous } \\
\text { Composition } \\
\mu \mathrm{g} / \mathrm{mL} \\
\end{array}$ & $\begin{array}{c}\text { Calculated/ } \\
\text { Measured } \\
\text { Ratio } \\
\end{array}$ & Comments \\
\hline oxalate & 1,231 & 1,360 & 0.91 & slight dissolution \\
\hline free $\mathrm{OH}$ & 15,793 & 14,900 & 1.06 & no change \\
\hline \multicolumn{5}{|c|}{ Opportunistic Analytes } \\
\hline fluoride & 2,432 & 2,750 & 0.88 & slight dissolution \\
\hline $\mathrm{Li}$ & 1.90 & 1.70 & 1.12 & slight precipitation \\
\hline Mo & 8.03 & 7.47 & 1.08 & no change \\
\hline $\mathrm{Ru}$ & [0.92] & [1.35] & {$[0.68]$} & possible slight precipitation \\
\hline $\mathrm{Se}$ & [55] & [44] & {$[1.3]$} & possible slight precipitation \\
\hline $\mathrm{Sn}$ & $<4.2$ & [6.35] & $<0.65$ & possible slight dissolution \\
\hline $\mathrm{V}$ & {$[0.45]$} & {$[0.43]$} & {$[1.0]$} & possible slight precipitation \\
\hline $\mathrm{W}$ & [15] & [16] & {$[0.96]$} & no change \\
\hline \multicolumn{5}{|c|}{$\begin{array}{l}\text { ASR }=8159 \\
\text { Reference date }=5 / 1 / 2008 \\
\text { Analyte uncertainties were typically within } \pm 15 \% \text {; results in brackets indicate that the analyte } \\
\text { concentrations were greater than the minimum detection limit (MDL) and less than the estimated } \\
\text { quantitation limit (EQL), and uncertainties were }>15 \% \text {. }\end{array}$} \\
\hline
\end{tabular}

\subsubsection{Permanganate Reduction}

The combination of the concentrated slurry (TI525-EvConc) containing permanganate with Group 1/2 supernatant did not noticeably diminish the solution color, i.e., some of the permanganate and/or manganate remained in solution. As discussed in Section 5, residual permanganate (from the final CUF processing dewater solution) was completely reduced in the ion exchange feed after combination with Group 5/6 supernatant, resulting in virtually complete removal of $\mathrm{Mn}$ as an insoluble solid from the aqueous phase. Several distinguishing supernatant characteristics stand out.

- The nitrite concentration in the ion exchange feed $(0.29 \mathrm{M})$ was $\sim 10 \times$ the concentration of the nitrite in the evaporator feed $(0.027 \mathrm{M})$ and nearly twice the nitrite concentration in the added Group $1 / 2$ supernatant $(0.17 \mathrm{M})$

- The free hydroxide concentration in the ion exchange feed $(2.89 \mathrm{M})$ was $\sim 5 \times$ higher than that of the evaporator feed $(0.60 \mathrm{M})$ and $\sim 40 \times$ higher than that of Group $1 / 2$ supernatant $(0.07 \mathrm{M})$

- The TOC concentration was not measured in the combined feeds, however the Group 6 supernatant TOC $(1,385 \mu \mathrm{g} / \mathrm{mL})$ was nearly twice that of Group 2 supernatant (765 $\mu \mathrm{g} / \mathrm{mL})$.

- The Mn concentration in the ion exchange feed (9.2E-3 M) was approximately half that of the combined evaporator feed $(0.017 \mathrm{M})$ before permanganate reduction occurred. 
As discussed in Section 6.3.2, the nitrite was depleted in the evaporator concentrate. The nitrite oxidation in the hydroxide matrix (refer to Equation 6.1) may have been the reducing source for the permanganate reduction. The relatively higher concentrations of these components in the ion exchange feed may have driven the permanganate reduction to completion. However, reducing organic components such as formate may also be involved in the permanganate reduction. More testing would be required to provide a definitive relationship and reaction kinetics between the nitrite and hydroxide concentrations versus permanganate reduction. However, it is reasonable to assume that had the supernatant that contacted the evaporator concentrate (still containing permanganate) contained substantially higher nitrite and hydroxide concentrations, as is often seen in tank waste, then more Mn precipitation would likely have occurred. 


\subsection{Summary and Conclusions}

The WTP pretreatment flowsheet process steps were applied to Group 5 REDOX waste combined with Group 6 S-Saltcake waste on a laboratory-scale basis. The composited solids were high in boehmite concentration, requiring high-temperature caustic leaching to promote $\mathrm{Al}$ dissolution, and were high in insoluble $\mathrm{Cr}\left(\mathrm{Cr}_{2} \mathrm{O}_{3}\right)$ concentration, requiring oxidative leaching to effect $\mathrm{Cr}$ dissolution. The composite aqueous phase was typical of tank waste supernatant containing high concentrations of dissolved salts. The composite was subjected to the pretreatment flowsheet process steps including:

- determination of the permanganate dosage needed for $\mathrm{Cr}$ removal

- caustic leaching for Al removal, washing, and filtration in the CUF

- oxidative leaching for Cr removal, washing, and filtration in the CUF

- ion exchange processing for Cs removal

- evaporation processing for recycle stream volume reduction

- blending of evaporator bottoms with tank waste.

The test was considered the demonstration test because it satisfied the need to demonstrate the entire pretreatment process flowsheet on actual tank waste material, resolving limitations identified in the "Oxidative Leaching Oversight Report" (D-05-DESIGN-013). The efficacy of the oxidant dosage determination conducted on a bench scale ( $\sim 1 \mathrm{~g}$ solids per test, parametric design) was evaluated relative to the performance of the oxidative leach processing conducted on the laboratory scale ( $\sim 270 \mathrm{~g}$ solids) in the CUF. Additionally, the fates of Pu and neutron absorbers ( $\mathrm{B}$ and $\mathrm{Cd}$ ) were evaluated through all flowsheet processing steps.

\subsection{Oxidant Dosage Determination}

Parametric testing was conducted to determine the oxidant dosage required to mobilize $\mathrm{Cr}$ as well as characterize concomitant $\mathrm{Pu}$ mobilization. Testing was conducted at room temperature $\left(\sim 24^{\circ} \mathrm{C}\right)$ for $6 \mathrm{~h}$ at 0.6 to $1.2 \mathrm{wt} \%$ UDS under various free-hydroxide concentrations and various $\mathrm{Mn} / \mathrm{Cr}$ mole ratios. The following observations and conclusions were made:

- A 0.95:1 Mn:Cr mole ratio mobilized 84\% of the $\mathrm{Cr}$ from the solids phase to the aqueous phase. Increasing the $\mathrm{Mn}: \mathrm{Cr}$ mole ratio resulted in increasing $\mathrm{Cr}$ mobilization topping out at $\sim 99 \%$ (1.38:1 Mn:Cr mole ratio). The amount of permanganate WTP will need to add during pretreatment processing will be driven in part by the required $\mathrm{Cr}$ mobilization.

- Hydroxide concentrations from 0.25 M to 1.4 M had no significant impact on the extent or rate of $\mathrm{Cr}$ dissolution.

- A small fraction of $\mathrm{Pu}$ was mobilized to the aqueous phase with the $\mathrm{Cr}$ during oxidative leaching. As the sodium hydroxide concentration increased from $0.25 \mathrm{M}$ to $1.4 \mathrm{M}$, the $\mathrm{Pu}$ concentration in the leachate and total fraction of Pu removed increased $\sim 7$-fold (see Figure 7.1). The pretreatment processing flowsheet will need to balance the volume required for caustic solids washing to reach a low sodium hydroxide concentration in 
preparation for oxidative leaching with the amount of $\mathrm{Pu}$ mobilization that can be tolerated in the final LAW product. The observed Pu solubility as a function of freehydroxide concentration was consistent with previously reported data (Delegard 2006).

- Oxidative leaching of $\mathrm{Cr}$ in the small-scale tests reached completion in $\leq 1 \mathrm{~h}$.

- Similar to $\mathrm{Cr}$, the $\mathrm{Pu}$ reached equilibrium concentration in $\leq 1 \mathrm{~h}$.

- The oxidized and dissolved $\mathrm{Cr}$ was present as chromate (Cr[VI]). The Pu oxidation state could not be assessed since analytical methods were not applicable in the highly colored permanganate matrix.

- The rate and extent of the oxidative leaching on the combined Group 5 and Group 6 material were similar to those of the Group 6 material alone, within experimental uncertainty. This indicated that the dilution of high-Cr solids in the boehmite-rich solids matrix did not retard the $\mathrm{Cr}$ dissolution rate or extent.

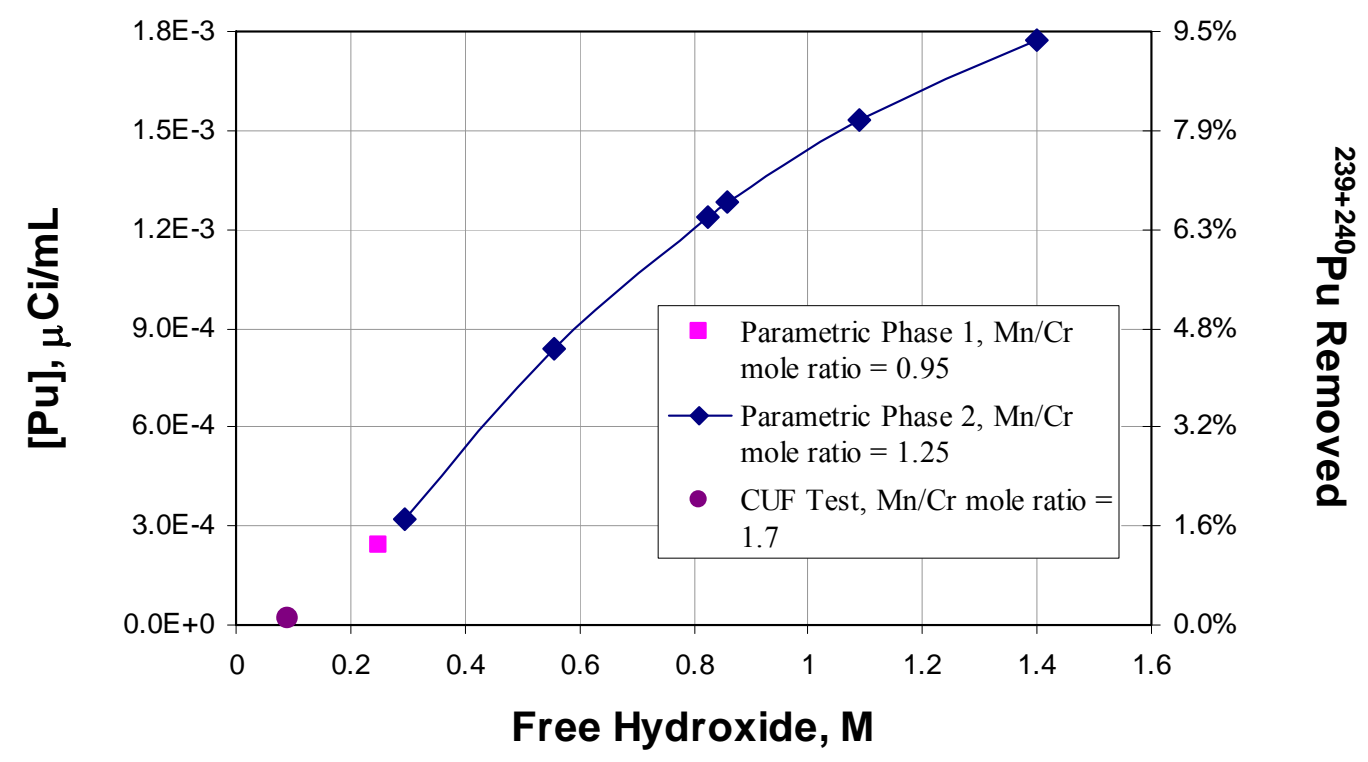

Figure 7.1. Plutonium Dissolution and Fraction Removed as Functions of $\mathrm{NaOH}$ Concentration during Parametric Testing and CUF Testing

\subsection{Demonstration Test}

Observations of the CUF processing (caustic and oxidative leaching) and downstream processing including ion exchange and evaporation are summarized as follows.

\section{CUF Processing}

The CUF testing incorporated all flowsheet processing, including initial dewatering, caustic leaching, six successive solids washing and filtration steps, oxidative leaching, and two successive solids washing steps in a successful demonstration of $\mathrm{Cr}$ dissolution from oxidative leaching. 
- Caustic leaching was conducted for $8 \mathrm{~h}$ at $100(+5 /-10)^{\circ} \mathrm{C}$ at $\sim 6.2 \mathrm{M}$ final free hydroxide and $5 \mathrm{wt} \%$ UDS.

o The caustic leaching depressed oxalate, fluoride, and Pu solubility whereas the subsequent washing increased these component solubilities. Both oxalate and fluoride are good complexants for Pu so their dissolution in the washing solutions could lead to elevated $\mathrm{Pu}$ concentrations in these solutions.

o Evaluation of the aqueous caustic leach solution and sequential wash solutions showed:

- Caustic leaching removed $\sim 46 \%$ of the $\mathrm{Al}$, and 2 to $6 \%$ of the $\mathrm{Cr}$ and $<0.2 \%$ of the $\mathrm{Pu}$ from the undissolved solids.

- The combined permeates from dewatering and sequential solids washing removed $\sim 48 \% \mathrm{Al}, 17 \% \mathrm{Cr}$, and $0.13 \% \mathrm{Pu}$ from the slurry (where the $\mathrm{Pu}$ and about half of the $\mathrm{Cr}$ were already present as part of the supernatant component before caustic leaching).

- Oxidative leaching was conducted with a Mn:Cr mole ratio of 1.7:1 at cell temperature $\left(27 \pm 3^{\circ} \mathrm{C}\right)$ for $6 \mathrm{~h}$ in a free-hydroxide matrix concentration of $0.09 \mathrm{M}$ and $\sim 6 \mathrm{wt} \% \mathrm{UDS}$.

o Evaluation of the aqueous oxidative leach and wash solutions showed that $>90 \%$ of the $\mathrm{Cr}$ and $0.04 \%$ of the ${ }^{239+240} \mathrm{Pu}$ had been leached from the solids phase. Rinsing of the slurry removed $80 \%$ of the dissolved $\mathrm{Cr}$; additional rinsing would have continued to remove soluble $\mathrm{Cr}$ from the CUF.

o The observed Pu solubility in the given free-hydroxide concentration was consistent with previously published data (Delegard 2006) and with the trends observed during parametric leach testing (see Figure 7.1).

o Within the experimental uncertainty, the $\mathrm{Cr}$ and $\mathrm{Pu}$ concentrations were shown to rapidly reach equilibrium (within $0.5 \mathrm{~h}$ ) consistent with observations from parametric testing.

- Extensive filtration testing, rheology measurements, and PSD analysis were conducted at key process junctures but are reported separately (Shimskey et al. 2008).

\section{Ion Exchange Processing}

Cesium ion exchange processing was conducted in a $22-\mathrm{mL}$ resin bed $(\mathrm{L} / \mathrm{D}=1.47)$ of spherical RF resin in prototypic flowsheet operations. The Na concentration in the waste feed solution was $4.5 \mathrm{M}$ and was processed at $3 \mathrm{BV} / \mathrm{h}$. Following feed displacement and water rinse, the resin was eluted with $15 \mathrm{BVs}$ of $0.5 \mathrm{M} \mathrm{HNO}_{3}$ at $\sim 1.4 \mathrm{BV} / \mathrm{h}$.

- The ion exchange feed was prepared by blending tank waste supernatant (Group 5 and 6) with the caustic leach permeate and a portion of the oxidative leach permeate, both obtained from upstream CUF processing. Nearly complete aqueous Mn reduction to an insoluble Mn compound occurred in $\leq 16 \mathrm{~h}$. Nearly $25 \%$ of the Pu was co-precipitated with $\mathrm{Mn}$. An estimated $1 \mathrm{~g}$ of Mn compound (dry mass basis) precipitated per $1 \mathrm{~L}$ of solution. Had the precipitation reaction occurred during the ion exchange processing, the precipitate could have accumulated on top of the resin bed, within the resin bed, or 
potentially within the resin pore structure; in either case, the resin bed could potentially be fouled. It is noted that WTP does not intend to combine supernatant with oxidative leach permeate solution downstream of the ultrafilters.

- Cesium breakthrough was not observed after processing 209 BVs of feed.

- The Pu in the ion exchange feed largely partitioned to the effluent (LAW); 4.2\% was found in the eluate (HLW), and $0.18 \%$ was found on the spherical RF ion exchanger after elution was complete. Therefore, at the end of the load, feed displacement, and water rinse steps, $\sim 4.5 \%$ of the total $\mathrm{Pu}$ in the feed had partitioned to the resin bed.

- The Cr and Ag (Ag was measured opportunistically) are elements of RCRA concern and were also found in the spent resin at 260 and $12.7 \mu \mathrm{g}$ per g dry resin, respectively. Since chromate is a component of the feed, its concentration on the resin probably represents a saturation point. Although Ag was not detected in the feed, $\geq 20 \%$ had concentrated onto the resin; Ag fractionation between the eluate and spent resin was determined and showed that $\sim 33 \%$ remained with the resin.

\section{Evaporation}

Evaporation processing combined 1) prototypic quantities of water-rinse permeates obtained from the caustic-leached solids and oxidatively leached solids (from the CUF), 2) a fraction of the permeate from the oxidatively-leached solids (from the CUF), 3) Cs ion exchange feed displacement and water rinse effluents, 4) simulated submerged bed scrubber solution, and 5) simulated UFP cleaning solution. Evaporation was conducted at $50^{\circ} \mathrm{C}$, reducing the total volume by a factor of 6.8 , resulting in a $5.7-\mathrm{M} \mathrm{Na}$ solution.

- Nominally 32 to $48 \%$ of the Pu appeared to be lost to the precipitated phase based on evaluation of the aqueous phase results.

- $\mathrm{Cd}, \mathrm{Fe}$, and Ni partitioned to the solids phase whereas B remained in the aqueous phase. Both oxalate and Mn partially precipitated ( $\sim 74 \%$ and $34 \%$, respectively).

\section{Combination of Evaporator Bottoms with Tank Waste Supernatant}

The evaporator bottoms were combined with the Group 1/2 permeate obtained from CUF processing and allowed to stand for 7 days.

- The Cr concentration remained static in the solution phase indicating that no chromate reduction or Cr precipitation occurred.

- The change in Pu concentration was not definitive. The ${ }^{238} \mathrm{Pu}$ concentration appeared to be reduced by half, indicating post-combination precipitation, while the ${ }^{239+240} \mathrm{Pu}$ concentration had slightly increased, indicating that no further precipitation occurred. It is recommended that additional testing be conducted to assess the Pu behavior.

- A significant fraction ( $\sim 50 \%)$ of Mn precipitated after adding the Group 1/2 supernate to the evaporator concentrate. In contrast, virtually $100 \%$ of the Mn had precipitated when Group 5/6 permeate was added to permanganate-bearing solution in preparation for ion exchange. Specific matrix parameters (e.g., nitrite and/or reducing organics) appeared to 
Table 7.2. Selected Analyte Partitioning Through Ion Exchange Processing

\begin{tabular}{|c|c|c|c|c|}
\hline Analyte & Effluent & Rinses & Eluant & Resin \\
\hline${ }^{238} \mathrm{Pu}$ & $89.4 \%$ & $1.66 \%$ & $<3.7 \%$ & $0.17 \%$ \\
\hline${ }^{239+240} \mathrm{Pu}$ & $93.5 \%$ & $1.50 \%$ & $4.23 \%$ & $0.18 \%$ \\
\hline $\mathrm{Al}$ & $99.5 \%$ & $1.68 \%$ & $0.015 \%$ & $9.3 \mathrm{E}-4 \%$ \\
\hline $\mathrm{B}$ & $56.7 \%$ & $0.93 \%$ & $42.2 \%$ & {$[0.010 \%]$} \\
\hline $\mathrm{Cd}$ & na & na & na & na \\
\hline $\mathrm{Cr}$ & $99.3 \%$ & $1.63 \%$ & [0.009\%] & $0.047 \%$ \\
\hline $\mathrm{Fe}$ & {$[27 \%]$} & {$[1.8 \%]$} & {$[1.6 \%]$} & $0.109 \%$ \\
\hline $\mathrm{Mn}$ & {$[72 \%]$} & {$[2.4 \%]$} & {$[7.8 \%]$} & $4.46 \%$ \\
\hline $\mathrm{Ni}$ & $<99 \%$ & $<2.0 \%$ & {$[15 \%]$} & $4.43 \%$ \\
\hline \multicolumn{5}{|c|}{ na $=$ not applicable, analyte was not detected. } \\
\hline \multicolumn{5}{|c|}{$\begin{array}{l}\text { Analyte uncertainties were typically within } \pm 15 \% \text {; results in brackets indicate that the } \\
\text { analyte concentrations were greater than the minimum detection limit (MDL) and less } \\
\text { than the estimated quantitation limit (EQL), and uncertainties were }>15 \% \text {. }\end{array}$} \\
\hline
\end{tabular}

Table 7.3. Selected Analyte Partitioning Through Evaporation Processing

\begin{tabular}{|l|c|c||}
\hline Analyte & Solids & Aqueous \\
\hline${ }^{238} \mathrm{Pu}$ & (a) & $52 \%$ \\
\hline${ }^{239+240} \mathrm{Pu}$ & (a) & $68 \%$ \\
\hline $\mathrm{Al}$ & $3.1 \%$ & $96 \%$ \\
\hline $\mathrm{B}$ & {$[>0.52 \%]$} & $>98 \%$ \\
\hline $\mathrm{Cd}$ & $68 \%$ & {$[8.3 \%]$} \\
\hline $\mathrm{Cr}$ & $>61 \%$ & $77 \%$ \\
\hline $\mathrm{Fe}$ & $39 \%$ & {$[>0.05 \%]$} \\
\hline $\mathrm{Mn}$ & $>66 \%$ & $35 \%$ \\
\hline $\mathrm{Ni}$ & na \\
\hline $\begin{array}{l}\text { (a) Results were confounded, see Section } 6 . \\
\text { Analyte uncertainties were typically within } \pm 15 \% ; \text { results in brackets indicate that the } \\
\text { analyte concentrations were greater than the minimum detection limit (MDL) and less } \\
\text { than the estimated quantitation limit (EQL), and uncertainties were }>15 \% .\end{array}$ \\
\hline
\end{tabular}

A pictorial representation of the overall $\mathrm{Pu}$ mass balance through the demonstration test is provided in Figure 7.2. Process flows are shown with arrows; the width of the arrow is proportional to the ${ }^{239+240} \mathrm{Pu}$ activity (shown in $\mu \mathrm{Ci}$ ). The loss of $\mathrm{Pu}$ associated with sub-sampling activities was excluded in this overall evaluation of $\mathrm{Pu}$ fractionation. Under the test and matrix conditions, $99.8 \%$ of the $\mathrm{Pu}$ in the feed material partitioned to the IHLW stream. Washing the caustic leached solids caused the largest mobilization of $\mathrm{Pu}$ from the solids into the aqueous phase; Pu mobilization from oxidative leaching was dwarfed in comparison. A fraction of the oxidative leach solution was added to the ion exchange feed to boost the Pu concentration to the ion exchanger; the WTP process does not incorporate this solution in the ion exchange feed. Of the $\mathrm{Pu}$ that was introduced to ion exchange, $95 \%$ passed through the ion exchange column as effluent, feed displacement, and water rinse. 


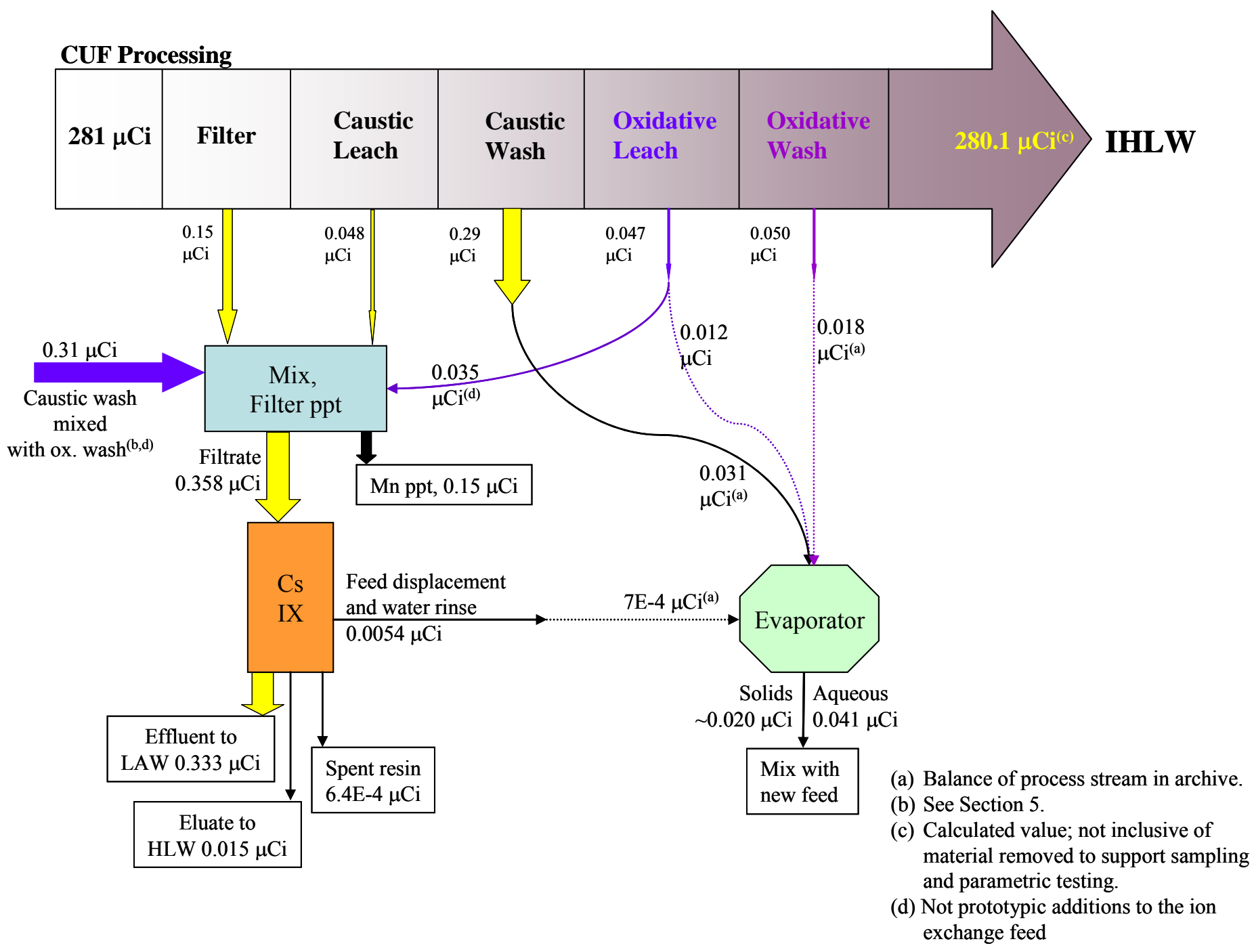

Figure 7.2. Pu Partitioning Through the Demonstration Test

( $\mathrm{Pu}$ activities based on ${ }^{239+240} \mathrm{Pu}$; line widths are proportional to $\mathrm{Pu}$ activity) 
Appendix A

\section{Analytical Methods}




\section{Appendix A: Analytical Methods}

This section describes the analytical methods used to determine the chemical and radiochemical composition of the sample slurries.

\section{A.1 Chemical and Radioisotope Characterization}

The following sections describe procedures used to support the chemical and radiochemical characterization of the solids and aqueous samples. Aqueous samples were distributed directly to the free hydroxide, ion chromatrography (IC), and TIC/TOC analytical workstations. The solids and liquids required a digestion step before distribution to the ICP-OES and radiochemistry workstations.

\section{A.1.1 Free Hydroxide}

The free hydroxide concentration was determined by potentiometric titration with standardized $\mathrm{HCl}$ according to procedure RPG-CMC-228, Determination of Hydroxyl $(\mathrm{OH})$ and Alkalinity of Aqueous Solutions, Leachates, and Supernates and Operation of Brinkman 636 Auto-Titrator. The free hydroxide was defined as the first inflection point on the titration curve. QC samples were generated at the analytical workstation and included a sample replicate determination, process blank, BS, and MS.

\section{A.1.2 Anions}

Anions were determined by ion chromatography with a Dionix ICS-2500 IC system equipped with a conductivity detector according to procedure RPG-CMC-212, Determination of Common Anions by Ion Chromatography. Additional sample dilutions from $100 \times$ to $25,000 \times$ were required to accurately measure the analytes. QC samples were generated at the analytical workstation and included a sample replicate determination, process blank, BS, and MS.

\section{A.1.3 TIC/TOC}

The TIC was determined by applying silver-catalyzed hot persulfate (HP) oxidation according to procedure RPG-CMC-385, Carbon Measured in Solids, Sludge, and Liquid Matrices. The hot persulfate wet oxidation method was used. This method takes advantage of acid decomposition of the carbonate (TIC measure) followed by oxidation of organic carbon (TOC measure) with acidic potassium persulfate at 92 to $95^{\circ} \mathrm{C}$. QC samples were generated at the analytical workstation and included a sample replicate determination, process blank, BS, and MS.

\section{A.1.4 Acid Digestion}

Aqueous samples were digested with acid according to procedure PNL-ALO-128, $\mathrm{HNO}_{3}-\mathrm{HCl}$ Acid Extraction of Liquids for Metals Analysis Using a Dry-Block Heater. The acid-digested solutions were brought to a nominal $25-\mathrm{mL}$ volume (resulting in a nominal $25 \times$ dilution where the initial sample size was 1-mL); absolute volumes were determined based on final solution weights and densities. As part of the analytical preparation batch, the ASO processed a digestion preparation blank (PB), a BS, and an MS. The spike solution contained a broad suite of stable elements; radionuclides were not included in the digestion preparation. Aliquots of the BS, MS, and PB, along with the sample aliquots, were delivered to 
the ICP-OES workstation for analysis; sample and PB aliquots were delivered to the radiochemical workstations for separations supporting specific radioisotope analysis.

\section{A.1.5 KOH Fusion}

The potassium hydroxide (KOH) fusion was conducted in the shielded analytical facility (hot cells) according to PNL-ALO-115, Solubilization of Metals from Solids using $\mathrm{KOH}-\mathrm{KNO}_{3}$ Fusion. A nominal sample size of 0.1 to $0.2 \mathrm{~g}$ dry solids was combined with a $\mathrm{KOH} / \mathrm{KNO}_{3}$ flux mixture and fused at $550^{\circ} \mathrm{C}$ for 1 hour in a nickel crucible. The fused material was acidified with $\mathrm{HNO}_{3}$, taken to a 100 -mL volume with de-ionized (DI) water, and then split for metals and radionuclide analysis. Samples were typically prepared in duplicate along with a fusion blank and a laboratory control sample (LCS) (SRM-2710, Montana Soil, purchased from the National Institute for Science and Technology [NIST]).

\section{A.1.6 HF-Assisted Acid Digestion}

The HF-assisted acid digestion was conducted in the shielded analytical facility (hot cells) according to PNL-ALO-138, $\mathrm{HNO}_{3}-\mathrm{HF}-\mathrm{HCl}$ Acid Digestion of Solids for Metals Analyses Using a Dry Block Heater. A nominal sample size of 0.1 to $0.2 \mathrm{~g}$ dry solids was contacted with a mixture of concentrated $\mathrm{HF}$ and $\mathrm{HNO}_{3}$ and evaporated to dryness in a Teflon ${ }^{\circledR}$ reaction tube. Concentrated $\mathrm{HCl}$ was then added, and the sample was evaporated to dryness a second time. Additional concentrated $\mathrm{HNO}_{3}$ and $\mathrm{HCl}$ were added, the reaction tube was capped tightly, and the mixture was heated in a dry-block heater at $95^{\circ} \mathrm{C}$ for $6.5 \mathrm{~h}$. The digestate was cooled, brought to a $50-\mathrm{mL}$ volume, and then split for metals analysis. The sample was prepared in duplicate along with a fusion blank and an LCS (SRM-2710, Montana Soil).

\section{A.1.7 Metals Analysis by ICP-OES}

Metals were measured by ICP-OES according to procedure RPG-CMC-211, Determination of Elemental Composition by Inductively Coupled Argon Plasma Optical Emission Spectrometry (ICPOES). The preparative QC samples (duplicate, PB, BS, MS) were processed along with analytical workstation QC (post digestion spike and serial dilution).

\section{A.1.8 U (KPA)}

Uranium was determined directly from solids samples prepared by $\mathrm{KOH}$ fusion and from aqueous samples prepared by acid digestion. Analysis was conducted with a Chem Chek Instruments KPA according to procedure RPG-CMC-4014, Rev. 1, Uranium by Kinetic Phosphorescence Analysis. The LCS did not contain U, so preparative QC was limited to the duplicate and PB. A post-digestion spike was conducted at the analytical workstation.

\section{A.1.9 Gamma Energy Analysis}

Gamma energy analysis was performed with direct or diluted samples that were prepared from acid digestion, fusion, or neat (direct or straight dilution). Sample counting was conducted according to procedure RPG-CMC-450, Gamma Energy Analysis (GEA) and Low-Energy Photon Spectroscopy (LEPS), using high-purity germanium detectors. Extended count times (up to $20 \mathrm{~h}$ ) were employed as needed to achieve low detection limits. In many cases, the Compton background from the high ${ }^{137} \mathrm{Cs}$ activity (661 keV) limited the achievable detection limit of lower-energy gamma emitters (e.g., ${ }^{241} \mathrm{Am}$ at $59 \mathrm{keV}$ ). The QC associated with the GEA analysis was composed of the sample duplicate and PB; because this is a direct analysis, no additional QC samples were required. 


\section{A.1.10 Gross Alpha and Gross Beta}

The gross alpha and beta activities were measured from aqueous samples prepared by acid-digestion, and washed-solids samples were prepared by $\mathrm{KOH} / \mathrm{KNO}_{3}$ fusion. Prepared sample aliquots were plated directly onto stainless steel planchets according to procedure RPG-CMC-4001, Source Preparation for Gross Alpha and Gross Beta Analysis. The mounts prepared for gross alpha analysis were counted with Ludlum alpha scintillation counters. The gross alpha analysis tends to be confounded by the dissolved solids in the sample matrix. The solids can absorb the alpha particles, decreasing the intensity relative to the detector, which biases the results low. The sources prepared for gross beta analysis were counted with an LB4100 gas-proportional counter. In both cases, counting operations were conducted according to procedure RPG-CMC-408, Rev.1, Total Alpha and Total Beta Analysis. The preparative QC included the sample duplicates and the preparation blank. The BS and MS were prepared at the analytical workstation on sample dilutions.

\section{A.1.11 Pu Isotopes: ${ }^{238} \mathrm{Pu}$ and ${ }^{239+240} \mathrm{Pu}$}

The ${ }^{238} \mathrm{Pu}$ and ${ }^{239+240} \mathrm{Pu}$ activities were measured from aqueous samples prepared by acid-digestion and washed solids samples prepared by $\mathrm{KOH} / \mathrm{KNO}_{3}$ fusion. Radiochemical separations were conducted according to procedure RPG-CMC-4017, Analysis of Environmental Water Samples for Actinides and Strontium-90 (analyte purification using ion exchange); source preparation was conducted according to RPG-CMC-496, Coprecipitation Mounting of Actinides for Alpha Spectroscopy (co-precipitation of PuF 3 with $\mathrm{LaF}_{3}$ ); and alpha counting was conducted according to RPG-CMC-422, Rev.1, Solutions Analysis: Alpha Spectrometry. The preparative QC included the sample duplicates and the preparation blank. The BS and MS were prepared at the analytical workstation on sample dilutions.

\section{A.1.12 Strontium-90}

The ${ }^{90} \mathrm{Sr}$ activities were measured from aqueous samples prepared by acid-digestion, and washedsolids samples were prepared by $\mathrm{KOH} / \mathrm{KNO}_{3}$ fusion. Radiochemical separation was conducted according to procedure RPG-CMC-476, Strontium-90 Separation Using Eichrom Strontium Resin; source preparation and beta counting were conducted according RPG-CMC-474, Measurement of Alpha and Beta Activity by Liquid Scintillation Spectrometry.

\section{A.2 Crystal Form and Habit}

This section describes the methods used to determine the crystal forms and habits of the tank solid samples. The solids crystal characteristics were determined on small aliquots of the solids. In all cases, the solids sample fractions were allowed to air dry at room temperature in preparation for analysis. This effort was intended to minimize morphological changes that might occur upon heating. The methods applied for XRD, SEM, and TEM evaluations are discussed in the following sections.

\section{A.2.1 X-Ray Diffraction}

The sample mounts for XRD examination were prepared from the dried solids according to procedure RPL-PIP-4, Preparing Sealed Radioactive Samples for XRD and Other Purposes. Specimens were pulverized to a powder with a boron carbide mortar and pestle, mixed with an internal standard (rutile, $\mathrm{TiO}_{2}$, or alumina, $\mathrm{Al}_{2} \mathrm{O}_{3}$ ), and mounted on a glass slide. In some cases, the internal standard was omitted to provide better clarity of the sample diffraction pattern free from potential interference from the internal standard diffraction pattern. The XRD examination was conducted according to procedure PNNL-RPG- 
268, Solids Analysis, $X$-Ray Diffraction Using RGD \#34. Process parameters included examination of the X-ray 2-theta range from 5 to 65 degrees with a step size of 0.02 degrees and a dwell time of 20 seconds.

Phase identification was performed with JADE, Version 8.0 (Materials Data Inc., Livermore, CA) software search and peak match routines with comparison to the International Centre for Diffraction Data (ICDD) database PDF-2, Version 2.0602 (2006). The ICDD database included the Inorganic Crystal Structure Database (ICSD) maintained by Fachinformationszentrum, Karlsuhe, Germany. Phase identification incorporated chemistry restrictions based on the elements determined from chemical analysis.

\section{A.2.2 Scanning Electron Microscopy}

A small sample was transferred with a wooden Q-tip stem onto carbon tape supported by an aluminum pedestal mount. The sample was analyzed with the radiation-shielded Amray Model 1610T SEM according to RPL-611A-SEM, Scanning Electron Microscope Examinations. In selected cases, the mount was carbon-coated. Selected sample areas were evaluated by X-ray EDS for qualitative elemental composition.

\section{A.2.3 Transmission Electron Microscopy}

The TEM samples were prepared in a two-step methanol rinsing process. A small amount of the sludge slurry was mixed and transferred into methanol; a drop of the methanol slurry was transferred into a second vial containing methanol; then a drop of this second solution was deposited onto a lacey carbon TEM grid. The particles were air-dried on the lacey copper grid. Note that the sample drying process may induce changes in the morphology of the particle agglomerates. However, the objective of the TEM investigation was to look at the fundamental characteristics and sizes of individual particle crystallites that are not dependent on drying effects.

The TEM examinations were performed on an FEI Tecnai G2-30 (FEI Inc., Hillsboro, OR) with a field emission filament operating at $300 \mathrm{keV}$ equipped with a Scanning Transmission Unit and High Angle Annular Dark-Field Detector (HAADF), energy dispersive X-ray detector, and a Gatan Imaging Filter (GIF), model GIF2000 (Gatan Inc., Pleasanton, CA) at the Harry Reid Center for Environmental Studies at the University of Nevada, Las Vegas (UNLV). Because the TEM system at UNLV was not equipped with a digital camera at the camera plate position, diffraction patterns could not be readily obtained but were obtained on an FEI Tecnai 30S-Twin (FEI Inc., Hillsboro, OR) TEM operated at 300 $\mathrm{keV}$ and equipped with a Gatan ORIUS (Gatan, Inc., Pleasanton, CA) digital camera within the Radiochemical Processing Laboratory. Particle or area analysis was performed by identifying the composition with EDS, EELS, and selected area electron diffraction (SAED). Images were obtained with either the HAADF on the scanning transmission electron microscopy (STEM) system or conventional bright-field imaging. Energy-filtered images were also obtained with the Gatan image filter to produce element-specific area maps.

\section{A.2.4 Electron Energy-Loss Spectroscopy}

The EELS spectra were obtained with 0.6-, 2-, and 3-mm entrance apertures and an energy dispersion of 0.1 to $0.5 \mathrm{eV} / \mathrm{ch}$ annel. The core-loss spectra were collected with an integration time between 1 and 20 s. To reduce potential beam reduction, the acquisition time was kept as small as possible. The spectra were collected in the imaging mode of the transmission electron microscope and were corrected for dark 
current and channel-to-channel gain variation of the charge coupled device (CCD) detector. The coreloss regime was energy calibrated, and the energy drift was measured while data were being acquired by collecting zero-loss spectra before or after core-loss spectra were collected. The position of the C-K (1s) peak at $284 \mathrm{eV}$ (arising from transitions to the $\pi^{*}$ molecular orbital) from the TEM lacy carbon support film was used to evaluate the energy calibration and as a means of roughly checking that the energy resolution was sufficient for collecting data.

\section{A.2.5 X-Ray Energy Dispersive Analysis}

EDS analyses were conducted using the TIA (Tecnai Imaging and Analysis) software system (FEI Inc., Hillsboro, OR) on the TEMs. All EDS analyses contained an artifact from the X-ray fluorescence of the $\mathrm{Cu}-\mathrm{K}$ lines derived from the copper from the grid. The weaker $\mathrm{Cu}-\mathrm{L}$ lines were not generally visible. Quantitative analysis was conducted with internal k-factors. The analyses were accurate to $10 \%$ for the light elements (aluminum through to zinc) but for heavier elements, such as uranium, and strontium, errors may be significantly larger and are considered more qualitative. Oxygen and other light elements cannot be quantified with EDS.

\section{A.2.6 Electron Diffraction}

Electron diffraction patterns were obtained on the Gatan ORIUS camera and internally calibrated to a known phase. The electron diffraction d-spacings were accurate to $10 \%$. However, very large d-spacings (i.e., > $8 \AA$ ) were imprecise. SAED results were compared to phases found in the ICDD database or reported in the literature.

\section{A.3 Physical Properties}

The physical-property characterization (wt\% UDS and wt\% centrifuged solids) was conducted according to procedure RPL-COLLOID-02, Rev. 1, Measurement of Physical and Rheological Properties of Solutions, Slurries and Sludges, which is consistent with the WTP guidelines document. ${ }^{\left({ }^{a}\right)}$ Sample sizes were generally between 3 and $16 \mathrm{~g}$. The samples were collected in volume-graduated, glass, centrifuge tubes (10-mL and $15-\mathrm{mL}$ size tubes were used).

The samples were centrifuged at $\sim 1000 \mathrm{G}$ for 1 hour. The total sample volume and solids volume were recorded to assess the vol\% wet centrifuged solids (WCS). The centrifuged supernatants were decanted and transferred to tared graduated cylinders and measured for mass and volume. The supernatant density was then calculated and compared to the value measured in the CUF from the Coriolis densitometers, and compared to measured density of decanted supernatant when available. The remaining wet centrifuged solids were weighed in the centrifuge tubes to determine wet centrifuged solids densities. The supernatant samples were transferred to tared glass vials. Both the supernatant fractions and the residual solids fractions (containing interstitial supernatant) were transferred to a $50^{\circ} \mathrm{C}$ oven and initially dried for a minimum of $24 \mathrm{~h}$. The oven temperature was then raised to $105^{\circ} \mathrm{C}$ and the sample drying continued until constant mass was attained. The data collected were processed as described by Smith and Prindiville ${ }^{(a)}$ to determine the volume and weight percent of wet solids (total, settled, and centrifuged), densities, total undissolved solids, and dissolved solids content.

(a) 24590-WTP-GPG-RTD-001, Rev 0, "Guidelines for Performing Chemical, Physical, and Rheological Properties Measurements,” G. L. Smith and K. Prindiville, May 2002. 
Aqueous solution densities were determined from replicate mass measures of 0.5 - or 1-mL pipetted volume deliveries. The pipet was performance-checked daily before each use.

\section{A.4 Surface Area (BET)}

Samples were prepared for surface-area measurements in an effort to minimize solidification into a monolith upon drying. To this end, the solids were rinsed twice with ethanol and twice again with diethyl ether according to procedure TPR-RPP-WTP-486, Procedure for BET Sample Preparation Using Ethanol and Ethyl Ether as Drying Agents. Each rinse was conducted in a centrifuge tube. The solids were well suspended in the rinse solution, and then the phases were separated by centrifuging and decanting. The final ethyl ether rinse was used to transfer the solids slurry to the sample cell. The diethyl ether was then evaporated at room temperature directly from the sample cell.

The sample was further dried and out-gassed with the Quantachrome Instruments Monosorb Model MS-21 (Boynton Beach, FL) outgassing station. This entailed pre-flushing nitrogen through the sample cell for $\sim 10 \mathrm{~min}$ and then heating and flushing for overnight $(>10 \mathrm{~h})$ at $110^{\circ} \mathrm{C}$.

The surface-area measurements were conducted according to OCRWM-BET-01, Surface Area Measurement with a Monosorb Gas Analyzer, which is consistent with ASTM method D5604-96, Test Method B (Single-Point Surface Area by Flowing Gas Apparatus). The flow gas used in the measurement mode was composed of $30 \%$ nitrogen in helium. The system was calibrated per manufacturer instructions. The system performance was assessed with a $29.9 \pm 0.75 \mathrm{~m}^{2} / \mathrm{g}$ carbon surface area standard Lot D-6 obtained from Micromeritics (Norcross, GA). 
Appendix B

Parametric Leach Data 


\section{Appendix B: Parametric Leach Data}

Table B.1 shows the chromate concentration during Phase 1 test (in support of Figure 3.6). The reaction temperature was at ambient condition, $\sim 22^{\circ} \mathrm{C}$.

Table B.1. Tabulated Results for Phase 1

\begin{tabular}{|c|c|c|c|c|c||}
\hline \multirow{3}{*}{$\begin{array}{c}\text { Time, } \\
\text { h }\end{array}$} & \multicolumn{5}{|c|}{ Mn/Cr Mole Ratio } \\
\cline { 2 - 6 } & 0.79 & 0.95 & 0.95 & 1.21 & 1.38 \\
\hline 0 & $5.41 \mathrm{E}-4$ & $5.00 \mathrm{E}-4$ & $5.07 \mathrm{E}-4$ & $5.10 \mathrm{E}-4$ & $5.06 \mathrm{E}-4$ \\
\hline 1 & $8.72 \mathrm{E}-3$ & $9.34 \mathrm{E}-3$ & $9.46 \mathrm{E}-3$ & $1.06 \mathrm{E}-2$ & $1.12 \mathrm{E}-2$ \\
\hline 2 & $8.73 \mathrm{E}-3$ & $9.68 \mathrm{E}-3$ & $9.60 \mathrm{E}-3$ & $1.08 \mathrm{E}-2$ & $1.15 \mathrm{E}-2$ \\
\hline 4 & $8.79 \mathrm{E}-3$ & $9.84 \mathrm{E}-3$ & $9.63 \mathrm{E}-3$ & $1.09 \mathrm{E}-2$ & $1.14 \mathrm{E}-2$ \\
\hline 6 & $9.03 \mathrm{E}-3$ & $9.80 \mathrm{E}-3$ & $9.70 \mathrm{E}-3$ & $1.07 \mathrm{E}-2$ & $1.15 \mathrm{E}-2$ \\
\hline \multicolumn{5}{|c|}{ Cr Concentration, M (ICP-OES Analysis) } \\
\hline 6 & \multicolumn{7}{|c|}{ n/a } & $1.08 \mathrm{E}-2$ & $1.10 \mathrm{E}-2$ & $\mathrm{n} / \mathrm{a}$ & $\mathrm{n} / \mathrm{a}$ \\
\hline 6 & $\begin{array}{l}\text { (a) Chromate was measured for indication only. } \\
\text { n/a = not analyzed }\end{array}$ \\
\hline
\end{tabular}

Table B.2 shows the Na, Al, Mn, total Cr, Cr(VI), and ${ }^{239+240} \mathrm{Pu}$ and ${ }^{238} \mathrm{Pu}$ concentrations during oxidative leaching Phase 2 test. The $\mathrm{Mn} / \mathrm{Cr}$ mole ratio was 1.25 ; the reaction temperature was at ambient condition, $\sim 22^{\circ} \mathrm{C}$. Data support Figures 3.8 and 3.9. 
Table B.2. Tabulated Results for Phase 2

\begin{tabular}{|c|c|c|c|c|c|c|c|c|c|}
\hline \multicolumn{2}{|c|}{ Process Conditions } & \multicolumn{6}{|c|}{ Concentration, $\mathbf{M}$} & \multicolumn{2}{|c|}{$\begin{array}{c}\text { Concentration, } \\
\mu \mathrm{Ci} / \mathrm{mL}\end{array}$} \\
\hline $\begin{array}{c}\text { [NaOH] } \\
M \\
\end{array}$ & $\begin{array}{c}\text { Time, } \\
\mathbf{h}\end{array}$ & $\mathrm{Na}$ & Al & Mn & Total Cr & $\begin{array}{c}\mathrm{Cr} \\
(\mathrm{VI})^{(\mathbf{a})}\end{array}$ & $\begin{array}{c}\% \\
\text { Diff. }^{(b)} \\
\end{array}$ & ${ }^{238} \mathrm{Pu}$ & ${ }^{239+240} \mathrm{Pu}$ \\
\hline \multirow[t]{5}{*}{0.30} & 0 & 2.96E-1 & $1.20 \mathrm{E}-3$ & $<9.5 \mathrm{E}-7$ & $4.45 \mathrm{E}-4$ & $4.06 \mathrm{E}-4$ & $8.6 \%$ & 2.98E-7 & $5.96 \mathrm{E}-7$ \\
\hline & 1 & $3.05 \mathrm{E}-1$ & $2.55 \mathrm{E}-3$ & $2.15 \mathrm{E}-3$ & $9.02 \mathrm{E}-3$ & 7.98E-3 & $11.6 \%$ & $4.31 \mathrm{E}-5$ & 3.05E-4 \\
\hline & 2 & 3.11E-1 & 2.71E-3 & $2.07 \mathrm{E}-3$ & $9.28 \mathrm{E}-3$ & 8.23E-3 & $11.4 \%$ & 4.07E-5 & 3.04E-4 \\
\hline & 4 & $3.11 \mathrm{E}-1$ & 2.81E-3 & $1.12 \mathrm{E}-3$ & $9.14 \mathrm{E}-3$ & $8.21 \mathrm{E}-3$ & $10.1 \%$ & $3.92 \mathrm{E}-5$ & 2.83E-4 \\
\hline & 6 & 3.07E-1 & $2.98 \mathrm{E}-3$ & 2.05E-3 & $9.16 \mathrm{E}-3$ & 8.23E-3 & $10.1 \%$ & $3.94 \mathrm{E}-5$ & 2.79E-4 \\
\hline \multirow[t]{5}{*}{0.55} & 0 & $5.47 \mathrm{E}-1$ & $1.25 \mathrm{E}-3$ & $<9.6 \mathrm{E}-7$ & $4.49 \mathrm{E}-4$ & 4.12E-4 & $8.2 \%$ & 3.61E-7 & $1.36 \mathrm{E}-6$ \\
\hline & 1 & 5.71E-1 & $2.86 \mathrm{E}-3$ & $2.10 \mathrm{E}-3$ & 9.52E-3 & 8.29E-3 & $12.9 \%$ & 1.09E-4 & 7.70E-4 \\
\hline & 2 & $5.53 \mathrm{E}-1$ & $2.94 \mathrm{E}-3$ & $1.83 \mathrm{E}-3$ & $9.26 \mathrm{E}-3$ & 8.37E-3 & $9.5 \%$ & $9.57 \mathrm{E}-5$ & 7.19E-4 \\
\hline & 4 & $5.56 \mathrm{E}-1$ & 3.39E-3 & $1.72 \mathrm{E}-3$ & $9.16 \mathrm{E}-3$ & 8.33E-3 & $9.1 \%$ & $1.04 \mathrm{E}-4$ & $7.50 \mathrm{E}-4$ \\
\hline & 6 & $5.54 \mathrm{E}-1$ & $3.94 \mathrm{E}-3$ & $1.85 \mathrm{E}-3$ & $9.34 \mathrm{E}-3$ & $8.41 \mathrm{E}-3$ & $10.0 \%$ & $1.03 \mathrm{E}-4$ & 7.20E-4 \\
\hline \multirow{5}{*}{$\begin{array}{c}0.85 \\
\text { Trial A }\end{array}$} & 0 & 8.48E-1 & 1.32E-3 & [1.2E-4] & $4.60 \mathrm{E}-4$ & 4.34E-4 & $5.7 \%$ & $6.28 \mathrm{E}-7$ & 3.17E-6 \\
\hline & 1 & 8.59E-1 & 3.17E-3 & $1.91 \mathrm{E}-3$ & $9.40 \mathrm{E}-3$ & 8.49E-3 & $9.7 \%$ & $1.54 \mathrm{E}-4$ & $1.11 \mathrm{E}-3$ \\
\hline & 2 & 8.68E-1 & 3.73E-3 & $1.22 \mathrm{E}-3$ & 9.72E-3 & 8.75E-3 & $10.0 \%$ & $1.61 \mathrm{E}-4$ & 1.15E-3 \\
\hline & 4 & 8.56E-1 & $4.46 \mathrm{E}-3$ & $1.33 \mathrm{E}-3$ & $9.43 \mathrm{E}-3$ & 8.71E-3 & $7.7 \%$ & $1.50 \mathrm{E}-4$ & $1.10 \mathrm{E}-3$ \\
\hline & 6 & 8.52E-1 & $4.90 \mathrm{E}-3$ & 1.11E-3 & $9.25 \mathrm{E}-3$ & $8.58 \mathrm{E}-3$ & $7.3 \%$ & $1.60 \mathrm{E}-4$ & $1.14 \mathrm{E}-3$ \\
\hline \multirow{5}{*}{$\begin{array}{c}0.81 \\
\text { Trial B }\end{array}$} & 0 & 8.14E-1 & $1.28 \mathrm{E}-3$ & $<9.5 \mathrm{E}-7$ & $4.71 \mathrm{E}-4$ & $4.45 \mathrm{E}-4$ & $5.6 \%$ & 2.49E-7 & 2.73E-6 \\
\hline & 1 & 8.21E-1 & 3.05E-3 & $1.11 \mathrm{E}-3$ & $9.46 \mathrm{E}-3$ & 8.39E-3 & $11.3 \%$ & 1.43E-4 & $1.02 \mathrm{E}-3$ \\
\hline & 2 & $8.40 \mathrm{E}-1$ & $3.66 \mathrm{E}-3$ & $1.10 \mathrm{E}-3$ & 9.94E-3 & 8.61E-3 & $13.4 \%$ & $1.45 \mathrm{E}-4$ & $1.02 \mathrm{E}-3$ \\
\hline & 4 & 8.40E-1 & 4.34E-3 & $1.11 \mathrm{E}-3$ & 9.77E-3 & 8.56E-3 & $12.3 \%$ & $1.52 \mathrm{E}-4$ & $1.07 \mathrm{E}-3$ \\
\hline & 6 & 8.14E-1 & $4.81 \mathrm{E}-3$ & 1.12E-3 & $9.55 \mathrm{E}-3$ & 8.61E-3 & $9.8 \%$ & 1.53E-4 & $1.10 \mathrm{E}-3$ \\
\hline \multirow[t]{5}{*}{1.1} & 0 & $1.07 \mathrm{E}+0$ & $1.36 \mathrm{E}-3$ & [2.8E-6] & $4.82 \mathrm{E}-4$ & $4.54 \mathrm{E}-4$ & $5.8 \%$ & $6.85 \mathrm{E}-7$ & 5.38E-6 \\
\hline & 1 & $1.11 \mathrm{E}+0$ & $3.54 \mathrm{E}-3$ & $1.26 \mathrm{E}-3$ & 9.92E-3 & 8.75E-3 & $11.8 \%$ & $1.82 \mathrm{E}-4$ & 1.33E-3 \\
\hline & 2 & $1.10 \mathrm{E}+0$ & 4.12E-3 & $1.07 \mathrm{E}-3$ & 9.82E-3 & 9.16E-3 & $6.7 \%$ & 1.89E-4 & $1.32 \mathrm{E}-3$ \\
\hline & 4 & $1.09 \mathrm{E}+0$ & 5.13E-3 & 7.07E-4 & $9.88 \mathrm{E}-3$ & 9.02E-3 & $8.6 \%$ & 2.02E-4 & $1.35 \mathrm{E}-3$ \\
\hline & 6 & $1.09 \mathrm{E}+0$ & $5.58 \mathrm{E}-3$ & $6.01 \mathrm{E}-4$ & 9.73E-3 & 8.88E-3 & $8.7 \%$ & $1.80 \mathrm{E}-4$ & $1.33 \mathrm{E}-3$ \\
\hline \multirow[t]{5}{*}{1.39} & 0 & $1.38 \mathrm{E}+0$ & [1.5E-3] & $<4.9 \mathrm{E}-6$ & 5.03E-4 & $4.60 \mathrm{E}-4$ & $8.6 \%$ & $1.70 \mathrm{E}-6$ & $1.06 \mathrm{E}-5$ \\
\hline & 1 & $1.40 \mathrm{E}+0$ & 4.07E-3 & 7.67E-4 & 9.92E-3 & 8.86E-3 & $10.6 \%$ & 2.09E-4 & $1.44 \mathrm{E}-3$ \\
\hline & 2 & $1.43 \mathrm{E}+0$ & $5.04 \mathrm{E}-3$ & $1.29 \mathrm{E}-3$ & $1.03 \mathrm{E}-2$ & 8.93E-3 & $13.7 \%$ & 2.01E-4 & $1.51 \mathrm{E}-3$ \\
\hline & 4 & $1.39 \mathrm{E}+0$ & 5.72E-3 & 8.91E-4 & $9.90 \mathrm{E}-3$ & 9.14E-3 & $7.6 \%$ & 2.16E-4 & $1.53 \mathrm{E}-3$ \\
\hline & 6 & $1.39 \mathrm{E}+0$ & $6.32 \mathrm{E}-3$ & $7.56 \mathrm{E}-4$ & $9.96 \mathrm{E}-3$ & 8.90E-3 & $10.6 \%$ & 2.17E-4 & $1.57 \mathrm{E}-3$ \\
\hline \multicolumn{10}{|c|}{$\begin{array}{l}\text { (a) Chromate was measured for indication only. } \\
\text { (b) Percent difference between the chromate and total Cr concentrations: }([\mathrm{Cr}]-[\mathrm{Cr}(\mathrm{VI})]) \div[\mathrm{Cr}] \text {. } \\
\text { Analyte uncertainties were typically within } \pm 15 \% \text {; results in brackets indicate that the analyte concentrations were greater than } \\
\text { the minimum detection limit (MDL) and less than the estimated quantitation limit (EQL), and uncertainties were }>15 \% \text {. } \\
\text { ASR } 8060\end{array}$} \\
\hline
\end{tabular}


Appendix C

Concurrence Requests 


\section{Appendix C: Concurrence Requests}

Three concurrence requests are provided in this appendix:

1) WTP/RPP-MOA-PNNL-00103

Recommendation for bench-scale testing supporting parametric batch contact testing of Group 5/6 material

2) WTP/RPP-MOA-PNNL-00259

Recommendation for filtration, caustic leaching and

3) $\quad$ WTP/RPP-MOA-PNNL-00091 oxidative leaching test matrix in the Group 5/6 CUF UFP cleaning solution simulant formulation

Copies of concurrences from WTP are also included following each concurrence request. These take the form of a signed memorandum or e-mail. 


\section{Pacific Northwest National Laboratory}

Operated by Battelle for the

U.S. Department of Energy

September 10, 2007

Mr. Haukur R. Hazen

WTP/RPP-MOA-PNNL-00103

Bechtel National Inc.

2435 Stevens Center Place, MSIN: H4-02

Richland WA 99352

Dear Mr. Hazen:

Subcontract NO. 24590-QL-HC9-WA49-00001 - Project 53019 (WA\#2007-004)

Recommendations for Bench Scale Oxidative Leach Actual Waste Test

The purpose of this letter is to seek concurrence with the recommendation for bench-scale testing defined in TP-RPP-WTP-456 Pretreatment Demonstration Applying Oxidative Leaching to Hanford Tank. Waste, Task 5.

Prior to performing the CUF test, the test plan calls for a bench scale oxidative leach test to determine the quantity of permanganate to be added. As part of this bench-scale test, concurrences on specific processing conditions for caustic leaching and oxidative leaching were required.

Deviations from the test plan are suggested to better align the bench-scale test with the planned CUF test. A discussion of the recommendations and deviations are provided. Then, to place these discussions in context, the full process steps are defined with lines next to text where specific WTP approval is sought and bolded/underlined text noting suggested deviations from the test plan. Additionally, the affected test plan pages are attached showing in track-change mode where the exceptions are noted.

\section{Requirement:}

The test plan requires the following information to be provided for the caustic leaching process (see step 3.1 of the test plan).

Specific leach and wash process conditions will be forwarded to the BNI R\&T lead prior to conduct of the leach step; these conditions will include:

1) Contact solution volume and $\mathrm{NaOH}$ molarity.

2) Contact temperature (expected range 85 to $100^{\circ} \mathrm{C}$ ).

3) Wash solution volume.

4) Wash solution $\mathrm{NaOH}$ molarity.

902 Battelle Boulevard • P.O. Box 999 • Richland, WA 99352

Telephone (509) 375-4373 Email gordon.beeman@pnl.gov $\mathbf{m a x}$ (509) 375-2323 
Mr. Haukur R. Hazen

September 10, 2007

\section{Recommendation:}

The following corresponding recommendations are provided:

Conduct a batch leach on the bench-scale aliquot at the following conditions

1. $\mathrm{NaOH}$ will be added in quantity and concentration such that the anticipated dissolved $\mathrm{Al}$ will remain in solution at $25^{\circ} \mathrm{C}$. The calculated hydroxide concentration to maintain $\mathrm{Al}$ solubility will be derived from the previously published work ( $\mathrm{H}$. Li et al. Journal of Colloid and Interface Science 286 (2005) 511-519).

A probable test scenario will be conducted as follows. Any changes to the test slurry quantity will incorporate appropriate changes to the added $\mathrm{NaOH}$.

Add $84 \mathrm{~mL}$ of $9.5 \mathrm{M} \mathrm{NaOH}$ solution to $62.5 \mathrm{~g}$ slurry $^{1}$ mass containing $\sim 20 \%$ UDS. This quantity is expected to result in a $6.45 \mathrm{M}$ free hydroxide solution which should be sufficient to maintain $0.79 \mathrm{M} \mathrm{Al}$ in solution. A 12 -h leach time at $100^{\circ} \mathrm{C}$ is anticipated to dissolve $52 \%$ of the boehmite and $100 \%$ of the gibbsite. Under these process conditions, the total $\mathrm{Al}$ concentration is estimated to be about $0.79 \mathrm{M}$.

2. Leach temperature of $100^{\circ} \mathrm{C}$.

3. Wash solution volume will be determined based on the results from Group 6 actual waste parametric testing (TP-RPP-WTP-467, Section 6.3.4 and Concurrence Request WTP/RPPMOA-PNNL-00057). ${ }^{(2)}$ Two options (a and b) are possible. The wash condition choice will depend on the observed Pu mobilization to the aqueous phase. If $\mathrm{Pu}$ mobilization at $1.25 \mathrm{M}$ free hydroxide condition is not significantly higher than that of the $0.25 \mathrm{M}$ free hydroxide condition, option (a) will be chosen. Otherwise, option (b) will be chosen.

a) Wash the leached centrifuged solids three successive times with $0.01 \mathrm{M} \mathrm{NaOH}$, each wash volume is equal to the volume of the centrifuged solids. Washing will continue until the free hydroxide is $<1 \mathrm{M}$.

b) Wash the leached centrifuged solids multiple successive times with $0.01 \mathrm{M} \mathrm{NaOH}$, each wash volume is equal to the volume of the centrifuged solids. Washing steps will continue until the final hydroxide concentration is $<0.25 \mathrm{M}$. (Note that exceeding three washes diverges from the test plan; a test plan exception will need to be made.)

4. Wash solution composition is $0.01 \mathrm{M} \mathrm{NaOH}$.

\section{Requirement:}

The test plan calls for approval of the protocol for determining the permanganate dosage.

PNWD will seek approval to proceed with the protocol even if the report supporting TP-RPP-WTP-453 is not yet approved.

${ }^{1}$ ) Slurry was defined in Concurrence Request WTP/RPP-MOA-PNNL-00102, Recommendation for Feed Composition.

$\left(^{2}\right)$ Letter May 16, 2007 to FR Aravena from GH Beeman, Request for Approval of the Group 6 Oxidative Leaching Test Matrix. 
Mr. Haukur R. Hazen

September 10, 2007

\section{Recommendation:}

PNNL recommends the following strategy for determination of the oxidative leach condition:

The bulk caustic-leached and washed solids will be sub-divided equally into 5 sub-samples (nominally $0.9 \mathrm{~g}$ each). The $\mathrm{Mn}: \mathrm{Cr}$ mole ratios are shown in

Table 1.

Table 1. Oxidative Leach Bench-Scale Test

\begin{tabular}{|c|c|}
\hline $\begin{array}{c}\text { Mn:Cr mole } \\
\text { ratio }\end{array}$ & Number of tests \\
\hline 0.85 & 1 \\
\hline 1.0 & 2 \\
\hline 1.25 & 1 \\
\hline 1.5 & 1 \\
\hline
\end{tabular}

- The free hydroxide concentration will be equivalent to the final hydroxide reached after washing is completed and the volume is adjusted to a phase ratio of 1:100 with $0.25 \mathrm{M} \mathrm{NaOH}$. No adjustment for the volume of added permanganate will be incorporated.

- The samples will be processed at ambient temperature (in the fume hood this is nominally $21^{\circ} \mathrm{C}$, with a range of 19 to $27^{\circ} \mathrm{C}$ ).

- The defined quantity of $1 \mathrm{M} \mathrm{NaMnO}_{4}$ will be added to each sample, time of addition is defined as $T_{0}$; the duration of oxidation will continue as defined in the test plan (6 h).

\section{Deviation from Test Plan}

In order to better match the planned processing steps during the CUF testing, differences from the test plan will need to be incorporated.

\section{Requirement (Task 5, step 3.2)}

The test plan requires: "The leach process will be conducted for $8 \mathrm{~h}$ with good agitation such that particles remain suspended in solution."

\section{Recommendation}

We recommend the leach continue for $12 \mathrm{~h}$ to better match the degree of solids dissolution that will be obtained during the CUF test (the leach in the CUF test is planned for $12 \mathrm{~h}$ ).

\section{Requirement (Task 5, step 6.0)}

Inhibited water equal to the volume of centrifuged solids will be added to the centrifuged solids and re-mixed ( $15 \mathrm{~min})$. The solution will be sampled for hydroxide analysis.

\section{Recommendation}


Mr. Haukur R. Hazen

September 10, 2007

We recommend adding a greater volume $(100 \mathrm{~mL})$ of $\mathrm{NaOH}$ solution, concentration equivalent to the last wash solution, at this point such that the slurry can be homogenously suspended and accurately sub-sampled into the five test aliquots for the oxidant dosage test.

\section{Requirement (Task 5, step 12.0)}

The test plan requires: "The sludge will be washed with inhibited water. The phase separation (centrifuging and decanting) and water wash will be repeated three times each with a contact volume of inhibited water of nominally $3 \times$ the sludge slurry volume $\left(V_{S_{2}}\right)$. The three wash solutions will be combined and analyzed for metals (ICP-OES) and Pu.

\section{Recommendation}

At the conclusion of the oxidative leach, the solids will have concentrated significant betaactivity sources (primarily ${ }^{90} \mathrm{Sr} /{ }^{90} \mathrm{Y}$ ). We recommend the wash volume be increased to nominally $30-\mathrm{mL}$ and the decant process leave about $10-\mathrm{mL}$ of solution in contact with the solids. This manipulation approach will provide a significant source of shielding (water) for hands-on manipulation. It is understood that this washing is not prototypic of the oxidatively-leached solids washing steps in the CUF, however, the residual solids phase analysis will accurately reflect the water-insoluble component composition.

\section{Full Processing Conditions for Bench-Scale Test}

The following steps summarize the bench-scale test. The text with a line to the left indicates steps where BNI concurrence was required. Bold and underlined text indicates a change from the test plan that will be accommodated as an ICN to the test plan.

\section{Feed Preparation}

- Representative subsamples of Group 5 and Group 6 slurries will be combined as described in Concurrence Request WTP/RPT-MOA-PNNL-00102 Recommendation for Feed Composition.

- Slurry will be sampled for wt $\%$ UDS, liquid and solid will be measured for Pu and metals, solid will be evaluated by XRD, SEM, and TEM.

- Excess supernatant will be removed to result in a targeted $20 \mathrm{wt} \%$ UDS.

\section{Caustic Leach}

Caustic leach conditions for the blended waste slurry are proposed below based on a slurry mass of $62.5 \mathrm{~g}$ containing $20 \mathrm{wt} \%$ UDS, expected aluminum concentration in solids (described in Concurrence Request WTP/RPT-MOA-PNNL-00102 Recommendation for Feed Composition), and leach factors of $52 \%$ dissolution of Group 5 aluminum (assumed beohmite) and $100 \%$ dissolution of Group 6 aluminum (assumed gibbsite):

- Add $84 \mathrm{~mL}$ of $9.5 \mathrm{M} \mathrm{NaOH}$,

- Place slurry container in a water bath,

- Increase water bath temperature to target of $100(+5 /-10)^{\circ} \mathrm{C}$,

- Leach for $\underline{\mathbf{1 2}}$ hours with agitation where $\mathrm{T}_{0}$ is the time at which $90^{\circ} \mathrm{C}$ is attained in the water bath, 
Mr. Haukur R. Hazen

September 10, 2007

- Cool the slurry by removing the slurry container from the water bath and allow to equilibrate to the ambient hot cell temperature (cooling is anticipated to extend during offshift and the following step will be conducted during the following business day),

- Centrifuge, decant, and analyze liquid for metals, free hydroxide, and Pu.

The final sodium concentration is expected to be $\sim 7.9 \mathrm{M}$ and the free hydroxide is expected to be $\sim 6 \mathrm{M}$.

\section{Wash Following Caustic Leach}

All wash processing will be conducted at the cell temperature $\left(\sim 27^{\circ} \mathrm{C}\right)$.

- Add a volume $0.01 \mathrm{M} \mathrm{NaOH}$ equal to $\sim 1 \times$ the solids volume for wash 1 , agitate $\sim 15 \mathrm{~min}$, centrifuge, remove aqueous portion (expected $[\mathrm{OH}] \sim 3.5 \mathrm{M}$ ).

- Add a volume $0.01 \mathrm{M} \mathrm{NaOH}$ equal to $\sim 1 \times$ the solids volume for wash 2 , agitate $\sim 15 \mathrm{~min}$, centrifuge, remove aqueous portion (expected $[\mathrm{OH}] \sim 2.1 \mathrm{M})$.

- Add a volume $0.01 \mathrm{M} \mathrm{NaOH}$ equal to $\sim 1 \times$ the solids volume for wash 3, agitate $\sim 15 \mathrm{~min}$, centrifuge, remove aqueous portion (expected $[\mathrm{OH}] \sim 1.3 \mathrm{M}$ ).

- Repeat wash as per wash 3 processing if option (a) was selected to drive down the free hydroxide concentration to a target $\leq 1 \mathrm{M}$.

- Repeat wash as per wash 3 processing if option (b) was selected to drive down the free hydroxide concentration to a target $0.25 \mathrm{M}$.

- Add $\sim 100-\mathrm{mL} \mathrm{NaOH}$ solution. The added $\mathrm{NaOH}$ concentration will be equivalent to the last equilibrated wash solution. Agitate $\sim 15 \mathrm{~min}$ (UDS $\sim 6 \%$ ) to allow for accurate sample subdivision.

- Combine the decanted wash solutions and sample for metals and Pu.

- Sample the final contact solution for free hydroxide, $\mathrm{Pu}$, and metals determination. Sample the slurry to determine the $\mathrm{wt} \%$ UDS; sample the solids to determined $\mathrm{Pu}$ and metals concentration and evaluate by XRD, SEM, and TEM.

- Split slurry into 5 aliquots for oxidative leach testing. (Each sample is expected to contain $\sim 0.9$ g UDS.)

\section{Oxidative Leach Testing}

The oxidative leach testing will be conducted at anticipated process temperature $\left(45 \pm 5^{\circ} \mathrm{C}\right)$.

- Adjust the phase ratio (volume of solution to mass of solids) to 100 by adding additional $0.25 \mathrm{M} \mathrm{NaOH}$.

- Add the $\mathrm{NaMnO}_{4}$ in ratios as shown in

- Table 1. 
Mr. Haukur R. Hazen

September 10, 2007

- Agitate the slurry samples at room temperature for $6 \mathrm{~h}$. Agitation will be conducted congruently to work described by Rapko et. al ${ }^{(3)}$ using a 5-position stir plate with double-spin fin stir bars with the stir-plate rotational setting at $500 \mathrm{rpm}$

- The supernatant fractions will be sampled periodically (nominally $0.25,1,2,4$, and 6 h) to evaluate chromate (Cr oxidative leach kinetics).

\section{$\mathrm{UV} / \mathrm{Vis}$ Analysis}

Chromate measurement will be conducted using UV/Vis according to the protocol described by Rapko et al. ${ }^{(a)}$

- Permanganate in solution will be destroyed with hydrogen peroxide in a 20:1 peroxide to initial permanganate mole ratio.

- The peroxide will be allowed to react with the permanganate for $15 \mathrm{~min}$.

- Absorbance will be measured at $372 \mathrm{~nm}$. Appropriate dilutions will be applied to remain in the linear response region of the spectrometer. The spectra will also be evaluated at 500-570 $\mathrm{nm}$ and $550-700 \mathrm{~nm}$ to assess potential presence permanganate and manganate ions. Complete destruction of $\mathrm{MnO}_{4}^{2-}$ is required; its presence contributes to the $372 \mathrm{~nm}$ signal.

- Permanganate dosage for the CUF testing will be determined after evaluating the chromate measurement results.

\section{Post Oxidative Leach Washing Process Steps}

The duplicate test conducted at a 1:1 Cr:Mn mole ratio will be further washed and analyzed to provide mass balances on one of the test materials and identify residual sludge phases.

- Phase separate the sludge by centrifuging and decanting, leaving $\sim 10-\mathrm{mL}$ supernatant in contact with the solids. (Note that the residual fluid in contact with the solids is key to maintaining radiological dose to manageable levels for hands-on work. The fluid provides significant shielding to the beta dose [primarily from $\left.{ }^{90} \mathrm{Sr} /{ }^{90} \mathrm{Y}\right]$ ).

- Analyze the supernatant for metals, Pu. The oxidation state of $\mathrm{Cr}$ will be determined by difference (moles total $\mathrm{Cr}$ minus moles chromate $=$ moles $\mathrm{Cr}(\mathrm{III})$ ). Oxidation states for soluble Mn will be determined by UV/Vis (permanganate and manganate) and total Mn will be determined by ICP-OES. (The Pu oxidation state cannot be measured in this matrix due to interference of manganate in the $\mathrm{UV} / \mathrm{V}$ is spectrometer.)

- Add $\sim 30-\mathrm{mL} 0.01 \mathrm{M} \mathrm{NaOH}$ for wash 1, agitate $\sim 15 \mathrm{~min}$, centrifuge, remove aqueous portion leaving $10-\mathrm{mL}$ in contact with solids (to provide beta-shielding) (expected [OH] $\sim 0.06 \mathrm{M})$.

- Add $\sim 30-\mathrm{mL} 0.01 \mathrm{M} \mathrm{NaOH}$ for wash 2, agitate $15 \mathrm{~min}$, centrifuge, remove aqueous portion leaving $10-\mathrm{mL}$ in contact with solids (to provide beta-shielding) (expected [OH] $\sim 0.02 \mathrm{M})$.

$\left({ }^{3}\right)$ WTP-RPT-164 Process Development for Permanganate Addition During Oxidative Leaching of Hanford Tanks Sludges, Rapko et al. [draft report] supporting TP-RPP-WTP-453. 
Mr. Haukur R. Hazen

September 10, 2007

- Add $\sim 30-\mathrm{mL} 0.01 \mathrm{M} \mathrm{NaOH}$ for wash 3, agitate $15 \mathrm{~min}$, centrifuge, remove aqueous portion leaving $10-\mathrm{mL}$ in contact with solids (to provide beta-shielding) (expected $[\mathrm{OH}]$ $\sim 0.004 \mathrm{M}$ ).

- The decanted wash solutions will be combined for analyzed for metals and Pu.

- The washed sludge will be suspended in a low volume of $0.01 \mathrm{M} \mathrm{NaOH}$, split for analysis, and analyzed for metals, Pu, total mass, and characterized by SEM, XRD, and TEM. 
Mr. Haukur R. Hazen

September 10, 2007

\section{Attachment}

Proposed revisions to text in the Test Plan TP-RPP-WTP-456 are shown in track-change mode.

\section{B. Task 5, Bench Scale Oxidative Leach Actual Waste Test}

This task shall verify, using actual waste, the procedure developed for determining the oxidant dosage for oxidative leaching in Task 3 (TP-RPP-WTP-453) using simulants. The oxidant dosage determined from this task will then be used in the process demonstration test (Task 6 ) with one of the selected wastes.

The Task 5 processing is summarized in Figure 1. The general pretreatment process flowsheet steps (phase separation, caustic leaching, oxidative leaching, and solids washing) will be mimicked during testing of two small-scale actual tank waste samples. Mass balance of fluids and solids will be tracked to the extent practical. 
Mr. Haukur R. Hazen

September 10, 2007

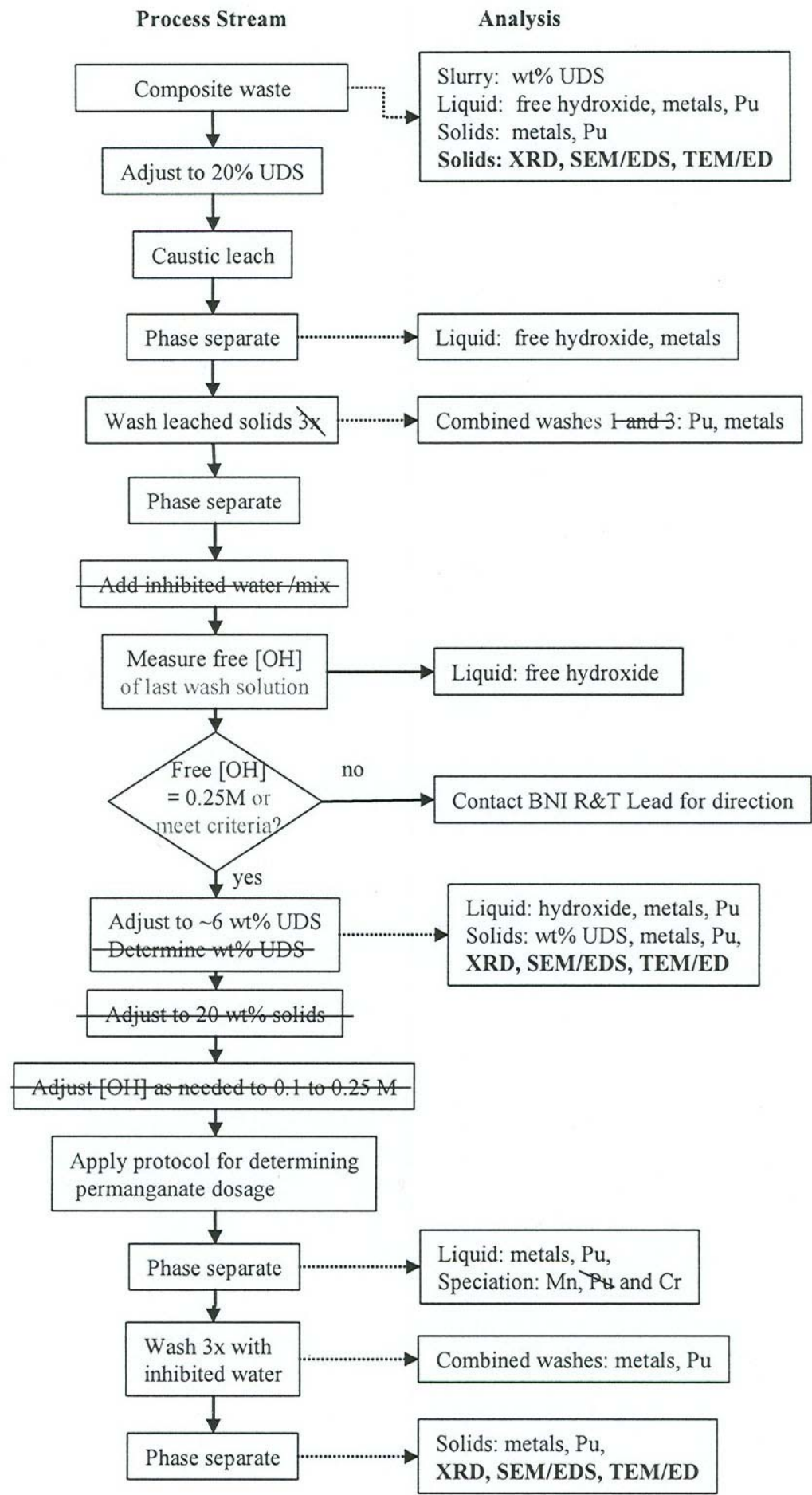

Figure 1. Task 5 Processing Summary

(Analyses supporting EFRT Issue M12 [24590-WTP-PL-ENG-06-0024] are bolded) 
Mr. Haukur R. Hazen

September 10, 2007

1.0 The composite slurry wt $\%$ UDS will be determined. The liquid and solids will be sampled for characterization of $\mathrm{Pu}$ (analysis by AEA) and metals (analysis by ICP-OES). The liquid will be analyzed for free hydroxide. Sludge particles will be examined by XRD, SEM, and TEM.

2.0 Slurry sample aliquots of sufficient size to accommodate at least $2 \mathrm{~g}$ undissolved solids per oxidative leach test will be prepared for caustic leaching. The slurry will be centrifuged and sufficient supernatant liquid will be removed or added to result in a slurry containing $20 \mathrm{wt} \%$ UDS, or as directed by the BNI R\&T Lead. This will be defined as the slurry volume $\left(=\mathrm{V}_{\mathrm{S} 1}\right)$.

3.0 The sludge will be caustic leached.

3.1 Specific leach and wash process conditions will be forwarded to the BNI R\&T lead for concurrence prior to conduct of the leach step; these conditions will include:

3.1.1 Contact solution volume and $\mathrm{NaOH}$ molarity.

3.1.2 Contact temperature (expected range 85 to $100^{\circ} \mathrm{C}$ ).

3.1.3 Wash solution volume.

3.1.4 Wash solution $\mathrm{NaOH}$ molarity.

3.1.5 Final target free hydroxide concentration

3.2 The leach process will be conducted for $12 \mathrm{~h}$ with good agitation such that particles remain suspended in solution.

4.0 The leached sludge will be cooled to ambient temperature $\left(20-30^{\circ} \mathrm{C}\right)$, centrifuged, and then the supernatant will be decanted. The leach solution will be characterized for metals, free hydroxide, and $\mathrm{Pu}$.

5.0 The leached sludge will be washed with the conditions defined in Step 0 .

5.1 Each wash/slurry will be agitated $\sim 15 \mathrm{~min}$ at room temperature.

5.2 After each wash step, the solids and liquids will be phase-separated using centrifuging and decanting.

5.3 The wash solutions will be combined and sampled for metals and $\mathrm{Pu}$ analysis.

6.0 An excess of $\mathrm{NaOH}$ solution (molarity equivalent to the last wash solution free hydroxide molarity) will be added to the centrifuged solids and re-mixed ( $\sim 15 \mathrm{~min})$ to allow for accurate sub-division of the slurry. The equilibrated solution will be sampled for hydroxide analysis.

HOLD POINT: The liquid associated with the last slurry contact will be measured for free hydroxide. If the free hydroxide concentration is $\leq 0.25 \mathrm{M}$, then the test will continue with step 7.0. If the free hydroxide is $>0.25 \mathrm{M}$, then PNWD will contact the BNI R\&T Lead for direction. 
Mr. Haukur R. Hazen

September 10, 2007

7.0 A sample of the slurry will be taken to determine the wt $\%$ UDS. A sample of the washed sludge will be taken to characterize the Pu concentration, metals (analysis by ICP-OES), and particles (XRD, SEM, TEM). A sample of the contact solution will be taken for $\mathrm{Pu}$ and metals analysis.

8.0 Sufficient liquid will be removed (or added) to reach a $20 \%$ UDS concentration, or as directed by the BNI R\&T Lead. The new slurry volume $\left(=\mathrm{V}_{\mathrm{S} 2}\right)$ will be recorded.

9.0 A volume of $19 \mathrm{M} \mathrm{NaOH}$ will be added to the slurry, if necessary, such that the free hydroxide molarity is within the target range of 0.1 to $0.25 \mathrm{M}$.

10.0 The washed sludge will then be subjected to the oxidative leaching protocol: agitated contact for $6 \mathrm{~h}$ at room temperature with the sodium permanganate oxidant dosage determined using the protocol (redox titration or other) developed in TP-RPP-WTP-453 (CCN 145091). PNWD will seek approval to proceed with the protocol even if the report supporting TPRPP-WTP-453 is not yet approved.

11.0 The oxidative-leached sludge will be phase-separated using centrifuging and decanting. The contact liquid (from oxidative leaching) will be analyzed for metals (B, Cd, Cr, Mn, Fe, Ni by ICP-OES), $\mathrm{Pu}$, and oxidation state speciation of $\mathrm{Cr}$ and $\mathrm{Mn}$. $\mathrm{Cr}$ and $\mathrm{Mn}$ oxidation states will be determined using spectroscopy in solution, as practical. ${ }^{(4)}$

12.0 The sludge will be washed with inhibited water. The phase separation (centrifuging and decanting) and water wash will be repeated three times each with a contact volume of inhibited water of nominally 10 to $15 \times$ the sludge slurry volume $\left(V_{S_{2}}\right)$. The three wash solutions will be combined and analyzed for metals (ICP-OES) and Pu.

13.0 Following washing, the sludge will be analyzed for metals (ICP-OES), Pu, total mass, and phase characterization (SEM, TEM and XRD).

Please contact Sandy Fiskum (376-7015) or Reid Peterson (376-5340) if you have any questions or need any further information.

Sincerely,

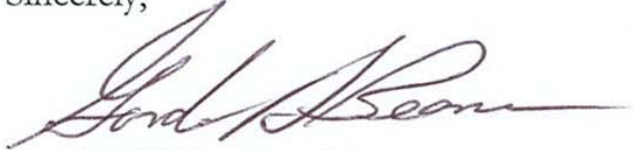

Gordon H. Beeman, Manager

RPP-WTP Support Program

( $\left.{ }^{4}\right)$ The amount of $\mathrm{Cr}$ as $\mathrm{Cr}(\mathrm{VI})$ can be determined by visible spectroscopy in solution. (Note that a 24-h hold time for $\mathrm{Cr}(\mathrm{VI})$ does not apply to the caustic solution matrix; $\mathrm{Cr}(\mathrm{VI})$ is stable in alkaline solutions (Rapko et al 2004). Total $\mathrm{Cr}$ is determined by ICP-OES. The $\mathrm{Cr}$ (III) fraction is ascribed to the difference of total $\mathrm{Cr}$ and $\mathrm{Cr}(\mathrm{VI})$ (where the $\mathrm{Cr}(\mathrm{VI})$ concentration is significantly less than total $\mathrm{Cr}$ concentration). $\mathrm{Mn}(\mathrm{VI})$ and $\mathrm{Mn}(\mathrm{VII})$ can also be seen qualitatively by visible spectroscopy. In alkaline solution $\mathrm{Mn}(\mathrm{IV})$ or $\mathrm{Mn}(\mathrm{III})$ should be insoluble. (The Pu oxidation state cannot be measured in this matrix due to interference of manganate in the UV/Vis spectrometer.) 
Mr. Haukur R. Hazen

September 10, 2007

GHB: $\mathrm{c}^{2}$

Enclosures

cc: Project File/LB

C.13 


\section{Concurrences}

From: Damerow, Frederick

Sent: Wednesday, September 05, 2007 11:26 AM

To: 'Peterson, Reid A'

Cc: Barnes, Steven M; Sundar, Parameshwaran S; Fiskum, Sandra K; Snow, Lanee A; Beeman, Gordon H; Huckaby, James; Markillie, Jeffrey; WTP R\&T Docs

Subject: RE: Test Concurrence Request TP456 Task 5 rev b.doc

Reid,

Based on our conversation this morning and my subsequent discussion with Steve Barnes, I concur with proceeding on this test approach for the Group 5/6 combination.

Fred Damerow

R\&T Systems and Pretreatment Manager

fwdamero@bechtel.com

off 509-371-4516

cell 509-531-5538

ETC1 P135

From: Peterson, Reid A [mailto:reid.peterson@pnl.gov]

Sent: Wednesday, September 05, 2007 9:03 AM

To: Damerow, Frederick

Cc: Barnes, Steven M; Sundar, Parameshwaran S; Fiskum, Sandra K; Snow, Lanee A; Beeman, Gordon H; Huckaby, James; Markillie, J effrey

Subject: FW: Test Concurrence Request TP456 Task 5 rev b.doc

Fred/Steve,

Attached is a minor revision based on some wordsmithing that Sundar has provided to Sandy.

Please let us know ASAP if you are prepared to proceed. This is the critical path to the next CUF run and we have already lost our next window of opportunity and are at risk of pushing things out further. With holidays coming - and they will be here quicker than we can imagine - we are going to end up 2-3 CUF run's behind if we aren't don't get going.

Reid.

From: Fiskum, Sandra K

Sent: Wednesday, September 05, 2007 7:48 AM

To: Peterson, Reid A

Subject: Test Concurrence Request TP456 Task 5 rev b.doc

Reid, This version incorporates Sundar's wordsmithing. Note that I still need the concurrence letter reference for the waste feeds identified.

I left you a voice mail indicating that Sundar wants the second waste form identified in the first concurrence letter. One waste for ox leach testing is the Group 5/6 combo. He wants the other waste also identified. 
I would really like these concurrences resolved before you take off so we can move forward in your absence.

Thanks,

Sandy

$<<$ Test Concurrence Request TP456 Task 5 rev b.doc >> 


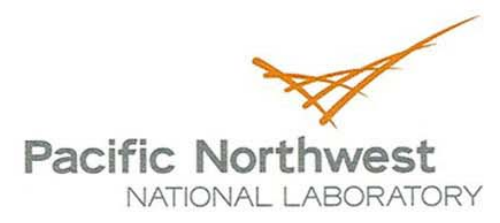

July 31,2008

Mr. Haukur R. Hazen

WTP/RPP-MOA-PNNL-00259

Bechtel National Inc.

2435 Stevens Center Place, MSIN: H4-02

Richland WA 99352

Dear Mr. Hazen:

Subcontract NO. 24590-QL-HC9-WA49-00001 - Project 53019 (WA\#2007-019)

Recommendations for Feed Composition, Bench-Scale Testing, and CUF Testing Using Group 5 and 6 Together for Caustic and Oxidative Leach Testing

The purpose of this letter is to document the concurrence given for the recommendations for feed composition, bench-scale testing, and CUF testing using Group 5 and 6 together for caustic and oxidative leach testing. Testing was performed as defined in TP-RPP-WTP-456 Pretreatment Demonstration Applying Oxidative Leaching to Hanford Tank Waste, and TP-RPP-WTP-467 Characterization and Small Scale Testing of Hanford Wastes to Support the Development and Demonstration of Leaching and Ultrafiltration Pretreatment Process. Verbal and email concurrence was issued prior to the start of testing on 11/4/07 based on the document below.

\section{Recommendations for Filtration, Caustic Leaching, and Oxidative Leaching Test Matrix in the Group 6/5 CUF Test}

This test will cover the crossflow filtration, caustic leaching, and oxidative leaching test for Group 6/Group 5 composite tank waste slurry. Accordingly, this work addresses determination of the filtration and leaching behavior at the bench-scale using the CUF system as described in Task 6 of TP-RPP-WTP-456 (as well as Section 6.4 of TP-RPP-WTP-467). The proposed test sequence is summarized in scheme shown in Figure 1.

The initial filtration testing, low solids test matrix, will be conducted with $\sim 2 \mathrm{~L}$ of Group 6 composite waste slurry diluted to $\sim 4 \mathrm{wt} \%$ UDS. Actual Group 6 supernatant at $\sim 5 \mathrm{M}$ sodium will be added back to $\sim 70 \%$ of concentrated slurry to provide the $\sim 4 \mathrm{wt} \%$ UDS slurry. This slurry will be dewatered to the minimum CUF operating volume, then Group 5 samples, consisting of $\sim 70 \%$ of the remaining 3 bottles $(\sim 0.9 \mathrm{~L})$, and additional Group 6 supernatant $(\sim 1 \mathrm{~L})$, added for dewatering to a target of $20 \mathrm{wt} \%$ UDS to generate a dewatering curve. Permeate will then be added back to give $\sim 1.5 \mathrm{~L}$ of slurry at approximately $16 \mathrm{wt} \%$ UDS for filtration matrix testing. All filtration testing will be conducted at $25+/-5^{\circ} \mathrm{C}$. The filtration test matrix was developed based upon median target transmembrane pressure (TMP) of $40 \mathrm{psi}$ and median target axial velocity (AV) of $13 \mathrm{ft} / \mathrm{s}$. 
Mr. Haukur R. Hazen

July 31,2008

Approximately 120 grams of solids from the un-treated Group 5 and 6 waste composites are available for additional caustic leach tests. Two additional caustic leaching tests using this material will be performed. By comparing the reaction rates of the un-processed material in these two tests and to material processed in the CUF, the impact of CUF solids shearing on the extent of $\mathrm{Al}$ leaching can be examined. The first test will be conducted at the same $w t \%$ UDS and caustic as the CUF test corresponding to the caustic leaching conditions in UFP2 vessel. The second test will be conducted at $4 \mathrm{wt} \%$ UDS and total sodium concentration of the leach would be $\sim 6.7 \mathrm{M}$ corresponding to caustic leach conditions in UFP1 vessel. Approximately $4-8$ grams of solids would be used for each test.

\section{Dewatering:}

Dewatering will be done on the initial $\sim 4 \mathrm{wt} \%$ Group 6 slurry to the CUF minimum operating volume ( $1.2 \mathrm{~L})$. Then Group 5 slurry and additional Group 6 supernatant will be added for continued dewatering to a target of $\sim 20 \mathrm{wt} \%$ UDS. The supernatant will contain approximately 4.5 $\mathrm{M} \mathrm{Na}$. After dewatering, a filtration test matrix will be conducted. Following completion of the test matrix, a slurry sample will be removed for caustic leach parametric tests.

Figure 2 provides a summary of sodium molarity during dewatering for the first five years of operating the Waste Treatment Plant. Inspection of this figure indicates that $4.5 \mathrm{M} \mathrm{Na}$ is within the range of conditions expected to be seen during the initial dewatering of slurry and bounds approximately $50 \%$ of the batches. 
Mr. Haukur R. Hazen

July 31,2008



Figure 1. Proposed test scheme for Group 6/5 composite waste sample.

\section{C.18}


Mr. Haukur R. Hazen

July 31, 2008



Figure 1 (continued). Proposed test scheme for Group 6/5 composite waste sample. 
Mr. Haukur R. Hazen

July 31,2008



Figure 1 (continued). Proposed test scheme for Group 6/5 composite waste sample. 
Mr. Haukur R. Hazen

July 31,2008

Fraction of batches bounded by the sodium molarity during initial dewatering

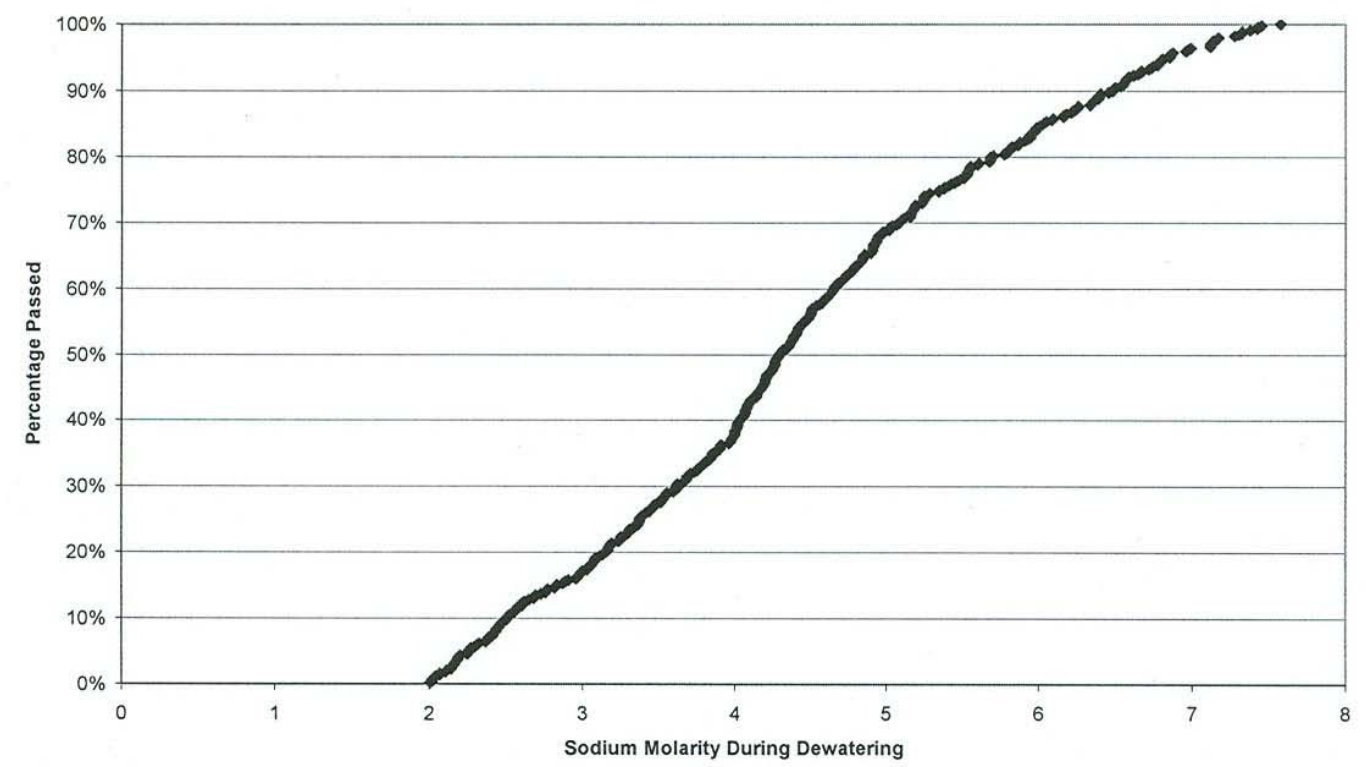

Figure 2. Projected WTP sodium molarity during initial dewatering.

\section{Dewater Process Steps (more details provided in this section):}

- First prepare a low-solids slurry by combining the $\sim 70 \%$ of the Group 6 composite waste slurry and an appropriate volume of actual Group 6 supernatant to provide $\sim 2 \mathrm{~L}$ of slurry at a target of $4 \mathrm{wt} \%$ UDS and $5 \mathrm{M}$ sodium.

- Conduct low solids filtration test matrix, Table 1. (This will provide filtration data for Group 6 only waste slurry.)

- Dewater to minimum CUF operating volume ( $1.2 \mathrm{~L}$ and $\sim 6 \mathrm{wt} \% \mathrm{UDS}$ ).

- Add Group 5 composite waste and an appropriate volume of Group 6 supernatant to provide $\sim 4 \mathrm{~L}$ of slurry ( $\sim 6 \mathrm{wt} \%$ UDS). Using the expected volume ratios and sodium concentration data, the expected sodium concentration is $4.5 \mathrm{M}$. (Note that $4 \mathrm{~L}$ is the maximum operating level of the CUF.)

- Dewater to target of $20 \mathrm{wt} \%$ UDS or as low volume as possible to generate a detailed dewater curve.

- Add back permeate to give a total volume of $\sim 1.5$ Liter ( $16 \mathrm{wt} \%$ UDS). Conduct a high solids matrix test as shown in Table 2. (If rheology, air entrainment or temperature control does not allow operation at $16 \mathrm{wt} \%$, permeate will be added back such that the test matrix could be carried out.)

- Remove a slurry sample for parametric leach tests with high sheared solids. The tests are to be performed like the early parametric leach tests without sheared solids. The solids will be well washed and slurried at $\sim 1 \mathrm{wt} \%$ UDS and leached at 3, 5 and $7 \mathrm{M} \mathrm{NaOH}$. 
Mr. Haukur R. Hazen

July 31,2008

Table 1. Low Solids Filtration Test Matrix at targeted 4 wt $\%$ USD*

\begin{tabular}{|l|l|l|l|}
\hline Test number & $\begin{array}{l}\text { Duration } \\
\text { (hours) }\end{array}$ & $\begin{array}{l}\text { Target TMP** } \\
(\mathrm{psi})\end{array}$ & $\begin{array}{l}\text { Target Axial } \\
\text { Velocity** } \\
(\mathrm{ft} / \mathrm{s})\end{array}$ \\
\hline 1 & 3 & 40 & 13 \\
\hline 2 & 1 & 30 & 11 \\
\hline 3 & 1 & 30 & 15 \\
\hline 4 & 1 & 50 & 15 \\
\hline 5 & 1 & 50 & 11 \\
\hline 6 & 1 & 40 & 13 \\
\hline 7 & 1 & 40 & 9 \\
\hline 8 & 1 & 40 & 17 (or max) \\
\hline 9 & 1 & 20 & 13 \\
\hline 10 & 1 & 60 & 13 \\
\hline 11 & 1 & 40 & 13 \\
\hline
\end{tabular}

* Resulting from Group 6 solids being diluted to $4 \mathrm{wt} \%$ UDS with excess permeate.

** Actual conditions may vary based upon slurry volume and rheology. All conditions may not be obtainable. 
Mr. Haukur R. Hazen

July 31,2008

Table 2. High Solids Filtration Test Matrix at targeted $16 \mathrm{wt} \%$ UDS*

\begin{tabular}{|l|l|l|l|}
\hline Test number & $\begin{array}{l}\text { Duration } \\
\text { (hours) }\end{array}$ & $\begin{array}{l}\text { Target TMP** } \\
(\mathrm{psi})\end{array}$ & $\begin{array}{l}\text { Target Axial } \\
\text { Velocity** } \\
(\mathrm{ft} / \mathrm{s})\end{array}$ \\
\hline 1 & 2 & 40 & 13 \\
\hline 2 & 1 & 40 & 17 (or max) \\
\hline 3 & 1 & 40 & 9 \\
\hline 4 & 1 & 40 & 13 \\
\hline 5 & 1 & 20 & 13 \\
\hline 6 & 1 & 60 & 13 \\
\hline 7 & 1 & 40 & 13 \\
\hline
\end{tabular}

* Resulting from the addition of Group 5 slurry (UDS $\sim 18 \mathrm{wt} \%$ ) to the Group 6 solids/permeate mixture in CUF, dewatering to $20 \mathrm{wt} \%$ UDS, then diluting with additional Group 6 permeate to target UDS.

** Actual conditions may vary based upon slurry volume and rheology. All conditions may not be obtainable.

\section{Leaching:}

Caustic leach conditions for the blended waste slurry are proposed below based on a slurry volume of $\sim 1.5 \mathrm{~L}$ at $\sim 16 \mathrm{wt} \%$ UDS, expected aluminum solid concentration, and leach factors of $80 \%$ dissolution of Group 5 aluminum (assumed beomite) and 80\% dissolution of Group 6 aluminum (assumed gibbsite):

Add $2.3 \mathrm{~L}$ of $10 \mathrm{M} \mathrm{NaOH}$ (adjust as needed for $\mathrm{Al}$ solubility at $25^{\circ} \mathrm{C}$ ), leach for 8 hours at $100^{\circ} \mathrm{C}$, and add water as needed during the caustic leach lost by evaporation to maintain a constant volume. The final sodium concentration is expected to be $\sim 7.7 \mathrm{M}$. Examining Figure 3, a summary of the sodium molarity during caustic leaching for the first 5 years of WTP operation, leaching at $7.7 \mathrm{M}$ bounds over $70 \%$ of the expected batches. 
Mr. Haukur R. Hazen

July 31,2008

Fraction of batches bounded by the sodium molarity during caustic leaching

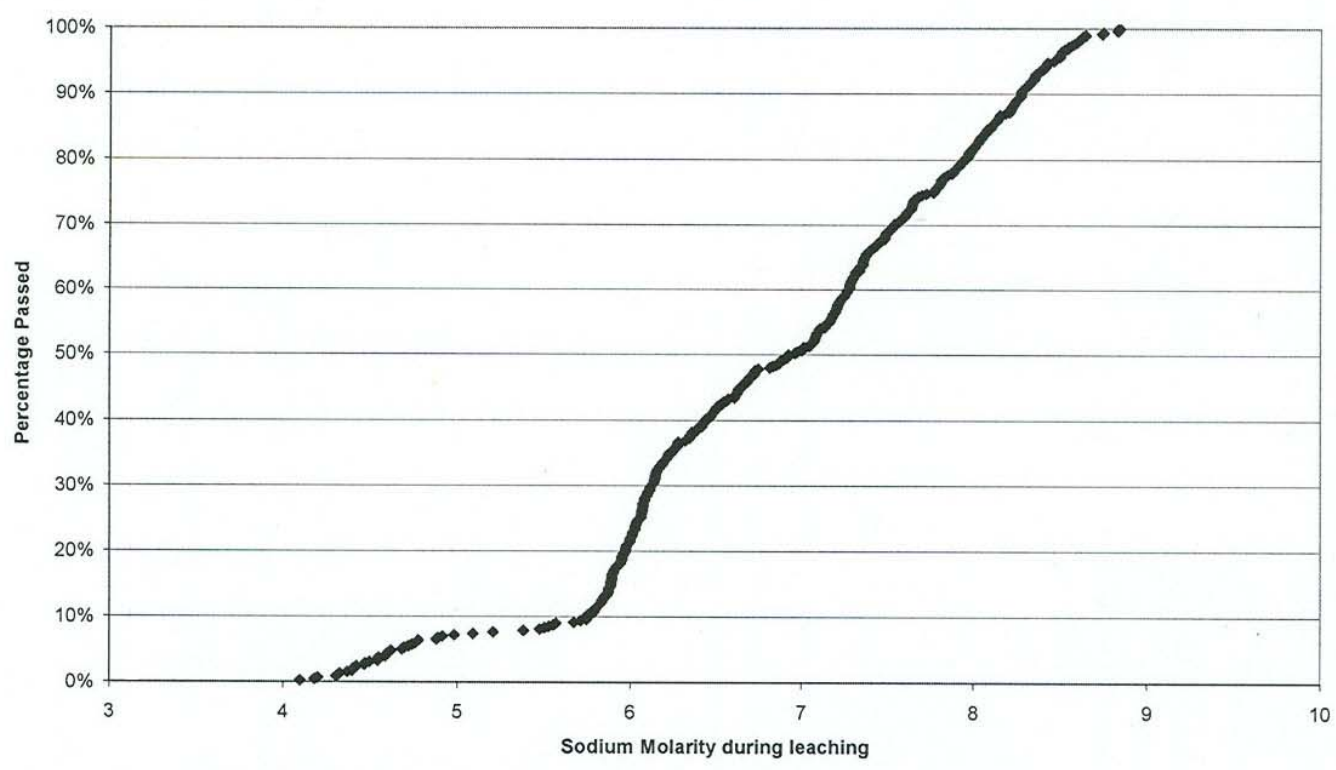

Figure 3. Projected WTP sodium molarity during caustic leaching.

Caustic Leaching Process Steps (more details provided in this section):

- Retrieve all solids from CUF and isolate in slurry feed reservoir for leaching.

- Assuming $~ 1.5 \mathrm{~L}$ of $\sim 16 \mathrm{wt} \%$ UDS at $4.5 \mathrm{M}$ sodium, add $2.3 \mathrm{~L}$ of $10 \mathrm{M} \mathrm{NaOH}$. (These leaching conditions have been estimated to produce a solution saturated with $\mathrm{Al}$ at $25^{\circ} \mathrm{C}$ at the conclusion of the leaching process.)

- Heat from $25^{\circ} \mathrm{C}$ to $100^{\circ} \mathrm{C}$ in 5.3 hours.

- Leach for $8 \mathrm{~h}$ at $100(+5 /-10)^{\circ} \mathrm{C}$.

- Cool from $100^{\circ} \mathrm{C}$ to $25^{\circ} \mathrm{C}$ in 12 hours.

\section{Post Caustic Leach Dewater Process Steps:}

- Dewater leached solids at $25^{\circ} \mathrm{C}, \mathrm{TMP}=40 \mathrm{psi}$, and AV $=13 \mathrm{ft} / \mathrm{s}$. Dewater to a target of $\sim 1.2 \mathrm{~L}$ or to minimum operating volume of CUF ( $8.3 \mathrm{wt} \%$ undissolved solids (UDS)).

\section{Post Caustic Leach Washing:}

The number of wash steps will be determined based on the results from Group 6 parametric testing and evaluation of the Pu mobilization to the aqueous phase. Current plans are based on washing until the free hydroxide is equal to or below $0.25 \mathrm{M}$. It is estimated that six equal volume wash steps will be conducted to reduce the free hydroxide below the target level of $0.25 \mathrm{M}$.

\section{Post Caustic Leach Washing Process Steps:}

- Add equal volume of caustic wash solution (1.53 M NaOH) for wash 1, dewater to a target of $\sim 1.2 \mathrm{~L}$ or to minimum operating volume of CUF ( $10 \mathrm{wt} \%$ UDS). 
Mr. Haukur R. Hazen

July 31,2008

- Add equal volume of caustic wash solution $(0.66 \mathrm{M} \mathrm{NaOH})$ for wash 2 , dewater to a target of $\sim 1.2 \mathrm{~L}$ or to minimum operating volume of CUF ( $10 \mathrm{wt} \% \mathrm{UDS})$.

- Add equal volume of caustic wash solution $(0.24 \mathrm{M} \mathrm{NaOH})$ for wash 3, dewater to a target of $\sim 1.2 \mathrm{~L}$ or to minimum operating volume of CUF ( 10 wt $\%$ UDS).

- Add equal volume of caustic wash solution $(0.09 \mathrm{M} \mathrm{NaOH})$ for wash 4 , dewater to a target of $\sim 1.2 \mathrm{~L}$ or to minimum operating volume of CUF ( $10 \mathrm{wt} \%$ UDS).

- Add equal volume of caustic wash solution $(0.02 \mathrm{M} \mathrm{NaOH})$ for wash 5 , dewater to a target of $\sim 1.2 \mathrm{~L}$ or to minimum operating volume of CUF ( $10 \mathrm{wt} \%$ UDS).

- Add equal volume of caustic wash solution $(0.01 \mathrm{M} \mathrm{NaOH})$ for wash 6 to reduce free hydroxide concentration below $0.25 \mathrm{M}$, dewater to a target of $\sim 1.2 \mathrm{~L}$ or to minimum operating volume of CUF ( $10 \mathrm{wt} \%$ UDS).

- Remove slurry sample for $\mathrm{Cr}$ parametric studies. Oxidative leaching tests will be conducted on the caustic leached/washed solids at 1.25:1 Mn:Cr ratio at $0.25,0.5,0.75,1.0$ and $1.25 \mathrm{M}$ $\mathrm{NaOH}$. Theses parametric tests are intended to bound the quantity of $\mathrm{Pu}$ that will dissolve. These tests are not intended to be prototypic, but rather to provide an additional input into the washing requirements to ensure limited $\mathrm{Pu}$ oxidation

\section{Oxidative Leaching Process Steps:}

- Retrieve all solids from CUF and isolate in slurry feed reservoir for leaching.

- Assuming $~ 1.2 \mathrm{~L}$ of $\sim 10 \mathrm{wt} \%$ UDS and all $\mathrm{Cr}$ in the initial waste remaining insoluble, add a 1:1 mole ratio of $1 \mathrm{M} \mathrm{NaMnO}_{4}(173 \mathrm{~mL})$ or other ratio as determined by the Group 6/5 screening tests, and leach for $6 \mathrm{~h}$ at ambient hot cell temperature, $\sim 27^{\circ} \mathrm{C}$.

- Sample supernatant fraction at $0.5,1,2,4$, and 6 hours during oxidative leaching and analyze supernatant fraction for metals (total $\mathrm{Cr}$ ) and $\mathrm{Pu}$.

\section{Post Oxidative Leach Dewater Process Steps:}

- Dewater will be removed, since volume addition is so little, proceed to first wash.

\section{Post Oxidative Leach Washing Process Steps:}

- Add equal volume of inhibited water $(0.01 \mathrm{M} \mathrm{NaOH})$ for wash 1 , dewater to a target of $\sim 1.2$ $\mathrm{L}$ or to minimum operating volume of CUF ( $11 \mathrm{wt} \%$ UDS).

- Add equal volume of inhibited water $(0.01 \mathrm{M} \mathrm{NaOH})$ for wash 2 , dewater to a target of $\sim 1.2$ $\mathrm{L}$ or to minimum operating volume of CUF ( $11 \mathrm{wt} \% \mathrm{UDS})$.

- Add equal volume of inhibited water $(0.01 \mathrm{M} \mathrm{NaOH})$ for wash 3, dewater to a target of $\sim 1.2$ $\mathrm{L}$ or to minimum operating volume of CUF ( $11 \mathrm{wt} \% \mathrm{UDS})$.

- Sample at this point, before addition of solids from Group 5 leach test.

- Add back final leached and washed solids from Group 5 test to give a volume of $\sim 4 \mathrm{~L}(\sim 7$ wt $\%$ UDS).

- Dewater to $\sim 1.4 \mathrm{~L}(\sim 20 \mathrm{wt} \%$ UDS) and conduct a high solids matrix test as shown in Table 3.

- Drain slurry from CUF and retain for potential use, only dispose at the guidance of the client.

- Clean CUF and determine clean water $(0.01 \mathrm{M} \mathrm{NaOH})$ flux. 
Mr. Haukur R. Hazen

July 31,2008

Table 3. High Solids Filtration Test Matrix at targeted $20 \mathrm{wt} \%$ UDS

\begin{tabular}{|l|l|l|l|}
\hline Test number & $\begin{array}{l}\text { Duration } \\
\text { (hours) }\end{array}$ & $\begin{array}{l}\text { Target TMP** } \\
(\mathrm{psi})\end{array}$ & $\begin{array}{l}\text { Target Axial } \\
\text { Velocity** } \\
(\mathrm{ft} / \mathrm{s})\end{array}$ \\
\hline 1 & 1 & 40 & 13 \\
\hline 2 & 1 & 40 & 9 \\
\hline 3 & 1 & 40 & 17 (or max) \\
\hline 4 & 1 & 40 & 13 \\
\hline 5 & 1 & 20 & 13 \\
\hline 6 & 1 & 60 & 13 \\
\hline 7 & 1 & 40 & 13 \\
\hline
\end{tabular}

* Based on combining washed leached slurry from Group 5 CUF test with the washed oxidative leach slurry from this test, and dewatering the mixture to the target UDS.

** Actual conditions may vary based upon slurry volume and rheology. All conditions may not be obtainable.

\section{Sample Plan:}

The sample collection and analysis plan will be implemented as defined in the test plan.

If you have any questions, please contact Reid Peterson on 376-5340.



Gordon H. Beeman, Manager

RPP-WTP Support Program

GHB: $\mathrm{c}^{2}$

cc: SK Fiskum (PNNL

RA Peterson (PNNL)

RW Shimskey (PNNL)

PS Sundar (BNI)

Project File/LB 


\section{Concurrences}

From: Gilbert, Robert A (Rob)

Sent: Tuesday, October 30, 2007 10:56 AM

To: Barnes, Steven

Cc: Peterson, Reid A; Bang, Ricky; Sundar, Parameshwaran S; Shimskey, Rick W; Hallen, Richard T

Subject: RE: Approval of Group 6-5 CUF Test Plan

Steve,

I concur with the test conditions specified for the Group 5/6 CUF testing.

Thanks

Rob Gilbert

From: Peterson, Reid A [mailto:reid.peterson@pnl.gov]

Sent: Tuesday, October 30, 2007 10:02 AM

To: Gilbert, Robert A (Rob)

Cc: Barnes, Steven; Bang, Ricky; Sundar, Parameshwaran S; Shimskey, Rick W; Hallen, Richard T

Subject: FW: Approval of Group 6-5 CUF Test Plan

Comments attached.

Reid.

From: Gilbert, Robert A (Rob)

Sent: Tuesday, October 30, 2007 9:53 AM

To: Sundar, Parameshwaran S; Bang, Ricky

Cc: Barnes, Steven; Peterson, Reid A

Subject: RE: Approval of Group 6-5 CUF Test Plan

Sundar,

I have two remaining questions marked in redline/all caps. Please let me know the answers.

Thanks

Rob Gilbert

From: Sundar, Parameshwaran S [mailto:pssundar@bechtel.com]

Sent: Monday, October 29, 2007 4:16 PM

To: Gilbert, Robert A (Rob); Bang, Ricky

Cc: Barnes, Steven; Peterson, Reid A

Subject: Approval of Group 6-5 CUF Test Plan

I mportance: High 
ROB, RICKY:

According to your request today at the weekly progress meeting, I am attaching the final version of the Group 6-5 hot CUF tests under oxidative leach process demonstration with actual waste tests under test plan TP-RPP-WTP-456 Rev 0.

All the comments internal to BNI have been resolved and it now requires ORP approval. The scope in this plan incorporates all the resolutions that were discussed during our comment resolution meeting on October 18.

Please let me know of your concurrence by COB, Thursday, November 1.

Regards,

SUNDAR

<<Group 6-5 CUF Test Request - OxLeach TP456 Task 6 - final - 102607.doc〉> 


\section{Pacific Northwest National Laboratory \\ Operated by Battelle for the \\ U.S. Department of Energy}

August 23, 2007

Mr. Haukur R. Hazen

WTP/RPP-MOA-PNNL-00091

Bechtel National Inc.

2435 Stevens Center Place, MSIN: H4-02

Richland WA 99352

Dear Mr. Hazen:

Subcontract NO. 24590-QL-HC9-WA49-00001 - Project 53019 (WA\#2007-004)

Concurrence Request for UFP Cleaning Solution Simulant

\section{DRAFT}

Date: $4 / 4 / 07$

Concurrence

\section{Request}

Test Plan Document

Number

Test Plan Title

TP-RPP-WTP-456

Pretreatment Demonstration Applying Oxidative

Subject

Leaching to Hanford Tank Waste

Test Plan Section

UFP Cleaning Solution Simulant

4.0

Section 4.1 .2 of TP-RPP-WTP-456 states that the UFP cleaning solution simulant will be prepared. The simulant formulation recipe was to mimic the recipe provided by SRNL. Mark Barnes indicated this simulant is prepared by dissolving $4.8 \mathrm{~g} \mathrm{AZ}-102$ simulant sludge solids in 1 liter of $2 \mathrm{M}$ nitric acid (email communication 8/25/06).

Subsequent discussion with Jake Reynolds and Ernie Lee indicated that the cross flow filters will not be cleaned with $2 \mathrm{M}$ nitric acid and instead will be rinsed with caustic. Jake provided a listing of the components in the resultant cleaning solution vector to the FEP (email communication 3/28/07, with copy to Sundar).

It is proposed that the UFP cleaning solution simulant mimic that of the caustic leach cleaning process with resulting formulation provided by J. Reynolds.

902 Battelle Boulevard • P.O. Box 999 • Richland, WA 99352

Telephone (509) 375-4373 Email gordon.beeman@pnl.gov $\mathbf{m a x}$ (509) 375-2323 
Mr. Haukur R. Hazen

August 23, 2007

The liquid and solid phase simulant compositions were evaluated. Feed vector components were screened based on the following criteria

1) aqueous component fraction present at $>1 \mathrm{E}-4 \mathrm{~kg} / \mathrm{h}$

2) solids component fraction present at $>1 \mathrm{E}-2 \mathrm{~kg} / \mathrm{h}$

3) radionuclide components were eliminated $(\mathrm{U}, \mathrm{Pu}, \mathrm{Th}$, etc.)

The component concentrations in the aqueous fraction were estimated by assuming a 1-h integration time to convert $\mathrm{kg} / \mathrm{h}$ to $\mathrm{kg}$ and dividing the analyte mass by the water content of $408 \mathrm{~L}$ (based on a density of $1.018 \mathrm{~g} / \mathrm{mL}$.

The aqueous portion cationic composition is shown in Table 1. The sum of the cation charge is 0.136 equivalents per liter.

Table 1. Cation composition of Aqueous Phase

\begin{tabular}{|lcrccc|}
\hline Cations & $\mathrm{kg}$ & $\mathrm{FW}$ & moles & Molarity & Equivalents \\
\hline $\mathrm{Na}$ & $1.28 \mathrm{E}+00$ & 22.99 & $5.56 \mathrm{E}+1$ & $1.36 \mathrm{E}-1$ & 0.136 \\
$\mathrm{~K}$ & $2.96 \mathrm{E}-04$ & 39.0983 & $7.58 \mathrm{E}-3$ & $1.86 \mathrm{E}-5$ & $1.86 \mathrm{E}-05$ \\
$\mathrm{Sr}^{(\text {a) }}$ & $1.85 \mathrm{E}-04$ & 87.62 & $2.11 \mathrm{E}-3$ & $5.16 \mathrm{E}-6$ & 0 \\
$\mathrm{Ce}^{(\text {a) }}$ & $1.44 \mathrm{E}-04$ & 140.12 & $1.03 \mathrm{E}-3$ & $2.51 \mathrm{E}-6$ & 0 \\
$\mathrm{~Pb}^{(\text {a) }}$ & $1.34 \mathrm{E}-04$ & 207 & $6.48 \mathrm{E}-4$ & $1.59 \mathrm{E}-6$ & 0 \\
$($ a) Not added-too dilute for consideration & & \\
\hline
\end{tabular}

The anionic composition is shown in Table 2. The sum of the anionic charge is 0.132 equivalents per liter. The final $\mathrm{pH}$ is calculated to be $\sim 12.9$.

Table 2. Anionic composition of Aqueous Phase

\begin{tabular}{|c|c|c|c|c|c|}
\hline Anions & $\mathrm{kg}$ & FW & moles & Molarity & Equivalents \\
\hline $\mathrm{C}_{2} \mathrm{O}_{4}^{-2}$ & 7.99E-01 & 88 & $9.08 \mathrm{E}+0$ & $2.22 \mathrm{E}-02$ & $-4.45 \mathrm{E}-2$ \\
\hline $\mathrm{NO}_{3}^{-}$ & 2.07E-02 & 62 & 3.33E-1 & 8.17E-04 & $-8.17 \mathrm{E}-4$ \\
\hline $\mathrm{NO}_{2}^{-}$ & $1.36 \mathrm{E}-02$ & 46 & $2.96 \mathrm{E}-1$ & 7.24E-04 & $-7.24 \mathrm{E}-4$ \\
\hline $\mathrm{CO}_{3}^{-2}$ & 4.40E-03 & 60 & $7.34 \mathrm{E}-2$ & $1.80 \mathrm{E}-04$ & $-3.59 E-4$ \\
\hline $\mathrm{SO}_{4}^{-2}$ & $5.92 \mathrm{E}-04$ & 96.06 & $6.17 \mathrm{E}-3$ & $1.51 \mathrm{E}-05$ & $-3.02 E-5$ \\
\hline $\mathrm{PO}_{4}^{-3}$ & $1.59 \mathrm{E}-04$ & 94.97 & $1.68 \mathrm{E}-3$ & 4.11E-06 & $-1.23 \mathrm{E}-5$ \\
\hline $\mathrm{Cl}^{-}$ & $9.90 \mathrm{E}-03$ & 35.45 & $2.79 \mathrm{E}-1$ & 6.84E-04 & $-6.84 E-4$ \\
\hline $\mathrm{OH}^{-}$(free) & 0.5612687 & 17 & $3.24 \mathrm{E}+1$ & 7.94E-02 & $-7.94 \mathrm{E}-2$ \\
\hline $\mathrm{Al}\left(\right.$ as $\left.\mathrm{AlOH}_{4}^{-}\right)$ & $4.26 \mathrm{E}-03$ & 26.98154 & $1.58 \mathrm{E}-1$ & $3.87 \mathrm{E}-04$ & $-3.87 \mathrm{E}-4$ \\
\hline $\mathrm{Cr}(\mathrm{VI})$ (as & & & & & \\
\hline $\left.\mathrm{CrO}_{4}{ }^{2-}\right)$ & $2.00 \mathrm{E}-02$ & 51.996 & $3.84 \mathrm{E}-1$ & $9.41 \mathrm{E}-04$ & $-1.88 \mathrm{E}-3$ \\
\hline $\mathrm{Si}$ (as & & & & & \\
\hline $\left.\mathrm{SiO}_{2}(\mathrm{OH})_{2}{ }^{2-}\right)$ & $1.97 \mathrm{E}-02$ & 28.0855 & $7.02 \mathrm{E}-1$ & $1.72 \mathrm{E}-03$ & $-3.44 \mathrm{E}-3$ \\
\hline
\end{tabular}

The proposed aqueous phase formulation is shown in Table 3. 
Mr. Haukur R. Hazen

August 23, 2007

Table 3. Proposed Aqueous Phase UFP Cleaning Solution Simulant Composition

\begin{tabular}{|c|c|c|c|c|c|c|}
\hline \multirow[b]{2}{*}{ Reagent } & \multirow[b]{2}{*}{ Analyte } & \multirow{2}{*}{$\begin{array}{c}\text { Targeted } \\
\text { analyte conc. } \\
\text { M }\end{array}$} & \multicolumn{2}{|c|}{$\begin{array}{c}\text { Reagent } \\
\text { mass needed }\end{array}$} & \multicolumn{2}{|c|}{ Molarity } \\
\hline & & & \multicolumn{2}{|c|}{ for 1-L } & $\mathrm{NO}_{3}$ & $\mathrm{Na}$ \\
\hline $\mathrm{Na}_{2} \mathrm{C}_{2} \mathrm{O}_{4}$ & oxalate & $2.22 \mathrm{E}-2$ & 2.9808 & $\mathrm{~g}$ & & $4.45 \mathrm{E}-2$ \\
\hline $\mathrm{Al}(\mathrm{OH})_{3}$ & $\mathrm{Al}$ & 3.87E-4 & 0.0503 & g & & \\
\hline $\mathrm{Na}_{2} \mathrm{CrO}_{4}$ & $\mathrm{Cr}$ & $9.41 \mathrm{E}-4$ & 0.1524 & $\mathrm{~g}$ & & $1.88 \mathrm{E}-3$ \\
\hline $\mathrm{NaCl}$ & $\mathrm{Cl}$ & $6.84 \mathrm{E}-4$ & 0.0400 & $\mathrm{~g}$ & & $6.84 \mathrm{E}-4$ \\
\hline $\mathrm{NaH}_{2} \mathrm{PO}_{4}$ & $\mathrm{P}$ & 4.11E-6 & 0.0005 & $\mathrm{~g}$ & & 4.11E-6 \\
\hline $\mathrm{Na}_{2} \mathrm{SO}_{4}$ & $\mathrm{SO}_{4}^{-2}$ & $1.51 \mathrm{E}-5$ & 0.0021 & $\mathrm{~g}$ & & $3.02 \mathrm{E}-5$ \\
\hline $\mathrm{NaNO}_{3}$ & $\mathrm{NO}_{3}^{-}$ & $8.17 \mathrm{E}-4$ & 0.0694 & $\mathrm{~g}$ & 8.17E-4 & 8.17E-4 \\
\hline $\mathrm{KNO}_{3}$ & K & $1.86 \mathrm{E}-5$ & 0.0019 & $\mathrm{~g}$ & $1.86 \mathrm{E}-5$ & \\
\hline $\mathrm{NaOH}(50 \%$ soln $)$ & $\mathrm{Na}$ & 7.94E-2 & 6.3546 & g & & 7.94E-2 \\
\hline $\mathrm{Na}_{2} \mathrm{SiO}_{3}-9 \mathrm{H}_{2} \mathrm{O}$ & $\mathrm{Si}$ & $1.72 \mathrm{E}-3$ & 0.4889 & $\mathrm{~g}$ & & $3.44 \mathrm{E}-3$ \\
\hline $\mathrm{NaNO}_{2}$ & $\mathrm{NO}_{2}^{-}$ & $7.24 \mathrm{E}-4$ & 0.0499 & $\mathrm{~g}$ & & $7.24 \mathrm{E}-4$ \\
\hline $\mathrm{Na}_{2} \mathrm{CO}_{3}$ & $\mathrm{C}$ & $1.80 \mathrm{E}-4$ & 0.0190 & g & & $3.59 \mathrm{E}-4$ \\
\hline \multicolumn{5}{|c|}{ analyte sum fraction: } & $8.35 \mathrm{E}-4$ & $1.32 \mathrm{E}-1$ \\
\hline \multicolumn{5}{|c|}{ analyte target fraction: } & 8.17E-4 & $1.32 \mathrm{E}-1$ \\
\hline \multicolumn{5}{|c|}{ percent of target: } & 102 & 100 \\
\hline
\end{tabular}

The solids component fraction was slightly more difficult to discern. Table 4 shows the compounds predicted in the UFP cleaning solution at levels $>1 \mathrm{E}-2 \mathrm{~kg} / \mathrm{h}$ in order of decreasing abundance. The $\mathrm{U}$ and $\mathrm{Th}$ compounds were deleted from consideration.

Table 4. Solids Composition of the UFP Cleaning Solution
\begin{tabular}{|lcc|}
\hline Compound & $\mathrm{kg} / \mathrm{h}$ & Relative mass ratio \\
\hline $\mathrm{Fe}_{2} \mathrm{O}_{3}$ & $1.90 \mathrm{E}+00$ & $2.28 \mathrm{E}-01$ \\
$\mathrm{Na}_{2} \mathrm{C}_{2} \mathrm{O}_{4}$ & $1.83 \mathrm{E}+00$ & $2.19 \mathrm{E}-01$ \\
$\mathrm{Na}_{2} \mathrm{SiO}_{3} \cdot 8 \mathrm{H}_{2} \mathrm{O}$ & $1.56 \mathrm{E}+00$ & $1.87 \mathrm{E}-01$ \\
$\mathrm{MnO}_{2}$ & $9.02 \mathrm{E}-01$ & $1.08 \mathrm{E}-01$ \\
$\mathrm{Al}(\mathrm{OH})_{3}$ & $9.00 \mathrm{E}-01$ & $1.08 \mathrm{E}-01$ \\
$\mathrm{Mn}_{3} \mathrm{O}_{4}$ & $4.43 \mathrm{E}-01$ & $5.32 \mathrm{E}-02$ \\
$\mathrm{Ca}_{5} \mathrm{OH}\left(\mathrm{PO}_{4}\right)_{3}$ & $2.66 \mathrm{E}-01$ & $3.19 \mathrm{E}-02$ \\
$\mathrm{NaAlSiO}_{4}$ & $2.40 \mathrm{E}-01$ & $2.87 \mathrm{E}-02$ \\
$\mathrm{Bi}_{2} \mathrm{O}_{3}$ & $1.40 \mathrm{E}-01$ & $1.67 \mathrm{E}-02$ \\
$\mathrm{Na}_{2} \mathrm{U}_{2} \mathrm{O}_{7}$ & $5.62 \mathrm{E}-02^{(2)}$ & not considered \\
$\mathrm{Mg}_{2}(\mathrm{OH})_{2}$ & $3.98 \mathrm{E}-02$ & $4.77 \mathrm{E}-03$ \\
$\mathrm{Ni}_{2}(\mathrm{OH})_{2}$ & $3.59 \mathrm{E}-02$ & $4.30 \mathrm{E}-03$ \\
$\mathrm{Cd}(\mathrm{OH})_{2}$ & $2.66 \mathrm{E}-02$ & $3.20 \mathrm{E}-03$ \\
$\mathrm{ZnO}$ & $2.46 \mathrm{E}-02$ & $2.95 \mathrm{E}-03$ \\
$\mathrm{ThO}$ & $2.12 \mathrm{E}-022^{(2)}$ & not considered \\
$\mathrm{ZrO}$ & $1.65 \mathrm{E}-02$ & $1.99 \mathrm{E}-03$ \\
$\mathrm{Nd}(\mathrm{OH})_{3}$ & $1.47 \mathrm{E}-02$ & $1.76 \mathrm{E}-03$ \\
\hline $\mathrm{Total}$ mass in $1 \mathrm{~h}$ & $8.34 \mathrm{E}+00$ & $1.00 \mathrm{E}+00$ \\
$($ a) $\mathrm{Mass}$ not included in total. & \\
\hline
\end{tabular}

\section{C.31}


Mr. Haukur R. Hazen

August 23, 2007

The proposed solids composition is presented as two subcomponent mixtures in Table 5 and Table 6. Mixture 1 would be prepared by addition of nitrate salts to water followed by precipitation in hydroxide solution. This mixture would then be centrifuged to collect the solids, decanted to remove supernatant, and suspended by addition of $\sim 10 \mathrm{~mL}$ of the simulant aqueous phase.

Table 5. Mixture 1, Preparation of Metal Hydroxides

\begin{tabular}{lccccc} 
& $\begin{array}{c}\text { metal } \\
\text { nitrate, } \\
\text { per 1-g } \\
\text { solids }\end{array}$ & $\begin{array}{c}\text { precipitated } \\
\text { hydroxide }\end{array}$ & $\begin{array}{r}\text { metal } \\
\text { hydroxide, } \mathrm{g} \\
\text { per 1-g solids }\end{array}$ & $\begin{array}{c}\text { target } \\
\text { mass } \\
\text { fraction }\end{array}$ & $\begin{array}{c}\text { achieved } \\
\text { mass } \\
\text { fraction }\end{array}$ \\
\hline $\mathrm{Mg}\left(\mathrm{NO}_{3}\right)_{2} \cdot 6 \mathrm{H}_{2} \mathrm{O}$ & 0.0211 & $\mathrm{Mg}(\mathrm{OH})_{2}$ & 0.0048 & $4.77 \mathrm{E}-3$ & $4.80 \mathrm{E}-3$ \\
$\mathrm{Ni}\left(\mathrm{NO}_{3}\right)_{2} \cdot 6 \mathrm{H}_{2} \mathrm{O}$ & 0.0134 & $\mathrm{Ni}(\mathrm{OH})_{2}$ & 0.0043 & $4.30 \mathrm{E}-3$ & $4.28 \mathrm{E}-3$ \\
$\mathrm{Cd}\left(\mathrm{NO}_{3}\right)_{2} \cdot 4 \mathrm{H}_{2} \mathrm{O}$ & 0.0067 & $\mathrm{Cd}(\mathrm{OH})_{2}$ & 0.0032 & $3.20 \mathrm{E}-3$ & $3.19 \mathrm{E}-3$ \\
$\mathrm{Nd}\left(\mathrm{NO}_{3}\right)_{3} \cdot 6 \mathrm{H}_{2} \mathrm{O}$ & 0.0039 & $\mathrm{Nd}(\mathrm{OH})_{3}$ & 0.0016 & $1.76 \mathrm{E}-3$ & $1.60 \mathrm{E}-3$ \\
\multicolumn{5}{c}{$\sum \mathrm{M}(\mathrm{OH})_{x} 0.0139 \mathrm{~g}$} \\
\end{tabular}

Mixture 2 would be prepared by combining the dry mineral phases. The mineral combination would then be slurried with the aqueous simulant and combined with Mixture 1. Additional aqueous phase would be added to result in a calculated $2 \%$ solids slurry.

Table 6. Mixture 2, Preparation of Balance of Mineral Phases

\begin{tabular}{|c|c|c|c|c|c|}
\hline Compound & $\begin{array}{l}\text { target mass } \\
\text { fraction }\end{array}$ & $\begin{array}{l}\text { mass, } g \text { per } \\
1-g \text { mixture }\end{array}$ & $\mathrm{Na}$ & $\mathrm{Al}$ & $\mathrm{Si}$ \\
\hline $\mathrm{Fe}_{2} \mathrm{O}_{3}$ & $2.28 \mathrm{E}-01$ & 0.2250 & & & \\
\hline $\mathrm{MnO}_{2}$ & 1.08E-01 & 0.1068 & & & \\
\hline $\mathrm{Al}(\mathrm{OH})_{3}$ & $1.08 \mathrm{E}-01$ & 0.1080 & & 0.3736 & \\
\hline $\mathrm{Mn}_{3} \mathrm{O}_{4}$ & 5.32E-02 & 0.0525 & & & \\
\hline $\mathrm{Ca}_{5} \mathrm{OH}\left(\mathrm{PO}_{4}\right)_{3}$ & 3.19E-02 & 0.0320 & & & \\
\hline $\mathrm{NaAlSiO}_{4}^{\left({ }^{(a)}\right.}$ & 2.87E-02 & 0 & 0 & 0 & 0 \\
\hline $\mathrm{NaAlSi}_{2} \mathrm{O}_{6}^{\left({ }^{(a)}\right.}$ & $2.87 \mathrm{E}-02$ & 0.0287 & 0.0653 & 0.0383 & 0.0798 \\
\hline $\mathrm{Bi}_{2} \mathrm{O}_{3}$ & 1.67E-02 & 0.0165 & & & \\
\hline $\mathrm{ZnO}$ & 2.95E-03 & 0.0029 & & & \\
\hline $\mathrm{ZrO}_{2}$ & 1.99E-03 & 0.0020 & & & \\
\hline $\mathrm{Na}_{2} \mathrm{C}_{2} \mathrm{O}_{4}$ & 2.19E-01 & 0.2170 & 0.7450 & & \\
\hline $\mathrm{Na}_{2} \mathrm{SiO}_{3} \cdot 9 \mathrm{H}_{2} \mathrm{O}$ & $1.87 \mathrm{E}-01$ & 0.1946 & 0.0315 & & 0.0192 \\
\hline \multicolumn{3}{|c|}{ analyte sum fraction: } & 0.1125 & 0.0412 & 0.0272 \\
\hline \multicolumn{3}{|c|}{ analyte target fraction: } & 0.1110 & 0.0423 & 0.0251 \\
\hline \multicolumn{3}{|c|}{ percent of target: } & $101 \%$ & $97 \%$ & $108 \%$ \\
\hline \multicolumn{6}{|c|}{$\begin{array}{l}\text { (a) } \mathrm{NaAlSiO}_{4} \text { could not be found. } \mathrm{NaAlSi}_{2} \mathrm{O}_{6} \text {, natural jadeite, could be found; } \\
\text { substitution of this compound will need to be evaluated by BNI. BNI staff are } \\
\text { welcome to provide alternate suggestions. }\end{array}$} \\
\hline
\end{tabular}

\section{Uncertainties}

The aqueous fraction shows excellent cation anion balance. All components have good solubilities in the hydroxide matrix. 
Mr. Haukur R. Hazen

August 23, 2007

The solids composition, as provided by J Reynolds holds a couple of questions with respect to phase stability in contact with the aqueous phase. The sodium oxalate in solution is $2.9 \mathrm{~g} / \mathrm{L}$. The solubility of sodium oxalate in water is $37 \mathrm{~g} / \mathrm{L}$. It should be considered a high probability that the aqueous phase will further dissolve sodium oxalate from the solid phase. The $\mathrm{Al}(\mathrm{OH})_{3}$ in the solid phase may similarly dissolve in the hydroxide solution $(\mathrm{pH} \sim 12.9)$. The $\mathrm{NaAlSiO}_{4}$ material could not be found on internet searches. A substitute is provided, $\mathrm{NaAlSi}_{2} \mathrm{O}_{6}$ (jadeite), however applicability of this will need further evaluation by BNI staff. The $\mathrm{Na}_{2} \mathrm{SiO}_{3} \cdot 9 \mathrm{H}_{2} \mathrm{O}$ is soluble in dilute $\mathrm{NaOH}$ solution and is likely to dissolve in the aqueous simulant. Particle size distribution is not known, thus no effort was made meet a PSD range.

Simulant development is typically a large scope of work requiring several trial formulations and analysis. The simulant preparation proposed is a single trial on a best effort basis. The resulting mix will require analysis (solids and liquid phases) after a suitable aging time. Analysis scope will include:

$\begin{array}{lll}\text { Liquid } & \text { Solid } & \begin{array}{l}\text { metals } \\ \text { anions } \\ \text { hydroxide }\end{array}\end{array}$

Technical questions should be directed to Reid Peterson, 376-1571.

Sincerely,

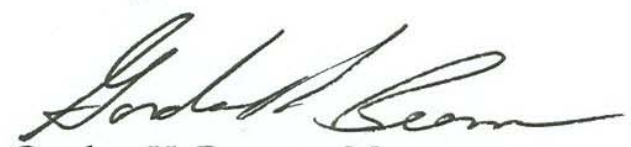

Gordon H. Beeman, Manager

RPP-WTP Support Program

GHB: $\mathrm{c}^{2}$

cc: Project File/LB 
Mr. Gordon H. Beeman

Pacific NW National Laboratory

P. O. Box 999, MSIN K2-20

Richland, Washington 99352
CCN: 159560

BRN: WTP/RPP-MOA-BNI-00064

September 12, 2007

CONTRACT NO. DE-AC27-01RV14136 - HANFORD TANK WASTE TREATMENT AND IMMOBILIZATION PLANT, MEMORANDUM OF AGREEMENT (MOA), 24590QL-HC9-WA49-00001, PNNL R\&T SUPPORT, WORK AUTHORIZATION (WA) 2007-004, CONCURRECNE WITH PNNL'S RECOMMENDATION FOR UFP CLEANING SOLUTION SIMULANT

Reference: CCN 159533 dated 23 August 2007, PNNL letter no. WTP / RPP-MOA-PNNL00091 Revised Concurrence Request for UFP Cleaning Solution Simulant Dear Mr. Beeman:

With regard to PNNL's above referenced letter, BNI concurs with PNNL's recommendation for cleaning solution stimulant.

Should you have any further questions or comments concerning this matter, please do not hesitate to call the undersigned at (509) 371-2301.

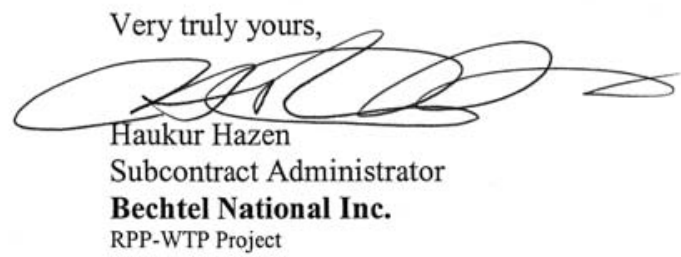

Distribution

William L. Graves

Juvy M. Simon

Fred Damerow

PDC - Subcontract File B-7

\begin{tabular}{ll|c|c|c|}
\cline { 3 - 5 } & & $\begin{array}{c}\text { Letter } \\
\text { Copy } \\
\text { w/att }\end{array}$ & $\begin{array}{c}\text { Letter } \\
\text { Copy } \\
\text { Only }\end{array}$ & $\begin{array}{c}\text { E- } \\
\text { Mail }\end{array}$ \\
\cline { 3 - 5 } WTP & MS6-P1 & & & $\mathrm{X}$ \\
\cline { 3 - 5 } WTP & MS14-3A & & & $\mathrm{X}$ \\
\cline { 3 - 5 } WTP & MS6-P1 & & & $\mathrm{X}$ \\
\cline { 3 - 5 } WTP & MS9-A & $\mathrm{X}$ & & \\
\cline { 3 - 5 } & &
\end{tabular}

Bechtel National, inc. 


\section{Distribution}

No. of

\section{Copies}

\section{ONSITE}

4 Bechtel National, Inc.

WTP R\&T Docs (2) H4-02

P. S. Sundar H4-02

S. Barnes H4-02

15 Pacific Northwest National Laboratory

S. K. Fiskum (2) P7-25

J. M. Billing P7-25

E. C. Buck P7-27

R. C. Daniel P7-22

K. Draper K6-75

M. K. Edwards P7-25

D. E. Kurath K3-52

G. J. Lumetta P7-25

L. M. Peurrung K9-09

R. A. Peterson P7-22

R. L. Russell K6-24

R. W. Shimskey P7-25

L. A. Snow P7-25

Project File P7-28 